\title{
Comparative Analyses for Selected Clean Coal Technologies in the International Marketplace
}

\section{DO NOT MICROFILM COVER}

Environmental Assessment and Information Sciences Division Argonne National Laboratory

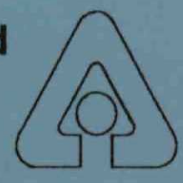

Operated by The University of Chicago, under Contract W-31-109-Eng-38, for the United States Department of Energy 


\section{Argonne National Laboratory}

Argonne National Laboratory, with facilities in the states of Illinois and Idaho, is owned by the United States government, and operated by the University of Chicago under the provisions of a contract with the Department of Energy.

This technical memo is a product of Argonne's Environmental Assessment and Information Sciences (EAIS) Division. For information on the division's scientific and engineering activities, contact:

Director, Environmental Assessment and

Information Sciences Division

Argonne National Laboratory

Argonne, Illinois 60439-4815

Telephone (708) 972-3759

Presented in this technical memo are preliminary results of ongoing work or work that is more limited in scope and depth than that described in formal reports issued by the EAIS Division.

\section{Disclaimer}

This report was prepared as an account of work sponsored by an agency of the United States Government. Neither the United States Government nor any agency thereof, nor any of their employees, makes any warranty, express or implied, or assumes any legal liability or responsibility for the accuracy, completeness, or usefulness of any information, apparatus, product, or process disclosed, or represents that its use would not infringe privately owned rights. Reference herein to any specific commercial product, process, or service by trade name, trademark, manufacturer, or otherwise, does not necessarily constitute or imply its endorsement, recommendation, or favoring by the United States Government or any agency thereof. The views and opinions of authors expressed herein do not necessarily state or reflect those of the United States Government or any agency thereof.

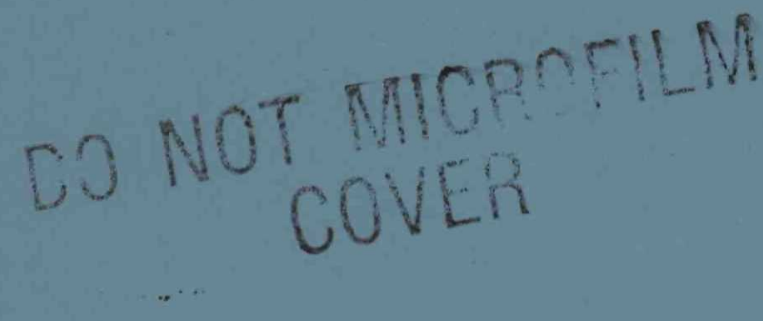

Reproduced from the best available copy. Available from the National Technical Information Service (NTIS), U.S. Department of Commerce, 5285 Port Royal Road, Springfield, Virginia 22161.

NTIS price codes:

Printed copy A14

Microfiche $A 01$ 


\section{DISCLAIMER}

This report was prepared as an account of work sponsored by an agency of the United States Government. Neither the United States Government nor any agency Thereof, nor any of their employees, makes any warranty, express or implied, or assumes any legal liability or responsibility for the accuracy, completeness, or usefulness of any information, apparatus, product, or process disclosed, or represents that its use would not infringe privately owned rights. Reference herein to any specific commercial product, process, or service by trade name, trademark, manufacturer, or otherwise does not necessarily constitute or imply its endorsement, recommendation, or favoring by the United States Government or any agency thereof. The views and opinions of authors expressed herein do not necessarily state or reflect those of the United States Government or any agency thereof. 


\section{DISCLAIMER}

Portions of this document may be illegible in electronic image products. Images are produced from the best available original document. 


\section{Comparative Analyses for Selected Clean Coal Technologies in the International Marketplace}

by C.B. Szpunar and J.L. Gllette

with contributions by T. Bleakley, ${ }^{\star}$ L.W. Carlson, ${ }^{*}$ R.D. Doctor, ${ }^{*}$ H.S. Huang, ${ }^{\star}$ K.A. Hub, L.D. Kenkeremath, D.M. Kenskı, D.M. Kern, M.R. Kochan, J.L. Nehrıng, R.S. Smıth, and P.A. Traczyk

International Coal and Environmental Studies Section, Environmental Assessment and Information Sciences Division, Argonne National Laboratory, 9700 South Cass Avenue, Argonne, Illinols 60439

July 1990

Work sponsored by United States Department of Energy, Assistant Secretary for Fossil Energy, Office of Clean Coal Technology 


\section{CONTENTS}

ACKNOWLEDGMENTS $\ldots \ldots \ldots \ldots \ldots \ldots \ldots \ldots \ldots \ldots \ldots \ldots \ldots \ldots \ldots \ldots \ldots \ldots \ldots \ldots$

ACRONYMS $\ldots \ldots \ldots \ldots \ldots \ldots \ldots \ldots \ldots \ldots \ldots \ldots \ldots \ldots \ldots \ldots \ldots \ldots \ldots \ldots \ldots \ldots \ldots$

CHEMICAL SYMBOLS $\ldots \ldots \ldots \ldots \ldots \ldots \ldots \ldots \ldots \ldots \ldots \ldots \ldots \ldots \ldots \ldots \ldots \ldots$

UNITS OF MEASURE $\ldots \ldots \ldots \ldots \ldots \ldots \ldots \ldots \ldots \ldots \ldots \ldots \ldots \ldots \ldots \ldots \ldots \ldots \ldots \ldots$

ABSTRACT $\ldots \ldots \ldots \ldots \ldots \ldots \ldots \ldots \ldots \ldots \ldots \ldots \ldots \ldots \ldots \ldots \ldots \ldots \ldots \ldots \ldots$

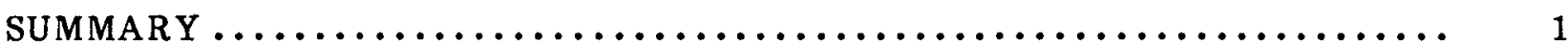

$1 \quad$ INTRODUCTION $\ldots \ldots \ldots \ldots \ldots \ldots \ldots \ldots \ldots \ldots \ldots \ldots \ldots \ldots \ldots \ldots \ldots \ldots \ldots \ldots$

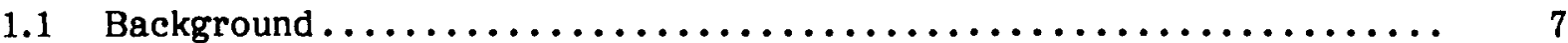

1.2 Selection of Clean Coal Technologies $\ldots \ldots \ldots \ldots \ldots \ldots \ldots \ldots \ldots \ldots \ldots . . \ldots$

1.2.1 Precombustion Technologies ....................... 8

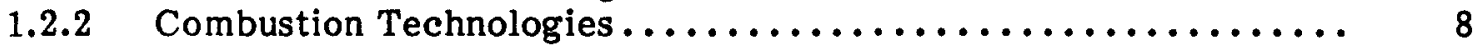

1.2.3 Postcombustion Technologies ..................... 9

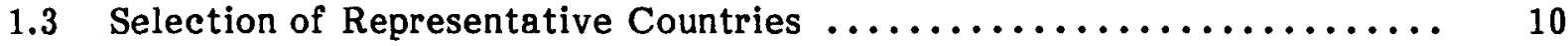

1.4 Report Organization $\ldots \ldots \ldots \ldots \ldots \ldots \ldots \ldots \ldots \ldots \ldots \ldots \ldots \ldots \ldots \ldots \ldots . . \ldots$

2 SELECTED CHARACTERISTICS OF TWELVE CLEAN COAL

TECHNOLOGIES ................................ 11

2.1 Advanced Coal Preparation ............................ 15

2.1.1 Applicable Market ............................. 15

2.1.2 Influence of Coal Type .......................... 16

2.1.3 Plant Size and Modularity Considerations ................. 16

2.1.4 Status of Commercialization ...................... 16

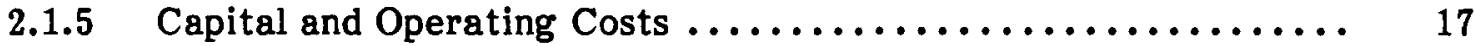

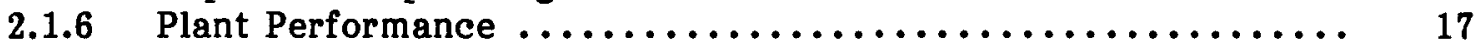

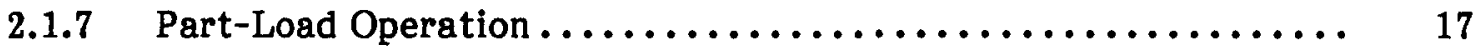

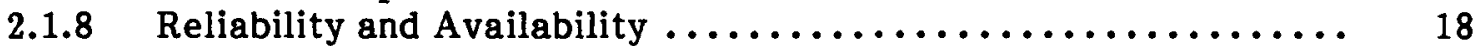

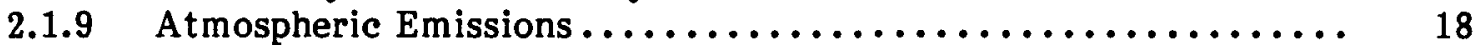

2.1.10 Production of Solid Waste ........................ 18

2.1.11 Consumable Requirements ........................ 18

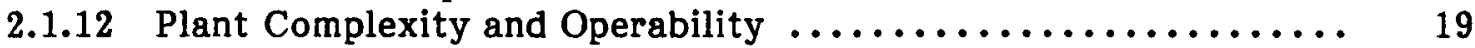

2.1.13 General Comments .............................. 19

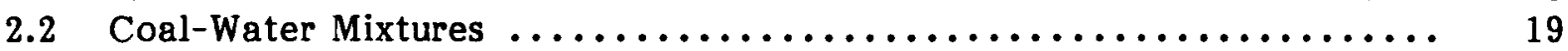

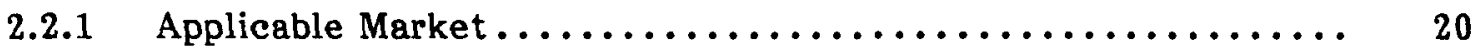

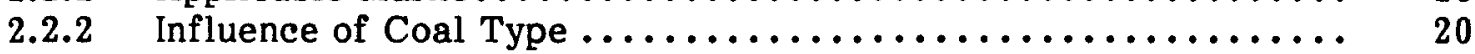

2.2.3 Plant Size and Modularity Considerations ................ 20

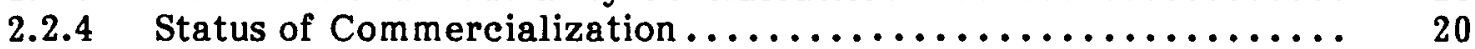

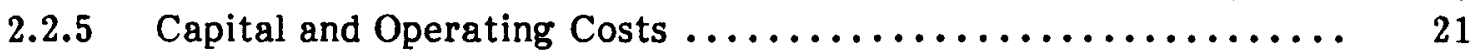

2.2.6 Plant Performance ............................ 21

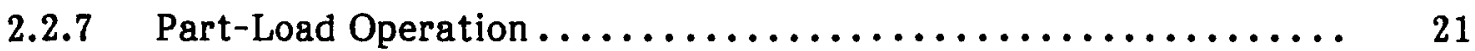

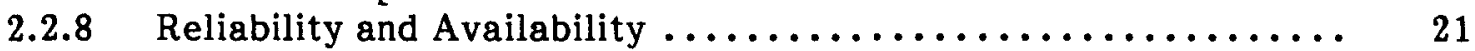

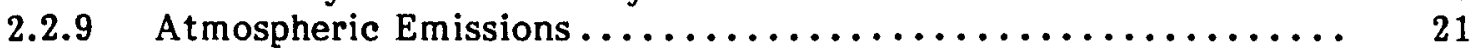

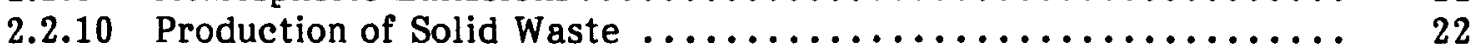

2.2.11 Consumable Requirements ......................... 22 


\section{CONTENTS (Cont'd)}

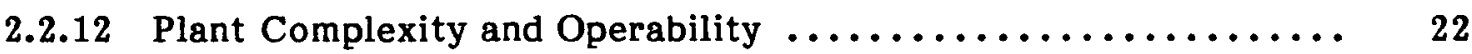

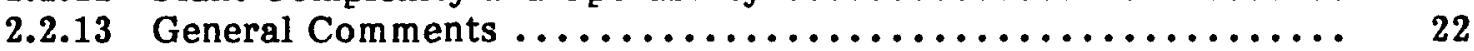

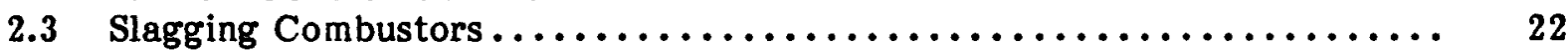

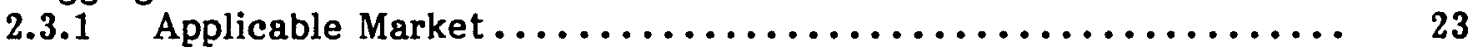

2.3.2 Influence of Coal Type ........................ 23

2.3.3 Plant Size and Modularity Considerations ................. 24

2.3.4 Status of Commercialization ...................... 24

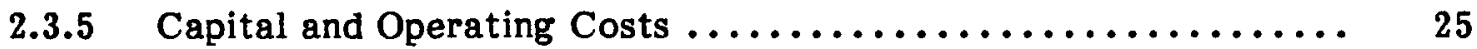

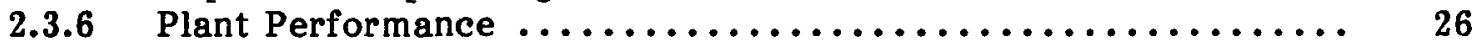

2.3.7 Part-Load Operation .......................... 26

2.3.8 Reliability and Availability ..................... 26

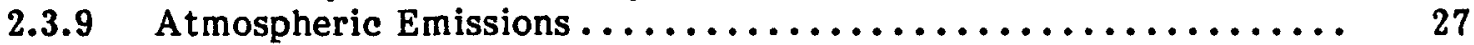

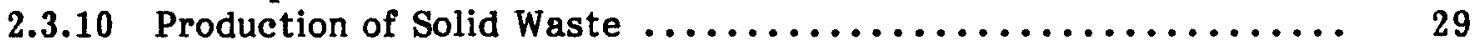

2.3.11 Consumable Requirements ....................... 29

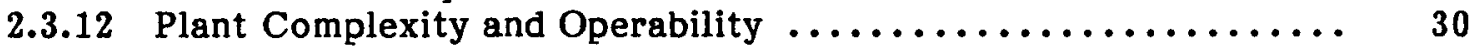

2.3.13 General Comments .......................... 30

2.4 Integrated-Gasification Combined-Cycle System $\ldots \ldots \ldots \ldots \ldots \ldots \ldots \ldots$

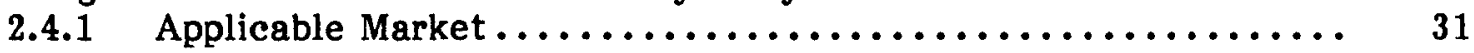

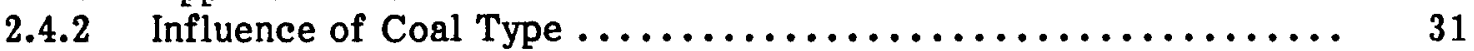

2.4.3 Plant Size and Modularity Considerations ............... 33

2.4.4 Status of Commercialization ..................... 33

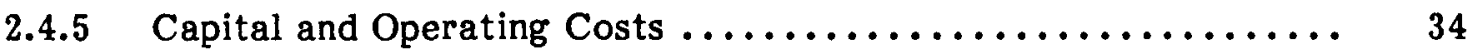

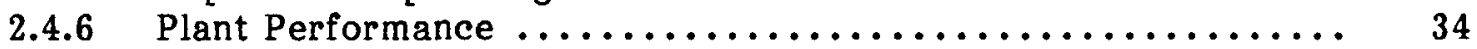

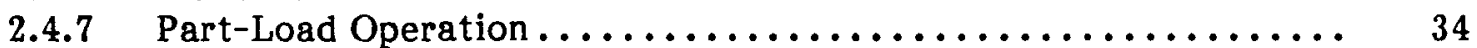

2.4.8 Reliability and Availability ...................... 34

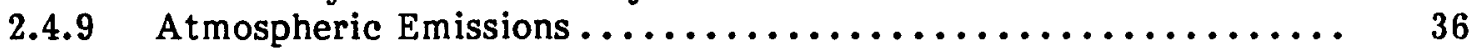

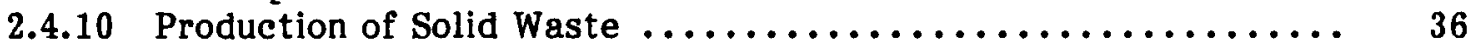

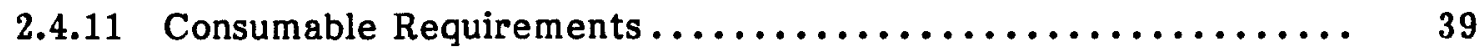

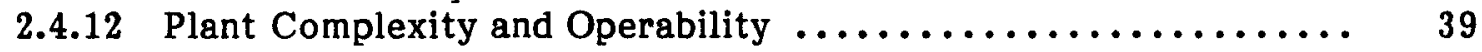

2.4.13 General Comments .......................... 39

2.5 Atmospheric Fluidized-Bed Combustion $\ldots \ldots \ldots \ldots \ldots \ldots \ldots \ldots \ldots \ldots \ldots . \ldots$

2.5.1 Applicable Market .......................... 41

2.5.2 Influence of Coal Type .......................... 42

2.5.3 Plant Size and Modularity Considerations ............... 43

2.5.4 Status of Commercialization...................... 43

2.5.5 Capital and Operating Costs ....................... 43

2.5.6 Plant Performance ............................ 44

2.5.7 Part-Load Operation .......................... 44

2.5.8 Reliability and Availability $\ldots \ldots \ldots \ldots \ldots \ldots \ldots \ldots \ldots \ldots \ldots \ldots \ldots \ldots$

2.5.9 Atmospheric Emissions ......................... 45

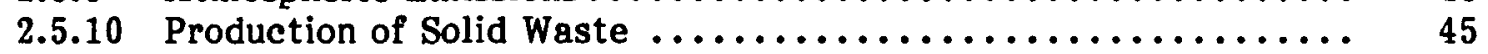

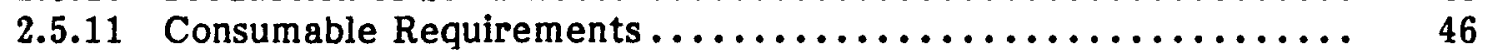

2.5.12 Plant Complexity and Operability $\ldots \ldots \ldots \ldots \ldots \ldots \ldots \ldots \ldots \ldots . \ldots \ldots$

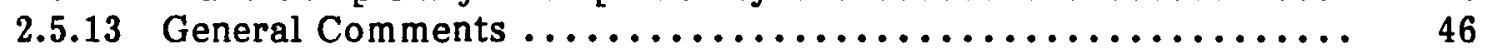

2.6 Pressurized Fluidized-Bed Combustion $\ldots \ldots \ldots \ldots \ldots \ldots \ldots \ldots \ldots \ldots \ldots . . \ldots$

2.6.1 Applicable Market ........................... 47

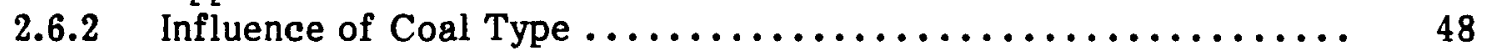

2.6.3 Plant Size and Modularity Considerations ................ 48

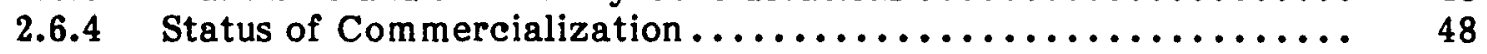

2.6.5 Capital and Operating Costs ........................ 49

2.6.6 Plant Performance ............................. 49 


\section{CONTENTS (Cont'd)}

2.6.7 Part-Load Operation $\ldots \ldots \ldots \ldots \ldots \ldots \ldots \ldots \ldots \ldots \ldots \ldots \ldots, \quad 49$

2.6.8 Reliability and Availability $\ldots \ldots \ldots \ldots \ldots \ldots \ldots \ldots \ldots \ldots \ldots$

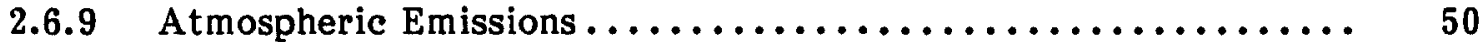

2.6.10 Production of Solid Waste $\ldots \ldots \ldots \ldots \ldots \ldots \ldots \ldots \ldots \ldots \ldots, \quad 50$

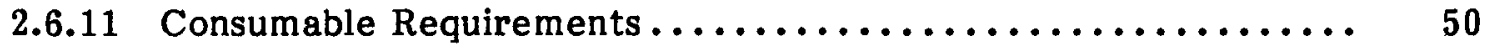

2.6.12 Plant Complexity and Operability $\ldots \ldots \ldots \ldots \ldots \ldots \ldots \ldots \ldots, \quad 50$

2.6.13 General Comments ............................. 51

2.7 Limestone-Injection Multistage-Burner Combustion $\ldots \ldots \ldots \ldots \ldots \ldots \ldots .51$

2.7.1 Applicable Market $\ldots \ldots \ldots \ldots \ldots \ldots \ldots \ldots \ldots \ldots \ldots \ldots \ldots, \quad 51$

2.7 .2 Influence of Coal Type $\ldots \ldots \ldots \ldots \ldots \ldots \ldots \ldots \ldots \ldots \ldots \ldots, 52$

2.7.3 Plant Size and Modularity Considerations .................. 52

2.7.4 Status of Commercialization $. \ldots \ldots \ldots \ldots \ldots \ldots \ldots \ldots \ldots \ldots, 53$

2.7.5 Capital and Operating Costs $\ldots \ldots \ldots \ldots \ldots \ldots \ldots \ldots \ldots \ldots \ldots, 53$

2.7.6 Plant Performance ................................. 53

2.7.7 Part-Load Operation ................................ 54

2.7.8 Reliability and Availability $\ldots \ldots \ldots \ldots \ldots \ldots \ldots \ldots \ldots \ldots \ldots, \quad 55$

2.7.9 Atmospheric Emissions ............................ 55

2.7.10 Production of Solid Waste $\ldots \ldots \ldots \ldots \ldots \ldots \ldots \ldots \ldots \ldots \ldots . .55$

2.7.11 Consumable Requirements ......................... 55

2.7.12 Plant Complexity and Operability $\ldots \ldots \ldots \ldots \ldots \ldots \ldots \ldots \ldots, \quad 56$

2.7.13 General Comments ............................... 56

2.8 Gas-Reburning Sorbent-Injection Technology $\ldots \ldots \ldots \ldots \ldots \ldots \ldots \ldots \ldots, 56$

2.8.1 Applicable Market $\ldots \ldots \ldots \ldots \ldots \ldots \ldots \ldots \ldots \ldots \ldots \ldots \ldots, \quad 57$

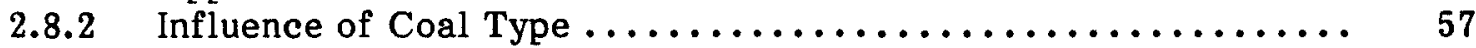

2.8.3 Plant Size and Modularity Considerations ................ 58

2.8.4 Status of Commercialization $\ldots \ldots \ldots \ldots \ldots \ldots \ldots \ldots \ldots \ldots, \quad 58$

2.8.5 Capital and Operating Costs $\ldots \ldots \ldots \ldots \ldots \ldots \ldots \ldots \ldots \ldots \ldots, \quad 58$

2.8.6 Plant Performance $. \ldots \ldots \ldots \ldots \ldots \ldots \ldots \ldots \ldots \ldots \ldots \ldots \ldots \ldots \ldots \ldots,{ }_{58}$

2.8.7 Part-Load Operation $. \ldots \ldots \ldots \ldots \ldots \ldots \ldots \ldots \ldots \ldots \ldots \ldots, \quad 59$

2.8.8 Reliability and Availability $\ldots \ldots \ldots \ldots \ldots \ldots \ldots \ldots \ldots \ldots \ldots, 59$

2.8.9 Atmospheric Emissions ........................... 59

2.8.10 Production of Solid Waste $\ldots \ldots \ldots \ldots \ldots \ldots \ldots \ldots \ldots \ldots \ldots \ldots, 59$

2.8.11 Consumable Requirements $. \ldots \ldots \ldots \ldots \ldots \ldots \ldots \ldots \ldots \ldots \ldots, \quad 59$

2.8.12 Plant Complexity and Operability $\ldots \ldots \ldots \ldots \ldots \ldots \ldots \ldots \ldots, 59$

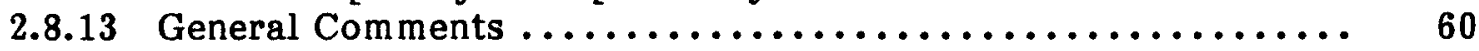

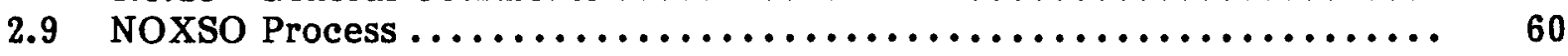

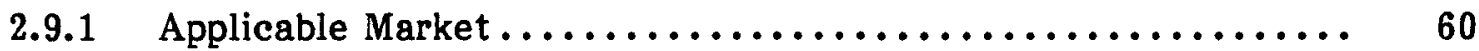

2.9.2 Influence of Coal Type $\ldots \ldots \ldots \ldots \ldots \ldots \ldots \ldots \ldots \ldots \ldots \ldots, 6 \ldots \ldots, 61$

2.9.3 Plant Size and Modularity Considerations $\ldots \ldots \ldots \ldots \ldots \ldots \ldots \ldots, 61$

2.9.4 Status of Commercialization $\ldots \ldots \ldots \ldots \ldots \ldots \ldots \ldots \ldots \ldots, 61$

2.9.5 Capital and Operating Costs $\ldots \ldots \ldots \ldots \ldots \ldots \ldots \ldots \ldots \ldots \ldots \ldots, 61$

2.9.6 Plant Performance $. \ldots \ldots \ldots \ldots \ldots \ldots \ldots \ldots \ldots \ldots \ldots \ldots \ldots, 6,62$

2.9.7 Part-Load Operation ................................ 62

2.9.8 Reliability and Availability $\ldots \ldots \ldots \ldots \ldots \ldots \ldots \ldots \ldots \ldots \ldots \ldots, 63$

2.9.9 Atmospheric Emissions .............................. 63

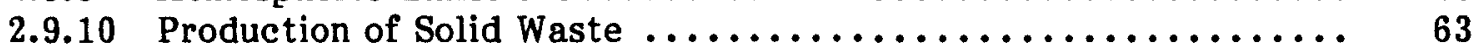

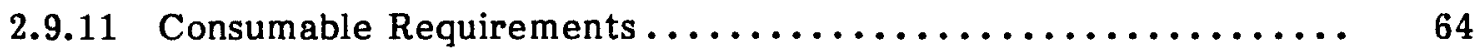

2.9.12 Plant Complexity and Operability ....................... 64

2.9.13 General Comments ............................... 64

2.10 Spray-Dryer Process .................................... 65

2.10.1 Applicable Market $\ldots \ldots \ldots \ldots \ldots \ldots \ldots \ldots \ldots \ldots \ldots \ldots \ldots, 65$ 


\section{CONTENTS (Cont'd)}

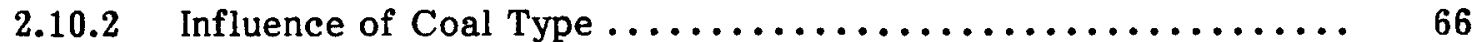

2.10.3 Plant Size and Modularity Considerations .................

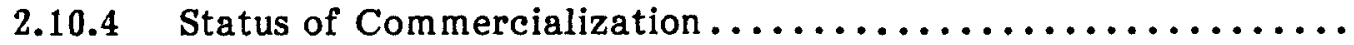

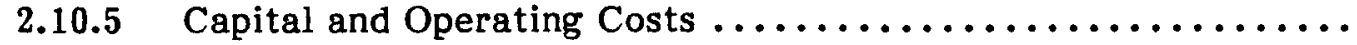

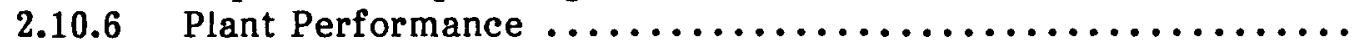

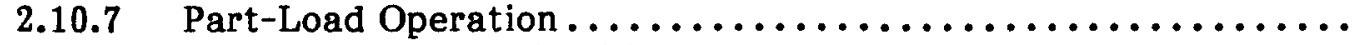

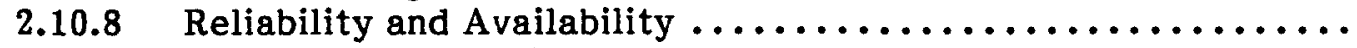

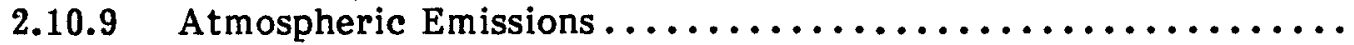

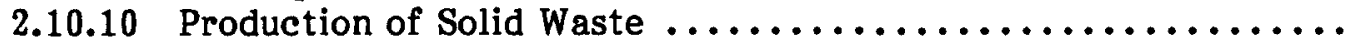

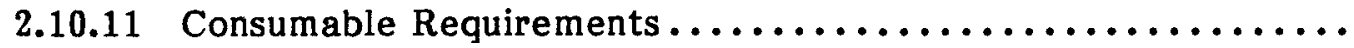

2.10.12 Plant Complexity and Operability $\ldots \ldots \ldots \ldots \ldots \ldots \ldots \ldots \ldots$

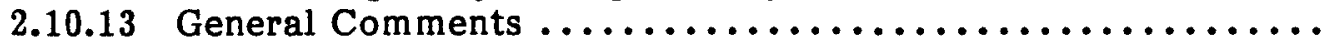

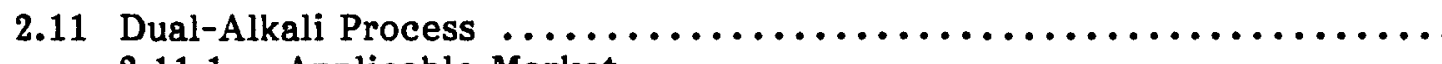

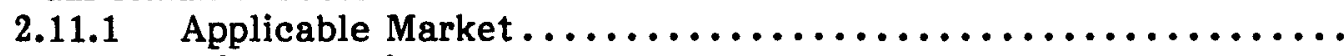

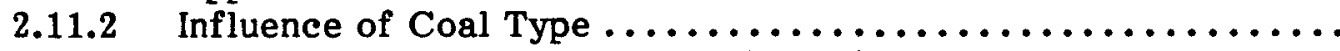

2.11.3 Plant Size and Modularity Considerations ................

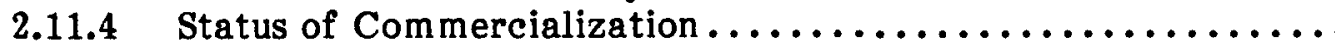

2.11.5 Capital and Operating Costs $\ldots \ldots \ldots \ldots \ldots \ldots \ldots \ldots \ldots \ldots \ldots$

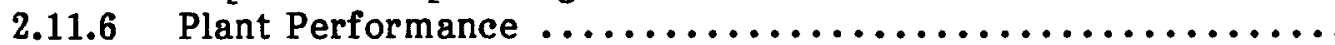

2.11.7 Part-Load Operation ............................

2.11.8 Reliability and Availability $\ldots \ldots \ldots \ldots \ldots \ldots \ldots \ldots \ldots \ldots \ldots \ldots$

2.11 .9 Atmospheric Emissions .........................

2.11.10 Production of Solid Waste $\ldots \ldots \ldots \ldots \ldots \ldots \ldots \ldots \ldots \ldots \ldots$

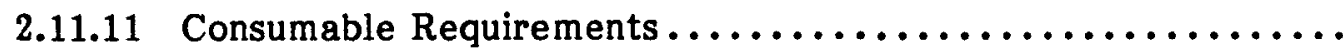

2.11.12 Plant Complexity and Operability ...................

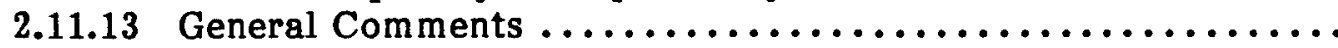

2.12 Selective Catalytic Reduction $\ldots \ldots \ldots \ldots \ldots \ldots \ldots \ldots \ldots \ldots \ldots \ldots \ldots \ldots$

2.12.1 Applicable Market ..........................

2.12.2 Influence of Coal Type $\ldots \ldots \ldots \ldots \ldots \ldots \ldots \ldots \ldots \ldots \ldots \ldots \ldots \ldots$

2.12.3 Plant Size and Modularity Considerations ...............

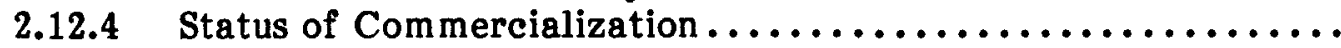

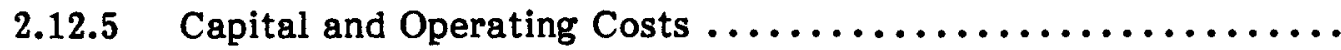

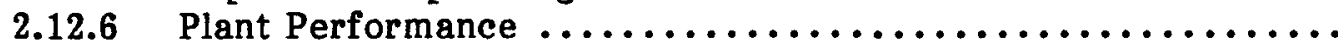

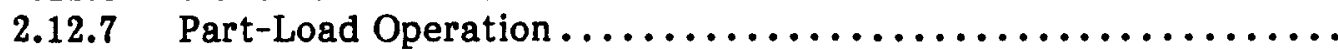

2.12 .8 Reliability and Availability $\ldots \ldots \ldots \ldots \ldots \ldots \ldots \ldots \ldots \ldots \ldots$

2.12.9 Atmospheric Emissions ........................

2.12.10 Production of Solid Waste $\ldots \ldots \ldots \ldots \ldots \ldots \ldots \ldots \ldots \ldots \ldots$

2.12.11 Consumable Require ments ........................

2.12.12 Plant Complexibility and Operability $\ldots \ldots \ldots \ldots \ldots \ldots \ldots \ldots \ldots$

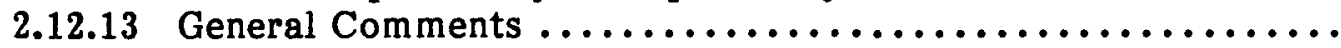

3 TRENDS IN INTERNATIONAL RESEARCH, DEVELOPMENT, AND

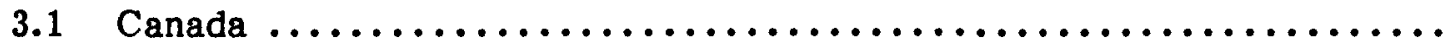

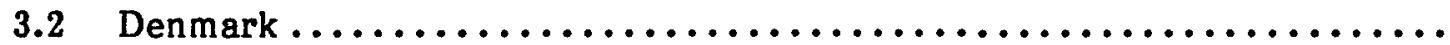

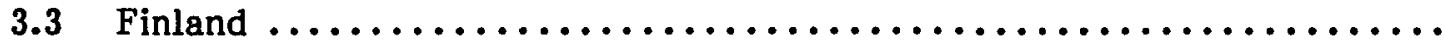

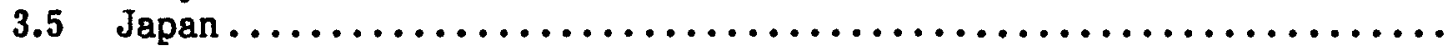

3.6 The Netherlands $\ldots \ldots \ldots \ldots \ldots \ldots \ldots \ldots \ldots \ldots \ldots \ldots \ldots \ldots \ldots \ldots \ldots \ldots$

3.7 Peoples' Republic of China $\ldots \ldots \ldots \ldots \ldots \ldots \ldots \ldots \ldots \ldots \ldots \ldots \ldots \ldots \ldots$ 


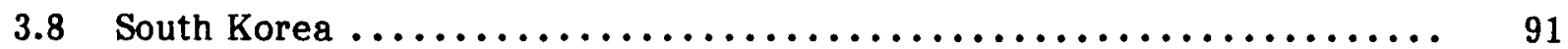

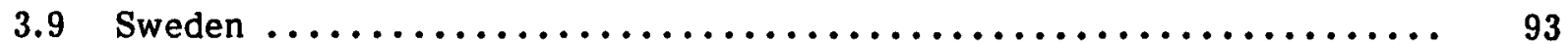

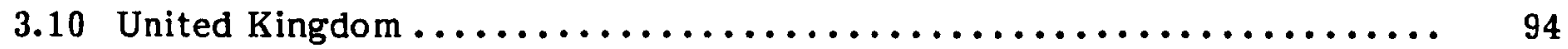

3.11 Federal Republic of Germany $\ldots \ldots \ldots \ldots \ldots \ldots \ldots \ldots \ldots \ldots \ldots \ldots, 95$

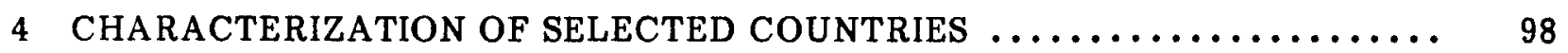

$4.1 \quad$ Italy $\ldots \ldots \ldots \ldots \ldots \ldots \ldots \ldots \ldots \ldots \ldots \ldots \ldots \ldots \ldots \ldots \ldots \ldots \ldots \ldots \ldots \ldots$

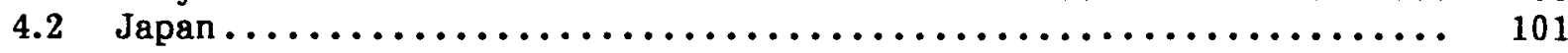

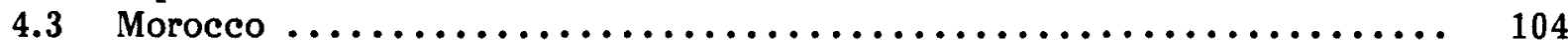

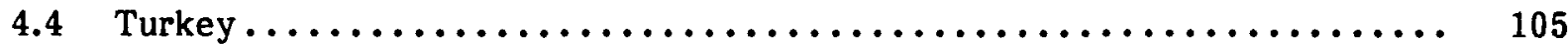

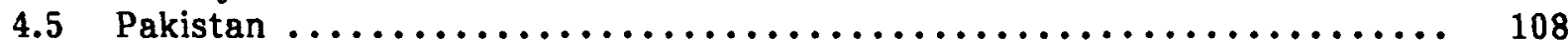

4.6 Peoples' Republic of China $\ldots \ldots \ldots \ldots \ldots \ldots \ldots \ldots \ldots \ldots \ldots \ldots \ldots \ldots \ldots \ldots \ldots 110$

4.7 Poland ......................................... 113

5 COMPARATIVE ANALYSES OF POTENTIAL MARKETS ............. 116

5.1 Step 1: Preliminary Technology/Country Matches ............... 116

5.2 Step 2: Economic Analyses of Specific Clean Coal Technology

Alternatives by Country ............................ 118

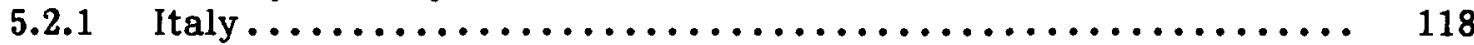

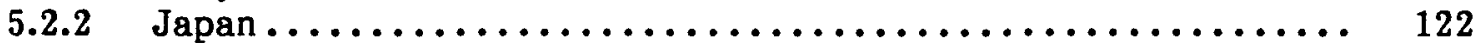

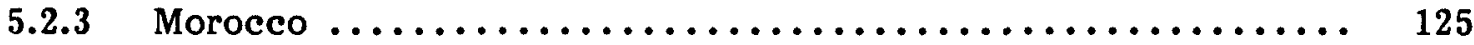

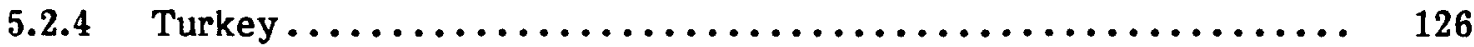

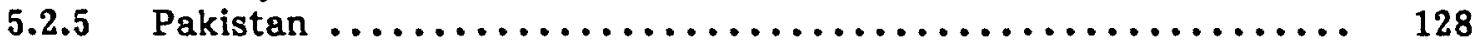

5.2.6 Peoples' Republic of China ....................... 129

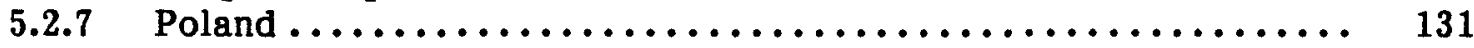

6 TRADE-RELATED ISSUES AND BARRIERS $\ldots \ldots \ldots \ldots \ldots \ldots \ldots \ldots \ldots \ldots \ldots \ldots$

6.1 General Business Strategies and Concerns $\ldots \ldots \ldots \ldots \ldots \ldots \ldots \ldots \ldots \ldots \ldots$

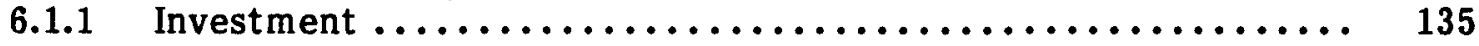

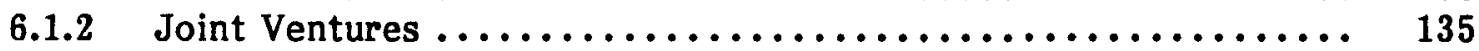

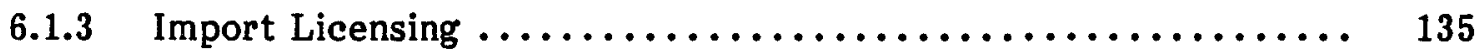

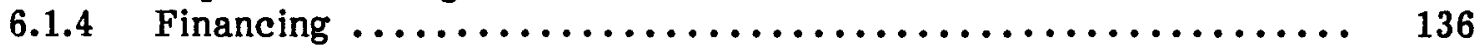

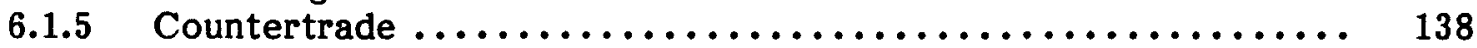

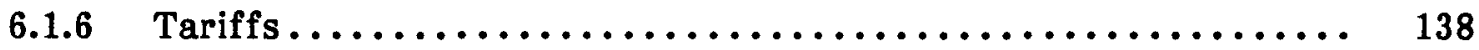

6.1.7 Nontariff Barriers .......................... 139

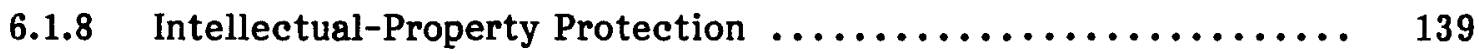

6.1.9 Export-Control Laws .......................... 140

6.1.10 Trade, Promotion, and Financing Policies ............... 140

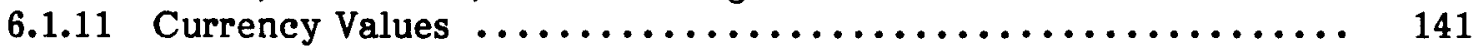

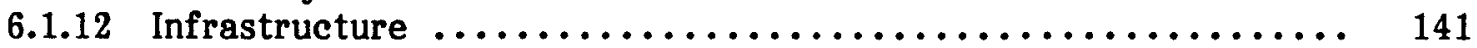

6.1 .13 Technology Adaptation ........................ 142

6.2 Comparison of Specific Trade-Related Issues by Country . . . . . . . . 142

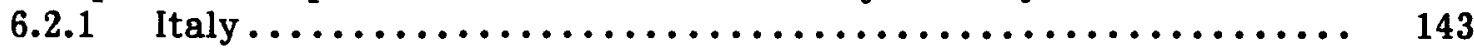

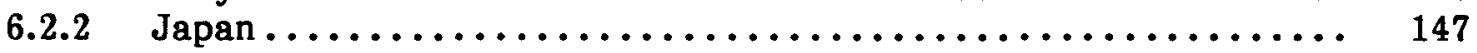

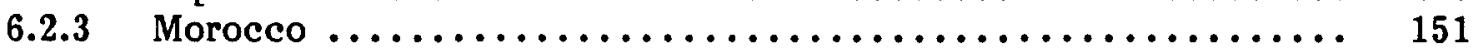

6.2 .4 Turkey $\ldots \ldots \ldots \ldots \ldots \ldots \ldots \ldots \ldots \ldots \ldots \ldots \ldots \ldots \ldots \ldots \ldots \ldots \ldots \ldots \ldots$ 


\section{CONTENTS (Cont'd)}

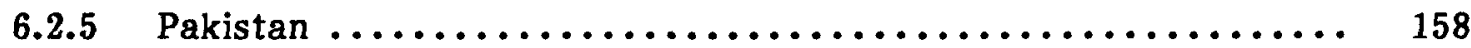

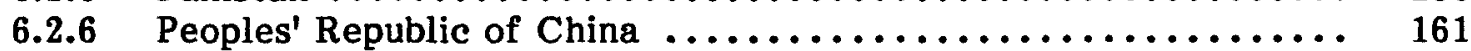

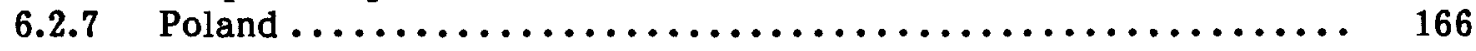

7 IDENTIFICATION OF LIKELY MARKET NICHES $\ldots \ldots \ldots \ldots \ldots \ldots \ldots \ldots \ldots \ldots$

7.1 Precombustion Technologies $\ldots \ldots \ldots \ldots \ldots \ldots \ldots \ldots \ldots \ldots \ldots \ldots \ldots \ldots \ldots \ldots$

7.2 Combustion Technologies $\ldots \ldots \ldots \ldots \ldots \ldots \ldots \ldots \ldots \ldots \ldots \ldots \ldots \ldots \ldots \ldots \ldots \ldots$

7.3 Postcombustion Technologies ........................ 174

8 STATUS OF THE U.S. DEPARTMENT OF ENERGY'S CLEAN COAL

TECHNOLOGY DEMONSTRATION PROGRAM $\ldots \ldots \ldots \ldots \ldots \ldots \ldots \ldots \ldots$

8.1 Negotiated Clean Coal Technology Demonstration Projects ......... 176

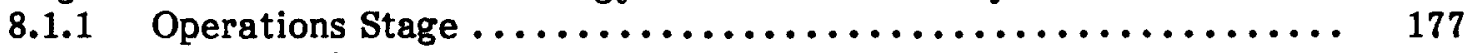

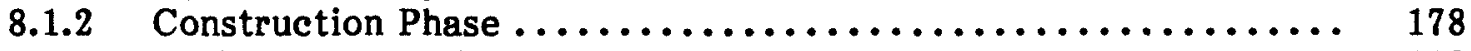

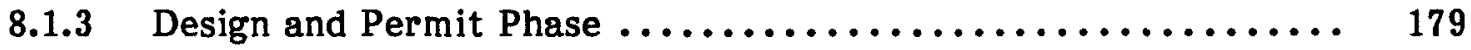

8.2 Applicability in the International Market $\ldots \ldots \ldots \ldots \ldots \ldots \ldots \ldots \ldots \ldots \ldots$

9 IMPLICATIONS FOR THE U.S. DEPARTMENT OF ENERGY'S CLEAN COAL

TECHNOLOGY DEMONSTRATION PROGRAM ................ 182

9.1 Issue 1: Testing Non-U.S. Coals ...................... 182

9.2 Issue 2: Conducting Demonstration Projects Abroad ............. 184

9.3 Issue 3: Increasing Technology Adaptability $\ldots \ldots \ldots \ldots \ldots \ldots \ldots \ldots \ldots \ldots$

9.4 Issue 4: Increasing Public Awareness of Coal $\ldots \ldots \ldots \ldots \ldots \ldots \ldots \ldots \ldots \ldots$

9.5 Issue 5: Using "Windows of Opportunity" Effectively ............. 186

9.6 Issue 6: Dealing with Barriers to Commercialization ............. 186

REFERENCES $\ldots \ldots \ldots \ldots \ldots \ldots \ldots \ldots \ldots \ldots \ldots \ldots \ldots \ldots \ldots \ldots \ldots \ldots \ldots \ldots$

APPENDIX A: Technology Descriptions and Demonstrations............ 211

APPENDIX B: Partial List of Electricity Generating Facilities

Representing Major Sites in Selected Provinces of the

Peoples' Republic of China $\ldots \ldots \ldots \ldots \ldots \ldots \ldots \ldots \ldots \ldots \ldots \ldots . \ldots 277$

APPENDIX C: Activities Subject to Moroccanization Law ............. 289

APPENDIX D: Cost Comparisions for Coal-Water Mixtures ............. 293

APPENDIX E: Selective Catalytic Reduction at EPDC's Takehara Plant

in Japan ................................... 299 


\section{TABLES}

S.1 Assessment of Likely Interest in Clean Coal Technologies for Electric Utility Applications in the Seven Countries Selected

as Representative ................................ 3

S.2 Likely Market Niches for U.S. Clean Coal Technologies ............. 4

2.1 Main Characteristics of the Precombustion Technologies $\ldots \ldots \ldots \ldots \ldots \ldots$

2.2 Main Characteristics of the Combustion Technologies $\ldots \ldots \ldots \ldots \ldots \ldots \ldots$

2.3 Main Characteristics of the Postcombustion Technologies ............ 14

2.4 Cost Comparison of Retrofit and Repowering Technologies $\ldots \ldots \ldots \ldots \ldots$

2.5 Capital Cost Comparison: Circulating Fluidized-Bed

Combustor versus Slagging Combustor $\ldots \ldots \ldots \ldots \ldots \ldots \ldots \ldots \ldots \ldots \ldots \ldots$

2.6 Cost Comparison of Utility Unit Conversion $\ldots \ldots \ldots \ldots \ldots \ldots \ldots \ldots \ldots \ldots$

2.7 Economic Comparison of KRW and Texaco IGCC Plants $\ldots \ldots \ldots \ldots \ldots$

2.8 Pollutant Emissions from the Cool Water Plant ................. 36

2.9 Pollutant Emissions of BGL IGCC Technology $\ldots \ldots \ldots \ldots \ldots \ldots \ldots \ldots \ldots \ldots$

2.10 Environmental Emissions and Resource Requirements of KRW

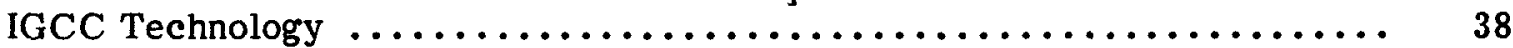

2.11 Estimated Power Required to Operate a NOXSO Unit for a

1000-MWe Power Plant ............................. 63

3.1 Clean Coal Technologies at the Developmental or Commercial

Stage, by Combustion Category and Country .................. 81

4.1 Electric Utility Capacity, by Selected Country ................. 98

4.2 Electric Utility Coal-Fired Capacity, by Selected Country ........... 99

4.3 Japanese Electric Utility Capacity, by Unit Size and

Fuel Type, $1985 \ldots \ldots \ldots \ldots \ldots \ldots \ldots \ldots \ldots \ldots \ldots \ldots \ldots \ldots \ldots \ldots \ldots \ldots \ldots \ldots \ldots \ldots$

4.4 Japanese Electrical Generation, by Fuel Type, $1986 \ldots \ldots \ldots \ldots \ldots \ldots \ldots \ldots$

4.5 Japanese Electric Utility Capacity, by Unit Age and

Fuel Type, $1985 \ldots \ldots \ldots \ldots \ldots \ldots \ldots \ldots \ldots \ldots \ldots \ldots \ldots \ldots \ldots \ldots \ldots \ldots \ldots \ldots \ldots$

4.6 Moroccan Electric Utility Capacity, by Unit Size and

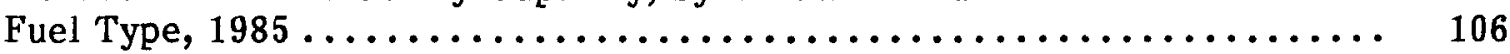

4.7 Moroccan Electric Utility Capacity, by Unit Age and

Fuel Type, $1985 \ldots \ldots \ldots \ldots \ldots \ldots \ldots \ldots \ldots \ldots \ldots \ldots \ldots \ldots \ldots \ldots \ldots \ldots \ldots \ldots$ 


\section{TABLES (Cont'd)}

4.8 Turkish Electric Utility Capacity, by Unit Size and

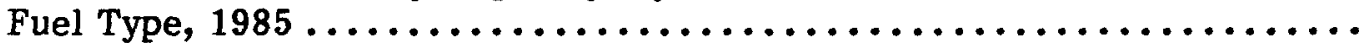

4.9 Pakistani Electric Utility Capacity, by Unit Age and

Fuel Type, 1985 ...................................... 109

5.1 Assessment of Likely Interest in Clean Coal Technologies for Electric Utility Applications in the Seven Countries Selected as

Representative ................................. 117

5.2 Assessed Technology/Country Matches $\ldots \ldots \ldots \ldots \ldots \ldots \ldots \ldots \ldots \ldots \ldots \ldots$

7.1 Likely Market Niches for U.S. Clean Coal Technologies ............ 173 


\section{ACKNOWLEDGMENTS}

The authors wish to thank C. Lowell Miller and Jack S. Siegel, U.S. Department of Energy, Office of Clean Coal Technology, for their support and direction in this threeyear effort. The authors acknowledge the contributions of George E. Dials, who initiated and assisted the project in its early phases. Appreciation is extended to several Argonne personnel: to Mary Warren and Marita Moniger for editing this report and to R. Lanham, A. O'Carroll, and the entire staff of the Energy, Environmental, and Biological Research Office's Word Processing Center for producing this report. 


\section{ACRONYMS}

\begin{tabular}{|c|c|}
\hline ABB & ASEA Brown Boveri \\
\hline $\mathrm{AD}$ & Altbach-Deizisau Power Station (FRG) \\
\hline ADB & Asian Development Bank \\
\hline$A / E$ & architectural/engineering \\
\hline AFBC & atmospheric fluidized-bed combustion/combustor \\
\hline AID & U.S. Agency for International Development \\
\hline$B \& W$ & Babcock \& Wilcox Company \\
\hline $\mathrm{BFBC}$ & bubbling fluidized-bed combustion \\
\hline BGC & British Gas Corporation \\
\hline BGL & British Gas Corporation/Lurgi \\
\hline $\mathrm{BOO}$ & build, own, and operate \\
\hline BOOT & build, own, operate, and transfer \\
\hline BOT & build, operate, and transfer \\
\hline c.i.f. & cost, insurance, and freight \\
\hline CIPS & Central Illinois Public Service Company \\
\hline CIPU & Interministerial Committee for the Coordination of Industrial Policy (Italy) \\
\hline CCT & clean coal technology \\
\hline CFBC & circulating fluidized-bed combustion/combustor \\
\hline CHP & central heating and power \\
\hline COCOM & Coordinating Committee on Multilateral Exports Control \\
\hline COM & coal-oil mixture \\
\hline $\mathrm{CTF}$ & component test facility \\
\hline CWM & coal-water mixture \\
\hline DOE & U.S. Department of Energy \\
\hline EER & Energy and Environmental Research Corporation \\
\hline EIA & Energy Information Administration \\
\hline ENDESA & Empresa Nacional de Electricidad (Spain) \\
\hline ENEL & Ente Nazionale per l'Energia Elettrica (Italy) \\
\hline EPA & U.S. Environmental Protection Agency \\
\hline EPRI & Electric Power Research Institute \\
\hline ESP & electrostatic precipitator \\
\hline FBC & fluidized-bed combustion/combustor \\
\hline FGC & flue-gas cleanup \\
\hline FGD & flue-gas desulfurization \\
\hline FID & Foreign Investment Department (Turkey) \\
\hline FLI & furnace limestone injection \\
\hline FRG & Federal Republic of Germany (West Germany) \\
\hline FTC & Foreign Trading Company \\
\hline FY & fiscal year \\
\hline
\end{tabular}




\begin{tabular}{|c|c|}
\hline GATT & General Agreement for Tariffs and Trade \\
\hline GDP & gross domestic product \\
\hline GNP & gross national product \\
\hline GOT & Government of Turkey \\
\hline GRSI & gas-reburning sorbent-injection system \\
\hline HHV & higher heating value \\
\hline HRSG & heat recovery steam generator \\
\hline IADB & Inter-American Development Bank \\
\hline IBRD & International Bank for Reconstruction and Development \\
\hline ICSID & International Conference on the Settlement of Investment Disputes \\
\hline IDA & International Development Association \\
\hline IEA & International Energy Agency \\
\hline IFC & International Finance Corporation \\
\hline IGCC & integrated coal-gasification combined cycle \\
\hline IMF & International Monetary Fund \\
\hline IMI & Institute Mobiliare Italiano \\
\hline JFTC & Japan Foreign Trade Commission \\
\hline KAIST & Korean Advanced Institute of Science and Technology \\
\hline KIER & Korean Institute of Energy and Resources \\
\hline KRW & Kellogg-Rust-Westinghouse \\
\hline LIMB & limestone-injection multistage burner \\
\hline METC & Morgantown Energy Technology Center \\
\hline MFN & most-favored nation (under the GATT) \\
\hline MHD & magnetohydrodynamies \\
\hline MITI & Ministry of International Trade and Industry (Japan) \\
\hline MOFERT & Ministry of Foreign Economic Relations and Trade (PRC) \\
\hline NEA & National Energy Administration (Sweden) \\
\hline NSPS & New Source Performance Standards \\
\hline O\&M & operations and maintenance \\
\hline OECD & Organization for Economic Cooperation and Development \\
\hline OMPI & Office Marocain de la Propriete Industrielle \\
\hline ONE & Office National de l'Electricite (Moroceo) \\
\hline OPEC & Organization of Petroleum Exporting Countries \\
\hline OPIC & Overseas Private Investment Corporation \\
\hline $\mathrm{PC}$ & pulverized coal \\
\hline $\mathrm{PCF}$ & pulverized-coal fired \\
\hline PCT & Patent Cooperation Treaty \\
\hline PETC & Pittsburgh Energy Technology Center \\
\hline PFBC & pressurized fluidized-bed combustion/combustor \\
\hline
\end{tabular}




\begin{tabular}{|c|c|}
\hline PRC & Peoples' Republic of China \\
\hline PSF & Price Stabilization Fund \\
\hline$R \& D$ & research and development \\
\hline RD\&D & research, development, and demonstration \\
\hline RCRA & Resource Conservation and Recovery Act \\
\hline SCR & selective catalytic reduction \\
\hline SDA & spray dryer absorber \\
\hline SNCR & selective noncatalytic reduction \\
\hline STP & standard temperature and pressure \\
\hline TEK & Turkish Electricity Authority \\
\hline TDP & U.S. Trade and Development Program \\
\hline TVA & Tennessee Valley Authority \\
\hline $\mathrm{UCC}$ & Universal Copyright Convention \\
\hline U.K. & United Kingdom \\
\hline UN & United Nations \\
\hline U.S. & United States \\
\hline USTR & U.S. Trade Representative's Office \\
\hline VAT & value-added tax \\
\hline VKR & VEBA Kraftwerke Ruhr (FRG) \\
\hline WIPO & World Intellectual Property Organization \\
\hline
\end{tabular}

xiv 


\section{CHEMICAL SYMBOLS}

\begin{tabular}{|c|c|}
\hline $\mathrm{Ca}$ & calcium \\
\hline $\mathrm{CaO}$ & calcium oxide (lime or quicklime) \\
\hline $\mathrm{CaCO}_{3}$ & calcium carbonate (calcite or limestone) \\
\hline $\mathrm{CaS}$ & calcium sulfide \\
\hline $\mathrm{CaSO}_{3}$ & calcium sulfite \\
\hline $\mathrm{CaSO}_{4}$ & calcium sulfate \\
\hline $\mathrm{Ca}(\mathrm{OH})_{2}$ & calcium hydroxide (slaked lime) \\
\hline $\mathrm{CH}_{4}$ & methane \\
\hline $\mathrm{CO}$ & carbon monoxide \\
\hline $\mathrm{CO}_{2}$ & carbon dioxide \\
\hline $\operatorname{COS}$ & carbonyl oxysulfide \\
\hline $\mathrm{H}_{2}$ & hydrogen \\
\hline $\mathrm{H}_{2}^{2} \mathrm{~S}$ & hydrogen sulfide (hydrosulfuric acid) \\
\hline $\mathrm{H}_{2} \mathrm{SO}_{4}$ & sulfuric acid \\
\hline $\mathrm{HCl}$ & hydrogen chloride (hydrochloric acid) \\
\hline $\mathrm{HCN}$ & hydrogen cyanide (hydrocyanic acid) \\
\hline MIBC & methyl isobutyl carbinol \\
\hline $\mathrm{N}_{2}$ & nitrogen \\
\hline $\mathrm{Na}_{2} \mathrm{CO}_{3}$ & sodium carbonate \\
\hline $\mathrm{NaHSO}_{3}$ & sodium bisulfite \\
\hline $\mathrm{Na}_{2} \mathrm{SO}_{3}$ & sodium sulfite \\
\hline $\mathrm{Na}_{2} \mathrm{SO}_{4}$ & sodium sulfate \\
\hline $\mathrm{NH}_{3}$ & ammonia \\
\hline NO & nitrogen monoxide (nitric oxide) \\
\hline $\mathrm{NO}_{x}$ & nitrogen oxides \\
\hline $\mathbf{S}$ & sulfur \\
\hline $\mathrm{SO}_{2}$ & sulfur dioxide \\
\hline $\mathrm{SO}_{3}$ & sulfur trioxide (sulfite) \\
\hline $\mathrm{SO}_{\mathbf{x}}$ & sulfur oxides \\
\hline
\end{tabular}




\section{UNITS OF MEASURE ${ }^{\mathrm{a}}$}

\begin{tabular}{|c|c|c|c|}
\hline bbl & barrel & ppm & parts per million \\
\hline Btu & British thermal unit & $\begin{array}{l}\text { ppmv } \\
\text { psi }\end{array}$ & $\begin{array}{l}\text { parts per million, volume } \\
\text { pounds per square inch }\end{array}$ \\
\hline${ }^{\circ} \mathrm{C}$ & $\begin{array}{l}\text { degree Celsius } \\
\text { centimeter }\end{array}$ & $\begin{array}{l}\text { psia } \\
\text { psig }\end{array}$ & $\begin{array}{l}\text { pounds per square inch absolute } \\
\text { pounds per square inch gauge }\end{array}$ \\
\hline d & day & & second \\
\hline $\mathrm{DM}$ & deutsche mark & $\begin{array}{l}\operatorname{sef} \\
\operatorname{sef} m\end{array}$ & $\begin{array}{l}\text { standard cubic feet } \\
\text { standard cubic feet per minute }\end{array}$ \\
\hline${ }^{\circ} \mathrm{F}$ & degree Farenheit & & \\
\hline $\mathrm{ft}_{3}$ & foot & & tonne or metric ton $(2200 \mathrm{lb})$ \\
\hline $\mathrm{ft}^{\mathrm{s}}$ & cubic foot & $\begin{array}{l}\text { ton } \\
\text { tonne }\end{array}$ & $\begin{array}{l}\text { short ton }(2000 \mathrm{lb}) \\
\text { metric ton }(2200 \mathrm{lb})\end{array}$ \\
\hline g & gram & TWh & terawatt-hour \\
\hline gal & gallon & & \\
\hline gpm & grams per minute & yr & $\begin{array}{l}\text { year } \\
\text { dollor }\end{array}$ \\
\hline GW & gigawatt & $\$$ & dollar \\
\hline h & hour & & \\
\hline in. & inch & & \\
\hline kg & kilogram & & \\
\hline $\mathrm{km}$ & kilometer & & \\
\hline $\mathrm{km}^{2}$ & square kilometer & & \\
\hline kt & kiloton & & \\
\hline $\begin{array}{l}\mathrm{kW} \\
\mathrm{kWe}\end{array}$ & $\begin{array}{l}\text { kilowatt } \\
\text { kilowatt (electric) }\end{array}$ & & \\
\hline $\mathrm{kWh}$ & kilowatt-hour & & \\
\hline lb & pound & & \\
\hline $\mathrm{m}_{3}$ & meter & & \\
\hline$m^{3}$ & cubic meter & & \\
\hline $\mathrm{mg}$ & $\begin{array}{l}\text { milligram } \\
\text { minute }\end{array}$ & & \\
\hline $\begin{array}{l}\min \\
\mathrm{MJ}\end{array}$ & $\begin{array}{l}\text { minute } \\
\text { megajoule }\end{array}$ & & \\
\hline MW & megawatt & & \\
\hline MWe & megawatt (electric) & & \\
\hline MWh & megawatt-hour & & \\
\hline MWt & megawatt (thermal) & & \\
\hline
\end{tabular}

$a_{\text {Throughout this document, the units of measure cited in the text correspond with those }}$
used in the original source. 


\title{
COMPARATIVE ANALYSES FOR SELECTED \\ CLEAN COAL TECHNOLOGIES IN THE \\ INTERNATIONAL MARKETPLACE
}

by

\author{
C.B. Szpunar and J.L. Gillette
}

\begin{abstract}
Clean coal technologies (CCTs) are being demonstrated in research and development programs under public and private sponsorship. Many of these technologies could be marketed internationally. To explore the scope of these international opportunities and to match particular technologies with markets appearing to have high potential, a study was undertaken that focused on seven representative countries: Italy, Japan, Morocco, Turkey, Pakistan, the Peoples' Republic of China, and Poland. The results suggest that there are international markets for CCTs and that these technologies can be cost competitive with more conventional alternatives. The identified markets include construction of new plants and refurbishment of existing ones, especially when decision makers want to decrease dependence on imported oil. This report describes potential international market niches for U.S. CCTs and discusses the status and implications of ongoing $\mathrm{CCT}$ demonstration activities.
\end{abstract}

\section{SUMMARY}

Increased coal use is anticipated not only in developed countries, where the demand for electricity and manufactured products is continuing to increase, but also in newly developed and developing countries, where attempts are being made to expand industrial production and provide sufficient electricity for their rapidly growing economies. As is true with any energy resource, the challenge in expanding coal use is to do it safely, efficiently, and effectively, while minimizing adverse environmental impacts.

Extensive research, development, and demonstration ( $R D \& D$ ) is being undertaken to further improve coal-based technologies, so that use of the world's vast coal resources can be expanded while adhering to strict environmental standards. In the United States and abroad, RD\&D on clean coal technologies (CCTs) -- a new generation of advanced coal-based technologies -- is being sponsored, in part through jointed funded ventures, by both private and public entities. These advanced technologies are environmentally cleaner and, in many cases, more efficient and less costly than conventional coal combustion processes. 
The United States is well positioned to play an expanding role in meeting energy technology demands in the international marketplace. The CCT Demonstration Program, which is spearheaded and managed by the U.S. Department of Energy (DOE) in full partnership with U.S. industry, provides a needed proving ground for innovative coalbased technologies. Its precombustion, combustion, and postcombustion technologies, once tested and proven at the demonstration level, are expected to be applicable in both the industrial and electric utility sectors for new and retrofit situations. Internationally, these technologies are expected to provide distinct advantages over conventional coalbased technologies even when indigenous or other non-U.S. coal supplies are used.

The DOE CCT Demonstration Program involves the selection of some of the most promising of these innovative technologies and the introduction of these technologies into the commercial marketplace through the demonstration process. In this way, a group of advanced, more efficient, more economical, and environmentally responsible coal-based alternatives will be made available to U.S. and international markets.

Twelve technologies were selected as representative of technologies under development for use in new or refurbished industrial or electric utility applications. Included are the following:

- Two generic precombustion technologies: two-stage froth-flotation coal beneficiation and coal-water mixtures (CWMs).

- Four combustion technologies: slagging combustors, integratedgasification combined-cycle (IGCC) systems, atmospheric fluidizedbed combustors (AFBCs), and pressurized fluidized-bed combustors (PFBCs).

- Six postcombustion technologies: limestone-injection multistage burner (LIMB) systems, gas-reburning sorbent-injection (GRSI) systems, dual-alkali flue-gas desulfurization (FGD), spray-dryer FGD, the NOXSO process, and selective catalytic reduction (SCR) systems.

These 12 technologies are discussed in detail in Section 2 and Appendix A.

Section 3 presents a synopsis of $R D \& D$ activities in foreign countries actively developing coal-based technologies that could compete with U.S. technologies in the international marketplace.

In Section 4, the seven countries selected as representative of the diversity evident in potential international markets are characterized with respect to energy demand, fuel resources and exploitation, electrical generating capacity, current and proposed environmental situation, and other issues relevant to the potential implementation of CCTs. Italy and Japan were selected as representative of European and Pacific Basin industrialized countries with an expressed interest in expanding coal consumption. Morocco and Turkey were chosen as representative of countries whose industrial bases, though newly developed, are continuing to grow at significant rates and 
whose electricity demand and overall economy are also growing rapidly. Pakistan and the Peoples' Republic of China (PRC) represent less-developed countries in the early stages of large-scale industrialization whose rapid economic growth is expected to continue and whose indigenous energy resources are significant. Finally, Poland was selected because of its extensive coal resources, its level of coal exports and domestic coal consumption, and its ability to represent an evolving Eastern Europe.

After market niches were identified, economic assessments were performed for preliminary technology/country matches for the electric utility sector (Table S.1). Various assumptions were made as to technology applications and fuel costs in each selected country.

In addressing international trade aspects, elements beyond the traditional ones -demand, supply, and cost -- must be considered. In Section 6, the report focuses on country-specific circumstances as to the following trade-related issues and barriers to international trade: investment options, tariffs, trade policies, financing options, licensing agreements, protection of intellectual property, currency values, and technology adaptation.

TABLE S.1 Assessment of Likely Interest in Clean Coal Technologies for Electric Utility Applications in the Seven Countries Selected as Representative ${ }^{\mathrm{a}}$

\begin{tabular}{|c|c|c|c|c|c|c|c|}
\hline \multirow[b]{2}{*}{$\mathrm{CCT}$} & \multicolumn{7}{|c|}{ Country } \\
\hline & Italy & Japan & Morocco & Turkey & Pakistan & PRC & Poland \\
\hline \multicolumn{8}{|l|}{ Precombustion } \\
\hline & $\mathrm{X}$ & - & - & $\mathrm{x}$ & $\mathrm{X}$ & $\mathrm{X}$ & $\mathrm{XX}$ \\
\hline CWM & $\mathrm{XX}$ & $\mathbf{X X}$ & $\mathrm{X}$ & $\mathrm{x}$ & $\mathrm{X}$ & - & - \\
\hline \multicolumn{8}{|l|}{ Combustion } \\
\hline combustor & $\mathrm{xX}$ & $\mathrm{xx}$ & $\mathrm{x}$ & $\mathrm{x}$ & $\mathrm{X}$ & - & - \\
\hline IGCC & $\mathrm{X}$ & $\mathrm{XX}$ & $\mathrm{X}$ & $\mathrm{x}$ & $\mathrm{X}$ & $\mathrm{X}$ & $\mathrm{XX}$ \\
\hline $\mathrm{AFBC}$ & $\mathrm{x}$ & $\mathrm{X}$ & $\mathrm{XX}$ & $\mathrm{XX}$ & $\mathrm{XX}$ & $\mathrm{XX}$ & $\mathrm{XX}$ \\
\hline PFBC & - & $\mathrm{X}$ & - & $\mathrm{X}$ & $\mathrm{X}$ & $\mathrm{X}$ & $X X$ \\
\hline \multicolumn{8}{|l|}{ Postcombustion } \\
\hline LIMB & - & - & - & $\mathrm{x}$ & - & $\mathrm{X}$ & $\mathrm{X}$ \\
\hline GRSI & - & - & - & - & - & $\mathrm{x}$ & $\mathrm{X}$ \\
\hline Dual-alkali FGD & - & - & - & - & - & $\mathrm{x}$ & $\mathrm{X}$ \\
\hline Spray-dryer FGD & - & - & - & $\mathrm{X}$ & - & $\mathrm{X}$ & $\mathrm{x}$ \\
\hline NOXSO & $\mathrm{X}$ & $\mathrm{X}$ & - & - & - & $\mathrm{X}$ & $\mathrm{x}$ \\
\hline SCR & $\mathrm{X}$ & $\mathrm{XX}$ & - & - & - & - & $\mathrm{X}$ \\
\hline
\end{tabular}

\footnotetext{
${ }^{\mathrm{XXX}}$ indicates potential strong interest; $\mathrm{X}$ indicates potential less strong
} interest; and - indicates little or no interest (at this time). 
The likely market niches discussed in detail in Section 7 are highlighted in Table S.2. With respect to coal beneficiation, potential markets likely exist in Turkey, Pakistan, the PRC, and Poland. In these countries, demand stems from the desire or need to improve the quality of indigenous coals and lignites. The objective is to use these resources more efficiently in domestic facilities in an environmentally sound manner and/or to improve the quality of exported coals. In Italy, the likely market niche is related to CWM preparation. A market niche for CWMs may also exist in Japan, where the economic advantage apparently lies in displacing oil used to generate electricity. A small market niche may also exist in Morocco.

With respect to the combustion CCTs, slagging combustors could be used to retrofit oil-fired electrical generating capacity and yield large reductions in electrical generation cost in Japan and Turkey. Smaller, but positive, economic advantages are anticipated in Pakistan, Italy, and perhaps Morocco. Significant market niches exist for the IGCC, AFBC, and PFBC technologies virtually across the board as the selected countries expand their electrical generating capacity but remain mindful of costs, the

\section{TABLE S.2 Likely Market Niches for U.S. Clean Coal Technologies ${ }^{a}$}

\begin{tabular}{|c|c|c|c|c|c|c|c|}
\hline \multirow[b]{2}{*}{ CCT } & \multicolumn{7}{|c|}{ Country } \\
\hline & Italy & Japan & Morocco & Turkey & Pakistan & PRC & Poland \\
\hline \multicolumn{8}{|l|}{ Precombustion } \\
\hline Beneficiation & $*$ & - & - & $*$ & $*$ & $*$ & $*$ \\
\hline CWM & - & $\mathrm{XX}$ & $*$ & - & - & - & - \\
\hline \multicolumn{8}{|l|}{ Combustion } \\
\hline $\begin{array}{l}\text { Slagging } \\
\text { combustor }\end{array}$ & $\mathrm{X}$ & $\mathrm{XX}$ & $*$ & $\mathrm{XX}$ & $\mathrm{x}$ & - & - \\
\hline IGCC & $\mathrm{XX}$ & $\mathrm{XX}$ & $\mathrm{X}$ & $\mathrm{XX}$ & $\mathrm{Xx}$ & $\mathrm{xx}$ & $\mathrm{XX}$ \\
\hline $\mathrm{AFBC}$ & $\mathrm{XX}$ & $*$ & $\mathrm{X}$ & $\mathrm{X}$ & $X X$ & $\mathrm{XX}$ & $X X$ \\
\hline PFBC & - & $X X$ & - & $*$ & $*$ & $\mathrm{X}$ & $x x$ \\
\hline \multicolumn{8}{|l|}{ Postcombustion } \\
\hline LIMB & - & - & - & * & - & $*$ & $*$ \\
\hline GRSI & - & - & - & - & - & $*$ & $*$ \\
\hline Dual-alkali FGD & - & - & - & - & - & 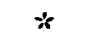 & $*$ \\
\hline Spray-dryer FGD & - & - & - & $*$ & - & $*$ & $*$ \\
\hline Noxso & $*$ & 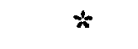 & - & - & - & $*$ & $*$ \\
\hline SCR & $*$ & 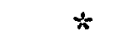 & - & - & - & - & $*$ \\
\hline
\end{tabular}

\footnotetext{
${ }^{a} \mathrm{XX}$ indicates strong economic advantages over alternatives; $\mathrm{X}$ indicates less strong economic advantages over alternatives; * indicates that the technical capabilities are of interest but have not been economically evaluated; - indicates little or no perceived technical interest or no economic advantage over alternatives.
} 


\section{$\sqrt{6}$}

applicability of indigenous resources, and environmental concerns. In almost every case, each of four types of combustion technology generates electricity more inexpensively than a new oil-fired power plant. This cost differential encourages exploitation of domestic coal, lignite, or oil shale resources where available or the import of coal rather than the continued import of oil.

Postcombustion CCTs were shown to be most applicable in the PRC and Poland, and less applicable in Turkey, where coal is burned with few or no emission controls. Italy and Japan were shown to have potential market niches for the NOXSO process and SCR technology because significant degrees of nitrogen oxide control could come to be required of oil-fired as well as coal-fired facilities. However, although a significant potential Japanese market was identified, U.S. companies may find it difficult to compete with Japanese experience and RD\&D in SCR. Moreover, postcombustion markets are more a function of government policy-making than economics.

Sections 8 and 9 , respectively, briefly summarize the current status of the DOE CCT Demonstration Program and present recommendations based on known implications of the program. As of mid-1990, agreements have been signed for 13 demonstration projects in the CCT Demonstration Program. Of these, three are in operation, three are under construction, and seven are being designed or are in the permit phase. These projects have been valued at $\$ 806$ million, with the government's share currently at $35 \%$. Twenty-six other projects have been selected and are awaiting review or approval or are the subject of negotiation. This latter group has been valued at $\$ 2.024$ billion, with the government share at $37 \%$. 
$\varnothing$ 


\section{INTRODUCTION}

\subsection{BACKGROUND}

Coal is an abundant resource found in many locations throughout the world. It continues to be one of the most widely used fuels, having many applications in everyday life. Although most coal is currently used in the generation of electricity, coal has also been used for cooking, residential heating, transportation, and industrial processes. Its use in the industrial and electric utility sectors is expected to grow as countries attempt to reduce their dependence on imported oil and increase their exploitation of indigenous resources like coal. Increased coal use is anticipated not only in developed countries, where the demand for electricity and manufactured products is continuing to increase, but also in newly developed and developing countries, where attempts are being made to expand industrial production and provide sufficient electricity for rapidly growing economies.

As is true with any energy resource, the challenge in expanding coal use is to do it safely, efficiently, and effectively, while minimizing adverse environmental impacts. In the past, coal has had a bad reputation. It brought to mind black clouds emerging from smokestacks and soot-covered windowsills, cars, and clothing. In more recent years, however, improvements in combustion efficiency, particulate removal via electrostatic precipitators (ESPs), and sulfur dioxide $\left(\mathrm{SO}_{2}\right)$ removal via flue-gas desulfurization (FGD) allow coal to be burned while meeting strict environmental standards. Improved efficiencies have also reduced carbon dioxide $\left(\mathrm{CO}_{2}\right)$ emissions per unit of energy output. The amount of $\mathrm{CO}_{2}$ being emitted is becoming more important as concern about global warming intensifies.

Extensive research, development, and demonstration (RD\&D) is being undertaken to further improve coal-based technologies, so that use of the world's vast coal resources can be expanded while adhering to strict environmental standards. By developing a slate of technological options, decision makers have greater latitude in balancing the needs of a growing population, desired economic expansion, environmental concerns, and costs. Ongoing $\mathrm{RD \& D}$ is resulting in such advances as improved coal cleaning processes, more efficient combustion technologies, and improved FGD systems that increase $\mathrm{SO}_{2}$ control without producing large quantities of solid waste. The projects are working with a wide range of coals and involve refurbishment of existing plants as well as construction of new ones, in both industrial and electric utility applications.

The large coal RD\&D programs in many countries and companies are evidence of the widespread interest in coal-based technologies. In both the United States and abroad, RD\&D on clean coal technologies (CCTs) -- a new generation of advanced coal-based technologies -- is being sponsored, in part through jointly funded ventures, by both private and public entities. These advanced technologies are environmentally cleaner and, in many cases, more efficient and less costly than conventional coal combustion processes. 


\subsection{SELECTION OF CLEAN COAL TECHNOLOGIES}

Many coal-based technologies are the subject of intense RD\&D, with the objective of making them commercially available in the near to intermediate future. The 12 technologies selected for the purposes of this study as representative of the technology options under development fall into three categories: precombustion, combustion, and postcombustion technologies. The 12 options are appropriate for new construction and retrofit at industrial or electric utility facilities, the main applications considered in this study.

In the following subsections, the 12 technologies selected are briefly described. Appendix A contains additional technical details and brief descriptions of demonstration projects.

\subsubsection{Precombustion Technologies}

In the precombustion category, two generic technologies were considered. The first of these is advanced physical coal preparation, or beneficiation. Although several advanced processes are being researched and developed, the two-stage froth-flotation process was selected as representative of this general category. Advanced physical coal preparation offers the potential for increased removal of ash and sulfur. These benefits are of interest in international markets because countries with lower quality coals want to develop their indigenous resources, whether for internal consumption or international trade.

The second of these technologies is the coal-water mixture (CWM). This option offers the possibility of converting existing oil-fired capacity to coal-fired capacity, while minimizing modification of the combustor and ancillary equipment. The mixtures can be produced from raw coal or from coal that has been beneficiated. The particular type used for any given application reflects a balance between the added cost of beneficiation and the capital cost of facility modification, any necessary derating of the facility, and the cost of replacing the energy lost because of derating. CWMs are particularly interesting in countries currently dependent on imported oil (e.g., Italy and Japan).

\subsubsection{Combustion Technologies}

Four technologies were considered in the combustion category. The slagging combustor is designed mainly to replace oil-fired burners in existing boilers, thus reducing dependence on imported oil. It burns coal at moderate temperatures, which minimizes nitrogen oxides $\left(\mathrm{NO}_{\mathrm{x}}\right)$ production, and sorbents can be used to control $\mathrm{SO}_{2}$ emissions.

Integrated coal-gasification combined-cycle (IGCC) systems, which are most likely to be used in the electric utility sector, offer the potential for very efficient use of coal while providing the high levels of control of atmospheric emissions commonly associated with coal use. Several types of gasification processes and a wide variety of 
coal types and sulfur contents can be accommodated. The basic technology can also be used in industrial cogeneration facilities or to produce ammonia or chemical feedstocks.

Atmospheric fluidized-bed combustors (AFBCs) can be used in industrial and electric utility applications for both refurbishment and new construction. These combustors can fire the lower quality coals often found in developing countries, while maintaining environmental standards at or near the levels now required in the United States and other industrialized countries.

Pressurized fluidized-bed combustors (PFBCs) offer improved efficiency compared with AFBCs, while maintaining high environmental standards. Several versions of the PFBC are in various stages of research and development (R\&D). The particular concept examined in this study has a water/steam-cooled bed; the exhaust gases from the combustor have sufficient energy to drive a gas turbine, and the steam generated drives a steam turbine. This combined-cycle concept results in a very efficient power plant. The most likely market for this technology is new power plants with a capacity of at least 200-300 MW.

\subsubsection{Postcombustion Technologies}

Six postcombustion technologies were considered in this study. All are designed to control $\mathrm{SO}_{2}$ and/or $\mathrm{NO}_{\mathrm{x}}$ emissions, although some of them are capable of higher removal efficiencies than others. Two of these -- limestone-injection multistage burner (LIMB) and gas-reburning sorbent-injection (GRSI) -- are envisioned as viable options in countries whose $\mathrm{SO}_{2}$ and $\mathrm{NO}_{\mathrm{x}}$ emission standards for new plants are not as strict as those in the United States. These technologies could also be of interest in countries now burning coal without any emission controls, but which are interested in instituting controls on their plants.

The dual-alkali and spray-dryer FGD technologies can both meet U.S. $\mathrm{SO}_{2}$ emission standards for new facilities. They could be used in foreign countries with similar emission requirements. These technologies, particularly dual-alkali FGD, have found widespread application in the U.S. industrial sector. It is now evident that some $\mathrm{NO}_{x}$ control may also be achieved through use of appropriate additives.

High levels of simultaneous $\mathrm{SO}_{2}$ and $\mathrm{NO}_{\mathrm{x}}$ control can be achieved with some of the postcombustion technologies being developed. Many of these advanced technologies are also designed to regenerate the sorbent and to produce a marketable product (e.g., elemental sulfur or fertilizer). These advances greatly reduce the solid waste disposal problem associated with some of the current control options. The NOXSO process, which achieves $90 \%$ removal of both pollutants, was selected as representative of these technologies.

The selective catalytic reduction (SCR) process is being developed, with the objective of attaining high levels of $\mathrm{NO}_{\mathrm{x}}$ control in oil-and coal-fired facilities. This technology is expected to be of interest in countries where $\mathrm{NO}_{\mathrm{x}}$ emissions are, or are anticipated to be, high and where high levels of control are, or will be, mandated. 


\subsection{SELECTION OF REPRESENTATIVE COUNTRIES}

Seven countries were selected as representative of the diversity of potential international markets for U.S. CCTs. Italy and Japan were selected as representative of European and Pacific Basin industrialized countries with an expressed interest in expanding coal consumption. Morocco and Turkey were chosen as representative of countries whose industrial bases, though newly developed, are continuing to grow at significant rates and whose demand for electricity and overall economies are also growing rapidly. Pakistan and the Peoples' Republic of China (PRC) represent less developed countries in the early stages of large-scale industrialization and whose rapid economic growth is expected to continue and whose indigenous energy resources are significant. Finally, Poland was selected because of its extensive coal resources, its level of coal exports and domestic coal consumption, and its ability to represent an evolving Eastern Europe.

Including Poland in this evaluation provided the opportunity to examine the potential for CCTs in a market that differs from the other six, in that coal is already being consumed in large quantities even though the country may be considered to be "developing." Recent political, social, and economic changes in Poland and throughout Eastern Europe may also help to create opportunities for CCTs (as well as for other products) where there had previously been little or no chance for U.S. market penetration.

\subsection{REPORT ORGANIZATION}

The work presented in this report builds upon the results of three earlier tasks. The first of these tasks involved characterizing selected countries with respect to energy demand, fuel resources, fuel use, electrical generating capacity, current and proposed environmental requirements, fuel resources, and similar issues, all of which are relevant to the potential market for CCTs. This work was performed in 1988 and is summarized in Section 4. (Poland was added at a later date.) The second task dealt with RD\&D activities in countries actively developing coal-based technologies that could compete with U.S. technologies in international markets as of 1988 . These foreign RD\&D activities are summarized in Section 3. The third task required detailed characterization of the technologies considered in this study. Section 2 and Appendix A contain these descriptions and analyses.

In Section 5, potential market niches are identified, and the selected CCTs and some alternatives are compared as to economic feasibility. Consideration of international trade issues with respect to CCTs requires analysis of elements in addition to demand, supply, and cost; therefore, Section 6 discusses tariffs, trade policies, financing options, licensing agreements, and other such factors. The final determination of likely market niches, based on the results reported in earlier sections, is presented in Section 7.

The current status and implications of the CCT Demonstration Program, jointly undertaken by the U.S. Department of Energy (DOE) and industry participants, are discussed in Sections 8 and 9, respectively. 


\section{SELECTED CHARACTERISTICS OF TWELVE CLEAN COAL TECHNOLOGIES}

How extensively our CCTs can penetrate foreign markets will depend on how well we match the characteristics of our technologies to circumstances in individual countries. Also, U.S. vendors will probably not be selected unless their technology packages are more attractive than those offered by other international vendors. This section briefly characterizes important aspects of the 12 CCTs selected for their representativeness and potential applicability. The competitiveness of the technologies is discussed in Section 5.

CCTs are being developed here and abroad to reduce reliance on oil imports, to increase use of indigenous resources, and to minimize the adverse environmental impacts of coal combustion, and to do so at acceptable cost. The advanced technologies can be applied to new plants or retrofitted to existing plants. Benefits include reduced emissions of $\mathrm{SO}_{2}, \mathrm{NO}_{\mathrm{x}}$, and particulate matter, as well as better techniques for cleaning coal and for disposing of solid wastes generated by coal-based technologies. Some CCTs yield by-products of potential commercial value. In DOE's CCT Demonstration Program, which is being conducted in full partnership with U.S. industry, opportunities are also being sought to market U.S. coals already demonstrated as suitable for particular CCT applications.

In general, CCTs can be implemented in developing countries if the technologies are commensurate with educational and training levels in the country and are more cost effective than more traditional alternatives. Because foreign applications of ten involve plants smaller than those normally found in the United States, the CCTs should also operate well in small sizes. Finally, the competitiveness of a particular CCT may be enhanced if some of its components can be supplied by local vendors.

Tables 2.1-2.3 compare several important characteristics of the 12 precombustion, combustion, and postcombustion CCTs selected for this study. These tables suggest that:

1. All of the technologies are applicable to the electric utility sector, and most of them are applicable to the varied industrial sector.

2. The technologies span the spectrum of coal types and all internationally traded coals.

3. All of the technologies address control of $\mathrm{SO}_{2}, \mathrm{NO}_{\mathrm{x}}$, and/or particulates; many of them can meet U.S. New Source Performance Standards (NSPS).

4. With continued $R D \& D$, all of the technologies will likely be available commercially within the next 5 to 10 years. 
TABle 2.1 Main Characteristics of the Precombustion Technologies

\begin{tabular}{|c|c|c|c|c|}
\hline $\mathrm{CCT}$ & Market & $\begin{array}{l}\text { Most Likely } \\
\text { Coal Type } \\
\text { for Indicated } \\
\text { Market }\end{array}$ & $\begin{array}{c}\text { Operating } \\
\text { Characteristics }\end{array}$ & $\begin{array}{c}\text { Anticipated } \\
\text { Commercialization }\end{array}$ \\
\hline Beneficiation ${ }^{a}$ & $\begin{array}{l}\text { Primarily electric } \\
\text { utility sector (to } \\
\text { reduce } \mathrm{SO}_{2} \text { emis- } \\
\text { sions and improve } \\
\text { plant operability) }\end{array}$ & $\begin{array}{l}\text { Bituminous; } \\
\text { high and } \\
\text { medium sul- } \\
\text { fur }\end{array}$ & $\begin{array}{l}30-50 \% \text { sulfur } \\
\text { removal (depends on } \\
\text { coal); } 40-60 \% \text { ash } \\
\text { removal }\end{array}$ & Present to 1995 \\
\hline $\mathrm{CWM}^{\mathrm{b}}$ & $\begin{array}{l}\text { Industrial and } \\
\text { electric utility } \\
\text { sectors (mainly } \\
\text { to replace oil) }\end{array}$ & $\begin{array}{l}\text { Al1 coals } \\
\text { possible; } \\
\text { bituminous } \\
\text { experience }\end{array}$ & $\begin{array}{l}\text { Energy content of } \\
9,000-10,000 \text { Btu/1b; } \\
\text { sulfur and ash levels } \\
\text { depend strongly on } \\
\text { coal and level of } \\
\text { cleaning; derating } \\
\text { likely with retrofit }\end{array}$ & $\begin{array}{l}\text { Present to } 1995 \\
\text { (depends on oil } \\
\text { price) }\end{array}$ \\
\hline
\end{tabular}

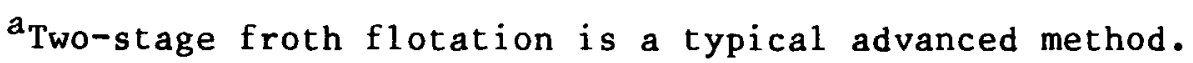

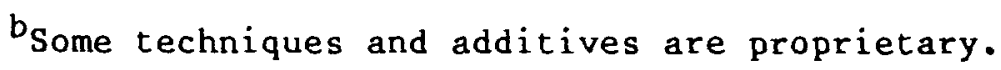


TABLE 2.2 Main Characteristics of the Combustion Technologies

\begin{tabular}{|c|c|c|c|c|}
\hline CCT & Market & $\begin{array}{l}\text { Most Likely } \\
\text { Coal Type } \\
\text { for Indicated } \\
\text { Market }\end{array}$ & $\begin{array}{c}\text { Operating } \\
\text { Characteristics }\end{array}$ & $\begin{array}{c}\text { Anticipated } \\
\text { Commercialization }\end{array}$ \\
\hline $\begin{array}{l}\text { Slagging } \\
\text { combustor }\end{array}$ & $\begin{array}{l}\text { Electric utility and } \\
\text { industrial sectors } \\
\text { (primarily to retrofit } \\
\text { oil-fired boilers) }\end{array}$ & $\begin{array}{l}\text { Subbituminous- } \\
\text { bituminous; } \\
\text { low ash }\end{array}$ & $\begin{array}{l}90 \% \text { ash removal; } 50-60 \% \\
\mathrm{SO}_{2} \text { removal; capable of } \\
\text { meeting NSPS for } \mathrm{NO}_{\mathrm{x}} ; \\
\text { particulates controlled }\end{array}$ & $\begin{array}{l}\text { Present to } 1995 \\
\text { well }\end{array}$ \\
\hline IGCC & $\begin{array}{l}\text { Primarily new utility } \\
\text { boilers larger than } \\
100 \mathrm{MW}\end{array}$ & $\begin{array}{l}\text { Lignite- } \\
\text { bituminous }\end{array}$ & $\begin{array}{l}\text { Very low emissions of } \\
\mathrm{SO}_{2} \text {, } \mathrm{NO}_{\mathrm{x}} \text {, and parti- } \\
\text { culates }\end{array}$ & $\begin{array}{l}\text { Present to } 1995 \\
\text { by Texaco, BGL; } \\
1995-2000 \text { by KRW a }\end{array}$ \\
\hline $\mathrm{AFBC}$ & $\begin{array}{l}\text { Electric utility and } \\
\text { industrial sectors } \\
\text { (new and retrofit } \\
\text { applications in a } \\
\text { range extending from } \\
0.1 \text { MWt to } 250 \text { MWe) }\end{array}$ & $\begin{array}{l}\text { Lignite to } \\
\text { anthracite }\end{array}$ & Capable of meeting NSPS & Present to 1995 \\
\hline PEBC & $\begin{array}{l}\text { New utility and } \\
\text { large-scale industrial }\end{array}$ & $\begin{array}{l}\text { Bituminous } \\
\text { experience; } \\
\text { wide variety } \\
\text { of coals }\end{array}$ & $\begin{array}{l}\text { Capable of meeting NSPS } \\
\text { for } \mathrm{SO}_{2} \text { and particulates; } \\
\mathrm{NO}_{\mathrm{x}} \text { emissions much lower } \\
\text { than NSPS }\end{array}$ & $1995-2000$ \\
\hline
\end{tabular}

$a_{B G L}$ is British Gas Corporation/Lurgi and KRW is Kellogg-Rust-Westinghouse. 
TABLE 2.3 Main Characteristics of the Postcombustion Technologies

\begin{tabular}{|c|c|c|c|c|}
\hline $\mathrm{CCT}$ & Market & $\begin{array}{c}\text { Most Likely } \\
\text { Coal Type } \\
\text { for Indicated } \\
\text { Market }\end{array}$ & $\begin{array}{c}\text { Operating } \\
\text { Characteristics }\end{array}$ & $\begin{array}{c}\text { Anticipated } \\
\text { Commercialization }\end{array}$ \\
\hline LIMB & $\begin{array}{l}\text { Retrof it when } \\
50-60 \% \mathrm{SO}_{2} \text { and } \\
50 \% \mathrm{NO}_{\mathrm{x}} \text { removal } \\
\text { is adequate }\end{array}$ & $\begin{array}{l}\text { Lignite to bituminous; } \\
\text { low to medium sulfur }\end{array}$ & $\begin{array}{l}50-60 \% \mathrm{SO}_{2} \text { remova1; } \\
\cong 50 \% \mathrm{NO}_{\mathrm{x}} \text { removal }\end{array}$ & Present to 1995 \\
\hline GRSI & $\begin{array}{l}\text { Retrofit when } \\
50-60 \% \mathrm{SO}_{2} \text { and } \\
\mathrm{NO}_{\mathrm{x}} \text { removal is } \\
\text { adequate }\end{array}$ & $\begin{array}{l}\text { Bituminous } \\
\text { experience }\end{array}$ & $\begin{array}{l}\text { Requires natural gas; } \\
50-60 \% \mathrm{SO}_{2} \text { and } \mathrm{NO}_{\mathbf{x}} \\
\text { removal }\end{array}$ & $1995-2000$ \\
\hline $\begin{array}{l}\text { Dual-a } 1 \mathrm{kali} \\
\text { FGD }\end{array}$ & $\begin{array}{l}\text { Electric utility } \\
\text { and industrial } \\
\text { sectors (retrofit } \\
\text { and new) }\end{array}$ & $\begin{array}{l}\text { Subbituminous to } \\
\text { bituminous; medium } \\
\text { to high sulfur }\end{array}$ & $\begin{array}{l}\text { Capable of meeting NSPS } \\
\text { on } \mathrm{SO}_{2} \text { (produces less } \\
\text { solid waste than most } \\
\text { other present-day FGD } \\
\text { systems; highly reliable) }\end{array}$ & Present to 1995 \\
\hline $\begin{array}{l}\text { Spray-dryer } \\
\text { FGD }\end{array}$ & $\begin{array}{l}\text { Electric utility } \\
\text { and industrial } \\
\text { sectors (retrofit } \\
\text { and new) }\end{array}$ & $\begin{array}{l}\text { Subbituminous to } \\
\text { bituminous; 1ow to } \\
\text { medium sulfur }\end{array}$ & $\begin{array}{l}\text { Capable of meeting } \\
\text { NSPS on } \mathrm{SO}_{2}\end{array}$ & Present to 1995 \\
\hline NOXSO & $\begin{array}{l}\text { Large utility } \\
\text { boilers burning } \\
\text { high-sulfur coals }\end{array}$ & $\begin{array}{l}\text { Bituminous } \\
\text { experience; high } \\
\text { sulfur }\end{array}$ & Capable of meeting NSPS & $1995-2000$ \\
\hline SCR & $\begin{array}{l}\text { Electric utility } \\
\text { sector (retrofit } \\
\text { and new when high } \\
\text { No removal is } \\
\text { required) }\end{array}$ & $\begin{array}{l}\text { Coals with high ash } \\
\text { (catalyst erosion) } \\
\text { and/or trace elements } \\
\text { (catalyst poisoning) } \\
\text { may be excluded }\end{array}$ & $\begin{array}{l}\text { Capable of } 80 \% \mathrm{NO}_{\mathrm{x}} \\
\text { removal (operates opti- } \\
\text { mally at } 350-400^{\circ} \mathrm{C} \text { ) }\end{array}$ & $\begin{array}{l}\text { Present to } 1995 \\
\text { in the FRG and } \\
\text { Japan; 1995- } \\
2000 \text { in United } \\
\text { States }\end{array}$ \\
\hline
\end{tabular}




\subsection{ADVANCED COAL PREPARATION}

In general, beneficiation processes reduce the ash and inorganic sulfur content of coals. Advanced coal preparation processes are being developed to further reduce ash and sulfur content and to increase Btu recovery.

The environmental benefits of advanced coal preparation processes derive mainly from lower $\mathrm{SO}_{2}$ emissions and decreased amounts of ash to be collected and disposed of at the ultimate point of consumption, such as a power plant. Lower ash levels also improve power plant operation. However, some of these beneficiation processes yield a product that costs more to ship because of the smaller size of the particles and the amount of associated moisture.

Coal beneficiation can take place either in the country of origin or in the importing country. Because the costs and associated benefits largely depend on the coal involved, little can be ascertained without investigation and analysis of specific coals.

Section A.1.1 in Appendix A contains a technical description of the two-stage froth-flotation system, one of several advanced physical coal cleaning technologies. Information about technology demonstrations of this technology is found in Section A.1.2. Sections 2.1.1-2.1.13 present various aspects that affect the marketing of this technology.

\subsubsection{Applicable Market}

Two forces drive the current market for coal cleaning. First, modern automated mining technologies tend to mine floor and ceiling material with the coal, and this material must be removed before the coal is marketed. This removal step would not be required if clean coals were used. Second, cleaned coals, which have a lower ash content as well as a lower sulfur content, improve boiler availability and efficiency. These two forces should continue to play an important role in the marketplace.

The fine grind of some cleaned coals increases the reactivity of the coal, which degrades its combustion properties. It also presents a nuisance problem (windblown fines) and a safety issue (spontaneous combustion). Finely ground clean coals are especially suitable for mine-mouth power plants and coal-slurry pipelines.

There is no commercial two-stage froth-flotation system now in operation. First, the economics of cleaning coal fines is marginal. Second, in the present economic climate, the low cost of fossil fuels and the problems of transporting the product coal to market have not provided sufficient incentive for technology commercialization. If the coal fines were repelletized for shipment, the product from these two-stage systems would be accepted in the marketplace. However, repelletization would not convert the feed coals into environmental compliance coals, except in a limited number of cases. Also, repelletization would increase the cost of a product that is already expensive, given current conditions. Electric utilities tend to buy the cheapest coal without necessarily looking at the final system cost, which includes plant costs that depend on coal quality. 


\subsubsection{Influence of Coal Type}

Two-stage froth-flotation systems are principally applicable to high-sulfur bituminous coals. System performance is coal specific. Bench-scale testing suggests that neither low-rank coals nor anthracite is a likely candidate for such systems (Hucko, 1987).*

Unlike FGD, which is generic in its application, physical coal cleaning is coal specific. Reductions in $\mathrm{SO}_{2}$ emissions typically average near $30 \%$ for run-of-mine coals, a value considerably below the $90 \%$ levels achieved by FGD. Furthermore, although it is generally more cost effective to reduce sulfur content by physically cleaning the coal than by FGD, a coal-specific survey showed that this is not always the case (Doctor et al., 1985).

Combining coal cleaning with postcombustion FGD may provide optimal sulfur control at power plants. An economic study could determine at what point it becomes cost effective to switch from coal cleaning to FGD or to a combination of the two. The utility might then enjoy the benefits of coal cleaning in its plant boiler while scaling back on the size of the FGD system and the amount of waste produced and reagent consumed.

\subsubsection{Plant Size and Modularity Considerations}

The typical U.S. commercially operated coal preparation plant processes approximately 5000 tons/d. Plants process amounts ranging from 200 to 20,000 tons/d. A $1000-\mathrm{MW}$ power plant firing high-Btu coal would have to be supplied by a coal preparation plant ( $40 \%$ capacity factor) processing approximately 7680 tons/d (Keeth et al., 1983).

The froth-flotation circuit is not envisioned as a stand-alone technology, but rather as one used in conjunction with conventional coal-cleaning circuits. For example, for a plant processing $\mathbf{7 6 8 0}$ tons/d, the froth-flotation system would probably handle only $15 \%$ of the tonnage. The equipment used in coal cleaning circuits has always been highly modularized, which makes the scaling up of pilot facilities both straightforward and rapid.

\subsubsection{Status of Commercialization}

Two-stage froth flotation can be characterized as having a firm technical foundation; that is, it will not require further development or breakthroughs in design before it can be commercialized. To date, the incremental costs of fines recovery and

\footnotetext{
*The floatability of coal increases as its rank increases from lignite to bituminous coals of low and medium volatility. Its floatability then decreases as its rank increases to anthracite. The low floatability of low-rank coals has been attributed to their high moisture and oxygen content. Anthracite is less floatable than bituminous coals because anthracite is more like graphite in its composition, whereas bituminous coals are more like hydrocarbons (Spadone, 1986).
} 
beneficiation have not favored introducing this technology into the marketplace. However, an increase in coal price and/or the phasing in of more restrictive land use regulations would favor commercialization.

\subsubsection{Capital and Operating Costs}

Spadone (1986) reports capital costs for the forth-flotation circuit (Pittsburgh Energy Technology Center [PETC] system) of $\$ 25,000-30,000 /$ ton $/ \mathrm{h}$. (All dollar amounts in this Section 2.1.5 are in 1983 U.S. dollars.) This range of values includes costs associated with materials handling, crushing, dewatering, and disposing of dry wastes. PETC has projected the operating and maintenance costs of the circuit at \$2.00$2.50 /$ ton. This range is presumably the cost increment above the baseline coal-cleaning cost, given the assumption that $85 \%$ of the coal is preprocessed in a conventional coal cleaning plant at a cost of $\$ 9.00 /$ ton. Presuming $40 \%$ utilization, Spadone adjusted the costs for a froth-flotation cleaning plant processing 700 tons $/ \mathrm{h}$. The total cost reported is $\$ 13.06 /$ ton of coal cleaned. For an Illinois coal (4\% sulfur*) undergoing $29 \%$ beneficiation, this estimate translates into $\$ 563 /$ ton of $\mathrm{SO}_{2}$ abated.

\subsubsection{Plant Performance}

An average value of $30 \%$ sulfur reduction is expected. Because the physical coal cleaning plant is decoupled from the pulverized-coal-fired boiler, it does not directly affect boiler efficiency.

The Electric Power Research Institute (EPRI) led an effort in the electric utility industry to study the effects of coal quality on the performance of power plants (Mehta and Dooley, 1988). However, it was concluded that many coal quality effects (e.g., slagging, fouling, corrosion, and fly ash erosion) are difficult to predict because of insufficient field data and limited understanding of combustion processes. Until further studies are undertaken, it may a mistake to generalize.

\subsubsection{Part-Load Operation}

Power plants typically stockpile more than a 30-day supply of coal if the coal is transported from external sources; the volume for mine-mouth plants is about half that amount. Because coal cleaning and power generation are decoupled, the turndown ratio at the power plant is unaffected by operation of the coal preparation plant, and vice versa.

\footnotetext{
*Throughout this report, the indicated percentages of sulfur in coal are weight percentages.
} 


\subsubsection{Reliability and Availability}

The two-stage froth-flotation system is expected to be a circuit that is integrated into the overall design of a deep (i.e., high ash removal) coal cleaning plant. The solids-handling equipment that grinds, sieves, and transports millions of tons of coal annually has high preventive maintenance requirements, which partly accounts for its low availability. An availability of $40 \%$ is considered optimistic.

\subsubsection{Atmospheric Emissions}

The two-stage froth-flotation system has no atmospheric emissions associated with its operation. On average, it should abate approximately $30 \%$ of the sulfur emissions from a pulverized-coal-fired boiler being fed the product from a coal cleaning plant.

Coal cleaning has no associated particulate emissions. In fact, the process reduces the ash content of the fuel, which makes it easier to remain within the opacity limitations for the downstream pulverized-coal-fired boiler. The heating value of the coal improves with cleaning, and the pulverized-coal-fired boiler operates with somewhat higher efficiency; therefore, the $\mathrm{NO}_{\mathrm{x}}$ emissions per $10^{6}$ Btu would remain the same, but less coal would be burned to produce the same amount of electricity. The result is a reduction in annual $\mathrm{NO}_{\mathrm{x}}$ emissions. Specific data, however, are unavailable.

\subsubsection{Production of Solid Waste}

Production of solid waste is reduced by introducing a fines cleaning circuit (e.g., froth flotation) that treats coal that would otherwise be taken to the "gob" pond. If gob is assumed to be typically composed of $55 \%$ ash and $45 \%$ coal fines, and if $90 \%$ of the coal fines is recovered, then the amount of solid waste to be disposed of would be reduced by $40 \%$.

\subsubsection{Consumable Requirements}

The surfaces of coal macerals, ash-forming minerals, and pyrites can be made either hydophilic or hydrophobic through use of trace levels of reagents in the aqueous frothing media. The quantities of these consumables needed for commercial operation can be inferred from the ranges used during commercial-scale tests of two-stage froth flotation at Inland Steel Company's Lancashire No. 25 preparation plant (Ornusal, 1984). (These quantities are in pounds of consumable per ton of coal processed.)

$\begin{array}{lll}\text { MIBC (methyl isobutyl carbinol) } & 0.1-0.3 \\ \text { HCl (hydrochloric acid) } & 0 & -1.1 \\ \text { Aero depressant } 633 & 0.5-0.9 \\ \text { Aero xanthate } 350 & 0 & -1.0 \\ \text { Potassium amyl xanthate } & 0.4-0.8\end{array}$


The optimal concentration of surfactant will vary, depending on the coal; however, the above volumes are good indicators of consumable requirements.

\subsubsection{Plant Complexity and Operability}

Two-stage froth flotation represents an increased level of technical complexity for physical coal cleaning circuits. Single-stage froth flotation is widely used. The second stage reverses the chemistry of the aqueous carrier so that materials that formerly were hydrophobic become hydrophilic, and vice versa. The operation is not straightforward and will require careful oversight by a trained engineer. In addition, if the plant were fed a batch of highly oxidized coal, the float-sink portion of the circuit would experience only minor perturbations, but the froth-flotation portion of the circuit could fail to show any beneficiation. This complexity of operation may constitute a barrier to widespread implementation in the United States as well as in developing countries.

\subsubsection{General Comments}

Two-stage froth flotation has been demonstrated to be a technically feasible approach to cleaning fine coals. One of its advantages is that it can be easily integrated into conventional coal cleaning circuits. However, as with other technologies for cleaning coal fines, it does not appear to be economic under current market conditions. Changes in coal markets and/or the phasing in of new land use regulations may change this forecast. If the market develops, there are a significant number of qualified equipment and system vendors that could meet near-term market demand.

\subsection{COAL-WATER MIXTURES}

Coal-water mixtures (CWMs) are composed of 65-75\% (by weight) coal and about $1 \%$ chemical additives; the rest is water. These mixtures have been designed to substitute, in certain applications, for oil, without significant alterations to the plant or without derating the plant capacity.

The principal market for CWMs is existing oil-fired units because studies have generally indicated that, for new units, it is cheaper to use coal directly than to use a CWM. The environmental impact of CWM applications depends on the characteristics of the oil that was previously burned in the unit. In some instances, using low-sulfur coal in the $\mathrm{CWM}$ can lower $\mathrm{SO}_{2}$ emissions. However, ash disposal and related concerns are expected to persist. Also, deratings may be significant, depending on the design of the oil-fired furnace.

CWMs should be considered when a country needs to reduce its dependence on imported oil or when it needs to reduce its expenditures for imported oil. National policy or strategy may dictate one or the other. The CWM technology is being pursued internationally by the United States, Italy, Canada, Sweden, and the PRC, among 
others. Although the technology is currently available, its cost obviates its implementation by U.S. electric utilities.

Along with DOE, EPRI is one of the principal sponsors of CWM in the United States. Its work on coal-oil mixtures started in 1974 and on coal-water slurries (i.e., CWMs) in 1978. The economic advantages of CWMs resulted in EPRI subsequently focusing its research efforts entirely on this alternative (EPRI Journal, 1984). Low oil prices have meant that there has been little motivation for electric utilities to advance the use of this fuel. Nonetheless, EPRI continues to fund a small amount of work on this technology (EPRI, 1986a) in order to provide fuel supply insurance for future scenarios that include disruptions in oil supply.

Section A.2.1 contains a technical description of CWMs. Information about technology demonstrations of CWMs is found in Section A.2.2. Sections 2.2.1-2.2.13 present various aspects that affect the marketing of this technology.

\subsubsection{Applicable Market}

For electric utility applications, the primary market for CWMs is for retrofit of existing oil-fired units. The market for industrial retrofit also has potential. However, industrial concerns with large demands for steam may want to use CWMs if new oil-fired units are unacceptable or if coal is difficult to use because of lack of space, materialshandling problems, or coal transport problems.

\subsubsection{Influence of Coal Type}

CWMs can be made from anthracite and low-rank coals, as well as from bituminous coals. However, anthracite does not produce an acceptable CWM unless some other fuel (e.g., alcohol) is added to provide adequate combustion performance. Lowrank coals may produce an acceptable CWM, depending on the specific physical and chemical properties of the coal.

\subsubsection{Plant Size and Modularity Considerations}

Major factors to be considered include the availability of a CWM manufacturing facility large enough to provide a competitive fuel and an efficient transportation network and/or distribution system. For development and testing of commercial fuels, a CWM plant would need to produce 30,000-100,000 tons/yr; for commercial-scale applications, a tenfold increase in plant capacity would be required.

\subsubsection{Status of Commercialization}

CWM applications can apparently be economically justified. However, additional boiler tests, combined with use of advanced coal preparation techniques, would be desirable. Nonetheless, CWMs could be quickly supplied if a firm commitment to this fuel were made by a specific user. 


\subsubsection{Capital and Operating Costs}

Burning CWMs in oil-fired boilers required modifications and additions to the burner. Ash removal and handling must also be addressed. The cost ot these modifications and additions for large U.S. electric utility units has been estimated at $\$ 100-300 / \mathrm{kW}$. If sulfur-control equipment is needed, expenditures will be higher. Depending on economic assumptions, the location of the CWM plant, and market factors, a reasonable estimate at this time is $\$ 3.00-5.00 / 10^{6}$ Btu for delivered fuel.

\subsubsection{Plant Performance}

The thermal efficiency of a plant using a CWM is about $2 \%$ less than that of an oil-fired plant, depending on design conditions. For units smaller than about $50 \mathrm{MW}$, the heat rate may range from 11,000 to $12,000 \mathrm{Btu} / \mathrm{kWh}$ at full load.

\subsubsection{Part-Load Operation}

A three-to-one turndown ratio is EPRI's goal for retrofitting oil-fired units for CWMs (EPRI, 1982).

\subsubsection{Reliability and Availability}

Information that would provide a reasonable statistical basis for assessing reliability and availability is lacking. Compared with oil-fired units of similar design, CWM-fired units would have additional factors that would tend to reduce reliability and availability. Examples are burner-tip lifetime and ash buildup on furnace surfaces. However, design goals for CWMs are expected to keep such factors within an acceptable range.

\subsubsection{Atmospheric Emissions}

Sulfur dioxide, $\mathrm{NO}_{\mathrm{x}}$, and particulate emissions are expected to meet existing federal standards. Sulfur dioxide emissions depend on the sulfur content of the coal and use of $\mathrm{SO}_{2}$ control systems. In general, with a high level of coal cleaning before production of the CWM, the amount of ash input to the boiler tends to be lower than for a conventional coal-fired plant. Cleaning of the flue gas to meet standards should therefore be less burdensome. Nitrogen oxide emissions should meet existing standards; however, because of burner design, there may be less design flexibility. Nevertheless, the high water content of the fuel is expected to keep thermally produced $\mathrm{NO}_{\mathbf{x}}$ at low levels. 


\subsubsection{Production of Solid Waste}

Solid wastes resulting from $\mathrm{SO}_{2}$ cleanup and ash collection are normally expected to be higher than for an oil-fired unit, but lower than for a conventional coal-fired plant. The details of waste production depend on fuel characteristics.

\subsubsection{Consumable Requirements}

Consumable requirements depend on the fuel and the ambient conditions at the plant. In terms of water, steam, electricity, and sorbent requirements, no unusual materials are warranted.

\subsubsection{Plant Complexity and Operability}

Plants using CWMs are certainly be more complex and probably are somewhat more difficult to operate than oil-fired plants. With developmental experience, however, the increased difficulty is not expected to be a barrier to commercialization. The plants should be acceptable for many industrial applications.

\subsubsection{General Comments}

The CWM fuel concept should be applicable in industrializing and developing countries (Bechtel Group, Inc., 1987). The designs are somewhat similar to those using other fuel systems. However, developing countries would probably not be inclined to be the first commercial users of this or any other particular technology.

\subsection{SLAGGING COMBUSTORS}

Slagging combustors (including advanced cyclone combustors) burn coal, simultaneously controlling $\mathrm{SO}_{2}, \mathrm{NO}_{x}$, and particulate levels during the combustion process. The combustor is attached to the boiler. The inlet to the combustor has air and fuel connections. Internally, the ash is separated in a molten phase from the combustion gases by a swirling action before the hot exhaust gases enter the boiler. To control $\mathrm{SO}_{2}$ emissions, a sorbent (usually limestone) is usually injected into the combustor and the product calcium sulfate is removed with the slag. Formation of $\mathrm{NO}_{\mathrm{x}}$ is inhibited by maintaining a fuel-rich environment during initial combustion. The solid products from the combustor consist of ash, calcium and sulfur compounds, and unused calcined limestone.

The major thrust of this process is to remove sufficient ash so that oil-fired boilers can be used in a coal-burning mode. The reductions in $\mathrm{SO}_{2}$ and $\mathrm{NO}_{\mathrm{x}}$ emissions are added benefits. New boiler plants could be designed to use this combustion technology. Extensive R\&D has been carried out by private U.S. firms. 
The major markets for slagging combustors are in areas where oil-fired plants are currently in use. Some developing countries have developed or may develop the ability to manufacture this equipment (e.g., the combustion vessel and portions of the coal-handling and size-reduction systems). In-country firms could be licensed by U.S. suppliers. Although coal type is not a limiting feature of this technology, higher ash coals and those with poor slagging characteristics are less desirable.

Section A.3.1 contains a technical description of slagging combustors. Information about technology demonstrations of this technology is found in Section A.3.2. Sections 2.3.1-2.3.13 present various aspects that affect the marketing of this technology.

\subsubsection{Applicable Market}

Slagging combustors can replace oil- and gas-fired combustors in large-scale commercial, industrial, and utility settings. In the United States alone, approximately 60,000 coal-, gas-, and oil-fired combustors are candidates for slagging-combustor retrofit. (Of these, utilities operate 33,000 and industries operate 25,000 .) In addition, slagging combustors can be considered for the approximately 2500 new industrial and utility boilers expected to come on line each year (Coal Tech Corp., 1987). Commercial and industrial applications include steam production for process heating, site heating, and electricity production in cogeneration units. Utility applications involve producing steam for generating electricity. Because of their compactness, slagging combustors are especially desirable for plants with space constraints.

A variety of applications are possible. Slagging combustors can be installed at direct and indirect coal-fired gas turbine power plants. Existing coal burners can be retrofitted for greater reductions in pollutant emissions. Because of similarities in their operation, middle-aged cyclone combustors that burn high-sulfur coal are good candidates for slagging-combustor retrofit (Gupta et al., 1987). Also, because of similarities in emissions, oil-fired boilers are particularly suitable for slagging-combustor retrofit. Derating is minimal for this application.

\subsubsection{Influence of Coal Type}

Coal type is not an intrinsically limiting variable in the use of slagging combustors. The viscosity characteristics of the slags are generally favorable for most of the subbituminous and bituminous coals generally used for steam generation. However, low-ash coals are best (Zanis, 1987) because high-ash coals may cause tap clogging and related problems. The coal used to fuel slagging combustors must be crushed, pulverized, or slurried. The size of the pulverized coal is typically $70 \%$ minus 200 mesh, but some of it is as fine as $70 \%$ minus 325 mesh (Makansi, 1987).

The sulfur content of the coal determines the amount of sorbent used. Because coals having more sulfur tend to cost less than coals having less sulfur, the added cost of extra sorbent is somewhat offset. 
Coal types that have been tested in slagging combustors include West Virginia bituminous ( $0.80 \%$ sulfur); Illinois bituminous (1.75\% and $2.75 \%$ sulfur); Ohio No. 6 , Middle Kittanning seam (1.8\% sulfur); and Canadian CWM using Pennsylvania bituminous coal ( $2-4 \%$ sulfur $)$.

\subsubsection{Plant Size and Modularity Considerations}

Slagging combustors (1-20 MWt) have been built and operated at atmospheric pressure for thousands of hours. The sizes of industrial and commercial combustors of this type generally fall within the above range (Zauderer et al., 1987; Krippene, 1987). Units larger than $20 \mathrm{MWt}$ have been designed. However, utility boilers require combustion heat release ratings an order of magnitude higher than those for projected unit sizes. Scaling up to utility size can probably be achieved by means of multiple units, just as utilities use a modular approach in achieving high boiler firing rates (Coal Tech Corp., 1987). Such modularity has several operational advantages. Partial boiler loads can be handled by using fewer combustors operating at maximum efficiency. In addition, certain repairs and servicing can be accomplished in the inoperative mode. Generally, the modern cyclone types of slagging combustors are the same size as the burner units being replaced. Therefore, in converting from oil or gas to coal, the boiler system need not be derated.

Certain components may be have to be added at facilities retrofitted with slagging combustors. Because slagging combustors require crushed, pulverized, or slurried coal, coal preparation equipment must be available (Makansi, 1987). If limestone injection is used, limestone crushing and handling equipment must be obtained. If the fuel was oil or gas, coal storage equipment must be added. Facilities for storing slag are also necessary. A baghouse may be needed to replace an ESP. Section A.3.2.2 lists the components that had to be added to retrofit the Coal Tech Corp. demonstration boiler.

An 8.7-MW slagging combustor is five feet in diameter and eight feet long. Relative to fluidized-bed combustors (FBCs), slagging combustors are compact. Slagging combustors are therefore desirable for facilities having space constraints.

\subsubsection{Status of Commercialization}

Since 1988, Coal Tech Corp. and TRW have been marketing industrial slagging combustor systems. They have partially demonstrated their technology in industrial settings. Both combustors burn pulverized coal, but the ability to burn CWMs is in the offing. Programs to demonstrate utility boilers are underway. For example, TRW (in a cost-sharing program with DOE, industrial, and other governmental partners) is retrofitting four slagging combustor modules, each rated at $47 \mathrm{MWt}$, to an existing utility boiler (Orange \& Rockland Utility's Lovett Station, Unit 3) rated at $69 \mathrm{MWe}$.

In early 1989, several companies were prepared to sell slagging combustor systems. However, realistic commercialization of this technology -- meaning 
that customers could choose among several systems with identical thermal capacities and pollutant emission specifications -- is not expected until the mid-1990s.

Other companies developing slagging combustor technology include Avco Research Laboratory, Progress Technology Corp., Energy and Environmental Research, and Transalta (Ruth and Payne, 1987). Transalta bought into Rockwell International's slagging combustor technology development (Makansi, 1987).

\subsubsection{Capital and Operating Costs}

Capital and operating cost data for actual commerial installations are unavailable because slagging combustor technology is so new. Several cost comparisons have been published that look favorably upon slagging combustor systems in relation to AFBC systems. Estimates are provided in Tables 2.4-2.6.

A Sargent and Lundy study (Gupta, 1987) reports costs associated with burning a bituminous coal (3.1\% sulfur) in a 580-MW cyclone-fired boiler with a slagging combustor. Other retrofit technologies examined in this study included LIMB and GRSI. Repowering with AFBC and IGCC was also considered. Table 2.4 shows that, compared with the other retrofit technologies considered in the study, the slagging combustor had the highest cost.

The capital cost for the slagging combustor case is $\$ 400 / \mathrm{kW}$, and the total cost of electricity production is $19 \mathrm{mills} / \mathrm{kWh}$. Although this capital cost is considerably higher than the cost of the other retrofit options, the differences in the total cost of electricity are not as great. This similarity can be attributed to the high cost of sorbent (for the LIMB case) and natural gas and sorbent (for the GRSI case). When compared with the repowering options, the slagging combustor has an intermediate capital cost, but a total cost of electricity that is lower than that for repowering with AFBC or IGCC.

Stone and Webster also prepared capital cost data for the slagging combustor (Zanis, 1987). Those data reflect the capital cost of installing slagging combustors at a new 250-MW boiler burning Illinois No. 6 bituminous coal. The costs for the slagging combustor steam generator were developed by adjusting the pricing for an oil-fired boiler to include the costs of a large-scale multiple combustor system that was extrapolated from current performance and design data. This approach assumes that a slagging combustor system will be developed that addresses the high solids loading associated with limestone injection. The slagging combustor data are compared with the capital cost of installing a circulating fluidized-bed combustor (CFBC) at the new boiler. Table 2.5 presents the data and design details.

Stone and Webster also prepared capital cost estimates that reflect retrofitting specific utility installations with slagging combustors and CFBCs (Table 2.6). The sites are Northern States Power Company's Black Dog Unit 2, Florida Light and Power's Sanford Unit 4, and Orange \& Rockland Utility's Lovett Unit 3. 
TABLE 2.4 Cost Comparison of Retrofit and Repowering Technologies

\begin{tabular}{lccc}
\hline Technology & $\begin{array}{c}\text { Capacity } \\
(\mathrm{MW})\end{array}$ & $\begin{array}{c}\text { Capital } \\
\text { Cost } \\
(\$ / \mathrm{kW})\end{array}$ & $\begin{array}{c}\text { Cost of } \\
\text { Electricity } \\
\text { (mills/kWh) }\end{array}$ \\
\hline $\begin{array}{l}\text { Retrofit } \\
\text { Slagging combustor }\end{array}$ & 580 & 400 & 19 \\
$\begin{array}{l}\text { LIMB (with low-NO } \\
\text { burners) }\end{array}$ & 60 & 150 & 10 \\
GRSI & 100 & 120 & 15 \\
$\begin{array}{l}\text { Repowering } \\
\text { AFBC }\end{array}$ & & & \\
IGCC & 60 & 300 & 23 \\
\hline
\end{tabular}

Source: Gupta et al. (1987).

\subsubsection{Plant Performance}

Combustion efficiency (i.e., carbon conversion) for slagging combustor systems has been demonstrated to exceed $98 \%$. Indeed, $99.5 \%$ carbon conversion, as measured by ultimate analysis of slag and effluent, is not uncommon. Projected plant heat rates are in line with other developed combustion systems. Table 2.5 indicates that the net plant heat rate is estimated to be only slightly higher (2\%) for the slagging combustor than for the CFBC. However, plant heat rate projections of $9900 \mathrm{Btu} / \mathrm{kW}$ (Zanis, 1987) and a heat rate of $9275 \mathrm{Btu} / \mathrm{kW}$ estimated by TRW for the Lovett plant are indicative of the level of uncertainty in the performance of this technology.

\subsubsection{Part-Load Operation}

Slagging combustors have demonstrated a turndown ratio of three to one from maximum rated firing rates in tests lasting hundreds of hours (Krippene, 1987). In addition to the inherent reduced firing rate of a given combustion unit, the turndown of a modularized boiler's combustion system can be increased by shutting down banks of combustors. Thus, the turndown is equivalent to that now accomplished with existing combustion systems.

\subsubsection{Reliability and Availability}

Data are limited regarding the reliability and availability of slagging combustor systems. There is simply too little history to make realistic projections. However, the 
TABLE 2.5 Capital Cost Comparison: Circulating Fluidized-Bed Combustor versus Slagging Combustor

\begin{tabular}{|c|c|c|}
\hline Parameter & CFBC & $\begin{array}{l}\text { Slagging } \\
\text { Combustor }\end{array}$ \\
\hline Size (MWe) & $2 \times 125$ & 250 \\
\hline Cycle conditions $\left(\mathrm{psi} /{ }^{\circ} \mathrm{F} /{ }^{\circ} \mathrm{F}\right)$ & $2400 / 1000 / 1000$ & $2400 / 1000 / 1000$ \\
\hline Number of fuel feed points & $4-6$ & $10-12$ \\
\hline $\mathrm{SO}_{2}$ capture $(\%)$ & 90 & 90 \\
\hline Steam generator efficiency $(\%)$ & 88.1 & 86.4 \\
\hline Net plant heat rate $(B t u / k W h)$ & 9690 & 9922 \\
\hline \multicolumn{3}{|l|}{ Capital cost $\left(\$ 10^{6}\right)$} \\
\hline Boiler plant & 103 & 82 \\
\hline Materials handling & 19 & 19 \\
\hline Turbine plant & 26 & 26 \\
\hline Balance of the plant & 98 & 98 \\
\hline Total direct cost & 246 & 225 \\
\hline Indirects and distributables & 25 & 22 \\
\hline Contingency & 41 & 38 \\
\hline Total estimate & $\overline{312}$ & $\overline{285}$ \\
\hline Total $(\$ / k W)$ & 1250 & 1140 \\
\hline
\end{tabular}

Source: Zanis (1987).

4000 hours of tests conducted in Cleveland by TRW (Krippene, 1987) indicate that the combustor was available more than $90 \%$ of the time. The largest contributor to unavailability was the dense-phase coal-transport feed system. The total availability of the TRW demonstration boiler was $83.8 \%$.

\subsubsection{Atmospheric Emissions}

Emissions of gaseous pollutants can be controlled in slagging combustor systems.

- Nitrogen Oxides. The $\mathrm{NO}_{\mathrm{x}}$ emission problem has been addressed by using staged combustion. The first stage is operated at a stoichiometry of $\mathbf{0 . 7}$, and the overall stoichiometry of the system is greater than one. Excess air is used to keep final temperatures below $2700-2900^{\circ} \mathrm{F}\left(21500-1600^{\circ} \mathrm{C}\right)$. The NSPS for $\mathrm{NO}_{\mathrm{x}}$ is 
TABLE 2.6 Cost Comparison of Utility Unit Conversion

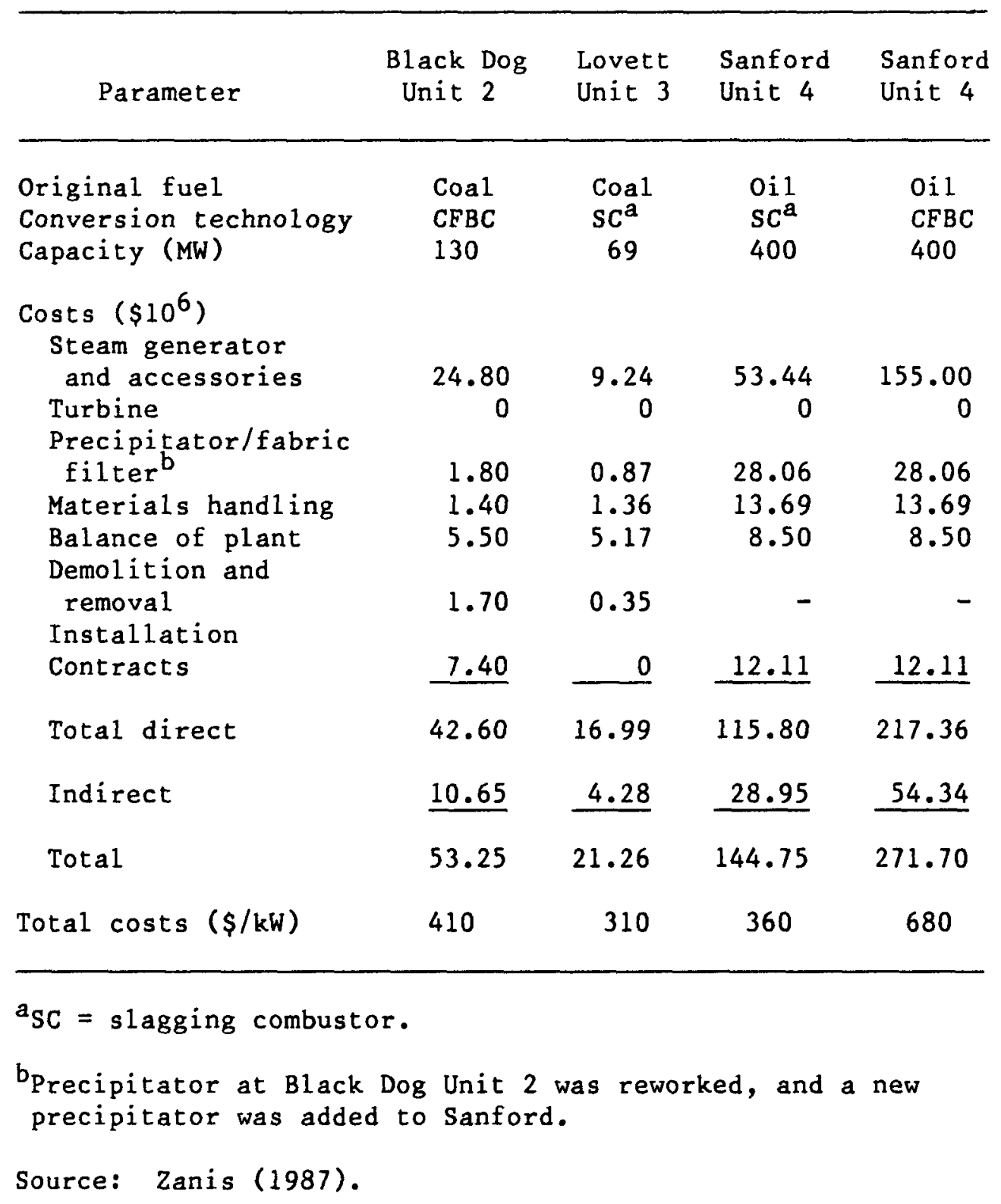

450 parts per million (ppm); most staged slagging combustors achieve 200-250 ppm at a stoichiometry ratio of 0.7 in the first stage. However, there is considerable variation in final $\mathrm{NO}_{\mathbf{x}}$ levels with first-stage stoichiometry. Thus, good local as well as global mixing and overall control of flow rates are extremely important. For the TRW and Coal Tech Corp. demonstrations, $\mathrm{NO}_{\mathrm{x}}$ emissions were 300 and $211 \mathrm{ppm}$, respectively.

- Sulfur Oxides. The reductions in sulfur oxide emissions achieved by slagging combuster systems have not been as universally acceptable 
as those for $\mathrm{NO}_{\mathrm{x}^{*}}$ Claims of up to $90 \%$ reduction abound in the literature. The reduction in $\mathrm{SO}_{2}$ emissions of ten depends strongly on the ratio of sorbent to sulfur. At higher sorbent injection rates, more $\mathrm{SO}_{2}$ is removed. Sorbent economics is a major factor for a given design combustor. Empirically changing the injection conditions and locations is the approach generally taken to optimization. Sulfur dioxide reductions of $50 \%$ at a sorbent-tosulfur ratio of three have been consistently achieved. With fully developed systems at the same sorbent-to-sulfur ratio, 70\% reductions seem likely. The issue of steady state versus transient injection of sorbent, in terms of relative effectiveness, remains unresolved. The claims of $90 \% \mathrm{SO}_{2}$ reduction need to justified by daily operations. However, during bench-scale tests at Transalta, $90 \% \mathrm{SO}_{2}$ removal was achieved with bituminous and subbituminous coals.

- Particulates. Because of high ash retention in the slag, particulates are generally well controlled in slagging combustor systems. However, a fabric-filter baghouse or other cleanup equipment may have to be installed to capture the very fine particles of fly ash and unsulfated sorbent produced during combustion.

During the TRW demonstration, ash retention in the slag was $83 \%$. Because sorbents were not used, the material collected was coal ash. Although Coal Tech Corp. did not measure ash retention directly, stack opacity was used as a correlation factor. Stack opacity was $10-20 \%$ for $60 \%$ of the test, which indicates "good" slag retention. For the balance of the test, stack opacity fluctuated between $10 \%$ and $50 \%$. The Transalta test combustor experienced slag recovery in the 50-70\% range.

\subsubsection{Production of Solid Waste}

Mineral matter, in the form of slag from the combustor, represents about $80 \%$ of total ash input. The remaining ash is collected by bag filters as fly ash in the form of extremely fine particles. Also part of the solid waste stream are calcium sulfate and unsulfated input limestone components (calcium oxide and calcium carbonate). This material is either combined with the slag, in the form of frit, or is collected as fine particles in the baghouse. The amount of sorbent depends on the ratio of sorbent to sulfur and on the level of sulfur in the coal. For typical coals having 10\% (by weight) mineral matter and $3 \%$ sulfur, solid waste requiring disposal may be more than double the original ash load.

\subsubsection{Consumable Requirements}

Water-cooled slagging combustors require high-pressure water at significant flow rates to ensure adequate cooling of metal surfaces subjected to high heat fluxes. If $3 \%$ sulfur coal is burned, if the sorbent-to-sulfur ratio is approximately three to one, and if 
no sorbent is recycled, reducing sulfur emissions requires an amount of sorbent equal to approximately $30 \%$ (by weight) of the coal. Sorbent supplies are therefore significant in terms of costs and storage space.

\subsubsection{Plant Complexity and Operability}

Because of their small furnace volumes, coal-fired cyclone boilers are excellent candidates for retrofit with slagging combustors. Oil- and gas-fired units are also suitable candidates. Installing slagging combustors on existing pulverized-coal units, however, may present a mismatch in heat transfer characteristics, because the relative quantities of heat absorbed in the radient and convective heat transfer areas will change from the original design conditions (Gupta et al., 1987).

Retrofitting conventional coal-fired facilities does not drastically affect the design of the original boiler or its operation (Makansi and Schwieger, 1987). Indeed, some of the problems experienced with pulverized-coal burners in some boilers are reduced after being retrofitted with slagging combustors. These problems include erosion, short furnace residence time, insufficient heat transfer, inadequate space, and insufficient ash removal (Margulis, 1988). However, the advantages of slagging combustors have yet to be proven commercially (Makansi, 1987).

\subsubsection{General Comments}

Although slagging combustors offer significant environmental advantages over established coal-combustion systems, they are a new technology. Further effort will be required before slagging combustors can become a mature technology.

\subsection{INTEGRATED-GASIFICATION COMBINED-CYCLE SYSTEM}

The integrated-gasification combined-cycle (IGCC) technology gasifies coal, removing sulfur, nitrogen, and ash before the derived gas is used in combustion turbines and boilers. A number of sponsors are proposing their own versions of the system, especially for the gasifier and associated cleanup equipment.

Coal gasification takes place at high temperatures in a number of modules, each of which has a capacity of $50 \mathrm{MWe}$. One or more of these modules serve as a spare. The gasifiers can be designed for use with various coals, with most of the designs using oxygen rather than air. The full-load heat rate is about $9000 \mathrm{Btu} / \mathrm{kWh}$, with coal characteristics and design specifics influencing the heat rate. A demonstration plant (Cool Water) exhibited a much higher heat rate, but proposed modifications in the technology are expected to lower this rate.

In general, IGCCs systems have excellent environmental protection attributes. The gasification and cleanup steps are designed such that $\mathrm{SO}_{2}$ and particulate emissions from the plants are very low; $\mathrm{NO}_{\mathrm{x}}$ formation and emissions can also be kept low. The system for removing sulfur can be designed to produce a commercial by-product. And, 
with reduced heat rates, $\mathrm{CO}_{2}$ emissions are expected to be lower than those from pulverized-coal plants with FGD.

EPRI has researched the complete IGCC configuration; development of IGCC concepts has also occurred internationally. Commercially, the concept is ready for application under favorable, project-specific economic conditions. The IGCC technology has the most potential in markets that exhibit high demand for electricity and that can effectively use base-load IGCC units. An IGCC system can also be used to repower existing conventional units, thereby improving environmental performance, increasing efficiency, increasing electrical capacity, and extending the useful life of much of the original equipment.

Section A.4.1 contains a technical description of the IGCC technology. Information about IGCC technology demonstrations is found in Section A.4.2. Sections 2.4.1-2.4.13 present various aspects that affect the marketing of this technology.

\subsubsection{Applicable Market}

An IGCC power plant is intended for base-load electric utility operation, although part-load operation is acceptable from the standpoints of operation and efficiency. In a relatively new concept called "phased addition," natural-gas-fired turbines are installed and operated in a peaking mode. When demand for electricity increases, heat recovery steam generators (HRSGs) and a steam turbine are installed to create a combined cycle for intermediate or base-load operation. Finally, when economics dictate, gasifiers are added to create the full IGCC plant. As noted above, the IGCC technology can also be used to repower existing facilities.

\subsubsection{Influence of Coal Type}

\subsubsection{Texaco Gasifier}

The Texaco gasifier must run at a temperature high enough for the slag (liquid ash) to flow freely, but not so hot that refractory life becomes unacceptably short. Within this temperature constraint, the desirability of different coals must be evaluated through consideration of carbon conversion, oxygen consumption, and refractory replacement cost.

Three of the numerous tests run with the Texaco gasifier are discussed here. Tests at EPRI's Montebello Research Laboratory involved gasification of an Illinois No. 6 and a Pittsburgh No. 8 bituminous coal (Texaco, Inc., 1987). The concentration of coal in the slurries was generally just above $60 \%$ (by weight), with the Pittsburgh coal running slightly higher than the Illinois coal. An additive used in three of the Pittsburgh coal runs increased the solids concentration to well above $60 \%$. Higher slurry concentrations resulted in more efficient conversion. In the majority of cases, carbon conversion was 98-99\%. Cold-gas efficiency (i.e., fraction of chemical energy originally in the coal that 
ends up as chemical energy in the gas) ranged from just under $70 \%$ to $74 \%$, and up to $77 \%$ in the slurry additive cases. The tests lasted from 14 to 24 hours.

Four U.S. coals were tested on a Tennessee Valley Authority (TVA) Texaco gasifier (Tennessee Valley Authority, 1987). Illinois No. 6 and Pittsburgh No. 8 coals were gasified, along with a Utah and a Maryland coal. Carbon conversion was in the low to middle 90\% range, which was lower than percentages reported for tests at EPRI's Montebello Research Laboratory. As a result, cold-gas efficiencies were in the middle to high $60 \%$ range. The Maryland coal had a high ash fusion temperature, which was lowered by adding a limestone fluxing agent. The coals were tested under a variety of operating conditions; satisfactory mechanical performance and safe operation were demonstrated in all major processing areas and for all equipment.

More recently, a similar set of coals was tested at the Cool Water IGCC generating station (Clark, 1988). The Sufco coal used in these tests is a low-sulfur Utah coal; the Lemington coal is an Australian coal with a high ash fusion temperature. Carbon conversion was similar to that cited by EPRI (i.e., 97-99\%). These tests differed from the other two in that the gas produced was used to fuel a combined cycle to commercially generate electricity. The changeover from one coal to another was made without interrupting power generation. For the Sufco coal, net plant efficiencies improved from $29.5 \%$ in 1986 to $31 \%$ in 1988.

No inherent restrictions on coal type, either physical or chemical, are known to apply to the Texaco gasifier. Lignite is attractive as a fuel because it exists in great quantities in some regions of the United States, and its cost per unit heating value may in some cases be lower than that of higher rank coals. Lignite has not yet been used in a Texaco gasifier, although that possibility is discussed in a report that focuses on alternative coal feed methods (Energy Conversion Systems, Inc., 1986). Cold-gas efficiencies higher than $80 \%$ were predicted in all but the water slurry case. All of these delivery systems need further development and testing.

\subsubsection{British Gas Corporation/Lurgi (BGL) Fixed-Bed Gasifier}

Limited operating data have been reported for the BGL fixed-bed gasifier. An EPRI (1981) report gives results for Rossington, a standard reference coal, and for Pittsburgh No. 8, a coal from the Champion plant in Pennsylvania. Fluxing was successful with both boiler-fired slag and limestone. The report did not include coal analyses. Cold-gas efficiency was 87-90\% for the Rossington coal and 81-87\% for the Pittsburgh No. 8 coal. EPRI, British Gas Corp., and the Gas Research Institute are funding tests with U.S. bituminous coals for a commercial-scale BGL fixed-bed gasifier. A 15-day test was successfully completed in 1987 on a Pittsburgh No. 8 coal, and more tests were planned (Bechtel Group, Inc., 1988).

Like all fixed-bed gasifiers, the BGL unit is limited as to the quantity of fines it can accept directly on top of the bed. If fines exceed approximately 15\%, they are pelletized or briquetted with a binder and fed in with the balance of the coal. Alternatively, the excess fines can be injected in a water slurry via tuyeres. A unique 
feature of the BGL gasifier, the tuyeres deliver tars and oils to the combustion zone. Limestone is used as a fluxing agent to maintain adequate fluidity in the bottom slag.

Subbituminous coal and lignite apparently have not been considered for the BGL gasifier.

\subsubsection{Kellogg-Rust-Westinghouse (KRW) Fluidized-Bed Gasifier}

The KRW fluidized-bed gasifier has not been developed to the same degree as the two discussed above. It has been tested on a variety of coals such as Pittsburgh No. 8 and Wyoming subbituminous (M.W. Kellogg Co., 1987). Carbon conversion of about $90 \%$ and cold-gas efficiency of about $70 \%$ were achieved. Lignite has also been tested. Although advertisements have claimed that all U.S. coals can be used (KRW Energy Systems, Inc., 1986), data are lacking for some coal types such as those with high ash fusion temperatures. These coals are expected to be problematic in that ash agglomeration is critical in the $\mathrm{KRW}$ process. Because the coal is crushed to minus 0.25 in. for injection, no problem with fines apparently exists.

\subsubsection{Plant Size and Modularity Considerations}

The Texaco and BGL gasifiers are sized commercially to provide approximately 120-140 MWe per unit. Because of the need to provide spare capacity for maintenance or forced outages, one extra gasifier is usually required for each 500 -MWe plant.

A commercial-scale KRW gasifier has not yet been operated, but will probably be about $50 \mathrm{MWe}$. Because of the smaller size of this gasifier, the number of spare gasifiers needed may be about twice that for the other two options. The KRW gasifier has been proposed for an oxygen-blown, cold-gas cleanup IGCC producing $547 \mathrm{MWe}$ (Fluor Engineers, Inc., 1985).

An important factor in modularity is the oxygen plant needed to produce medium-Btu coal gas. The cost of this equipment, which depends on its scale, is leading toward a plant size of $500 \mathrm{MWe}$; however, smaller plants have been proposed (Bechtel Group, Inc., 1988). All three gasifiers operate in the oxygen-blown mode with cold-gas cleanup. Unlike the other two, the KRW gasifier is also being developed to operate in the air-blown mode with hot-gas particulate and sulfur cleanup. If operated in the airblown mode, IGCC plants may be economic in the 50-100 MWe range. This mode of operation has also been proposed for the dry ash Lurgi gasifier.

\subsubsection{Status of Commercialization}

The Cool Water IGCC demonstration project began producing power commercially in mid-1984. The Texaco gasifier option is therefore deemed ready for commercial use, pending favorable economics. 
A commercial-scale BGL gasifier has been demonstrated in the British Gas Corp. facility in Westfield, Scotland. The extensive testing (e.g., load swing simulation) of this gasifier for use in a power plant should allow it to be successfully demonstrated in the early 1990s.

The KRW gasifier is in an earlier stage of development and will require further testing, both of the gasifier and the hot-gas cleanup technology. It could be demonstrated by the late 1990 s.

\subsubsection{Capital and Operating Costs}

Fluor Engineers, Inc., has compared the economics of oxygen-blown KRW and Texaco gasifiers rated at approximately $500 \mathrm{MWe}$ (Table 2.7). Preliminary economic analyses for an air-blown gasifier indicate that its capital costs may be somewhat lower than those for an oxygen-blown gasifier. This difference can be partly attributed to the absence of an oxygen plant (KRW Energy Systems, Inc., 1986).

\subsubsection{Plant Performance}

Data suggest that full-load heat rates for IGCCs with advanced gas turbines run around 9000-9100 Btu/kWh. However, a value of $8660 \mathrm{Btu} / \mathrm{kWh}$ has been reported for a 500-MWe BGL IGCC (EPRI, 1986b). Also, the KRW system operating on lignite has been shown to be about $10 \%$ less efficient $(10,040 \mathrm{Btu} / \mathrm{kWh})$ (EPRI, 1986b).

\subsubsection{Part-Load Operation}

The gasification trains and gas turbines of IGCC power plants are expected to be modular in design. For this reason, such systems can be expected to experience only moderate increases in heat rate at partial load.

The operating efficiency of an IGCC system at part load was addressed by Stanford University (1987). The analysis considered two cases: (1) as the load dropped, all gasification trains were reduced in operating level equally, and (2) when the load was low enough, one or two of the trains were taken off line. The second case resulted in higher efficiency. For example, by operating only two gas turbines and one oxygen train, as opposed to the three gas turbines and two oxygen trains required for full-power operation, the IGCC system could be operated at 50\% load with only a very small increase over the full-load heat rate (EPRI, 1986b). However, because of the restart requirements for a gasification train, it may be preferable to keep all trains in operation, especially if the drop in load is expected to be of short duration.

\subsubsection{Reliability and Availability}

Experience at Cool Water indicates that a mature plant should be able to achieve availabilities of $68 \%$, with both forced and scheduled outages taken into consideration 
TABLE 2.7 Economic Comparison of KRW and Texaco IGCC Plants

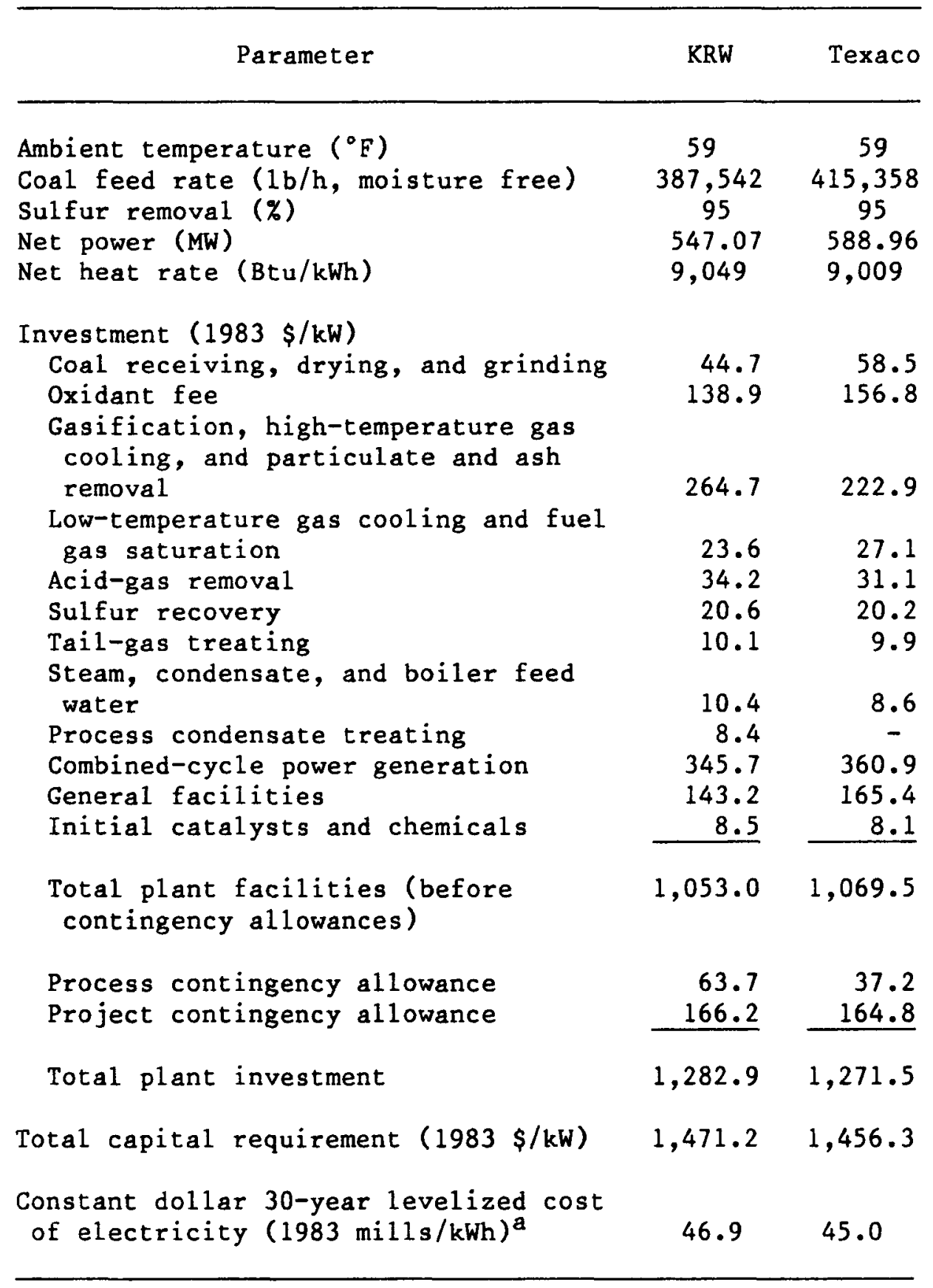

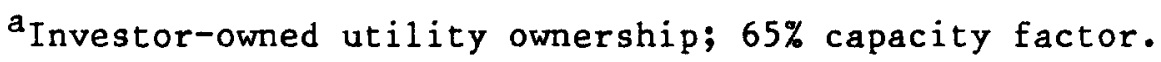

Source: Fluor Engineers, Inc. (1985). 
(Arinc Research Corp., 1988). Furthermore, increased design modularity and more experience in operation and maintenance are expected to allow the next generation of IGCCs to achieve availabilities in excess of $80 \%$ (EPRI, 1986b).

\subsubsection{Atmospheric Emissions}

The operating permit for the Cool Water plant establishes far more stringent emissions limits for $\mathrm{SO}_{2}, \mathrm{NO}_{\mathrm{X}}$, and particulates than were required for any other fossilfuel power plant. As shown in Table 2.8, these requirements were met or exceeded. Because BGL and KRW IGCC plants do not yet exist, Tables 2.9 and 2.10, respectively, give calculated emissions estimates.

\subsubsection{Production of Solid Waste}

Most IGCC concepts involve generation of solid waste (e.g., elemental sulfur and gasification slag). The sulfur can be sold to generate additional revenues. The slag, which has been classified as nonhazardous, could be used as a lightweight aggregate or as roadbed filler. Therefore, the slag also has some potential market value (Watts, 1989).

The quantity of slag produced is a function of several parameters that include the coal used, the efficiency of the plant, and the type of sulfur control. Experimental

TABLE 2.8 Pollutant Emissions from the Cool Water Plant

\begin{tabular}{|c|c|c|c|}
\hline \multirow[b]{2}{*}{ Pollutant } & \multicolumn{3}{|c|}{ Emissions $\left(1 \mathrm{~b} / 10^{6} \mathrm{Btu}\right)$} \\
\hline & $\begin{array}{l}\text { EPA } \\
\text { NSPS }\end{array}$ & $\begin{array}{l}\text { Plant } \\
\text { Permits }\end{array}$ & $\begin{array}{l}\text { Plant Test } \\
\text { Results }\end{array}$ \\
\hline $\begin{array}{l}\mathrm{NO}_{\mathrm{x}} \\
\mathrm{SO}_{2} \\
\text { Particulates }\end{array}$ & $\begin{array}{l}0.60 \\
0.24 \\
0.03\end{array}$ & $\begin{array}{l}0.13 \\
0.034 \\
0.01\end{array}$ & $\begin{array}{l}0.056 \\
0.017 \\
0.008\end{array}$ \\
\hline \multicolumn{4}{|c|}{$\begin{array}{l}{ }^{a} \text { Cool Water plant permit for low-sulfur } \\
\text { coal operation, with low-sulfur coal } \\
\text { defined therein as coal containing less } \\
\text { than } 0.7 \% \text { sulfur. }\end{array}$} \\
\hline \multicolumn{4}{|c|}{$\begin{array}{l}b_{1987} \text { EPA performance test results for } \\
\text { Sufco coal. }\end{array}$} \\
\hline
\end{tabular}


TABLE 2.9 Pollutant Emissions of BGL IGCC Technology

\begin{tabular}{|c|c|c|c|}
\hline \multirow[b]{2}{*}{ Pollutant } & \multicolumn{3}{|c|}{ Emissions } \\
\hline & $\begin{array}{l}1 \mathrm{~b} / \mathrm{h} \\
\text { or } \\
\mathrm{g} / \mathrm{min}\end{array}$ & ppmv ${ }^{a}$ & $1 \mathrm{~b} / 10^{6} \mathrm{Btu}$ \\
\hline \\
\hline \multicolumn{4}{|l|}{$\begin{array}{l}\text { Flue gas from liquor } \\
\text { incineration }\end{array}$} \\
\hline $\mathrm{NO}_{x}\left(\right.$ as $\left.\mathrm{NO}_{2}\right)$ & 12 & 63 & 0.007 \\
\hline $\mathrm{SO}_{2}^{\mathrm{x}} \mathrm{2}$ & 30 & 124 & 0.018 \\
\hline $\mathrm{CO}^{2}$ & 11 & 94 & 0.007 \\
\hline Particulates & 4 & - & 0.002 \\
\hline $\mathrm{HCN}$ & 3 & - & 0.002 \\
\hline $\mathrm{HCl}$ & 2 & - & 0.001 \\
\hline \multicolumn{4}{|l|}{ Hydrocarbons/organic } \\
\hline carbon & 4 & - & 0.002 \\
\hline \multicolumn{4}{|l|}{ Flue gas from $\mathrm{HRSG}^{\mathrm{b}}$} \\
\hline $\mathrm{NO}_{2}\left(\right.$ as $\left.\mathrm{NO}_{2}\right)$ & $\begin{array}{l}537 \\
318\end{array}$ & $\begin{array}{l}75^{c} \\
46\end{array}$ & $\begin{array}{l}0.321 \\
0.190\end{array}$ \\
\hline \multicolumn{4}{|l|}{ Solid waste $(1 \mathrm{~b} / \mathrm{h})$} \\
\hline \multicolumn{4}{|l|}{$\begin{array}{l}\text { Gasification slag to } \\
\text { ash pond }\end{array}$} \\
\hline Slag & 22,661 & & \\
\hline $\mathrm{H}_{2} \mathrm{O}$ & $387,944^{\mathrm{d}}$ & & \\
\hline Tótal & 410,605 & & \\
\hline \multicolumn{4}{|l|}{ Incineration residue (salt) } \\
\hline Sodium chloride & 157 & & \\
\hline Sodium carbonate & 72 & & \\
\hline Potassium carbonate & 22 & & \\
\hline Heavy metals & trace & & \\
\hline Water & 25 & & \\
\hline Total & 276 & & \\
\hline \multirow{2}{*}{\multicolumn{4}{|c|}{$\begin{array}{l}\text { Liquid pollutant ( } \mathrm{g} / \mathrm{min}) \\
\text { Slag water to river from }\end{array}$}} \\
\hline & & & \\
\hline ash pond & 776 & & \\
\hline Once-through cooling water & & & \\
\hline return to river & $70,500^{e}$ & & \\
\hline
\end{tabular}

$a_{\text {ppmv }}=$ parts per million, volume.

$b_{\text {HRSG }}=$ heat recovery steam generator .

${ }^{1} 15 \%$ oxygen, dry (corrected for heat rate); corresponding actual, uncorrected $\mathrm{NO}_{x}$ emission is 107 ppmv.

Most of this water overflows from the ash pond into the James River.

e Temperature rise of $13^{\circ} \mathrm{F}$.

Source: Bechtel Group, Inc. (1988). 
TABLE 2.10 Environmental Emissions and Resource Requirements of KRG IGCC Technology

\begin{tabular}{|c|c|c|}
\hline & $\begin{array}{l}\text { Illinois } \\
\text { Coal Case }\end{array}$ & Lignite Case \\
\hline $\begin{array}{l}\text { Case designation } \\
\text { Plant location } \\
\text { Ambient temperature }\left({ }^{\circ} \mathrm{F}\right)\end{array}$ & $\begin{array}{l}\text { Illinois } \\
59\end{array}$ & $\begin{array}{c}\text { Northeast Texas } \\
95\end{array}$ \\
\hline 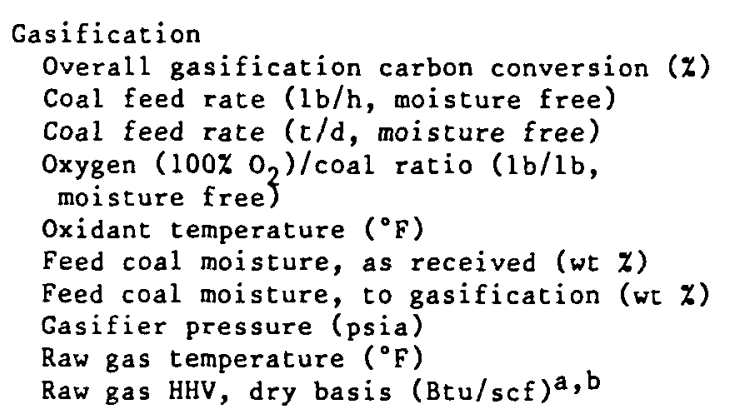 & $\begin{array}{c}94.9 \\
387,542 \\
4,650.5 \\
\\
0.61 \\
254 \\
12.0 \\
5.0 \\
465 \\
1,850 \\
324.2\end{array}$ & $\begin{array}{c}97.6 \\
455,508 \\
5,466.1 \\
\\
0.62 \\
279 \\
34.9 \\
15.0 \\
465 \\
1,750 \\
309.3\end{array}$ \\
\hline $\begin{array}{l}\text { Power system } \\
\text { Temperature of fuel gas to gas turbine }\left({ }^{\circ} \mathrm{F}\right) \\
\text { Moisture in fuel gas (wt } \% \text { of moist fuel) } \\
\text { Gas turbine expander inlet temperature }\left({ }^{\circ} \mathrm{F}\right) \\
\text { Steam conditions (psig/ } /{ }^{\circ} \mathrm{F} /{ }^{\circ} \mathrm{F} \text { ) } \\
\text { Condenser pressure (in. Hg absolute) } \\
\text { HRS stack temperature }\left({ }^{\circ} \mathrm{F}\right)^{a} \\
\text { Gas turbine net power (MW) } \\
\text { Steam turbine net power (MW) } \\
O_{2} \text { plant expander power output (MW) } \\
\text { Plant power consumed (MW) } \\
\text { Net plant power output (MW) }\end{array}$ & $\begin{array}{c}570 \\
30.0 \\
2,200 \\
1450 / 996 / 1000 \\
2.0 \\
284 \\
397.35 \\
216.51 \\
0.53 \\
67.32 \\
547.07\end{array}$ & $\begin{array}{c}570 \\
24.0 \\
2,200 \\
1450 / 970 / 970 \\
3.0 \\
288 \\
340.70 \\
225.06 \\
0.68 \\
90.88 \\
475.56\end{array}$ \\
\hline $\begin{array}{l}\text { Overall system } \\
\mathrm{SO}_{2} \text { emissions (tons } \mathrm{SO}_{2} / \mathrm{MW}-\mathrm{yr} \text { ) } \\
\left.\mathrm{SO}_{2} \text { emissions ( } 1 \mathrm{~b} / 10^{6} \mathrm{Btu}\right) \\
\mathrm{NO}_{\mathrm{x}} \text { emissions, corrected (ppmv dry) } \\
\text { Process and deaerator makeup water } \\
\text { ( } \mathrm{g} / \mathrm{min} \text { per } 1000 \mathrm{MW}) \\
\text { Cooling-tower makeup water, } \\
\text { ( } \mathrm{g} / \mathrm{min} \text { per } 1000 \mathrm{MW}) \\
\text { Cooling-water circulation rate } \\
\text { ( } \mathrm{g} / \mathrm{min} \text { per } 1000 \mathrm{MW}) \\
\text { Cooling-tower heat rejection ( } \mathrm{z} \text { of coal HHV) } \\
\text { Air cooler heat rejection ( } \% \text { of coal HHV) } \\
\left.\text { Feed coal HHV ( } 10^{6} \mathrm{Btu} / \mathrm{h}\right) \\
\text { Net heat rate (Btu/kWh) } \\
\text { Overall system efficiency, coal power } \\
\text { ( } \% \text { of coal HHV) }\end{array}$ & $\begin{array}{l}11.3 \\
0.28 \\
<75 \\
2,121 \\
2,819 \\
255.6 \\
28.21 \\
1.34 \\
4,950.4 \\
9,049 \\
37.72\end{array}$ & $\begin{array}{l}3.5 \\
0.08 \\
<75 \\
1,353 \\
6,091 \\
352.0 \\
34.88 \\
1.25 \\
4,776.1 \\
10,043 \\
33.98\end{array}$ \\
\hline 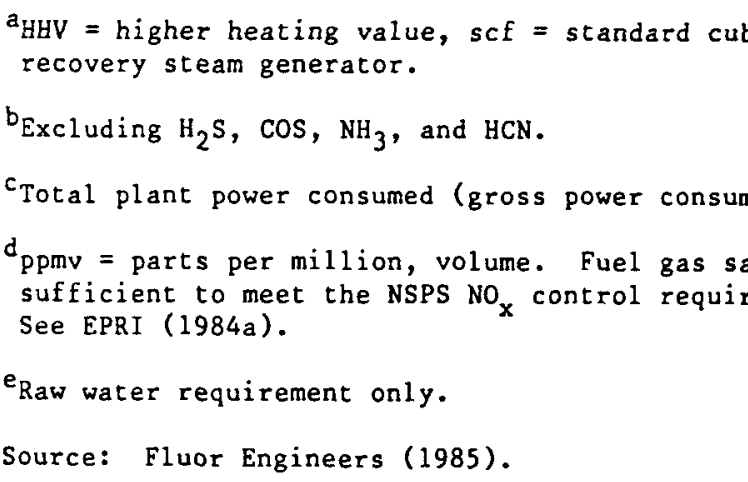 & $\begin{array}{l}\text { on). } \\
\text { ation levels } \\
\text { nt of } 75 \mathrm{ppm}\end{array}$ & $\begin{array}{l}\text { orrected). } \\
\text { orre man }\end{array}$ \\
\hline
\end{tabular}


and estimated values for slag production are about 75-150 lb/MWh. The high end of this range corresponds to high ash coals and/or in situ (i.e., in the gasifier) sulfur removal (Fluor Engineers, Inc., 1985; EPRI and Radian Corp., 1988). The quantity of sulfur produced depends on the coal used, the efficiency of sulfur removal, and the plant efficiency. Values range from less than $5 \mathrm{lb} / \mathrm{MWh}$ for low-sulfur coals to $30 \mathrm{lb} / \mathrm{MWh}$ for a high-sulfur Illinois Basin coal (Fluor Engineers, Inc., 1984; EPRI and Radian Corp., 1988).

\subsubsection{Consumable Requirements}

Each of the IGCC design concepts requires many of the same catalysts and chemicals as any coal-based power plant (e.g., feedwater demineralizers and feedwater treatment chemicals). In addition, there are some requirements for nonstandard chemicals. For example, a 600-MWe plant firing Illinois No. 6 coal would annually require 30 tons of Selexol solvent for removing sulfur from the hot gas stream. Approximately 12 tons of Claus plant catalyst would also be required annually to recover sulfur from the Selexol process and to convert it into a marketable form. Some 400 cubic feet of Scot catalyst and 8 tons of Scot chemicals would also be required annually for treating the tail gases from the sulfur removal system.

\subsubsection{Plant Complexity and Operability}

An IGCC plant combines technologies typical of power plants and chemical plants; therefore, extensive operator training, as was carried out at the Cool Water IGCC plant (EPRI and Radian Corp., 1988), is required. The first-of-its-kind Cool Water plant has received a lot of attention; similar attention would likely be paid to a new IGCC plant in a developing country. However, as the technology matures, plant operation should become more routine. Equipment and feedstock changes should become rare or

nonexistent. Since many petrochemical plants are now operated successfully in developing countries, IGCC plants should be no less successful. Of the three gasifiers discussed above, the fixed-bed BGL technology is expected to be the simplest to operate (Bechtel Group, Inc., 1988).

\subsubsection{General Comments}

Fundamental differences exist between power plants based on IGCC technology and those based on standard boilers fired with pulverized coal. Energy is extracted at a higher temperature in the gas turbine than is possible in a steam turbine alone. Thus, on thermodynamic grounds, IGCC can theoretically achieve higher efficiencies than a pulverized-coal-fired plant. Efficiencies should increase as improvements occur in gas turbine technology. Also, in an IGCC plant, gaseous and solid emissions are dealt with before combustion. The treated steam is therefore lower in mass and higher in pressure, which results in a 300 -fold decrease in the volume needing treatment for particulate and sulfur removal. This decrease in volume significantly affects plant size and cost. IGCC plant waste products are of ten in the form of elemental sulfur or sulfuric acid, either of which can be marketed as by-products, which improves the economics of the process. 
The IGCC spent sorbent is recycled in a Claus plant, whereas the sorbent used in a standard boiler fired with pulverized coal is usually a once-through material (e.g., limestone) that must be disposed of with sulfated waste in landfills. $\mathrm{NO}_{\mathrm{x}}$ control is also easier and more efficient in an IGCC plant.

Innovations in IGCC design will occur both in fundamental aspects (e.g., improvements in hot-gas cleanup and increases in gas-turbine firing temperature) and cycle refinements (e.g., intercooled steam-injected gas turbine). Although coal-fired cycles will never attain the efficiency of natural-gas-fired cycles, the differences should narrow and eventually lead to coal being the most economical fuel.

\subsection{ATMOSPHERIC FLUIDIZED-BED COMBUSTION}

Fluidized-bed combustion (FBC) has a lengthy history. The concept was first applied to the Winkler coal gasification process in Germany more than 60 years ago (Patterson, 1987). During the early 1950s, a fluidized-bed burner (primarily a retrofit device) was developed in France for use in generating steam on a small commercial scale in coal-fired boilers. By the $1960 \mathrm{~s}$, basic investigations of FBC were underway in the United Kingdom, the PRC, and the United States. The initial emphasis was on atmospheric fluidized-bed combustion (AFBC). The renewed interest in this technology during the 1960 s can be attributed to its ability to remove $\mathrm{SO}_{2}$ from flue gas and thereby meet U.S. Environmental Protection Agency (EPA) emission limitations without resorting to installation of costly FGD systems.

In the mid-1970s, skyrocketing oil prices, which favored exploitation of domestic resources, and increased sensitivity to environmental issues heightened interest in AFBC as a power-generating option. In the United States, AFBC research facilities have been sponsored or built by various federal agencies, national laboratories, and private industrial process and engineering firms. The principal advantages of the technology include increased control of emissions, ability to adapt to low-grade fuels, enhanced heat transfer in the boiler tubes, and significantly smaller boilers.

The FBC concept can be used, usually in combination with a solid material, with solid, liquid, or gaseous fuels. During combustion, air from a distribution chamber separates and suspends or transports the fuel and solid components of the bed. Heat transfer to the boiler tubes is effective at low temperatures (e.g., $1550^{\circ} \mathrm{F}$ or $845^{\circ} \mathrm{C}$, which enables the efficient use of the $\mathrm{SO}_{2}$ sorbent, usually limestone. Thermal efficiencies are expected to be slightly lower for an AFBC plant than for a pulverizedcoal-fired plant with FGD.

The main environmental benefit is removal of about $90 \%$ of the $\mathrm{SO}_{2}$ generated as calcium sulfate in a dry solid waste system. Ash can also be removed easily; however, to meet particulate emission requirements, a baghouse or some other technology to control fines is required. The production of $\mathrm{NO}_{\mathrm{x}}$ is reduced because of the low combustion temperatures. The technology appears to be economically and environmentally competitive with other coal-burning technologies, especially for relatively small boilers. 
Research and development activity on AFBC is taking place worldwide. Commercial applications for small units are aided by the ease of shop assembly and transportability of units with steaming capacities of up to $200,000 \mathrm{lb} / \mathrm{h}$. Utility demonstration plants are in operation or under construction. The technology is also applicable for programs to extend the life of power plants by installing new boilers.

The ability to design AFBC plants for use with various fuel types contributes significantly to the potential for using a variety of coals. Moreover, reasonable changes in coal quality usually do not lead to significant reductions in power output for a given plant design. The relative ease of operation and maintenance of this technology is evidenced by its use in the industrial sector of the United States and in foreign countries like the PRC.

Section A.5.1 contains a technical description of the AFBC technology. Information about AFBC technology demonstrations is found in Section A.5.2. Sections 2.5.1-2.5.13 present various aspects that affect the marketing of this technology.

\subsubsection{Applicable Market}

AFBC is applicable to a wide range of markets in which environmental performance and fuel flexibility are considerations. In industry, the principal application is supplying heat for process, agricultural, or community needs. Its popularity is seemingly enhanced by its ability to accept low-quality fuel. The capacity of the industrial boilers ranges from a few thousand to a half million pounds of steam produced per hour, which is equivalent to approximately $50 \mathrm{MWe}$. As measured by actual installations and orders, the technology has penetrated many different industrial (e.g., pulp and paper, food processing, cement, and manufacturing) and institutional markets (e.g., universities and army bases).

The utility sector has also become an important market for AFBC technology because of aging power plants, increases in demand for electricity, and ever more stringent environmental requirements for new power plants. In utility applications, AFBC power plants are primarily intended for base-load operation, but can function in a cycling capacity. Studies are underway at two demonstration plants to examine the effects of turndown at utility scale.

As a repowering technology, AFBC has the potential to significantly extend the operating life of a coal-fired plant. A repowered coal-fired plant retains much of its existing solids-handling equipment and virtually all of its steam cycle, electricalgenerating, and power-conditioning hardware. Repowered plants exhibit improved ability to control emissions, increased efficiency in generating electricity, and enhanced operating cost effectiveness.

The AFBC technology is likely be selected for new plants being constructed to meet future growth in electric power demand, but not until the long-term reliability of this option has been proved under utility operating conditions and until the range of conditions under which AFBC power plants are most economical has been established. 


\subsubsection{Influence of Coal Type}

The main concern today is how to design a large AFBC unit that is efficient and economical while also providing for fuel flexibility. Even though fuel flexibility is a fundamental advantage of AFBC technology, fuel properties still play a critical role in boiler design, especially in the design of auxiliaries. Too great a change in properties sometimes leads to drastic reductions in performance or even inoperability. Characteristics of coal and ash that are important for fluidized beds include charcombustion reactivity, friability, and swelling and fragmentation. Although fluidized beds typically operate below ash fusion temperatures, formation of low-melting eutectics can lead to agglomeration of the particles constituting the bed, which can lead to defluidization (Darguzas et al., 1987).

Duqum et al. (1987) conducted laboratory-scale (AFBC unit 2 in. in diameter) experiments on Texas lignite, Sarpy Creek subbituminous coal, Kentucky No. 9 bituminous coal, and green petroleum coke to determine the combustion profiles, fragmentation tendencies, and attrition characteristics of these solid fuels. Lower-rank coals of sizes typically used in AFBC units did not swell or fragment. However, the bituminous coal swelled significantly during devolatilization. For particles 0.25 in. and larger in diameter, swelling coupled with intraparticle thermal gradients caused fragmentation. Work by Petrill and Stallings (1987) showed that combustion profiles for different fuels indicate that reactivity decreases with increasing coal rank, and burnout time varied almost linearly with the initial particle size.

Perna et al. (1987) conducted tests on Kentucky No. 9 bituminous coal and other coals in a $1 \mathrm{ft} \times 1 \mathrm{ft} F B C$ to determine the effects of superficial gas velocity, bed temperature, bed height, coal and limestone feed sizes, ratio of bed material recycle to coal feed, and ratio of calcium to sulfur on performance. The results of these tests indicate that recycling fly ash significantly improves the overall combustion efficiency of each coal considered.

For the purpose of characterizing AFBC fuels, Babcock \& Wilcox and EPRI jointly undertook a project to develop a bench-scale test rig and a computer model. By the end of 1989, some 15 different coals were to have been tested at bench scale and above. The developers expected that these bench-scale tests and the computer model would provide the information necessary to design AFBC units without the need for confirmation testing at large AFBC facilities (Tavoulareas, 1987).

Tests at TVA's 20-MW pilot plant confirmed the above-mentioned bench-scale results for Kentucky No. 9 coal, the design fuel for TVA's 160-MW demonstration project, and indicated that unit performance may be improved through use of other coals. For example, a Montana subbituminous coal (Sarpy Creek), which is more reactive than Kentucky No. 9, showed improved performance in the overbed feed mode. This finding is significant because the underbed feed mode has consistently resulted in superior boiler performance.

In the case of Northern States Power's Black Dog Unit 2, Sarpy Creek coal had previously caused fouling and slagging when the boiler was in a conventional configuration. Given the results of its fuels research, Northern States Power now 
anticipates satisfactory burning at much higher capacities. In addition, the high alkali content of the ash should ease absorption of $\mathrm{SO}_{2}$ in the furnace.

\subsubsection{Plant Size and Modularity Considerations}

Industrial boilers produce from a few thousand to half a million pounds of steam per hour, which is equivalent to up to approximately $50 \mathrm{MWe}$. Most utility boilers are characteristically larger than the largest industrial units, with a minimum capacity of about $100 \mathrm{MWe}$. Utility designs are typically modular (to keep the bed tractable), and several bed modules may be contained in a single furnace. The beds are arranged either horizontally (ranch style) or vertically (stacked). The reliability of a string of parallel modules is typically greater than the reliabilty of a single large unit. An advantageous feature of the larger-scale units is the freeboard volume available to further enhance the combustion and sulfur removal processes begun in the bed. Proper design of the freeboard conditions yields combustion efficiencies near $99 \%$ and reductions in required limestone sorbent consumption ratios $(\mathrm{Ca} / \mathrm{S})$ to less than two to one (Singer, 1981).

For units larger than $50 \mathrm{MWe}$, the combustion zone area is so large that additional heat removal is required. It can be accomplished directly by increasing the waterwall surface through additional division walls or indirectly by adding an external fluid-bed heat exchanger whereby a controllable amount of solids can be routed through a heat recovery cooler and then recycled back to the furnace.

The most important remaining unresolved design problem is the size and arrangement of the large recycling cyclones, which are inherent in the CFBC concept. Attempts to produce a satisfactory 500-MW design concept have not been successful. Currently, a 500-MW unit would consist of two 250-MW units operating in parallel (Tavoulareas, 1987).

\subsubsection{Status of Commercialization}

The AFBC technology is commercially established for industrial heating. Systems undergoing startup represent various supplier designs, primary fuels, and fuel combinations. For utility applications, the technology is at the demonstration stage, with a number of different organizations and electric utilities collaborating on projects.

\subsubsection{Capital and Operating Costs}

The main advantages of AFBC technology, as compared with a plant fired with pulverized coal and equipped with FGD, are: (1) elimination of scrubbers, which results in reduced capital and operating costs and improved reliability; (2) inherent fuel flexibility, which allows for some fuel switching without significant performance penalties; (3) ability to fire lower-quality fuels; and (4) realization of benefits from converting existing boilers. Such conversions can be economical and result in reduced emissions, while extending the life of the unit and possibly increasing its rating. Dunlop (1984) reports that total capital requirements for 200-MWe AFBC plants designed 
for different fuels appear to be 10-15\% lower than those for equivalent plants fired with pulverized coal and equipped with FGD systems.

Two features of AFBC technology that are difficult to quantify are the value of fuel flexibility and modular construction. Fuel switching is driven by changes in the costs of fuels available to each power plant operator. Most U.S. power plants have access to a number of fuels that come from different coal-producing regions, that use different means of transport, and that have different fuel characteristics. Modular construction can significantly reduce capital costs, although benefits are site specific and depend on plant size. Modules can be installed incrementally in phases, making it easier to manage capital investment while taking advantage of economics of scale. In general, staged modular expansion shortens construction time and lowers the costs of bringing new capacity on line.

\subsubsection{Plant Performance}

The test results from TVA's pilot-plant (20-MW) study confirmed many of the expectations established for AFBC technology in earlier work in a small-scale unit. The pilot plant operated with Kentucky No. 9 coal for 18,000 hours. Underbed coal feed and recycle of fly ash from the cyclone collectors produced combustion efficiencies of $97 \%$. A weight ratio of recycled fly ash to coal feed of 2.0-2.5 was necessary to achieve this level of efficiency. Underbed feed achieved $90 \% \mathrm{SO}_{2}$ capture at a calcium-to-sulfur ratio of 2.3 and a recycle ratio of 2.5. Overbed feed required higher calcium-to-sulfur and recycle ratios to obtain $90 \% \mathrm{SO}_{2}$ capture (EPRI, no date).

\subsubsection{Part-Load Operation}

The principal constraint on load control is the narrow range of bed temperatures that allows efficient capture of sulfur with limestone, the preferred sorbent. There appears to be general agreement that sulfur capture is optimal at bed temperatures of $1550 \pm 50^{\circ} \mathrm{F}\left(845 \pm 30^{\circ} \mathrm{C}\right)$. Outside this range, sorbent utilization is apparently reduced, making operations less economical. To circumvent this problem, two basic strategies have been used: bed slumping and velocity turndown (Fox et al., 1986).

Bed slumping depends on compartmentalizing the fluidizing air distributor such that a portion of the boiler can be defluidized and essentially removed from service. Two important disadvantages of this method are that boiler output tends to change in a stepwise fashion and that restarting slumped compartments can be difficult because of solids clinkering, especially with overbed coal feeding.

Small changes in the immersed heat-transfer area can significantly change the heat balance of the bed because of the large in-bed heat-transfer coefficients. Thus, turndown can also be achieved by reducing the air velocity such that the bed level and heat losses are reduced. Therefore, less coal has to be fed to maintain operation in the critical temperature range. To do this over a significant range requires careful modeling of bed expansion and heat-transfer characteristics. TVA reports successful tests of this method in its 20-MW pilot plant (Lewis et al., 1981). Velocity turndown allowed for a 
$20 \%$ reduction in load. Combining velocity turndown with changes in recycle ratio allowed load changes of $45 \%$. The pilot plant also demonstrated the ability to slump compartments and restart them. Combining velocity turndown, recycle, and slumping allowed operation at $35 \%$ of full load. Results of this five-year study are being applied to the design and testing of the TVA $160-\mathrm{MW}$ demonstration plant discussed in Section A.5.2.3.

\subsubsection{Reliability and Availability}

In general, the reliability and availability of AFBC systems is expected to surpass those of conventional plants fired with pulverized coal. Technical papers detailing operating experience reveal that many of the problems in demonstration plants have been with auxiliary systems (e.g., fuel-handling, ash-handling, and fly-ash-collection systems) rather than with the boiler itself (Makansi and Schwieger, 1987).

\subsubsection{Atmospheric Emissions}

Burning coal in $\mathrm{FBC}$ boilers basically produces $\mathrm{SO}_{\mathrm{x}}, \mathrm{NO}_{\mathrm{x}}$, and particulates. Sulfur dioxide emissions from a limestone-fed FBC boiler are expected to be comparable to those from a conventional coal-fired power plant with FGD, whereas $\mathrm{NO}_{\mathrm{x}}$ emissions are expected to be somewhat lower. Particulate emissions are of concern, but should be comparable in quantity to those from conventional combustion per unit of feed energy fired. However, AFBC particulates are potentially more hazardous because of their size distribution and composition, which makes them difficult to capture. The median diameter of particles emitted from FBC units appears to be smaller than those emitted from conventional coal-fired power plants.

Volatile potentially trace metals and hydrocarbons preferentially condense on the smaller particles, thus potentially increasing their health hazard. Furthermore, FBC fly ash forms at relatively low temperatures and does not fuse like conventional fly ash. For this reason, FBC fly ash can more easily release components such as metals and hydrocarbons. Because of lower operating temperatures and incomplete combustion, FBC is expected to have a higher hydrocarbon emission rate than that for conventional combustion. Results reported from recent studies are in conflict as to the health effects of hydrocarbons from FBC (DOE, 1988c).

Published information on emissions from commercial FBC units is scarce. In the utility sector, Northern States Power's Black Dog plant has achieved a fourfold decrease in $\mathrm{SO}_{2}$ emissions compared with those before the retrofit. Nitrogen oxides have been reduced by $50 \%$ (Power, 1987).

\subsubsection{Production of Solid Waste}

AFBC generates a nonhazardous solid waste stream that includes coal ash, calcium sulfate, unreacted limestone, and other fluidized-bed components. This solid waste is expected to be useful for construction aggregate or other uses. Although such 
commercial uses are being aggressively investigated, the existence of adequate markets for the volumes predicted to be generated is questionable. The amount of solid waste is a function of how much sulfur must be removed and how much excess limestone must be used. AFBC is expected to generate more solid waste on a dry basis than conventional wet-limestone FGD systems. Because of its higher density, AFBC waste requires less land for disposal than equivalent amounts of FGD sludge.

\subsubsection{Consumable Requirements}

The amount of limestone required depends on the degree of sulfur removal desired. For reasons of economy, the amount of fresh limestone being fed must be kept as low as possible. Therefore, the best way to lower $\mathrm{SO}_{2}$ emissions is to recycle the unsulfated sorbent that would otherwise be disposed of. With under-bed feed and a calcium-to-sulfur ratio of 2-2.5 and a recycle ratio of $2-2.5,90 \%$ of the $\mathrm{SO}_{2}$ can be removed. Limestone is a widely distributed and plentiful mineral.

\subsubsection{Plant Complexity and Operability}

The wide acceptance of AFBC technology in the industrial sector leads one to conclude that complexity and operability are not barriers to commercialization. However, important technical issues remain unresolved, particularly with respect to large utility boilers. The most significant of these issues center on coal and sorbent feeding, sorbent utilization, load control, erosion and corrosion, scaling methods for design of large boilers, and heat transfer.

In the utility sector, care was taken at the Northern States Power's Black Dog plant demonstration to include operating personnel as much as possible in all phases of the project. Nevertheless, startup was delayed by unexpected problems with boiler clinker, water chemistry, and existing ESPs. At Colorado-Ute Electric Association's Nucla station (Section A.5.2.8), significant bending of and damage to the structure occurred when operators restarted fluidizing fans during a shutdown, thereby igniting unburned fuel in the bed, which, in turn, caused an abrupt temperature rise and thermal expansion outside normal operating limits. The uncertainties at the Black Dog and Nucla plants stand out because almost every recent AFBC plant of smaller size has apparently performed up to and even above design specifications for reliability, efficiency, and environmental control (International Coal Report, 1987d).

\subsubsection{General Comments}

Internationally, emission standards have been tightened, especially in several European countries and Japan.* This tightening is forcing new approaches and

\footnotetext{
*The typical $\mathrm{SO}_{2}$ emissign standard in the Federal Republic of Germany, Switzerland, and Sweden is $0.4 \mathrm{lb} / 10^{6} \mathrm{Btu}$ (even for small plants), whereas the typical U.S. emission standard is $1.2 \mathrm{lb} / 10^{6} \mathrm{Btu}$ (for 73-MW plants).
} 
influencing choices among different technologies. Simple bubbling fluidized-bed combustion (BFBC) appears inadequate to meet the strictest standards. Newer and more complicated forms of the technology that employ internal recycle and staged combustion are being considered. The stricter emissions standards are also encouraging adoption of the CFBC technology, particularly for plants of larger capacity (Baker, 1986).

From an economic perspective, future coal, gas, and oil prices will continue to influence the pace of AFBC development. Given the added flexibility of fuel switching, the argument can be made that all forms of AFBC technology are economically competitive under certain market conditions.

\subsection{PRESSURIZED FLUIDIZED-BED COMBUSTION}

The PFBC technology is very similar to the AFBC technology, except that the combustion air is pressurized (10-20 atmospheres) to reduce combustor size and to obtain net power from an expansion turbine-compressor arrangement. The net plant heat rate is expected to be significantly lower than that for an AFBC plant.

Emissions of $\mathrm{SO}_{2}$ are controlled by use of an $\mathrm{SO}_{2}$ sorbent, usually dolomite. Low operating temperatures inhibit $\mathrm{NO}_{\mathrm{x}}$ formation. Particulate control in the hot gas flowing to the turbine expander is required for equipment longevity and for reducing or eliminating the need for particulate removal in the plant outlet stream.

Currently, R\&D on this concept is occurring worldwide, which probably will result in its commercialization. For now, progress appears to lag that of the AFBC concept. The PFBC is most applicable to the electric utility market. Its potential is probably greater as an option for new plants, rather than as a retrofit option for existing plants. Various coal types can be specified.

Section A.6.1 contains a technical description of the PFBC technology. Information about technology demonstrations is found in Section A.6.2. Sections 2.6.12.6.13 present various aspects that affect the marketing of this technology.

\subsubsection{Applicable Market}

The PFBC technology is applicable within a wide range of markets that include large industrial power-generation systems and electric utilities. With commercialization of standard modules based on the Tidd PFBC demonstration project (Section A.6.2.3), the module size may limit economic applications to something larger than $80 \mathrm{MWe}$.

The Federal Republic of Germany (FRG or West Germany) believes the PFBC market will become very broad and generalized. The more immediate applications are expected to be for utility power generation and district heating (cogeneration), both of which are considered compatible with PFBC design. This "young" technology already offers significant advantages over conventional power cycles, especially with regard to meeting pollution standards and yielding higher overall energy conversion efficiencies with correspondingly lower capitalization and operating costs. 


\subsubsection{Influence of Coal Type}

For PFBC systems, there does not seem to be any restrictions as to coal type or size. Coal is crushed to nominal minus $1 / 8$ inch in a water-based, paste-fuel-injection system. Fines are accepted as is. The preferred method of coal delivery is a slurry feed that uses approximately $25 \%$ water as a carrier and a conventional concrete-type pump.

Coking coal is no problem because it is the nature of fluidized beds to segregate the individual fuel particles. The combustion temperature $\left(1600^{\circ} \mathrm{F}\right.$ or $\left.870^{\circ} \mathrm{C}\right)$ is below the ash fusion temperature of any common coal. Large amounts of ash can be tolerated. High-sulfur coals are tolerated well because of the very high absorption efficiency of the bed material at relatively low calcium-to-sulfur ratios.

\subsubsection{Plant Size and Modularity Considerations}

At present, the ASEA/Babcock Group has standardized on a 200-MWt unit combustion module. The intent is to combine these modules inside a common pressure vessel to permit growth beyond $200 \mathrm{MWt}$. There are plans for a system that incorporates four 200-MWt modules for the Philip Sporn plant in New Haven, West Virginia. The pressure vessel for this plant would be 80 feet in diameter and 100 feet high. Some cost data are lacking; however, they should be forthcoming in the near future. The costs are expected to be realistic because of the modular nature of construction. Larger plant sizes can be estimated on the basis of combinations of modular components and their associated construction costs.

In FRG, the size range under consideration is $300-700 \mathrm{MWe}$, a range that could support a modular approach to construction. Two modules would be supplied instead of one, and common support facilities would be used.

\subsubsection{Status of Commercialization}

Component testing has produced technical information that should lead to a successful demonstration at the $70-\mathrm{MWe}$ (nominal output) Tidd PFBC plant. The Tidd plant is scheduled to begin operation in 1990, with testing and data collection efforts to continue through 1992. Although the Tidd project is slated for 10 years of operation and includes a three-year test program, commitments to commercial plants are expected in the mid-1990s. For commercial applications, the size of the modules will be scaled up to $320 \mathrm{MWe}$. Commercial units are expected to begin operation after 1995 but before 2000 .

The FRG expects trial operation of a complete 330-MWe PFBC power-generation system by 1995 . The present pilot plant, which represents the current stage of development, is limited to operations at approximately $5 \%$ of full scale. It is expected to demonstrate only those components directly associated with the combustion system. The turbines and cooling systems are believed to be sufficiently well developed to present no additional problems. 


\subsubsection{Capital and Operating Costs}

Estimates of current capital costs for a utility-scale power plant (250-500 MW) are on the order of $\$ 1500-1700 / \mathrm{kW}$, with first-year, nonfuel operating costs of 15-17 mills/kWh (EPRI, 1986b). These cost estimates are highly uncertain. Proponents of PFBC plants claim that costs are significantly lower than those for conventional plants. Others indicate a standoff, with lower fuel costs being the main advantage of the PFBC option. Resolving this uncertainty requires demonstration plant operating results and commercial pricing.

The FRG expects capital costs to be only $80 \%$ of those of a conventional coalfired power plant. The lower cost of the PFBC technology is attributed primarily to less steel being required and no need for add-on pollution control equipment. Thus, a 700-MWe PFBC plant is expected to require an investment of DM 800 million. Fuel expenses are expected to be approximately $90 \%$ of those associated with a conventional coal-fired plant, principally because of the higher efficiency. However, the extra cost of sorbent is expected to reduce overall savings. This cost will depend strongly on local availability of sorbent. Modular construction suggests a more linear relationship between cost and size, except for siting or land-related costs. Because combustion efficiency is high for almost any coal, costs are relatively insensitive to coal type. However, the sulfur content of the coal influences the quantity of sorbent required.

\subsubsection{Plant Performance}

Target performance for PFBCs is an overall thermodynamic efficiency of 40-42\%, which is significantly higher than that for conventional coal-fired plants. With expected increases in operating temperatures, coupled with the use of existing higher temperature materials, projected operating efficiencies could exceed 50\%. However, the need to capture sulfur and operate efficient cleanup systems may prevent achieving higher efficiencies. The FRG predicts an overall net plant efficiency of $42 \%$, which translates into a heat rate of $8125 \mathrm{Btu} / \mathrm{kWh}$.

\subsubsection{Part-Load Operation}

Individual fluidized beds cannot be derated by more than about a factor of two. However, the bed depth can be lowered, and the heat-transfer surface can be reduced, as was discussed with AFBCs. In addition, in the larger modular systems, whole beds can be taken out of service to effect turndown. By adapting this technique, turndowns approaching four to one can be expected.

If the supply of bed air, fuel, and water is shut off, the load can be reduced rather quickly. The bed will slump but remain heated for several hours to a temperature above the minimum required for reignition. The major problem with this mode of operation is control of piping wall temperatures within the bed. This piping normally operates at temperatures substantially below that of the bed. When the coolant is shut off, the piping wall temperatures will soar. Provision must be made for steam cooling or bed dumping. 


\subsubsection{Reliability and Availability}

The only information available regarding reliability comes from the extensive test and development work done on boiler tubes and gas turbine components at the ASEA component development facility in Sweden. The Tidd demonstration project should generate valuable plant data on reliability and availability. Availability is expected to be high for new systems, but life expectancy has yet to be established.

\subsubsection{Atmospheric Emissions}

Reduced atmospheric pollution is one of the selling features of PFBC systems. Ninety percent of the sulfur in high-sulfur coal can be readily captured. Emissions of $\mathrm{NO}_{x}$ depend on the amount of fuel-bound nitrogen, but an emission rate of $0.08 \mathrm{lb} / 10^{6} \mathrm{Btu}$ has been projected. Particulate emissions below EPA standards are currently achievable with standard cyclone technology in conjunction with hot gas ESPs. The higher efficiency of $\mathrm{PFBC}$ systems results in less $\mathrm{CO}_{2}$ being produced than with conventional coal-combustion technology.

\subsubsection{Production of Solid Waste}

A PFBC plant produces twice as much solid waste needing disposal as a conventional coal-combustion plant. Sorbent can be recycled within the bed to maximize the uptake of sulfur through formation of calcium sulfate. The FRG hopes to market gypsum to the building industry. The extent to which this by-product can be profitably marketed remains to be determined.

\subsubsection{Consumable Requirements}

With the exception of the increased sorbent requirement, the consumables for a $\mathrm{PFBC}$ system are expected to be similar to those for conventional coal-combustion plants equipped with limestone-based scrubbers.

\subsubsection{Plant Complexity and Operability}

Although PFBC-based plants are somewhat more complicated from a process engineering standpoint than conventional coal-combustion plants, this technology is a workable alternative.

In addition, training of personnel is not a barrier to commercialization. It is common practice for technically trained personnel to be provided to operate complex systems as part of the overall contract. In the beginning, the plant is operated vendorsupplied trained personnel who then train local people "on the job" until they are able to assume full responsibility for operations. 


\subsubsection{General Comments}

Although the Tidd project uses high-sulfur bituminous coal from Ohio as the basis for design, PFBC plants are expected to be able to fire a wide range of coals. Moreover, no technical problems are anticipated in meeting NSPS with PFBC units. As with all new technologies, however, costs and reliable performance are major issues. Many of the physical operating parameters for the pilot plants (e.g., combustor operating pressure and temperature and steam conditions) are quite similar. These similarities are in part attributable to a worldwide information network and the optimal temperature region for $\mathrm{SO}_{2}$ capture by the sorbent. The results of tests and economic studies suggest that the PFBC concept will be ready for commercialization in the mid-1990s.

\subsection{LIMESTONE-INJECTION MULTISTAGE-BURNER COMBUSTION}

The limestone-injection multistage-burner (LIMB) combustion concept was initially considered as a simple means of controlling $\mathrm{SO}_{2}$ emissions from existing boilers by injecting limestone into the furnace with the coal. Experiments have refined the concept in terms of sorbent injection, flue gas humidification, and sorbent recycle.

The primary environmental benefit is a 50-60\% reduction in $\mathrm{SO}_{2}$ emissions from conventional boilers. The resultant increased particulate loading of the flue gas of ten requires adjustments or additions to the existing removal systems. At the time the LIMB technology is retrofitted to conventional boilers, steps can be taken in some situations to control $\mathrm{NO}_{\mathrm{x}}$ emissions through addition of low- $\mathrm{NO}_{\mathrm{x}}$ burners.

$R \& D$ on sorbent injection is being conducted internationally, although much of the work is based in the United States. This technology is being applied mainly to existing boilers; however, it could be applied to new boilers in conjunction with other sulfur-removal techniques such as precombustion coal cleaning. The technology has been applied to a number of coals, from low-sulfur lignites to high-sulfur bituminous coals. The technology is best suited to high-moisture coals and to conditions requiring low levels of sulfur removal.

Section A.7.1 contains a technical description of the LIMB process. Information about technology demonstrations is found in Section A.7.2. Sections 2.7.1-2.7.13 present various aspects that affect the marketing of this technology.

\subsubsection{Applicable Market}

The LIMB process was developed mainly as a potentially less costly alternative for retrofit applications for which $50-60 \% \mathrm{SO}_{2}$ removal was adequate. This process can also apply to new boilers burning low- to medium-sulfur coals, either singly or more likely in combination with precombustion coal cleaning, but only if no more than about $70 \% \mathrm{SO}_{2}$ removal is required. However, it is doubtful whether the LIMB technology is economical when applied to new applications for which more than $90 \% \mathrm{SO}_{2}$ removal is required. Sorbent requirements would simply be too great in comparison with other alternatives for controlling $\mathrm{SO}_{2}$. 
For retrofit applications, the LIMB process technically can be applied to all types and sizes of utility boilers burning various types of coal. Available results from commercial-scale units have shown that this process is particularly suited for coals such as the brown coals, which have high moisture content.

Although the LIMB process has not been tested on U.S. industrial stoker boilers, several commercial systems have been retrofitted to traveling-grate and stoker boilers in the FRG. In comparison with utility boilers, however, the limited upper-furnace space available within typical stoker boilers would likely make the LIMB process less effective in terms of $\mathrm{SO}_{2}$ removal. Also, the limited length of the ductwork for humidification would make collecting the extra particulate matter extremely difficult. Even for utility boiler applications, economic evaluations suggest that this process is best suited to existing boilers, and particularly to plants having little remaining life, operating normally at low capacity factors, and burning low- to medium-sulfur coals. As elaborated on below, LIMB is basically a $\mathrm{SO}_{2}$-control process that has highly variable operating costs and that requires a small capital investment when compared with wet scrubbing FGD systems.

\subsubsection{Influence of Coal Type}

The LIMB technology has been implemented to control the $\mathrm{SO}_{2}$ content of flue gases from commercial-and pilot-scale boilers burning a wide variety of coals that range from low-sulfur brown coals to high-sulfur bituminous coals. In general, the technology works better with high-moisture coals and does not appear to be sensitive to mineral content. The sulfur content, on the other hand, dictates the amount of sorbent required, which may be excessive for coals containing more than $3.5 \%$ sulfur. In addition, calcium utilization decreases at the high calcium-to-sulfur stoichiometric ratio needed for high $\mathrm{SO}_{2}$ removal. As already mentioned, the LIMB technology is probably best suited for old boilers that burn low- to medium-sulfur coals. However, improvements in this technology could make it economical for boilers firing high-sulfur coals (3-3.5\%).

\subsubsection{Plant Size and Modularity Considerations}

Adequate mixing of the injected sorbent with the flue gas is critical to the dehydration and calcination of the sorbent and subsequent reaction of the sorbent with $\mathrm{SO}_{2}$ in the flue gas. The sorbent-injection systems for large furnaces with wide upperfurnace areas must be designed well or the mixing of solids and gas may not be adequate. All of the commercial units installed in the FRG and Austria have been smaller than $300 \mathrm{MWe}$. Technically, sorbent injection units with strong penetration can be designed to overcome this potential problem.

To ensure good mixing of solids and gas, the entire LIMB system should consist of several individual units installed at different locations on each of several furnace walls. This arrangement allows for load-following capability, as discussed below. 


\subsubsection{Status of Commercialization}

The LIMB technology is considered commercially available for utility and industrial boilers burning low- to medium-sulfur coals. The large-scale demonstration projects in the United States, which are mainly aimed at utility boilers burning mediumto high-sulfur coals, may further improve the economic prospects of this technology and provide a comprehensive and reliable data base for future commercial applications.

\subsubsection{Capital and Operating Costs}

The economic competitiveness of the LIMB technology depends on the levels of $\mathrm{SO}_{2}$ capture and calcium utilization. Major factors influencing these levels include (1) sorbent properties, (2) upper-furnace/boiler temperatures and residence times, (3) sorbent mixing and dispersion within the upper furnace, (4) extent of humidification, and (5) residence time inside the flue gas ductwork. (Longer residence times result in additional $\mathrm{SO}_{2}$ capture downstream of the air preheater.) Consequently, the economics of LIMB applications are strongly boiler-specific. In addition, attaining reasonable capital and operating cost estimates requires assessing the impact of sorbent injection on heat-transfer tubes, particulate-control devices (particularly ESPs), and the solid waste handling and disposal systems.

The several engineering studies conducted to estimate the cost of retrofitting LIMB systems to U.S. utility boilers produced comparable results (Offen et al., 1987; Ireland et al., 1986; Kaplan et al., 1986). Levelized costs for controlling $\mathrm{SO}_{2}$ depend greatly on the $\mathrm{SO}_{2}$ removal rates achieved by the technology. If the promising results obtained with lime hydrates at the Edgewater demonstration plant (i.e., 50\% $\mathrm{SO}_{2}$ removal at a calcium-to-sulfur ratio of 1.8 ) can be reliably achieved in long-term tests, levelized control costs should fall in the range of $\$ 800-900 /$ ton of $\mathrm{SO}_{2}$ removed for a $200-\mathrm{MWe}$ boiler burning coal containing $2.5 \%$ sulfur. These costs will vary with plant size and sulfur content of the coal.

\subsubsection{Plant Performance}

The effect of LIMB installation on boiler efficiency has not been adequately evaluated. Issues that may measurably affect boiler efficiency include (Offen et al., 1987):

- Power consumed by sorbent transport and the humidification system.

- Auxiliary power consumed by increased sootblowing.

- Increased levels of excess furnace air because of the sorbent transport air. 
- Net energy gain or loss from the difference between the endothermic dehydration and calcination and the exothermic sulfation reactions.

- Power consumed in pulverizing the sorbent.

The magnitude of the net energy gain or loss due to the chemical reactions depends on the type and quantity of sorbent injected. Estimates have indicated that, for high-sulfur coal, carbonate-based sorbents would decrease boiler efficiency by 1-2\%. Hydrated sorbents, on the other hand, would increase boiler efficiency about $0.5 \%$ because the amount of heat released during sulfation is greater than that needed for dehydration. If all effects on efficiency are considered, the decrease in total power plant output has been estimated to be about $0.5 \%$ with lime hydrate sorbents and higher with limestone sorbents.

The essential elimination of $\mathrm{SO}_{3}$ (sulfite) in flue gas with the sorbent-injection process significantly reduces the acid dew point, thereby providing potential for further heat recovery in the air preheater. If this additional heat could be recovered and used, it could offset some of the other energy losses. However, such recovery and use can be very difficult in retrofit applications.

\subsubsection{Part-Load Operation}

The ability to follow variations in boiler load is one of the most important considerations in designing and installing LIMB technology. The calcium hydrate sorbent is believed to be less sensitive to such variation than the limestone sorbent because of the high temperature (about $2200-2400^{\circ} \mathrm{F}$ or $1200-1300^{\circ} \mathrm{C}$ ) required for calcining the limestone. The LIMB package tends to be designed for operation at high boiler loads. At low boiler load (e.g., $30 \%$ of full boiler load), the temperature of the flue gas at the upper furnace will be several hundred degrees lower than that under full-load operation. The decreased temperature of the flue gas results in decreased calcination, which reduces calcium utilization and $\mathrm{SO}_{2}$ removal.

As already mentioned, sorbent injectors have been installed at several locations and levels along the furnace walls to provide a load-following capability for the LIMB technology. Such arrangements have also been used with lime hydrate sorbent to ensure that sorbents are injected into the most favorable temperature environments of the upper furnace under varying conditions of boiler load.

Aside from the need to inject sorbents into the right temperature zone $\left(800-1200^{\circ} \mathrm{C}\right)$ in the upper furnace, operation at reduced boiler loads is expected to result in improved $\mathrm{SO}_{2}$ removal because of the increased contact time between the sorbent and the flue gas in the convective-heat-transfer section of the boiler. This expectation has been borne out by all published results. 


\subsubsection{Reliability and Availability}

The large U.S. demonstration projects have been plagued by sorbent-handling problems; therefore, sufficient operating time has not accumulated to adequately assess this important issue. The commercial-scale sorbent-injection units in the FRG and Austria have reportedly operated well. However, no information has been reported concerning the reliability and availability of these installations. The increased fouling of heat-transfer tubes in the upper furnace resulting from lime-sorbent injection has largely been resolved by increased frequency of soot blowing. The reaction products generally have not been very sticky and therefore have apparently been amenable to this blowing operation.

With one or two exceptions, all commercial LIMB installations outside the United States involve boilers firing low- to medium-sulfur coals. Information regarding reliability and availability from these installations may not apply directly to LIMB installations involving boilers firing the high-sulfur coals of ten used in the United States.

\subsubsection{Atmospheric Emissions}

A potential environmental impact associated with LIMB technology is the decreased efficiency of the existing ESPs in removing particulates, which, along with increases in the amount of particulate in the flue gas, can result in an increase in the amount of particulate emitted from the stack. The level of increase cannot be accurately estimated, in part because it is likely to be site specific. In addition, various techniques (e.g., humidification, pulse energization, and addition of conditioning chemicals) are commercially available for upgrading ESP performance.

\subsubsection{Production of Solid Waste}

The major environmental impact of the LIMB process is associated with disposal of large quantities of spent sorbent. Spent sorbent is generated at an estimated rate of 0.6 ton/MWh, or about 30 tons/h for a 500-MWe plant burning coals with the following specifications: $2.5 \%$ sulfur, $12,000 \mathrm{Btu} / \mathrm{lb}$ calorific value, and a calcium-to-sulfur ratio of 1.8 for $50 \% \mathrm{SO}_{2}$ removal. Because of the high alkali content (unused calcium) in the spent sorbent, the suitability of disposing of them in facilities designed for wet-FGD sludges or spray-dry-scrubbing wastes has been questioned. Economic analyses by EPRI have indicated that the per-ton disposal cost of solid wastes from the LIMB process would probably be slightly higher than that for spray-dry-scrubbing wastes.

\subsubsection{Consumable Requirements}

For the LIMB process, sorbent requirements are proportional to the sulfur content of the coal, the level of $\mathrm{SO}_{2}$ removal, and the extent of calcium utilization. For a coal containing $3 \%$ sulfur and having a calorific value of $12,000 \mathrm{Btu} / \mathrm{lb}$, the limehydrate requirement for $50 \% \mathrm{SO}_{2}$ removal at a calcium-to-sufur ratio of 1.8 is estimated to be 0.13 ton per ton of coal, or about 0.06 ton/MWh. If additives are used to enhance 
$\mathrm{SO}_{2}$ removal, the additives required are typically less than $5 \%$ of the sorbent required. The power required for operating the LIMB process, as discussed above, is estimated to be less than $\mathbf{0 . 5 \%}$ of the electricity generated by the plant. The water required for humidifying the flue gas is not yet well defined but should be less than that needed for the spray-dry-scrubbing process, or about 1 gram per minute per megawatt (1 gpm/MW).

\subsubsection{Plant Complexity and Operability}

Because the LIMB technology does not require additional large reaction vessels, it is conceptually simpler than conventional wet-FGD systems. However, transporting and injecting fine, dry sorbents is more complex than handling the slurries typical of conventional FGD systems. Maintaining the collection efficiency of existing ESPs seems to require inclusion of a water humidification subsystem. Design and installation of a compact and effective water-injection system to achieve adequate flue-gas humidification inside the existing ductwork will be crucial to the success of the LIMB technology. Should other means be required to restore ESP performance, the LIMB technology could lose its advantage of simplicity relative to the spray-dry-serubbing process.

In terms of operability, the major concerns are the handling of fine, dry sorbents and the performance of existing ESPs, especially for applications involving boilers burning high-sulfur coals. Also, the effect of injected sorbent on heat-transfer surfaces (e.g., fouling and plugging) has yet to be assessed for commercial-scale units. The loadfollowing capability of the LIMB technology will probably not be much different from that of conventional FGD systems.

\subsubsection{General Comments}

Its simplicity of design and associated low capital investment make the LIMB technology particularly attractive to developing and industrializing countries. This technology requires neither a high level of technical sophistication nor extensive process instrumentation and controls. However, now that technology of this type has become commercially available in the FRG and other European countries for low- to mediumsulfur coals, competition from these countries in marketing the LIMB technology to developing and industrializing countries is expected to be keen.

\subsection{GAS-REBURNING SORBENT-INJECTION TECHNOLOGY}

The need for controlling both $\mathrm{SO}_{2}$ and $\mathrm{NO}_{\mathrm{X}}$ emissions has led to integration of two trechnologies: gas reburning and sorbent injection (GRSI). In the United States, this technology will likely be selected for retrofit applications that require about 50\% removal. It is expected that 50\% removal of $\mathrm{NO}_{\mathrm{x}}$ and $50-70 \%$ removal of $\mathrm{SO}_{2}$ will be attainable with GRSI.

The reduction in $\mathrm{NO}_{\mathrm{x}}$ emissions is achieved by controlling the temperature in the primary combustion zone and reburning the flue gas in a fuel-rich zone created by 
directing natural gas to the reburning zone in an amount equal to about $15-20 \%$ of the total Btu input. Much of the $\mathrm{NO}_{\mathbf{x}}$ created in the primary combustion zone is reduced to nitrogen in this reburning process.

The reduction in $\mathrm{SO}_{2}$ emissions is accomplished in two ways (assuming that the primary fuel is coal or oil with some initial sulfur content). First, the substitution of natural gas for $15-20 \%$ of the primary fuel reduces the $\mathrm{SO}_{2}$ emissions by a like amount. Second, a sorbent such as limestone or hydrated lime is injected into the flue gas, where it reacts with the $\mathrm{SO}_{2}$ to form a dry, solid product that can be removed in an ESP, a baghouse, or some other device for controlling particulates. Approximately 50\% of the $\mathrm{SO}_{2}$ can be removed in this way, which means that the overall $\mathrm{SO}_{2}$ reduction can approach 70\%.

Section A.8.1 contains a technical description of the GRSI technology. Information about GRSI technology demonstrations is found in Section A.8.2. Sections 2.8.1-2.8.13 present various aspects that affect the marketing of this technology.

\subsubsection{Applicable Market}

GRSI is applicable to all types of coal-fired boilers (Lisauskas et al., 1987). In some circumstances, GRSI may prove to be a better retrofit option than a low $-\mathrm{NO}_{\mathbf{x}}$ burner. Unlike some low-NO $\mathrm{N}_{\mathrm{x}}$ burners, GRSI does not have the problems related to increased flame length. And, low-NO $\mathrm{N}_{\mathbf{x}}$ burners are not applicable to all types of boilers. GRSI may be especially effective for use in cyclone furnaces. However, the application of GRSI to pre-NSPS boilers may be limited because of the use of over-fire air.

GRSI may provide an attractive alternative for retrofit of older boilers in efforts to comply with more stringent emissions standards. However, the higher price of gas may limit the attractiveness of the concept. For new plants, this technology may have limited attractiveness compared with other technologies that emphasize emission control. Sulfur removal is limited and probably not cost effective at high removal efficiencies.

\subsubsection{Influence of Coal Type}

Pilot testing of the GRSI technology has been conducted with bituminous coals from the following seams: Lower Kittanning, Illinois No. 6, Pennsylvania, and Wyodak. The Energy and Environmental Research Corp. (EER) demonstration is slated to use a high-sulfur bituminous coal from the Midwest. The gas reburning technology does not appear to be influenced by coal type. 


\subsubsection{Plant Size and Modularity Considerations}

Currently, the GRSI technology has been tested at the pilot scale only. However, an EER project is slated to demonstrate GRSI applicability in $40-, 80-$, and $117-\mathrm{MW}$ plants.

The following equipment may be needed to adapt a wall-fired boiler to GRSI: over-fire-air ports, dampers, duct work, and windbox; flow measurement equipment; control dampers; fuel ports; modified coal piping; burner management system; and gashandling equipment.

\subsubsection{Status of Commercialization}

Reburning and sorbent injection as separate technologies for controlling emissions have a longer history than the combination of the two. However, GRSI as a combined technology is not expected to be commercially available in the near future. Industrial-scale demonstrations are necessary to define GRSI's commercial costs and performance.

\subsubsection{Capital and Operating Costs}

Costs must be estimated because there is no plant experience to date. The estimates depend on the assumptions made as to the retrofitability of the various technologies and their resultant performance. In general, if low- $\mathrm{NO}_{\mathbf{X}}$ burners and sorbent injection are technically feasible, emission cleanup costs (expressed in dollars per ton removed) for this alternative and for GRSI are similar, for comparable levels of $\mathrm{NO}_{x}$ and $\mathrm{SO}_{2}$ removal. Some studies favor low $-\mathrm{NO}_{\mathrm{x}}$ burners and sorbent injection, while others favor GRSI.

The total capital requirement for the GRSI process appears to be $\$ 45-50 / \mathrm{kW}$ (Bartok et al., 1987). However, special factors are important in cost comparisons. For example, if ash problems dictate a boiler derating, the GRSI technology may be attractive because less coal is used per unit of output. Another special factor is the price of gas relative to that of coal. Large differences in price make the GRSI technology unattractive.

\subsubsection{Plant Performance}

Compared with a plant having no $\mathrm{NO}_{\mathrm{x}}$ or $\mathrm{SO}_{2}$ controls, a plant with GRSI technology will have a slightly higher net heat rate (Burns and Roe, 1988). Results from actual technology demonstrations are needed before the efficiency and net output of a GRSI plant can be assessed. However, the penalities are believed to be insignificant. 


\subsubsection{Part-Load Operation}

The turndown ratio, emissions control effectiveness, and fuel efficiency depend to some degree on the performance characteristics of the unmodified plant. Modifications to the burners and air ports can help in achieving a higher turndown ratio. However, the needed mixing of the gases from the first (coal-fired) combustion zone with the natural gas injected into the second combustion zone can be somewhat impaired at

low loads and lead to proportionately less $\mathrm{NO}_{\mathrm{x}}$ destruction. In general, the part-load performance of the reburning process is uncertain.

\subsubsection{Reliability and Availability}

To date, the GRSI process has not been tested on a long-term, continuous basis. Percentages are not available on facility reliability and availability.

\subsubsection{Atmospheric Emissions}

The GRSI technology is expected to reduce $\mathrm{SO}_{2}$ emissions by 50-70\% and $\mathrm{NO}_{\mathrm{x}}$ emissions by about 50\%. However, if $\mathrm{NO}_{\mathrm{x}}$ emissions at a plant are already low or near acceptable, the GRSI technology may not be able to reduce $\mathrm{NO}_{\mathbf{x}}$ emissions by $50 \%$.

\subsubsection{Production of Solid Waste}

Ash is the principal waste and depends on the coal. The calcium-based sorbent and its sulfated form are the other main wastes. Their amounts depend on the sulfur content of the coal and the amount of excess sorbent needed to attain the desired sulfur removal efficiency.

\subsubsection{Consumable Requirements}

The GRSI process consumes lime, coal, and natural gas. A 100-MW, cyclonefired plant retrofitted with GRSI technology would consume coal at a rate of 44 tons/h. Natural gas usage has been estimated at about 4 tons/h. Approximately 5 tons/h of hydrated lime would be consumed if coal containing $3.1 \%$ sulfur were burned with a calcium-to-sulfur ratio of two.

\subsubsection{Plant Complexity and Operability}

The reburning stage adds a level of complexity to conventional coal-fired power plants. Although the technologies and techniques used in the GRSI process are relatively straightforward, combining the two techniques requires increased sophistication and training to ensure that plants operate efficiently and meet environmental requirements. 


\subsubsection{General Comments}

Plants incorporating GRSI technology would have about the same operating characteristics as plants using other technologies for $\mathrm{NO}_{\mathrm{x}}$ and $\mathrm{SO}_{2}$ control. Until information on actual performance is acquired under DOE's CCT Demonstration Program, there will be little basis for this technology being selected and used for emission control. Because GRSI is predominantly a retrofit technology for coal-fired boilers, it appears an unlikely technology for significant application in developing countries.

\subsection{NOXSO PROCESS}

The NOXSO process is a postcombustion technology for combined $\mathrm{SO}_{2}$ and $\mathrm{NO}_{\mathbf{X}}$ removal. Sodium carbonate, which is deposited on a gamma-alumina substrate having high surface area, comes into contact with flue gas in a fluidized bed at a temperature of approximately $120^{\circ} \mathrm{C}$. The cleaned flue gas is directed to an ESP, baghouse filter, or other particulate-collection device before exiting the stack.

The reacted and unreacted sorbent on its carrier solid are extracted from the bed and directed to a second fluidized bed, which is heated with hot air, where the $\mathrm{NO}_{x}$ is desorbed. The heated spent sorbent is then regenerated by treating it sequentially with a reducing gas and low-pressure steam to reduce the absorbed sulfur compounds. The regenerated sorbent is then returned with make-up sorbent to the fluidized-bed absorption reactor.

It is environmentally beneficial to reduce $\mathrm{NO}_{\mathrm{x}}$ and $\mathrm{SO}_{2}$ emissions by up to $90 \%$ without generating large amounts of solid waste. Sulfur removed from the flue gas can be converted into elemental sulfur and sulfuric acid for commercial use. As mentioned above, particulates can be removed from the flue gas by conventional devices.

Research and development on this patented process is ongoing in the United States. The market for this technology is expected to include large base-load power plants fueled with high-sulfur coal. The process requires reducing gases (e.g., methane or mixtures of hydrogen and carbon monoxide). The NOXSO process should be suitable for most coal types and should be attractive when disposal of solids or sludges produced by some other emission control process is costly.

Section A.9.1 contains a technical description of the NOXSO process. Information about NOXSO technology demonstrations is found in Section A.9.2. Sections 2.9.1-2.9.13 present various aspects that affect the marketing of this technology.

\subsubsection{Applicable Market}

Although the NOXSO process can technically be applied to all coal-combustion situations, preliminary economic evaluation of this process suggests that it is probably best suited for large utility boilers burning high-sulfur coals. Like all other dry, 
regenerable flue-gas cleanup (FGC) processes, this process should be particularly applicable to plants that lack easy access to landfills for ash and sludge disposal and that are located near a market for sulfur by-products.

The NOXSO process is still at the pilot-scale stage of development. However, as is true of all regenerable systems, its complexity will likely limit its applicability with respect to industrial boilers.

\subsubsection{Influence of Coal Type}

To date, the NOXSO process has been tested only on flue gases from eastern high-sulfur bituminous coals. The coal burned in the pilot-scale tests at DOE's PETC was a Pittsburgh Seam coal (Yeh et al., 1987).

It has not been documented whether the high moisture content of flue gas from high-moisture, low-rank coals adversely affects the performance of NOXSO sorbents. Also, it is not known whether trace elements in the flue gas from certain types of coal adversely affect NOXSO sorbents via mechanisms like pore plugging or formation of stable, nonregenerable compounds.

\subsubsection{Plant Size and Modularity Considerations}

To date, the NOXSO process has been evaluated only at sizes equivalent to $1 \mathrm{MWe}$. An integrated pilot plant equivalent to $5 \mathrm{MWe}$ has been laid out and is expected to be constructed and evaluated in the near future.

In the case of large utility boilers, the NOXSO process would probably be modular, with each module being sized to treat an amount of flue gas equivalent to that produced by a 100 to $150-\mathrm{MWe}$ boiler. For utility applications, incorporating one or two spare modules would ensure improved system reliability and availability.

\subsubsection{Status of Commercialization}

The NOXSO process was expected to be commercially available by 1995 . However, on the basis of its current development, this expectation appears extremely optimistic. The process will probably not be commercially available before 1997 .

\subsubsection{Capital and Operating Costs}

The NOXSO process was economically evaluated in a study sponsored by EPRI (Stearns Catalytic Corp., 1986). Costs were estimated in 1982 U.S. dollars for a nominal 1000-MWe plant (actually two 500-MWe units). The capital-cost estimates assume a system of 10 fluidized-bed absorbers, eight of which are in operation and two of which are spares. Each unit is 25 feet in diameter, with an 80 -foot straight side and cone bottom. A Texaco gasification subsystem produces the synthetic gases needed for 
regenerating reacted sorbents. Each absorber contains about 200 tons of sorbent and operates at a pressure drop of 22 inches of water and a residence time of 45 minutes. The design coal for the boiler was an Illinois coal containing $4 \%$ sulfur. Ninety percent $\mathrm{SO}_{2}$ removal was assumed.

Total process capital for the NOXSO system is estimated to be $\$ 134.60 / \mathrm{kWe}$ (Stearns Catalytic Corp., 1986). Based on including 21\% for overall project contingency and $14 \%$ for process contingency and a three-year construction schedule, the total plant investment and the total capital requirement for the NOXSO system were estimated to be $\$ 232.40 / \mathrm{kWe}$ and $\$ 246.80 / \mathrm{kWe}$, respectively. The net power generated, excluding the NOXSO and particulate-removal systems, was calculated to be $1044 \mathrm{MWe}$. Including the NOXSO and particulate-removal systems reduces the net power output to $989 \mathrm{MWe}$.

The following assumptions were made in estimating the annual operating and maintenance (O\&M) cost: (1) a sorbent feed rate of $880 \mathrm{lb} / \mathrm{h},(2)$ a coal feed rate to the gasifier of 13.1 ton $/ \mathrm{h},(3)$ an oxygen feed rate to the gasifier of $10.7 \mathrm{ton} / \mathrm{h}$, and (4) a lowpressure steam rate of $6300 \mathrm{lb} / \mathrm{h}$ for regeneration. Additionally, the overall maintenance factor for the process was assumed to be $3.8 \%$ of the total process capital (determined in the EPRI evaluation). The first-year O\&M cost was estimated to be about $5 \mathrm{mills} / \mathrm{kWh}$ for this system.

EPRI also reported on a limited set of sensitivities. The economics of the NOXSO process are sensitive to sorbent feed and attrition rates, sorbent cost, and byproduct value.

\subsubsection{Plant Performance}

Some of the NOXSO subsystems have not been completely worked out; therefore, overall efficiency has not been measured by incorporating the process into a boiler facility. Table 2.11 breaks down the estimated power requirements to operate a complete NOXSO plant for treating flue gases from a nominal 1000-MWe power plant (Stearns Catalytic Corp., 1986). The total power requirement for the NOXSO system appears to be in the range of 5-6\% of the nominal power output of the power plant.

\subsubsection{Part-Load Operation}

Systems for cleaning flue gas are normally sized for treating flue gas from coalfired boilers at their maximum operating loads. At low boiler loads, the quantity of flue gas decreases and the time the gas resides in each of the reaction vessels increases. For the NOXSO process, this situation should result in increased removal of $\mathrm{SO}_{2}$ and $\mathrm{NO}_{\mathrm{x}}$ at the same sorbent flow rate. Or, the sorbent feed rate could be decreased to maintain the same levels of $\mathrm{SO}_{2}$ and $\mathrm{NO}_{\mathrm{x}}$ removal. 
TABLE 2.11 Estimated Power Required to Operate a NOXSO Unit for a 1000-MWe Power Plant

\begin{tabular}{lr}
\hline \multicolumn{1}{c}{ Component } & $\begin{array}{c}\text { Power } \\
\text { Consumption } \\
\text { (MW) }\end{array}$ \\
\hline Reagent feed & 0.4 \\
SO ${ }_{2}$ removal & 1.2 \\
Flue-gas handling & 23.4 \\
Regeneration & 24.9 \\
By-product production & 0.3 \\
Waste handling & 0.4 \\
General support & 0.2 \\
Particulate removal & 4.0 \\
Total & 54.8 \\
\hline
\end{tabular}

\subsubsection{Reliability and Availability}

Assessing the reliability and availability of the entire NOXSO system has been impossible because no large-scale NOXSO plant has been in operation. Because of its complexity and the need to handle large quantities of solid sorbents, the NOXSO process is expected to be less reliable than most of the once-through FGC systems (e.g., spraydry scrubbers). Additionally, the need to operate the regeneration units at $600^{\circ} \mathrm{C}$ results in long startup and shutdown procedures. The long startup time could affect system availability if a spare regeneration train must quickly replace a failed train. Another potential problem is the reliability of the solids-handling equipment in a hightemperature application.

\subsubsection{Atmospheric Emissions}

After FGC by means of the NOXSO process and conventional particulate collection, the amounts of $\mathrm{SO}_{2}, \mathrm{NO}_{\mathrm{x}}, \mathrm{CO}_{2}$, and particulate in flue gas exiting the stack are estimated to be $2.7,0.4,735$, and 0.007 ton/h, respectively. These amounts are based on a new plant (nominally $1000 \mathrm{MWe}$ ) burning high-sulfur (4\%) Illinois coal and meeting all applicable environmental regulations (Stearns Catalytic Corp., 1986).

\subsubsection{Production of Solid Waste}

No major environmental impacts are expected from incorporating the NOXSO process into a coal-fired plant. The major additional sources of environmental concern are the slightly increased ash loading in the flue gas from the sorption vessel due to 
attrition of the sorbent and the effluent from the by-product recovery subsystem. However, both sources are commonly encountered in other settings. The amount of sorbent attrition has been estimated to be $0.44 \mathrm{ton} / \mathrm{h}$ for the hypothetical $1000-\mathrm{MWe}$ plant. A small quantity of spent catalyst would also result from by-product recovery. Because the regeneration portion of the NOXSO system has not yet been fully developed, the amount of spent catalyst cannot be accurately estimated.

\subsubsection{Consumable Requirements}

Sorbent requirements for the NOXSO process depend strongly on the sorbent attrition rate. For a plant consisting of two 500-MWe units burning high-sulfur coal and experiencing a sorbent attrition rate of $0.03 \%$ of the sorbent mass-circulation rate, the amount of fresh sorbent required has been estimated to be about $0.44 \mathrm{ton} / \mathrm{h}$ (Stearns Catalytic Corp., 1986). This volume is also the amount of solid waste, in addition to fly/bottom ash, that must be disposed of from the process. Fuel requirements for heating and desorbing the reacted sorbents are estimated to be $7200 \mathrm{lb} / \mathrm{h}$ of No. 6 oil for the 1000-MWe plant. (If appropriate, the heat-equivalent amounts of coal or natural gas could be used to replace fuel oil in this process.)

The sorbent-regeneration and by-product-recovery subsystems are still under development; therefore, the requirements for reducing gas, steam for the regeneration, and process water for by-product recovery cannot now be accurately estimated. In its EPRI-sponsored study, Stearns Catalytic Corp. (1986) estimates that, for a plant consisting of two 500-MWe units at full load, the total process water requirement is $680 \mathrm{gpm}$, and the low-pressure-steam requirement is $6300 \mathrm{lb} / \mathrm{h}$.

\subsubsection{Plant Complexity and Operability}

The NOXSO process is fairly complicated, involving both absorption and extensive regeneration subsystems. Skilled and experienced personnel may be required for operating and maintaining the entire plant. The process generates little additional wastes other than more fly ash and some lost sorbent, and it can produce valuable sulfur compounds. These features should make the NOXSO process particularly attractive to those developing and less-developed countries with limited available land but a skilled labor force.

\subsubsection{General Comments}

The NOXSO process, which is still at the pilot-scale stage, has not attracted much attention outside the United States. A recent agreement between DOE and W.R. Grace \& Co. to jointly develop and commercialize this process has enhanced its chances of success. EPRI, in its economic evaluation of a variety of FGC processes, whether commercially available or under development, placed the NOXSO process among the low-cost technologies in the category of combined $\mathrm{SO}_{2}$ and $\mathrm{NO}_{\mathrm{x}}$ control. However, the annual operating cost of the process is strongly affected by the sorbent attrition rate and the price for the by-product, both of which are not yet established. The ongoing life- 
cycle tests of the sorbent are expected to confirm the chemical and physical stability of the sorbent. Significant work is still needed on the regeneration and by-product

subsystems. The progress, or lack of progress, during the next two to three years will be crucial in determining whether the NOXSO process can move into the commercial arena in the near to intermediate future.

\subsection{SPRAY-DRYER PROCESS}

The spray-dryer FGD process combines two commercially available technologies: spray drying and particulate collection. In the first step, a sorbent is mixed with water to form a slurry. (The sorbent is typically lime or limestone, although sodium-based compounds such as soda ash have also been used.) In some applications, the slurry is mixed with spent sorbent, a recycling step that provides for more complete use of the sorbent. The slurry is sprayed as a fine mist into a drying chamber, where the atomized droplets come in contact with the hot, $\mathrm{SO}_{2}$-laden flue gas. Upon contact, two things happen. First, water droplets begin to evaporate, which lowers the temperature of the flue gas. Second, $\mathrm{SO}_{2}$ is absorbed by the droplets, reacting with the sorbent to produce calcium (or possibly sodium) sulfite and water. Some of this sulfite is oxidized by oxygen in the flue gas to form sulfate.

A portion of the dried particulate matter falls to the bottom of the drying chamber. The remainder is entrained in the cooled flue gas and transported to an ESP or baghouse with fabric filters. After particulate removal, the flue gas is released to the atmosphere. Most of the $\mathrm{SO}_{2}$ reduction takes place in the drying chamber, although significant reduction can take place in the fabric filter.

Most of the demonstrations of the spray-dryer FGD process have involved low- or medium-sulfur coals. However, extensive work has also shown that significant $\mathrm{SO}_{2}$ reductions can be achieved with high-sulfur coals. In principle, this technology is applicable to all coal types and sulfur contents. However, there may be a practical limit on sulfur content (about 3.5\%) because of difficulties in injecting enough slurry into the drying chamber without causing condensation problems. In high-sulfur applications, the cost of the sorbent also places practical limits on sulfur content and on achieving removal efficiencies above 70-80\%.

Section A.10.1 contains a technical description of the spray-dryer FGD process. Information about technology demonstrations of this process is found in Section A.10.2. Sections 2.10.1-2.10.13 present various aspects that affect the marketing of this technology.

\subsubsection{Applicable Market}

The spray-dryer FGD process was developed to compete with wet FGD processes. The main advantages of the dry process as against its wet counterparts are: (1) production of dry waste, which is easier to dispose of; (2) lower power and water requirements; (3) simplicity, which translates into better availability and reliability; and (4) less troublesome operation of the gas-slurry reaction chamber. The small water 
requirement, on the other hand, places an upper limit on how much active sorbent and recycled spent sorbent can be mixed with water and injected into the reaction chambers.

In general, the Danish lime-based spray-dryer FGC technology (NIRO Atomizer) is considered to be well established and applicable to all types and sizes of boilers burning low- to medium-sulfur coals. Although existing boilers of this type could theoretically be retrofitted with this technology, the space available could prove to be a constraint. Still, dry systems are perceived as more advantageous than wet systems for retrofit applications because of their relative compactness.

Even though the spray-dry scrubbing process does not use calcium as efficiently as the wet FGD systems, overall economics appears to favor the dry system over the wet systems, at least in applications involving large utility boilers burning low- to mediumsulfur coals.

\subsubsection{Influence of Coal Type}

For applications involving boilers burning coal with more than $3.5 \%$ sulfur, the limit on the amount of water-sorbent slurry that can be injected into the drying chamber, without causing condensation problems, severely constrains the level of $\mathrm{SO}_{2}$ removal achievable. This constraint is especially stringent during low-load operation, when the temperature of the flue gas exiting the air preheater is typically $15-20^{\circ} \mathrm{F}\left(8-12^{\circ} \mathrm{C}\right)$ lower than during full-load operation. This limitation appears to be the main reason, apart from uncertainties related to economics, that no commercial spray-dry scrubber has been installed on new utility boilers that burn coal with more than $3.5 \%$ sulfur and that must achieve $90 \% \mathrm{SO}_{2}$ removal. However, such scrubbers can be retrofitted to existing utility and industrial boilers firing high-sulfur coal if only a moderate level of $\mathrm{SO}_{2}$ removal $(70-80 \%)$ is required.

The chlorine content of coal significantly affects the design and performance of spray-dryer FGD systems. In contrast to what has generally been observed with wet FGD systems, the presence of chlorine generally improves $\mathrm{SO}_{2}$ removal because of the formation of calcium chloride, a compound that traps moisture. On the other hand, the high water content of the dried solid materials exiting the drying chamber necessitates a slightly higher flue gas temperature at the outlet to avoid potential condensation and corrosion problems in the downstream particulate-collection devices.

No other constituent has been reported to significantly affect $\mathrm{SO}_{2}$ removal and system operation. The moisture content of the coal requires an adjustment in the amount of water injected into the spray-dryer system.

\subsubsection{Plant Size and Modularity Considerations}

To date, the Danish lime-based spray-dryer FGD system has been applied to commercial coal-fired boilers that range in size from small industrial boilers to utility boilers as large as 860 MWe. For large boilers, the system is modularized. The largest 
available individual module can treat an amount of flue gas equivalent to that produced by a 150-MWe boiler. The modular approach provides the load-following capability needed for large utility boilers and also improves system reliability and availability.

Regardless of boiler size, low boiler loads can lead to undesirable gas/slurry mixing patterns inside the drying chamber. However, this effect is largely offset by the proportionately longer gas-residence time associated with low-load operation.

\subsubsection{Status of Commercialization}

The Danish lime-based spray-dryer FGD system has been commercially available since the early $1980 \mathrm{~s}$.

\subsubsection{Capital and Operating Costs}

The economics of a large number of FGD processes, including the spray-dryer FGD process, have been studied in detail (Stearns Catalytic Corp., 1986). This EPRIsponsored study was based on a 1000-MWe power plant and economic criteria established in EPRI's technology assessment guide (EPRI, 1986b).

For the case in which a high-sulfur (4\%) Illinois coal was assumed, total process capital was estimated at $\$ 71 / \mathrm{kW}$ within a total capital requirement of $\$ 134 / \mathrm{kW}$ (in 1982 U.S. dollars). The 30-year levelized cost of electricity was estimated to be $15.5 \mathrm{mills} / \mathrm{kWh}$.

In the case of low-sulfur coal, total process capital and total capital requirements were estimated at about $\$ 65 / \mathrm{kW}$ and $\$ 111 / \mathrm{kW}$ (in 1982 U.S. dollars), respectively (Stearns Catalytic Corp., 1983). The levelized 30-year cost of electricity was calculated to be $7.5 \mathrm{mills} / \mathrm{kWh}$. Note that the incremental cost of electricity, based on including spray-dryer FGD, is highly sensitive to the sulfur content of the coals.

\subsubsection{Plant Performance}

In operating spray-dryer FGD systems, energy is consumed by the fans that drive flue gas through the system, by the pumps that deliver the slurries and waters, and by the motor or high-pressure pump that drives the atomizers. In addition, comparatively small amounts of energy are consumed by the slaker, agitators, conveyors, bucket elevators, gate valves, and other minor equipment. The total energy required for these operations typically amounts to about $7-8 \mathrm{~kW} / 10^{3}$ standard cubic feet/minute (scfm) of flue gas from boilers burning high-sulfur (4\%) coal. This amount translates into a power requirement of about $8.5-10 \mathrm{MWe}$ for a $500-\mathrm{MWe}$ power plant, or about 1.7-2.0\% of total plant output (Stearns Catalytic Corp., 1986).

Boilers burning low-sulfur coals require less power to operate the spray-dryer FGD system. For a nominal 1000-MWe boiler burning western low-sulfur (0.5\%) coal, the 
power requirement was estimated to be about $1.2 \%$ of total plant output (Stearns Catalytic Corp., 1983).

\subsubsection{Part-Load Operation}

For small, single-chamber systems, the spray-dryer FGD unit has been designed to operate successfully from full load down to $33 \%$ of full load. As already mentioned, the slightly inferior slurry/gas mixing pattern encountered in low-load operation is largely offset by the increased gas/particulate residence time in the drying chamber.

For large utility boilers, the modular design possible with this process provides load-following capability. The largest spray-dryer FGD system at the Northern States Power's Sherburne Unit 3, has been successfully operated from full load down to $25 \%$ of full load (Donnelly et al., 1988).

\subsubsection{Reliability and Availability}

Typically, to ensure adequate system reliability and availability in utility boiler applications, redundant components are built into FGD systems For example, the spraydryer scrubber system constructed for the largest utility boiler ( $860 \mathrm{MWe}$ ) at Sherburne includes two spare spray dryers, along with the six routinely needed for treating flue gas (Donnelly et al., 1988). The availability of commercial spray-dryer FGD systems in the United States and abroad is very good. For the six U.S. utility-scale units in operation since 1985 , reported availability data range from $96 \%$ to virtually $100 \%$. Similarly sized units installed in Europe have generally registered comparable system availabilities (Felsvang et al., 1988).

\subsubsection{Atmospheric Emissions}

The spray-dryer FGD system can control $\mathrm{SO}_{2}$ and particulate levels in flue gas from coal-fired boilers to within regulatory limits. The actual levels of $\mathrm{SO}_{2}$ and particulates in the flue gas as it exits the spray-dryer system depend on the level of control required and the sulfur and mineral contents of the coal. Coal-fired plants may also emit other atmospheric pollutants that result from the storage and handling of pebble lime and from transport of dry solid waste to the disposal site.

\subsubsection{Production of Solid Waste}

Lime-based spray-dryer FGD systems affect the environment most by generating large quantities of dry solid wastes. The amount of waste generated, as well as the amount of fresh lime required for the system, depends strongly on the sulfur content of the coal and on the level of $\mathrm{SO}_{2}$ control desired. The quantity of solid waste generated was estimated to be 158.3 tons/h (including 63.2 tons/h of fly ash) for a nominal 1000 MWe plant burning high-sulfur coal (Stearns Catalytic Corp., 1986). For a plant burning 
low-sulfur-coal, the amount of solid waste generated is, as expected, considerably less, that is, about 48.9 tons/h (including 38.2 tons/h of fly ash) (Stearns Catalytic Corp., 1983).

The leaching characteristics of solid waste from commercial spray-dryer FGD systems have been investigated; in each case, the researchers concluded that the wastes are not Resource Conservation and Recovery Act (RCRA) wastes (Farber et al., 1983b; Dawson et al., 1988a). However, because of their high elemental calcium content, these wastes will undoubtedly have to be conditioned before being disposed of in a landfill. One treatment option is the addition of water.

Other minor environmental intrusions may result from storing and handling pebble lime and from transporting dry waste to the disposal site.

\subsubsection{Consumable Requirements}

Major resources, other than electricity, required for operating the Danish spraydryer FGD system are pebble lime and process water. For a nominal 1000-MWe power plant burning Illinois high-sulfur (4.0\%) coal and operating at full load, the amount of pebble lime required was estimated to be 49.6 tons/yr, and the raw process water required was estimated at 1010 gpm (Stearns Catalytic Corp., 1986).

The pebble lime required for the spray-dryer FGD system depends strongly on the sulfur content of the coal and the level of $\mathrm{SO}_{2}$ removal desired. For a nominal 1000-MWe plant burning low-sulfur (0.5\%) subbituminous coal, the pebble-lime consumption rate was estimated to be 5.4 tons/h (Stearns Catalytic Corp., 1983). However, the raw process water required was estimated at about $860 \mathrm{gpm}$, that is, not significantly different from the amount required for burning high-sulfur coal.

\subsubsection{Plant Complexity and Operability}

The Danish lime-based spray-dryer FGD system has fewer components than commercial wet FGD systems and is therefore less complex and more reliable. In general, spray-dryer scrubbers are straightforward to operate and do not require highly skilled personnel. Servicing rotary atomizers, on the other hand, requires experience.

The first-generation unit installed at Argonne National Laboratory (Section A.10.2) responded slowly (an hour or more) to variations in stack $\mathrm{SO}_{2}$ levels. Design of a quick-response head tank reduced response time to a few minutes. Other improvements in design and equipment are being made at several of the commercial units to further enhance system operability. Since 1985, an annual meeting has been held to facilitate exchange of information concerning improvements to spray-dryer FGD systems. 


\subsubsection{General Comments}

The Danish lime-based spray-dryer FGD system is well established and highly reliable. With financial assistance from the Danish government, the developer of the process has been aggressively marketing this process in the United States and in developing and industrializing countries (e.g., the PRC). In a licensing arrangement with the PRC, Niro Atomizer is supplying only key components such as the atomizer, gas disperser, product conditioner, double-flap valves, and instrumentation and control system, in addition to basic engineering and technical support. Licensing flexibility and aggressive marketing have made the Danish system very competitive worldwide. This system will certainly provide strong competition in developing and industrializing countries for U.S.-based FGD technologies.

\subsection{DUAL-ALKALI PROCESS}

The dual-alkali process incorporates two loops; the first removes $\mathrm{SO}_{2}$ from the flue gas, and the second regenerates the sorbent. In the first loop, sodium carbonate reacts with $\mathrm{SO}_{2}$ to produce a clear liquor of sodium sulfite/bisulfite. This clear liquor is an improvement over the slurries used in conventional FGD systems. First, the pumps and nozzles for handling the slurries and other slurry-sensitive items are eliminated. Second, solids scaling in the absorber portion of the system is avoided. Both of these advantages result in availabilities higher than those typically realized in slurry-based FGD systems.

In the second loop, the clear liquor from the first loop is exposed to a hydratedlime slurry so that the sodium sorbent can be regenerated for recycle back to the first loop. The regeneration reactions produce a mixture of calcium sulfite and sulfate solids similar to the solids produced in conventional FGD systems. The only difference is that the dual-alkali process solids are high in sodium.

This technology can be used with any type of coal, irrespective of its sulfur content, ash content, or heating value. High-sulfur coal applications may be the most efficient because the operational advantages of the clear liquor outweigh the disadvantage of potential leaching of sodium from the waste produced. Applicable to industrial- and utility-scale facilities, the technology can be used for retrofitting existing plants and for new ones.

Section A.11.1 contains a technical description of the dual-alkali process. Information about technology demonstrations of the process is found in Section A.11.2. Sections 2.11.1-2.11.13 present various aspects that affect the marketing of this technology.

\subsubsection{Applicable Market}

The applicable market for the dual-alkali process is the electric utility and industrial FGD market, both for new and retrofit applications. Although this process has been operated very successfully on more than $2.3 \mathrm{GW}$ of scrubber capacity, this level 
represents only $3.5 \%$ of committed scrubber capacity (Hance, McKibbon, and Jones, 1990). In the electric utility sector, lime and limestone FGD and spray-dryer FGD systems continue to dominate. In the industrial sector, the dual-alkali systems have thus far dominated. A continuation of this latter trend is likely.

Plants burning high-sulfur coals will continue to be the most effective application of the dual-alkali process. In this arena, the operational advantages of clearsolution scrubbing outweigh the disadvantage of possibly leaching sodium from the sludge produced. In addition, the likelihood of more stringent $\mathrm{NO}_{\mathrm{x}}$ emission standards in future reauthorizations of the Clean Air Act may make the dual-alkali technology, in conjunction with metal-chelate additives, very attractive.

\subsubsection{Influence of Coal Type}

The dual-alkali process can be used to remove sulfur from flue gas from plants burning any coal, regardless of sulfur content, heating value, or ash content. However, the technology should achieve its greatest market penetration in applications involving boilers burning coals with a sulfur content higher than $2 \%$.

\subsubsection{Plant Size and Modularity Considerations}

There are no issues relating to size range or modularity that are expected to impede further commercialization and deployment of the dual-alkali process. Commercial-scale installations have ranged from small industrial boilers ( $1 \mathrm{MWe})$ to a utility demonstration unit (600 MWe).

Typical design practice for aqueous scrubbers yields a parallel train of three spray-tower absorbers, each providing $35 \%$ of the needed capacity, and one spare absorber that can be swung on-line when required (e.g., while maintenance is being performed on one of the other absorbers). The current economics (based on work by Stearns-Roger for EPRI) assumes this configuration. However, a trend is now evident toward reducing the number of absorber modules and eliminating the spare. It should be easy to adapt the dual-alkali process to this trend. Within the medium term, one- or two-module systems for 500-MW plants may become typical.

\subsubsection{Status of Commercialization}

The dual-alkali system is commercially available for use in both the industrial and electric utility sectors; it is the dominant FGD process in the industrial sector.

The commercial-scale demonstration of limestone dual-alkali technology at the Central Illinois Public Service Company (CIPS) Newton Power Station, Unit 1, has led to a number of patents on equipment and process innovations. This utility and Codan Associates (Salt Lake City, Utah) have participated in this cooperative venture since 1984. 


\subsubsection{Capital and Operating Costs}

The results of a survey of FGD system costs conducted by Stearns-Roger for EPRI (Keeth et al., 1983) show that the cost effectiveness of the dual-alkali process was considered to be comparable to that of other established FGD technologies. A levelized busbar cost of $15.6 \mathrm{mills} / \mathrm{kWh}$ was projected for controls at a grass-roots boiler fired with pulverized high-sulfur (4\%) coal. This cost is composed of the following cost elements:

\section{Cost Element}

Capital ( $\$ 162 / \mathrm{kW})$

Fixed operating

Variable

Total levelized

Reference case levelized

Levelized busbar for FGD
Cost

(mills/kWh)

$$
6.3
$$

10.3

19.4

3.8

15.6

For this case (i.e., a 1000-MW power plant burning Illinois No. 6 coal [4\% sulfur]), the cost per ton of $\mathrm{SO}_{2}$ removed is $\$ 669$.

In the above analysis, no credit was taken for the improvements in system availability that have consistently been demonstrated by the dual-alkali process. Also, the commercial-scale demonstration at the Newton Power Station postdates the study from which the figures are quoted. The only systems operating at lower cost are the Japanese Chiyoda and Dowa systems.

In the case of the Chiyoda and Dowa systems, the economics need further definition before conclusions can be drawn regarding cost advantages. Testing of the Dowa system at TVA's Shawnee Test Facility has been limited to pilot-scale tests (Jackson et al., 1981). Also, even advocates have cited the need for metallurgy that is more acid resistant. The Chiyoda system was expected to undergo its first industrialscale demonstration with high-sulfur coal during 1989. Both the Chiyoda and Dowa systems have projected cost advantages that are related to the production and sale of gypsum. However, the extent of the U.S. market for FGD by-product gypsum has continued to be debated. Thus, the above cost advantages should be treated with caution.

\subsubsection{Plant Performance}

Parasitic power consumption by nonregenerable FGD systems is typically less than 3\%; for regenerable systems, somewhat more power is required. Stearns-Roger has estimated that $3.3 \%$ of power output is consumed by the dual-alkali process (Keeth et al., 1983). 


\subsubsection{Part-Load Operation}

FGD systems have been designed to be flexibile enough to easily follow boiler loads over a limited range. In general, the economical range of operation for the boiler turndown ratio should be the same as that for the FGD-system ratio, and the turndown ratio would probably not exceed $33 \%$. Because most boilers are designed with a turndown ratio of about 3 to 1 , dual-alkali FGD systems may also be considered to have a turndown ratio of about 3 to 1 .

Wet FGD systems experience operating problems when they follow rapid swings in boiler load. The dual-alkali process represents an additional level of complexity. As a consequence, although the volume of scrubber liquor held within the FGD system provides for significant buffering capacity, domestic FGD systems are usually considered as applicable to base-load units with limited load-following capacity. The environmental regulations in some parts of Europe (e.g., Denmark and the FRG) have demanded rapid load-following capacity as part of FGD system design. These design demands have been met.

\subsubsection{Reliability and Availability}

The high availabilities demonstrated by dual-alkali applications have been one of the technology's chief attractions. When the technology is installed at plants burning high-sulfur coal, availabilities are typically $95 \%$ and higher.

\subsubsection{Atmospheric Emissions}

The $\mathrm{SO}_{2}$-removal efficiencies achieved by dual-alkali systems are either the same as or higher than those achieved by conventional lime and limestone FGD. Sulfur dioxide removals higher than 95\% have been sustained for extended periods of time. A major factor contributing to the advantage of dual-alkali systems over slurry FGD systems has been the use of a clear scrubbing liquor. In addition, because the limestone is regenerated in a second loop after scrubbing, very low levels of excess limestone use have been observed. Ninety percent limestone utilization is considered to be the typical design condition.

Combining dual-alkali scrubbing with the addition of metal chelates may result in $\mathrm{NO}_{\mathrm{x}}$ removals of $70 \%$ or higher (for high-sulfur coals) (Harkness, Doctor, and Livengood, 1987). However, this approach to combined $\mathrm{SO}_{\mathrm{x}} / \mathrm{NO}_{\mathrm{x}}$ control is still being developed.

Particulates are collected with ESPs or baghouses ahead of the scrubbing process, with a typical efficiency of $99.8 \%$. To be effective, aqueous FGD systems must provide for intimate contact between the gaseous and liquid phases. Prescrubber particulate collection plus scrubbing virtually eliminates particulate emissions. 


\subsubsection{Production of Solid Waste}

The solid waste produced annually from a $1000-\mathrm{MW}$ boiler burning an Illinois No. 6 coal ( $4 \%$ sulfur) amounts to 914 acre-feet. This volume is lower than that associated with most other current FGD systems. The sludge is dewatered to $70 \%$ solids, which is a very high value. A lime or fly ash fixative could be used, but such use is not essential. The issue of the sodium content of the waste and possible leaching has already been discussed. Future regulations may require the use of a lined landfill.

\subsubsection{Consumable Requirements}

The Stearns-Roger projections of consumable requirements for two 500-MW boilers with installed limestone FGD systems appear below (Keeth et al., 1983):

\begin{tabular}{|c|c|}
\hline Chemical & Quantity \\
\hline Limestone & 1.05 stoichiometric ratio \\
\hline Lime & $3 \%$ of solids \\
\hline Soda ash & 0.0425 stoichiometric ratio \\
\hline Water & $1.25 \mathrm{gal} / \mathrm{min} / \mathrm{MW}$ \\
\hline
\end{tabular}

The operating experience at the CIPS Newton Power Station demonstrated a calcium-tosulfur ratio of 1.1 and a sodium-to-sulfur ratio of $\mathbf{0 . 0 5}$. Water consumption was not reported. These results corroborate the design values, showing that the targets represent reasonable goals that can likely be obtained in the future.

\subsubsection{Plant Complexity and Operability}

The dual-alkali process appears more complicated than conventional limestone FGD. In a study conducted several years ago, Doctor (1982) showed that electric utilities operating their first FGD systems of ten experience up to a year of startup problems with conventional limestone FGD systems. Those starting to operate dual-alkali systems appeared to spend less time in shakedown operations, usually only a few months. Apparently, the dual-alkali technology offers some inherent startup advantages.

\subsubsection{General Comments}

The dual-alkali process is firmly based technically and is being commercially operated, predominantly in the industrial sector. The process is more reliable than other FGD systems in that there are fewer scaling problems.

This technology can be adapted for either lime or limestone. The demonstration results indicate that limestone may offer the most potential for achieving economical operation. Sodium leaching from the sludge disposal area remains an inherent disadvantage of the dual-alkali process. 


\subsection{SELECTIVE CATALYTIC REDUCTION}

The SCR process decreases the amount of $\mathrm{NO}_{\mathrm{x}}$ in flue gas by adding ammonia in the presence of a catalyst. This technology can be applied to flue gas from various energy conversion devices. In the case of utility boilers, the reactor is usually placed downstream of the economizer so that process temperatures are in the optimal range $\left(600-750^{\circ} \mathrm{F}\right.$ or $\left.315-400^{\circ} \mathrm{C}\right)$. Catalyst lifetime -- an important economic factor -- is influenced by the amount of fly ash and the characteristics of the flue gas. In some concepts, designers have proposed removing the ash from the flue gas before contact with the catalyst.

The main environmental benefit is large reductions in $\mathrm{NO}_{\mathrm{x}}$ emissions (70-80\%) from coal-burning facilities without generating solid or liquid wastes other than the spent catalyst. However, reducing $\mathrm{NO}_{\mathrm{X}}$ emissions by this means is very expensive.

Current $R \& D$ efforts are international in scope, with the largest program underway in Japan where work has been ongoing for 25 years. The SCR technology has been installed worldwide on about $15,000 \mathrm{MW}$ of new and existing capacity over the last decade. Coal characteristics are quite important in deciding whether to use the SCR technology. In Japan, low- and medium-sulfur, low-ash coals have been used. The catalyst can be eroded by ash as well as poisoned by trace elements in the ash. High levels of $\mathrm{SO}_{2}$ in the flue gas can result in its oxidation to $\mathrm{SO}_{3}$, which in turn also poisons the catalyst.

Although the SCR process has been installed in numerous noncoal and somewhat fewer coal applications, it will probably not be considered for use in developing countries or be widely installed in coal-fired plants abroad until much more experience has been gained. One reason for its nonacceptance is the high cost of this capital-intensive technology.

Section A.12.1 contains a technical description of the SCR process. Information about technology demonstrations of this process is found in Section A.12.2. Sections 2.12.1-2.12.13 present various aspects that affect the marketing of this technology.

\subsubsection{Applicable Market}

In Japan, the SCR process has been widely applied in the electric utility sector, both for existing and new units (Kuroda et al., 1989). In Europe, the FRG and Austria have seven utility applications (Cichanowicz, 1987). The boilers involved range from 30 to $1000 \mathrm{MW}$.

For 25 years, Japan has been the major developer of SCR technology. Initial applications of SCR in Japan have been primarily on gas- and oil-fired boilers. For this reason, the Japanese did not experience problems related to fly ash and erosion. The Japanese installations therefore experienced relatively long catalyst lifetimes. The most advanced coal-fired operating information has come from the FRG and includes data on erosion, plugging, ammonia slip, and catalyst life. 
The SCR technology can be applied to oil-, gas-, or coal-fired boilers. However, as SCR technology is currently developed, coal-fired applications of SCR may be restricted to boilers burning low- and medium-sulfur coals that do not contain significant trace metals in the ash.

\subsubsection{Influence of Coal Type}

In Japan, the SCR process has been working well with low- and medium-sulfur, low-ash coals. U.S. coals may be inappropriate for use with this technology because of their high trace-metal content. Research on this problem is underway.

Several operating difficulties related to sulfur have arisen. Sulfur dioxide is oxidized to $\mathrm{SO}_{3}$ in the presence of the catalyst. The $\mathrm{SO}_{3}$ in turn poisons the catalyst, which makes it ineffective at that site. The $\mathrm{SO}_{3}$ also reacts with ammonia and other chemical species to form sulfates that mask the catalyst, thereby making it ineffective. Further, formation of ammonium sulfate contributes to an increase in the pressure drop and possible clogging of the air heater, which reduces the efficiency of the power plant. As the concentration of $\mathrm{SO}_{3}$ increases, the acid dew point increases, which could lead to corrosion of components. If corrosion-resistant materials cannot be developed, the system must be operated above the dew point, thus reducing boiler efficiency.

U.S. coals contain trace metals that are not present in Japanese coals. For example, potassium in the coal used at EPRI's Arapahoe SCR Test Facility deactivated the catalyst much sooner than expected. Also, iron found in U.S. coal from the Midwest self-catalyzes the oxidation of $\mathrm{SO}_{2}$ to $\mathrm{SO}_{3}$.

Coals high in silica content may also be incompatible with the SCR process. High ash content has contributed to erosion of the catalyst. Even if much of the ash is removed before the SCR process, the remaining fine particles cling to the catalyst and interfere with its effectiveness. Just the right amount of ash is needed to remove sediment from the catalyst without causing erosion damage.

A high-ash coal was used at a pilot plant at Rheinbisch-Westfalischen Elektrizstatsverke in the FRG. Erosion damage was not observed during the SCR process. However, to prevent erosion, the reactor had been oversized by $25 \%$, and the gas velocity through the reactor was lower than usual.

The arsenic present in certain coals also deactivates catalysts. Catalyst researchers in the FRG and Japan are developing an arsenic-resistant catalyst.

\subsubsection{Plant Size and Modularity Considerations}

The SCR process can be applied to a wide range of boiler sizes. In retrofit applications, space constraints may limit the capacity of the SCR system. Space constraints may also control where the SCR system can be located. The reactors can be added in a modular manner so that plant expansion can be accommodated. This modular design concept also provides for improved reliability. 


\subsubsection{Status of Commercialization}

Although SCR technology is commercially available in Japan and Europe, it is not commercially applied in the United States. Possible reasons for its not being applied in the United States include (1) possible inapplicability to U.S. coals because of differences in mineral-matter content, (2) lack of $\mathrm{NO}_{\mathrm{x}}$ regulations stringent enough to justify using the SCR process, and (3) its prohibitive cost with respect to other available $\mathrm{NO}_{\mathrm{x}}$ reduction technologies (Damon and Ireland, 1987).

For the SCR process to be commercially applicable in the United States, some difficulties must be overcome. One difficulty is developing a catalyst that does not deactivate in the presence of minerals inherently present in U.S. coals. Also, to make SCR more economical, a longer catalyst lifetime must be achieved. Clogging difficulties, if present, also must be overcome.

\subsubsection{Capital and Operating Costs}

At a joint EPRI/EPA conference on $\mathrm{NO}_{\mathbf{x}}$ control, one of the papers presented included information on retrofitting the SCR process to a tangential boiler fired with high-sulfur coal (Kuroda et al., 1989). The cost estimates are based on European operating experience. Among the assumptions made were the following: a catalyst life of four years, a catalyst cost of $\$ 330-660 / \mathrm{ft}^{3}$, an ammonia slip of $5 \mathrm{ppm}$, and a catalyst resistant to trace-element fouling. In a addition, a high-dust SCR configuration was assumed.

The estimates of capital cost (in 1985 U.S. dollars) for these two cases were $\$ 92 / \mathrm{kW}$ for $70 \%$ removal and $\$ 101 / \mathrm{kW}$ for $80 \%$ removal. The third case examined also involved $80 \%$ removal, but the initial cost of the catalyst was reduced to $\$ 330 / \mathrm{ft}^{3}$. The capital cost for this case was estimated at $\$ 78 / \mathrm{kW}$, a value that is $23 \%$ lower than that for the reference case.

Levelized costs of electricity attributable to the SCR process are 6.6 and $6.0 \mathrm{mills} / \mathrm{kWh}$ for the reference catalyst cost and $80 \%$ and $70 \%$ removal, respectively. The lower initial catalyst cost would reduce the cost for the $80 \%$ removal case to $5.2 \mathrm{mills} / \mathrm{kWh}$. The effect of catalyst lifetime was also examined. If the lifetime were assumed to be two years instead of four, the levelized cost of electricity for $80 \%$ removal would increase from $6.6 \mathrm{mills} / \mathrm{kWh}$ to approximately $8.5 \mathrm{mills} / \mathrm{kWh}$. On the other hand, if the lifetime were assumed to be six years, the levelized cost would be reduced to about $5.8 \mathrm{mills} / \mathrm{kWh}$.

Operating experience at the Southern California Edison SCR Test Site with lowand medium-sulfur coals indicates that SCR technology costs are sensitive to the desired level of $\mathrm{NO}_{\mathrm{x}}$ reduction, the fuel composition, and the concentration of the inlet $\mathrm{NO}_{\mathrm{X}}$. However, catalyst lifetime dominates the total levelized cost for the SCR process. Therefore, credible cost estimates require that catalyst lifetimes be accurately predicted. Capital costs were projected to be $\$ 60-107 / \mathrm{kW}$ (in 1985 U.S. dollars). Levelized costs were estimated to be $6.2-16.4$ mills $/ \mathrm{kWh}$ for a 30 -year plant life 
and one-year catalyst life. Sensitivity studies indicate that increasing the catalyst lifetime from one to two years reduced levelized costs by $35 \%$.

SCR operating costs obtained from the experience of two European utility SCR units are consistent with those derived from the Southern California Edison experience. The cost for retrofitting the plants (300-500 MW) was $\$ 75-100 / \mathrm{kW}$; the levelized cost for a two- to three-year catalyst life was estimated at 5-10 mills/kWh.

\subsubsection{Plant Performance}

Including an SCR system will affect several components of a coal-fired plant. Pressure drops will increase, which has the effect of decreasing plant efficiency. Use of ammonia will also adversely affect the air heater, the ESP, the FGD system, and the water-treatment and waste-handling systems. The net plant heat rate is expected to increase 2-3\%.

\subsubsection{Part-Load Operation}

SCR systems can be operated even if the load is fluctuating; however, a formal turndown ratio has not been determined. At low flue gas flow rates, entrained solids may accumulate on the catalyst surface, thereby deactivating it.

\subsubsection{Reliability and Availability}

The SCR experience reviewed for this report amounts to just under 20,000 hours of operation. After startup problems were resolved, major shutdowns or breakdowns were not reported. Although none of the documentation states a specific reliability number, reliability is nonetheless expected to be high because of SCR's extensive commercial use and modular design.

\subsubsection{Atmospheric Emissions}

The major concern with respect to atmospheric emissions is release of ammonia. Operating experience to date suggests that, during normal operation, ammonia concentrations in the exhaust gas are expected to be on the order of $5 \mathrm{ppm}$.

\subsubsection{Production of Solid Waste}

Other than spent catalyst, the SCR process generates no solid waste. 


\subsubsection{Consumable Requirements}

The principal consumable (other than catalyst material) is ammonia. A 150-MW plant with an uncontrolled $\mathrm{NO}_{\mathrm{x}}$ concentration of $600 \mathrm{mg} / \mathrm{m}^{3}$ in the flue gas would require approximately $250 \mathrm{lb} / \mathrm{h}$ of ammonia to reduce the $\mathrm{NO}_{\mathrm{x}}$ level to $200 \mathrm{mg} / \mathrm{m}^{3}$.

\subsubsection{Plant Complexity and Operability}

The SCR technology adds a significant amount of complexity to the design and operation of a power plant. Tightly controlled operations are needed to balance ammonia feed rates so that the required $\mathrm{NO}_{\mathrm{x}}$ removal can be achieved while keeping the ammonia slip at a reasonable level and without deactivating the catalyst too quickly.

\subsubsection{General Comments}

Using the SCR process on coal-based systems is comparatively new. Experience with high-sulfur coals and coals with high concentrations of trace metals is limited. It is unlikely that this technology will find significant coal-fired application in developing countries before much more experience is gained. 


\section{TRENDS IN INTERNATIONAL RESEARCH, DEVELOPMENT, AND DEMONSTRATION OF CLEAN COAL TECHNOLOGIES}

This section focuses on RD\&D trends in countries whose CCTs are expected to be competing with those of the United States in the international marketplace. The countries chosen are Canada, Denmark, Finland, Italy, Japan, the Netherlands, the Peoples' Republic of China, South Korea, Sweden, the United Kingdom, and the Federal Republic of Germany. They were chosen because they use coal and have exhibited serious concern about emission of acid-rain precursors and other fossil-fuel-derived pollutants.

To the extent possible, public and private information was obtained for this study. The information was assembled along the following lines:

- Energy use and reserves.

- Specific governmental incentives for promoting the use, marketing, and research of CCTs.

- Highlights of the attitudes prevailing in each country that affect its energy technology choices.

- Public and private RD\&D programs related to CCTs.

- Specific CCTs being pursued in the precombustion, combustion, and postcombustion categories, with emphasis on demonstration, commercialization, and deployment.

- Emissions guidelines and regulations.

Table 3.1 lists the specific technologies that are of interest and/or under study in each of the 11 countries selected.

\subsection{CANADA}

Canada has abundant reserves of oil, natural gas, and coal. In 1986 , the $469 \mathrm{TWh}$ of electricity generated was supplied by the following sources: hydro (65\%), coal (17\%), and nuclear (15\%) (International Energy Agency [IEA], 1988b; Organization for Economic Cooperation and Development [OECD], 1988a). A significant amount of industrial energy demand was met in 1986 and is probably now being met by wood fuel. The provinces of Quebec, Prince Edward Island, and Newfoundland did not have in 1986 and do not now have any coal-fired utilities.

The Canadian government does not explicitly promote widespread conversion to coal (Mitchell, 1988). The focus of governmental activity in this area has shifted to consumer education and information, industry support, and demonstration activities in cooperation with the private sector and provincial governments. However, strong 
TABLE 3.1 Clean Coal Technologies at the Developmental or Commercial Stage, by Combustion Category and Country

\begin{tabular}{|c|c|c|c|}
\hline Country & Precombustion & Combustion & Postcombustion \\
\hline Canada & $\begin{array}{l}\text { Coal gasification } \\
\text { Coal liquefaction }\end{array}$ & $\begin{array}{l}A F B C \\
\mathrm{CFBC} \\
\mathrm{CWM} \\
\text { Low-NO }{ }_{x} \\
\text { burners } \\
\text { In-furnace } \\
\text { sorbent } \\
\text { injection }\end{array}$ & $\begin{array}{l}\text { FGD: wet and dry } \\
\text { FGD: dual alkali process }\end{array}$ \\
\hline Denmark & & $\begin{array}{l}\text { Low-NO }_{x} \\
\text { burners }\end{array}$ & $\begin{array}{l}\text { ESP } \\
\text { Comb. } \mathrm{SO}_{2} / \mathrm{NO}_{\mathrm{x}} \text { removal } \\
\text { FGD: spray-dry process } \\
\text { FGD: limestone/gypsum } \\
\text { SCR } \\
\text { Selective noncatalytic } \\
\text { reduction }\end{array}$ \\
\hline Finland & & $\begin{array}{l}\mathrm{AFBC} \\
\mathrm{CFBC}\end{array}$ & $\begin{array}{l}\text { FGD: spray-dry process } \\
\text { FGD: sorbent in jection }\end{array}$ \\
\hline Italy & $\begin{array}{l}\text { CWM } \\
\text { Coal beneficiation } \\
\text { Coal gasification }\end{array}$ & $\begin{array}{l}\text { AFBC } \\
\text { CWM } \\
\text { Low-NO } \\
\text { burners }\end{array}$ & $\begin{array}{l}\text { FGD: 1 imestone/gypsum } \\
\text { SCR }\end{array}$ \\
\hline FRG & Coal liquefaction & $\begin{array}{l}\text { AFBC } \\
\text { CFBC } \\
\text { PFBC } \\
\text { IGCC } \\
\text { Low-NO } \\
\text { burners }\end{array}$ & $\begin{array}{l}\text { FGD: lime/limestone } \\
\text { SCR } \\
\text { Selective noncatalytic } \\
\text { reduction } \\
\text { Comb. } \mathrm{SO}_{2} / \mathrm{NO}_{\mathrm{x}} \text { removal }\end{array}$ \\
\hline Japan & $\begin{array}{l}\text { Coal gasification } \\
\text { Coal liquefaction } \\
\text { Low-NO }{ }_{x} \text { burners }\end{array}$ & $\begin{array}{l}\text { AFBC } \\
\text { CWM } \\
\text { SCR }\end{array}$ & $\begin{array}{l}\text { FGD: dry } \\
\text { FGD: sorbent injection }\end{array}$ \\
\hline $\begin{array}{l}\text { Nether- } \\
\text { lands }\end{array}$ & Coal gasification & $\begin{array}{l}\mathrm{AFBC} \\
\mathrm{PFBC}\end{array}$ & $\begin{array}{l}\text { FGD: sorbent in jection } \\
\text { Hot-gas cleanup }\end{array}$ \\
\hline PRC & $\begin{array}{l}\text { Coal washing } \\
\text { Coal gasification }\end{array}$ & $\begin{array}{l}\text { AFBC } \\
\text { PFBC }\end{array}$ & $\begin{array}{l}\text { FGD: dry } \\
\text { FGD: sorbent injection }\end{array}$ \\
\hline $\begin{array}{l}\text { South } \\
\text { Korea }\end{array}$ & $\begin{array}{l}\text { Coal liquefaction } \\
\text { Coal beneficiation } \\
\text { Coal pyrolysis }\end{array}$ & $\begin{array}{l}\text { CWM } \\
\text { AFBC }\end{array}$ & $\begin{array}{l}\text { FGD: dry } \\
\text { FGD: sorbent injection }\end{array}$ \\
\hline
\end{tabular}




\section{TABLE 3.1 (Cont'd)}

\begin{tabular}{llll}
\hline Country & Precombustion & Combustion & Postcombustion \\
\hline Sweden & CWM manufacture & AFBC & FGD: wet and dry \\
& Coal gasification & $\begin{array}{l}\text { PFBC } \\
\text { Multibed } \\
\text { FBC } \\
\text { In-furnace } \\
\text { sorbent } \\
\text { injection }\end{array}$ & \\
United & Coal washing & & \\
Kingdom & Coal gasification & \\
& Coal liquefaction & PFBC & \\
& Coal pyrolysis & &
\end{tabular}

environmental awareness and significant concern about acid-rain-precursor emissions continue to foster CCT development. Advanced coal technologies are in commercial use in a range of applications from electric utilities and large and small industrial facilities to residential and commercial settings.

Energy $\mathrm{RD} \& \mathrm{D}$ sponsored by the federal government includes $\mathrm{SO}_{2} / \mathrm{NO}_{\mathrm{x}}$ reduction in tangentially fired boilers, staged combustion with sorbent injection, slagging-burner concepts, and FGD with wet and dry scrubbers (IEA, 1986b). Waste management research sponsored by the federal government focuses on coal conversion, wastewater treatment technology, characterization of wastes from FGD, sorbent injection, FBC, and evaluation of disposal options (Beshai, 1986; IEA, 1985a, 1986a; Ministry of Energy, Mines, and Resources, 1986).

Private-sector R\&D is being carried out primarily by electric utilities (IEA, 1986c). Projects include pilot-scale development of a limestone injection process, development of the Rockwell slagging burner for new and retrofit applications to power plants, AFBC waste assessment, fly-ash evaluation and utilization studies, CWM technology development, and coal/petroleum coprocessing (Schmid, 1986; Trivett et al., 1985).

Precombustion category $\mathrm{RD} \& \mathrm{D}$ has focused on a coal-liquefaction process for simultaneously upgrading subbituminous coal and heavy oil to transportation fuel. This technology was demonstrated at a 15-tons/d pilot plant in Alberta.

Combustion category RD\&D has focused on CWMs (Cook et al., 1985; Whaley et al., 1983; Whalley et al., 1985) and FBC (Friedrich et al., 1985). A 100-tons/d CWM preparation facility has been used for large-scale pilot testing, and $\mathrm{CWM}$ burners designed by Babcock and Wilcox Co. have been tested at an operational generating 
station. Future plans call for testing a Swedish CWM technology in a 20-MW boiler originally designed for oil. A wear-resistant CWM atomizer that can also burn oil has been tested and is expected to become commercially available. A CWM is also being tested for use in small industrial and residential FBC applications (Gray et al., 1986). Two 40,000-1b/h bubbling-bed FBC units using Foster-Wheeler boilers constitute the first commercial-scale demonstration of FBC boilers in Canada. Other FBC research includes a 22-MW CFBC steam generator that fires high-sulfur coal (Anthony et al., 1985) and shale oil and design of a 70-MW combined-cycle PFBC plant.

Postcombustion category RD\&D has focused on characterizing fly ash associated with dry and wet FGD systems.

Seven eastern Canadian provinces have agreed to a major reduction in $\mathrm{SO}_{2}$ emissions by 1994. There is no national policy for control of $\mathrm{NO}_{\mathrm{x}}$ emissions, although there are national guideline emission limits (Vernon, 1988). Disposal of wastes from coal utilization is not yet a matter of national policy.

Provincial governments have also issued binding emissions standards for some regions and localities (IEA, 1987a). The major utility in Ontario, in response to newly imposed provincial standards, plans to retrofit several of its fossil-fuel units, primarily with FGD. It also plans to pursue such noncontrol technology measures as use of lowsulfur coal, increased importation of electricity, and construction of hydro and nuclear units. Saskatchewan, although not subject to emissions targets, is working on sorbent injection and concentric-firing low- $\mathrm{NO}_{\mathbf{x}}$ systems that can burn lignite. Alberta, also not subject to emissions targets, is pursuing design studies of a commercial-scale IGCC plant and is researching coal beneficiation combined with oil agglomeration.

\subsection{DENMARK}

Denmark has indigenous oil and natural gas resources; only small amounts are exported. The country imports both coal and oil. Renewable energy sources are not expected to replace coal in the near future, but they are expected to account for an increasing percentage of the country's gross energy consumption. In 1986, the $30.7 \mathrm{TWh}$ of electricity generated was supplied by the following sources: coal (92\%), oil (5\%), and natural gas (2\%), with the remaining $1 \%$ supplied by other resources (e.g., hydro, geothermal, and renewable energy) (IEA, 1988a; OECD, 1988a; Danish Ministry of Energy, 1987).

Although there are no specific governmental incentives to promote the marketing or use of CCTs, some programs may indirectly affect their use (Gulev, 1988). Older segments of Danish industry are eligible for governmental subsidies to help them comply with environmental regulations. In addition, under a special appropriation, and as a direct extension of $R \& D$ work, the government can collaborate with private companies in marketing and developing energy technology products (Jordan, 1988).

Ongoing energy RD\&D reflects the Danish policy objective of widespread oil independence, focusing as it does on development of indigenous and renewable fuels (IEA, 1986c, 1988a). The Danes are world leaders in RD\&D of wind-power technology and 
agricultural waste fuels. In addition, studies are in progress to exploit the North Sea oil fields. CCT research is limited to postcombustion desulfurization technologies and combustion modifications to control $\mathrm{NO}_{\mathrm{x}}$ emissions (IEA, 1987a). This latter area may expand because more regulations are pending for more stringent control of emissions (National Agency of Environmental Protection, 1987, 1988).

The Danish initiative to maximize use of indigenous and renewable energy resources may inhibit market penetration of new coal technologies in Denmark. For example, legislation was passed to prohibit construction of coal-fired district-heating plants where indigenous fuels are available. In addition, tax incentives are being offered to the residential and commercial sectors to use natural gas and renewable energy sources.

In addition to regulating $\mathrm{SO}_{2}$ and $\mathrm{NO}_{\mathrm{x}}$ emissions (Vernon, 1988), the Danish government has developed a policy plan that (1) endorses evaluation of all potential sources of air pollution; (2) endorses FGD as a favored technology for abating air pollution, with emphasis on best available technology and reusable waste by-products (e.g., gypsum); (3) recommends use of tall stacks to dilute unavoidable emissions from stationary sources; and (4) gives a higher priority to renewable fuels over oil and gas (Royal Danish Ministry of Foreign Affairs, 1984).

Public-sector RD\&D does not include any CCT research projects. Private-sector RD\&D is conducted primarily by Danish utilities, which are experimenting with a range of $\mathrm{NO}_{\mathbf{x}}$-control technologies, including $\mathrm{SCR}$, selective noncatalytic reduction, and the Haldor-Topsoe combined $\mathrm{SO}_{2}-\mathrm{NO}_{x}$ removal process.

The development of precombustion technologies or the need for coal beneficiation is limited because the government strictly regulates the sulfur content of imported coal and the country lacks indigenous coal reserves.

In the combustion category, development is focused on the commissioning of two 350-MW central heating and power (CHP) plants equipped to burn pulverized coal in burners modified for low- $\mathrm{NO}_{\mathbf{x}}$ emissions.

In the postcombustion category, the focus has been on FGC equipment. Because particulate matter was the first pollutant to be regulated, ESPs, bag houses, and cyclones are in wide commercial use in Denmark. FGD units are used to a limited extent, but are expected to be used more upon enactment of more stringent emissions limits.

\subsection{FINLAND}

In 1986 , the 49.3 TWh of electricity generated in Finland was supplied by the following sources: nuclear (40\%), hydro (26\%), coal (18\%), and oil and natural gas (6\%) (IEA, 1988b; OECD, 1988a). The concern evident as to the safety of nuclear energy, following the accident at Chernobyl, has resulted in speculation that Finland may consider decommissioning some of its nuclear facilities. Industry experts are concluding that CCTs could prove viable if substantial nuclear capacity has to be replaced. 
There are no specific governmental incentives for marketing or using CCTs in Finland. However, the government is subsidizing research in the area of alternatives to oil that may indirectly encourage coal research (Haikonen, 1988; Heinonen, 1988).

The trends in energy RD\&D in Finland are affected by the country's lack of coal reserves (Finnish Ministry of Trade and Industry, 1987). Both its public and private sectors conduct $R \& D$ on combustion and postcombustion technologies, and have participated in joint research activities (IEA, 1987a; Lohisto, 1988).

One such joint activity, a CCT project named Leikki (Finnish for "flame"), is focused primarily on FBC. A Finnish company, Pyropower, Inc., is the world's leading manufacturer of CFBCs and is the major supplier of CFBCs used in some of Finland's medium-sized cogeneration plants. Pyropower also has larger-scale combustors com mercially available (Evans, 1988).

In the postcombustion category, $\mathrm{RD} \& \mathrm{D}$ is limited but expected to increase. Of the three FGD units in operation in Finland, two are spray-dry scrubbing systems, and the third is an experimental sorbent injection system. Because of $\mathrm{SO}_{2}$ regulations, conventional coal-combustion plants in Finland are expected to be fitted with FGD equipment rather than retrofitted with some other advanced combustion technology.

In 1987, Finland enacted $\mathrm{SO}_{2}$ emission standards. $\mathrm{NO}_{\mathrm{x}}$ emissions are not regulated; however, research in $\mathrm{NO}_{\mathrm{x}}$ reduction is ongoing (Vernon, 1988). Finland has achieved the emission standards set by the European Economic Community, thereby demonstrating its ongoing environmental concern and implying a potential demand for CC'Ts.

\subsection{ITALY}

Italy depends strongly on imported energy to meet domestic demand. France's nuclear overcapacity has enabled it to supply Italy in recent years with electricity at an attractive price. Imports make up about $10 \%$ of Italy's electricity supply; at this level, the limit imposed by transmission-line capacity has been reached. In 1986, the $192 \mathrm{TWh}$ of electricity generated was supplied by the following sources: oil (40\%), hydro (25\%), coal (17\%), gas (13\%), and nuclear (5\%) (IEA, 1988b; OECD, 1988a). Energy demand continues to grow. An energy shortage in the southern European Mediterranean area has been predicted for as early as 1995 (Coal Week International, 1988).

There appear to be no specific governmental incentives promoting the use of CCTs in Italy. Renewed environmental awareness, especially since the Chernobyl accident, has seemingly strengthened the resolve of Italy's "Green Party," an organization concerned not only with nuclear energy issues, but also with the contribution of coal-fired power plants to formation of acid-rain precursors. However, in an attempt to counter the opposition to increased use of fossil fuel, the government may well decide to offer incentives to companies promoting CCTS.

Diversification of energy sources is a key theme in Italy's energy strategy (Poggi and Velona, 1988; Scacchi, 1988). In response to policy directives, Italian research is 
aimed toward using coal in an environmentally acceptable manner. Most of Italy's power plants are oil-fired; to provide for fuel flexibility and price stability, all new fossil-fuel power plants must be capable of burning coal, gas, or oil (DOE, 1988a).

Coal-technology $R D \& D$ is concentrating on alternative fuels; CWMs, for example, could play a significant role in multifuel applications. The main areas of research are slurry preparation and handling, boiler fouling and erosion, and burner design. Italy's coal research encompasses all stages of coal exploitation: precombustion, combustion, and postcombustion. Except for CWM preparation and combustion, most of the projects are being planned or are in the small-scale-testing stage (Ercolani, 1988; Trebbi, 1988).

In Italy, most coal-based RD\&D is undertaken by the private sector (IEA, 1986c), with most of the work on precombustion technologies. Work on CWMs is being pursued extensively at all levels of development (Bossoni, 1988; Sparacino, 1988). Other projects include (1) coal beneficiation (coupled with use of a solvent to agglomerate carbon particles) in combination with the Snamprogetti REOCARB ${ }^{\text {m }}$ process to produce a clean CWM fuel; (2) coal gasification with an entrained-bed gasifier operating at $3 \mathrm{~kg} / \mathrm{h}$; and (3) a $20-\mathrm{kg} / \mathrm{h}$ syngas pilot plant (Carugati et al., 1985).

Italian combustion technology research is focused on FBCs because of the current emphasis on use of indigenous high-sulfur fuels (Arena et al., 1984). In response to industry pressure to use high-sulfur Sardinian coal, a CFBC has been ordered for testing purposes. Commercial-scale projects are also planned. Pilot-sized facilities exist for all types of FBC studies. Also ongoing is research related to developing CWM burners. Snamprogetti and Tosi are retrofitting 200-MWe boilers in the Soviet Union with a burner capable of using either CWMs or coal-oil mixtures (COMs) (Girardi, Guidi, and Penati, 1988). Other research being conducted is in the areas of burner modifications to reduce $\mathrm{NO}_{\mathrm{x}}$ emissions, slagging combustors, and gas reburning (DeMiechele and Ligasacchi, 1984).

In the postcombustion category, RD\&D is focusing on FGD systems and $\mathrm{NO}_{\mathrm{x}}$ reduction. New Italian power plants are expected to be fitted with FGD systems; commercially available units can be ordered to fit the custom needs of individual power plants. Gypsum-producing FGD systems appear to be favored. All new plants are equipped with enough space to install SCR, although the SCR equipment will likely be imported from Japan. Some pilot-scale research is underway on the effectiveness of SCR in retrofit scenarios (Dinelli and Rea, 1986).

Until recently, air pollution in Italy has not been considered of crisis proportions. Nevertheless, as a member of the United Nations $30 \%$ Club, Italy is committed to reducing $\mathrm{SO}_{2}$ emissions by $30 \%$ of 1980 levels by 1990 . Enforcement of air pollution regulations is deemed a joint responsibility of regional and national authorities. Regulations control emissions of $\mathrm{NO}_{\mathrm{x}}, \mathrm{SO}_{2}$, and particulates by electric utilities (Vernon, 1988). The sulfur content of the coals burned is also regulated. 


\subsection{JAPAN}

Japan has few indigenous energy resources and relies heavily on imports. The country's energy plan promotes a balanced mix of energy sources, the mix to include nuclear, hydro, fossil fuels, and renewables. In 1986, the $676 \mathrm{TWh}$ of electricity generated in Japan was supplied by the following sources: oil (28\%), nuclear (25\%), gas (19\%), coal (15\%), and hydro (13\%) (IEA, 1988b; OECD, 1988a). The country is moving toward increased reliance on nuclear power plants. Indeed, nuclear-generated electricity is increasing at a much faster rate than coal-generated electricity.

Governmental incentives are aimed primarily at coal producers; however, some incentives are provided to electric utilities in the form of rate considerations to defray the costs of required pollution-control equipment when domestic coal is used (Yancik, 1988).

The capacity of coal-fired power plants is expected to increase slightly from $9 \%$ to $11 \%$ of total generating capacity by 1995 . The Japanese are leaders in treating flue gas, both as to domestic $\mathrm{R} \& \mathrm{D}$ and commercial activity. A strong program to control emissions is in place, and novel FGD systems and $\mathrm{NO}_{\mathrm{x}}$ reduction technologies are favored for large plants. Flue-gas treatment options being pursued in Japan include wet and dry systems for $\mathrm{SO}_{2}$ and $\mathrm{NO}_{\mathrm{x}}$ control and $\mathrm{SCR}$ for $\mathrm{NO}_{\mathrm{x}}$ control. $\mathrm{SCR}$ units are in operation for coal-fired utility boilers. Low-dust SCR systems are preferred. Considerable research is also underway on modifications to improve combustion. Other technologies of interest are coal slurries and coal gasification. And, as a result of the interest in coal-slurry technology, a significant amount of work is being undertaken on coal cleaning and transport. Solid wastes are of serious concern because of the severe shortage of land for disposal. A waste-minimization policy has effectively forced use of regenerable or similar systems (Coal Mining Research Centre, 1986).

New coal-based RD\&D is carried out in the public sector under the auspices of the Ministry of International Trade and Industry (IEA, 1987a, 1987b). For example, there is a major technology development program that emphasizes fairly long term technologies (e.g., coal liquefaction and coal gasification). Short-term research is being conducted on demonstration-scale FBC technology for power generation with in-bed desulfurization and low $\mathrm{NO}_{\mathrm{x}}$ formation; coal-liquid mixtures; and low-rank coalutilization technologies. The Ministry also funds the $R \& D$ programs of the Coal Mining Research Centre. Among these programs are work on flue-gas treatment, FBC technology, coal-liquid mixtures, coal-handling technology, coal-ash-utilization technology, and coal gasification.

In the private sector, Japanese industry is a leader in CCT RD\&D and commercial activities. The focus is on technologies to reduce $\mathrm{NO}_{\mathrm{x}}$ and $\mathrm{SO}_{2}$ emissions, AFBC development, and CWMs (New Energy Development Organization, 1987; IEA, 1986c).

Several precombustion CCT projects are underway. Tests have been performed on 5- and 40-tons/d combined-cycle fluidized-bed gasification systems. Also, a project has been initiated to construct and operate a coal-gasification pilot plant with a 200-tons/d coal gasifier using a hot-gas cleanup system and a 13-MW gas turbine. 
Generating power with a combined-cycle coal-gasification system is also being studied by the research arm of the electric power industry. A PFBC/gasification project that uses a variety of coal feedstocks to produce high-Btu gas is operating at pilot scale. Under construction is a 250-tons/d bituminous-coal liquefaction pilot plant that uses the $\mathrm{NEDOL}^{\mathrm{m}}$ process for direct liquefaction of subbituminous and low-rank bituminous coals. A brown-coal liquefaction project is also in progress, in collaboration with the Australian government. Coal-liquefaction projects include programs in coal cleaning and development of slurry pumps.

Combustion CCT projects include AFBCs and CWMs. A 40,000-lb/h AFBC pilot plant to test the burning of various coal types has been constructed in Kyushu (Nakabayashi, 1987). Since the success of this government/industry joint effort, other private companies have become involved in commercializing this technology. Several Japanese companies are manufacturing bubbling- and circulating-AFB boilers, two under license from American manufacturers (Fujiwara et al., 1987; Makansi and Schwieger, 1987).

Various aspects of coal-slurry technology have been investigated by many different organizations in Japan. A significant 75-MW CWM demonstration project at the Nakoso Power Station is underway (Konishi et al., no date). The unit being used for the demonstration was originally designed for the firing of low-grade domestic coal. The study encompasses coal-slurry preparation, transportation, storage, and combustion. Most recently, the emphasis has been on developing large-capacity CWM burners (Kaneko et al., no date). Another project involves a new slurry manufacturing plant whose highefficiency transport system is scheduled for testing at pilot-plant scale. COMs manufactured by two units, each with a capacity of 70 tons/h, are used as fuel for two thermal power units, each rated at $265 \mathrm{MW}$ (Kaji, no date). The plant that produces the COM also manufactures the CWM.

Postcombustion CCT projects focus on desulfurization and denitrification, and also on waste management. Developing and upgrading of flue-gas treatments (e.g., dry $\mathrm{SO}_{2}$ removal, high-efficiency electrostatic precipitation, and simultaneous $\mathrm{SO}_{2}$ and $\mathrm{NO}_{\mathrm{x}}$ removal) are underway because present systems are considered inadequate for coal-fired plants that will likely be located in or near large population centers (Okamatsu, 1986). A significant shortage in land for waste disposal has resulted in research on utilization of combustion wastes. For example, several projects are aimed toward using coal ash, especially in road-building materials.

Because of rapid economic growth in the 1960 s and the accompanying industrial development, pollution has become a major issue in Japan. Public awareness of environmental pollutants has been spurred by a number of cases involving health damage. As a result, the government has instituted ambient air quality standards and limits on emission rates. Japan has a four-tiered system of regulating pollutants: national emission-rate limits, national emission-load limits, municipal ordinances, and agreements between local authorities or citizen groups and large emission sources. This last tier is generally the most stringent. For example, the national emission-rate limit for a specific utility coal-fired boiler may be $400 \mathrm{ppm}$, whereas the local agreement may require 170 ppm (Vernon, 1988). 
To meet $\mathrm{SO}_{2}$ emission-rate limits, Japan has initiated a major program of FGD installation. A high percentage (85\%) of coal-fired power plants, as well as many industrial installations, are equipped with FGD systems. SCR is the favored approach to $\mathrm{NO}_{\mathbf{x}}$ control and has been used for coal-fired units in Japan for many years.

\subsection{THE NETHERLANDS}

Because of strong competition from natural gas, coal use in the Netherlands is relatively modest. In 1986 , the $67.2 \mathrm{TWh}$ of electricity generated was supplied primarily by the following sources: gas (62\%), coal (26\%), nuclear (6\%), and oil (5\%) (IEA, 1988b; OECD, 1988a). Coal use for electricity generation is expected to increase; as a result, CCT RD\&D appears to have some priority with respect to national energy policy.

Dutch governmental incentives focus on industrial energy conservation, with an emphasis on coordinated RD\&D and market introduction of conservation technologies. In general, the government supports energy research in fields in which industry is not very active, with the result that government- and industry-sponsored research are generally complementary (IEA, 1983, 1985b, 1986c). This emphasis may change because increased coal exploitation will necessitate implementing CCTs in tandem with meeting environmental objectives (Van Teeffelen, 1988).

Public-sector priorities for the Dutch RD\&D program are energy conservation, coal-combustion technologies, renewables, and nuclear-waste management (IEA 1986b). Private-sector RD\&D is focused on gas and oil. Much of the country's oil use is concentrated in the petrochemical and refining industries, in which fuel switching to coal is very difficult and costly. In addition, uncertainty prevails about the viability of new coal-burning technologies, especially FBC (IEA, 1985a, 1987b).

The following example CCT research projects span the precombustion, combustion, and postcombustion categories:

- A planned 240-MW gasification demonstration unit that will employ either Shell or Texaco technology.

- An AFBC test facility (4 MW) for firing coal, oil, and gas.

- Design and testing of flow baffles in the freeboard of the combustion unit to increase the residence time of char particles and avoid fly-ash recirculation.

- Improvement of the emission characteristics of small, shallow, bubbling AFBCs, and research on regenerative sulfur capture.

- Studies of the fluidization behavior, heat-transfer characteristics, process dynamics, freeboard phenomena, and combustor modeling for PFBCs.

- Tests to study the influence of FGD on emissions other than $\mathrm{SO}_{2}$. 
- Development of instruments to measure the annoyance factor in deposition of coal dust.

- Use of an experimental PFBC facility and a materials test rig to research hot-gas cleanup.

- Use and disposal of fly ash, bottom ash, and FGD waste products.

- Creation of an organization to market coal combustion by-products.

All existing power plants with a life expectancy beyond 1999 are expected to be equipped with FGD. Strict environmental emissions standards for $\mathrm{SO}_{2}$ and $\mathrm{NO}_{\mathbf{x}}$ are expected to be implemented through a general administrative order (Vernon, 1988).

\subsection{PEOPLES' REPUBLIC OF CHINA}

Proven coal reserves in the PRC are considered to be the largest in the world. More than two-thirds of the reserves are bituminous coal, with a substantial portion of the remainder being anthracite. However, production has been hampered by a lack of expertise and adequate modern mining equipment. The PRC has sought foreign financing to import technology and equipment, and coal has been given the highest priority in the country's overall energy and industrial development program (Johnson, 1987; World Bank, 1987a). The PRC also has significant oil and gas reserves and has begun to develop nuclear energy.

Thermal generating capacity accounted for almost $77 \%$ (318 TWh) of the total electricity generated (411 TWh) in 1985 (United Nations, 1987). The remaining 22\% was generated by hydroelectric plants. The hydro option is expected to receive strong development support from the government; however, its share of the electricity generated is projected to decline because of the extensive development of the country's nuclear energy capacity.

No specific governmental incentives to develop, market, and use CCTs are evident in the PRC. However, the ever higher demand for coal and promulgated environmental protection measures have indirectly initiated a wide range of $R D \& D$ and commercialization activities (Foster-Wheeler Corp., 1987).

The PRC's industrial sector consumes a lot of energy. Its consumption is twice that of countries such as South Korea and the United States per industrial output value. Factors contributing to this inefficiency include the dominance of coal as an industrial fuel, the large number of small plants in energy-intensive industries, and the slow progress being made in upgrading boiler technology. In recent years, the PRC has attempted to modernize its technology base. Efforts have increased to secure western technology, and internal $R \& D$ is underway, with a primary focus on advanced coalutilization technologies like FBC (Asian Development Bank, 1987; International Coal Report, 1987a,b,c). 
Because coal quality is a major problem in the PRC, governmental plans call for increased coal beneficiation. Energy planning and power-plant-siting studies have been undertaken to effectively and economically use the middlings (i.e., the combustible materials recovered in the washing process). Because of its low calorific value, it is uneconomical to transport middlings over great distances.

Coal gasification produces feedstock for ammonia production and fuel for a variety of industrial heating applications. Potential future uses under study include combined-cycle power plants. A new demonstration project, with engineering and equipment supplied by U.S. companies, is also planned. The plan envisions incorporating a pressurized ash-agglomerating FBC gasifier into an industrial setting.

Combustion researchers in the PRC developed FBC technology for the chemical and textile industries. Its use has been expanded to heating, power generation, and sintering of minerals. FBC boilers with steam generation rates of $2-20$ tons $/ \mathrm{h}$ are currently available for industrial use, and boilers with steam generation rates of 35 and 130 tons/h are available for power stations. The thermal efficiency of FBC boilers burning low-grade fuels is about 65-80\%. More than 2500 FBC boilers have been installed throughout the country, making the PRC the largest user of this technology in the world. However, most of these units are small industrial boilers incorporating an atmospheric, bubbling technology. Only a handful of FBC power generating boilers are in operation. In Chinese coal-mining areas, FBC boilers are being used to provide steam for industrial processes and for home heating, and FBC technology has proved effective in utilizing wastes at mine-mouth power plants. China has successfully exported FBC boilers to clients overseas because of their highly competitive price. However, high domestic demand to meet the country's modernization needs will preclude most future export activity.

Because of the severe pollution problems faced by the PRC, its leading energy research centers are investigating several types of flue-gas treatment to be used in conjunction with FBC technology. A campaign against air pollution began in 1985 and has been reinforced by passage of legislation. Although there is a high degree of centralgovernment planning, the $\mathrm{PRC}$ is highly decentralized with respect to implementation. Pollution control is the responsibility of local authorities. Poor management and lax environmental supervision prevail despite environmental protection laws. Consequently, pollution appears to be worsening in many cities. Funds allocated for environmental control are limited and inadequate, and PRC environmental officials are concerned that cleanup targets will not be reached.

\subsection{SOUTH ROREA}

Sustained economic growth, together with the concomitant increase in energy consumption, has prompted the South Korean government to search for alternative energy sources to meet energy demand. The government's plans for resource diversification over the long term include increased use of coal and decreased use of oil for power generation and in the industrial sector. Anthracite is Korea's only indigenous fossil fuel. Limited reserves and constraints on production will gradually force reductions in its use (Yager, 1984). 
Rapid growth in its heavy industries and expanded commercial activities have led South Korea to enlarge its energy supply network. Most of this development has involved construction of nuclear power plants and a few oil-fired power plants. The utility industry is a minor user of coal. The major coal users are steel mills and manufacturers of construction materials, including cement plants. From 1986 to 1991, coal-fired electrical capacity is expected to increase approximately $700 \%$, from 750 to $6000 \mathrm{MW}$. South Korea prefers to purchase low-sulfur, low-ash coals from the PRC and the Soviet Union because prices are about half those of imports from the United States.

To encourage the use of imported bituminous coal, the government provides financial support and tax incentives for (1) coal-facility installation, (2) construction and distribution networks for small-quantity consumers, (3) establishment of common facilities in industrial complexes, and (4) development of utilization techniques (International Coal Report, 1988).

Energy research in South Korea is leaning toward combustion research and postcombustion pollution-control techniques (Denysyk, 1988). However, this research is limited to technology transfer of advanced burners and pollution-control technologies. South Korea imports and uses coals with low sulfur and ash contents. Its strategy, apparently, is to control pollutant emissions largely by using quality coal, rather than by using costly pollution-control devices.

Public-sector research is carried out by the Korean Institute of Energy and Resources and the Korea Advanced Institute of Science and Technology. Private-sector $\mathrm{CCT}$ projects are numerous and focus on $\mathrm{AFBC}$ and $\mathrm{CFBC}$ installations.

In the precombustion, combustion, and postcombustion categories, the CCTs being pursued are the same as or similar to those pursued in the United States. Joint projects with the United States include FBC technology, coal liquefaction, coal-slurry mixtures, and coal pyrolysis.

Precombustion coal cleaning activities focus on domestically produced anthracite. Although much of the anthracite mined is used "as is," some activity is evident in the area of "air-tabling." A dry cleaning technique is employed.

In the combustion category, South Koreans see CWMs as the most promising fuel alternative for general industrial applications. They generally view CWMs as a future substitute for No. 6 fuel oil. DOE's Pittsburgh Energy Technology Center has assisted a South Korean oil company in its entry into CWM manufacturing and utilization (Rhee, 1988). This assistance has resulted in the licensing of ARCOAL, a U.S. technology developed by Atlantic Research Corp. In this successful project, a Bunker $\mathrm{C}$ plant firing No. 6 oil is expected to be retrofitted for CWM use. A CWM feed rate of 40 tons/h will initially be used; when the conversion is complete, the feed rate will increase to as high as 160,000 tons/h. Boiler derating is predicted to be $15-45 \%$ (Kang, 1986; Kim, 1986).

Combustion research has also focused on $\mathrm{FBC}$ technology for reducing $\mathrm{SO}_{2}$ emissions during combustion. The use of low-grade fuels in the FBC process is being studied (Makansi and Schwieger, 1987). Also in progress are IGCC feasibility studies and the CWM demonstration project discussed above. 
As in many developing countries, air pollution has become one of the main environmental concerns. The Korean environmental agency has promulgated air-quality and coal-specification standards. Postcombustion research activity has focused on programs to control particulates. The effect of FGD on sulfur emissions and control of $\mathrm{NO}_{\mathrm{X}}$ is also being studied (Seek, 1986).

\subsection{SWEDEN}

In 1986, the 139 TWh of electricity generated in Sweden was supplied by the following sources: nuclear (51\%), hydro (44\%), and fossil fuels (4\%) (IEA, 1988b; OECD, 1988a). The great environmental concern exhibited by the Swedish people will likely result in existing coal-fired facilities being retrofitted with CCTs to comply with strict governmental regulation of pollutant emissions. Combustion technologies are the main target of Swedish CCT research. Most of the CCTs being investigated have been scaled up to the demonstration level.

There are no governmental incentives to directly encourage the marketing or use of CCTs in Sweden. However, a subsidy program encourages all types of alternative energy technologies, including CCTs (Emson, 1988).

Public-sector RD\&D in Sweden is controlled by the National Energy Administration (NEA) (Brandels, 1988), which strongly influences governmental energy funding and sponsors various CCT projects. Private-sector RD\&D, which focuses on research into solid fuels, exceeds public-sector RD\&D in terms of funding (IEA, 1986b; Lekas, 1988).

Combustion technology RD\&D focuses on FBC and sorbent injection. In Sweden, FBCs are at all stages of development, and PFBCs and CFBCs are commercially available. The world's first commercial PFBC power plant is located in Stockholm (Coal and Synfuels Technology, 1988; Lillestolen, 1988). Two PFBC units that were retrofitted to an oil-fired facility now generate $131 \mathrm{MW}$ of electricity and $217 \mathrm{MW}$ of heat and operate at $41 \%$ efficiency. Two additional PFBCs are planned, which will boost facility capacity to $267 \mathrm{MW}$ of electricity and $423 \mathrm{MW}$ of heat. Also available is a multibed combustor that consists of two CFBCs in series. Multibed combustors are being touted as more compact and better at controlling $\mathrm{NO}_{\mathrm{x}}$ emissions than AFBCs. Two privatesector companies are studying injecting sorbent into the combustion chamber; this work is at the demonstration stage.

Postcombustion technologies under study include wet and dry FGD; six full-scale plants are in operation. A commercial SCR unit is also in operation.

Sweden has enacted some of the most stringent $\mathrm{SO}_{2}$ and $\mathrm{NO}_{\mathrm{x}}$ emission regulations in the world. These regulations may preclude the building of any new coalfired facilities (Vernon, 1988). The environmental restraints extend beyond air pollution to nuclear power. The decommissioning of 2 of 12 nuclear power plants has been legislated. Plans to make up for this lost capacity are varied, but include the purchase of electricity from neighboring countries, including Poland. Concern about the detrimental effects of hydropower has also prompted legislation to limit its development (IEA, $1987 \mathrm{a})$. 


\subsection{UNITED KINGDOM}

In 1986, the $301 \mathrm{TWh}$ of electricity generated in the United Kingdom was supplied by the following sources: coal (67\%), nuclear (20\%), and oil (10\%) (IEA, 1988b; OECD, 1988a). To satisfy growing demand, additional coal-fired capacity is planned.

The stated objective of the United Kingdom's energy policy is to ensure adequate and secure energy supplies at the lowest long-term cost. The position of the government is that the role of market forces has been strengthened through the privatization of British Gas and the projected privatization of the Central Electricity Generating Board and its related affiliates (IEA, 1986b, 1987a).

To date, governmental financing to support the domestic coal industry has been significant. The unsubsidized electricity and gas industries have both earned substantial operating profits of late. They are financing their capital requirements from revenues, making substantial repayments of historic debt to the government.

Government policy directs the reduction in total $\mathrm{SO}_{2}$ emissions. Pollutioncontrol strategies recently proposed would restrict $\mathrm{SO}_{2}$ emissions even further (Vernon, 1988). However, there is no stated target or policy for reducing $\mathrm{NO}_{\mathrm{x}}$ emissions. Regarding waste disposal, there appear to be no specific policies for combustion waste.

Within the country's broader energy policy framework, the RD\&D policy encourages support for work that would not otherwise be done by the nationalized industries or the private sector. For the near term, research is directed toward development of AFBC boilers and CWMs (for industrial applications) and toward development of advanced combustion technologies, with particular emphasis on PFBC and gasification (for electricity generation). For the long term, producing synthetic natural gas by hydrogasification is being investigated.

Public-sector research primarily consists of technical and economic comparisons between conventional coal-fired power plants and those based on advanced coalcombustion technologies that incorporate the combined-cycle approach and FGD. Private-sector research related to CCTs takes place at British Coal, the Central Electricity Generating Board, and British Gas. Direct governmental support for technology development is modest. Private-sector $R D \& D$ focuses on maintaining or expanding the markets for coal, while minimizing the adverse environmental impacts of coal use (IEA, 1986a, 1987b).

The following CCT precombustion RD\&D areas are being actively pursued:

- Development of a granular coal-injection system that uses coal granules that are larger than usual, thereby resulting in 30-40\% less energy consumption for coal preparation compared with pulverizedcoal injection. Studies indicate that the system requires less capital equipment, is easier to handle, and is less prone to self-combustion. 
- Development of an air-blown fluidized-bed gasification technology for generating clean fuel gas of low calorific value for industrial applications.

- Development of a direct, two-stage coal-liquefaction process based on solvent extraction and subsequent extract hydrogenation to yield a range of lighter premium products.

- Development of a two-stage hydropyrolysis process in which primary tar vapors are passed over hydrotreating catalysts to produce distillates.

- Development of a British Gas/Lurgi slagging gasifier with a pressurized fixed bed.

Combustion CCT research has focused on the following areas:

- A major development program in PFBC is ongoing through a joint project based on a large experimental unit built at Grimethorpe. This funded phase has a long-term approach that sets a target of 1995 for ordering coal-fired generating capacity. An earlier 90-MW combustor test facility, also built at Grimethorpe, has yet to be demonstrated on a production scale.

Two main technical problems affect the design of a commercial plant of this type. The first is the erosion of the steam-raising tubes in the bubbling bed by the abrasive ash. The second is the ability of the gas-turbine blade materials to survive operation at around $850^{\circ} \mathrm{C}$ in the potentially corrosive gas leaving the cyclone train.

- Technical and economic studies are underway on direct, in-furnace limestone injection, as compared with conventional FGD. Research on staged combustion for reducing $\mathrm{NO}_{\mathrm{x}}$ formation is also being conducted.

Ongoing postcombustion CCT research is concentrating on particulate emissions

and FGD. Improvements in powdered-coal burner design are being sought, and advanced combined cycles are being investigated. In addition, a chloride prescrubber designed to counter the high average chlorine content of British coals $(0.25 \%)$ is to be tested at pilot scale. The data obtained are expected to be sufficient for scaling up to a full-sized plant.

\subsection{FEDERAL REPUBLIC OF GERMANY}

In 1986 , the $408 \mathrm{TWh}$ of electricity generated in the FRG was supplied by the following sources: coal (56\%), nuclear (29\%), natural gas (6\%), and oil (3\%) (IEA, 1988b; OECD, 1988a). 
The FRG's policy covering RD\&D encompasses the complete cycle of coal use, from mining to flue-gas control. Certain aspects of coal use are being promoted: improving the economic feasibility of coal use, while protecting the environment and taking cognizance of social concerns. Industry is heavily involved in governmentsupported RD\&D of CCTs. In FRG policy discussions, the relationship between energy and environmental policies remains the predominant issue. Ambitious national laws and regulations to combat air pollution have been enacted and are being implemented. The emission limits for large coal-fired installations and regulations for measuring and monitoring their emissions are among the strictest environmental protection regulations in the world (Vernon, 1988; Ellison, 1988).

The government of the FRG is especially concerned about its hard-coal mining industry, primarily to ensure security of supply. Sale of FRG coal to electric utilities and iron and steel companies is ensured by means of long-term, government-encouraged agreements between the involved parties. These agreements are supported by a comprehensive system of subsidies that compensate for the higher cost of using domestic coals. The federal government has supported CCTs through research on control technologies and demonstration of their applicability. Governmental assistance is also available in the form of tax relief for pollution-control expenditures.

As already stated, domestic coal is a key feature of the FRG's short- and medium-term energy supply picture. The main thrust of fossil-energy research is expected to be the demonstration and application of environmentally favorable technologies, especially advanced combustion technologies, new means of power generation, and coal-conversion processes. Both the public and private sectors are conducting research to this end (IEA, 1986a, 1987a,b).

Precombustion CCT research has focused on design and construction of an industrial-scale coal-liquefaction plant whose feedstock is brown coal; however, falling oil prices have halted construction plans. The FRG operates the world's largest coalliquefaction pilot plant.

Coal-gasification technologies are being developed to use the gas produced from coal to generate power. Other critical components for combined-cycle processes include gas cleaning equipment and high-temperature gas turbines. A state-of-the-art demonstration was conducted at a 230-MW pilot power station.

In the combustion category, CCT research has emphasized FBC and IGCC technologies. The experience to date with FBC indicates the possibility of adapting configurations that will meet environmental regulations without flue-gas treatment. An example of such a configuration is the Lurgi CFBC plant at Luenen. In 1986, the FRG had 43 pilot and demonstration plants using AFBC technology; half of these used expanded CFBC. AFBC technology is commercially available in capacities from 40 to $400 \mathrm{MW}$. The world's largest FBC (280 MW) is located in the FRG, producing electricity and steam for district heating. The FRG government also supports RD\&D projects for development of PFBCs. However, FRG companies contributed significantly to the construction and operation of the IEA project at Grimethorpe. 
Postcombustion CCT research has been significant in the FRG because all facilities, whether new or old, must be equipped with FGD equipment. Most of the FGD systems are lime/limestone scrubbers that produce by-product gypsum. The scrubbers are comparable to those in use in the United States and Japan. Selection of systems has been influenced by the need for rapid retrofit of FGD systems and the need to minimize waste generation. Sorbent injection has not been favored by the federal authorities because it limits the reuse of fly ash. Sorbent injection tends to be used only as an interim measure until FGD equipment can be fitted.

The low- $\mathrm{NO}_{\mathrm{x}}$ burners developed in the FRG are now in widespread use. Other $\mathrm{CCT}$ processes also being tested or installed include the following: selective noncatalytic reduction, SCR, electron-beam dry scrubbers, absorption processes, and oxidation/absorption. In the electric utilities sector, numerous $\mathrm{NO}_{\mathrm{x}}$-removal test, pilot, and demonstration plants are under construction or in the planning stage. About twothirds of these are committed to the SCR process. Initial FRG experience with SCR in its retrofit program has uncovered problems with space constraints at existing plants. 


\section{CHARACTERIZATION OF SELECTED COUNTRIES}

Section 4 characterizes the domestic situation with respect to coal production and use in each of the countries selected as representative of international markets with potential for export of U.S. coal and CCTs. The information provided helps to establish a base from which to identify specific marketing opportunities. Most of these opportunities are associated with generating electricity and, to a lesser extent, with generating heat and steam for industrial applications. One of the most important indicators of the potential for exporting U.S. coal and CCTs is a country's medium-term growth in electric utility capacity, that is, the growth from 1990 through 2000 . Table 4.1 gives 1985 capacities and those estimated for 2000 , by selected country.

A second important indicator of export potential is the actual and forecasted additions to electric utility coal-fired capacity in the medium term (Table 4.2). The wide variation evident in capacity and average annual growth rates, as well as in other coaluse parameters, indicates that the selected countries are likely to represent the range of coal situations in the world.

Coal use is expected to continue to grow, partly as a result of efforts to find substitutes for oil. Increasingly stringent environmental regulations will tend to promote the use of CCTs. Successful development and commercialization of U.S. CCTs should have a positive effect on the international market for U.S. goods and services.

Although the overall potential for exporting U.S. CCTs is promising, the individual technologies will need to be adapted to the requirements of specific countries and particularly to the specialized needs of developing countries. For example, how well

TABLE 4.1 Electric Utility Capacity, by Selected Country

\begin{tabular}{|c|c|c|c|}
\hline \multirow[b]{2}{*}{ Country } & \multicolumn{2}{|c|}{ Capacity (GW) } & \multirow{2}{*}{$\begin{array}{l}\text { Average } \\
\text { Annual } \\
\text { Growth (\%) }\end{array}$} \\
\hline & 1985 & 2000 & \\
\hline Italy & 56.0 & 70.0 & 1.5 \\
\hline Japan & 149.0 & 225.0 & 2.8 \\
\hline Morocco & 2.2 & 3.9 & 3.9 \\
\hline Turkey & 9.1 & 39.0 & 10.2 \\
\hline Pakistan & 5.8 & 14.0 & 6.0 \\
\hline PRC & 82.0 & 231.0 & 7.2 \\
\hline Poland & 30.1 & 42.5 & 2.3 \\
\hline
\end{tabular}

Source: IEA (1987b). 
TABLE 4.2 Electric Utility Coal-Fired

Capacity, by Selected Country

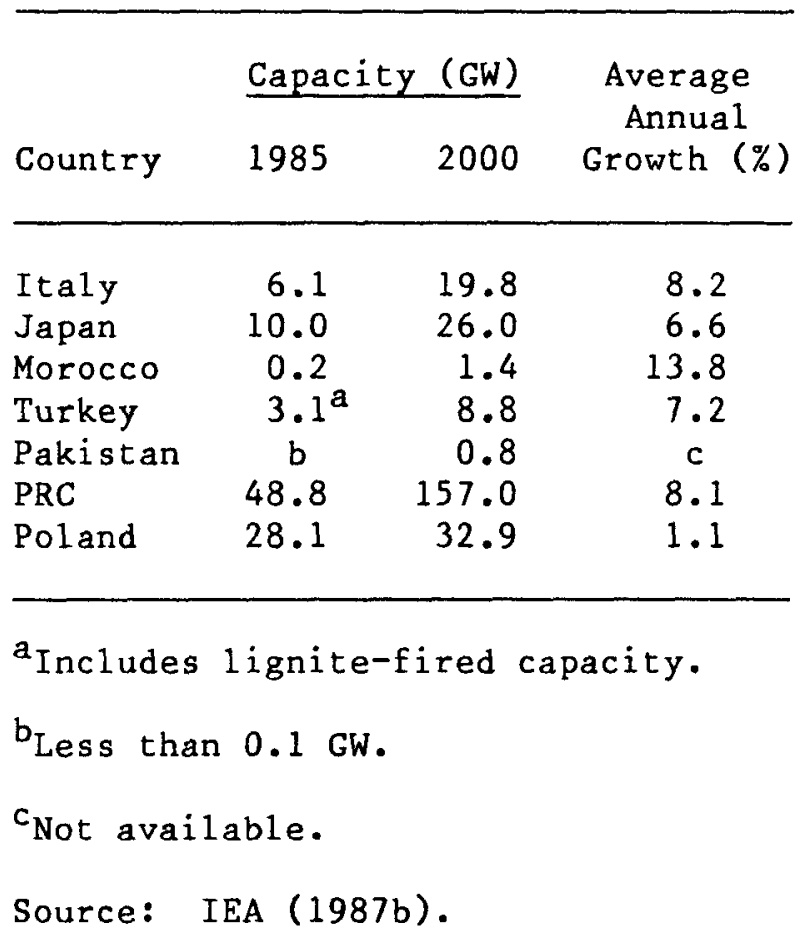

a technology operates in small units and the simplicity of its design are likely to be more important in developing countries than in the United States. Also, large reductions in pollutant emissions are probably less important in developing countries than low cost. Thus, in developing countries, the keys to successful marketing of CCTs are "smaller," "simpler," and "cheaper." In addition, a country's desire to use indigenous or easily imported coals may require that marketers of a technology show that these coals can be used.

The seven selected countries -- Italy, Japan, Morocco, Turkey, Pakistan, the PRC, and Poland -- are profiled in Sections 4.1-4.7. The discussions focus on coal demand and use, as well as possible applications for U.S. coals and CCTs.

\subsection{ITALY}

Italy depends on imported oil for more than $60 \%$ of its energy. In 1987, the 20 million tonnes of coal imported supplied only about $10 \%$ of the country's energy needs. A little less than $50 \%$ of this coal was characterized as metallurgical; the rest was steam coal for the electric utility industry.

Italy has an active program to substitute coal-based fuels for oil in large boilers and to construct coal-fired power plants. Italy's commitment to control $\mathrm{SO}_{2}$ and $\mathrm{NO}_{\mathrm{x}}$ emissions is in line with other European countries. Italy also has active R\&D programs in some CCT areas. 
In 1987, the United States was Italy's largest coal supplier, providing about 50\% of its imports. At that time, about 2 million tonnes of indigenous lignite was being mined annually for utility use. Electricity generation is predicted to grow at about $3 \%$ per year through the year 2000; by that year, the electric utility sector could require 25 million tonnes of coal. In addition, by the year 2000 , the industrial sector could require about 6 million tonnes of steam coal. Tonnages of this magnitude, plus the tonnage needed for coke in steel production (metallurgical coal), will make Italy a very large coal importer.

Recognizing that Italy has been highly dependent on oil-fired capacity brought on line in the 1970 s and 1980 s, the Ente Nazionale per l'Energia Elettrica (ENEL) now plans to bring new coal-fired capacity on line. In 1985, the country's electrical generating capacity was mostly oil $(23.8 \mathrm{GW})$ and hydro $(18.3 \mathrm{GW})$, with some gas $(6.1 \mathrm{GW})$ and coal $(6.1 \mathrm{GW})$. By $2000,15 \mathrm{GW}$ of additional capacity, mostly coal-based, is expected to come on line. With almost $25 \mathrm{GW}$ of oil and gas capacity expected to be maintained into the next century (IEA, 1987b), ENEL is investigating the use of plant life extension and repowering strategies to provide generating capacity, even though $67 \%$ of Italy's thermal generating capacity is less than 15 years old. ENEL's strategy for securing a stable electricity supply is to have multifueled plants offering flexibility and stable fuel prices. The plants accounting for most of ENEL's capacity are larger than $600 \mathrm{MW}$; however, the individual modules that make up those plants are usually only 160 or $320 \mathrm{MW}$.

Equipment and designs are being developed in Italy for industrial applications of coal-based technology. One research-scale 1.5-MW AFBC is operating in Livorno; a 270-MW FBC is scheduled to begin operation in the late 1990s. One Italian manufacturer, Ansaldo, offers AFBC units that burn coal or wood waste. Aerimpianti, Ansaldo, and Foster-Wheeler have built a municipal cogeneration power plant (19-MWe, 40-MWt). A cogeneration demonstration is being designed for the industrial market by Snamprogetti, Agip Coal, and Nuovo Pignore, with one atmospheric and one pressurized boiler to be installed at San Giuseppe di Cairo.

Italy has been encountering many problems in siting new facilities. Among these are geographic limitations, complex licensing procedures, and strenuous objections on the part of local citizens. People object to being dislocated during construction and fear loss of property values attributable to the presence of a power station. More importantly, a burgeoning environmental movement, led by Italy's Verdi (Green) Party, is beginning to take hold. Plant repowering or life extension through implementation of CCTs may help counter some of these siting difficulties (Szpunar and Gillette, 1989).

Pollution in Italy has not, until recently, been considered of crisis proportions because of (1) the high buffering capacity of Italian soils, which makes them resistant to acidic products of fossil-fuel combustion, and (2) the Alps, which act as a barrier to longrange pollutant transport. Nevertheless, as a member of the United Nations $30 \% \mathrm{Club}$, Italy is committed to reducing $\mathrm{SO}_{2}$ emissions by $30 \%$ of 1980 levels by 1990 . The 1980 levels were about 3.3 million tonnes, of which 1.55 million tonnes is estimated to derive from electricity generation. At new plants, emissions are limited to $400 \mathrm{mg}$ of $\mathrm{SO}_{2}$ and $650 \mathrm{mg}$ of $\mathrm{NO}_{\mathrm{x}}$ per cubic meter of flue gas. A limit of $1200 \mathrm{mg} \mathrm{\textrm {SO } _ { 2 }}$ per cubic meter of flue gas has been set for existing power plants that convert from oil to coal. 
Imported coal must not contain more than $1 \%$ sulfur. However, production of high-sulfur lignite from the reopened Sulcis mine in Sardinia may offer some opportunities to market U.S. CCTs. The argument can be made that the environmental consequences of using this fuel could be less than or comparable to those from burning $1 \%$ sulfur coal in conventional coal-based plants (Szpunar and Gillette, 1989).

Coal technology RD\&D is focused on alternative fuels like CWMs because they can be handled, transported, and burned like oil. CWMs are especially suited for retrofit of existing plants. CWMs are also expected to play a significant role in new multifueled power plants. Although the Italian government allocated only $\$ 0.5$ million to coal $R \& D$ in 1985 , the private sector conducts its own research in slurry preparation and handling, boiler fouling and erosion, and burner design. Facilities for demonstrating coal preparation include a $500-\mathrm{kt} / \mathrm{yr}$ facility at Porto Torres sponsored by Enichem-Anie, which was scheduled to be completed in 1989. Snamprogetti and Tosi are retrofitting 200-MW boilers at Belovo in the Soviet Union with a burner capable of using CWMs. A 75-MW CWM power plant is being constructed in Cassano d'Adda, Italy.

Research is ongoing on burner modifications to reduce $\mathrm{NO}_{\mathrm{x}}$ formation. The Babcock and Wilcox burners expected to be applied at Brindisi Nord and Sud are expected to reduce $\mathrm{NO}_{\mathrm{x}}$ by $60 \%$.

\subsection{JAPAN}

In 1987, Japan imported approximately $27 \%$ of the coal traded on the world market, more than any other country. Of the approximately 90 million tonnes of coal imported, 70\% was for metallurgical use. Only $13 \%$ of Japan's coal demand was supplied from domestic resources. Even this low level of use of indigenous coal is being phased out, partly because of the high cost.

The Japanese have stringent requirements for control of $\mathrm{SO}_{2}$ and $\mathrm{NO}_{\mathrm{x}}$ emissions. In many instances, allowable emissions depend on agreements between local authorities and industry. Process design and equipment for emissions control, as well as the power plants themselves, are supplied by national firms.

The demand for coal is expected to increase most in the steam-coal sector because of Japan's desire to become less dependent on imported oil. Metallurgical coal imports are not expected to increase significantly despite increases in the production of steel for export. Environmental concerns and economic benefits could result in a market for some CCTs, although Japanese industry would probably be the equipment supplier. In keeping with its policy of diversifying its coal sources, Japan is involved in foreign coal development. In 1987, coal imports from the United States amounted to 10 million tonnes, a value well below the historic high of about 25 million tonnes in 1982 .

Coal, oil, gas, nuclear, and hydro facilities contribute materially to Japan's electricity supply. The largest amount of capacity is oil-fired and the smallest is coalfired. The total capacity of coal-fired units rated from 100 to $299 \mathrm{MW}$ is about equal to that of units rated 300 to $599 \mathrm{MW}$. Larger units are now being constructed. Table 4.3 gives the breakdown in electric utility capacity, by fuel type and unit size. Table 4.4 provides a breakdown of 1986 electrical generation, by fuel type. 
TABLE 4.3 Japanese Electric Utility Capacity, by Unit Size ${ }^{\mathrm{a}}$ and Fuel Type, 1985

\begin{tabular}{|c|c|c|c|c|c|c|c|c|c|c|}
\hline \multirow[b]{3}{*}{ Fuel } & \multicolumn{10}{|c|}{ Unit Size (MW) } \\
\hline & \multicolumn{2}{|c|}{$<50$} & \multicolumn{2}{|c|}{$50-99$} & \multicolumn{2}{|c|}{$100-299$} & \multicolumn{2}{|c|}{$300-599$} & \multicolumn{2}{|c|}{$600+$} \\
\hline & MW & No. & MW & No. & MW & No. & MW & No. & MW & No. \\
\hline $0 i 1^{b}$ & 0 & 0 & 964 & 11 & 12,779 & 67 & 25,899 & 65 & 11,000 & 17 \\
\hline Gas & 0 & 0 & 0 & 0 & 2,842 & 13 & 8,895 & 20 & 12,690 & 18 \\
\hline $\mathrm{Coal}$ & 0 & 0 & 570 & 8 & 4,166 & 24 & 3,900 & 8 & 700 & 1 \\
\hline $\begin{array}{l}\text { Hydro/geo- } \\
\text { thermal }\end{array}$ & & & & & & & & & & \\
\hline Nuclear & $\begin{array}{r}1,601 \\
0\end{array}$ & $\begin{array}{r}45 \\
0\end{array}$ & $\begin{array}{r}4,126 \\
0\end{array}$ & $\begin{array}{r}38 \\
0\end{array}$ & $\begin{array}{r}9,722 \\
0\end{array}$ & $\begin{array}{r}36 \\
0\end{array}$ & $\begin{array}{l}6,712 \\
4,900\end{array}$ & $\begin{array}{r}22 \\
9\end{array}$ & $\begin{array}{r}0 \\
17,998\end{array}$ & $\begin{array}{r}0 \\
20\end{array}$ \\
\hline
\end{tabular}

${ }^{a}$ Numbers are based on average unit sizes at multiunit plants from the nine major Japanese utilities.

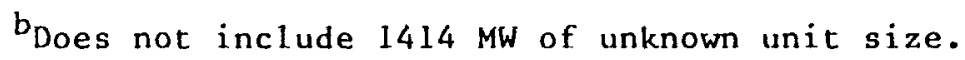

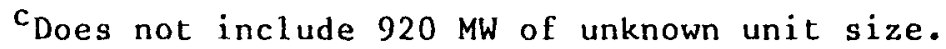

dDoes not include $9765 \mathrm{MW}$ of unknown unit size.

Source: IEA (1987b).

Installed capacity is expected to increase annually by an average of about $2.8 \%$ to the year 2000 , when it is expected to reach $225 \mathrm{GW}$. During this period, coal use for steam generation is expected to increase at $4.7 \%$ per year. The anticipated high growth rates for total and coal-fired generation may provide an opening for U.S. CCTs. However, Japanese technology and industry competition are expected to be formidable. For example, Japanese manufacturers are already offering coal-fired AFBCs, as well as FGD and SCR equipment for high-level $\mathrm{SO}_{2}$ and $\mathrm{NO}_{\mathrm{x}}$ removal.

Almost all coal-fired capacity in Japan is less than 25 years old. On the basis of available data (Thomas and Cragg, 1987), $32 \%$ of Japanese electric utility coal-fired capacity is $0-5$ years old, $11 \%$ is $6-15$ years old, and $51 \%$ is $16-25$ years old. For older plants, some measures to extend their lives, along with associated changes, are probably being considered. Oil-fired
TABLE 4.4 Japanese Electrical Generation, by Fuel Type, 1986

\begin{tabular}{lr}
\hline \multicolumn{1}{c}{ Fuel } & TWh \\
\hline Oil & 197 \\
Nuclear & 168 \\
Natural gas & 124 \\
Coal & 99 \\
Other & 87 \\
Total & 675 \\
& \\
\hline & \\
a Hydroelectric, \\
geothermal, and \\
other renewables. \\
\multicolumn{2}{l}{ Source: IEA } \\
\multicolumn{2}{l}{ (1987b). }
\end{tabular}


units in Japan are also relatively new; conversion of some of these units to CCTs might be cost effective. Table 4.5 provides data on Japanese electric utility capacity, by unit age. However, the replacement market is not likely to be significant through the end of the century.

At least 25 industrial FBCs are on line, for a total of $1240 \mathrm{MWt}$. Most of these units are coal-fired combustors. The following Japanese manufacturers offer coal-fired AFBCs for industrial use: Babcock-Hitachi, Ishikawajima-Harima (under license from Foster-Wheeler), Kawasaki, Mitsubishi, and Mitsui (under license from Battelle and Riley Stoker). The results of a survey indicated that 10 orders for CFBCs came from Japanese companies and that eight of them were for coal-fired units. All 10 orders were placed with Japanese boiler manufacturers (Makansi and Schwieger, 1987).

Following the success of a $40,000-1 b / h$ AFBC pilot plant, Kawasaki Heavy Industries and Mitsui Aluminum Co. designed and built a commercial AFBC to repower two existing 150,000-1b/h boilers at Wakammatsu in Kyushu. Also, a 320,000-lb/h (steam) AFBC demonstration plant based on the earlier success was designed by Babcock-Hitachi K.K. and the Electric Power Development Corporation. Finally, Babcock-Hitachi K.K. and Hitachi Ltd. have built a 50-MW AFBC demonstration plant.

A 75-MW CWM project has been demonstrated at Nakoso by Joban Joint Power, Tokyo Electric Power, and Tohoku Electric Power, with the cooperation of Mitsubishi, Babcock-Hitachi K.K., and Ishikawajima-Harima.

TABLE 4.5 Japanese Electric Utility Capacity, by Unit Age and Fuel Type, 1985

\begin{tabular}{|c|c|c|c|c|c|c|c|c|c|c|}
\hline \multirow[b]{3}{*}{ Fuel } & \multicolumn{10}{|c|}{ Age (yr) } \\
\hline & \multicolumn{2}{|c|}{$0-5$} & \multicolumn{2}{|c|}{$6-15$} & \multicolumn{2}{|c|}{$6-25$} & \multicolumn{2}{|c|}{$26-40$} & \multicolumn{2}{|c|}{$40+$} \\
\hline & MW & No. & MW & No. & MW & No. & $\mathrm{MW}$ & No. & MW & No. \\
\hline $0 i 1^{a}$ & 3,425 & 7 & 27,696 & 59 & 16,226 & 69 & 2,672 & 23 & - & - \\
\hline Gas & 4,790 & 7 & 14,245 & 25 & 5,392 & 19 & 0 & 0 & 0 & 0 \\
\hline $\mathrm{Coal}^{\mathrm{b}}$ & 2,650 & 5 & 950 & 2 & 4,280 & 27 & 456 & 5 & 0 & 0 \\
\hline Ilydro/geo- & & & & & & & & & & \\
\hline thermal ${ }^{c}$ & 4,569 & 19 & 8,091 & 50 & 4,703 & 60 & 1,083 & 24 & 490 & 6 \\
\hline Nuclear & 6,704 & 13 & 16,194 & 22 & - & - & - & - & - & - \\
\hline Total & 22,138 & & 67,176 & & 30,601 & & 4,211 & & 490 & 6 \\
\hline
\end{tabular}

\footnotetext{
a Does not include 1537 MW of unknown age.

${ }^{b}$ Does not include 920 MW of unknown age.

${ }^{\mathrm{C}}$ Does not include $9856 \mathrm{MW}$ of unknown age.

Source: Thomas and Cragg (1987).
} 
Public awareness of environmental pollutants has been spurred by a number of cases involving health damage. The ambient air quality standards and emission-rate limits that have been promulgated are among the strictest in the world. Air quality has improved since the mid-1970s. In particular, $\mathrm{SO}_{2}$ levels have decreased (Japanese Environment Agency, 1986); ambient $\mathrm{NO}_{\mathrm{x}}$ levels rose from $0.022 \mathrm{ppm}$ in 1970 to a high of $0.028 \mathrm{ppm}$ in 1979 , before declining to $0.025 \mathrm{ppm}$ in 1985 . In 1985 and 1986, regulation of air emissions was extended to smaller boilers, that is, those having a firing rate above about 2 million Btu/h.

Sulfur dioxide control has been achieved by use of low-sulfur fuels, FGD, and oil desulfurization. About 1500 FGD units are now in operation. About $85 \%$ of coal-fired plants in Japan are equipped with FGD systems. Nitrogen oxides are being controlled by SCR and other means. Because of limited land for waste disposal, all FGD systems produce a usable by-product (e.g., gypsum).

In 1986, the government's budget for coal RD\&D was $\$ 200$ million, which represents $9 \%$ of the total energy $R D \& D$ budget. These funds were used primarily for long-term coal-liquefaction and coal-gasification programs and for medium-term FBC demonstration activities under the New Energy Development Organization. The Ministry of International Trade and Industry also funds coal $R \& D$, as do other major Japanese research institutes.

Tests have been performed on 5- and 40-tons/d combined-cycle fluidized-bed gasification systems. One New Energy Development Organization project consists of a coal gasifier with a 200-tons/d capacity, a hot-gas cleanup system, and a 13-MW gas turbine. Another is a 250-tons/d coal-liquefaction pilot plant for subbituminous and lowlevel bituminous coals.

The Japanese have been very active in flue-gas treatment, both with respect to domestic RD\&D and commercialization activities. The focus has been on SCR, combustion modifications for $\mathrm{NO}_{\mathrm{x}}$ reduction, and wet and dry $\mathrm{FGD}$. Leading vendors are Mitsubishi Heavy Industries, Sumitomo Heavy Industries, Tokyo Engineering Corp., Ube Industries, and Kawasaki Heavy Industries (Szpunar and Gillette, 1989).

Japan has been a strong proponent of SCR technology to reduce $\mathrm{NO}_{\mathbf{x}}$ emissions. U.S. proprietary advances in this area could have marketing potential. One example is power generation with IGCC technology, which results in very low $\mathrm{SO}_{2}, \mathrm{NO}_{\mathrm{x}}$, and particulate emissions. If a combined $\mathrm{SO}_{2}$ and $\mathrm{NO}_{\mathbf{x}}$ removal technology like NOXSO achieved very low emissions, it could also be of interest.

\subsection{MOROCCO}

Morocco is highly dependent on energy imports. In 1986, imports amounted to almost $90 \%$ of all commercial energy consumed, of which about $80 \%$ was oil. Coal use amounted to about 1.5 million tonnes, or $15 \%$, with domestic production accounting for almost 50\%. In 1986 and 1987, the United States was the major exporter of coal to Morocco. By the late 1990s, annual oil and coal imports are expected to reach 6 and 3 million tonnes, respectively. However, an increase in coal imports and use is currently impeded by lack of an adequate coal-handling and transportation infrastructure. 
Approximately $90 \%$ of Morocco's electric generating capacity, or $2200 \mathrm{MW}$, is provided by the Office National de l'Electricite (ONE). Current plans for meeting baseload demand call for retirement of much of the oil-fired capacity in favor of coal (ONE, 1985). This objective could provide a market for U.S. CCTs and additional U.S. coal exports. In the long range, the country plans to commission both nuclear capacity (600 MW) and oil-shale power plants at some time near 2010. However, if Morocco succeeds in tieing into the European power grid through Spain, the long-term electrical generation picture could change.

To meet the demand for electricity, Morocco has relied until recently on numerous, small hydroelectric plants and several oil-fired steam generators. Coal-fired generation had been limited to the $165-\mathrm{MW}$ mine-mouth power plant at Jerada. In general, Moroccan boilers are smaller and less efficient than typical boilers in the United States. Only six units are larger than $100 \mathrm{MW}$. Table 4.6 provides information on Morocco's electric utility capacity, by size and fuel type. Table 4.7 gives the capacity of various generating types, by age range. As of 1985 , most of the units are less than 15 years old.

Industrial boilers are primarily oil-fired and small by U.S. standards (i.e., smaller than $50,000 \mathrm{Btu} / \mathrm{h}$ ). The industrial sectors using such boilers include food, phosphate, cement, glass, brick, paper and pulp, chemicals, and textiles. In 1985, most of the coalfired boilers were in the food industry. In 1985, the total capacity of the 42 large Morrocan boilers (i.e., larger than $50,000 \mathrm{Btu} / \mathrm{h}$ ) was about 4.4 billion $\mathrm{Btu} / \mathrm{h}$.

At this time, there are no apparent environmental concerns related to energy, and specific information on $\mathrm{SO}_{2}$ and $\mathrm{NO}_{\mathrm{x}}$ emissions is not available. If Moroccan regulations exist, they are not enforced; compliance with any standards would appear to be largely voluntary. Any use of CCTs would be based on economic attractiveness.

Because the levels of energy use and electricity generation are small compared with those in other countries, the Moroccan market for U.S. coal and CCTs is also small. FBCs with thermal efficiencies higher than those of currently used boilers and with flexibility as to the fossil fuel fired could be of interest to this country. FBCs designed to burn the indigenous oil shale may also have some potential.

\subsection{TURKEY}

Turkey has substantial lignite and hydropower resources, but more limited oil, gas, and hard-coal resources. Because of increases in population and industrial activity, annual consumption of primary energy increased about $4 \%$ between 1973 and 1985 . In 1987, domestic energy sources supplied about $56 \%$ of the country's energy needs. Although some coal was imported, oil was the main source of imported energy. Approximately $40 \%$ of Turkey's export earnings was used to meet foreign currency requirements for imported energy. 
TABLE 4.6 Moroccan Electric Utility Capacity, by Unit Size and Fuel Type, 1985

\begin{tabular}{|c|c|c|c|c|c|c|}
\hline \multirow[b]{3}{*}{ Fuel } & \multicolumn{6}{|c|}{ Unit Size (MW) } \\
\hline & \multicolumn{2}{|c|}{$0-50$} & \multicolumn{2}{|c|}{$>50-100$} & \multicolumn{2}{|c|}{$\geq 100-300$} \\
\hline & MW & No. & MW & No. & MW & No. \\
\hline Oil & $24^{a}$ & $\mathrm{~b}$ & 60 & 1 & 900 & 3 \\
\hline Gas & 136 & 40 & 0 & 0 & 0 & 0 \\
\hline Coal & 0 & 0 & 0 & 1 & 165 & 1 \\
\hline Hydro & 256 & 19 & 94 & 1 & 263 & 2 \\
\hline Nuclear & 0 & 0 & 0 & 0 & 0 & 0 \\
\hline Other ${ }^{c}$ & 192 & b & 0 & 0 & 0 & 0 \\
\hline Total & 608 & $b$ & 214 & 3 & 1328 & 6 \\
\hline \multicolumn{7}{|c|}{$\begin{array}{l}{ }^{a} \text { Diesel plants. } \\
{ }^{b} \text { Unknown. }\end{array}$} \\
\hline \multicolumn{7}{|c|}{$\begin{array}{l}\text { c Independent producers and isolated power } \\
\text { centers. }\end{array}$} \\
\hline Source: & \multicolumn{6}{|c|}{ ONE (1985). } \\
\hline
\end{tabular}

TABLE 4.7 Morocean Electric Utility Capacity, by Unit Age and Fuel Type, 1985

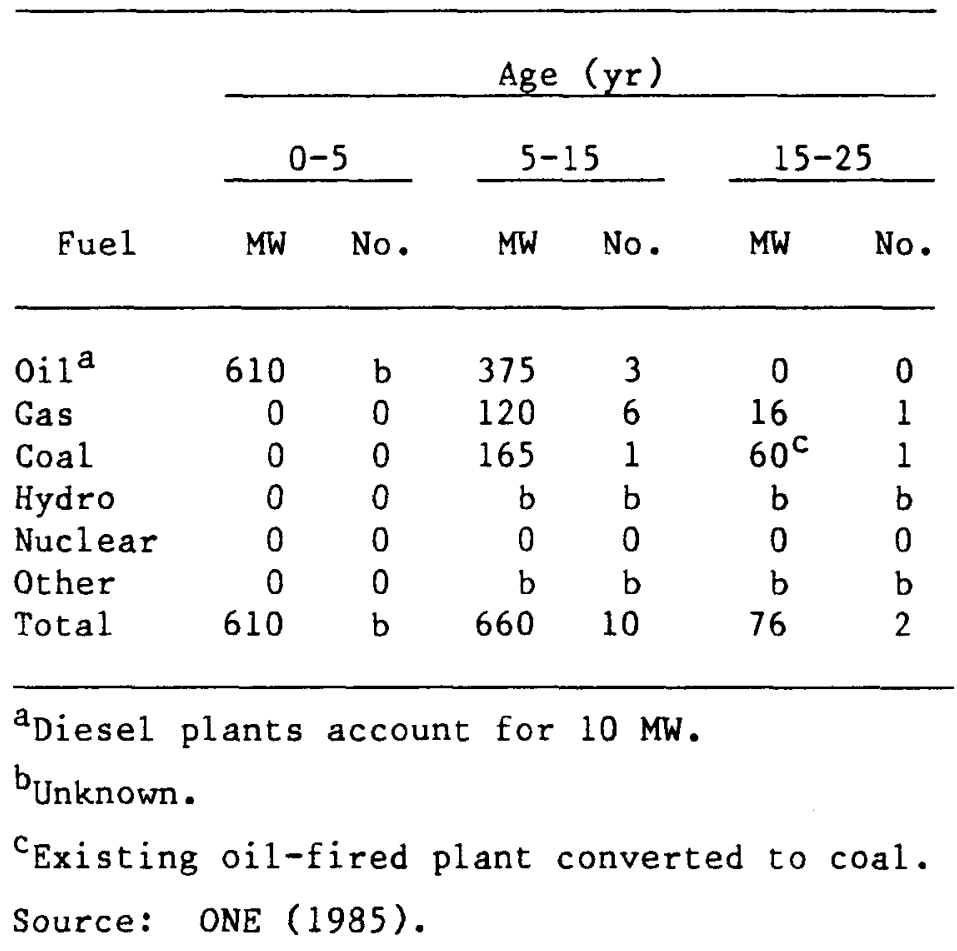


Energy has become one of Turkey's cornerstones in formulating development policy. Both hydropower and coal are scheduled to play a significant role in the growth of the electrical power industry. In 1987, Turkey produced about 42 million tonnes of lignite and about $\mathbf{3 . 6}$ million tonnes of hard coal. Imports of metallurgical and steam coal amounted to about 4 million tonnes. Coal imports are expected to supply steamcoal needs. In 1986, the United States was the largest coal supplier; in 1987, Australia was the largest. As part of its developmental policy, the Turkish government is encouraging foreign firms to work in concert with private Turkish firms to provide needed facilities, especially in the electrical generation field. Much of Turkey's new coal-fired capacity is expected to involve foreign participatory arrangements.*

In 1985 , installed capacity was about $9.0 \mathrm{GW}$ : hydro $(3.9 \mathrm{GW})$, coal $(3.1 \mathrm{GW}$, of which $3.0 \mathrm{GW}$ is lignite-fired), and oil $(2.0 \mathrm{GW})$. Plans are to more than quadruple capacity to $39 \mathrm{GW}$ by 2000 , with a tripling of coal- and lignite-fired capacity. About $5.2 \mathrm{GW}$ of new coal-fired capacity is expected to be designed for imported coal. Thus, a potential may exist for U.S. CCTs and coals in supplying this new capacity. With its extensive privatization (build, own, operate, and transfer) efforts, or similar foreign arrangements, Turkey is expected to serve as a model for any developing country whose private sector is likely to finance, build, own, operate, and subsequently transfer major power plants to the state utility. Turkey would like to have at least three of the five planned power stations financed and built by foreign suppliers, thereby transferring the initial risk for these stations. The three Turkish plants being considered are Gazi (1400 MW), Tekirday (960 MW), and Aliaga (1000 MW).

Most of the generating capacity in Turkey is quite new. As of 1985, $75 \%$ of all capacity was less than 15 years old; therefore, the market for replacing these units is expected to remain small over the next 10 to 15 years. However, converting some oilfired capacity to coal-fired capacity may be feasible. Most of Turkey's generating units are small, with 11 of 21 thermal plants being smaller than $50 \mathrm{MW}$. New installations are expected to be larger. Table 4.8 lists the electrical capacities of state plants, by size range.

Industrial boilers account for an estimated 75\% of Turkey's coal consumption and $25 \%$ of its lignite consumption. In 1986, the cement industry consumed 3 million tonnes of coal. About 500,000 tonnes was imported from the Soviet Union for blending purposes. Turkey has one 16-MW FBC at Izmir. A number of Turkish firms manufacture steam boilers of various sizes.

In Turkey, concerns about protecting the environment are focused mainly on water pollution and solid waste. Only a few emission requirements have been set forth; however, air pollution is especially severe in the cities of Ankara, Erzurum, and Istanbul. In 1987, Ankara began importing steam coal and blending it with domestic lignite to reduce $\mathrm{SO}_{2}$ levels in the city. This action may serve as a stopgap measure until natural gas becomes the major heating fuel in the mid-1990s.

\footnotetext{
*Three arrangements are possible: (1) build, operate, and transfer (BOT); (2) build, own, and operate (BOO); and (3) build, own, operate, and transfer (BOOT).
} 
TABLE 4.8 Turkish Electric Utility Capacity, by Unit Size and Fuel Type, 1985

\begin{tabular}{|c|c|c|c|c|c|c|c|c|}
\hline \multirow[b]{3}{*}{ Fuel } & \multicolumn{8}{|c|}{ Unit Size (MW) } \\
\hline & \multicolumn{2}{|c|}{$0-99$} & \multicolumn{2}{|c|}{$100-299$} & \multicolumn{2}{|c|}{$300-499$} & \multicolumn{2}{|c|}{$500+$} \\
\hline & MW & No. & MW & No. & MW & No. & MW & No. \\
\hline Therma1 & 275 & 11 & 454 & 4 & 1374 & 3 & 1940 & 3 \\
\hline Hydro & 615 & 34 & 704 & 4 & 0 & & 2370 & $?$ \\
\hline
\end{tabular}

Source: Turkish Electricity Authority (1985).

Current control measures consist of ESPs at thermal power stations and some mixing of limestone with domestic fuel. Stack height is used as a design factor in reducing local $\mathrm{SO}_{2}$ levels. Nitrogen oxide emissions from lignite combustion are not considered to be a major problem because of this fuel's low combustion temperature. The main environmental problem areas are domestic heating, followed by industrial and utility boilers. Industries and electric utilities will probably adopt FGD for control. Pollutants from domestic heating will probably be controlled through use of smokeless fuels and district-heating schemes whose viability will depend on housing unit density. Turkey has only recently implemented emission-rate limits; detailed information is unavailable about the applicability and enforcement of these limits.

In 1985 , Turkey's expenditures on coal $R \& D$ totaled about $\$ 400,000$, or $17 \%$ of its total spending on energy $R \& D$. Considerable attention has been focused on determining operating conditions and design parameters of various pilot-scale FBCs that fire Turkish lignite. Other research interests include briquetting of lignite, production of smokeless fuel, desulfurization of lignite, gasification and liquefaction of lignite, production of coke, and use of solid wastes (i.e., ash and slag) in construction materials.

U.S. firms could enter into technology agreements with Turkish firms. If some financing were available from U.S. commercial interests, CCT technologies could be marketed in Turkey.

\subsection{PAKISTAN}

The energy consumed in Pakistan increased by almost $5 \%$ yearly from 1980 to 1985; growth from 1985 to 2000 is expected to remain at that level (i.e., 5-6\% yearly). The scarcity of energy has become a major constraint in Pakistan's economic growth. In the past, the problem has been compounded by $12 \%$ annual growth in electricity consumption (Government of Pakistan, 1986). Because of frequent blackouts and other supply shortages, it has been difficult to determine the true growth in electricity demand. Rapid growth in energy demand and low domestic energy production have 
prompted the government to lessen the country's dependence on oil imports by promoting fuel substitution and development of indigenous energy resources (e.g., coal and hydropower). This policy could help create a market for CCTs, in that it provides for converting plants from oil to coal and for constructing new plants capable of burning of high-sulfur, high-ash coals, including indigenous lignite.

The availability of domestic coal is limited because of low production. Measured reserves are about 200 million tonnes. Gross heating values range from 5800 to $9900 \mathrm{Btu} / \mathrm{lb}$; at 4-6\%, the sulfur content is high. These subbituminous coals or lignite will not support many large power plants. Imported coals also face impediments because of infrastructure limitations. For example, harbor and transportation facilities would have to be constructed before imported coal could become much of a factor.

In 1988, installed capacity in Pakistan totaled $6.2 \mathrm{GW}$, as follows: hydro $(2.9 \mathrm{GW})$, oil (1.2 GW), gas (1.2 GW), high-speed diesel (0.8 GW), and coal (12 MW). By the late 1990s, an additional $2 \mathrm{GW}$ of hydropower and $800 \mathrm{MW}$ of coal-fired capacity are expected to be added. One or two 250-MW conventional power plants at Lakhra could burn domestic lignite. Another $800 \mathrm{MW}$ of coal-fired capacity may be added in the 1990s; some of this capacity could be designed for imported coal. Smaller, privately financed projects are also under consideration.

In $1985,30 \%$ of Pakistan's electrical generating capacity, excluding hydro, is less than 5 years old and $67 \%$ is less than 15 years old (Table 4.9). Newer plants average $72 \mathrm{MW}$, while older plants average only $13 \mathrm{MW}$. No power plant is larger than $210 \mathrm{MW}$

TABLE 4.9 Pakistani Electric Utility Capacity, by Unit Age and Fuel Type, 1985

\begin{tabular}{|c|c|c|c|c|c|c|c|c|}
\hline \multirow[b]{3}{*}{ Fuel } & \multicolumn{8}{|c|}{ Age (yr) } \\
\hline & \multicolumn{2}{|c|}{$0-5$} & \multicolumn{2}{|c|}{$5-15$} & \multicolumn{2}{|c|}{$15-25$} & \multicolumn{2}{|c|}{$25-40$} \\
\hline & MW & No. & $\mathrm{MW}$ & No. & MW & No. & MW & No. \\
\hline oil & 750 & 7 & 596 & 14 & 718 & 22 & 46 & 11 \\
\hline Gas & 117 & 6 & 368 & 16 & 99 & 8 & 0 & 0 \\
\hline Coal & 0 & 0 & 0 & 0 & 15 & 2 & 0 & 0 \\
\hline Nuclear & 0 & 0 & 0 & 0 & 70 & 1 & 0 & 0 \\
\hline Other & 0 & 0 & 112 & 80 & 6 & 1 & 0 & 0 \\
\hline Total $b$ & 867 & 12 & 1076 & 110 & 908 & 34 & 46 & 11 \\
\hline \multicolumn{9}{|c|}{$\begin{array}{l}\text { ancludes } 112 \mathrm{MW} \text { of cane waste fuel and } 6 \mathrm{MW} \text { of pulp waste } \\
\text { fuel. }\end{array}$} \\
\hline \multicolumn{9}{|c|}{${ }^{b}$ Excludes $2900 \mathrm{MW}$ of hydroelectric capacity. } \\
\hline Source: & $\begin{array}{l}\text { Water } \\
1986) ;\end{array}$ & $\begin{array}{l}\text { and } P \\
\text { Kara }\end{array}$ & $\begin{array}{l}\text { wer Dev } \\
\text { hi Elec }\end{array}$ & & & $\begin{array}{l}\text { ority } \\
\text { o. }(19\end{array}$ & $\begin{array}{l}(1985, \\
35) .\end{array}$ & \\
\hline
\end{tabular}


(Government of Pakistan, 1986). Pakistan's one nuclear power plant at Kanupp is operating at about half capacity for safety reasons. No environmental regulations affecting electricity generation are known to exist in Pakistan.

On the industrial side, Pakistan has approximately 3000 combustors. In 1985 , boiler capacity totaled roughly 38 billion $B t u / h$, which represents a $22 \%$ increase over 1980. Almost 70\% of the industrial boilers are gas-fired. Coal-fired boilers account for only $1 \%$ of the installed units and less than $1 \%$ of the installed capacity. Typically, the boilers are quite small, with boilers under 50 million Btu/h accounting for more than $90 \%$ of the installed units and more than $40 \%$ of the total capacity. Large industrial boilers (i.e., those larger than 100 million $B t u / h$ ) account for less than $2 \%$ of the units and about $33 \%$ of total capacity. Pakistan's industrial boilers are relatively new, with roughly $80 \%$ of total units and capacity being less than 25 years old.

There appear to be no applicable environmental regulations. The Pakistani government appears to be focusing on the other major problems facing this very poor country.

The Pakistani government appears to be encouraging private-sector investment in power generation. Under certain conditions, public utilities can purchase electricity from privately operated power plants. To that end, private-sector power generation projects are being negotiated with the Water and Power Development Authority and the Karachi Electric Supply Corporation. In support of this effort, the U.S. Agency for International Development and the World Bank have provided technical and financial assistance and training.

Pakistan currently consumes very little coal and has few immediate environmental concerns to encourage development and adoption of CCTs. Although the known deposits of lignite are not extensive, these resources could be used in highefficiency electrical generation facilities. If CWMs for use in existing small boilers were developed, they could be marketed to Pakistani industries to reduce the country's dependence on imported oil. In the electric utility sector, CWMs could provide dual-fuel capability for existing oil-fired plants.

\subsection{PEOPLES' REPUBLIC OF CHINA}

The PRC has the world's largest known reserves of coal and hydropower, and $2.6 \%$ of the world's known petroleum reserves (East-West Center, 1989). Coal is by far the most important energy source, accounting for $75 \%$ of primary energy consumption. No major country outside of Eastern Europe has a higher percentage of coal use. In 1987, 855 million tonnes of coal was produced; 70 million tonnes of lignite was also produced. By 2000 , coal production is expected to reach $1200-1400$ million tonnes.

The PRC envisions becoming a major coal exporter to Pacific Rim countries. It has recently invested money and manpower to improve the coal infrastructure: mine supply, rail transport, and port-handling facilities. 
Chinese coal mines are either central (typically larger mines serving national and export demands) or local (typically smaller, locally controlled operations serving regional demands). The local mines have largely been responsible for the increase in coal production over the last few years. A major factor in this growth has apparently been the infusion of market forces into the pricing structure for the local and state mines. The central mines are also achieving excellent production rates as a result of the injection of Western and Japanese mining technology. Still, only $40 \%$ of the major mines are mechanized. With the help of continued purchases of technology and equipment from the United States, Japan, the FRG, and the United Kingdom, the PRC plans to have 56\% of its mines mechanized by 1995 .

Although much of the Chinese coal is low in sulfur content, it of ten is high in ash content. To increase the export potential of its coal, the PRC has recently stepped up development of its coal washing facilities. Cleaned coal offers improved end-use efficiencies and reduced transport costs. In 1983, it was estimated that only $18 \%$ of the PRC's coal was washed. By 1995, the PRC plans to have built sufficient facilities for $56 \%$ of its coal production to be washed.

The growth in installed electrical generating capacity has slowed in recent years; in 1985, total installed capacity was $82 \mathrm{GW}$. Annual demand now exceeds available supply by 45-50 TWh. This power shortage, which amounts to about $15 \%$ of industrial electricity requirements, is likely to continue for the medium term. Under current plans, all new thermal capacity is expected to be coal based. Between 1980 and 2000, the annual growth in demand for electricity is projected to average 6.0-7.5\% (excluding the demand that is met through industrial cogeneration).

A partial listing of electrical generating facilities representing the major sites in selected provinces is given in Appendix B. This listing demonstates that many PRC plants were built in the 1950 s and 1960s. Anticipated or planned increments over the next 10 years are also listed in Appendix B.

The PRC's economy suffers from imbalances in resource allocation because of an extensive but shrinking system of state-controlled prices and subsidies. For the most part, energy prices have remained fixed since the late 1950s. To encourage industrial development, industrial fuel prices were set artificially low, while households and others paid two to three times the industrial price. By the $1980 \mathrm{~s}$, effective utilization of industrial energy had declined to about 25\%, nearly half the level found in Japan. In 1983, the PRC made some reforms by adopting multi-tiered pricing for energy and mineral products. More fundamental energy price reform has yet to be undertaken because of fears that rationalization of energy prices will cause higher prices in every other sector of the economy as well (East-West Center, 1989).

If rapid economic growth continues, most of the PRC's industrial boiler capacity may be new by the end of the century. Hence, the particular boiler technology installed will play a critical role in the country's efforts to improve the efficiency of coal use and to reduce air pollution from coal consumption.

The Chinese first began working on FBC technology in 1965. Since then, more than 2500 FBCs have been installed throughout the country, making the PRC the largest 
user of this technology in the world. However, most of these units are small industrial boilers (bubbling, atmospheric technology) that fire low-grade coal. Only a handful of FBCs for generating electricity are in operation. There are 21 boiler works in the PRC that can manufacture bubbling, atmospheric FBCs. Among these are Jiangxi, Canton, Changchun, Jinan, and Sichuan. The annual output of the 21 boiler works is more than 250 units whose capacities range from 4 to $130 \mathrm{t} / \mathrm{h}$ of coal.

The role of cogeneration in the PRC is small and, by international standards, the technology used is not very advanced. Installed cogeneration capacity totals approximately $4.9 \mathrm{GW}$. Today, industry (especially metals, chemicals, and building materials) accounts for at least $50 \%$ of coal consumption and $75 \%$ of electricity consumption.

Air pollution caused by coal combustion is already a severe problem in urban areas. Although Chinese coal reserves are, on the whole, relatively low in sulfur, the sheer quantities of coal consumed and the limited use of pollution-control technologies have resulted in high concentrations of particulates and $\mathrm{SO}_{2}$ in many northern cities. Although the national control standard for $\mathrm{SO}_{2}$ is an annual average of $0.15 \mathrm{mg} / \mathrm{m}^{3}$, many cities exceed the standard frequently and sometimes by several orders of magnitude during the winter.

The largest sources of air pollution are industrial and household (i.e., cooking and heating) coal combustion. The larger industrial plants and power stations generally have more efficient combustion systems and discharge $\mathrm{SO}_{2}$ from relatively tall stacks.

No data on total $\mathrm{SO}_{2}$ and $\mathrm{NO}_{\mathrm{x}}$ emissions are available. In the early 1980s, an estimate yielded a $\mathrm{NO}_{\mathrm{x}}$ emission density of approximately $0.4 \mathrm{t} / \mathrm{km}^{2}$. This value compares with a 1980 U.S. emission density of about $2.2 \mathrm{t} / \mathrm{km}^{2}$. The government has long been aware that its dependency on coal combustion for power plants and industrial boilers would present major air-pollution problems.

The objectives of the government's policy for the electrical utility sector include (1) expand electrical generating capacity as rapidly as possible; (2) develop mine-mouth coal-fired power plants near ports and load centers; (3) convert oil-fired units to coal; and (4) develop nuclear power in areas where other forms of energy are scarce.

Current $\mathrm{R} \& \mathrm{D}$ is focusing on $\mathrm{CFBC}$ and PFBC technology. Tsinghua University has designed and installed several CFBCs and expects to install a $30-t / h$ unit at the Guizhou chemical fertilizer plant. This project is also expected to include research on recovering sulfur because the $P R C$ would like to reduce its dependence on sulfur imports. The use of limestone as a $\mathrm{SO}_{\mathbf{x}}$ retainer has been demonstrated and applied. Through a joint research program with Foster-Wheeler Development Corp. and Ishikawajima-Harima of Japan, Tsinghua University is also working on second-generation FBC technology.

The Chinese have also been long interested in coal gasification. Efforts were initiated in the 1950s, and the PRC is now the world's largest producer of synthetic gas from coal. Synthetic gas is typically used in plants that manufacture machinery and chemicals. A new demonstration of a pressurized, ash-agglomerating, fluidized-bed 
gasifier was scheduled to be operational at the First Heavy Machinery Works in Fularji in 1988. The U.S. firms Kellogg Co. and $\mathrm{KRW}$ Inc. have been responsible for the engineering and equipment for this project. Other coal-utilization research of interest includes development of pulverized-coal burners with precombustion burners and FGD research (World Bank, 1987a).

The government's desire for rapid growth in electrical generating capacity and an imminent need to improve air quality could stir up interest in CCTs, including IGCC. Because the PRC has vast coal reserves and high mining capability, coal beneficiation techniques could also prove marketable.

\subsection{POLAND}

Poland depends on domestic coal and lignite as its primary sources of energy. For many years, this dependence has imposed heavy environmental costs on the Polish economy and population. Indeed, much of Poland's air and water pollution can be traced to the high energy intensity of Polish industrial production.

Nevertheless, given the ongoing changes in Eastern Europe's political, social, and economic structures, it should be possible (and very desirable) to reduce the rate and extent of current pollution. The following steps can be taken: (1) exercise an integrated network approach in managing existing coal-burning plants, (2) install FGD equipment on existing units, (3) beneficiate the coal before its transport and use, and (4) introduce CCTs being developed in the United States and abroad.

Poland has substantial reserves of both hard coal and lignite. Recoverable reserves of the former are estimated to be 42.6 billion tonnes and of the latter to be 3.0 billion tonnes. Accompanied by difficult geological conditions, the hard coal is mined deep underground; the lignite deposits are suitable for open-pit mining.

Considered currently recoverable are only 2 million tonnes of oil and an amount of gas equivalent to 163 million tonnes of oil (Craig, 1990). Each year, about 14 million tonnes and 8 billion $\mathrm{m}^{3}$, respectively, of oil and gas are imported exclusively from the Soviet Union (United Nations, 1989). Nuclear power, which was to have started up in the early 1990s, has recently been delayed indefinitely for financial reasons and because of technical difficulties.

Trailing only the PRC, the United States, and the Soviet Union in hard-coal production (DOE, 1989b), Poland had achieved an annual hard-coal production rate of more than 190 million tonnes. The approximately 80 million tonnes of lignite produced per year are used solely for domestic consumption, primarily at mine-mouth power stations. A power station at Belchatow has increased its lignite consumption from 24 million tonnes per year to more than 38 million tonnes per year. Mine expansion continues, and the mined lignite is burned in $12360-\mathrm{MW}$ units.

Under the Communist regime, government policy had called for stabilizing annual hard-coal production at 195 million tonnes by 1990 (Gorst, 1987) and lignite production at more than 80 million tonnes. However, increases in hard-coal production 
require considerable capital investment, and the necessary funds are not available. Therefore, increases achieved in fuel extraction have been occurring in open-pit lignite mines rather than in underground hard-coal mines. In 1989, hard-coal production only reached 178 million tonnes (International Coal Report, 1990).

Of the hard coal produced in Poland, more than 160 million tonnes per year is consumed domestically (United Nations, 1988). More than 55\% is consumed in generating electricity and for combined $\mathrm{CHP}$ use. About $20 \%$ is consumed directly in the residential/commercial sector in individual homes and about $15 \%$ in producing steel. Of the Polish lignite produced, more than $95 \%$ is burned in power plants to produce electricity for public distribution.

Coal and lignite account for almost $99 \%$ of Poland's fuel input for electricity generation. Thus, coal's contribution to electricity generation in Poland is 28 percentage points higher than that of the United Kingdom (71\%), the next highest country among free-market economies (IEA, 1988b). In 1988, total installed capacity in Poland was $28.9 \mathrm{GW}$, of which $17.8 \mathrm{GW}(62 \%)$ was fired on hard coal and $9.1 \mathrm{GW}$ (31\%) on lignite (World Bank, 1987b; Computer Centre of Power Systems, 1989). The remaining 2.0 GW (7\%) was hydroelectric capacity, which was associated primarily with pumped storage facilities used to meet peak loads. An additional $3.1 \mathrm{GW}$ of industrial capacity was available for self-generation.

Accounting for more than $80 \%$ of Poland's primary energy consumption, coal is considered to be the rational response to the perceived availability of a cheap and domestically available fuel. However, this percentage is extremely high in comparison with percentages in Western market economies. For example, in most OECD countries, coal accounts for less than 25\% of primary energy consumption. Even Australia, which exports more than three times as much coal as Poland, depends on coal for less than 50\% of its domestic energy consumption (IEA, 1988b). However, the percentage in the PRC is $75 \%$, which is more like the percentage in Poland.

At the heart of the Polish system is the assumption that coal will or should be used, unless there are overwhelming technical reasons for substituting other fuels. Thus, natural gas is used for high-temperature processes, as in other industrialized countries, but Poland invariably depends on coal for raising steam and space heating, even when gas might be more economical, convenient, or environmentally desirable.

Some sectors of the economy would prefer to use coals of higher quality (i.e., higher calorific value) than they are able to obtain under the present system of central allocation. In the electric utility sector, a shift to higher quality would enable some power stations to substantially improve their conversion efficiency, thereby achieving fuel savings of about $10 \%$. Because the electric utility sector accounts for about $55 \%$ of hard-coal consumption in Poland, any shift in its demand for coal would immediately affect the balance between demand and supply for different grades of coal. However, on the supply side, many mines would not be able to operate profitably, if the coal price structure were too heavily weighted against low-grade coals. 
Increasing the fuel supply in Poland, and especially the lignite supply, is considered to be an appropriate and easier solution to meeting increased energy demand than investing to achieve higher energy efficiency, energy conservation, and fuel substitution. Consumption of lignite and poor-quality hard coal is very high. On a hardcoal-equivalent basis, nearly 97\% of Poland's 1987 total energy production (180 million tonnes) is coal and lignite (United Nations, 1989). Because most domestically consumed coal is not cleaned, a relatively dirty material is handled and burned without pollution control. The result is air and water pollution problems for the country.

In Poland, coal beneficiation has been controversial, partly because of Polish institutional arrangements. Miners have viewed beneficiation as an incremental production cost that results in loss of product volume. Power plant operators have viewed coal beneficiation as a means of lowering the cost of generating electricity through increased plant efficiency and decreased cleanup costs with respect to effluents and solid waste. Up to $50 \%$ of the sulfur in many Polish coals could probably be removed by precombustion cleaning.

Equipment applications are being developed. For example, DOE is involved in collaboratively retrofitting a coal-fired power plant in Krakow with an advanced clean coal technology that has been successfully demonstrated in the United States in a power plant of comparable size. The mandate is for the retrofit to "be carried out by one or more U.S. companies using U.S. technology and equipment manufactured in the United States" (U.S. Congress, 1989). DOE is also working with the Poles "to assess and develop the capability within Poland to manufacture or modify boilers, furnaces, smelters, or other equipment that will enable industrial facilities within Poland to use fossil fuels cleanly" (U.S. Congress, 1989).

For decades, Poland has relied on exports of hard coal to finance imports. Any increase in domestic consumption or decrease in domestic production reduces the supply available for export and thereby the hard currency this transaction represents. 


\section{COMPARATIVE ANALYSES OF POTENTIAL MARKETS}

In assessing potential international markets for U.S. coals and CCTs, the first step was to match, in preliminary fashion, the most promising CCTs with the seven countries selected as being representative for the purposes of this marketing study. The second step was to complete economic analyses for the technology/country matches. The purpose of the analyses was to compare the alternative matchings in a quantitative manner so that the potential for economic benefit from implementing the CCTs would be evident. The results of the two steps are presented below.

\subsection{STEP 1: PRELIMINARY TECHNOLOGY/COUNTRY MATCHES}

On the basis of the information summarized in Sections 4.1-4.7, preliminary matches were made between the candidate CCTs and the countries selected as representative (Table 5.1). These matches reflect our qualitative assessment of energy demand in the individual countries (supported by information published in the open literature) and the potential ability of the various CCTs to meet this demand. The factors considered in this assessment were (1) projected growth in the demand for electricity, (2) size and makeup of existing and projected electrical generating capacity, (3) fuels now used to generate electricity or that could be readily accessible for that purpose, and (4) nature of existing or likely environmental regulations. These four factors are briefly discussed below.

1. Projected Growth in the Demand for Electricity. The particular products and services needed within the individual countries are important in selecting appropriate energy technologies. Increased demand for electricity could necessitate constructing new or modernizing existing generating capacity. Whether the increase in demand is for base-load, intermediate, or peaking capacity affects which technologies are most appropriate. Changing or growing energy demands and the demand load factor within the industrial sector can also influence technology selection. Plant reliability, resource requirements, waste disposal needs, and other disparate factors must also be considered.

2. Current and Projected Electrical Generating Capacity. How energy is currently supplied in the electric utility and industrial sectors is important in selecting new technologies. Also needing consideration are the existence and duration of shortfalls in electricity supply. Plant maintenance practices and import tariff policies can be important in this regard. The current fuel mix is also significant (see item 4 below), in that displacement of a more costly fuel by coal may be advantageous. The age of existing facilities can be important because retiring the facility must be weighed against such alternatives as adding pollution control or extending the life of the facility, perhaps by repowering with a new technology. 
TABLE 5.1 Assessment of Likely Interest in Clean Coal Technologies for Electric Utility Applications in the Seven Countries Selected as Representative ${ }^{\mathrm{a}}$

\begin{tabular}{|c|c|c|c|c|c|c|c|}
\hline \multirow[b]{2}{*}{$\mathrm{CCT}$} & \multicolumn{7}{|c|}{ Country } \\
\hline & Italy & Japan & Morocco & Turkey & Pakistan & PRC & Poland \\
\hline \multicolumn{8}{|l|}{ Precombustion } \\
\hline Beneficiation & $x$ & - & - & $x$ & $x$ & $x$ & $x x$ \\
\hline CWM & $\mathrm{XX}$ & $\mathrm{XX}$ & $\mathrm{x}$ & $\mathrm{x}$ & $\mathrm{X}$ & - & - \\
\hline \multicolumn{8}{|l|}{ Combustion } \\
\hline $\begin{array}{l}\text { Slagging } \\
\text { combustor }\end{array}$ & $X X$ & $\mathrm{XX}$ & $x$ & $X$ & $\mathrm{X}$ & - & - \\
\hline IGCC & $\mathrm{X}$ & $\mathrm{XX}$ & $\mathrm{X}$ & $\mathrm{X}$ & $\mathrm{X}$ & $\mathrm{X}$ & $x x$ \\
\hline$A F B C$ & $\mathrm{x}$ & $\mathrm{X}$ & $X X$ & $\mathrm{XX}$ & $\mathrm{Xx}$ & $\mathrm{XX}$ & $x x$ \\
\hline $\mathrm{PFBC}$ & - & $\mathrm{x}$ & - & $\mathrm{X}$ & $\mathrm{X}$ & $\mathrm{X}$ & $\mathrm{xx}$ \\
\hline \multicolumn{8}{|l|}{ Postcombustion } \\
\hline LIMB & - & - & - & $\mathrm{x}$ & - & $\mathrm{x}$ & $\mathrm{X}$ \\
\hline GRSI & - & - & - & - & - & $\mathrm{x}$ & $x$ \\
\hline Dual-alkali FGD & - & - & - & - & - & $\mathrm{X}$ & $\mathrm{x}$ \\
\hline Spray-dryer FGD & - & - & - & $\mathrm{x}$ & - & $\mathrm{x}$ & $\mathrm{X}$ \\
\hline NOXSO & $\mathrm{x}$ & $\mathrm{X}$ & - & - & - & $\mathrm{x}$ & $\mathrm{X}$ \\
\hline SCR & $X$ & $X X$ & - & - & - & - & $\mathrm{X}$ \\
\hline
\end{tabular}

${ }^{a X X}$ indicates potential strong interest; $X$ indicates potential less strong interest; and - indicates little or no interest (at this time).

3. Fuel Availability. One of the most important factors in selecting appropriate technologies is the availability and price of alternative fuels. Many countries in the international marketplace have little or no indigenous fuel resources and therefore rely heavily on energy imports. In many cases, this imported energy is in the form of oil, a commodity of uncertain price and unreliable supply. Furthermore, the indigenous fuel resources may be undeveloped, of low calorific value, and/or of high ash, moisture, and sulfur content. Also needing consideration is the existing infrastructure for supplying fuel (e.g., mine facilities, road and rail transport, ports, and pipelines) or the difficulties in developing such an infrastructure. Technologies should not be selected without considering each of these factors along with the country's desire to reduce imports, to increase the use of domestic fuels, to diversify fuel supplies, and to apply national policies. 
4. Environmental Regulations. Although some foreign countries do not have or in some cases do not enforce domestic environmental regulations, there is growing awareness that environmental issues must be considered as part of the overall energy picture. Some countries (e.g., Japan and the FRG) have been world leaders in controlling atmospheric emissions from power plants. Some countries (e.g., Italy) have signed a United Nations agreement to reduce $\mathrm{SO}_{2}$ emissions by $30 \%$ of their 1980 levels by 1990 . Some international lending organizations (e.g., The World Bank) now insist that environmental issues be considered before approving loans to finance power projects. The likelihood that a country will mandate control of $\mathrm{SO}_{2}$ or $\mathrm{NO}_{\mathrm{x}}$ emissions, along with the expected stringency of that control, can influence the technologies most appropriate for that country. The types of fuels either currently used or projected for future use affect the appropriateness of certain technologies with respect to environmental issues.

These factors, together with preliminary qualitative assessments, influenced the preliminary technology/country matches presented in Table 5.1. These matches were then analyzed in more detail, and on a country-specific basis, by estimating in-country cost and performance parameters and by comparing the CCT alternatives with some other commonly implemented technologies. Section 5.2 discusses these analyses and comparisons with respect to each country's demand profile.

\subsection{STEP 2: ECONOMIC ANALYSES OF SPECIFIC CLEAN COAL TECHNOLOGY ALTERNATIVES BY COUNTRY}

Table 5.2 summarizes the results of the economic analyses performed for most of the preliminary technology/country matches presented in Table 5.1. The data used in the analyses were gleaned from both published (e.g., EPRI, 1986b and 1989 and OECD, 1989) and unpublished sources. Because of the level of uncertainty in some of these data, a simple parametric treatment was undertaken with respect to some of the variables. The overall intent was to evaluate the potential for economic benefit from implementing these technologies, rather than to provide rigorous analyses leading to definitive decisions regarding their use.

In the following sections, the countries selected as representatives are treated with respect to potential CCT applications and the related economic considerations. Section 6 addresses how market- and other trade-related issues might affect CCT marketability.

\subsubsection{Italy}

\subsubsection{Potential CCT Applications in Italy}

In recent years, groups in Italy have worked extensively to develop the CWM option. Significant adoption of this technology would address several of the energy and 
TABLE 5.2 Assessed Technology/Country Matches

\begin{tabular}{|c|c|c|c|}
\hline Country & Situation & $\begin{array}{l}\text { Applicable } \\
\text { Technology }\end{array}$ & Savings (levelized basis) \\
\hline Italy & $\begin{array}{l}\text { New plant } \\
(600 \mathrm{MW}) \\
\text { oil retrofit } \\
(250 \mathrm{MW})\end{array}$ & $\begin{array}{l}\text { PC/FGD, a AFBC, IGCC } \\
\text { slagging combustor }\end{array}$ & $\begin{array}{l}\text { Up to } 25 \% \\
10-15 \%\end{array}$ \\
\hline Japan & $\begin{array}{l}\text { New plant } \\
(500 \mathrm{MW}) \\
\text { oil retrofit } \\
(250 \mathrm{MW})\end{array}$ & $\begin{array}{l}\text { IGCC, PC/FGD } \\
\text { PFBC } \\
\text { Slagging combustor }\end{array}$ & $\begin{array}{l}33 \% \\
20 \% \\
\text { Positive (not quantified) }\end{array}$ \\
\hline Morocco & $\begin{array}{l}\text { New plant } \\
(200 \mathrm{MW})\end{array}$ & $\mathrm{AFBC}, \mathrm{IGCC}, \mathrm{PC} / \mathrm{FGD}$ & Positive (not quantified) \\
\hline Turkey & $\begin{array}{l}\text { New plant } \\
(500 \mathrm{MW}) \\
\text { 0il retrofit } \\
(200 \mathrm{MW})\end{array}$ & $\begin{array}{l}\text { IGCC } \\
\text { AFBC, PC/FGD } \\
\text { Slagging combustor }\end{array}$ & $\begin{array}{l}20 \% \\
10 \% \\
20 \%\end{array}$ \\
\hline Pakistan & $\begin{array}{l}\text { New plant } \\
(100 \mathrm{MW}) \\
\text { oil retrofit } \\
(250 \mathrm{MW})\end{array}$ & $\begin{array}{l}\text { IGCC } \\
\text { AFBC, PC/FGD } \\
\text { Slagging combustor }\end{array}$ & $\begin{array}{l}\text { More positive (not quantified) } \\
\text { Positive (not quantified) } \\
\text { Positive (not quantified) }\end{array}$ \\
\hline PRC & $\begin{array}{l}\text { New plant } \\
(500 \mathrm{MW})\end{array}$ & $\begin{array}{l}\text { IGCC } \\
\mathrm{PC} / \mathrm{FGD}, \quad \mathrm{AFBC}\end{array}$ & $\begin{array}{l}\text { Most positive } \\
\text { Positive }\end{array}$ \\
\hline Pol and & $\begin{array}{l}\text { New plant } \\
(350 \text { or } \\
500 \mathrm{MW})\end{array}$ & $\begin{array}{l}\mathrm{PC} / \mathrm{FGD}, \mathrm{IGCC} \\
\mathrm{AFBC}, \mathrm{PFBC}\end{array}$ & $\begin{array}{l}\text { Lignite - } 15 \mathrm{mills} / \mathrm{kWh} \\
\text { Bituminous }-8 \mathrm{mi} 11 \mathrm{~s} / \mathrm{kWh}\end{array}$ \\
\hline
\end{tabular}

apulverized-coal FGD.

environmental concerns facing the Italian government and the country's electric utility and industrial sectors. First, such adoption would help reduce Italy's heavy dependence on imported oil (Section 4.1). Second, converting existing oil-fired plants to CWM plants would provide a dual fuel capability, a stated goal for all new Italian power plants. Third, by extending the life of existing facilities, concurrent with converting to CWM plants, ENEL can add capacity while minimizing capital outlays and avoiding some of the difficulties associated with siting new power plants.

Use of cleaned coal in CWMs would enable coal to be used without having to provide extensive disposal sites for solid waste. In addition, by displacing oil of higher 
sulfur content, CWMs would help Italy meet its commitment to the United Nations to reduce its $\mathrm{SO}_{2}$ emissions by $30 \%$ of the 1980 level.

Slagging combustors could offer Italy many of the same potential benefits as CWMs. The current dependence on imported oil could be reduced. Again, use of cleaned coal in these combustors would allow such conversions to take place with minimal environmental impact. Additionally, the $\mathrm{SO}_{2}$ and $\mathrm{NO}_{\mathrm{x}}$ emission characteristics of slagging combustors can be advantageous in their own right.

The reopening of the Sulcis mine in Sardinia could prompt interest in at least two other CCTs. Beneficiation could make the Sulcis high-sulfur lignite usable by ENEL and others. Depending on the washing characteristics of this lignite, which are yet to be determined, it may be able to serve as the coal source for CWMs.

The AFBC technology is another CCT that is coming to the fore because of this mine reopening. It could help expand electrical generating capacity, while burning the high-sulfur lignite in an environmentally responsible manner. Existing collaborative agreements regarding AFBCs suggest significant interest in this option on the part of the Italian government.

Another potential CCT application is the IGCC plant. Because of the potential for very low emissions of $\mathrm{SO}_{2}$ and moderate emissions of $\mathrm{NO}_{x}$, the IGCC technology can be used to expand electrical generating capacity, while helping to lower atmospheric emissions from the electric utility sector. The fact that IGCC performance is relatively insensitive to coal type is desirable for countries like Italy that must import their coal and that would like the potential for multiple fuel sources.

Italy's membership in the United Nations $30 \%$ Club could result in some interest in alternative means of treating flue gas. The Japanese-developed SCR process (because of its applicability to both oil- and coal-fired capacity) and the NOXSO process (because of its ability to simultaneously remove large amounts of $\mathrm{SO}_{2}$ and $\mathrm{NO}_{\mathrm{x}}$ ) appear to be the most likely candidates.

Because most of Italy's coal imports now come from Australia and the United States, the applicable CCTs should be demonstrated as being capable of operating efficiently with these coals. If these imported coals or the Sulcis lignite were demonstrated with the aforementioned CCTs, the resulting operating and performance data would reveal appropriate opportunities for retrofit and new construction in the Italian electric utility sector.

\subsubsection{Economic Comparisons with Respect to Italy}

We had to make various assumptions in comparing the economics of the most promising CCTs with the other energy options now used in Italy. These assumptions were based partly on published and unpublished information from other analysts and partly on our perceptions as available information and data were examined. The analyses that follow provide initial insight into the competitiveness of U.S. CCTs but cannot be perceived as conclusive as to specific projects. 
Economic conditions in Italy do not appear to constitute an insurmountable barrier to any of the capital-intensive energy technologies, including those in the DOE CCT Demonstration Program. Capital costs appear to be only slightly higher than those for the corresponding unit in the United States. In addition, there do not appear to be significant tariffs to drive up the price of imported technologies, parts, or services. Interest rates appear to be reasonable, with $5 \%$ per year being representative of the real rate expected in the state-owned electric utility industry. However, fuel costs are relatively high in Italy. Information available in early 1990 suggests values of $\$ 3.00 / 10^{6}$ Btu for imported coal and $\$ 4.50 / 10^{6}$ Btu for imported oil.

Cost estimates and comparisons were made for two options of interest to the Italian electric utility sector. The first option encompasses plant types that would probably be considered in expansions of existing electrical generating capacity. At $600 \mathrm{MW}$, these plants have the capacity appropriate for new power plants in Italy. The four technology alternatives examined are a residual-oil-fired unit, a pulverized-coal FGD unit, an AFBC, and an IGCC coal plant. For purposes of this comparison, we assumed that the oil-fired plant would not be equipped with an FGD system. This assumption is somewhat questionable in that the oil currently burned in Italy has a higher sulfur content than is allowed in imported coal and so would probably require an FGD system. However, the assumption is reasonable because it results in a conservative comparison, that is, one biased against the coal-based options.

The resultant estimates for new power plants suggest that each of the three CCTs could produce electricity at a lower cost than a new oil-fired plant without FGD. First-year savings of up to $10 \%$ could be realized. For a 30 -year plant lifetime, $2 \%$ annual real escalation in oil price, and constant coal prices, the savings from implementing the CCTs could go as high as $25 \%$ (on a levelized basis).

The second option examined the alternatives available for existing oil-fired capacity. The plants could continue to operate as is or could be converted to a coalbased alternative. In this comparison, a plant size of $250 \mathrm{MW}$ was used because this size is representative of the oil-fired units that would be most likely be considered for conversion. The coal-based options examined were the slagging combustor and a CWM. These options were compared with the option of continuing to burn residual oil over the 15-year plant lifetime assumed to be remaining. For the slagging combustor option, a cost of $\$ 300$ per kilowatt was used for converting the original facility to receive coal and sorbent and for solid-waste disposal. An additional cost of $\$ 375 / \mathrm{kW}$ was used for the combustors, feed mechanisms, and ash-handling and other auxiliary equipment used in direct support of the combustors.

We defined two scenarios to examine the CWM options. The first assumed that the coal would be cleaned such that only a small investment $(\$ 50 / \mathrm{kW})$ in the existing facility would be required and that no derating of net electrical output would occur. We estimated that the need for highly cleaned coal and the preparation and transport of the CWM would add $\$ 2.50 / 10^{6}$ Btu to the basic coal price of $\$ 3.00 / 10^{6}$ Btu. The total delivered fuel cost would therefore be $\$ 5.50 / 10^{6} \mathrm{Btu}$.

The second scenario was based on the coal not being cleaned as much as in the first case, which then necessitated more extensive (and expensive) plant modifications. 
An estimate of the delivered fuel cost is $\$ 4.10 / 10^{6} \mathrm{Btu}$, and an estimate of the necessary plant modification cost is $\$ 200 / \mathrm{kW}$. We further assumed that, even with the more extensive modifications, a derating of $30 \%$ would result from the conversion from oil to a CWM.

The estimated cost of electricity from these converted facilities was compared to the cost of continuing to burn residual oil in the existing plants. The estimated firstyear cost based on the slagging combustor retrofit was identical to that of the original facility. However, when the costs were levelized over the remaining 15-year plant lifetime, a significant advantage of approximately 10-15\% was evident for the slagging combustor retrofit.

The CWM scenario results suggest that, under the assumed economic conditions, continuing to burn residual oil would be less expensive than the alternative. Electricity costs from the oil-fired plant would be 20-35\% less than those based on the CWM retrofit on a first-year basis and 15-25\% less on a 15-year levelized basis. The critical parameters driving these differentials are the costs for oil and the CWMs and the amount of derating together with the corresponding cost of replacement electricity.

Other options of potential interest in Italy are the postcombustion cleanup technologies and the precombustion coal preparation technologies. Both of these would be beneficial in controlling the atmospheric emissions resulting from increased coal use. These options are not compared here because decisions on their use will likely be driven more by policy considerations than by cost comparisons. If the Italian government were to set goals for controlling atmospheric emissions, these technologies would likely be applied. If not, the postcombustion cleanup systems will not be applied. In either case, some application of coal cleaning technologies might occur, but the market would likely be linked to development of the CWM option.

Another potentially large market for CCTs in Italy is that of repowering existing facilities. Repowering involves replacing portions of existing power plants with technologies like AFBC, PFBC, or IGCC. The life of the portions of the existing plant that are not replaced is typically extended so that the operating characteristics and expected lifetimes match those of the new CCT portion of the plant.

The economics of repowering are very site-specific and thus beyond the scope of these analyses. However, because the assessments for new power plants suggest a strong potential for CCTs, we conclude that the potential is also strong for repowering facilities with these same technologies. This belief was reinforced by papers presented at the recent GEN-UPGRADE 90 Conference held in March 1990 in Washington, D.C. (EPRI, 1990).

\subsubsection{Japan}

\subsubsection{Potential CCT Applications in Japan}

As is true of all countries currently relying heavily on imported oil, Japan could make efficient use of both CWMs and slagging combustors. By retrofitting these 
technologies to some of the existing oil-fired units, and by extending their lives through refurbishments, when necessary, the Japanese electric utilities could displace much of the approximately $200 \mathrm{TWh}$ of electricity generated in oil-fired power plants.

The rapid growth in demand for electricity expected in Japan (Section 4.2) will require a concomitant expansion of its electrical generating capacity. The IGCC option, which is under development in the DOE CCT Demonstration Program, could play an important role in this expansion. This technology could offer several advantages that would be of particular interest in Japan. First, IGCC systems produce small quantities of solid waste. This consideration is important in Japan where land for solid waste disposal is extremely limited. Second, the ability of IGCC systems to operate efficiently with a variety of coals is important in countries like Japan that have very limited or no indigenous fossil energy reserves. Third, IGCC systems emit very little $\mathrm{SO}_{2}$ and $\mathrm{NO}_{x}$, which is important in countries like Japan that have taken very strong steps to control these atmospheric emissions.

Japan has attempted to control $\mathrm{NO}_{\mathrm{x}}$ emissions through flue-gas treatment, particularly SCR. Although there is a large and growing market for this technology, Japan's lead may make it very difficult for U.S. companies to make much headway. However, other flue-gas treatment options (e.g., NOXSO) that achieve high percentages of $\mathrm{SO}_{2}$ and $\mathrm{NO}_{\mathrm{x}}$ removal, could potentially find significant niches in the Japanese marketplace. Sorbent-injection technologies would probably not be marketable to any extent in Japan because they do not remove enough $\mathrm{SO}_{2}$ even as they generate large quantities of solid waste. The spray-dryer and dual-alkali technologies offer higher pollutant removal efficiencies, but they too yield comparatively large amounts of solid waste.

At this time, FBCs probably merit only moderate consideration for new Japanese power plants. These technologies offer high levels of $\mathrm{SO}_{2}$ control and moderate $\mathrm{NO}_{\mathrm{x}}$ emissions. However, because Japan must import nearly all its coal, it requires that only low-sulfur coals be burned. This requirement neutralizes one of the advantages of FBC. However, there may be a market for FBC options in cases in which reboilering or repowering of existing facilities is being considered. As noted in Section 5.2.1.2, comparative assessments of repowering options are very site-specific and therefore have not been undertaken for this study. As was the case in Italy, however, reports of repowering assessments suggest that there is a substantial CCT repowering market in Japan.

Because Japan has such limited indigenous coal resources, coal cleaning techniques appear to be of little interest except in very special cases in which Japanese coal specifications cannot be met by outside suppliers.

\subsubsection{Economic Comparisons with Respect to Japan}

The economics of selected options for generating electricity were compared in the manner described for Italy (Section 5.2.1). Considerable evidence suggests that the capital cost of large facilities (e.g., power plants) is considerably higher in Japan than in the United States or Europe. This premium as to capital cost has been estimated to be as 
high as $46 \%$ (OECD, 1989). This premium can be important when comparing options (e.g., coal-fired versus oil-fired capacity) because the reference capital costs are quite different and any premium would tend to exaggerate these differences. We used the $46 \%$ premium in the reference-case analyses that follow. For purposes of comparison, we examined 500-MW units with IGCC, pulverized-coal FGD, and oil-fired boilers.

Fuel costs are also quite high in Japan. Although future costs are difficult to predict, estimated costs of $\$ 2.35 / 10^{6}$ Btu for coal and $\$ 6.15 / 10^{6}$ Btu for oil appear to be reasonable. We used these values in the reference-case analyses.

As was the case with Italy, we assumed that either of two CWM options could help reduce Japan's dependence on imported oil. We again assumed that a very clean CWM could be produced at a cost of $\$ 2.50 /$ Btu above the cost of the feedstock coal. Facilities burning this fuel would not suffer any derating, and only a nominal investment would be required to convert the plant from oil to $\mathrm{CWM}$ operation. A less clean CWM could be produced at a cost of $\$ 1.10 / 10^{6}$ Btu above the cost of the feedstock coal. However, this fuel would require considerable investment in soot blowers and various particulate-control and ash-handling equipment. And, even with this additional equipment, the derating of the plant would be significant. We used a derating of $30 \%$ in the reference-case analysis.

The analysis results suggest that the electricity generated at any new coal-based power plant of approximately 500-MW capacity would be considerably less expensive than the electricity generated at a new oil-fired plant. First-year costs for the IGCC and pulverized-coal FGD plants would be comparable. The electricity from the PFBC plant would be about $20 \%$ more expensive than the electricity from the IGCC plant, whereas that from the oil-fired plant would be almost $50 \%$ more expensive than that from the IGCC plant.

In the results presented above, the overwhelming driver is the large difference in the cost of coal and oil in Japan (a margin of $\$ 3.80 / 10^{6} \mathrm{Btu}$ ). Although there is significant evidence that the margin is this large, we deemed it worthwhile to investigate the effect of a decrease in this margin on the overall conclusions. Sensitivity analyses suggest that the margin would have to reduced to less than $\$ 1.30 / 10^{6}$ Btu before the first-year cost of electricity from the new oil-fired plant would be less than that from the IGCC plant. (As a point of reference, note that internationally traded coal at $\$ 33 /$ ton and crude oil at $\$ 20 / \mathrm{bbl}$ have a price differential of approximately $\$ 2.20 / 10^{6}$ Btu.)

Retrofit applications in Japan should yield results and conclusions similar to those for new power plants. For plants with 15 years of life remaining, the electricity generated at a 250-MW plant that has been converted to burn coal in a slagging combustor would be significantly less expensive than the electricity generated in an oilfired plant. Before the oil-fired plant becomes less costly than the slagging combustor plant, the margin in fuel price would have to fall to about $\$ 2.15 / 10^{6} \mathrm{Btu}$, which is $\$ 0.85$ higher than the $\$ 1.30 / 10^{6}$ Btu for new power plants. 
The cost of electricity from power plants burning the very clean CWM is also estimated to be lower than the cost of electricity generated at oil-fired plants, but not as low as the cost of the electricity generated at the slagging-combustor plant. The cost of electricity from power plants burning the less clean $\mathrm{CWM}$ and experiencing a $30 \%$ derating is nearly equal to that of electricity from the oil-fired plant.

Important factors in comparing the costs associated with CWMs and oil-fired generation include the margin in fuel price between oil and feedstock coal, the cost of CWM preparation, and the derating experienced by the plant following conversion to a CWM feed. For example, if the price of oil were $\$ 5.05 / 10^{6} \mathrm{Btu}$ (instead of $\left.\$ 6.15 / 10^{6} \mathrm{Btu}\right)$, and if all other parameters were held at their reference-case values, the electricity generated at the oil-fired plant would be equal to the cost of the electricity generated at the plant burning the very clean $\mathrm{CWM}$ and significantly less expensive than the electricity generated at the plant burning the less clean CWM. On the other hand, if the cost of preparing the very clean CWM were reduced from the reference value of $\$ 2.50$ per million Btu, the cost differential between oil and coal would be decreased even further, while the cost advantage for the CWM would be maintained.

As noted above, the CWM plant experiencing the $30 \%$ derating would have an electricity cost equal to that of the original oil-fired plant. However, if the derating were to increase or decrease, or if the capital investment required for the conversion were to change, there could be swings in either direction as to cost advantage.

\subsubsection{Moroceo}

\subsubsection{Potential CCT Applications in Morocco}

The electric utility in Morocco operates a comparatively small system (about $2200 \mathrm{MW}$ ) that depends heavily on oil. The stated policy of the Morocean government is to retire much of this capacity in favor of coal-fired plants. One 165-MW mine-mouth plant is operating, as is a $60-\mathrm{MW}$ unit that was converted from oil to coal.

There are only four oil-fired power plants in Morocco larger than $50 \mathrm{MW}$. Although these units could be converted to coal (as has already been done for the one 60-MW plant mentioned above), and although such conversion would be consistent with the stated policy, the most promising market for CCTs appears to be new capacity. As a developing country, Morocco is expected to expand its electrical generating capacity concurrent with its economic growth (Section 4.3). Appearing particularly suitable for Morocco is the AFBC technology. This option would enable Morocco to use its existing coal resources to the extent feasible and to continue to burn coal imported from the United States. It would also allow for the future exploitation of Morocco's extensive domestic oil shale deposits. The IGCC option also appears promising, but more so for the long term. It is flexible as to coal type and could be phased in by first using natural gas (which is already used to some extent in the electric utility sector) before installing the gasifier. 
There are no environmental regulations covering atmospheric emissions from Moroccan power plants. This fact, coupled with the fact that only a limited amount of coal is currently burned, suggests that CCTs that are aimed solely at flue-gas cleanup would be of little current interest. If the AFBC and IGCC options were selected for capacity expansion, any interest in coal beneficiation techniques would be negated, at least as far as power plants were concerned. The advent of emission regulations covering the industrial sector could potentially alter this viewpoint, but this market would likely be a secondary one at best.

\subsubsection{Economic Comparisons with Respect to Moroceo}

The economic information available for Morocco remains sketchy and must be viewed as having large uncertainties associated with it. Nevertheless, we performed economic analyses on the basis of the best available data for new 200-MW power plants. The AFBC, IGCC, and pulverized-coal FGD technologies were compared to conventional oil-fired capacity. On the basis of the first-year cost of electricity, the oil-fired plant was found to be slightly cheaper than the CCTs considered for Morocco. However, when costs were levelized over the lifetime of the plants, the three CCTs were significantly less expensive. This reversal in relative economics stems from the assumption that the cost of oil will escalate far faster than the cost of coal.

Sensitivity analyses suggest that the above general conclusions are likely to be valid for any reasonable assumptions as to current fuel prices and anticipated price escalation. In addition, although the precise break-even costs obviously depend on the assumptions made, the AFBC, IGCC, and pulverized-coal FGD alternatives do have potential and could be economically implemented in Morocco. Each of these CCT options should be carefully considered on its merits on a site-specific basis.

\subsubsection{Turkey}

\subsubsection{Potential CCT Applications in Turkey}

Unlike several of the representative countries considered in this study, Turkey has indigenous sources of coal, lignite, oil, natural gas, and hydropower. However, many of these resources have not been exploited, with the result that Turkey imports almost $50 \%$ of the energy it consumes (Section 4.4). Oil accounts for most of this imported energy.

Current plans call for extensive expansion of Turkey's coal-fired electrical generating capacity, with much of the new capacity expected to use imported coal. In the electric utility sector, the potentially viable CCT candidates appear to be pulverized-coal FGD, FBC, and IGCC. All of these technologies can be operated efficiently with imported coal. More importantly, FBC and IGCC are flexible, in that domestic coal or lignite could be blended with imported coal or used alone. Future policies and economics would dictate which of these alternatives would be chosen. 
Because large quantities of imported oil are consumed in the electric utility sector, CCTs designed to displace oil have some potential, although not as much as technologies designed for new construction. Coal beneficiation options will have some potential in the near term, as attempts are made to reduce emissions from the commercial and residential sectors. However, current plans for the electric utility sector appear to be based on continued use of imported coal.

Technologies for treating flue gas also could be marketed if the Turkish government were to change its policy and decide to control emissions from existing facilities. However, this market is considered to be comparatively small and dependent on the sulfur content of the coal burned in individual facilities. In particular, the operators of plants that burn imported coal currently purchase low-sulfur coal; therefore, this market has limited potential.

\subsubsection{Economic Comparisons with Respect to Turkey}

The economics of the most viable options for the Turkish electric utility sector were compared. For new plants, oil-fired power plants were compared with the three coal-based technologies discussed above. For these comparisons, we assumed a plant size of $500 \mathrm{MW}$. The costs of constructing new facilities in Turkey were taken from several sources that discuss proposed BOT (build, operate, and transfer) arrangements. The AFBC technology appears to be the most promising of the alternatives, partly because Turkey is in a relatively early stage of technical development.

The economic comparisons were based on the assumption that coal could be purchased and delivered to a power plant for approximately $\$ 2.25 / 10^{6} \mathrm{Btu}$. This value represents the high end of a range of prices reported to be applicable in Turkey. Because detailed information on oil prices in Turkey was not readily available, we assumed that the marginal cost between coal and oil would be the same as that in Italy, that is, $\$ 1.50 / 10^{6} \mathrm{Btu}$. The reference-case oil price in Turkey was thus taken as $\$ 3.75 / 10^{6} \mathrm{Btu}$.

The cost of electricity from each of the coal-based technologies was estimated to be less than cost of electricity from a new oil-fired plant. The cost for the IGCC plant would be the lowest, that is, almost $20 \%$ less than the cost for a new oil-fired plant. Electricity generated by the AFBC and pulverized-coal FGD technologies was estimated to cost about the same, with the cost being about $10 \%$ less than the cost of oil-generated electricity.

The sensitivity analyses conducted suggest that the price of oil would have to drop to about $\$ 3.20 / 10^{6} \mathrm{Btu}$ (a margin of $\$ 0.95$ above coal) for the oil-generated electricity to cost the same as electricity generated by the AFBC or pulverized-coal FGD technologies. Further, the price of oil would have to drop to about $\$ 2.60 / 10^{6}$ Btu (a margin of $\$ 0.35$ above coal) to compete with the IGCC technology. In these sensitivity analyses, the other parameters were assumed to remain at their reference values.

Retrofit applications were examined by comparing plants utilizing slagging combustors and two CWMs with plants fired by oil. These comparisons assumed a $200-\mathrm{MW}$ unit with a remaining lifetime of 15 years. Continuing to generate electricity 
with oil was found to be less costly than implementing either of the CWM options. However, converting to slagging combustors would result in lower costs. In the first year, the electricity generated at a slagging combustor plant would cost about $10 \%$ less than the electricity generated at the oil-fired plant. If costs were levelized over the remaining 15-year lifetime, the electricty generated by the slagging combustor plant would cost about $20 \%$ less.

Sensitivity analyses suggest that, if the price of oil dropped to about $\$ 3.40 / 10^{6} \mathrm{Btu}$ (a margin of $\$ 1.15$ above coal), the first-year cost of electricity from the slagging combustor plant would be about the same as that from the original oil-fired plant. However, even in this case, the levelized cost of electricity over the 15-year remaining lifetime would be less for the slagging combustor plant.

\subsubsection{Pakistan}

\subsubsection{Potential CCT Applications in Pakistan}

Pakistan is another of the representative countries having extensive indigenous coal and/or lignite reserves. However, these resources have not yet been developed commercially to any great extent. Almost $50 \%$ of the current electrical generating capacity is hydroelectric. Oil- and natural-gas-fired capacity and high-speed diesel generators account for most of the rest. There is only $12 \mathrm{MW}$ of coal-fired capacity in Pakistan; however, another $800 \mathrm{MW}$ of capacity is expected to come on line in the late 1990s.

Pakistan suffers from frequent power shortages. As discussed in Section 4.5 , the most pressing need in the electric utility sector is for additional capacity. Current plans are not only to continue to import coal, but also to develop indigenous high-ash, highsulfur lignite resources. The indigenous lignite could very probably be used with the AFBC option. This technology would allow this high-sulfur fuel to be used efficiently with a high level of $\mathrm{SO}_{2}$ emission control. Moreover, Pakistan has large quantities of limestone, which could be used by the AFBCs.

The PFBC and IGCC CCTs also offer significant advantages that could be realized as Pakistan expands its electrical generating capacity. These technologies emit very little $\mathrm{SO}_{2}$ and only moderate amounts of $\mathrm{NO}_{\mathrm{x}}$. The IGCC option is particularly attractive because it is relatively insensitive to coal type and therefore amenable to Pakistan's steam coal resources.

The high-ash lignite indigenous to Pakistan could profit from beneficiation. As already mentioned, the cleaning characteristics of this fuel would have to be established through research. Cleaning could also produce fuel to be used in CWMs, thereby offering a dual fuel capability for existing oil-fired plants.

Slagging combustors and $\mathrm{CWMs}$ have some potential for reducing Pakistan's dependence on imported oil. Using cleaned coal for these CCT options would allow the conversion from oil to coal-based fuel to be accomplished with minimal impact on the 
environment (Section 5.2.1.1). In Pakistan, there is expected to be little interest in fluegas treatment because so little coal is currently burned and because there are no known environmental regulations.

As is true for many of the other countries considered in this study, the IGCC, AFBC, and pulverized-coal FGD technologies can potentially compete with oil-fired power generation. The incremental nature of the additions to electrical generating capacity being considered in Pakistan point to the appropriateness of small, modular units.

\subsubsection{Economic Comparisons with Respect to Pakistan}

The capital and operating costs for the various units considered were estimated principally from information contained in unpublished studies performed by Argonne National Laboratory for the World Bank. These cost data were supplemented by other published information. In the economic comparisons below, new power plants were assumed to be $100 \mathrm{MW}$.

The results of the economic analyses suggest that each of the three CCTs (i.e., IGCC, AFBC, and pulverized-coal FGD) would be able to generate electricity at a lower cost than a new oil-fired plant even though we assumed severe conditions. For example, we assumed that the coal burned in these facilities contained more than $5 \%$ sulfur and that $80-90 \%$ of the $\mathrm{SO}_{2}$ emitted is removed. The costs for the AFBC and pulverized-coal FGD options are similar, and both are higher than the costs for the IGCC alternative.

Retrofitting existing oil-fired power plants with slagging combustors and CWMs was compared with continuing to generate electricity with unmodified facilities. These analyses yielded estimates indicating that retrofitting existing oil-fired plants with slagging combustors would likely result in costs lower than those for oil-fired plants, but that the CWM options are unlikely to be competitive in Pakistan.

\subsubsection{PEOPLES' REPUBLIC OF CHINA}

\subsubsection{Potential CCT Applications in the PRC}

Coal and lignite are used throughout the PRC (Section 4.6), and all projections point to expansion of their use. Although these fuels typically contain little sulfur, their widespread use and the sheer volumes burned have caused the national environmental control standards to be exceeded, of ten by orders of magnitude. There are few controls on atmospheric emissions.

The PRC has been among the world leaders in using AFBCs. The versions of this technology being developed as part of the DOE CCT Demonstration Program offer improved efficiency and better $\mathrm{SO}_{2}$ control than the combustors currently used in the PRC. PFBCs offer additional advantages along these same lines. The IGCC option offers many of the same advantages; in addition, it can more easily adapt to a variety of 
coal types. Furthermore, the sulfur removed from the coal and lignite feeds can be recovered and used to reduce the country's dependence on imported sulfur. Coal beneficiation looks promising because so much coal and lignite are consumed in the electric utility, industrial, commercial, and residential sectors. It will be important to ascertain the effectiveness of different beneficiation technologies on the coals and lignites indigenous to the PRC.

Also having potential for widespread application in the PRC are technologies that treat flue gas. Stricter control of emissions is anticipated because so much coal is being consumed (and even more will be consumed in the years ahead) and because air quality is so poor in some areas. Of the flue-gas technologies, those that address $\mathrm{NO}_{\mathbf{x}}$ emissions only (e.g., SCR) will elicit less interest because the inherent properties of the coal and lignite indigenous to the PRC tend to limit $\mathrm{NO}_{\mathbf{x}}$ emissions to some extent.

In the near term, slagging combustors and CWMs would appear to be of little interest in the PRC because these technologies are generally considered to be most suitable for retrofitting oil- and gas-fired units. Only a comparatively small number of such units are operating in the PRC.

The PRC differs from most countries selected as representative for this study in that it burns significant quantities of coal and only a comparatively small quantity of oil. Aggressive plans to expand coal utilization in both the electric utility and industrial sectors are being implemented. Therefore, elucidating the market for CCTs requires determining the lowest-cost option among the coal-based technologies. In such determinations, the tradeoffs inherent in consuming some of the low-quality indigenous coal as against high-quality imported coal should be considered. Another important factor in selecting one technology over another is the ability of a technology to burn imported coal initially and then changing to domestic coal. Such conversions could take place after the mining industry in the PRC becomes more fully developed and a transportation infrastructure for delivering the coal to end-use facilities becomes more firmly established.

\subsubsection{Economic Comparisons with Respect to the PRC}

The economics of the following four coal-based technologies were compared: pulverized-coal FGD, AFBC, PFBC, and IGCC. We examined two coal scenarios with respect to these technologies. The first scenario involves importing a coal of high energy content and low sulfur content (1\% or less). (The PRC plans to develop an export market for an indigenous coal having these characteristics; however, the coal has not yet been mined in large quantities.) In the second scenario, the coal burned is a domestic coal having a sulfur content of $3 \%$ and an energy content of about $8000 \mathrm{Btu} / \mathrm{lb}$. Although fuel costs in the PRC are highly uncertain, we based the reference-case analyses on the assumption that the domestic high-sulfur coal would cost $\$ 1.00 / 10^{6} \mathrm{Btu}$ and the imported (or better quality domestic coal) would cost $\$ 2.00 / 10^{6} \mathrm{Btu}$. Because the PRC needs power plants of large capacity, the comparisons are based on new 500-MW plants. 
The analysis results suggest that, of the four coal-based options considered, the IGCC option would have the lowest costs for both the imported and domestic coals. The electricity generated by the pulverized-coal FGD and AFBC plants is estimated to cost 5-10\% more than the electricity generated by the IGCC plant. This cost differential can be attributed to the lower efficiencies and higher variable operating and maintenance costs of the former technologies. The costs estimated for the PFBC plant are 10-30\% higher than those for the IGCC plant. In this comparison, the capital cost of the PFBC is important, as is the cost of the sorbent (assumed to be dolomitic limestone). This last cost is particularly important for the case involving the high-sulfur domestic coal.

\subsubsection{Poland}

\subsubsection{Potential CCT Applications in Poland}

As discussed in Section 4.7, domestic coal is a major factor in the Polish economy and life-style. Exported worldwide, coal also fuels almost all of Poland's electrical generating capacity. However, its widespread use causes air and water pollution. These factors combine to suggest several opportunities for implementing U.S. CCTs in Poland.

The current levels of coal use and air pollution provide the impetus for adopting postcombustion flue-gas treatment technologies. Each of the postcombustion CCTs considered in this study could help reduce atmospheric emissions in Poland. These technologies can be used to control $\mathrm{SO}_{2}$ and/or $\mathrm{NO}_{x}$, whether in new or retrofit situations and whether for power plants or industrial facilities. The most appropriate option in any given application depends on site-specific factors such as the required pollutant control level, the age of the facility, the availability of sorbents and land for waste disposal, and capital and operating costs. Poland offers a variety of opportunities for successful application of postcombustion CCTs.

Polish coal reserves include bituminous coal and low-quality lignite. The sulfur content of the bituminous coal and lignite ranges, respectively, from $0.5 \%$ to $3.5 \%$ and from $0.3 \%$ to $0.8 \%$ (World Energy Conference, 1989). Much of the coal mined for export is cleaned; however, the coal preparation plants tend to operate with very high reject rates, with the result that a significant amount of the resource is lost (American Mining Congress Journal, 1990). Advanced coal beneficiation techniques offer a means of producing a cleaner fuel for export as well as for domestic consumption. Cleaning processes that recover more of the resource and clean more deeply would allow the indigenous resources to be exploited more efficiently while reducing atmospheric emissions. Also, the coal traded in international markets could perhaps be processed to yield a higher calorific value. Exporting a higher quality coal could help improve Poland's balance of payments.

The new power plants needed to replace aging and inefficient plants and to meet the increasing demand for electricity constitute another potential market for CCTs in Poland. Capable of meeting this need are AFBCs, PFBCs, IGCC plants, and pulverizedcoal FGD units. Each of these technologies can burn the bituminous coal or lignite 
indigenous to Poland and can be built in the sizes needed for expanding the electrical generating system, that is, 350-500 $\mathrm{MW}$.

At this time, there appears to be little or no interest on the part of Poland in CWMs and slagging combustors. Very little electricity is generated in oil-fired power plants; therefore, little or no opportunity exists for retrofitting existing electrical generating capacity with either of these CCTs. Because some oil is burned in the industrial sector, it is theoretically possible to displace some of this oil. However, this market is perceived as being quite small.

\subsubsection{Economic Comparisons with Respect to Poland}

As noted above, opportunities apparently abound in Poland for implementing U.S. CCTs for electricity generation. Because oil is not being used to fuel large power plants, and because oil-fired capacity is not perceived as a viable option over the long term, we compared the various CCT options and did not analyze options involving alternative fuels.

In the comparisons, we assumed plant capacities of $350 \mathrm{MW}$ and $500 \mathrm{MW}$ because these sizes bracket the size range likely to be of interest in Poland. Two coal scenarios were examined. The first scenario assumes that low-quality indigenous lignite would fuel the technologies. This assumption is consistent with the current practice of using the lignite domestically while exporting significant percentages of the mined bituminous coal. The second scenario assumes that the higher-quality bituminous coal would be used and that the price of this coal would equal its estimated export value. This second scenario is in keeping with the fact that some bituminous coal is consumed in the electric utility sector. An opportunity is thereby provided to quantitatively evaluate the CCT options under different, but nonetheless feasible, situations.

For the cases considered, the comparisons show that the electricity generated with low-quality lignite costs 5-7 mills/kWh less than the electricity generated by a similar power plant fired with bituminous coal. Although this differential could vary with changes in fuel price, these comparisons seem to support current Polish practice with respect to electrical generating capacity.

The analyses suggest that the pulverized-coal FGD option could produce the lowest cost electricity for the two plant sizes considered and with either fuel type. Of the four CCTs considered, the IGCC option produces the next cheapest electricity. The cost differential between the pulverized-coal FGD and IGCC options increases slightly with installed capacity, but is always less when bituminous coal rather than low-quality lignite is burned. For each case examined, the AFBC option yielded the third lowest cost, leaving the PFBC option with the highest generation cost.

As a point of reference, we also estimated the cost of generating electricity from a new oil-fired plant. Assuming an oil price of $\$ 3.45 / 10^{6}$ Btu (i.e., approximately $\$ 20 / \mathrm{bbl}$, which is inexpensive given the cost of the oil now being imported into Poland), we estimated that electricity from the new oil-fired plant would cost about $15 \mathrm{mills} / \mathrm{kWh}$ more than electricity from a pulverized-coal FGD plant fired with lignite fuel and about 
$8 \mathrm{mills} / \mathrm{kWh}$ more than electricity from a pulverized-coal FGD plant fired with bituminous coal. Thus, the CCTs promise significant economic advantages over oil-fired generation in Poland. 


\section{TRADE-RELATED ISSUES AND BARRIERS}

The growth in demand for energy and the services provided by the energy sector have clearly offered U.S. companies many opportunities to export their products and technology. The situation has also presented a substantial challenge, however, because although "off-the-shelf" products are suitable for meeting the needs of the United States and other industrialized countries, they are sometimes not so suitable for other countries -- especially newly developed or developing ones. Furthermore, even after a technology has been adapted to the technical requirements of a particular country, the marketing opportunity is still likely to be complicated by other issues that pose significant barriers to the marketing and exporting of U.S. CCTs abroad. These issues, as highlighted below, greatly affect the transition from perceived market potential to actual export sales.

Section 6 provides additional data relevant to assessing the potential market in each of the countries selected for this study, by treating several aspects of trade-related information on a country-specific basis. Each country is profiled with respect to (1) pertinent political and economic information; (2) business practices, laws, and regulations that constrain or promote trade; (3) intellectual and industrial property protection related to imported and/or advanced coal technologies; (4) potential marketing channels (such as the establishment of overseas operations, licensing, and joint ventures); and (5) pertinent aspects of financing trade. The information discussed in this section is intended to assist U.S. business entrepreneurs in forming plans of action with respect to potential CCT trade opportunities.

\subsection{GENERAL BUSINESS STRATEGIES AND CONCERNS}

This section summarizes the various entry strategies, barriers, rules, and regulations for exporting or otherwise transferring U.S. CCTs to the selected countries. It also addresses possible marketing strategies in light of the assessments of the most applicable technologies (Section 5). The overall objective is to make U.S. CCT developers aware of the potential opportunities and risks in the international marketplace. Complementing the previous technical sections, this section provides technology developers with the information they need to make preliminary decisions on whether to export, license, or implement a joint venture based on the needs and applicability of certain technologies in the targeted countries. It also provides information on how to get the technology into the countries.

General entry strategies are presented for technology firms that are contemplating expanding their operations to overseas markets. Although there are many more strategies than those discussed in this section, the descriptions of the select group of generally accepted entry and financing options provided here offer the reader some insight into their advantages and disadvantages and some suggestions on specific entry methods for the targeted markets. No single strategy is suggested for any of the selected countries; a combination of several strategies might actually be the most appropriate method for entry. 
The particular strategy that is chosen to enter a foreign country's market is of ten the decisive factor in the success or failure of a marketing initiative. Many complex issues must be considered in an analysis of marketing options. For example, the internal policies and conditions of the firm attempting to enter the market will influence the type of approach taken. Important firm-specific factors include the availability of capital resources, the degree to which the firm wishes to retain control over the product (in terms of technological integrity and quality), the firm's long-term corporate strategies, the experience of the personnel involved, and the firm's breadth of knowledge of specific overseas markets. The strategies described here afford U.S. manufacturers or technology holders varying degrees of control and potential for profit.

\subsubsection{Investment}

Investing in a local market provides a firm with the most control in an overseas market. It requires the most capital and managerial investment, and it is not only a costly but also a risky undertaking. A complete understanding of the rules for hostcountry operation, taxation, labor laws, and capital repatriation, among other topics, is necessary. In terms of strategic placement of a company's physical resources, the advantages of investing in a local market are as follows: (1) the proximity between the product and the customer is enhanced, (2) local labor may be less expensive, and (3) rawmaterial inputs may be easier to procure. Above all, recognition that the company's product is manufactured domestically may provide it with an edge when there are many outside competitors. The disadvantages are these: (1) managerial resources may have to be diverted to operate the foreign operation successfully, (2) start-up costs will tend to be extremely high, and (3) the operations will be subject to the controls of foreignnational regulations.

\subsubsection{Joint Ventures}

Entering into a joint-venture arrangement with a local partner is another viable strategy for establishing overseas operations. A joint venture allows a U.S. firm to ally itself with a partner knowledgeable in local regulations and local markets and yet disperse some of the capital and managerial risks. The control and risks associated with a joint-venture arrangement are somewhat less than those associated with a wholly owned operation.

\subsubsection{Import Licensing}

Transferring technology through licensing is another alternative to direct market penetration. The advantages of licensing over joint ventures or some other equity investment include lower political and currency risks and lower transportation costs. These risk factors might otherwise cause an increase in the cost of a product, making it uncompetitive in the foreign market. Licensing reduces or eliminates the barriers that act to increase the cost of the imported physical commodity (such as tariffs and transportation costs) as well as any quantitative import restrictions that might be 
imposed on the product or its components. Through licensing, a U.S. technology firm can also expect to gain relatively quick entry into a foreign market, with less legal and financial risk than that normally associated with joint ventures or local operations. There are risks in any licensing agreement, however, including loss of marketing supervision and quality control. An even larger risk to some firms is the potential competition that could come in the future from the firm's licensee. Import licensing is of ten used to preclude a product's entry into a country by imposing country-specific rules and regulations on foreign-business transactions, quotas, or local-content requirements.

\subsubsection{Financing}

Financing is another option that a firm should consider when attempting to expand into overseas markets. Financing for CCT projects is expected to occur in the form of the medium- to long-term loans or grants that are given for large projects. A wide variety of options are available to CCT developers seeking financial assistance for a large project. Many projects similar in size to the CCT projects discussed in this report are now being worked on under some kind of joint venture or equity-share arrangement (e.g., a syndication of banks, financial institutions, and/or private firms) to spread the costs and risks to a larger group.

In most industrialized countries, credit and sources of financing for large projects are usually readily available. Japan presently leads all countries in grants and development loans, and Italy is home base to some of the largest banks in the world -Credito Italiano and the Istituto Mobiliare Italiano, for example. In developing countries, however, there is generally a limited supply of capital and credit to finance large projects; hence, international lending agencies and the U.S. government have become widely used sources of financing for international transactions.

The current major players, in terms of funds distributed for large energy projects, are multilateral lending organizations that draw on the combined financial resources of the industrialized countries. One is the World Bank, which includes the International Bank for Reconstruction and Development (IBRD), the International Development Association (IDA), and the International Finance Corporation (IFC). The others are regional development banks: the Asian Development Bank (ADB), the InterAmerican Development Bank (IADB), and the African Development Bank. All these institutions lend the capital needed for energy facilities and projects for which privatesector capital markets are usually not adequate. The terms of their loans are more favorable than those offered by commercial loans. For example, IBRD loans, which account for the bulk of World Bank loans, generally have a grace period of three to five years; the interest rate is related to the Bank's cost of borrowing; and member governments (and public or private entities of the member governments) are eligible for World Bank loans on conventional terms.

The regional banks operate in a similar fashion to that of the World Bank. For example, the ADB promotes economic development and cooperation in developing Asian countries through conventional and concessional loans, technical assistance, and investment promotion. Any member government agency, public or private entity of the member governments, or international or regional agency concerned with economic 
development in the region is eligible for $\mathrm{ADB}$ assistance (Levine et al., 1989). The regional development banks fund a range of energy-sector activities similar to those funded by the World Bank, but at a lower level. The ADB allocated U.S. $\$ 567$ million in funds for energy projects to developing countries in Asia and the Pacific in 1988, a sharp increase from the U.S. $\$ 332$ million provided in 1987 . The IADB provided a total of U.S. $\$ 405$ million in loans for energy projects in Latin America and the Caribbean in fiscal year (FY) 1988 (Levine et al., 1989).

In the World Bank, the IDA serves the poorer developing countries, providing interest-free credits with 10 -year grace periods and 40 - to 50-year maturities. The IFC raises financing for private companies and joint ventures or may take an equity position in a project. Its interest rates are more in line with commercial lending. The World Bank's annual energy lending (including credits from the IDA) quadrupled from U.S. \$1 billion in FY 1977 to about \$4 billion in 1987 (World Bank, 1988).

Some U.S. government sources of financing include the Export-Import Bank of the United States (Eximbank), the U.S. Agency for International Development (AID), and the U.S. Trade and Development Program (TDP). Eximbank is designed to facilitate U.S. exports and projects through credit support in the form of loans, guarantees, and insurance. Eximbank programs include direct loans, commercial guarantees and insurance, medium- and long-term credits, small-business credits, and working capital guarantees.

AID administers the U.S. bilateral foreign economic-assistance programs; this assistance includes loans to developing countries on concessionary terms (U.S. $\$ 130$ million in FY 1988 and $\$ 237$ million in 1989). The bulk of energy-related capital assistance has been provided to Egypt and Pakistan. AID's current energy-related activities focus on three areas: energy efficiency, expansion of energy supplies, and use of cleaner technologies, including fossil fuels and renewable energy sources. AID's programs include development assistance and the Economic Import Fund. Foreign governments and mixed private and public entities are eligible for the funding (Levine et al., 1989; DOC, 1985).

The TDP in the U.S. International Development Cooperation Agency finances a variety of planning services for projects in developing countries that are potential export markets for U.S. goods and services. TDP focuses on large public-sector projects, including energy development. Its loans in the energy sector amounted to U.S. \$6 million in FY 1988. To be considered for funding, projects must have a high priority within the development plan of the host country or international lending institution (such as the World Bank). All services under TDP are restricted to U.S. sources (Levine et al. 1989; DOC, 1985).

The industrialized countries of Japan and Italy maintain some of the largest banks in the world, with wide financing experience and a large credit base. In Turkey and Morocco, there are banks that are willing to finance technology projects with U.S. firms, but credit might be more difficult to secure, and there might be more performanceguarantee requirements built into the financing terms. Because Pakistan and the PRC are politically sensitive countries with inconvertible currencies and large debts, a U.S. CCT developer interested in these countries will probably try to find alternative methods 
to conventional project financing. Poland and Eastern Europe present a special case: outright grants appear to be the only plausible financing option for the near term.

\subsubsection{Countertrade}

When credit for an overseas market has been restricted or unavailable because of currency inconvertibility, economic instability, political risk, or other similar reasons, companies have turned to countertrade and -- usually as a last resort -- bartering. Countertrade is a method of transaction in which firms both sell to and buy from each other. It can be especially useful when raw materials from Country $A$ are scarce in Country B, and the trading of that scarce raw material can benefit Country B. Barter usually involves the transaction of commodities only, because credit is unavailable and the currency is totally inconvertible. Goods exchanged in this instance are theoretically of equal value. Barter is most of ten employed when all other avenues of financing have been exhausted or there appears to be no other viable option for trade.

\subsubsection{Tariffs}

Tariffs are the means by which a country taxes goods imported from another country. When the tariff rate is exceedingly high, the tariff acts as a deterrent (or barrier) to the import of the tariffed good. Tariff rates are usually based on the value of the goods being imported (ad valorem), but they may be controlled by international agreements or membership in international organizations. In addition to assessing an ad valorem duty, some countries may impose additional taxes or charges on imported goods. These additional charges may be in the form of wharf charges, stamp taxes, municipal taxes, or a variety of other charges disguised as import duties. These charges, when added to the normal customs duties assessed at the port of importation, may effectively raise the cost of the imported good so as to make the exportation of the good impractical.

The tariff rate for a particular technology or component in a particular country can be obtained by calling the appropriate country's desk officer at the U.S. Department of Commerce in Washington, D.C. (202-377-2000). Commercial counselors at each country's embassy usually have quotable tariff lists as well.

The need to determine a tariff rate occurs in situations such as these: when direct exporting (or sale) occurs, when only U.S. raw materials can be used, or when a tie-in arrangement has been established. With regard to direct exporting, representatives of Babcock \& Wilcox and Foster-Wheeler indicated that the cost of shipping usually makes conventional U.S. boilers uncompetitive with European boilers. Presumably, this constraint on the direct export of conventional boilers would also be applicable to U.S. CCTs, unless some particular CCT would be lighter, more modular, or less bulky than a conventional technology, thus making it easier and less costly to ship. Moreover, direct sale would probably not be a viable entry strategy for CCTs, because end-users in the utility and large industrial sectors might not have enough information or experience with CCTs to properly or effectively use them. Since precombustion and combustion CCTs represent a "Phase I" technology (never before introduced to the 
market), the marketing strategy employed must allow for complete exposure and public education so an awareness of the benefits and advantages can be fully realized.

\subsubsection{Nontariff Barriers}

In addition to imposing tariffs on imported goods and services, countries also may employ measures that act as nontariff barriers. By implementing practices that are more advantageous to home-market firms, nontariff barriers effectively restrain trade. One such measure is excessive government intervention in trade. Subsidies and state trading, for instance, give home-country goods and services a distinct advantage over imported goods and services. Other nontariff barriers include the quotas, restrictive forms of business transactions, and entry procedures in terms of classification, product standards, marking, and labeling. If entry procedures are not transparent (verifiable), major difficulties and delays may be experienced, thus hampering the import process.

\subsubsection{Intellectual-Property Protection}

Intellectual property rights are rights to the ownership of a process or product. The property can include patents, trademarks, copyrights, and trade secrets as well as computer software, mask works, and designs. Before a technology is transferred, the intellectual-property laws of the importing country should be examined to make sure they protect the intellectual-property rights associated with the technology being exported. Many countries still do not provide adequate intellectual-property protection, especially with respect to technology licensing. The number of instances of patent infringement and trademark piracy have increased in recent years. The U.S. Omnibus Trade and Competitiveness Act of 1988 addressed these infringement and piracy problems, and the U.S. government has identified chronic violators.

The U.S. government and industries have become concerned about transferring technologies to countries whose laws and regulations do not protect the patent rights to any technology transferred from the United States. For example, the PRC is not a signatory to the Paris Convention on the Protection of Industrial Property (Paris Union) or any other international agreements on the protection of industrial or intellectual property. This lack of commitment poses a real threat to U.S. business interests that would like to share the concepts they have developed in the international marketplace. There has recently been some headway in resolving these issues, but formal patent and trademark laws are still in the formulation stages. When there is no protection for property rights, investment incentives are less likely to be taken advantage of, even when the market potential is vast.

Under the "Special 301" authority, the U.S. Trade Representative (USTR) has been empowered with the responsibility of identifying countries that deny intellectualproperty protection. The Special 301 authority was "designed to enhance the Administration's ability to negotiate improvements in foreign intellectual-property regimes through bilateral and/or multilateral initiatives (U.S. Trade Representative, 1989b). The USTR has placed 17 countries on a "Watch List" for countries that "maintain intellectual property-related practices or barriers to market access that are of particular 
concern," and it has placed 8 countries on a "Priority Watch List" for countries deemed to be more serious offenders. With respect to the countries targeted in this study, Italy, Japan, Pakistan, and Turkey are on the Watch List and the PRC is on the Priority Watch List. Morocco is the only country from the group that has not been cited for inadequate intellectual-property protection. Poland and Eastern Europe have not been considered under the Special 301 authority at this time.

\subsubsection{Export-Control Laws}

Before any good or technology can be exported or transferred from the United States to an overseas market, an export license must be obtained through the U.S. Department of Commerce. If a technology is deemed strategic to national security, capable of being used for defense purposes, considered unpublished technical data, or a commodity in short supply, the U.S. government can deny an export license for that particular commodity. Thus, U.S. export-control laws may be the most significant factor in determining the success or failure of a marketing strategy abroad.

U.S. regulations on export licensing pertain to every commodity, service, or technology exported. Export licenses are designated as either general or validated. A general license implies that the commodity or technology can be freely exported. A validated license means that restrictions may apply to the commodity if it is being exported to a particular country; these must be identified, and the export cleared through the appropriate government agencies.

The countries discussed in this report are in "Country Group V," which are markets that are considered friendly and nonallied. As such, most goods can be freely exported to these markets. However, because the technologies are new, a determination will have to be made as to the "strategic" nature of the units or their components. First, tariff numbers will have to be applied to the commodity. Then the type of license required will be determined, on the basis of the nature of the commodity. If the commodity is not included on the commodity control list, a general license will probably be the only license required to effect the export. To learn more about the process or to make a specific determination as to whether a specific CCT or its components will require special licenses, one can call the U.S. Department of Commerce to make an appointment with an export-licensing counselor (202-377-4811).

\subsubsection{Trade, Promotion, and Financing Policies}

U.S. trade policies are of ten insufficient or ineffective when competing against the trade policies of other exporting countries. There is no national export policy in the United States. Western European and Japanese companies have already acquired much more experience in developing and marketing modern technology packages abroad to utilities, industrial users, and government entities. In fiercely competitive foreign markets, successful penetration of U.S. CCTs will require the design and development of favorable government-to-government trade agreements and creative and attractive financial and promotional inducements. Only then can U.S. CCT marketers hope to capture market shares from already established competitors and conventional 
technologies. To export U.S. CCTs in significant quantities requires not only the design of products that have a technological edge over the competition but also the development of a trade program that can compete with the programs of major exporting countries.

Companies representing the FRG, France, Australia, and Japan have already established a solid competitive presence in certain markets. U.S. marketing efforts must therefore examine the extent of current foreign involvement in specific market niches in the target countries and include assessments of the progress made by other countries and possible sectoral applications.

\subsubsection{Currency Values}

One question related to international trade is how the transactions should be done. Should U.S. dollars, other hard currency, or sof ter currency be used, or should the transaction be completed through barter or countertrade? In the PRC, because of a shortage of hard currency, many large transactions are completed through barter and countertrade. Barter does not usually include the transfer of money, but countertrade includes both monetary and nonmonetary transactions. Because many banks are hesitant to loan to the PRC, alternative financial arrangements are of ten sought.

As do the manufacturers of all goods and services sold in the international market, the U.S. manufacturers of CCTs will face risks associated with long-term export contracts, especially when the payment is to be made in a foreign currency. If the value of a currency declines before payment is received, a substantial loss of revenue may result. To protect themselves against this occurrence, many companies include a predetermined exchange rate in their contract with the importers. If the transaction is in the form of a joint venture abroad (with operations being established overseas rather than components being shipped from the United States), currency-exchange issues are not as critical. A more important consideration is that U.S. manufacturers may face competition from foreign companies whose relative currency-exchange rates provide more favorable incentives to potential customers.

\subsubsection{Infrastructure}

Several issues related to the coal-technology infrastructure must be dealt with when international markets for U.S. CCTs are being considered. Are transportation options available and adequate? Do ports and railroads exist and are they sufficient? An adequate coal-transportation infrastructure is a key element in the development of markets for CCTs. Those countries that lack both an adequate inland transportation network and port capacity might be constrained from significantly increasing their coal use until these systems can be built or enlarged. On the other hand, those countries that are developing their transportation infrastructure and that can absorb increased coal use could be viable candidates for U.S. CCTs. In many countries, railway improvements are essential if coal use is to increase dramatically. Improvements in port capacities and their utilization are also important. Szpunar et al. (1989) discusses alternative and innovative transport options within the Asian Pacific Basin. 


\subsubsection{Technology Adaptation}

Unlike the United States, with its sophisticated electric utility sector, some developing countries may prefer simpler (and perhaps more labor-intensive) technologies that more closely match their capabilities and requirements. Many boilers outside the United States are one-fourth the size of a typical U.S. boiler having the same general function. Frequently the need to adapt useful technologies to country-specific conditions and the need to demonstrate innovative technologies at a scale appropriate to the region become paramount. "Simpler, cheaper, and smaller" are concepts that must be addressed with respect to each individual country. Modularity may be a key to successful application abroad.

\subsection{COMPARISON OF SPECIFIC TRADE-RELATED ISSUES BY COUNTRY}

This section profiles each of seven countries with respect to tariffs, trade policies, financing options, licensing agreements, and a host of other factors appropriate to an analysis of market niches for CCTs. The seven countries were selected as being representative of the diversity of potential international markets.

Italy and Japan were chosen to represent industrialized nations with an expressed interest in expanding their current level of coal consumption. Being industrialized countries, they display a high and fairly stable gross domestic product (GDP),* with a low percentage of this GDP coming from the agricultural sector. They also exhibit a high level of industrialization, exemplified by the composition, amount, and diversity of their industries. Moreover, these countries exhibit strong, technologically sophisticated economies able to integrate and produce high-technology commodities.

Morocco and Turkey were chosen to represent industrializing countries. These countries display a growing GDP and a growing diversification of industrial bases. Despite the high growth rate in the industrial sector, the economies of these countries retain strong agrarian roots (DOE, 1988a).

Pakistan and the PRC were selected to represent developing countries in the early stages of large-scale industrialization and for which rapid growth can be expected to continue. Although these countries' economies rely on a few important heavy industries, they rely far more on agriculture.

Poland was chosen to represent the emerging markets in Eastern Europe, previously dominated by a centrally planned economy. With an economy in transition from being centrally planned to being driven by market forces, Poland is neither

\footnotetext{
*GDP is the value of goods and services within a country. GDP rates are a good indicator of the level of technical sophistication that exists in a given country. In general, the higher the GDP, the higher the level of industrialization. The higher the level of industrialization, the more sophisticated the industrial sector becomes, and the more it tends to move away from heavy industry and toward less labor-intensive, hightechnology industry.
} 
industrialized, industrializing, or developing. Heavy industry and strong agrarian sectors exist in changing social and political times. In Poland, there now exists an opportunity for CCTs where before there had been none.

\subsubsection{Italy}

\subsubsection{Background}

The United States and the Republic of Italy have maintained a strong trading relationship since the end of World War II (WWII). Two-way trade between the U.S. and Italy amounts to about U.S. \$15 billion annually, and Italy has become a dominant economic force in both the European Community and the world (U.S. Department of State, 1988). This economic growth was achieved through policies of economic liberalization after WWII and heavy investment in its infrastructure to support redevelopment.

Despite the many changes in its post-WWII government, Italy continues to be politically and economically stable. The environmental movement is growing in Italy, and the Green Party has become a rather vocal force in Parliament since its gains in the 1988 elections.

In terms of its indigenous energy resources, Italy can be characterized as being rather poor, having virtually no oil or coal but some natural gas. Italy's increasing demands for energy and lack of sufficient fossil fuel supplies has forced it to import more than $80 \%$ of its energy requirements, including almost all of its coal and oil and almost $60 \%$ of its natural gas requirements. Italy is highly dependent on oil imports from the Organization of Petroleum Exporting Countries (OPEC) and surrounding centrally planned economies. The Soviet Union supplies more than $20 \%$ of Italy's natural gas requirements through the European pipeline (DOE, 1989a).

\subsubsection{Investment in Italy}

Law No. 43 serves as the governing regulatory mechanism for foreign investments in Italy, and the Ministry of Foreign Trade provides the administrative rules for such investment. The official policy of the Italian government is to encourage all foreign investment, but extensive bureaucratic regulations tend to protract the authorization process. This bureaucracy does not seem to deter potential investors, however, since the U.S. ranks second (behind Switzerland) in Italian foreign investment.

To conduct business in Italy, individuals and firms are required to register with the local Chamber of Commerce, Industry, and Agriculture. This office is empowered by the Ministry of Industry and Commerce to act as its field representative. Investments are categorized as either productive (enterprises that augment Italy's foreign capital reserves) or nonproductive (enterprises not contributing to foreign capital reserves) and are regulated according to category (U.S. Department of State, 1988). 
All investments must be approved before their establishment by the Ministry of Industry and Commerce. Major investments that constitute U.S. \$8 million or more must be approved by the Interministerial Committee for the Coordination of Industrial Policy (CIPU). Investments are bifurcated, as stated above, into productive and nonproductive enterprises. The laws for a productive enterprise include the right to unlimited capital transfers, while nonproductive enterprises are prohibited from transferring capital for the first two years (Business International Corp., 1988a). Requirements for establishing a foreign branch are the same as those for investment. The types of business organizations commonly employed in Italy consist of the sole proprietorship; simple, general, limited, and limited-with-shares partnerships; limited-liability companies; cooperatives, and corporations (DOE, 1988a). Approximately 40\% of U.S. investments are wholly owned, while 6,500 U.S. firms are represented through subsidiaries, distributorships, or licenses (DOC, 1987b).

With respect to regional investment incentives, the Mezzorgiorno or southern region of Italy has been targeted by the Italian government as a region where incentives will be offered to attract investment. This region extends from Rome south to Sicily, Sardinia, Elba, and other smaller islands along the coast. Since Italy's move from a largely agricultural to a more industrialized economy after WWII, the Mezzorgiorno has experienced an exodus of its population to the more industrialized northern cities. This migration has resulted in a loss of productivity and a concomitant increase in unemployment in the south. To encourage industrial revitalization, development, and growth, incentives in the form of grants, tax remissions and value-added tax rebates, and low-cost government loans have been offered by the Italian government to investors who locate their facilities in the Mezzorgiorno, subject to the targeted schemes for designated industries. These incentives also apply to service and trade firms operating out of the region. The Agency for the Promotion and Development of the Mezzorgiorno (Agenzia per la Promozione della Svillupo del Mezzorgiorno) is responsible for carrying out the goals established by the government, but it is the ministerial-level Mezzorgiorno Department that approves all projects of the Agency (Business International Corp., 1987a).

Incentives exist even in the industrialized north central regions of Italy, largely in the form of low-cost loans and rebates for indirect taxes. Incentives for $R \& D$ are also made available through the Ministry of Industry and the Institute for Italian Mobilization (IMI, Instituto Mobiliare Italiano) (Business International Corp., 1987a).

\subsubsection{Intellectual- and Industrial-Property Protection}

Italy is a signatory to the Paris Union. As such, those U.S. patents and trademarks registered within both the United States and Italy are accorded the same protection in Italy as would be accorded an Italian product. Patents are valid for 20 years, without renewal or extension, from the date the application is filed. Italy's patent protection has been cited as somewhat weaker that of other European countries, but legislation to provide greater protection is pending (Business International Corp., 1987a). Italy has been placed on the Watch List by the USTR for its "insufficient" intellectual-property protection (U.S. Trade Representative, 1989b). 


\subsubsection{Import Policy and Import Licensing}

Most goods entering Italy are not subject to any import controls. In general, the only goods that carry a stipulation for licensing and controls are agricultural items. Energy-related goods do not require import licenses, and are not subject to any quota controls or prior notification approvals (DOC, 1987b).

As a member of the European Community, Italy is a signatory to the Harmonized System for the classification of goods and the assigning of tariff values on a value-added tax system (DOC, 1989c). The value-added tax is based on the cost, insurance, and freight (c.i.f.) values, plus duties accorded the goods in the tariff classification scheme and any applicable surcharge imposed upon the goods at the port of entry. (The European Community Affairs Office has quoted a duty rate of $5.5 \%$ ad valorem for small combustors imported into Italy [DOE, 1989a].)

Italy does not currently advocate specific "buy Italian" policies to preclude the purchase of foreign commodities or services, but it does impose quotas on imports from Japan in an effort to protect its domestic automobile industry, and it does regulate imports from centrally planned economies (Business International Corp., 1987a).

\subsubsection{Licensing and Technology Transfers}

Upon government approval, technology licensing is permitted. Under the U.S.Italy Double Taxation Agreement, royalties from patents and trademarks are exempt from withholding taxes, and royalties can be freely remitted (DOC, 1987b).

According to a recent statement by ENEL, Italy views itself as an exporter of energy technology (particularly with regard to South America and Africa). It is participating in more than 50 general cooperative arrangements with electric power organizations and government agencies in 40 countries, and it has "advisory and assistance" contracts with Italian foreign operations and other foreign partners (EER Technologies Corp., 1988). To help gain a presence in industrialized countries, ENEL intends to engage in cooperative research efforts to obtain knowledge about certain emerging and advanced technologies. The effects that this strategy could have on the export of U.S. technology to Italy remain to be seen, but it could inhibit the import of foreign technologies, including those from the United States.

\subsubsection{Joint Ventures}

A joint venture (Associazione in Partecipazione) in Italy "involves the participation by supplier of capital in the profits of the business" (DOC, 1987b). The operator manages the business and is solely responsible for the obligations assumed toward third parties. The party furnishing capital is responsible for any loss in direct proportion to the share in the net profit, limited to the amount of personal investment. 
One approach to establishing a joint venture in Italy is to do so with a stateowned company. Because the state's role in industry is pervasive, this strategy serves to circumvent some of the hurdles encountered when an industry must compete in fields controlled by state enterprises, which includes power generation. The Italian government advocates arrangements with its state-owned companies as a strategy for domestic growth. Instead of encouraging outright privatization schemes for these industries, however, the government appears to foster growth and participation in joint ventures with foreign companies. This industrial-policy-type approach, the government believes, could reduce the number of older, less profitable industries and strengthen Italy's participation in emerging, more profitable industries such as telecommunications and electronics (Business International Corp., 1987a).

\subsubsection{Financing Aspects and Other Considerations}

Like Japan, Italy possesses some of the largest banks in the world, with secure capital and financing mechanisms for large-scale, medium- to long-term financing requirements. Italy has an exposure at the Eximbank of approximately $\$ 125$ million (Foti, 1989). The Overseas Private Investment Corporation (OPIC) extends insurance coverage on all loans to Italy, and Italy is considered to be an extremely credit-worthy location for project financing (Luehmann, 1989). Relatively few problems are expected to be encountered in securing financing for U.S. CCT projects.

With respect to corporate taxation, no discriminatory tax laws against foreign investments are known to exist in Italy. Firms located in the country are subject to the national corporate income tax and the local income tax, which apply equally to foreign and domestic firms (Touche Ross International, 1985). A double-taxation treaty between the United States and Italy basically stipulates that taxes will be levied on the commercial or industrial profits of only those firms that have established permanent residence in Italy.

\subsubsection{Conclusions}

Italy is one of the strongest economies in the European Community today. All forms of investment, including joint ventures, are allowed under Italian law, and the United States is currently the second largest investor in the country. The import control laws have been greatly liberalized, and technology licensing is expected to pose no problems for the U.S. CCT developer or entrepreneur.

The Italian national energy plan calls for the diversification of energy sources and for all boilers to be capable of burning either coal, natural gas, or oil by the year 2000. Coal use is expected to grow, and oil use is expected to decrease. In short, the government's development plans allow for a more effective and widespread use of coal in an efficient, environmentally responsible manner. This situation provides the U.S. CCT supplier with a major opportunity to enter the Italian market. 


\subsubsection{Japan}

\subsubsection{Background}

Japan's success and prominence in post-WWII world markets has been labeled a phenomenon -- an economic miracle. The nation's success has prompted writings that praise the work ethic, business acumen, and savvy of the Japanese people. The Japanese government's policies after WWII have fostered domestic manufacturing and investment through subsidies and low capital costs and have protected the domestic market through barriers, collusive industrial practices, and joint R\&D support (U.S. Department of State, 1989a). Japan's Ministry of International Trade and Industry (MITI) was established after WWII to provide a set of guidelines and policies for the rebirth of the economy. MITI has become instrumental in targeting industries for growth and assisting those in decline. Although MITI's influence has waned since the early 1980s with the passage of more liberalized foreign-trade and investment laws, it still remains one of the top government ministries dealing with international trade in Japan (DOC, 1987a).

Some facts illustrate Japan's economic success: It led the world in 1989 for the third consecutive year in grant and assistance loans to developing countries; it is on a par with the United States as the world's leading economic power; and the standard of living in Japan is equal to that in the United States. However, just as this success has brought recognition to the once-isolated island nation, so it has wrought greater scrutiny by the world's other market leaders.

Japan has recently been the target of allegations by the United States of unfair trade practices. The U.S. government and U.S. businesses have cited exclusionary government procurement, technical barriers to trade, collusive and severe underbidding by Japanese businesses on Japanese government contracts, and intellectual-property infringement. The USTR's Special 301 list included Japan as an egregious offender in the area of foreign-trade barriers (DOC, 1988b).

Japan has few indigenous energy resources and must rely heavily on imports. Fifty-four percent of the country's total primary-energy requirements in 1987 was met by imported oil, mostly from OPEC countries. Japan is seeking a balanced mix of energy sources, including nuclear, coal, hydropower, and renewables, to help reduce this reliance on imports. Japan produces only a moderate amount of coal, and this production has been decreasing over the last decade. Japan is the largest importer of coal of all the OECD countries. Although Japan's industrial coal use is primarily in the iron and steel industry, its coal-generated electricity production is the third highest of all OECD countries.

Environmental pressure for advanced coal technology is high in Japan. A strong $\mathrm{SO}_{2}$ - and $\mathrm{NO}_{\mathrm{x}}$-control program is in place at both the federal and local levels. Flue-gas desulfurization and $\mathrm{NO}_{\mathbf{x}}$-reduction technologies are used on large plants, mostly with waste-minimization technologies. Heavy industrialization, large population centers, and limited land for waste disposal have made Japan a leader in the development of efficient emission control systems (DOE, 1988a). 


\subsubsection{Investment in Japan}

More than $50 \%$ of all direct foreign investment in Japan comes from the United States. Cumulative U.S. investment in Japan is approximately $\$ 3$ billion, which illustrates the strong trade commitment between the two countries (Booze, Allen, and Hamilton, Inc., 1987).

The law that regulates all investment in Japan is the Foreign Exchange and Foreign Control Law (Investment Law), effective since December 1980. Direct foreign investment can be made in the form of a branch office, wholly-owned subsidiary, licensing agreement, foreign operations, establishment of a joint venture, and other equity arrangements (U.S. Foreign and Commercial Service, 1986).

The Investment Law liberalized the forms of investment allowed under Japanese trade law and opened up new forms of investment for foreigners. For instance, a negative list was introduced for external transactions, which were previously prohibited. Also, the scrutiny previously applied by the government in establishing investment was liberalized so that only the most integral ministries are included in the approval process (Business International Corp., 1988b).

The government still prohibits investments on grounds of national security, adverse affects against Japanese businesses, and domestic economic welfare. Investments that are usually excluded from direct foreign investment and that are not yet liberalized include these: agriculture, fishery, and forestry; mining; petroleum refining; and leather manufacturing (Business International Corp., 1988b).

\subsubsection{Intellectual- and Industrial-Property Protection}

Japan is a member of the Paris Union, the Universal Copyright Convention (UCC), the World Intellectual Property Organization (WIPO), and the Patent Cooperation Treaty (PCT). Despite being a signatory to these conventions, however, Japan has been placed on the Watch List by the USTR (under the Special 301 provision of the Omnibus Trade and Competitiveness Act of 1988) as having denied "fair and effective protection of intellectual property rights" or "fair and equitable market access to United States persons that rely on intellectual property protection" (U.S. Trade Representative, 1989a). This status does not mean that intellectual- and industrial-property laws are not enforced in Japan; the USTR has stated that current regulations are not as far-reaching in scope as they might be. For instance, before 1988, Japan did not have a copyright law to protect computer software, and the patent office was cited for protracted examination and approval processes. The DOC (1987a) stated that the backlog is such that it often takes six to eight years for approval, versus two years in the United States. In 1987, Japan began accepting copyright registrations for intellectual property (Business International Corp., 1988b).

Japan's patent law differs significantly from the U.S. law in that Japan applies the "first to use" rule, and the United States applies the "first to invent" rule. Japan is, however, is a signatory to the PCT, which makes the application process less burdensome for the U.S. applicant. The PCT allows for international application of patent protection 
in signatory countries when designated on the patent application. However, being a signatory does not automatically grant universal protection; countries must be designated by the applicant for approval in foreign countries.

\subsubsection{Import Policy and Import Licensing}

Under the Foreign Exchange and Foreign Trade Control Law, Japanese import policy is controlled by MITI or an authorized foreign-exchange bank. Commodities that are restricted, under quota, or subject to approval must be granted approval by one of these organizations. Not all imports are subject to licensing, notification, approval, or payment, but those items designated as controlled or restricted are subject to strict import regulations (Business International Corp., 1988b).

"Quotas" for controlling imports have been placed on 22 agricultural products, 4 manufactured goods, and coal, for a total of 27 quotas. To import a restricted (quota) item, MITI and other relevant ministries must be notified in advance for approval. There are no restrictions on the import of technology for energy and electricity applications, nor does there appear to be any restriction on the import of the raw materials needed to construct advanced coal technologies (Bank of Tokyo, 1983).

\subsubsection{Licensing and Technology Transfers}

Licensing is used widely in Japan, and it can be a profitable method of gaining market entry with a new technology. The use of licenses also reduces the cultural and operational barriers that may be encountered in other forms of market entry. Although licensing usually entails less risk to the licensor, there is always a possibility of potential competition by the licensee, and the licensor must be alert about maintaining the integrity of the licensed technology (DOC, 1987a).

All licensing agreements must be submitted to the Ministry of Finance through the Bank of Japan and the appropriate Ministry of Industry. The Japan Foreign Trade Commission (JFTC) is also involved in the review and approval of licensing contracts. Within 30 days of submission of the licensing contract, approval is either given or waived by the relevant ministry and the JFTC.

The contract is the most important legal instrument between the licensor and the licensee. To prevent any competitive technologies from being licensed by the licensee, the contract should include a clause for the use of an exclusive license. In addition, patent protection should be secured by the licensor in the territories for which the licensee will be granted exclusive selling rights. The Foreign Exchange and Foreign Control Law is the administrative tool for the enforcement of licensing contracts (Business International Corp., 1988b).

There are no ceilings set on the payment of royalties or fees. The amount set should be specified in the contractual agreement set forth between the licensor and the licensee (Bank of Tokyo, 1983). 


\subsubsection{Joint Ventures}

The Investment Law provides for the establishment of joint ventures in Japan. The procedure of filing with the appropriate ministry through the Bank of Japan and the Ministry of Finance that is followed to establish a branch is also followed for joint ventures; in addition, the Fair Trade Commission must be notified (U.S. Foreign and Commercial Service, 1986).

The American Chamber of Commerce in Japan has reported that joint ventures between U.S. and Japanese companies have been established on a "50-50 equity basis without significant cash commitment" by the U.S. firm, usually when state-of-the-art technology is involved (Robertson, 1987). This mode presents an attractive entry vehicle for a U.S. firm that is constrained from investment financing but that wants to expand overseas.

\subsubsection{Financing Aspects and Other Considerations}

Japan is the leading force in the arena of development loans and assistance, and it maintains some of the largest banks in the world. One of the biggest mechanisms for development financing is the Official Development Assistance Program of the Overseas Economic Cooperation Fund. This fund is used for project and program development by government agencies and private firms. Examples of powerful Japanese banks are the Bank of Japan, Japan Development Bank, and the Export-Import Bank of Japan.

With respect to medium- and long-term financing, Japanese companies usually have little difficulty in financing large projects, and many banks promote policies of lending to overseas firms. Credit is relatively inexpensive (the official discount rate in 1988 was 2.5\%), and securing credit for an energy project in Japan is expected to pose relatively few problems for U.S. CCT developers or entrepreneurs (Business International Corp., 1988b).

\subsubsection{Conclusions}

Japan is one of the most industrialized countries in the world, with one of the highest GDPs, one of the highest standards of living, and a very sophisticated technological base. Although there have been many complaints by U.S. industry about Japan's closed nature, it is possible to enter the Japanese market in a variety of ways that are similar to those accepted in the United States. Because of Japan's lack of indigenous energy resources and its desire to decrease its dependence on energy imports, Japan has embarked upon a course to diversify its energy sources and find better ways to use its energy. This course includes developing new energy technologies and purchasing foreign technology. There is heavy environmental pressure in Japan to control and reduce emissions, which also opens an avenue for U.S. CCT developers.

Financing will probably not be an obstacle to marketing U.S. CCTs in Japan, but the competition in the Japanese marketplace will tend to make entry most difficult. Nevertheless, U.S. investment accounts for more than $50 \%$ of all direct investment in 
Japan, and licensing technology to Japan will probably not pose the same problems there that it would in other countries because of the United State's previous experience licensing in Japan.

\subsubsection{Morocco}

\subsubsection{Background}

The Kingdom of Morocco is a constitutional monarchy. Morocco and the United States have a long history of friendship and cooperation, embodied in the Treaty of Peace and Friendship, which was originally signed in 1787 and renegotiated in 1836 . This treaty constitutes the longest unbroken treaty in U.S. history (U.S. Department of State, 1989b).

The 1980s saw a strengthening of the relationship between the two countries in both aid and understanding. Although they have historically maintained a close trade relationship, the value of U.S. direct investment was estimated at slightly more than U.S. $\$ 100$ million in 1987. The United States has a continuing trade surplus with Morocco, which over the past few years has averaged approximately U.S. $\$ 330$ million per year.

Morocco is a net energy importer. Overall energy imports have constituted almost $90 \%$ of all commercial energy since 1986 . Oil imports account for more than $80 \%$ of Morocco's energy consumption. And of the nearly 900,000 tonnes of coal Morocco imported in 1986, approximately $85 \%$ came from the United States.

\subsubsection{Investment in Morocco}

The government of Morocco officially welcomes foreign investment by offering incentives to prospective investors in the form of tax holidays and investment codes. The Royal Decree on Investment or Moroccanization Law of August 1973 is the legal basis for all foreign investment. In 1983, the Industrial Investment Incentive Code liberalized the Law to allow a more conducive climate for investment. The Investment Code provides incentives in specified geographical areas for industrial and servicerelated projects. In November 1989, in an effort to liberalize the Investment Code and promote investment in Morocco, another Royal Decree stated that an investment filed in Morocco shall be considered as approved by the administration if, after two months, no action has been taken. This measure was designed to facilitate the investment process for foreign firms interested in doing business in Morocco (Washington Post, 1989a). Although there are still limitations on what constitutes a legal business entity in Morocco, the Royal Decree of 1989 attempts to eliminate costly administrative procedures that act to prohibit foreign investment.

The Moroccanization Law states that for certain industries (commercial banking, insurance, and other service-related activities), Moroccan citizens must hold at least $50 \%$ of the share capital and constitute a majority on the board of directors. (Appendix C contains the list of commodities and services for which "Moroceanization" is 
required.) Some manufacturing industries have voluntarily complied with this Law. Architectural and engineering firms, consulting firms, and other service-activity firms may also be subject to the Moroccanization Law. A firm investing its capital or equity in Morocco should thoroughly examine the Moroccanization Law to determine whether its activities are subject to this national legislation (Price Waterhouse, 1986).

Many types of foreign investments are allowed in Morocco, ranging from whollyowned subsidiaries to representative offices. The main types of companies include partnerships, limited partnerships, limited liability companies, and corporations, similar to those in the United States. The Commercial Code of Morocco allows for the free establishment of firms within the country. The only regulation with respect to reporting the establishment of a foreign enterprise is to notify the Secretariat of the Court of First Instance (DOC, 1986).

The Bilateral Investment Treaty between the United States and Morocco is an added incentive to doing business in Morocco. The treaty provides for capital repatriation, settlement of business disputes under the International Conference on the Settlement of Investment Disputes (ICSID), and national and most favored nation treatment (DOC, 1989a).

\subsubsection{Intellectual- and Industrial-Property Protection}

Morocco is a signatory to the Paris Union and, as such, accords national treatment to foreign-patent holders who have registered their patents in Morocco. Intellectual property is accorded protection for 20 years once registration is completed. At the end of each 20-year period, renewal may be made for another 20-year period. All intellectual property must be registered with the Industrial Property Office (Office Marocain de la Propriete Industrielle, OMPI). Morocco is the only country in this study that has not been cited by the USTR for inadequate intellectual-property protection under the Super 301 provision (DOC, 1986).

\subsubsection{Import Policy and Import Licensing}

Import licensing is used as a means of controlling goods that enter the country. All imported goods are subjected to import licensing and are divided into two categories, A and B. Goods on List A may be freely imported, while goods on List B are restricted by quota and may require a license. Licenses are granted through the Commercial Ministry, and prior approval is required for all imports (Price Waterhouse, 1986).

\subsubsection{Licensing and Technology Transfers}

Once the technology patent has been registered properly with the OMPI, the licensing agreements must be registered with OMPI to effect payment of royalties and technical fees. These fees are authorized through the Moroccan Exchange Office and are subject to a $10 \%$ withholding tax (DOC, 1986). 


\subsubsection{Joint Ventures}

Joint ventures are not considered legal business entities in Morocco. Although a joint venture could be the means to effect a construction contract, it would not enjoy the legal status of other business forums and would provide no legal protection in the case of breach of contract, etc. (Price Waterhouse, 1986).

\subsubsection{Financing Aspects and Other Considerations}

Morocco's exposure with Eximbank (all in preliminary commitments, at present) is approximately U.S. $\$ 250$ million, with about one-half of that amount tied to aircrafttechnology development and phosphate development and exports. Because most of the financing for Moroccan projects is "tied" (that is, certain requirements for exporting or importing commodities or services must be met to secure the financing), there is little interest in financing projects through Eximbank in the future (Kostic, 1989). Morocco has given the energy sector a high priority in its development plans, primarily to reduce its dependence on oil imports. Thus, financing through the many U.S. and international lending institutions appears to be a viable option.

\subsubsection{Conclusions}

Morocco has a long history of trade with the United States, despite the fact that the United States has maintained a $\$ 300$ million trade surplus for more than five years. Morocco's official government policy is to decrease its dependence on imported oil and develop domestic energy resources, which bodes well for U.S. CCT development.

Although foreign investment is encouraged by the government, aspects of the Moroccanization Law may make investment a difficult option. The November 1989 Royal Decree was designed to facilitate investment by expediting the process, but investors must still take the full Moroccanization Law into account. Joint ventures are not considered a legal business entity, but all other forms of investment are allowed, including partnerships, limited partnerships, limited liability companies, and corporations. Despite the fact that investment may pose some problems, the best options for U.S. CCT developers appear to be licencing or investment.

\subsubsection{Turkey}

\subsubsection{Background}

Before 1980, the economy of the Republic of Turkey was relatively closed and highly dependent on import substitution. Although this policy was initially beneficial for internal economic growth, it inhibited growth in hard-currency revenues. The Turkish government recognized that the only way to expand in foreign trade and investment was to liberalize its trade regime to allow for greater infusion of capital and integration of international trade. The import-substitution policies were replaced by export-oriented 
strategies, and the development of private enterprises was encouraged. Foreign private investment, which had been discouraged, was now highly encouraged by the government. These liberalization policies have proven to be quite effective; exports increased by more than $20 \%$ each year from 1980 to 1985 , and overall economic growth (measured by GDP) grew as well, at a rate of about 5\% per year between 1980 and 1985 (OECD, 1988b).

In terms of indigenous energy resources, Turkey possesses vast supplies of coal and lignite and some oil reserves, but it remains heavily dependent on oil imports. This dependence has led to the underutilization of its domestic energy resources (DOE, 1989a).

\subsubsection{Investment in Turkey}

To encourage foreign investment, the government of Turkey does not prohibit or preclude most common forms of business organization by foreigners. Typical forms of legitimate investment in the Turkish commercial codes include corporations, limited liability companies, joint ventures, branches, and subsidiaries. Turkish governmental policy allows for commissioned agents, distributors, and licensing arrangements as well. Because of the lack of foreign direct investment in Turkey, the Ozal administration has advocated the BOT model -- a turnkey-type arrangement. Under this scheme, a foreign firm builds a factory, plant, etc.; operates it while selling the output to the state at a fixed price; and then transfers the project to Turkish control (DOC, 1988c).

The Undersecretariat of Treasury and Foreign Trade under Turkey's Prime Minister is empowered with the sole responsibility of establishing foreign investment regulations and overseeing all foreign investment in Turkey. The Foreign Investment Department (FID), created by Decree No. 10353 in 1986, is the lead agency under which the Undersecretariat's Office operates. Since approval is required for all foreigninvestment and business transactions of any nature, applications for business in Turkey must be sent directly to and be approved by the FID before any action can be undertaken (Business International Corp., 1987b).

Turkish trade with the United States is based on, inter alia, the GATT, the U.S.Turkey Bilateral Investment Agreement, OECD guidelines, and the U.S.-Turkey Treaty of Friendship and Navigation. These treaties combine to form a codified trade policy intended to shape the direction of trade between the two countries. A U.S.-Turkey bilateral tax treaty is presently under negotiation (DOC, 1988c).

Previously only two forms of business organization were allowed for nonnational companies -- the limited liability company and the corporation. Now foreign investors are able to participate in a variety of standard business organizations. Investments must be registered with the Commercial Registry, and once registered, profits and income may be freely transferred. All forms of investment are gaining popularity in Turkey, the most popular being the limited liability company and the corporation. Although stateowned enterprises pervade the Turkish industrial sector (particularly mining, energy, and public utilities), there is a movement toward industry privatization. The government still 
controls about $47 \%$ of all industry but is increasingly willing to permit market forces to control the destiny of some industries (Business International Corp., 1987b).

With respect to regional investment incentives, the State Planning Organization controls and reviews all applications for incentives that are available to both domestic and foreign investors. Types of incentives include subsidies as well as exemptions or deferrals for duties and taxes, among others (DOC, 1989e). The government has designated areas in eastern and central Anatolia as investment-priority areas. Companies investing in the Anatolia region may be eligible for some of the incentives. In addition, there are no requirements for equity participation or export performance for eligible firms (Business International Corp., 1987b).

With respect to corporate taxation, the taxes in Turkey are rather high, and the tax structure is clearly spelled out for all types of business transactions. All foreign investment is subject to the central government tax rate of $46.8 \%$ of gross profit, but the tax rate is effectively raised to $48 \%$ with the addition of the taxes for the Defense Fund, Social Solidarity Fund, and Technical Training Fund. Patents and royalties are subject to a $26 \%$ tax rate on transfers. There is no applicable tax treaty between the United States and Turkey (Business International Corp., 1987b).

\subsubsection{Intellectual- and Industrial-Property Protection}

Turkey is a signatory to the Paris Union. The national law on patent protection is the Patent Law of 1880 , as amended, which provides protection for periods of 5 to 15 years. Applications for patent and trademark protection are made to the Foreign Investment Department. Patents that have been registered in the United States may be registered in Turkey through an agent, and exclusive rights will be accorded that patent as granted under the Turkish patent law. There have been complaints by the international community of patent and trademark piracy in Turkey, but the Turkish government has taken no action to deter such infringements. Although Turkey has been placed on the USTR Watch List for its inadequate intellectual-property protection, it is deemed to be making a good-faith effort toward resolving the inadequacies (U.S. Trade Representative, $1989 \mathrm{~b})$.

\subsubsection{Import Policy and Import Licensing}

Although the Turkish government espouses liberal trading policies, it still requires import licenses through the Undersecretariat for the Treasury and Foreign Trade, mainly for items that are grown or manufactured domestically (Business International Corp., 1987b). Of course, this type of licensing scheme acts as an nontariff barrier to imported items on the import-control list. Because of the liberalization of the import market in Turkey, many of the import controls have been lifted. The licenses are valid for an average of 6 months, but this period can be extended to 12 months in many cases. All goods imported into Turkey are subject to an import deposit (currently at $15 \%$ of the value of the imported goods) to be paid by the importer, refundable after foreign payment is made and the goods have been cleared through customs. Import deposits can be waived for certain categories of commodity, including those associated with electrical 
energy, if the imports are targeted for projects in special development areas. The FID determines whether an import license is required (Embassy of Turkey, 1989), which can delay the import process.

The government of Turkey implemented the Harmonized System on January 1, 1989 (the same date as U.S. implementation). Duties are assessed, as they were before, on the c.i.f. ad valorem basis of the goods (DOC, 1989e). Turkish tariffs, which are not subject to international agreements such as those followed by member countries of the European Community, are considerably higher than those in other countries. They contain charges such as a municipal tax (15\% of the customs duty), wharf tax (5\% of c.i.f. value), stamp tax (10\% of c.i.f. value), Support and Price Stabilization Fund tax (PSF, 8\% of the c.i.f.), and value-added tax (VAT, 1-15\% of the c.i.f value), in addition to all the duties, taxes and charges, fund levies, and customs-clearing expenses being charged. The duties themselves range from approximately $10 \%$ to a ceiling of $50 \%$ (Business International Corp., 1987b). For small combustors, the Commercial Office of the Turkish Embassy in the United States has quoted a tariff rate of $50 \%$ plus U.S. $\$ 1.00 / \mathrm{kg}$ for the weight of the combustor, in addition to the charges (municipal tax, wharf tax, etc.) cited above (DOE, 1989a).

According to the Ozal Administration policies for liberalizing trade in Turkey, the Turkish government has attempted to remove many types of nontariff barriers. Import licensing and import deposits, however, still remain largely intact (Business International Corp., 1987b). Furthermore, standards requirements, mainly in the area of labeling for machinery and mechanical equipment, act to preclude the expeditious entry of imported items.

\subsubsection{Licensing and Technology Transfers}

All technology licenses must be approved by and registered with the FID. Although licensing is currently not as popular in Turkey as it is in the other countries included in this study, the government does encourage such agreements, especially the exchange of technical information. Licensing agreements are drawn up by the seller and the contracted agent. The Turkish government has stated that the agreements should include technical support and should not contain any stipulations that would restrict the licensee's operations. Technology licenses are valid for the duration of the agreement between the contracting parties, but patent licenses must be registered annually with the FID (Business International Corp., 1987b).

The licensing regulations appear to be rather restrictive for the licensor, because the Turkish licensee has the right to set its own prices and because no limits may be placed on production or exports. For these reasons, the contracting parties should make sure that all stipulations are clearly written and understood, so no infringements on patents or technology are made and so each party fully understands its rights and responsibilities as contained in the written contract (Business International Corp., $1987 b)$.

Contracting parties to licensing agreements are free to determine their own royalty payments and licensing fees. As in all business transactions, the FID makes the 
final decision about accepting or rejecting an agreements The regulations are quite liberal for the payment of royalties and fees, and once approved by the FID, the royalties and fees can be freely transferred through Turkish commercial banks (Business International Corp., 1987b).

\subsubsection{Joint Ventures}

Joint ventures are encouraged by the government of Turkey because they are seen as contributing to the economy in terms of employment, technological advancement, and the generation of capital. As it does for all other investments and business transactions, the FID must approve all contracts for establishing joint ventures. Once approved, there is no limitation on the amount of capital repatriated, provided all stipulations under Decree No. 6224 (Law for the Encouragement of Foreign Capital) are met (DOC, 1988c).

\subsubsection{Financing Aspects and Other Considerations}

For the past several years, many Turkish banks have been promoting their financing programs. Since the economic liberalization in 1980, many banks have turned outward and are seeking to finance international projects within the country. The first major BOT project in Turkey, for a 1000-MW thermal power plant led by a Japanese consortium (a U.S. $\$ 900$ million contract), is nearing finalization (Financial Times, 1989). Its success could serve as a barometer for other such projects.

Foreign financing for energy projects has been made available to Turkey from the World Bank and other international lending institutions as well as through foreigncountry assistance programs and project credits. Japan, the FRG, Austria, and Soviet Bloc countries have been very competitive with their project credits in thermal plant construction. This heavy international competition makes the financing of projects more complicated, but it also reveals that there is a lot of activity underway in Turkey. Any difficulty in financing may be overcome by going through the World Bank and staying informed about the potential projects being financed by the World Bank.

\subsubsection{Conclusions}

Turkey seems to offer a promising marketing opportunity to U.S. CCT developers. Although it is characterized as an industrializing country, Turkey maintains strong ties to the European Community, and it is directing its development efforts toward importing more technology to diversify its industrial base -- heading toward modernization. Despite the fact that Turkey is characterized as a low-income country by the OECD and a middle-income country by the World Bank (OECD, 1988b), its GNP has increased by about $5.2 \%$ each year between 1970 and 1987 , and its total energy consumption (including noncommercial energy) has grown at about the same pace (Aybar, 1988). 
Despite not being wholly successful to date, the BOT program promoted by the Turkish government (including the BOO program and the BOOT program) does provide an incentive for U.S. CCT developers who wish to gain entry into the growing energy markets in Turkey. Both government and nongovernment sources are allowed to generate electric power; as of late 1988, there were nine companies in the process of establishing their own power plants through joint ventures and other investment schemes.

\subsubsection{Pakistan}

\subsubsection{Background}

The Islamic Republic of Pakistan, in its present-day state, was granted independence from India by the United Kingdom in 1947. It is a predominantly Muslim country (97\%) that has an Islamic court system as an integral part of its legal structure. Prime Minister Benazir Bhutto returned a democratic government to the country after more than a decade's hiatus. She strengthened Pakistan's relationship with the United States and other commonwealth nations and was granted increased amounts of monetary aid from these countries, and she lifted martial law. As long as the United States remains confident that Pakistan is not building nuclear facilities with weapons capabilities, the future for maintaining a strong U.S.-Pakistani economic and political relationship remains bright.

In 1988, the United States recorded a trade surplus with Pakistan on the order of U.S. $\$ 600$ million. Although the situation between the U.S. and Pakistan remains promising, problems within Pakistan's economy might require strong economic reforms and retrenchment to be effectively eliminated. These problems include a large budget deficit (8.5\% of GDP), a chronic current-account deficit (close to U.S. $\$ 2$ billion in 1988), and accelerating inflation (from $3.6 \%$ in 1987 to $7.0 \%$ in 1988) (Economist Intelligence Unit, 1989a). Pakistan's debt-service ratio has been hovering in the precariously high range of more than 25\% since 1985. Since Pakistan borrowed U.S. $\$ 830$ million from the International Monetary Fund (IMF) before Bhutto's party gained control, strict conditionality measures on slowing down the economy have been placed on Pakistan (Economist Intelligence Unit, 1989b).

Pakistan is ranked as one of the poorest countries in the world. Energy scarcity is a major factor that is prohibiting its economic growth, yet energy demand keeps

growing. Natural gas resources have been overutilized to such an extent that the government of Pakistan has initiated a policy restricting the further use of natural gas for power generation and discouraging its use for the cement industry. Hydroelectric plants are generally unreliable because of the cyclical nature of reservoir-water levels. Because almost $90 \%$ of Pakistan's oil requirements are met through imports, export earnings are continually ravaged. 


\subsubsection{Investment in Pakistan}

Since the beginning of the 1980s, the Pakistani government's policy has been to encourage private-sector investment. This policy extends to foreign private investment. The government especially welcomes foreign investment in industrial projects that require sophisticated technology and heavy capital outlays and in exportoriented and import-substitution industries (DOC, 1988a).

All investments or expansions must be approved by the Investment Promotion Bureau, which is responsible for approving new foreign investment. The government of Pakistan does not set a minimum or maximum on the amount of equity held by a foreign concern, but it does favor joint ventures and the use of local materials when possible (Business International Corp., 1989).

To protect against expropriation and to promote foreign investment, the Foreign Private Investment Act of 1976 was promulgated. This act guarantees repatriation of investments and profits and allows for remittance of salaries. U.S. investment in Pakistan was estimated at U.S. $\$ 120$ million in 1986; the majority of the investment was concentrated in fertilizers and pharmaceuticals.

In addition to the Treaty of Friendship and Commerce, which is the legal instrument for guiding investments, the Convention on the Avoidance of Double Taxation covers income taxes and the business profit tax in Pakistan (DOC, 1988a).

Although Pakistan places no legal restrictions on the percentage of foreign equity, in practice, officials discourage majority foreign ownership. In general, the government is favorable to foreign investment when it brings in advanced technology, managerial and technical skills, or marketing expertise. In particular, industrial projects that involve sophisticated technology and heavy capital outlays are encouraged.

An industrial policy statement issued along with the $1984 / 1985$ budget outlined five major factors that the government considers when deciding whether to approve a joint-venture project (Business International Corp., 1989): (1) usefulness in meeting overall national objectives; (2) contribution to capital and technical and managerial know-how; (3) discovery, mobilization, or better utilization of national resources; (4) favorable impact on Pakistan's balance of payments; and (5) contribution to increased employment opportunities.

\subsubsection{Intellectual- and Industrial-Property Protection}

Pakistan is not a member of the Paris Union, but it is a member of the WIPO, the UCC, and the Berne Copyright Union (DOC, 1988a). The United States and Pakistan are bound by a treaty of friendship and commerce, which acts as the legal framework for protection of industrial and intellectual property. This treaty also provides for the right to national treatment for persons and property, which is one of the major provisions of the Paris Union (U.S. Trade Representative, 1989a). Patents are enforceable for 16 years from the date of filing in Pakistan, whereas in the United States, they are enforceable for 17 years from the date they are issued. 
Pakistan has been cited for inadequate intellectual-property protection by the USTR under the Special 301 authority. There have been complaints of compulsory licensing of products and of the lack of a registration process for service marks. The USTR postulates that if the intellectual-property laws were strengthened, U.S. firms would be more willing to export to Pakistan (U.S. Trade Representative, 1989b).

\subsubsection{Import Policy and Import Licensing}

All imports into Pakistan require an import license, which is valid for one year from the date of issuance. For certain goods, there are limits on the value of import licenses; therefore, it is best to check the official government policy on the import of manufactured goods and raw materials (DOC, 1988a). There are also negative and restricted lists that severely constrain how a commodity can be imported and who can import it. Ceilings on the value of imported machinery have been established, and the negative and restricted lists are subject to amendment each year (U.S. Trade Representative, $1989 \mathrm{~b})$.

\subsubsection{Licensing and Technology Transfers}

Technology licensing may be a less complex method for entering the Pakistani marketplace. There are existing laws on paying royalties and technical fees in conformance with technology-transfer contracts. Licensing has proved to be an effective entry vehicle for U.S. firms and for many European firms. One drawback, however, is that royalties and fees have historically been low because of foreign-reserve shortages.

The Pakistani government sets standard terms to which all agreements must conform; if the agreements do conform, no prior clearance from the State Bank of Pakistan or the Ministry of Finance is officially required (Government of Pakistan, 1989). However, a copy of the agreement that establishes the payment of royalties or technical fees must be submitted to the State Bank of Pakistan in Karachi (DOC, 1988a). Pakistani law precludes remittance of royalties and technical fees if foreign ownership in a project exceeds 50\% (Business International Corp., 1989).

\subsubsection{Joint Ventures}

No known laws in Pakistan preclude the formation of, or equity by a foreign partner in, joint ventures. However, foreign ownership may be limited to ownership of equipment and technology and not include capital participation. Joint ventures must be approved by the Ministry of Finance before any operations begin (DOC, 1988a).

\subsubsection{Financing Aspects and Other Considerations}

There are no restrictions placed on loans to Pakistan, nor does Eximbank report any exposure in Pakistan. Energy development grants from AID totaled approximately $\$ 625$ million for the period 1983-1993. The World Bank loans Pakistan approximately 
U.S. \$250-300 million each year for energy development assistance. Pakistan has never rescheduled its debt and maintains a good credit rating with the World Bank.

According to the World Bank, an equity agreement has been negotiated with private foreign firms to construct a $1300-\mathrm{MW}$, oil-fired power plant in Pakistan under a BOO (build, own, and operate) agreement. This project is estimated to cost more than U.S. $\$ 1$ billion. A search for financing is being conducted, since none has been committed. This project would be the first involving a nonpublic energy facility undertaken in Pakistan. If it develops as planned, it could bode well for other privatesector energy-development work in the country in the future.

\subsubsection{Conclusions}

Pakistan is one of the poorest countries in the world and the third largest recipient of grants, loans, and assistance. The United States maintains a trade surplus with Pakistan. A continuing economic slowdown there has necessitated the implementation of austerity measures. In spite of this situation, Pakistan has been showing evidence of economic growth in the past five years, and the energy sector must be encouraged to continue to develop for the future development of the country. On the basis of the trade relationship as it is today, the prospect for the United States to do business in Pakistan is good. Grants and loans through various international lending institutions seem to be a viable option for project financing in Pakistan.

\subsubsection{Peoples' Republic of China}

\subsubsection{Background}

Trading with the PRC is expected to present new challenges and opportunities to the United States, especially to firms unfamiliar with the country, its economy, and its centralized planning mechanisms (DOC, 1988d). The mechanism for central planning is the State Planning Commission, which is responsible for planning and implementation at the national level. (Limited participation by provincial and municipal organizations is beginning to occur, however.) Five-year economic plans establish general goals and priorities for capital investment, production, and supply. Annual plans set performance targets for state-owned industrial and commercial enterprises and govern the allocation of state funds.

Because planning is centralized, project decision making is generally politically motivated by the State Planning Commission's five-year plans. As economic reform progresses, the State Planning Commission is expected to implement plans through indirect economic levers rather than direct administrative controls. Chinese foreign trading companies of ten act as the intermediaries in business transactions for utilities. Although a foreign trading company may be linked directly to the Ministry of Foreign Economic Relations and Trade (MOFERT), it is more likely to be linked to one of the ministries in charge of an industrial sector, to a provincial or municipal government, or directly to a state manufacturer or a consortium of enterprises (DOC, 1988d). 
The PRC has only been open for trade with the United States for 10 years, and its economy is very different from the market-based economy of the United States. Before the U.S.-China Trade Agreement was signed, the PRC's economic system was based largely on self-reliance, limited importing, and central planning. Since 1979, as a result of trade with the United States, it has evolved into a system that tolerates competitive forces and market allocation. In September 1988, the PRC initiated a policy of "economic retrenchment" to "cool" its overheated economy. This policy has resulted in tighter fiscal and monetary policies, tighter import controls, and a slowdown in productivity (DOC, 1989d).

After the student protest in June 1989, which culminated in the suppression of the prodemocracy movement by the People's Liberation Army, the PRC lost much of the international respect it had been gaining in the last few years. Numerous foreign businesses ceased operations for a time and transferred many of their workers out of the country. International lending has been suspended in many cases -- especially loans from the Asian Development Bank and the World Bank (Journal of Commerce, 1989). Insurance coverage through OPIC in the United States has been suspended as well. Those international lending institutions that have chosen to remain open to the PRC are increasing their scrutiny while remaining cautiously optimistic.

Although the tragedy at Tiananmen Square and the ensuing political shakeups within the PRC are transitory, the events have created a problem for the international trader or investor. The question remains as to how long this transition period may last. Leadership is in the midst of turmoil, with Deng Xiaoping (the PRC's paramount leader), Li Peng (the prime minister), and Yang Shangkun (the president) all struggling for some form of control over the military and the party. Whether the ensuing leadership results in more authoritarian control by the "hard-liners" (like Li and Yang) or whether reformist ideology will replace the hard-line ideology remains to be seen. This situation is one that should be closely monitored. If the communist hard-liners gain sufficient power, there may be a "great leap backward" from the advances made in the past decade during the Great Leap Forward, and a switch will be made from economic liberalization and a modicum of market-force determination to a more centrally controlled, less marketoriented state.

The China Business Review (1989) reported that authorities have already announced measures that aim to "recentralize" control over the trade regime and stabilize the rapidly deteriorating balance of trade. Import controls are being tightened, and foreign-trade authority is expected to be cut back to allow for more regulated control of necessary goods. The Washington Post $(1989 \mathrm{~b})$ reported that the PRC's leaders announced that economic policy would once again become more centralized and move away from free-market determinations.

The PRC is one of the world's most technologically underdeveloped countries in terms of both its energy and industrial sectors. It is also one of the least energyefficient countries. Despite these conditions, it has one of the highest ratios of energy consumption per capita of GDP. The problem of energy inefficiency is exacerbated by the PRC's poor-quality, indigenous coal. In spite of this gloomy picture with respect to energy, technology, and trade, the PRC has been striving to modernize its technology base through acquisition of Western technology and through joint-development efforts by 
establishing a technology base in advanced coal-utilization technology such as FBC. The PRC recognizes that to achieve economic growth, it will have to optimize its powergeneration capacity and increase its coal production to compete in the international coal-technology arena.

Four "modernizations" are called for in the State Planning Commission's official policy. The four sectors to be modernized are agriculture, industry, defense, and science and technology. The goal is to bring the PRC up to par with the more industrialized countries. These four sectors will receive special attention in the PRC's development plans. State incentives are accorded to foreign firms bringing in new technologies to develop any of these sectors.

\subsubsection{Investment in the PRC}

The government of the PRC officially welcomes foreign investment in the form of wholly-owned subsidiaries and joint ventures. The Law of the People's Republic of China on Joint Ventures Using Chinese and Foreign Investment is the legal instrument that recently paved the way and opened the door for investment in China. Several different forms of investment are allowed in the PRC, including equity and nonequity ventures and cooperative production agreements. Turnkey operations (in which a U.S. firm contracts to completely build a boiler unit and then transfer it to the PRC once construction is completed) are another form of entry into the PRC (DOC, 1988d).

There have been complaints that the government approval process for investments is protracted. Despite this situation, there were about $400 \mathrm{U}$.S. investment agreements in the PRC in 1987. The Chinese government is attempting to revamp some of the inadequacies in its foreign-investment approval system by limiting the approval process to three months and by revising economic laws to regulate the business environment. In 1986, a group formed by the State Council was established to review and revise foreign-investment policy (DOC, 1988d).

Six rounds of negotiations on the establishment of a bilateral-investment treaty have been held between the U.S. and the PRC. The tentative agreement would include regulations for fairness, trading-system transparency, and currency stability. The USTR reports that disagreement still remains over standards for national treatment, thirdparty arbitration (since the PRC is not a member of the ICSID), and expropriation (U.S. Trade Representative, 1989a).

\subsubsection{Intellectual- and Industrial-Property Protection}

The 1979 U.S.-China Trade Agreement requires both parties to protect the patents, trademarks, and copyrights belonging to citizens of the other country. The PRC has just become a member of the Paris Union but has yet to implement copyright law, and the PRC does not extend copyright or patent protection to computer programs. The PRC's patent law, in effect since 1985, applies to inventions, utility models, and designs. Patented inventions are protected for 15 years from the date of filing, and utility models and designs are protected for 5 years, with a possible renewal for 3 more 
years. Chinese law protects the first to file with the Chinese Patent Office rather than the first to invent. The Chinese Patent Office under the State Economic Commission registers patents. U.S. companies and individuals not residing in the PRC may request the Patent Agency in Shanghai, the Patent Agency for the China Council for the Promotion of International Trade in Beijing or Shenzhen, or the China Patent Agent Ltd. in Hong Kong to represent them in the application process (DOC, 1988d).

The PRC was cited recently for a lack of "adequate and effective protection of intellectual-property rights" and was placed on the Priority Watch List by the USTR (U.S. Trade Representative, 1989b). It was cited primarily for its lack of a copyright law, (including software), lack of bilateral copyright relations with the United States, and lack of enforcement of patent laws for inventions.

\subsubsection{Import Policy and Import Licensing}

The PRC uses import licensing as a means to control imports of goods that are also produced domestically. To maintain the domestic industry's output, goods that are deemed producible in the PRC may be protected from foreign imports. Imports may require certificates of approval from the government ministry that is in charge of the domestic industry that manufactures the imported product. Licenses may be required to import a particular commodity into the PRC, and the licensing requirement may vary for a given commodity, depending on the organization importing it. As it is in many business transactions, the licensing authority may be MOFERT, MOFERT offices in major economic regions, or provincial-level authorities (DOC, 1988d).

New import-licensing requirements for luxury goods are expected to have become effective on May 1, 1990, because of the current-account and balance-ofpayments deficits. It is also likely that consumer goods such as industrial equipment, machinery, and raw material imports will be subjected to the same sort of controls as those for luxury items if the economy fails to adjust (China Business Review, 1989).

The lack of trading-system transparency has been cited as a deterrent to trade, since rules and regulations are not always readily accessible and can vary from province to province. Furthermore, even when formal rules and regulations exist, guidance on the enforcement of these laws is virtually nonexistent (U.S. Trade Representative, 1989a). The greatest market barrier between the United States and the PRC, however, appears to be the lack of convertibility of the PRC currency, the renminbi.

Import licensing is the PRC's primary means of regulating foreign products and trade. The import-licensing scheme requires that information about a product's source and price be negotiated before the transaction is completed, which, in effect, allows the Chinese to shop for the lowest prices. This scheme has been effective enough to warrant claims from the United States and others that the licenses represent a serious trade barrier (U.S. Trade Representative, 1989a). 


\subsubsection{Licensing and Technology Transfers}

Licensing and technical-assistance agreements allow the PRC to acquire badly needed technology. PRC law generally prohibits any limitation on the licensee's use of the technology when the licensing agreement expires and limits the duration of most agreements to 10 years - a regulation that a prospective licensor should be aware of before entering into any licensing negotiations (DOC, 1988d).

Chinese law is unique (1) in that it requires that any technology that is being transferred to an entity must be "advanced" and "appropriate" and (2) in that the licensor is obligated to ensure that the technology, when installed, achieves the objectives stated in the contract. Licensing agreements may not restrict the licensee with respect to the raw materials, spare parts, or equipment used. U.S. companies that license technology to the PRC must structure their transactions to ensure that the contract meets the needs of both parties and provides protection of technological interests to the licensor for the duration of the contract (DOC, 1988d).

\subsubsection{Joint Ventures}

The Law of the PRC on Joint Ventures Using Chinese and Foreign Investment applies to all joint-venture agreements undertaken in the PRC. This law mandates that the PRC supply land, factory, infrastructure, labor, and some materials and machinery. The foreign investor is to provide the technology, capital equipment, marketing, management, and raw materials not available in the PRC. The chairman must be Chinese, and the foreign-investment share may not be less than $25 \%$. Joint ventures are usually in the form of equity joint ventures, which qualify as limited-liability corporations (Wik, 1984).

\subsubsection{Financing Aspects and Other Considerations}

The aftermath of the Tiananmen Square tragedy has incited a crisis in the public international lending community. The World Bank has declared that it will not consider any new projects until human rights violations are reassessed; OPIC insurance coverage (covering insurrection, expropriation, and currency devaluation) has been placed on hold until the U.S. Congress decides on the human-rights violations levied against the PRC; and the Asian Development Bank has suspended the processing of new loans (ostensibly because of the "slowdown in economic reform policies") (Journal of Commerce, 1989). Eximbank stated that it is maintaining a "restrained" business-as-usual environment for the PRC (Wickett, 1989). Eximbank never officially closed to the PRC and is continuing to make offers on projects when they have "full support by the PRC government" and when a U.S. company reguires the loan to secure the project. Private-financing institutions may be the best option for long-term project financing to the PRC, especially during the hiatus in public financing. 


\subsubsection{Conclusions}

In the near term, trading with the PRC is expected to be fraught with difficulties. The political system in the PRC is in a state of transition; austerity programs have been established to stabilize an overheated economy; and public financing will be difficult to secure.

Despite the fact that the PRC has a vast potential for the export and transfer of U.S. CCTs, extraneous factors, at least in the present, seem to thwart large utility or industrial plants from successfully implementing such U.S. advanced technologies. The onus of the problem seems to lie in the financial aspects of potential PRC/U.S. trade. Realistically, without viable financing options, many U.S. firms will be hesitant to expose themselves to the huge risks entailed in long-term, large-project financing. From a longer-term perspective, however, U.S. CCT developers probably realize that since the PRC's current position is transitory and since these projects will continue for a long time, some degree of risk may be amenable to assume. The PRC has maintained a very good credit rating internationally and has never defaulted on its public or private debt. The risks involved will need to be weighed heavily in any assessment of a project's viability in the PRC.

\subsubsection{Poland}

\subsubsection{Background}

Political and economic life in the Republic of Poland is in a state of uncertainty. Free elections resulted in East Europe's first noncommunist government with a strong commitment to reform, but many of the economic reforms called for in the new government's crash program have yet to be implemented successfully. As prices and unemployment have increased, productivity has dropped and wages have been frozen. The buying power of the average Pole decreased by $42 \%$ in five months (Reaves, 1990). The Solidarity-led government is facing its most serious challenge since coming to power in September 1989.

Previous attempts at economic reform in Poland met with considerable difficulty. Efforts to reduce bureaucratic control over the economy, encourage initiatives in both the state and private sectors, and increase Poland's reliance on market mechanisms were largely unsuccessful. Shortages have long plagued the economy, fueling consumer and worker discontent. Price and income issues have become the focus of significant waves of labor unrest. The government's loose credit policy and inability to hold the line on income growth have contribued to open inflation and an increase in the stock of money held by the public. The structure of the Polish economy remains tilted toward heavy industry, with a high level of industrial concentration and monopolist production accompanied by generally low energy efficiency in industrial processes. Demand for consumer goods has outstripped supply in spite of increases in production of consumer goods (DOC, 1989b). 
To hedge against inflation, the Polish people have resorted to holding material assets and foreign currencies. The market rate for hard currency had become several times higher than the official exchange rate. Many Poles depend on the thriving parallel economy, in which they can purchase otherwise unavailable goods with hard currency. The result is a widening gap in the living standards of those with access to hard currency and those without, and the growing desire of many Poles for employment abroad (DOC, $1989 b)$.

The new government that took office in September 1989 introduced an unprecedented, far-reaching, economic reform program that covers a wide range of areas including foreign investment, currency convertibility, taxation, antitrust regulations, and privatization of state enterprises. The reform program was successful in reducing the rate of inflation from $700 \%$ in September 1989 to $80 \%$ in January 1990 . The United States and the European Community are providing strong support as the reform program proceeds (Arsenault, 1990).

\subsubsection{Investment in Poland}

The Law on Economic Activity and the Foreign Investment Law, both adopted by the Polish Parliament on December 23, 1988, are expected to have far-reaching effects on the way business is conducted in Poland. With these laws, the almost exclusive monopoly of state and cooperative companies ended, and the Polish are now free to compete in business. Moreover, the citizens, their companies, and all other enterprises have open access to foreign trade. Banking is undergoing deregulation, and more liberal rules governing foreign currency transactions have been introduced (Burzynski, 1989). By January 1990, the Foreign Investment Agency, a government bureau devoted solely to promoting and supervising foreign investment in Poland, registered more than 800 joint ventures and foreign-owned businesses, and of that number, 60 involved U.S. partners.

The Polish market has many advantages, including low labor costs, a highly educated and skilled labor force, and a large domestic market with a strong demand for quality goods and services. However, foreign businessmen are still faced with significant difficulties. In 1989, Poland's economy continued to struggle with the demands of a U.S. $\$ 39$ billion hard-currency debt, an inefficient heavy industrial sector, and a restive work force.

Economic activity may be undertaken by foreign companies, banks, foundations, and other organizations with a foreign legal status, or by individuals domiciled abroad. Foreign-owned enterprises and joint ventures with foreign participation are allowed more favorable taxation and operating conditions than those enjoyed by Polish-owned enterprises (Burzynski, 1989). Following passage of a law on privatizaiton in the spring of 1990, Poland is expected to allow foreign investors to purchase shares of state enterprises undergoing privatization (Arsenault, 1990). There appears to be no restriction on the scope of economic activity in which foreign partners may participate. They may engage in business in any field -- industry, agriculture, construction, and trade and service -- in either the Polish domestic or export market (DOC, 1990). 
Foreign businesses operating in Poland are subject to an income tax, a turnover tax, and a payroll tax, in addition to property taxes and fees imposed by local authorities. The corporate income tax equals $40 \%$ of the firm's income, but it is decreased by $0.4 \%$ for each percentage point of the company's total sales that are exported, to a minimum of $10 \%$. Joint ventures and foreign-owned businesses are exempt from paying income tax for their first three years of operation. Payroll taxes equal about 50\% of employees' wages. Rates for the turnover tax to be paid depend on the type of investment; exempted from this tax are investments in sectors that are designated priority areas. In order, these areas include agricultural products/machinery and food processing; pharmaceuticals and medical products; chemicals; paper, packaging, and construction materials; environmental-protection and energy-conservation technology; telecommunications, electronics, and computers; printing and officeautomation equipment; transportation; and tourism-related products and services. Poland intends to replace the turnover tax system with a value-added tax in the next few years (DOC, 1990). Foreign businesses involved in priority areas may apply for a threeyear extension to their initial tax-exempt status of three years.

Foreign businesses and joint ventures have the right to repatriate $100 \%$ of their after-tax hard-currency surplus of export revenues over import expenditures. Under the recently signed U.S.-Poland Business and Economic Treaty, the Polish government agreed to eliminate restrictions on the transfer of domestic profits by 1995 (Arsenault, 1990). Dividends repatriated abroad are taxed at $15 \%$, which is lower than the normal $30 \%$ because of a bilateral agreement between the United States and Poland designed to prevent double taxation (DOC, 1990).

Before beginning operations, foreign businesses must obtain a permit from the Foreign Investment Agency. These prospective businesses must present the agency with a draft of the company's founding act and a feasiblity study demonstrating that the business will be profitable. The Foreign Investment Law requires that the Foreign Investment Agency make its decision on whether to grant a permit within two months of when the company filed its application (Burzynski, 1989).

Under the new Foreign Investment Law, joint ventures and foreign-owned businesses can hire an unlimited number of Polish workers, but a foreign business must obtain permission from local authorities to hire foreign labor. Foreign employees of the company (as distinct from new hires) are not reguired to obtain permission from Polish authorities. They need only obtain certification of their status as permanent residents (DOC, 1989b).

The availability of certain raw materials is limited in Poland, and they can only be purchased or exported by special permits. In 1989, these materials included coal, diesel and fuel oil, copper, aluminum, and silver. Difficulties in obtaining permits and securing prompt delivery of materials are not uncommon. A good network of contacts with Polish suppliers is critical to obtaining scarce raw materials. Energy and raw material prices rose sharply in early 1990 as a result of reduced or eliminated government subsidies (DOC, 1990). 


\subsubsection{Intellectual- and Industrial-Property Protection}

Poland is a member of the Paris Union. The U.S. Department of Energy recently concluded a bilateral agreement that also includes intellectual-property protection for specific projects.

\subsubsection{Import Policy and Import Licensing}

To encourage joint-venture activity and foreign investment, Poland has lifted or lessened import restrictions in some areas. Except for a limited number of commodities, no licenses are necessary for international trade (Burzynski, 1989).

In 1988, Poland passed new legislation that allows for the creation of free-trade zones in Poland. Companies operating in these zones can take goods into or out of them without obtaining permits or paying customs duties. As of mid-1989, 13 zones had been established (DOC, 1990). Provisions are underway to establish special economic zones where foreign companies will be permitted to operate exclusively in hard currency.

\subsubsection{Licensing and Technology Transfers}

Established foreign businesses can open representative offices to promote or service their products. Polish law differentiates between branch offices and technical information offices, and they are subject to separate operational and taxation conditions. Branch offices are free to advertise, conclude contracts, and purchase and sell goods on the Polish market. These offices are required to pay, in addition to the $40 \%$ income tax imposed on all foreign businesses in Poland, a $2 \% \operatorname{tax}$ on the value of goods they bring into Poland. Technical information offices are restricted in their activities to providing information on and servicing their company's products; they are not allowed to promote their products, negotiate sales contracts, or purchase or sell goods in Poland. Technical information offices are exempt from taxation, although they are required to enlist, for a fee, the services of one of the government agencies that specializes in representing foreign firms (DOC, 1990).

\subsubsection{Joint Ventures}

Poland encourages joint-venture activity. More liberal legislation implemented in January 1989 allows for 20-100\% foreign ownership of an industrial facility in Poland caps tax rates at $40 \%$ or less, and eases restrictions on profit repatriation. Companies may be formed as either a joint-stock or a limited-liability venture. The minimum foreign capitalization required is U.S. \$50,000, which must be converted to Polish currency (zlotys) at the official exchange rate.

Joint-venture projects in Poland are more and more frequently designed to bolster exports to Western markets. A typical project is one in which the Western investor places a plant and equipment in operation in Poland and accepts payment in 
Polish exports, which are of ten generated by the investment activity. The profitability of such projects varies widely from industry to industry (DOC, 1989b).

\subsubsection{Financing Aspects and Other Considerations}

Poland's trade surplus and inflow of remittances are still insufficient to meet its debt-service obligations. Poland's debt-service obligations, when measured against its export earnings, show that it is one of the most heavily debt-burdened countries in the world. Prospects for arresting the growth of Poland's hard-currency debt remain poor. One scenario developed by the Polish authorities, in consultation with the World Bank, envisions balancing the current account in 1991.

Poland has taken steps to regularize its debt situation with official Paris Club creditors. In 1986, Poland joined the IMF and the IBRD. It also became a member of the IFC and the IDA, both affiliates of the World Bank. The IMF and the World Bank have initiated a significant financial assistance program, which allows for World Bank loans of up to U.S. $\$ 2.5$ billion to Poland over the next five years.

The United States, with other Western nations, contributed to a U.S. $\$ 1$ billion stabilization fund to support Poland's currency, as reforms move the zloty toward full convertibility. In addition, the U.S. government has started up several independent initiatives to assist Poland, including OPIC-insurance and financing programs, the Eximbank's trade-credit-insurance program for exporters, the U.S. TDP's feasibility studies of industrial projects that identify potential U.S. export opportunities, the PolishAmerican Enterprise Fund (Arsenault, 1990), and the U.S. Congress legislation, "Support for East European Democracy (SEED) Act of 1989," which prompts a framework for democratic and economic support (U.S. Congress, 1989).

Foreign businesses operating in Poland must maintain bank accounts in zlotys. Company accounts in foreign currency are gradually being phased out, but individual accounts are still allowed. Deposits made in zloty accounts bear interest that varies on a monthly basis. The Polish National Bank sets the minimum interest rate each month to reflect anticipated inflation, and the Polish Parliament has instructed the bank to ensure positive real rates of interest on these accounts (DOC, 1990).

The United States is one of 17 nation members of the Coordinating Committee on Multilateral Exports Controls (COCOM), which reviews and controls exports to former East Bloc countries. Export restrictions focus on those items that are strategic and that can be effectively controlled. The Export Administration Act of 1979 requires the U.S. Commerce Department to remove licensing requirements for U.S. exports when it determines that items of comparable quality are freely available to East Bloc countries in sufficient quantities to render U.S. export controls ineffective (DOC, 1989c). At the COCOM meeting held in Paris in June 1990, an agreement was reached to sharply reduce controls on high-technology exports to Warsaw Pact nations (Chicago Tribune, 1990b). 


\subsubsection{Conclusions}

Overall, prospects for economic reform and adjustment in Poland remain uncertain. However, Poland is the largest market in Eastern Europe for U.S. exports. In 1989, the dollar value of U.S. exports rose $36 \%$ over the previous year (Federal Broadcast Information Service, 1990). U.S. investment has expanded as well, with approximately 60 American-Polish joint ventures now in operation. This situation reflects a more optimistic business climate. The best prospects for U.S. companies appear to be in products and technologies that will improve industrial efficiency and productivity. Western technology and management expertise appear quite necessary for Poland to modernize its uncompetitive industries (Arsenault, 1990). U.S. trade and investment with Poland is likely to increase even more as Poland continues moving toward a free-market economy. 


\section{IDENTIFICATION OF LIKELY MARKET NICHES}

This report has discussed the various types of CCTs being developed and demonstrated in the United States and other countries, reviewed the energy supply and demand conditions and environmental-control requirements in seven representative countries, compared the costs of specific potential CCT applications in these countries, and considered issues related to the international trade of U.S. goods and services. This section of the report serves to integrate this material in order to identify the most likely market niches for U.S. CCTs in the seven countries.

Although the focus of this study has been on the application of U.S. CCTs in these countries, many other opportunities exist for U.S. companies in these countries in addition to or in concert with the CCT applications. They include engineering and design services, resource exploration and development, infrastructure expansion and improvement, and the sale of U.S. coal. Although the application of U.S. CCTs would probably reinforce these other opportunities, this aspect has not been investigated in this study, nor has the full extent and range of the linkage with U.S. coal exports.

Likely market niches for particular U.S. CCTs are listed in Table 7.1. In identifying these market niches, this study assumes that any trade barriers discussed in Sec. 6 would be negotiated until a "level playing field" would be achieved, in which the U.S. CCTs could compete technically and economically with other options. The fact that this study does not deal directly with these barriers does not mean that they are unimportant but rather that their complexity would require extensive considerations beyond the realm of this study.

\section{T.1 PRECOMBUSTION TECHNOLOGIES}

Likely market niches have been identified for the two classes of precombustion CCTs considered in this study: advanced coal preparation and CWMs. Although economic comparisons were not made for the advanced coal-preparation technologies, likely markets are still believed to exist in five of the seven countries. In Turkey, Pakistan, the PRC, and Poland, these markets stem from the desire to significantly improve the quality of the indigenous coals, so they can be used more cleanly and efficiently in domestic facilities (producing better air quality) or so the quality of the coal being exported will be higher. In Italy, the likely market niche stems from a different source. Although some low-quality coals exist in Italy, advanced coalpreparation CCTs are more likely to be associated with the preparation of CWMs. In Italy, which has conducted a considerable amount of $R \& D$ on $C W M$ technology and is currently marketing it, there is a substantial requirement for adequately cleaning the coal before it is used to manufacture the CWM. U.S. advanced coal-preparation technologies could prove to be very valuable in this phase of the process. 
TABLE 7.1 Likely Market Niches for U.S. Clean Coal Technologies ${ }^{\text {a }}$

\begin{tabular}{|c|c|c|c|c|c|c|c|}
\hline \multirow[b]{2}{*}{$\mathrm{CCT}$} & \multicolumn{7}{|c|}{ Country } \\
\hline & Italy & Japan & Morocco & Turkey & Pakistan & PRC & Poland \\
\hline \multicolumn{8}{|l|}{ Precombustion } \\
\hline Beneficiation & $*$ & - & - & $*$ & $*$ & $*$ & $*$ \\
\hline CWM & - & $\mathrm{XX}$ & $*$ & - & - & - & - \\
\hline \multicolumn{8}{|l|}{ Combustion } \\
\hline $\begin{array}{l}\text { Slagging } \\
\text { combustor }\end{array}$ & $\mathrm{X}$ & $\mathrm{XX}$ & $*$ & $\mathrm{XX}$ & $\mathrm{X}$ & - & - \\
\hline IGCC & $\mathrm{XX}$ & $\mathrm{XX}$ & $\mathrm{X}$ & $\mathrm{xX}$ & $\mathrm{XX}$ & $\mathrm{XX}$ & $\mathrm{XX}$ \\
\hline $\mathrm{AFBC}$ & $\mathrm{XX}$ & * & $\mathrm{X}$ & $\mathrm{x}$ & $\mathrm{XX}$ & $\mathrm{XX}$ & $\mathrm{XX}$ \\
\hline $\mathrm{PFBC}$ & - & $\mathrm{XX}$ & - & $*$ & $*$ & $\mathrm{X}$ & $\mathrm{XX}$ \\
\hline \multicolumn{8}{|l|}{ Postcombustion } \\
\hline LIMB & - & - & - & $*$ & - & $*$ & $*$ \\
\hline GRSI & - & - & - & - & - & $*$ & $*$ \\
\hline NOXSO & $*$ & $*$ & - & - & - & $*$ & $*$ \\
\hline Spray-dryer FGD & - & - & - & $*$ & - & $*$ & $*$ \\
\hline Dual-alkali FGD & - & - & - & - & - & $*$ & $*$ \\
\hline SCR & $*$ & $*$ & - & - & - & - & $*$ \\
\hline
\end{tabular}

${ }^{\mathrm{a} X X}$ indicates strong economic advantages over alternatives; $\mathrm{X}$ indicates economic advantages over alternatives; * indicates technical capabilities of interest but not economically evaluated; and - indicates little or no perceived technical interest or no economic advantage over alternatives.

With respect to CWM technology, a probable market niche exists in Japan, where there is a strong economic incentive to use this CCT to displace current oil-generated electricity production ( $48 \mathrm{GW}$ in 1985 and estimated to be $43 \mathrm{GW}$ in 2000). A small market niche may also exist in Morocco (on the order of $1 \mathrm{GW}$ ), but this market was not evaluated in terms of economics. Potential markets had been thought to exist in Italy, Pakistan, and Turkey, but this study's economic evaluations indicate that CWM technology would not be competitive in these countries. In Italy in particular, the aggressive position of Italian companies and the Italian government would make it very difficult for U.S. companies to capture any significant portion of the CWM market there.

\subsection{COMBUSTION TECHNOLOGIES}

Several likely market niches have been identified for the four combustion CCTs. In many cases, these CCTs could provide strong economic advantages over the available alternatives. 
The slagging combustor could be used to retrofit oil-fired electricity capacity in Japan (40-50 GW) and Turkey (on the order of $2.5 \mathrm{GW}$ ), greatly reducing generation costs. Smaller but still positive economic advantages could also be realized in Pakistan and Italy. A small potential market for slagging combustors also exists in Morocco (as it did for CWMs), but this market was not evaluated in terms of economics.

A very large potential exists for marketing IGCC, AFBC, and PFBC technologies in the seven countries (along with many others in the world), because they need to expand their electricity generation capacity by building new plants while being mindful of costs, availability of indigenous resources, and environmental concerns. These U.S. CCTs compare very favorably with alternative technologies with respect to each of these issues. All three CCTs were found to be capable of producing electricity at a lower cost than an oil-fired power plant, and they would enable domestic coal, lignite, or oil shale to be used in place of the imported oil. The market potential is estimated to be $14 \mathrm{GW}$ in Italy, $16 \mathrm{GW}$ in Japan, $1.2 \mathrm{GW}$ in Morocco, $6 \mathrm{GW}$ in Turkey, $0.8 \mathrm{GW}$ in Pakistan, $100 \mathrm{GW}$ in the PRC, and $7 \mathrm{GW}$ in Poland.

Although the possibility is not specifically addressed in this study, the combustion CCTs could also be used to repower existing oil-fired facilities or refurbish coal-fired plants. Repowering could extend the life of existing plants while also providing many of the benefits associated with new facilities using the same basic technology. The repowering/retrofit market potential is estimated to be $30 \mathrm{GW}$ in Italy, $50 \mathrm{GW}$ in Japan, $1 \mathrm{GW}$ in Morocco, 4.5 GW in Turkey, $2 \mathrm{GW}$ in Pakistan, $50 \mathrm{GW}$ in the $\mathrm{PRC}$, and $25 \mathrm{GW}$ in Poland.

Another coal-based technology that is not considered to be a CCT, but from which significant economic and operational benefits can be obtained, is the PC/FGD option. This conventional technology was evaluated in some of the economic comparisons and found to offer advantages over noncoal alternatives in several cases.

\subsection{POSTCOMBUSTION TECHNOLOGIES}

Market niches for the six postcombustion CCTs are like to exist in those countries that currently burn coal and in which few or no emission controls are required. Of the industrializing/developing countries considered in this study, Poland and the PRC are considered the principal likely markets, although some potential for postcombustion CCTs also exists in Turkey. Market potential is estimated to be $25 \mathrm{GW}$ in Poland, $50 \mathrm{GW}$ in the PRC, and 4.5 GW in Turkey.

In the more industrialized countries, represented by Italy and Japan, market niches are likely for those CCTs that can attain significant levels of $\mathrm{NO}_{\mathrm{x}}$ control and that can be applied to oil-fired facilities as well as coal-fired ones. The NOXSO and SCR technologies fall into this category. These technologies also appear to have some market potential in Poland, where coal is widely used in power plants that are large enough to make the application of NOXSO or SCR quite feasible. A potentially significant market for SCR applications also exists in Japan, but it may be very difficult for U.S. companies to compete in this market because of the vast experience and ongoing $R \& D$ of Japanese companies. 
No economic evaluations or comparisons were made for the postcombustion CCTs, because the use of this type of technology is driven more by policy than by economics. Economic comparisons should be made to determine the most appropriate postcombustion CCT, but only after the government has decided which pollutants to control, which facilities to equip, and what level of control is required. Before such policy directives are indicated, it is premature to make that type of comparison. Thus, it is sufficient that this report merely identifies these potential market niches and discusses the conditions that have created them. 


\section{STATUS OF THE U.S. DEPARTMENT OF ENERGY'S CLEAN COAL TECHNOLOGY DEMONSTRATION PROGRAM}

The U.S. DOE CCT Demonstration Program is being cofunded by the government and industry to demonstrate a new generation of innovative coal-utilization processes in a series of full-scale facilities to be built across the United States. The program goal is to determine the most promising advanced coal-based technologies and, over the next decade, move them into the commercial marketplace through demonstration. In demonstrating and promoting innovative control technologies, proponents expect to achieve near-term reductions in the emissions associated with acid rain, specifically $\mathrm{SO}_{2}$ and $\mathrm{NO}_{\mathrm{x}}$ (DOE, 1989c).

In the longer-term, this program is intended to make available to the nation, as well as to the international marketplace, a menu of advanced, more efficient, more economical, and environmentally responsive coal-utilization technologies. The program has given special consideration to (1) projects that demonstrate retrofit technologies that can be applied to the largest number of existing sources (especially sources that, because of their size and location, contribute to transboundary air pollution) and (2) technologies that can be applied to facilities currently dependent on the use of high-sulfur coal.

The projects, as demonstrated, are expected to contribute significantly to the information base on coal, especially with respect to its utilization, economics, and environmental implications. Any essential data on the technical, environmental, economic, and operational performance of these technologies that are needed to reduce the uncertainties in the scaleup of subsequent commercial applications will be collected and catalogued. The technologies to be demonstrated should be capable of being applied to any type of U.S. coal and encompass new, retrofit, repowering, and conversion applications.

\subsection{NEGOTIATED CLEAN COAL TECHNOLOGY DEMONSTRATION PROJECTS}

Of the 39 projects selected for the U.S. DOE CCT Demonstration Program as of May 1990, 13 have been negotiated (DOE, 1990b). Three of these are in the operations phase: an advanced cyclone combustor, the LIMB extension and Coolside modification, and the Nucla circulating AFBC. Three are under construction: the Tidd PFBC, gas reburning/sorbent injection, and cement-kiln gas cleaning projects. And seven demonstration projects are still in the design and permit phase: a prototype commercial coal/oil coprocessing unit, an advanced slagging combustor for utility coal, both SOXNOX-ROX-BoX and WSA-SNOX flue-gas cleanup technologies, an advanced FGD system, an advanced wall-fired combustor, and a process for cleaning coke-oven gas.

The six active projects represent U.S.-government commitments of $\$ 108$ million and U.S. private-industry commitments of $\$ 174$ million. The seven upcoming projects represent U.S.-government commitments of $\$ 171$ million and U.S. private-industry commitments of $\$ 353$ million. Thus, these 13 projects are valued at $\$ 806$ million, with the government share currently at $35 \%$. The other 26 selected projects, valued at 
$\$ 2.024$ billion, with the government share projected currently at $37 \%$, are pending review, approval, and/or negotiations.

An update on the status of the $13 \mathrm{CCT}$ demonstration projects (operating, construction, and design phases) is provided in this section of the report. This background information should be considered before specific issues are raised pertaining to the near-term application of the U.S. DOE CCT Demonstration Program to the international scene, especially with respect to the countries and market niches identified in this study.

\subsubsection{Operations Stage}

\subsubsection{Advanced Cyclone Combustor - Coal Tech Corp.}

This project is designed to demonstrate the application of an advanced, horizontal, cyclone combustor with integral $\mathrm{SO}_{2}, \mathrm{NO}_{x}$, and ash-control systems. The cooperative agreement for this project was signed in March 1987; design, permitting, construction, and shakedown were completed by November 1987. Since then, the 30-million-Btu/h combustor has operated for more than 700 hours, while burning more than 200 tons of coal. These coals included those with both high and low ash-fusion temperatures and sulfur contents of 1.1 to $4.0 \%$. Combustion efficiencies achieved have been 90 to $95 \%$, and the slag rejection level has consistently been at $80 \pm 10 \%$. $\mathrm{NO}_{\mathrm{x}}$ reductions of up to $200 \mathrm{ppm}$ have been achieved, along with $\mathrm{SO}_{2}$ reductions of about 50\%. Efforts are currently underway to better understand the mechanisms of sulfur removal and to improve the sulfur capture and rejection into the slag.

\subsubsection{LIMB Extension and Coolside Modification - Babcock \& Wilcox Co.}

This project extends the EPA-funded demonstration of the LIMB process to include the testing of three additional coals and four additional sorbents. LIMB with humidification began continuous operation in September 1988. The Coolside modification, in which sorbent and water are injected into the flue gas downstream of the boiler, was added to the test system in mid-1989, after prior testing by DOE. Testing proceeds at Ohio Edison's Edgewater Station in Lorain, Ohio.

\subsubsection{Nucla Circulating AFBC - Colorado-Ute Electric Association, Inc.}

The Nucla power plant became part of the DOE CCT Demonstration Program in October 1988. Before to that time, Colorado-Ute Electric Association, EPRI, and others converted the original coal-fired plant into a circulating AFBC. This conversion, which had involved replacing the existing boiler with the circulating AFBC, refurbishing three $12-\mathrm{MW}$ steam turbines, adding a $74-\mathrm{MW}$ steam turbine, and updating and expanding the baghouse, was completed in 1987. 
In early 1989, after some initial startup difficulties involving refractory performance, fans, fuel and limestone-feed systems, and similar problems, a two-year operational testing program began. More than 4300 hours of operation had been accumulated by early 1990 . In some tests with the design coal (a low-sulfur Colorado coal), all boiler acceptance criteria were met, except the limestone feed rate required to meet $\mathrm{SO}_{2}$ emission standards was slightly higher than anticipated. Potential alternative fuels for additional testing include a Texas lignite and a high-sulfur bituminous coal from the Illinois Basin.

\subsubsection{Construction Phase}

\subsubsection{Tidd PFBC - American Electric Power Service Corp.}

The first U.S. PFBC to be operated in an integrated combined-cycle mode in utility operation will be demonstrated at Tidd. The combustor, supplied by ASEA Babcock and tested in Sweden, will power a 70-MWe commercial-scale unit tied into a fully operating power plant. Before the gas turbine is operated, plans are to burn highsulfur Ohio coal and to use cyclones to clean up the hot gas that is produced The demonstration is being conducted by American Electric Power Service Corp. on behalf of the Ohio Power Co. The pressure vessel was shipped to the Tidd plant in Brilliant, Ohio (about 75 miles down river from Pittsburgh) in May 1989. Operations were scheduled to begin in 1990 .

\subsubsection{Gas Reburning/Sorbent Injection - Energy and Environmental Research Corp.}

This postcombustion technology is being developed primarily to remove $\mathrm{NO}_{\mathrm{x}}$. Fuel is to be bypassed around the main combustion zone and injected above the main burners, to form a reducing zone in which $\mathrm{NO}_{\mathrm{x}}$ will be converted to reduced nitrogen compounds. Only about 15-20\% of the fuel is to be injected into the reburning zone. Three different boilers representing three different configurations are to be demonstrated: (1) a tangentially fired, $80-\mathrm{MWe}$ boiler owned by Illinois Power Co., located near Hennepin, Illinois; (2) a cyclone-fired, 40-MWe boiler owned by City, Water, Light, and Power Co., located in Springfield, Illinois; and (3) a wall-fired, 117-MWe boiler owned by Central Illinois Light Co., located near Bartonville, Illinois.

\subsubsection{Cement-Kiln Gas Cleaning - Passamaquoddy Tribe}

To demonstrate a scrubbing system for removing $\mathrm{SO}_{2}$ emissions from existing coal-burning cement kilns, a cement plant in Thomaston, Maine, that produces 470,000 tons of cement clinker per year is to be retrofitted with a recovery scrubber. The process uses kiln-waste dust as the scrubbing reagent and produces a recycle stream back to the kiln. Using a heat exchanger/evaporator, two potentially sellable by-products are expected to be produced, potassium-based fertilizer and distilled water, with no other wastes generated. 


\subsubsection{Design and Permit Phase}

\subsubsection{Prototype Commercial Coal/Oil Coprocessing Unit - Ohio Ontario Clean Puels, Inc.}

This project is being designed to demonstrate the coprocessing and conversion of high-sulfur, high-nitrogen, bituminous coal and poor-quality petroleum residuum to clean liquid fuels using ebullating-bed reactor technology. Process development testing for a facility to be located in Warren, Ohio, began in September 1988.

\subsubsection{Advanced Slagging Combustor for Utility Coal - TRW, Inc.}

An advanced coal combustor is expected to be demonstrated at a scale suitable for utility application. A boiler in an Orange and Rockland Utilities power plant located at Stony Point, New York, is to be retrofitted with four combustors. Pulverized-coal and limestone feed systems are to be included, and the heat-exchanger and gas-flow systems are to be modified.

\subsubsection{SOX-NOX-ROX-Box Flue-Gas Cleanup System - Babcock \& Wilcox Co.}

Ammonia and a calcium-based sorbent are to be injected upstream of a hightemperature baghouse to demonstrate the combined postcombustion flue-gas cleanup of $\mathrm{SO}_{2}, \mathrm{NO}_{\mathrm{x}}$, and particulates. The sorbent will react with $\mathrm{SO}_{2}$, and the product, along with the particulates, will be removed in the baghouse. In addition, in the presence of an SCR catalyst, $\mathrm{NO}_{\mathbf{x}}$ will be reduced by ammonia to nitrogen and water. This combined process in a single unit is expected to remove about $50 \%$ or more of the $\mathrm{SO}_{2}, 90 \%$ of the $\mathrm{NO}_{\mathrm{x}}$, and more than $99 \%$ of the particulates. The concept is to be demonstrated by retrofitting a 5-MWe slipstream of flue gas at Ohio Edison's R.E. Burger Station in Belmont County, Ohio.

\subsubsection{WSA-SNOX Flue-Gas Cleanup System - Combustion Engineering, Inc.}

This project will demonstrate the WSA-SNOX technology for catalytically removing both $\mathrm{SO}_{2}$ and $\mathrm{NO}_{\mathrm{x}}$ from flue gas and producing a sellable by-product (sulfuric acid). No sorbents are to be used; consequently, the waste by-products that normally result from their use will not be formed. Two catalytic reactors are to be used to convert $\mathrm{NO}_{\mathrm{x}}$ to nitrogen in an $\mathrm{SCR}$ reactor and then to oxidize the $\mathrm{SO}_{2}$ to $\mathrm{SO}_{3}$. The $\mathrm{SO}_{3}$ is to be subsequently hydrated and then condensed as hydrogen. A 35-MWe demonstration module is planned to retrofit Boiler No. 2 at Ohio Edison's 100 -MWe power plant, Niles Station, in Trumbull County, Ohio. High-sulfur Ohio coal is to be burned. Both $\mathrm{SO}_{2}$ and $\mathrm{NO}_{\mathrm{x}}$ emissions are expected to be reduced by $90 \%$ or more. 


\subsubsection{Advanced FGD System - Pure Air}

This retrofit project is expected to demonstrate a commercial-scale, advanced, limestone-scrubber FGD system. A single 529-MWe absorber module will clean the flue gas from four existing boilers. The system is to use a high-velocity concurrent-flow absorber, with direct injection of pulverized limestone. The system design includes a new and innovative single-loop process that produces commercial gypsum using in situ forced oxidation created by a rotary-air sprayer. A novel wastewater-evaporation system that should eliminate water disposal and treatment problems associated with discharge will be evaluated. A cyclic reheater is to be used to reduce the operating costs normally associated with steam reheat. The project is expected to demonstrate the system's capability to remove $90 \%$ or more of the $\mathrm{SO}_{2}$ at a price that is $50 \%$ less than the cost that can be achieved by currently available FGD systems. The demonstration site is Northern Indiana Public Service Co.'s Dean H. Mitchell Station located in Gary, Indiana.

\subsubsection{Advanced Wall-Fired Combustor - Southern Company Services, Inc.}

Three advanced $\mathrm{NO}_{\mathrm{x}}$-control technologies for retrofitting wall-fired, pulverizedcoal boilers are to be demonstrated: (1) an advanced over-fire air system, which consists of deep-stage, high-rate air injection; (2) a second-generation low- $\mathrm{NO}_{\mathrm{x}}$ burner; and (3) a low $-\mathrm{NO}_{\mathrm{x}}$ burner with over-fire air. The advanced $\mathrm{NO}_{\mathrm{x}}$-control technologies are to be sequentially applied to a 500-MWe, single-furnace, subcritical, wall-fired boiler at Unit No. 4 at Georgia Power Co.'s Hammond Plant, in Rome, Georgia.

\subsubsection{Cleaning Process for Coke-Oven Gas - Bethlehem Steel Corp.}

Plans are to retrofit the existing coke-gas cleaning plant, a coal chemical plant at Sparrows Point, Maryland. This plant currently consists of two batteries that recycle gas directly to the coke ovens without chemical recovery or cleanup. The gas from the coke oven is to be cooled using a recirculating liquor in a closed system, which will eliminate the emissions of benzene and other pollutants associated with the present mode of atmospheric gas cooling. Ammonia and hydrogen sulfide are to be removed by absorption into an ammonia-liquid solution, then steam stripping of the combined vapor stream is to occur. After this process, the ammonia is to be catalytically converted to hydrogen and nitrogen, and a portion of the hydrogen sulfide is to be oxidized to $\mathrm{SO}_{2}$ for subsequent processing.

\subsection{APPLICABILITY IN THE INTERNATIONAL MAREET}

Specific potential market niches have already been identified in Section 7 of this report. This section contains a few remarks summarizing the near-term applicability of these ongoing U.S. CCT demonstration projects (especially those on combustion and postcombustion technologies) to certain markets overseas. 
A number of boilers in Europe, the Far East, and elsewhere are smaller than U.S. boilers; modular types of CCTs like fluidized-bed combustors, which retain their high efficiencies at small sizes, may be ideal candidates for this market. CCTs that lend themselves to the cogeneration of usable heat and electricity could be especially interesting to certain developing nations; larger, base-load, coal-based power concepts could attract the interest of larger, more developed countries. Eastern European countries may look to the United States and other countries for lower-cost pollutioncontrol technologies (and financing packages) to retrofit older, dirtier plants without adding greatly to their already substantial economic burdens.

Increasingly stringent environmental regulations worldwide would significantly promote the use of U.S.-developed CCTs. However, the commercial success of CCTs will not depend solely on the regulatory climate. It is likely that the demand for internationally traded coal will grow slowly and steadily in most industrialized countries and quickly in developing countries. Thus the demand for U.S. CCTs should grow too, since they promise not only sophisticated environmental performance but also superior economic performance when compared with many of the available options.

In summary, the potential market for U.S. CCT exports is large, but it will be contingent upon the continued success of the U.S. governmental and industrial RD\&D programs and the timeliness with which these technologies are deployed relative to their competition. In particular, by using CCTs, the countries that depend on coal-based combustion to meet increasing demand for power and heat (the PRC, Poland, India, and Brazil, for example) will be able to advance their standards of living while using their natural resources in a clean, efficient, and environmentally sound manner. 


\section{IMPLICATIONS FOR THE U.S. DEPARTMENT OF ENERGY'S CLEAN COAL TECHNOLOGY DEMONSTRATION PROGRAM}

The analyses presented in this report suggest that, in the near to medium term, there is a significant potential international market for the CCTs currently being developed and demonstrated in the United States. Specific types of U.S. CCTs have been matched with specific market niches in seven representative countries in previous sections of this report.

This section discusses six issues pertinent to the U.S. DOE CCT Demonstration Program from an international perspective and offers some suggestions for DOE's consideration. The suggestions associated with the first issue, the testing of non-U.S. coals (Recommendations 1a-1d discussed in Sec. 9.1), are mutually exclusive; i.e., only one of the recommendations should be implemented. These recommendations are given in priority order. For the other five issues, only one recommendation is given for each issue (Recommendations 2-6 in Secs. 9.2-9.6), and each of these recommendations is not mutually exclusive; i.e., each may be implemented in concert with one or more of the others.

\subsection{ISSUE 1: TESTING NON-U.S. COALS}

A Congressional mandate states that coals tested in the U.S. DOE CCT Demonstration Program must originate from mines located in the United States. Government funds cannot be used to test internationally traded coals in the U.S. DOE CCT Demonstration Program.

Recommendation 1a: Modify the existing legislation to allow internationally traded coals from foreign sources to be used in applicable CCT demonstration projects, especially combustion and postcombustion projects, using government funds as appropriate.

The technologies and concepts involved in the CCT Demonstration Program, such as fluidized-bed combustion, slagging combustion, coal gasification, and coal-water slurries, are expected to become commercially available in the near term. The availability of these demonstrated CCTs may give the United States an advantage in marketing its coal abroad, since U.S. coal producers will be able to provide detailed data on a specific coal's performance in a demonstrated new technology. And U.S. manufacturers, with data on a technology's commercial-scale performance using U.S. coals, will be capable of linking U.S. coal exports and U.S. technology in a way that may significantly enhance U.S. competitiveness. That linkage may open new markets for U.S. coals. Hence, Congress is concerned about allowing non-U.S. coals in the test program, since it wants to give U.S. producers the edge.

The overseas market is expected to consider the use of innovative, demonstrated (i.e., proven) U.S. CCTs as a chief means of satisfying perhaps more stringent regional and local environmental requirements while substantially improving power-generation efficiencies. The CCTs should offer distinct advantages over conventional coal 
combustors, even in areas where indigenous coal or other foreign coal supplies are expected to be used. However, for these advantages to be effectively promoted, internationally traded coals must be demonstrated on U.S. CCTs. If they are not, the U.S. manufacturers may lose their edge over the competition before they even "get their hats into the ring."

Successful development and commercialization of U.S. CCTs is also expected to have a positive effect on the international market for ancillary U.S. goods and services. The testing of internationally traded coals (such as Australian, Colombian, and South African coals), and even of limited foreign indigenous supplies in certain cases (such as Indonesian Kalimantan coal, South Korean anthracite, or Thai Mae Moh or Krabi lignite), may pave the way for sales of coal technology and promote an increased demand for U.S. goods and services, such as architectural/engineering support, equipment sales, construction, management, and technical operation services.

Critics of the proposed change in legislative policy will invariably provide testimony showing that the United States "is giving away the store" and will ask, "What should we be doing about increasing U.S. coal exports?" The basis of this proposed recommendation, however, is the belief that demonstrations showing that a wide variety of coals can be used in these technologies and the establishment of performance parameters for these non-U.S. coals could strengthen and expand the role of U.S. CCTs in the international marketplace. In summary, the testing of internationally traded coals would be good for U.S. business and would assist the entire international coal community, including the U.S. coal industry.

Recommendation 1b: Modify the existing legislation to allow internationally traded, $U . S .-o w n e d$ foreign coals or coals from mines operated by U.S. firms to be demonstrated in applicable CCT demonstration projects, especially combustion and postcombustion projects, using government funds as appropriate.

U.S. corporations, which may be U.S.-based multinational corporations or affiliates (such as Exxon, Shell, and ARCO), have access to (operate, own, or control) a wide variety of coals from foreign sources. If one or more of these coals were to be tested in a U.S. CCT project and their applicability demonstrated, the results could be extrapolated to other similar foreign coals from that particular region of the world. The extrapolated results would provide the international market with data linking a U.S.affiliated foreign coal with a specific U.S.-demonstrated technology. In addition, demand for other U.S. goods and services could follow, which could be a considerable benefit.

Recommendation 1c: While heeding existing legislation that reflects the reluctance of the U.S. Congress to allow coals from foreign sources to be used in a governmentsponsored, government-funded demonstration, match specific U.S. coals to specific internationally traded coals, run them in various demonstration projects as surrogates, and extrapolate the results for commercial applications.

If the physical, chemical, petrographic, or other behavioral characteristics of specific U.S. coals were matched to those of specific internationally traded coals, the 
U.S. coals could be run as surrogates for the internationally traded coals in the U.S. CCT Demonstration Program. The data on these U.S. coals might serve to interest potential buyers in U.S. coal technology, to be used with the buyer's preferred coals, even if they were not U.S. coals.

Critics of the proposed policy change might provide testimony showing that in isolated instances during testing, a particular internationally traded coal might prove superior in some way to a specific U.S. coal. Using a surrogate coal would prevent this occurrence. Because no electric-system planner or procurer would recommend buying a particular coal for a system on which that coal had not been proven, however, this recommendation is only a short-term, partial, stop-gap measure.

Recommendation 1d: While heeding existing legislation that reflects the reluctance of the U.S. Congress to allow coals from foreign sources to be used in a governmentsponsored, government-funded demonstration, allow foreign participators to test the foreign coal of their choice in specific demonstration projects, at their own expense.

In a manner that is consistent and does not interfere with any contracted government and industry schedules or operating plans for a specific project in the CCT Demonstration Program, the United States should consider allowing a foreign coal producer to test a coal of its choice in a specific project at its own expense, during a normal hiatus in scheduled testing as subsequent to the completion of scheduled testing. This practice would generate more operating data on more types of coal, to the benefit of more interested buyers of U.S.-coal technology worldwide.

\subsection{ISSUE 2: CONDUCTING DEMONSTRATION PROJECTS ABROAD}

A Congressional mandate states that operations to be tested in the U.S. CCT Demonstration Program must be located within the territorial United States. Government funds within the spectrum of the U.S. CCT Demonstration Program may not be used to operate proposed projects that are sited abroad.

Recommendation 2: Modify the law to allow quid pro quo collaboration with foreign participants in specific projects located abroad, with U.S. government funds being leveraged abroad in anticipation of an international market for U.S. coal, coal technology, and/or goods and services.

In certain instances, it could prove advantageous to permit the demonstration of a U.S. CCT in a foreign setting using government funds -- for example, via a bilateral R\&D collaborative effort. Proposed test projects should be considered on a case-by-case basis and stand on their own merits. If a particular project is judged by DOE to be in the best interests of the U.S. industrial sector, the possibility of an exception should be raised with Congress. Any foreign-based project that might prove politically useful and financially promising to U.S. interests should not be excluded from the U.S. CCT program solely on the basis of its non-U.S. (or remote) location. This type of decision could also be made on the basis of humanitarian interests. 


\subsection{ISSUE 3: INCREASING TECHNOLOGY ADAPTABILITY}

Certain international applications of the technologies demonstrated in the U.S. CCT Program may require smaller, less complex designs and simpler operability, especially those in developing countries.

Recommendation 3: Focus more on modular design, construction, and operation in the U.S. DOE CCT Demonstration Program, i.e., increase the technology adaptability of the program.

Many applications abroad call for unit sizes that are smaller than those found in U.S. (and other) megaplants. This need occurs in industrialized Western Europe; in politically, socially, and economically changing Eastern Europe; in developing countries like Thailand, Turkey, and Taiwan; and in ever-increasing energy-demand centers in the Asian Pacific Basin. The focus of the U.S. CCT Demonstration Program should be adjusted to address the smaller, simpler needs of a variety of consumers, which when totaled, constitute a significant market.

\subsection{ISSUE 4: INCREASING PUBLIC AWARENESS OF COAL}

Much of the public still perceives coal to be a dirty source of energy. Natural gas and oil are viewed as being cleaner fossil fuels than coal and just as plentiful, despite forecasts to the contrary.

Recommendation 4: Increase public awareness of the U.S. DOE CCT Demonstration Program and its national and international ramifications with respect to coal, especially in situations where the expanded use of coal or the improved efficiency of coal use might be $a$ better option than the substitution of nuclear fuel or renewable energy sources.

The role of fossil fuels in global climate change needs to be considered. Moreover, all the uncertainties associated with the whole array of global-climate-change issues (including global warming and the existence, formation, and quantities of greenhouse gases, carbon dioxide, methane, et al.) need to be addressed. In addition, the call to reduce the use of fossil fuels -- especially in the developing countries, whose very existence and way of life require the use of such indigenous fuels, of ten their primary resource base -- needs to be considered. The uncertainties, the potential heavy costs of major actions, the importance of coal, and the international supply and demand situation -- all these issues need to be weighed, balanced, and put into perspective.

A more vigorous public-outreach effort with respect to coal appears warranted. It should be designed to make the nation aware of the huge U.S. and worldwide coal resources and the enormous $R \& D$ effort being expended by the United States to cleanly, efficiently, and economically use its natural resources in an environmentally responsible manner. The U.S. DOE CCT Demonstration Program is one component of this R\&D effort, and it should be employed extensively to address the above issues. An ancillary educational effort that would specifically address but not overemphasize the negative aspects of other energy alternatives could help greatly to encourage the public to 
consider more positively the improved efficiency and expanded use of coal to substitute for the use of nuclear fuel or renewable energy sources in certain situations.

Specific topics that might be considered for this effort include these:

- The role of fossil fuels in global climate change,

- Uncertainties in the science of global climate change,

- Uncertainties in forecasting greenhouse-gas emissions and climate change,

- The role of economic and energy development throughout the world,

- Technological solutions to energy problems, and

- International and domestic initiatives.

\subsection{ISSUE 5: USING "WINDOWS OF OPPORTUNITY" EPFECTIVELY}

Some people have been advocating the benefits of delaying the U.S. DOE CCT Demonstration Program until DOE has more information or actual project demonstration results. This hiatus would allow DOE to make more informed decisions with regard to the identification, selection, and funding of the more promising technologies in future rounds of the program. It would also help to ensure that the funds allocated to this program are effectively and efficiently spent (U.S. General Accounting Office, 1990).

Recommendation 5: Continue the demonstration program in a timely manner so that the U.S. CCT technologies can be demonstrated and improved in a time frame consistent with the needs of the international markets.

If this program does not continue as indicated, potential U.S. coal and CCT markets could be lost to other energy sources (like oil or gas) or other countries of fering coal-based technologies and services similar to those being offered by U.S. companies.

\subsection{ISSUE 6: DEALING WITH BARRIERS TO COMMERCIALIZATION}

U.S. CCT developers and entrepreneurs will require assistance in transferring their technologies abroad in a manner that will protect their intellectual-property rights and will offer them the potential for a profit that would be, at a minimum, commensurate with the risk taken.

Recommendation 6: Address and analyze in greater detail the barriers to successful commercialization abroad, especially those barriers related to protection of intellectualproperty rights, to assist U.S. entrepreneurs and industry in their efforts to penetrate the international marketplace. 
Instances of patent infringement and trademark piracy have increased in recent years. The U.S. Omnibus Trade and Competitiveness Act of 1988 addresses infringement and piracy problems. Under this Act, the U.S. Trade Representative is given "Special 301" authority to enhance the ability of the United States to negotiate improvements in foreign intellectual-property regimes through bilateral and/or multilateral initiatives. However, many countries still do not provide adequate intellectual-property protection, especially when technology licensing is involved. Before a technology is transferred, the intellectual-property laws and practices of the importing country should be examined to make sure that the U.S. technology being exported is protected. 


\section{REPERENCES}

American Electric Power Service Corp., 1988, AEP's TIDD Pressurized Fluidized Bed Combustion Demonstration Plant: An Update and a Review of Environmental Aspects, presented at Fourth Symp. on Integrated Environmental Control, held in Washington, D.C., March.

American Mining Congress Journal, 1990, How the U.S. Can Help Poland's Coal Industry, pp. 20-21, March.

Anthony, E.J., et al., 1985, The Fluidized-Bed Combustion of a High-Sulfur Maritime Coal in a Pilot-Scale Rig and Industrial FBC Boiler, Proc. Eighth International Conf. on Fluidized-Bed Combustion, sponsored by American Society of Mechanical Engineers, Boston, July.

Arena, U., et al., 1984, Combustion of a Water-Coal Mixture on a Fluidized Bed (in French), Revue Generale de Thermique, 23(276):805-809, Dec.

Arinc Research Corp., 1988, Cool Water Gasification-Combined-Cycle Power Plant: Availability Analysis, EPRI Report AP-5829, Electric Power Research Institute, Palo Alto, Calif., July.

Arsenault, M., 1990, Poland Economic Reforms Improve Opportunities for U.S. Firms, Business America, April 23.

ASEA Babcock, 1988a, AEP Repowers Tidd Power Plant at Brilliant, Ohio, with ASEA Babcock PFBC System Module, PFBC Update, Vol. 1, No. 1, April.

ASEA Babcock, 1988b, Tidd Repowering Construction Report, PFBC Update, Vol. 1, No. 2, summer.

Asian Development Bank, 1987, Economic Report on the PRC, Bangkok, Thailand, June.

Aybar, E.N., 1988, The Turkish Demand Perspective, Planning and Finance Department, Ministry of Energy and Natural Resources, Ankara, Turkey, June.

Baker, A., 1986, Atmospheric Fluidized Bed Combustion - International Perspectives and Prospects, presented at International Clean Coal Technology Congress, held in St. Louis, Oct.

Bank of Tokyo, Ltd., 1983, Setting Up Enterprises in Japan, Japan External Trade Organization, Tokyo.

Bartok, W., et al., 1987, Gas Reburning-Sorbent Injection - A Combined NO ${ }_{x} / S_{x}$ Control Technology, Proc. Joint Symp. on Stationary Combustion $\mathrm{NO}_{\mathrm{x}}$ Control, held in New Orleans, Aug., sponsored by U.S. Environmental Protection Agency and Electric Power Research Institute, EPRI Report CS-5361, Vol. 1, Palo Alto, Calif. 
Bechtel Group, Inc., 1987, Prefeasibility Study of Coal Use in Costa Rica, U.S. Agency for International Development, New York City, March.

Bechtel Group, Inc., 1988, A 180-MWe British Gas/Lurgi-Based IGCC Power Plant, EPRI Report AP-6011, Electric Power Research Institute, Palo Alto, Calif., Sept.

Beshai, J., 1986, Current Coal Research, Development, and Demonstration Projects in Canada, Ministry of Energy, Mines, and Resources, Canada Centre for Mineral and Energy Technology, Montreal.

Booze, Allen, and Hamilton, Inc., 1987, Direct Foreign Investment in Japan: The Challenge for Foreign Firms, prepared for the American Chamber of Commerce in Japan and the Council of the European Business Community, published by BAH, Washington, D.C., Sept.

Bossoni, T., 1988, Clean Coal Technologies and Projects in Italy, Energy Security -Alternatives to Oil, Proc. of Symp. held at Argonne, March, sponsored by U.S. Department of Energy and Italian Ministero dell Industria, Commercio e Artiginato, Argonne National Laboratory Report ANL/IEP-88-60, Argonne, Ill., pp. 156-160.

Boward, W.L., et al., 1986, Current Progress at the FMC Limestone Double Alkali Demonstration Plant, Proc. Ninth Symp. on Flue Gas Desulfurization, held in Cincinnati, Ohio, June, sponsored by Electric Power Research Institute, EPRI Report CS-4390, Vol. 2, Palo Alto, Calif., Jan.

Brandels, L., 1988, National Energy Administration, Stockholm, Sweden, personal communication, June.

British Gas Corp., 1981, U.S. Coal Test Program on BGC-Lurgi Slagging Gasifier, EPRI Report AP-1922, Electric Power Research Institute, Palo Alto, Calif., Aug.

Bunthoff, D., et al., 1988, 15 MWt - Pressurized Fluidized-Bed Pilot Plant of Deutsche Babcock Werke AG, presented at Seminar on FBC Technology for Utility Applications, held in May, sponsored by Electric Power Research Institute, Palo Alto, Calif.

Burgess, L.E., et al., 1983, The AFT Beneficiation System: A New Way to Clean Coal, presented at Fifth International Conf. on Coal Slurry Combustion Technology, held in Washington D.C., April, sponsored by Coal \& Slurry Technology Assn., Washington, D.C.

Burns and Roe, Inc., 1988, Performance/Cost Criteria for Potential CCTP-2 Technologies, U.S. Department of Energy, Pittsburgh Energy Technology Center, Pittsburgh, April.

Burzynski, A., 1989, Comments on Foreign Investment Law of 23rd December 1988, Polish Chamber of Foreign Trade, Warsaw, Poland.

Business International Corp., 1987a, Investment, Licensing, and Trading Conditions Abroad, Italy, New York City, July. 
Business International Corp., 1987b, Investment, Licensing and Trading Conditions Abroad, Turkey, Business International Corp., New York City, Sept.

Business International Corp., 1988a, Foreign Financing Operations, Italy, New York City, March.

Business International Corp., 1988b, Investment, Licensing, and Trading Conditions Abroad, Japan, New York City, May.

Business International Corp., 1989, Investment, Licensing, and Trading Conditions Abroad, Pakistan, New York City, Jan.

Calhoun, C.C., et al., 1987, Keystone Coal Industry Manual, McGraw-Hill, New York City.

Camponeschi, B., 1989, Pure Air, Allentown, Penn., personal communication, March.

Carugatai, A., et al., 1985, The Eniricerche Coal Gasification Approach, Proc. Fif th Annual Advanced Gasification Contractor's Review Meeting, U.S. Department of Energy/ Morgantown Energy Technology Center Report DOE/METC-85/6024, Morgantown, W. Va., June 25.

Chicago Tribune, 1990a, Colorado Utility Seeks Bankruptcy Protection, April 2.

Chicago Tribune, 1990b, U.S. to Loosen Controls on High-Tech Exports, June 8.

China Business Review, 1989, Recentralizing Trade, Washington, D.C., Sept.-Oct.

Chughtai, M.Y., 1988, Desulfurization Results for Three Different Firing Concepts, presented at First Combined FGD and Dry $\mathrm{SO}_{2}$ Control Symp., held in St. Louis, Oct. 2528, sponsored by U.S. Environmental Protection Agency and Electric Power Research Institute.

Cichanowicz, E., 1987, Applicability of European SCR Experience to Utility Operation, Proc. Joint Symp. on Stationary Combustion $\mathrm{NO}_{\mathbf{x}}$ Control, held in New Orleans, Aug., sponsored by U.S. Environmental Protection Agency and Electric Power Research Institute, EPRI Report CS-5361, Palo Alto, Calif.

Clark, E., 1988, Cool Water Gasification Program: An Update, EPRI J., B(6):45-48, Electric Power Research Institute, Palo Alto, Calif., Sept.

Coal Mining Research Centre, 1986, Annual Report-Summary: $R \& D$ on the Coal Utilization Technology, Tokyo.

Coal and Synfuels Technology, 1988, ASEA-ST AL Name Changes, March 4.

Coal Tech Corp., 1987, Advanced Cyclone Combustor with Integral Sulfur, Nitrogen, and Ash Control, Report to U.S. Congress, Perion, Penn., Feb. 
Coal Week International, 1988, Mediterranean Region to See Major Coal Growth, pg. 2, MeGraw-Hill, Inc., New York City, March 2.

Computer Center of Power Systems, 1989, Polish Power Industry in the Year 1988, Warsaw, Poland.

Cook, D.A., et al., 1985, Coal-Water-Fuel Firing Experience at Chatham \#2, Proc. Seventh International Symp. on Coal Slurry Fuels and Preparation, held May 21-24, sponsored by Coal \& Slurry Technology Assn., Washington, D.C.

Craig, D., 1990, The World Bank, Washington, D.C., personal communication, May.

Damon, J., and P. Ireland, 1987, Update Technical and Economic Review of SCR, Proc. Joint Symp. on Stationary Combustion $\mathrm{NO}_{\mathrm{x}}$ Control, held in $\mathrm{New}$ Orleans, Aug., sponsored by U.S. Environmental Protection Agency and Electric Power Research Institute, EPRI Report CS-5361, Palo Alto, Calif.

Danish Ministry of Energy, 1987, Energy and Denmark - Key Figures 1986, Copenhagen.

Darguzas, J.N., et al., 1987, Effect of Coal Switching on Circulating Fluidized-Bed and Pulverized-Coal Boilers in Utility Application, Proc. Fourth Annual Pittsburgh Coal Conf., held in Pittsburgh, Sept. 28-Oct. 2, sponsored by U.S. Department of Energy.

Dawson, G.W., et al., 1988a, Laboratory Characterization of Advanced $\mathrm{SO}_{2}$ Control ByProducts: Spray Dryer Wastes, EPRI Report CS-5782, Electric Power Research Institute, Palo Alto, Calif., May.

Dawson, G.W., et al., 1988b, Laboratory Characterization of Advanced $\mathrm{SO}_{2}$ Control By-Products: Furnace Sorbent Injection Wastes, EPRI Report CS-5783, Electric Power Research Institute, Palo Alto, Calif., May.

De Miechele, G. and S. Ligasacchi, 1984, Characterization of the Combustion of Oil-Coal Mixtures in an Industrial Boiler (in French), Revue Generale de Thermique, 23(276):805-809, Dec.

Denysyk, B., 1988, Global U.S.A. Inc., Washington, D.C., personal communication, July.

Dinelli, G. and M. Rea, 1986, Research for Optional Integrated Flue Gas Treatment, Proc. Sixth Symp. on the Transfer and Utilization of Particulate Control Technology, sponsored by Electric Power Research Institute, EPRI Report CS-4918, Vol. 1, Palo Alto, Calif., Nov.

DOC, 1985, Official U.S. and International Financing Institutions: A Guide for Exporters and Investors, U.S. Department of Commerce, International Trade Administration, Jan.

DOC, 1986, Overseas Business Report, Marketing in Morocco, U.S. Department of Commerce, International Trade Administration, June. 
DOC, $1987 \mathrm{a}$, Overseas Business Report, Marketing in Japan, U.S. Department of Commerce, International Trade Administration, April.

DOC, 1987b, Overseas Business Report, Marketing in Italy, U.S. Department of Commerce, International Trade Administration, Sept.

DOC, 1988a, Overseas Business Report, Marketing in Pakistan, U.S. Department of Commerce, International Trade Administration, Jan.

DOC, 1988b, Foreign Economic Trends and Their Implications for the U.S., Japan, U.S. Department of Commerce, International Trade Administration, Oct.

DOC, 1988c, Overseas Business Report, Marketing in Turkey, U.S. Department of Commerce, International Trade Administration, Nov.

DOC, 1988d, Overseas Business Report, Marketing in the Peoples' Republic of China, U.S. Department of Commerce, International Trade Administration, Dec.

DOC, 1989a, Foreign Economic Trends and Their Implications for the U.S., Morocco, U.S. Department of Commerce, International Trade Administration, Jan.

DOC, 1989b, Foreign Economic Trends and Their Implications for the U.S., Poland, U.S. Department of Commerce, International Trade Administration, Feb.

DOC, 1989c, Commerce Removes Export Controls on AT-Compatible Desk-Top Personal Computers, news release, U.S. Department of Commerce, July 18.

DOC, 1989d, Foreign Economic Trends and Their Implications for the U.S., Peoples' Republic of China, U.S. Department of Commerce, International Trade Administration, Sept.

DOC, 1989e, Turkish Desk Officer, U.S. Department of Commerce, personal communication, March.

DOC, 1990, Overseas Business Report, Doing Business in Poland, U.S. and Foreign Commercial Service Office in Warsaw and Office of Eastern Europe and Soviet Affairs, U.S. Department of Commerce, International Trade Administration, May.

Doctor, R.D., 1982, Utility Flue-Gas Desulfurization: Innovations and System Availability, Argonne National Laboratory Report ANL/ECT-11, March.

Doctor, R., et al., 1985, The Limits of Coal Cleaning as a Sulfur Reduction Strategy in the Midwest, J. Air Pollution Control Assn., 35(4):331-336, April.

DOE, 1987, Comprehensive Report to Congress - Clean Coal Technology Program, Tidd PFBC Demonstration Project, U.S. Department of Energy/Office of Fossil Energy Report DOE/FE-0078, Feb. 
DOE, 1988a, Potential Markets for Small Coal-Fired Combustors in OECD Countries: Country Screening, U.S. Department of Energy/Office of Fossil Energy Report DOE/FE0109, Aug.

DOE, 1988b, Status of U.S.-Italian Bilateral Projects on Energy Research and Development, presented at Symp. on Energy Security: Alternatives to Oil, held at Argonne, Ill., in March, sponsored by U.S. Department of Energy and Italian Ministero dell Industria, Commercio e Artiginato.

DOE, 1988c, Fluidized-Bed Combustion, Chapter 4 in Energy Technologies and the Environment, U.S. Department of Energy Report DOE/EH-0077, Oct.

DOE, 1989a, An Analysis of Markets for Small-Scale, Advanced Coal-Combustion Technology in Spain, Italy, and Turkey, U.S. Department of Energy/Office of Fossil Energy Report DOE/FE-0144, Sept.

DOE, 1989b, International Energy Annual: 1988, U.S. Department of Energy/Energy Information Administration Report DOE/EIA-0219(88), Oct.

DOE, 1989c, Clean Coal Technology Demonstration Program, Annual Report to Congress, U.S. Department of Energy/Office of Fossil Energy Report DOE/FE-0125, Feb.

DOE, 1990a, Clean Coal Technology: Topical Report Number 1, Tidd: The Nation's First PFBC Combined-Cycle Demonstration, U.S. Department of Energy, March.

DOE, 1990b, Clean Coal Technology Demonstration Program, Annual Report to Congress, U.S. Department of Energy/Office of Fossil Energy Report DOE/FE-0195P, March.

Donnelly, J.R., et al., 1986, Spray Dryer FGD Experience, JOY/NIRO Installation, Proc. Ninth Symp. on Flue-Gas Desulfurization, held in Cincinnati, Ohio, June, sponsored by Electric Power Research Institute, EPRI Report CS-4390, Palo Alto, Calif., Jan.

Donnelly, J.R., et al., 1987, JOY/NIRO Utility Spray Dryer FGD Operating Experience An Update, Proc. Tenth Symp. on Flue-Gas Desulfurization, held in Cincinnati, Ohio, June, sponsored by Electric Power Research Institute, EPRI Report CS-5167, Palo Alto, Calif., May.

Donnelly, J.R., et al., 1988, Update of JOY/NIRO U.S. Utility Spray Dryer FGD Systems, presented at First Combined $\mathrm{FGD}$ and Dry $\mathrm{SO}_{2}$ Control Symp., held in St. Louis, Oct. 25-28, sponsored by U.S. Environmental Protection Agency and Electric Power Research Institute.

Drehnel, D.C., 1988, SO ${ }_{x}$ out on a LIMB, Modern Power Systems, pp. 73-77, May.

Dunlop, W., 1984, Assessment of Alternative AFBC Steam Generator Designs, Electric Power Research Institute Report CS-5296, Palo Alto, Calif., July. 
Duqum, J.N., et al., 1987, Combustion Characteristics of Solid Fuels in an AFBC Unit, Proc. 1986 Seminar on AFBC Technology for Utility Applications, sponsored by Electric Power Research Institute, EPRI Report CS-5186, Palo Alto, Calif., July.

East-West Center, 1989, Asia-Pacific Report - Focus: China in the Reform Era, pp. 7583, Honolulu, Hawaii.

Economist Intelligence Unit, 1989a, Pakistan Country Report: Analysis of Economic and Political Trends Every Quarter, No. 2, Business International Corp., London.

Economist Intelligence Unit, 1989b, Pakistan Country Report: Analysis of Economic and Political Trends Every Quarter, No. 3, Business International Corp., London.

EER Technologies Corp., 1988, Summary of Translated Document - ENEL Programs 1988-1992 and Forecast for Coverage of Electrical Energy Requirements to the Year 2000, Reston, Va., June.

Electric Light and Power, 1987, EPRI Backs Three Full-Scale AFB Demo Projects, $65(4): 31$.

Electric Utility Week, 1990, Fluid-Bed Demo Plant on TVA System Giving Signs of Improved Operation, June 4.

Ellison, W., 1988, European Activities in $\mathrm{SO}_{2}$ and $\mathrm{NO}_{x}$ Emission Control, Proc. Energy Technology Conf., held in Washington, D.C., Feb., sponsored by U.S. Department of Energy.

Embassy of Turkey, 1989, Commercial Counselor, Washington, D.C., personal communication, March.

Emson, M., 1988, Swedish Mission, New York City, personal communication, June.

Energy Conversion Systems, Inc., 1986, Use of Lignite in Texaco Gasification-Based Combined-Cycle Power Plants, EPRI Report AP-4509, Electric Power Research Institute, Palo Alto, Calif., April.

Energy and Environmental Research Corp., 1987, Enhancing the Use of Coals by Gas Reburning and Sorbent Injection, Report to Congress, Washington, D.C., May.

England, G.C., et al., 1988, Prototype Evaluation of Dry Sorbent Injection at Whitewater (61 $\mathrm{MWe}$ ), presented at First Combined FGD and Dry $\mathrm{SO}_{2}$ Control Symp., held in St. Louis, Oct. 25-28, sponsored by U.S. Environmental Protection Agency and Electric Power Research Institute.

EPRI, 1981, U.S. Cool Test Program on BGC-Lurgi Slagging Gasifier, Electric Power Research Institute Report AP-1922, Palo Alto, Calif. 
EPRI, 1982, Coal-Water-Slurry as a Utility Boiler Fuel, Electric Power Research Institute Report CS-2287, Palo Alto, Calif., March.

EPRI, 1984a, Cost and Performance for Commercial Applications of Texaco-Based Gasification-Combined-Cycle Plants, Electric Power Research Institute Report AP-3486, Vols. 1 and 2, Palo Alto, Calif.

EPRI, 1984b, Coal-Water-Slurry Technology Development, Electric Power Research Institute Report CS-3374, Palo Alto, Calif.

EPRI, 1985a, Coal-Water-Slurry Test in an Industrial Boiler, Electric Power Research Institute Report CS-4268, Palo Alto, Calif., Sept.

EPRI, 1985b, Influence of Coal Particle Size on Coal-Water-Slurry Fuel Combustion, Electric Power Research Institute Report CS-4233, Palo Alto, Calif., Sept.

EPRI, 1986a, Study of Utility Boilers for a Coal-Water-Slurry Demonstration Test, Electric Power Research Institute Report CS-4473, Palo Alto, Calif., March.

EPRI, 1986b, Technical Assessment Guide: Electricity Supply, Electric Power Research Institute Report P-4463-SR, Palo Alto, Calif., May.

EPRI, 1987, Coal-Water-Slurry Transportation Alternatives, Electric Power Research Institute Report CS-5053, Palo Alto, Calif., Feb.

EPRI, 1989, Technical Assessment Guide: Electricity Supply, Electric Power Research Institute Report P-6587-L, Palo Alto, Calif., Sept.

EPRI, 1990, Proceedings: GEN-UPGRADE 90, International Symposium on Performance Improvement, Retrofitting, and Repowering of Fossil Fuel Power Plants, held in Washington, D.C., March 6-9, sponsored by International Energy Agency, U.S. Department of Energy, and Electric Power Research Institute, EPRI Report GS-6986, Palo Alto, Calif, Sept.

EPRI, no date, Test Results from AFBC Pilot Plant, Electric Power Research Institute, Technical Brief RP1860-1, Palo Alto, Calif.

EPRI Journal, 1984, Coal That Flows, Electric Power Research Institute, Palo Alto, Calif., July/Aug.

EPRI and Radian Corp., 1988, Cool Water Coal Gasification Program: Fifth Progress Report, Flectric Power Research Institute Report AP-5931, Palo Alto, Calif., Oct.

Ercolani, D., 1988, Coal Water Mixtures Programs: The Activities of the Companies of the ENI Group in the Field of Coal-Water Mixtures, Energy Security: Alternatives to Oil, Proc. of Symp. held at Argonne, March, sponsored by U.S. Department of Energy and Italian Ministero dell Industria, Commercio e Artiginato, Argonne National Laboratory Report ANL/IEP-88-60, Argonne, Ill., pp. 164-172. 
Evans, B., 1988, Pyropower, Inc., San Diego, Calif., personal communication, June.

Farber, P.S., 1982, Start-Up and Performance of a High Sulfur Dry Scrubber System, presented at annual meeting, held in New Orleans, June 20-25, sponsored by Air Pollution Control Assn., Pittsburgh.

Farber, P.S., et al., 1983a, Evaluation of a Spray Dryer Flue Gas Cleaning System on High Sulfur Coal, presented at Coal Technology '83, held in Houston, Nov.

Farber, P.S., et al., 1983b, Leachate of Dry Scrubber Wastes, presented at 76 th meeting, held in Atlanta, June, sponsored by the Air Pollution Control Assn., Pittsburgh.

Federal Broadcast Information Service, 1990, East Europe, Poland, Daily Report Supplement FBIS-EEU-90-04, Washington, D.C., March 9.

Felsvang, K.S., 1983, Status of the JOY/NIRO Dry FGD System and its Application for Removal of High Sulfur, High Chloride and $\mathrm{NO}_{x}$ from Flue Gases, presented at 1983 Joint Power Generation Conf., held in Indianapolis, Ind., Sept. 25-29.

Felsvang, K.S., et al., 1983, Acid Rain Prevention through New $\mathrm{SO}_{x} / \mathrm{NO}_{x}$ Dry Scrubbing Process, presented at Seventh Symp. on Flue-Gas Desulfurization, held in New Orleans, Nov. 1-4, sponsored by Electric Power Research Institute.

Felsvang, K.S., et al., 1988, Update of Spray Dryer FGD Experience in Europe and in the People's Republic of China, presented at First Combined FGD and Dry $\mathrm{SO}_{2}$ Control Symp., held in St. Louis, Oct. 25-28, sponsored by U.S. Environmental Protection Agency and Electric Power Research Institute.

Financial Times, 1989, Turkish Power Station Deal, FT Business Information Ltd., London, Oct. 25.

Finnish Ministry of Trade and Industry, 1987, Finland and Energy, Helsinki, Finland.

Fluor Engineers, Inc., 1984, Cost and Performance for Commercial Applications of Texaco-Based Gasification-Combined-Cycle Plants, EPRI Report AP-3486, Vols. 1 and 2, Electric Power Research Institute, Palo Alto, Calif., April.

Fluor Engineers, Inc., 1985, Cost and Performance of Kellogg Rust Westinghouse-Based Gasification-Combined-Cycle Plants, EPRI Report AP-4018, Electric Power Research Institute, Palo Alto, Calif., June.

FMC Corporation, 1985, Total Capability for FGD Systems, Air Quality Control Operation Report AQC-5000/685, Schaumburg, Ill., June.

Foster-Wheeler Corp., 1987, Prospects for U.S. Coal Technologies in the Global Marketplace, testimony before the U.S. House of Representatives, Committee on Science, Space and Technology, July 21. 
Foti, J., 1989, U.S. Department of Labor, personal communication, Oct. 25.

Fox, E.C., et al., 1986, Review of Fluidized-Bed Combustion Technology in the U.S., Energy, 11(12):1183-1200.

Friedrich, F.D., et al., 1985, Fluidized Bed Combustion of Coal Water Slurry, Proc. Seventh International Symp. on Coal Slurry Fuels and Preparation, held May 21-24, sponsored by Coal \& Slurry Technology Assn., Washington, D.C.

Fujiwara, K., et al., 1987, Fuel Evaluation and Operating Expreiences of Babcock-Hitachi Multiple Fuel Fluidized Bed in Japan, Proc. 10th International Conf. on Fluidized-Bed Combustion, sponsored by American Society of Mechanical Engineers, Boston.

Girardi, G., L. Guidi, and M. Penati, 1988, Coal-Water Mixtures in 200 MWe Boilers, Energy Security: Alternatives to Oil, Proc. of Symp. held at Argonne, March, sponsored by the U.S. Department of Energy and Italian Ministero dell Industria, Commercio e Artiginato, Argonne National Laboratory Report ANL/LEP-88-60, Argonne, Ill., pp. 189-209.

Gogineni, M.R., et al., 1988, Development and Demonstration of Sorbent Injection for $\mathrm{SO}_{2}$ Control on Tangentially Coal-Fired Utility Boilers, presented at First Combined FGD and Dry $\mathrm{SO}_{2}$ Control Symp., held in St. Louis, Oct. 25-28, sponsored by U.S. Environmental Protection Agency and Electric Power Research Institute.

Goldschmidt, K., 1987, VKR Full Scale SCR Experience on Hardcoal Fired Boilers, Proc. Joint Symp. on Stationary Combustion $\mathrm{NO}_{\mathrm{x}}$ Control, held in New Orleans, Aug., sponsored by U.S. Environmental Protection Agency and Electric Power Research Institute, EPRI Report CS-5361, Palo Alto, Calif.

Gorst, I., 1987, Gas and Nuclear Fuel Replacing Oil, Petroleum Economist, pp. 174, 191-192, May.

Government of Pakistan, 1986, Energy Yearbook, Ministry of Petroleum and Natural Resources, DGNRER, Karachi, Pakistan.

Government of Pakistan, 1989, Industrial Policy Package, Ministry of Industries, Karachi, Pakistan, July.

Gray, W.A., et al., 1986, Coal/Water Slurries: An Efficient Fuel for Light Industrial and Residential Applications, Proc. Eighth International Symp. on Coal Slurry Fuels and Preparation, held May 27-30, sponsored by Coal \& Slurry Technology Assn., Washington, D.C.

Gulev, J., 1988, Royal Danish Consulate, Chicago, personal communication, June.

Gupta, K.K., et al., 1987, Retrofit or Repowering for $\mathrm{SO}_{x}$ and $\mathrm{NO}_{x}$ Reductions for CoalFired Power Plants, Proc. Fourth Pittsburgh Coal Conf., held in Pittsburgh, Sept. 28Oct. 2, sponsored by U.S. Department of Energy. 
Haikonen, T., 1988, Consulate of Finland Trade Commission, Chicago, personal communication, June.

Hance, S.L., R.S. McKibben, and F.M. Jones, 1990, Summary Utility FGD Sumey: January-December 1988, PEI Associates, Inc., Cincinnati, Ohio, Jan.

Harkness, J.B.L., and R.D. Doctor, 1985, Development of Combined Nitrogen Oxide/Sulfur Oxide Environmental Control Technologies, Argonne National Laboratory Report ANL/ECT-14, Aug.

Harkness, J.B.L., R.D. Doctor, and C.D. Livengood, 1987, Enhancing Double-Alkali and Lime/Limestone Flue-Gas Desulfurization Chemistries to Promote $\mathrm{NO}_{x}$ Removal, Proc. Tenth Symp. on Flue-Gas Desulfurization, held in Cincinnati, Ohio, June, sponsored by Electric Power Research Institute, EPRI Report CS-5167, Palo Alto, Calif., May.

Harkness, J.B.L., et al., 1986, Flue Gas Desulfurization/Denitrification Using MetalChelate Additives, U.S. Patent No. 4,612,175, Sept. 16.

Haslbeck, J.L., and L.G. Neal, 1986, The NOXSO Process Development: An Update, Proc. Ninth Symp. on Flue Gas Desulfurization, held in Cincinnati, Ohio, June, sponsored by Electric Power Research Institute, EPRI Report CS-4390, Palo Alto, Calif., Jan.

Haslbeck, J.L., et al., 1988a, A Pilot-Scale Test of the NOXSO Flue Gas Treatment Process, NOXSO Corp., Library, Penn., June.

Haslbeck, J.L., et al., 1988b, NOXSO Demonstration Gives Encouraging Results, Modern Power System, pp. 39-43, May.

Hasibeck, J.L., et al., 1988c, Development Status of the NOXSO Combined $\mathrm{NO}_{x} / \mathrm{SO}_{2}$ Flue Gas Treatment Process, presented at Fourth Integrated Environmental Control Symp., held in Washington, D.C., March 2-4, sponsored by Electric Power Research Institute, Palo Alto, Calif.

Haslbeck, J.L., et al., 1989, Life Cycle Test of the NOXSO Process: Simultaneous Removal of $\mathrm{NO}_{x}$ and $\mathrm{SO}_{2}$ from Flue Gas, presented at annual meeting, held in Anaheim, Calif., June, sponsored by Air and Waste Management Assn., Pittsburgh.

Heinonen, J., 1988, Office of Council for Science and Technology, Finnish Embassy, Washington, D.C., personal communication, June.

Howe, W.C., 1987, Scope and Status of EPRI Research Activities in AFBC, Proc. 1986 Seminar on AFBC Technology for Utility Applications, sponsored by Electric Power Research Institute, EPRI Report CS-5186, pp. 1.1-1.31, Palo Alto, Calif., July.

Huang, H.S., et al., 1987, Simultaneous $\mathrm{NO}_{x}$ and $\mathrm{SO}_{2}$ Removal in a Spray Dryer System, presented at spring national meeting, held in Houston, March 29-April 2, sponsored by American Institute of Chemical Engineers. 
Hucko, R., 1987, Pittsburgh Energy Technology Center, Pittsburgh, personal communication, May.

IEA, 1983, Coal Use and the Environment, International Energy Agency, Organization for Economic Cooperation and Development, Paris.

IEA, 1985a, The Clean Use of Coal: A Technology Review, International Energy Agency, Organization for Economic Cooperation and Development, Paris.

IEA, 1985b, Energy Technology Policy, 1985 Review, International Energy Agency, Organization for Economic Cooperation and Development, Paris.

IEA, 1986a, Coal Research Projects, International Energy Agency, Organization for Economic Cooperation and Development, Paris.

IEA, 1986b, Energy Policies and Programmes of the IEA Countries, 1986 Review, International Energy Agency, Organization for Economic Cooperation and Development, Paris.

IEA, 1986c, Energy Research, Development, and Demonstration in the IEA Countries: 1986 Review, International Energy Agency, Organization for Economic Cooperation and Development, Paris.

IEA, 1987a, Clean Coal Technology: Programmes and Issues, International Energy Agency, Organization for Economic Cooperation and Development, Paris.

IEA, 1987b, Coal Research Projects - Supplement, International Energy Agency, Organization for Economic Cooperation and Development, Paris.

IEA, 1988a, Annual Report on Energy Policies and Programmes - Denmark, 1987, International Energy Agency, Organization for Economic Cooperation and Development, Paris.

IEA, 1988b, Coal Information - 1988, International Energy Agency, Organization for Economic Cooperation and Development, Paris.

International Coal Report, 1987a, Special Report - China, Issue 156, pp. 12-19, FT Business Information Ltd., London.

International Coal Report, 1987b, Special Report - China II, Issue 157, pp. 13-19, FT Business Information Ltd., London.

International Coal Report, 1987c, Special Report - China III, Issue 158, pp. 13-19, FT Business Information Ltd., London.

International Coal Report, 1987d, Inside Brief: Advanced Coal-Use Technology, Issue 186, p. 13, FT Business Information Ltd., London, Nov. 20. 
International Coal Report, 1988, S. Korea Considers Import Tariff Cut, Issue 200, p. 6, FT Business Information Ltd., London, June 17.

International Coal Report, 1990, Poles Confirm 6 Mt 1990 Export Cut, FT Business Information Ltd., London, Jan. 26.

Ireland, P.A., et al., 1986, Economics of Furnace Sorbent Injection for $\mathrm{SO}_{2}$ Emission Control, Proc. 1986 Joint Symp. on Dry $\mathrm{SO}_{2}$ and Simultaneous $\mathrm{SO}_{2} / \mathrm{NO}_{\mathrm{x}}$ Control Technologies, sponsored by U.S. Environmental Protection Agency and Electric Power Research Institute, EPRI Report CS-4966, Palo Alto, Calif., Dec.

Jackson, S.B., et al., 1981, Dowa Process Tests Shawnee Test Facility, U.S. Environmental Protection Agency Report 600/9-81-019a, Vol. 1, Sept.

Japanese Environment Agency, 1986, Quality of the Environment in Japan 1986, Government of Japan, Tokyo.

Johnson, T., 1987, China: Energy Sector Outlook, Economist Intelligence Unit, Business International Corp., London, June.

Jordan, E., 1988, Royal Danish Embassy, Washington, D.C., personal communication, June.

Journal of Commerce, 1989, Asian Banks Still Wary about China, Vietnam, Oct. 31.

JOY/NIRO, 1982, Seminar on Dry Scrubbing of High Sulfur Coals, Minneapolis, Minn., June 12-27.

Kaji, S., no date, Experience of COM Delivery, EPDC, Tokyo.

Kaneko, S., et al., no date, Development and Utilization of Large Capacity CWM Burners, EPDC, Tokyo.

Kang, S.W., 1986, Pilot-Scale Combustion Tests of CWM for a Modified Water-Tube Package Oil Boiler at KIER, Korean Institute for Energy Research, Taipei, Taiwan.

Kaplan, N., et al., 1986, Control Cost Modeling for Sensitivity and Economic Comparison, Proc. 1986 Joint Symp. on Dry $\mathrm{SO}_{2}$ and Simultaneous $\mathrm{SO}_{2} / \mathrm{NO}_{\mathrm{x}}$ Control Technologies, sponsored by U.S. Environmental Protection Agency and Electric Power Research Institute, EPRI Report CS-4966, Palo Alto, Calif., Dec.

Karachi Electric Supply Co., 1985, Power System Statistics, first issue, Karachi, Pakistan, Dec.

Keeth, R.J., et al., 1983, Economic Evaluations of FGD Systems, EPRI Report CS-3342, Vol. 1, pp. 10-1 to 10-33, Electric Power Research Institute, Palo Alto, Calif., Dec. 
M.W. Kellogg Co., 1987, Comprehensive Report to Congress, Clean Coal Technology Program - The Appalachian Project, U.S. Department of Energy/Office of Fossil Energy Report DOE/FE-0095, Dec.

Kenakkala, T., 1988, Status of the LIFAC Process, presented at First Combined FGD and Dry $\mathrm{SO}_{2}$ Control Symp., held in St. Louis, Oct. 25-28, sponsored by U.S. Environmental Protection Agency and Electric Power Research Institute.

Kim, T., 1986, Coal Water Fuel Project at Yukong, Energy, 11(12):1163-66, Nov.

Konishi, H., et al., no date, Coal Water Mixture Demonstration Test at Nakoso, EPDC, Tokyo.

Kostic, M., 1989, Eximbank, Washington, D.C., personal communication, Oct.

Krippene, B.C., 1987, Results of the 4000 Hour Endurance Test of TRW's Entrained Combustor, Proc. Fourth Pittsburgh Coal Conf., held in Pittsburgh, Sept. 28-Oct. 2, sponsored by U.S. Department of Energy.

KRW Energy Systems, Inc., 1986, KRW Process Development Unit (PDU) Fluidized Bed Coal Gasification/Hot Gas Cleanup, Proc. Sixth Annual Advanced Gasification Contractors' Review Meeting, Report DOE/METC-86/6043, p. 255, U.S. Department of Energy/Morgantown Energy Technology Center, Morgantown, W. Va., Aug.

Kuroda, M., et al., 1989, Recent Developments in the SCR System and Its Operational Experiences, Proc. Joint Symp. on Stationary Combustion $\mathrm{NO}_{\mathbf{x}}$ Control, held in San Francisco, March, sponsored by U.S. Environmental Protection Agency and Electric Power Research Institute.

Lekas, K., 1988, Energitveckling, AB, Stockholm, Sweden, personal communication.

Leonhardt, W., and F. Heinrich, 1988, A Coal-Based Cogeneration Plant with Pressurized Fluidized Bed Steam Generator - Presentation of the Results of the Planning Phase, presented at Seminar on FBC Technology for Utility Applications, held in May, sponsored by Electric Power Research Institute, Palo Alto, Calif.

Levine, M., et al., 1989, Energy Technology for Developing Countries: Issues for the U.S. National Energy Strategy, Lawrence Berkeley Laboratory Report LBL-28407, Dec.

Lewis, J.T., et al., 1981, Test Results of the EPRI/B\&W 6' $\times 6^{\prime}$ Fluidized Bed Combustor, presented at Coal Conversion Conf., held in Denver, sponsored by Institute of Gas Technology, Chicago.

Lillestolen, T., 1988, Flakt Manufacturing, Stockholm, Sweden, personal communication. 
Lisauskas, R., et al., 1987, Engineering and Economic Analysis of Retrofit Low NO Combustion Systems, Proc. Joint Symp. on Stationary Combustion $\mathrm{NO}_{\mathrm{x}}$ Control, held in New Orleans, Aug., sponsored by U.S. Environmental Protection Agency and Electric Power Research Institute, EPRI Report CS-5361, Vol. 1, Palo Alto, Calif.

Littlejohn, D., and S.G. Chang, 1984, Identification of Species in a Wet Flue Gas Desulfurization and Denitrification System by Laser Raman Spectroscopy, Environmental Science and Technology, 18(5):305-10, May.

Lohisto, Y., 1988, Energy Development Bureau, Helsinki, Finland, personal com munication, June.

Luehmann, E., 1989, Overseas Private Investment Corp., Washington, D.C., personal communication, Oct.

Ma, W.T., 1989, NOXSO Corp., Library, Penn., personal communication, Feb.

Makansi, J., 1987, Slagging Combustors Expand In-Furnace Coal Retrofit Options, Power, 12:33-36, March.

Makansi, J., and R. Schwieger, 1987, Fluidized Bed Boilers, Power, 12:S1-16, May 16.

Manfred, R.K., 1986, Coal-Water Slurry Fuel Utilization in Utility and Industrial Boilers, Chemical Engineering Progress, pp. 29-38, March.

Margulis, A.E., 1988, Potential Applications of Slagging Combustor Systems, Proc. Energy Technology Conf., pp. 94-118, Washington, D.C., March.

McCarthy, J.J., et al., 1987, Pilot Scale Studies on the Application of Reburning for $\mathrm{NO}_{x}$ Control, Proc. Joint Symp. on Stationary Combustion $\mathrm{NO}_{\mathrm{x}}$ Control, held in New Orleans, Aug., sponsored by U.S. Environmental Protection Agency and Electric Power Research Institute, EPRI Report CS-5361, Vol. 1, Palo Alto, Calif.

Mehta, A., and R.B. Dooley (eds.), 1988, Effect of Coal Quality on Power Plants, EPRI Report CS-5936-SR, Electric Power Research Institute, Palo Alto, Calif., Sept.

Meier, H.J., and D. Bunthoff, 1986, The Deutsche Babcock Low Pollution Power Plant with PFBC Power Plants, presented at Utility Conf. on PFBC Power Plants, held in Milwaukee, Wisc., June, sponsored by Electric Power Research Institute.

Miller, B.G., 1989, Coal-Water Slurry Fuel Utilization in Utility and Industrial Boilers, Chemical Engineering Progress, pp. 29-38, March.

Miller, K.J., and R.E. Hucko, 1980, A Technical Performance Comparison of Coal-Pyrite Flotation and HGMS, U.S. Department of Energy Report RI-PMTC-10(80), Nov. 
Mills, B., et al., 1985, Coal and Coke Water Slurries - Preparation and Combustion The European Solution, Proc. Second European Conf. on Coal Liquid Mixtures, held Sept. 16-18, sponsored by Institute of Chemical Engineers, published by Pergamon Press, London.

Ministry of Energy, Mines, and Resources, 1986, Annual Report 1985-1986, Ottawa, Ontario, Canada.

Mitchell, N., 1988, Ministry for Energy, Office of Mines and Resources, Ottawa, Ontario, Canada, personal communication, June.

Mori, T., and N. Shimizu, 1989, Operating Experience of SCR Systems at EPDC's CoalFired Power Stations, Proc. Joint Symp. on Stationary Combustion $\mathrm{NO}_{\mathrm{x}}$ Control, held in San Francisco, March, sponsored by U.S. Environmental Protection Agency and Electric Power Research Institute.

Mozes, M., et al., 1988, Sorbent Slurry Injection for $\mathrm{SO}_{2}$ Control, presented at First Combined FGD and Dry $\mathrm{SO}_{2}$ Control Symp., held in St. Louis, Oct. 25-28, sponsored by U.S. Environmental Protection Agency and Electric Power Research Institute.

Muzio, L.J., and G.R. Offen, 1987, Assessment of Dry Sorbent Emission Control Technologies, Part I: Fundamental Processes, J. Air Pollution Control Assn., $37(5): 641-654$, May.

Myerson, A.L., et al., 1957, Sixth Symposium on Combustion, sponsored by the Combustion Institute, Pittsburgh.

Nakabayashi, Y., 1987, Demonstration Test Program of the 50 MWe AFBC Boiler in Japan, Proc. 10th International Conf. on Fluidized Bed Combustion, sponsored by American Society of Mechanical Engineers, Boston.

Nakabayashi, Y., and R. Abe, 1987, Current Status of SCR in Japan, Proc. Joint Symp. on Stationary Combustion $\mathrm{NO}_{\mathrm{X}}$ Control, held in New Orleans, Aug., sponsored by U.S. Environmental Protection Agency and Electric Power Research Institute, EPRI Report CS-5361, Palo Alto, Calif.

National Agency of Environmental Protection, 1987, Long-Range Transboundary Air Pollution and Danish Controlling Initiatives, Copenhagen.

National Agency of Environmental Protection, 1988, Status on Energy and Air Pollution in Denmark, Copenhagen, May.

Necker, P., 1987, Operating Experience with the SCR DeNO ${ }_{x}$ Plant in Unit 5 of Altbach/Deizisau Power Station, Proc. Joint Symp. on Stationary Combustion $\mathrm{NO}_{\mathrm{x}}$ Control, held in New Orleans, Aug., sponsosred by U.S. Environmental Protection Agency and Electric Power Research Institute, EPRI Report CS-5361, Palo Alto, Calif. 
Necker, P., 1989, Experience Gained by Neckarwerke from Operation of SCR DeNO Units, Proc. Joint Symp. on Stationary Combustion $\mathrm{NO}_{\mathbf{x}}$ Control, held in San Francisco, March, sponsored by U.S. Environmental Protection Agency and Electric Power Research Institute.

New Energy Development Organization, 1987, Research and Development Projects Fiscal 1987, Tokyo.

Nolan, P.S., et al., 1988, Operation of the LIMB/Humidification Demonstration at Edgewater, presented at First Combined FGD and Dry $\mathrm{SO}_{2}$ Control Symp., held in St. Louis, Oct. 25-28, sponsored by U.S. Environmental Protection Agency and Electric Power Research Institute.

OECD, 1988a, OECD on Figures - Statistics on the Member Countries, OECD Observer, Vol. 152, Organization for Economic Cooperation and Development, Paris, June/July.

OECD, 1988b, Regional Problems and Policies in Turkey, Organization for Economic Cooperation and Development, Paris.

OECD, 1989, Projected Costs of Electricity from Power Stations for Commissioning in the Period 1995-2000, Organization for Economic Cooperation and Development, Paris.

Offen, G.R., et al., 1987, Assessment of Dry Sorbent Emission Control T echnologies, Part II: Applications, J. Air Pollution Control Assn., 37(8):968-980, Aug.

Okamatsu, S., 1986, Closing Remarks, presented at Flue Gas Treatment Workshop, held in Tokyo, Nov. 11-12, sponsored by International Energy Agency, Paris.

ONE, 1985, Annual Report, Office National de l'Electricite, Rabat, Morocco.

Ornusal, B., 1984, Evaluation of Advanced Coal Cleaning Processes for Applicability to Existing and Grassroot Coal Preparation Plants/Power Plants, Versar, Inc., Springfield, Va., Sept.

Patterson, W.C., 1987, Advanced Coal-Use Technology, Financial Times, FT Business Information Ltd., London.

Perna, M.A., et al., 1987, B\&W/EPRI Fuels Characterization Test Program - Initial Test Results from the $1^{\prime} \times 1^{\prime} A F B C$, Proc. 1986 Seminar on AFBC Technology for Utility Applications, Electric Power Research Institute Report CS-5186, pp. 23-1 to 23-24, Palo Alto, Calif., July.

Petrill, E.M. and J.W. Stallings, 1987, Overview of EPRI's Fuels Characterization Project, Proc. 1986 Seminar on AFBC Technology for Utility Applications, Electric Power Research Institute Report CS-5186, pp. 21-2 to 21-5, Palo Alto, Calif., July. 
Poggi, E., and F. Velona, 1988, Italian Electricity Sector: Supply Strategies through 2000, Energy Security: Alternatives to Oil, Proc. of Symp. held at Argonne, March, sponsored by U.S. Department of Energy and Italian Ministero dell Industria, Commercio e Artiginato, Argonne National Laboratory Report ANL/IEP-88-60, Argonne, Ill., pp. 25-37.

Power, 1987, Old Coal-Fired Units Retrofitted to AFB Operation, 100\% RDF, Vol. 12, pp. 46-48, April.

Price Waterhouse, 1986, Doing Business in Morocco, Casablanca.

Radak, L.J., 1987, Methanol as an Electric Utility Fuel, presented at World Methanol Conf., held in San Francisco, Dec.

Reaves, J.A., 1990, Warsaw Regime Faces Double Test, Chicago Tribune, May 27.

Rhee, K., 1988, Pittsburgh Energy Technology Center, Pittsburgh, personal communications, June and July.

Robertson, D.F., 1987, Planning a Joint Venture for the Japanese Market, J. of the American Chamber of Commerce, Tokyo, Dec.

Royal Danish Ministry of Foreign Affairs, 1984, Denmark and Energy, Copenhagen.

Ruth, L.A., and R. Payne, 1987, Development in Advanced Coal Combustion Technology, Proc. Fourth Pittsburgh Coal Conf., held in Pittsburgh, Sept. 28-Oct. 2, sponsored by U.S. Department of Energy.

Scacchi, A., 1988, Energy Supply Strategy for Large Metropolitan Areas, Energy Security: Alternatives to Oil, Proc. of Symp. at Argonne, Mar., sponsored by U.S. Department of Energy and Italian Ministero dell Industria, Commercio e Artiginato, Argonne National Laboratory Report ANL/IEP-88-60, Argonne, Ill., pp. 74-77.

Schmid, M.R., 1986, Commercialization of Coal Water Fuel in Canada, Proc. Eighth International Symp. on Coal Slurry Fuels and Preparation, held May 27-30, sponsored by Coal \& Slurry Technology Assn., Washington, D.C.

Schonbucker, G., 1989, Reduction of Nitrogen Oxides from Coal-Fired Power Plants by Using SCR Process - Experiences in the FRG Commercial Scale DENOX Plants, Proc. Joint Symp. on Stationary Combustion $\mathrm{NO}_{\mathrm{x}}$ Control, held in San Francisco, March, sponsored by U.S. Environmental Protection Agency and Electric Power Research Institute.

Seek, C.K., 1986, Current and Future Plans for Coal Use in Korea, Energy, 11(12):1091-95. 
Siemon, J.R., and R.W. Gregory, 1985, The Economic Potential of Coal-Water Mixtures, Proc. Second European Conf. on Coal Liquid Mixtures, held Sept. 16-18, sponsored by Institute of Chemical Engineers, published by Pergamon Press, London.

Simpson, J.L., and J.H. Wilhelm, 1986, Development and Demonstration of a Limestone Dual Alkali Process at Central Illinois Public Service Company's Newton Power Station, Proc. Ninth Symp. on Flue Gas Desulfurization, held in Cincinnati, Ohio, June, sponsored by Electric Power Research Institute, EPRI Report CS-4390, Vol. 2, Palo Alto, Calif., Jan.

Singer, J.E. (ed.), 1981, Combustion, Chapter 24 in Advanced Methods of Using Coal, Combustion Engineering, Inc., Windsor, Conn.

Spadone, S.J., 1986, U.S. Department of Energy, Washington, D.C., personal communication, Oct.

Sparacino, M., 1988, Coal-Water Mixtures in 75 MWe Boiler, Energy Security: Alternatives to Oil, Proc. of Symp. held at Argonne, March, sponsored by U.S. Department of Energy and Italian Ministero dell Industria, Commercio e Artiginato, Argonne National Laboratory Report ANL/IEP-88-60, Argonne, Ill., pp. 173-188.

Stanford University, 1987, Analysis of Off-Design Performance and Phased Construction of Integrated Gasification-Combined-Cycle Power Plants, EPRI Report AP-5931, Electric Power Research Institute, Palo Alto, Calif., Oct.

Staudinger, G., P. Melcher, and K. Eckersdorfer, 1988, Austrian Experience with Furnace Limestone Injection, presented at First Combined FGD and Dry $\mathrm{SO}_{2}$ Control Symp., held in St. Louis, Oct. 25-28, sponsored by U.S. Environmental Protection Agency and Electric Power Research Institute.

Stearns Catalytic Corp., 1983, Economic Evaluation of FGD Systems, Vol. 1: Throwaway FGD Processes, High- and Low-Sulfur Coal, EPRI Report CS-3342, Vol. 1, Electric Power Research Institute, Palo Alto, Calif., Dec.

Stearns Catalytic Corp., 1986, Economic Evaluation of FGD Systems, Vol. 5: The NOXSO and SOXAL Sodium-Based Processes and Four Additional Calcium-Based Processes, EPRI Report CS-3342, Electric Power Research Institute, Palo Alto, Calif., Oct.

Stern, R.D., 1988, An Overview of EPA's Program for Retrofit Sorbent Injection Technologies, presented at First Combined FGD and Dry $\mathrm{SO}_{2}$ Control Symp., held in St. Louis, Oct. 25-28, sponsored by U.S. Environmental Protection Agency and Electric Power Research Institute.

Szpunar, C.B., and J.L. Gillette, 1989, U.S. Clean Coal Technologies: International Markets and Competitive Issues, Proc. Sixth Annual Pittsburgh Coal Conference, held in Pittsburgh, Sept. 25-29, sponsored by U.S. Department of Energy. 
Szpunar, C.B., et al., 1989, Alternative and Innovative Transport Modes for Moving U.S. Steam-Coal Exports to the Asian Pacific Basin, Argonne National Laboratory Report ANL/EAIS/TM-13, Nov.

Tavoulareas, S., 1987, Atmospheric Fluidized-Combustion Technology - 1987 Status Update, Proc. Fourth Annual Pittsburgh Coal Conf., held in Pittsburgh, Sept. 28-Oct. 2, sponsored by U.S. Department of Energy.

Tennessee Valley Authority, 1987, Coal Gasification Test at TVA, EPRI Report AP-5047, Electric Power Research Institute, Palo Alto, Calif., Feb.

Texaco, Inc., 1987, Pilot Plant Evaluation of Illnois No. 6 and Pittsburgh No. 8 Coal for the Texaco Coal Gasification Process, EPRI Report AP-5029, Electric Power Research Institute, Palo Alto, Calif., Jan.

Thambimuthu, K.V., et al., 1985, Pilot-Scale Combustion Studies of Coal-Water Fuels: The Canadian R\&D Program, Proc. Second European Conf. on Coal Liquid Mixtures, held Sept. 16-18, sponsored by Institute of Chemical Engineers, published by Pergamon Press, London.

Thomas, S., and C. Cragg, 1987, Japanese Power Station Fuel Demand to 2000, FT Business Information Ltd., London.

Thomas, J.F., R.W. Gregory, and M. Takayasu, 1986, Atmospheric Fluidized-Bed Boilers for Industry, International Energy Agency Coal Research, London, Nov.

Touche Ross International, 1985, Tax Investment Profile, Italy, Reconta Touch Ross S.A.S., Milan, Italy, July.

Trebbi, G., 1988, Coal-Water Programs, Energy Security: Alternatives to Oil, Proc. of Symp. held at Argonne, March, sponsored by U.S. Department of Energy and Italian Ministero dell Industria, Commercio e Artiginatio, Argonne National Laboratory Report ANL/IEP-88-60, Argonne, Ill., pp. 161-163.

Trivett, G.S., et al., 1985, Coal-Limestone-Water Slurry Testing in Atmospheric Fluidized Bed Combustion, Proc. Eighth International Conf. on Fluidized-Bed Combustion, sponsored by American Society of Mechanical Engineers, Boston, July.

Turkish Electricity Authority, 1985, TEK Annual Report, Ankara, Turkey.

United Nations, 1987, 1985 Energy Statistics Yearbook, New York City.

United Nations, 1988, Annual Bulletin of Coal Statistics for Europe: 1980, 1984, 1985, 1986, 1987, New York City.

United Nations, 1989, 1987 Energy Statistics Yearbook, New York City. 
U.S. Congress, 1989, Support for East European Democracy (SEED) Act of 1989, Public Law 101-179.

U.S. Department of State, 1988, Investment Climate Statement, Italy, June.

U.S. Department of State, 1989a, Background Notes, Japan, Bureau of Public Affairs, Jan.

U.S. Department of State, 1989b, Background Notes, Morocco, Bureau of Public Affairs, July.

U.S. Foreign and Commercial Service, 1986, Establishing a Business in Japan, Washington, D.C.

U.S. General Accounting Office, 1990, Fossil Fuels: Pace and Focus of the Clean Coal Technology Program Need to Be Assessed, Report GAO/RCED-90-67, March.

U.S. Trade Representative, 1989a, National Trade Estimate Report on Foreign Trade Barriers, April.

U.S. Trade Representative, 1989b, Fact Sheet, "Special 301" on Intellectual Property, May 25.

Vandycke, M., et al., 1988, Four Years of Operating Experience with Direct In-Furnace $\mathrm{SO}_{2}$ Reduction at $600 \mathrm{MWe}$ Unit of Provence Power Station, presented at First Combined FGD and Dry $\mathrm{SO}_{2}$ Control Symp., held in St. Louis, Oct. 25-28, sponsored by U.S. Environmental Protection Agency and Electric Power Research Institute.

Van Teeffelen, W., 1988, Royal Netherlands Embassy, Washington, D.C., personal com munication.

Vernon, J., 1988, Emission Standards Handbook, International Energy Agency Coal Research, London.

Washington Post, 1989a, Morocco Royal Decision in Favour of Foreign Investors, Nov. 1.

Washington Post, 1989b, China Sets Sharp Turn for Economic Policies: Leaders Opt for Return to Central Planning, Nov. 30.

Water and Power Development Authority, 1985, Annual Report 1984-1985, Karachi, Pakistan.

Water and Power Development Authority, 1986, Power System Statistics, 11th Issue, Karachi, Pakistan, Sept.

Watts, D.H., 1989, Cool Water Operating Results - Implications for New GCC Plants, Proc. Sixth Annual Pittsburgh Coal Conf., held in Pittsburgh, Sept., sponsored by U.S. Department of Energy. 
Weir, A., Jr., et al., 1982, Evaluation of Methanol as a Boiler Fuel for Electric Power Generation, EPRI Report AP-2554, Electric Power Research Institute, Palo Alto, Calif., Aug.

Whaley, M., et al., 1983, The Development of Coal Water Mixture Technology for Utility Boilers in Eastern Canada, presented at Fifth International Conf. on Coal Slurry Combustion Technology, held in April, sponsored by Coal \& Slurry Technology Assn., Washington, D.C.

Whalley, H., et al., 1985, Coal-Water Fuel Developments in Eastern Canada: The Chatham and Charlottetown Demonstrations and Beyond, Proc. Seventh International Symp. on Coal Slurry Fuels and Preparation, held May 21-24, sponsored by Coal \& Slurry Technology Assn., Washington, D.C.

Wickett, K., 1989, Eximbank of the U.S., Washington, D.C., personal communication, Oct.

Wik, P., 1984, How to Do Business with the PRC, Reston Publishing Co., Inc., Reston, Va. World Bank, 1985, China, The Energy Sector, Washington, D.C., Sept.

World Bank, 1986a, Beilungang Thermal Power Project, staff appraisal report, Washington, D.C., May.

World Bank, 1986b, Yantan Hydroelectric Power Project, staff appraisal report, Washington, D.C., May.

World Bank, 1986c, Shuikou Hydroelectric Power Project, staff appraisal report, Washington, D.C., Nov.

World Bank, 1987a, China, The Energy Sector, Annex 3 of China, Long Term Development Issues and Options -- A World Bank Country Study, Washington, D.C.

World Bank, 1987b, Poland: Reform, Adjustment, and Growth. Annex IV, Energy Report 6736-POL, Washington, D.C.

World Bank, 1987c, Wujing Thermal Power Project, staff appraisal report, Washington, D.C., May.

World Bank, 1988, Recent World Bank Activities in Energy, Industry and Energy Department, Washington, D.C., June.

World Energy Conference, 1989, Survey of Energy Resources, New York City.

Yager, J.A., 1984, The Energy Balance in Northeast Asia, The Brookings Institution, Washington, D.C. 
Yancik, J., 1988, U.S. Department of Commerce, Office of Energy, personal communication.

Yeh, J.T., et al., 1987, The NOXSO Process: Simultaneous Removal of $\mathrm{SO}_{2}$ and $\mathrm{NO}_{x}$ from Flue Gas, presented at spring national meeting, held in Houston, March 29-April 2, sponsored by American Institute of Chemical Engineers, New York City.

Zanis, L., 1987, Slagging Combustors to Challenge Fluid Beds for New, Retrofit Jobs, Power, pp. 17-20, Aug.

Zauderer, B., et al., 1987, Test of an Advanced Cyclone Coal Combustor on an Industrial Boiler Using Coal Slurries as a Fuel, Proc. Fourth Pittsburgh Coal Conf., held in Pittsburgh, Sept. 28-Oct. 2, sponsored by U.S. Department of Energy. 
$211 / 212$

APPENDIX A:

TECHNOLOGY DESCRIPTIONS AND DEMONSTRATIONS 
tx 


\section{CONTENTS}

A.1 TWO-STAGE FROTH FROTATION $\ldots \ldots \ldots \ldots \ldots \ldots \ldots \ldots \ldots \ldots \ldots \ldots \ldots \ldots .215$

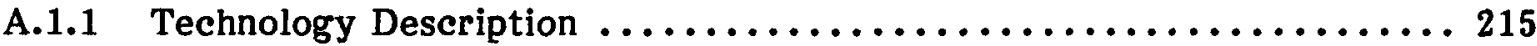

A.1.2 Technology Demonstrations .......................... 215

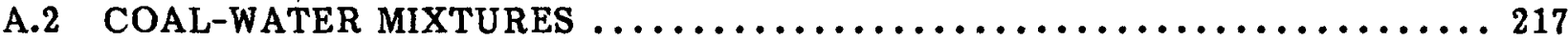

A.2.1 Technology Description and Costs ...................... 217

A.2.2 Technology Demonstrations ......................... 219

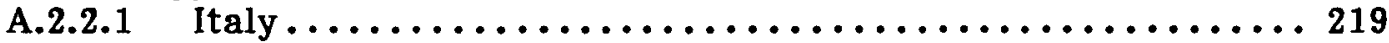

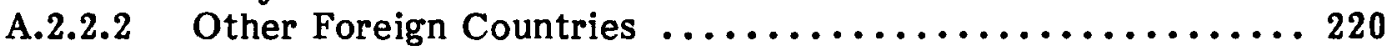

A.2.2.3 United States ........................... 220

A.3 SLAGgING Combustors $\ldots \ldots \ldots \ldots \ldots \ldots \ldots \ldots \ldots \ldots \ldots \ldots \ldots \ldots \ldots \ldots$

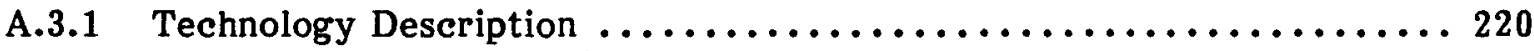

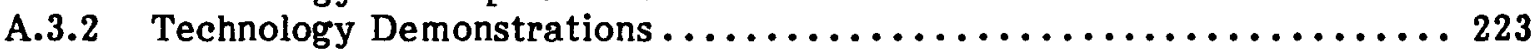

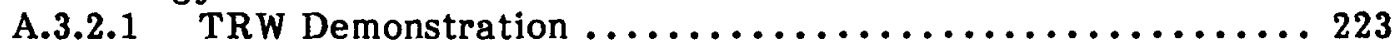

A.3.2.2 Coal Tech Corp. Demonstration $\ldots \ldots \ldots \ldots \ldots \ldots \ldots \ldots \ldots \ldots 224$

A.3.2.3 Transalta Pilot Test ......................... 225

A.4 INTEGRATED-GASIFICATION COMBINED-CYCLE SYSTEM . . . . . . . 225

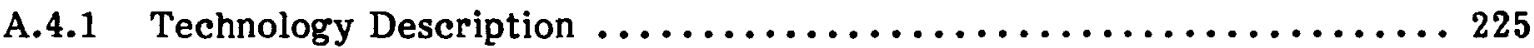

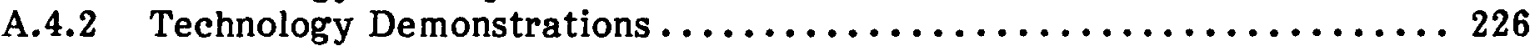

A.5 ATMOSPHERIC FLUIDIZED-BED COMBUSTION $\ldots \ldots \ldots \ldots \ldots \ldots \ldots \ldots \ldots \ldots 227$

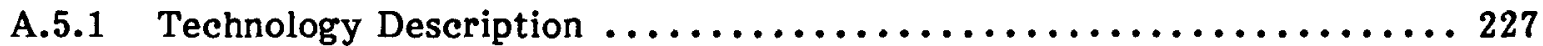

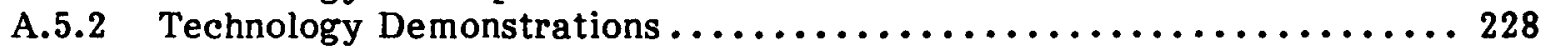

A.5.2.1 Northern States Power -- Black Dog Plant ............. 238

A.5.2.2 Tennessee Valley Authority -- Shawnee Power Station ...... 238

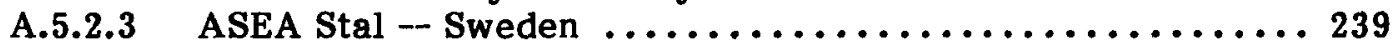

A.5.2.4 Deutsche Babcock/Vereinigte Kesselwerke -- FRG ........ 240

A.5.2.5 Thyssen/Standard Kessel - FRG ................. 241

A.5.2.6 Peoples' Republic of China ................... 242

A.5.2.7 Ahlstrom -- Finland ...................... 242

A.5.2.8 Colorado-Ute Electric Association - Nucla Station ....... 248

A.5.2.9 Lurgi -- FRG .......................... 248

A.5.2.10 Keeler/Dorr-Oliver -- United States ............... 249

A.5.2.11 Foster-Wheeler -- United States ................. 250

A.6 PRESSURIZED FLUIDIZED-BED COMBUSTION $\ldots \ldots \ldots \ldots \ldots \ldots \ldots \ldots \ldots \ldots \ldots$

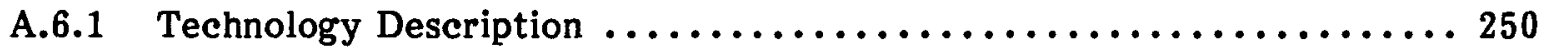

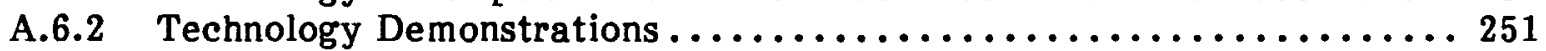

A.6.2.1 Grimethorpe -- United States/U.K./FRG ........... 251

A.6.2.2 ASEA -- Sweden ......................... 252

A.6.2.3 Tidd Power Plant - United States ................ 253

A.6.2.4 Deutsche Babcock -- FRG ..................... 254

A.7 LIMESTONE-INJECTION MULTISTAGE-BURNER COMBUSTION $\ldots \ldots \ldots \ldots 256$

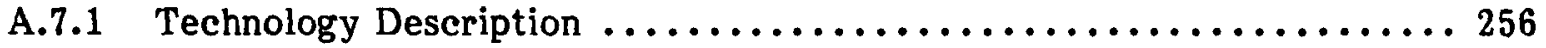

A.7.2 Technology Demonstrations ......................... 257

A.7.2.1 Ohio Edison -- Edgewater Station ................ 257

A.7.2.2 Virginia Power -- Yorktown Station ............... 258

A.7.2.3 Richmond Power \& Light -- Whitewater Valley Station ..... 258 


\section{CONTENTS (Cont'd)}

A.7.2.4 Foreign Countries ........................ 259

A.7.2.5 Research and Development Studies .............. 259

A.8 GAS-REBURNING SORBENT-INJECTION TECHNOLOGY $\ldots \ldots \ldots \ldots \ldots \ldots \ldots 260$

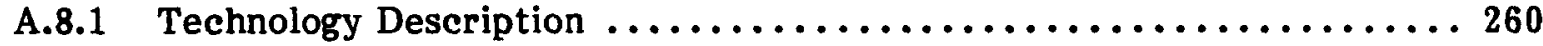

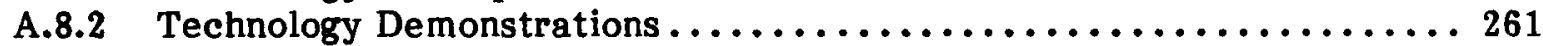

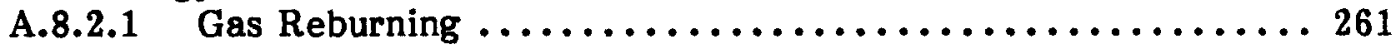

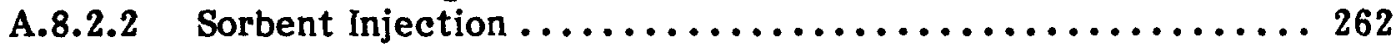

A.8.2.3 Gas Reburning and Sorbent Injection .............. 262

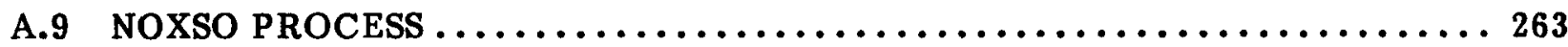

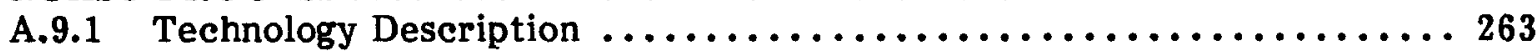

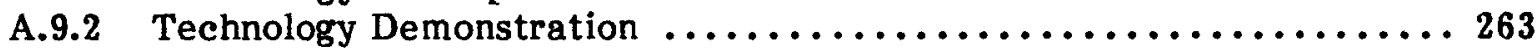

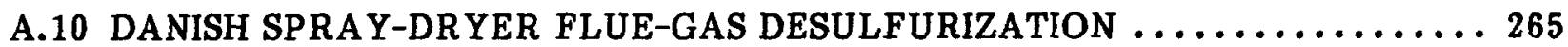

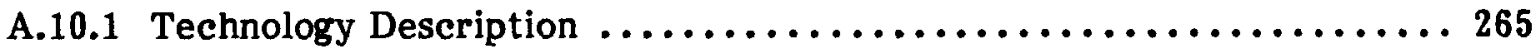

A.10.2 Technology Demonstrations ......................... 266

A.11 DUAL-ALKALI FLUE-GAS DESULFURIZATION $\ldots \ldots \ldots \ldots \ldots \ldots \ldots \ldots \ldots \ldots$

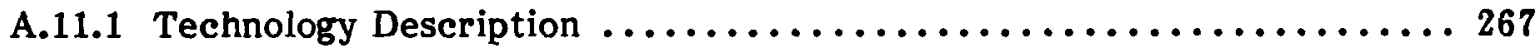

A.11.2 Technology Demonstration .......................... 269

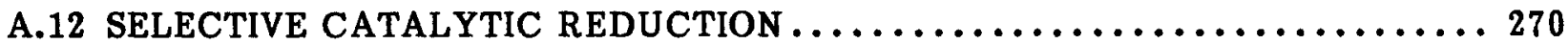

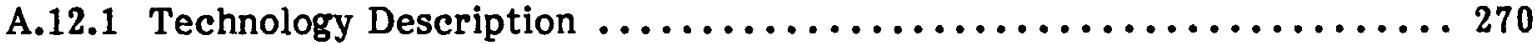

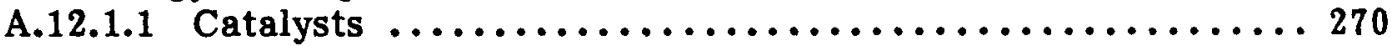

A.12.1.2 Process Configurations ....................... 270

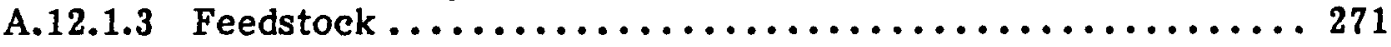

A.12.2 Technology Demonstrations .......................... 271

A.12.2.1 Altbach-Deizisau Power Station -- FRG ........... 271

A.12.2.2 VEBA Kraftwerke Ruhr -- FRG ................ 272

A.12.2.3 Walheim Power Station - FRG ................. 273

A.12.2.4 Heilbronn Power Station -- FRG ................ 273

A.12.2.5 Babcock Hitachi -- Japan .................... 274

A.12.2.6 EPDC -- Japan .......................... 274

\section{TABLES}

A.1 Experimental and Commercial Facilities Using Atmospheric

Fluidized-Bed Combustion .............................. 229

A.2 Coal-Technology Manufacturing and Research Organizations ........... 231

A.3 Industrial Atmospheric Fluidized-Bed Combustors ................ 243 


\section{APPENDIX A:}

\section{TECHNOLOGY DESCRIPTIONS AND DEMONSTRATIONS}

\section{A.1 TWO-STAGE FROTH FLOTATION}

\section{A.1.1 Technology Description}

The two-stage froth-flotation system is one of several advanced physical coalcleaning technologies that reduces sulfur dioxide $\left(\mathrm{SO}_{2}\right)$ emissions from pulverized-coalfired (PCF) boilers by separating the inorganic sulfur (present as iron pyrite) from the coal. It also reduces the quantity of ash-forming minerals that are fed to the boiler. Typically, the product from a coal-cleaning facility is of more consistent quality than the run-of-mine coal. This consistency, coupled with the reduction in iron pyrite and ashforming minerals, has been linked to reduced maintenance requirements for boilers. Quantifying this improvement has recently received increased attention (Mehta and Dooley, 1988).

Coal cleaning is one significant component of a comprehensive sulfur-reduction strategy. Depending on coal type, total sulfur removal of $30-50 \%$ is achievable with advanced physical coal cleaning. Two-stage froth flotation does not offer the prospect of significant reductions in sulfur emissions beyond the $30 \%$ pyritic sulfur rejection typical for Eastern and Illinois Basin high-sulfur coals. What it does offer is the prospect of recovering more of the calorific value from the coal while simultaneously reducing a solid-waste-handling problem associated with the fines disposal (the waste is commonly known as "gob").

The two-stage froth-flotation process has been developed over several decades, first by a number of foreign and domestic vendors and the U.S. Bureau of Mines and later by the U.S. Department of Energy (DOE)/Pittsburgh Energy Technology Center (PETC) (Ornusal, 1984; Spadone, 1986). In the first stage of the process, while coal is floated, the coarse coal, free pyrite, and other refuse are collected in the tailings. The clean coal from this first flotation stage is then repulped to form a 25-30\% solids slurry. In the second stage the slurry is treated with a depressant, pyrite collector, and frother to selectively float the remaining pyrite. The additives used in the DOE experiments include methyl isobutyl carbinol (MIBC) for the first stage and Aero Depressant 633, MIBC, and potassium amyl xanthate for the second stage. The float product from the second stage is sent to thickening cyclones. The supernate liquid is returned to the first stage of the system, while the concentrate is sent to a vacuum filter. The filter cake constitutes the product coal.

\section{A.1.2 Technology Demonstrations}

The technology for the two-stage froth flotation is a direct outgrowth of that for the single-stage flotation system, and many manufacturers can supply equipment that can be applied in the single-stage systems. In part, the large number of suppliers is a 
consequence of the variability in coals. No single flotation-cell design is capable of cleaning all coals optimally; hence, the cleaning-plant operators must test their coals in several different cells to find the optimal design.

Since single-stage froth flotation is almost the only process that is sufficiently developed to satisfactorily process coal fines (which typically account for $15 \%$ of the coal after handling), it is used frequently at coal preparation plants. As of 1987, flotation units were included in $42 \%$ of the 540 operating coal preparation plants reviewed by the Keystone Coal Industry Manual (Calhoun, 1987).

Equipment manufacturers include Bergbau-Forschung, Daniels Co., Diester Concentrator Co., Denver Equipment Co. (division of JOY), Dorr-Oliver, Galligher, Heyl and Patterson, Humboldt Wedag U.S.A., Sala Machine Works, Unifloc, and Wemco (division of Envirotech). Wemco and Denver Equipment Co. hold the largest share of the market, and both of these companies offer designs that are mechanically agitated with or without additional air sources. Any of these companies is in a position to provide equipment for use in two-stage froth-flotation systems.

Several pilot-scale demonstrations of advanced froth-flotation systems have taken place and are briefly discussed below:

- Bechtel National, Inc. (San Francisco, California) has successfully tested 20 -ton/h Bergbau-Forschung microbubble-flotation cells to produce low-ash coal (less than $2 \%$ ash on one sample) while maintaining an $80 \%$ Btu recovery. The Bechtel tests were jointly sponsored by DOE and the Electric Power Research Institute (EPRI) and took place at the Homer City Coal Cleaning Test Facility during the summer of 1987 . This system had been commercialized in Germany in 1982.

- AB Carbogel (Helsingborg, Sweden) demonstrated a two-stage froth-flotation system at a 4-ton/h pilot plant for the New Brunswick Electric Power Corp. in Chatam, New Brunswick, Canada (Whaley et al., 1983). For a harbor-seam coal, AB Carbogel reports a pyrite reduction of $80 \%$ and an ash reduction of $60 \%$, while maintaining a 93\% Btu recovery. However, these values do not apply to the coal fines but rather to the middlings fraction, which consists of minus 28-mesh material. Its application to coal fines and micronized coal is under development.

- Advanced Fuels Technology (Bridgeport, New Jersey) has achieved a high overall Btu recovery rate of $\mathbf{8 0 - 9 5 \%}$ after cleaning a 200-mesh slurry with a feed that has a density of $15-20 \%$ pulp (Burgess et al., 1983). Its spray flotation process has been tested at a 1-5 ton/h rate and is expected to be available in the near future. Advanced Fuels Technology claims to be using both a novel chemistry and a spray flotation approach, in which a dilute slurry is sprayed through a nozzle onto the surface of a beneficiation cell. The spraying 
action serves to shear apart flocculants, so trapped mineral matter is released. This system appears to yield better removal of mineral matter and maintain a high Btu recovery.

- DOE/PETC has demonstrated a unit with 1.5-2.0 ton/h capacity at the United Coal Co. coal preparation plant in Bristol, Virginia. The pyritic sulfur reduction was $85 \%$, ash reduction was $75 \%$, and Btu recovery was 65\% (Miller and Hucko, 1980).

\section{A.2 COAL-WATER MIXTURES}

Coal-water mixtures (CWMs) consist of $65-75 \%$ (by weight) coal and about $1 \%$ chemical additives; the rest is water. Existing oil-fired boilers require a number of changes if they are to burn CWMs. Modifications to the oil-system burner and additions to the boiler are needed. Ash removal and handling must also be addressed. If sulfurcontrol equipment is needed, even more expenditures are required. In summary, changing from oil to CWM fuel is not an inexpensive or insignificant effort. In addition, the capacity of the boiler usually needs to be downgraded because it is not capable of providing full output when fired with a CWM. Typical deratings are from $25 \%$ to $40 \%$, but values as high as $60 \%$ have been estimated. If the oil-fired units were initially designed to have coal capability, however, they do not require significant deratings to use CWMs.

Transportation from the slurry-manufacturing facility to the point of use is also required. In the United States, experience has been with small quantities of CWM fuel for testing. Rail, truck, and barge transportation have been used to deliver test fuels; pipeline transport has not yet been attempted. EPRI conducted a study (EPRI, 1987) that incorporated all four transportation modes and addressed the technical and economic issues involved. The focus was on understanding the characteristics and behavior of the particular slurries, so that equipment and operating procedures could be properly specified. CWMs can be safely transported, but special pumping and handling are required to prevent alteration of physical properties during transport.

Because of oil's easy availability and its current low price, the CWM supply industry is still in its infancy. Each of the potential suppliers has its own proprietary formulation for CWMs. Coal characteristics and chemical additives are the main factors that contribute to specification variations among suppliers.

\section{A.2.1 Technology Description and Costs}

Early experience with burning $\mathrm{CWMs}$ indicated the need to design burners specifically for CWM fuel. Flame stability at high turndown ratios, carbon-conversion efficiency, and burner-tip life were some of the issues addressed. Progress has been made in all these areas, but although burners are performing well, improvements are still desired. Dual-fuel capability for boilers is also being developed. This capability would allow easy switching between CWM and oil fuels and would reduce some of the impact of boiler derating. So far this goal has not been met. In general, the thermal efficiency of 
boilers using CWMs is three or four percentage points below that of coal-fired boilers and about two percentage points below that of oil-fired boilers. However, in oil-fired boilers, air preheating is employed to increase the thermal efficiency of the burners. If the fuel were not preheated, the thermal efficiency of CWMs would compare more favorably with oil. This is because the CWM requires some amount of preheating to achieve flame stability, and the design of a CWM plant includes fuel preheating.

The biggest problem associated with conversion to CWMs is the different amounts of ash that are in CWMs and in oil. The high ash level of CWMs necessitates boiler modifications and added flue-gas cleanup. The ash-disposal system becomes costly. Also, together with the boiler's physical size, the ash level and characteristics influence the amount of derating required because of erosion, fouling, and slagging. The ability to switch between two different CWM fuels is also strongly affected by the ash level and characteristics as well as the compatibility of the stabilizers in the two CWMs. Modifications in the oil storage and handling system are also required to accommodate a CWM. Special agitation is needed. Pumps have to be modified to low-shear devices. High temperatures, water content, and bacterial growth are other concerns (EPRI, 1984b, 1985a, 1985b).

Unless control measures are taken, plant emissions will generally increase as a result of a switch from oil to a CWM fuel. For the case of particulate emissions, the switch will be adverse; for $\mathrm{SO}_{2}$, it will probably be adverse because coal almost always has a higher sulfur content than oil. The level of nitrogen oxides $\left(\mathrm{NO}_{\mathrm{x}}\right)$ emissions will normally be lower than the applicable standard; however, it may be difficult to achieve lower $\mathrm{NO}_{\mathrm{x}}$ emissions by standard means such as low- $\mathrm{NO}_{\mathrm{x}}$ burners because of the unique requirements of burners designed for CWMs.

Even though extensive changes in the original oil-fired plant are not required, significant costs are involved. In the fuel-handling and storage systems, pumps must be modified to accommodate the density and fluid characteristics of the CWM, which are different from those of fuel oil. Burners and nozzles suitable for CWM fuel must be installed. Ash-removal and handling systems capable of dealing with higher ash levels than those in oil-fired plants need to be incorporated into the plant. Soot blowers and more forced-draft and/or induced-draft equipment must be supplied. Also, air heaters may be needed to aid flame stability and to increase the ambient temperature for the atomized fuel. Manfred (1986) estimated that the cost is $\$ 116-295 / \mathrm{kW}$ (1985 U.S. dollars) for such modifications. Siemon and Gregory (1985) estimated retrofit costs at \$25$75 / \mathrm{kW}$. Thus, there appears to be a significant difference in the estimated retrofit costs (about fourfold) between the EPRI-sponsored Manfred study and the Siemon and Gregory work. On the basis of the assumptions made, however, the EPRI costs appear to be more credible.

EPRI reports CWM fuel costs to be $\$ 2.80-3.50 / 10^{6}$ Btu at a production level of $10^{6}$ tons/yr (EPRI Journal, 1984). The range depends on coal costs, the amount of cleaning required, slurry-processing costs, and transportation costs. In the 1985 Siemon and Gregory study on the potential of $\mathrm{CWMs}$, costs are estimated to range from $\$ 3.00-$ $4.80 / 10^{6}$ Btu. Roughly half the value of each of this range's end points was due to the assumed cost of the two coals examined ( $\$ 45$ and $\$ 65 /$ tonne). The preparation cost of CWM based on the Snamprogetti's REOCARB process (excluding coal and transportation 
costs) was estimated by Mills et al. (1985) to be $\$ 7.70 /$ tonne for a 5 -million-tonne/yr plant, equivalent to $\$ 0.40 / 10^{6} \mathrm{Btu}$. (This estimate does not include coal cleaning costs.) This value is roughly one-half the cost presented by Siemon and Gregory for a highthroughput plant achieving 5 million tonnes/yr of $\mathrm{CWM}$ product. Information for the estimates is not complete; however, the Mills et al. estimates for REOCARB contain apparently low labor costs and low additive requirements. More information on cost for CWMs is provided in Appendix D.

\section{A.2.2 Technology Demonstrations}

Coal-water slurries have been widely researched and developed. Miller (1989) summarized some of the activities conducted in the United States, Italy, Canada, Sweden, Japan, Italy, the United Kingdom, South Korea, and the Peoples' Republic of China (PRC). The major technology demonstrations have taken place at boiler research facilities and power plants. Much of the information on slurry development and production has been generated by private firms.

\section{A.2.2.1 Italy}

Italian companies have been very active in the research and development (R\&D) of CWM fuel and its use, with fuel-supply diversification being a goal of the Italian national energy policy. The capability for a broader use of coal in the electrical and industrial sectors is sought through the development of CWMs and associated components for their deployment. In particular, a reduction in the use of oil in existing and new facilities is targeted. In the early 1980s, the acquisition of data for such conversions was a key objective of the Italian Generating Board (ENEL). In 1984, it was decided to convert an existing oil-fired boiler in a 35-MW unit at the Santa Gilla plant.

Research on burner design, boiler fouling, and equipment erosion was undertaken, in addition to work on the preparation and handling of slurries. One of the Italian companies, Snamprogetti, has developed a proprietary slurry-formation method called the REOCARB process. Another Italian company, Agipcoal, has identified about 700 industrial-sized boilers that are candidates for conversion from oil or gas to $\mathrm{CWM}$ fuel.

One of the large projects currently underway is the conversion of a boiler for a 75-MWe unit at the Cassano d'Adda power plant (Sparacino, 1988). The boiler, presently suitable for coal but normally using gas or oil, existed in cold standby condition when the conversion work was decided upon. Conversion costs were estimated at $\$ 220 / \mathrm{kW}$. Because the boiler has intrinsic coal-burning capability, no loss in generating capacity is anticipated as a result of conversion. The annual incremental operating and maintenance cost is estimated to be U.S. $\$ 0.6$ million for an operating duty of about 4,000 hours per year. The heat rate when CWM fuel is used is estimated to be about $10,000 \mathrm{Btu} / \mathrm{kWh}$ versus $9,200 \mathrm{Btu} / \mathrm{kWh}$ when oil is used.

Initially, in a year-long testing period starting in mid-1990, about 60,000 tons of CWM fuel from different suppliers is expected to be burned. A limit on the CWM's sulfur 
content has been established for the tests to avoid adding flue-gas scrubbing devices. The levels of nitrogen oxides $\left(\mathrm{NO}_{\mathrm{x}}\right)$ and particulate emissions are expected to meet U.S. federal standards. To meet particulate emission levels, an electrostatic precipitator (ESP) is planned to be installed. Expected performance factors are a 3:1 turndown ratio, no use of support fuel between $30 \%$ and $100 \%$ loadings of CWM, a carbon-conversion efficiency of $98 \%$ or more with $20 \%$ excess air, and an air preheated temperature of $100-$ $200^{\circ} \mathrm{C}$. If the cost of slurry is at least $\$ 1.10 / 10^{6} \mathrm{Btu}$ less than that of oil, the internal rate of return is expected to be higher than $5 \%$, the minimum acceptable value to the Italians.

To date, the largest Italian commitment to CWM slurry involves a contract with the Soviet Union for the conversion of a $200-\mathrm{MW}$ unit at Novosibirsk. This commitment involves constructing a CWM-preparation plant at Belovo and pumping stations for a 250-km pipeline to the plant. These efforts involve two Italian firms, Franco Tosi and Snamprogetti. The REOCARB CWM process is being tailored for use with the indigenous Soviet coal. Eventually the units at the giant Novosibirsk power plant are expected to use 5 million tonnes/yr of coal in the form of a CWM.

\section{A.2.2.2 Other Foreign Countries}

Canada has a significant development effort underway (Thambimuthu et al., 1985) and currently uses CWM fuel in the cement and iron ore industries. Sweden has tested slurry use in district-heating boilers and has demonstrated its suitability. Japan has emphasized testing and demonstration of slurries in electric power station boilers. Some of these tests used oil burners; others were planned and conducted on full-scale units.

\section{A.2.2.3 United States}

In addition to the work on developing CWMs for U.S. utility and industrial boilers, work is underway in the United States on using coal-slurry fuels for diesel-type and gasturbine engines. The Southwest Research Institute has announced the successful operation of a full-scale diesel engine for locomotives. At Morgantown Energy Technology Center (METC), researchers and contractors have tested CWMs in gasturbine component systems and in gas turbines. Commercial applications of CWMs for these engines are believed to be outside the scope and time scale for near-term application and are not expected in the medium term.

\section{A.3 SLAGGING COMBUSTORS}

\section{A.3.1 Technology Description}

A slagging combustor is a device that can simultaneously burn coal and control emissions of sulfur oxides $\left(\mathrm{SO}_{\mathrm{x}}\right), \mathrm{NO}_{\mathrm{x}}$, and particulates. The combustor is a ceramiclined cylinder that is positioned either horizontally or at an incline. Air and fuel enter 
one end of the cylinder, and hot combustion gases exhaust from the other end into the boiler. High-velocity swirling gas burns the material in the combustor. Coal ash melts into slag and is drained through a tap on the bottom of the combustor. A slagging combustor rated at $8.7 \mathrm{MW}$ is about 5 feet in diameter and 8 feet long.

A slagging combustor requires considerable cooling, which can be achieved with either water or air. If the combustor is water cooled, the cooling water can be flash evaporated and added to the system steam (Krippene, 1987). If it is air cooled, the cooling air can be used as combustion air (Coal Tech Corp., 1987). These cooling schemes must be integrated into the boiler system for efficient operation.

To control $\mathrm{SO}_{\mathrm{X}}$, a sorbent (usually limestone) is injected as dispersed fine particles, either into the combustion chamber or at its outlet, depending upon the particular designer's operating philosophy and experience. The limestone calcines to form reactive $\mathrm{CaO}$. The $\mathrm{CaO}$ captures the sulfur and, under oxidating conditions, forms $\mathrm{CaSO}_{4}$. The $\mathrm{CaSO}_{4}$ is removed with the slag or in a post-boiler flue-gas cleanup system. To inhibit $\mathrm{NO}_{\mathrm{x}}$ formation, the combustion is carried out in a fuel-rich environment. To control particulate levels in the furnace, the coal ash is melted into a molten slag and is tapped from the bottom of the combustor, and the major fraction is removed before it exhausts into the boiler.

Development of the slagging combustor was fostered by DOE in its coal-fueled magnetohydrodynamic (MHD) program in the early- to mid-1970s. Modern MHD coal combustors differ from their predecessors in that they operate at a pressure of several atmospheres, reject a high percentage of the ash ahead of the MHD channel, generate substantially lower quantities of gaseous atmospheric pollutants, and maintain high combustion (carbon-burnout) efficiencies. The current designs for slagging combustors are based on MHD combustor designs and experience and are intended for industrial and utility boiler retrofit and new installations.

Each combustor design has a unique configuration. A combustor may have a vertical, horizontal, or tipped-off-the-horizontal axis, with a cyclonic (tangential) or plug (one-dimensional) flow of particles and gases through the combustion chamber. The combustion process is usually separated into two sequential processes (staged) to permit optimized operation in meeting the design requirements related to emissions. The combustor walls may be insulated with ceramic refractory materials to reduce heat losses to the containment structure.

Staged combustion of coal takes place in all modern, high-performance coal combustors because it affords the combustor designer the opportunity to simultaneously meet the requirements of high combustion efficiency, high mineral-matter (ash/slag) rejection, low $\mathrm{NO}_{\mathrm{x}}$ production, and a possible means to reduce $\mathrm{SO}_{2}$ emissions.

Coal is burned in the first stage at an air-to-fuel ratio that is approximately 0.7 of that theoretically needed for complete combustion. At this stoichiometry, there is enough oxygen to burn all of the volatile matter and some of the fixed carbon (char) in the original coal particle. A fuel-rich gas is formed in the first stage; in the second stage, more air is added to complete the combustion process and to dilute the combustion products with excess air to control the final temperature of the mixed gas. 
The first-stage stoichiometry is high enough that combustion is not "starved" to such an extent that soot is formed. Char is characterized as being very porous (i.e., it has a large internal surface area). It contains the original mineral matter locked within the porous matrix of carbon. Soot, which is solid carbon that has condensed from the vapor phase into a dense, solid, particulate structure, has a surface area that is similar to the outside of the coal particle. The much larger surface area within the char particle permits much more rapid and efficient carbon combustion than does soot, because the combustion rate is limited in both cases by surface area.

Operation of the first stage at a stoichiometry of approximately 0.7 minimizes the production of $\mathrm{NO}_{\mathrm{x}}$. The combustion temperature at this lowered stoichiometry is high enough (approximately $2700-2900^{\circ} \mathrm{F}$ ) that the free nitrogen in the coal is driven of $\mathrm{f}$ without reacting, and low enough that the chemically bound nitrogen in the coal is decomposed. For most coals, operation of the first stage at this temperature range causes most of the mineral matter to liquefy and congeal, forming molten slag. Unfortunately, this temperature range is too high for optimal steady-state removal of $\mathrm{SO}_{2}$ using calcium-based sorbents.

Pulverized coals are almost universally used in modern slagging combustor systems. These atmospheric-pressure combustion systems have a high energy-release rate per unit volume, typically $10^{6} \mathrm{Btu} / \mathrm{h} / \mathrm{ft}^{3}$. Consequently, limited gas-residence time for combustion occurs. Through the use of finely ground coals, high heat-transfer rates are achieved and large initial surface areas are obtained. Coal is pulverized to 70\% minus 200 mesh (standard utility size) or as fine as $95 \%$ minus 300 mesh.

Most modern coal combustion systems feature vortex-swirl (tangential) flows. (The Transalta Corporation's plug-flow burner is a notable exception.) The swirl feature permits separation of the first-stage predecessor and combustion processes into optimal flow regimes. The coal-drying and devolatilization processes, which require only a few milliseconds each, are accomplished while particles are in free-flight trajectories in the first-stage gas volume. Volatiles burn quickly with the first-stage oxygen. The fluid dynamics are tailored such that the remaining char particles are either captured in the slow-moving boundary layer along the wall or impinge upon the wall and "float" on the molten slag. The relatively slow motion of the char results in longer residence times to complete primary combustion (actually the generation of fuel-rich gases). The highvelocity gas-flow paths must be controlled so that the slag is not re-entrained and passed along with the effluent into downstream systems.

Slag flow along the first-stage walls can be erosive and corrosive. The choice facing a combustor designer is whether or not to use a refractory ceramic liner. Chrome-alumina refractories developed during the MHD program survive slag attack better than do other formulations. However, all refractory must eventually be replaced. Another approach is to use a pin-studded metal wall; slag will adhere to it and solidify, thus forming a self-healing covering that reduces heat losses and protects the underlying metal from erosion and corrosion. Slag-insulated combustors must have very good control of gas dynamics and particle trajectories to obtain a sufficiently uniform slag covering that fulfills design heat-transfer requirements. Coal Tech Corp. favors installed refractory insulation, while TRW favors a self-adhering slag insulating layer. 


\section{A.3.2 Technology Demonstrations}

The text that follows describes commercial demonstrations of slaggingcombustor technology. Two of the demonstrations are industrial scale; one is a pilot test. Information on costs and solid-waste production for these demonstrations is not available at this time.

\section{A.3.2.1 TRW Demonstration}

TRW's commercial demonstration occurred at Argo Tech Manufacturing in Cleveland, Ohio (Krippene, 1987). Argo Tech is equipped with a 1941 field-erected Keeler boiler with a rating of $28,000 \mathrm{lb} / \mathrm{h}$ of steam. The boiler, originally a coal-fired stoker, was converted to burn oil and gas in the late 1960s. TRW installed its Model No. 35, 8.7-MW slagging combustor at Argo Tech. The combustor consists of a watercooled cylinder with a tangential air inlet and a slag-control baffle. Pulverized coal is fed into the combustor, entrained in swirling air flow, and burned while it is entrained. The coal ash is converted into a molten slag, adheres to the walls of the combustor, and flows out of the combustor through the slag tap. The hot combustion gases flow into the boiler.

TRW decided that it is inherently impossible to effectively capture sulfur under first-stage operating temperatures. The $2700-2900^{\circ} \mathrm{F}$ temperature level, which is optimal for $\mathrm{NO}_{\mathrm{x}}$ reduction and slagging, is too high for optimal sulfur kinetics. Sulfur is absorbed optimally at a temperature near $2200^{\circ} \mathrm{F}$. Higher temperatures redissociate the calcium-sulfur compounds back into $\mathrm{SO}_{2}$. Consequently, TRW injects sorbent into the gas stream after primary combustion.

In the demonstration, the system's water pressure (cooling water at $700 \mathrm{psig}$ and steam at $100 \mathrm{psig}$ ) was selected to show that the combustor could be suitable for higherpressure, larger industrial boilers. The coal burned during the demonstration was Ohio No. 6 Middle Kittanning Seam. This coal was pulverized at $70 \%$ minus 200 mesh. The coal characteristics were as follows:

$\begin{array}{lrll}\text { Carbon } & 74.1 \% & \text { Moisture } & 1.8 \% \\ \text { Hydrogen } & 5.0 \% & \text { Ash } & 9.1 \% \\ \text { Nitrogen } & 1.5 \% & \text { Volatiles } & 36.0 \% \\ \text { Oxygen } & 6.7 \% & \text { Fixed carbon } & \mathbf{5 3 . 1 \%} \\ \text { Sulfur } & 1.8 \% & \text { Heating value } & 13,415 \mathrm{Btu} / \mathrm{lb}\end{array}$

The demonstration at Argo Tech lasted 4000 hours. During the test, availability of the slagging combustor and dense fuel-feed system was 83.3\%; plant availability for steam production averaged 59.7\%. The turndown ratio demonstrated was $3: 1$. Cooling water was circulated to a flash tank, which increased total steam output $25 \%$ to $35,000 \mathrm{lb} / \mathrm{h}$. Slag recovery averaged $83 \%$. A baghouse was needed to capture the very fine particles produced during the combustion. The combustor was operated at a fuelrich stoichiometry of 0.8 to inhibit $\mathrm{NO}_{\mathrm{x}}$ formation. $\mathrm{NO}_{\mathrm{x}}$ emissions averaged 300 parts per million (ppm), well below the New Source Performance Standards (NSPS) limit of $450 \mathrm{ppm}$. Overfire air and other similar $\mathrm{NO}_{\mathrm{x}}$-reduction techniques might be used to 
further reduce $\mathrm{NO}_{\mathrm{x}}$ emissions. No attempts were made to reduce $\mathrm{SO}_{\mathrm{x}}$ emissions during this demonstration.

TRW was recently awarded a DOE commitment for $\$ 23.5$ million to demonstrate its advanced slagging combustor technology. TRW plans to retrofit two oil-fired units, one that is $69 \mathrm{MW}$ and another that is $46 \mathrm{MW}$. The total demonstration project cost is $\$ 49$ million.

\section{A.3.2.2 Coal Tech Corp. Demonstration}

The Coal Tech 40-hour demonstration occured at the Keeler-Dorr/Oliver Boiler Manufacturing Co. in Williamsport, Pennsylvania (Zauderer et al., 1987). The facility is equipped with a 6.67-MW oil/gas-fired Keeler boiler. Coal Tech installed its 8.7-MW aircooled slagging combustor on the boiler. The demonstration consisted of two continuous tests, one lasting 12 hours and one 24 hours.

Components necessary to retrofit the boiler included the slagging combustor, slurry storage and feed system, air-delivery system, limestone storage and feed system, slag-removal system, combustor- and boiler-control system, and stack-gas diagnostic system. The only original components that were removed to install the combustor were the gas burner and the air plenum.

The combustor burned 10 tons of coal-water slurry during the demonstration. The slurry fuel was supplied by the Cape Breton Developing Co. of Canada. The slurry had the following characteristics: $1 \%$ sulfur (dry weight), $1 \%$ ash (dry weight), and a higher heating value (HHV) of $10.6 \times 10^{6} \mathrm{Btu} / \mathrm{gal}$. For each test period, tests were conducted at air-to-fuel stoichiometric ratios of 1.1 and 1.2 .

When the boiler was fired with $67 \%$ (energy percentage) slurry fuel and $33 \%$ natural gas, the boiler/combustor efficiency was about 78\%. Maximum coal thermal input was 4.64 MW. A control malfunction during the demonstration prevented accurate measurement of boiler/combustor reverse efficiency. Based on the stack-gas temperature, the estimated thermal efficiency was in the low $80 \%$ range.

Coal Tech employs a transient method for sulfur capture. The limestone is injected during the high-temperature first stage, but its residence time is purposely limited so that the particles do not have time to come into thermal equilibrium. Thus, the particle temperature traverses the optimum scavenging zone but never reaches the dissociation zone. Obviously, tight control on particle trajectories is required to make this process work. Short residence times (approximately 20 milliseconds) for the small particles (reported to be in the minus 300 mesh range) are required.

In the demonstration, the calcium-to-sulfur ratios for each test were 2.4 and 1.6. The limestone feed rate was $40 \mathrm{lb} / \mathrm{h}$. The $\mathrm{NO}_{\mathrm{x}}$ emissions averaged $211 \mathrm{ppm}$, higher than test results from Argonne National Laboratory for a similar-sized combustor. These $\mathrm{NO}_{\mathrm{x}}$ emissions may be attributed to thermal $\mathrm{NO}_{\mathrm{x}}$ formed when the combustor operates at or near adiabatic conditions. 


\section{A.3.2.3 Transalta Pilot Test}

During bench-scale tests at Transalta, 90\% $\mathrm{SO}_{2}$ removal was achieved using bituminous and subbituminous coals. Subbituminous coal did not require any sorbent to achieve $\mathrm{SO}_{2}$-removal efficiencies. This slagging combustor was operated at a pressure of 6 atmospheres. Minimal $\mathrm{NO}_{\mathrm{x}}$ emisssion rates were achieved at a stoichiometric ratio of 0.7. The Transalta test combustor was rated at $28 \times 10^{6} \mathrm{Btu} / \mathrm{h}$ and burned an eastern bituminous coal, Illinois No. 6, and North Dakota Zap lignite. The coal was $70 \%$ minus 325 mesh. A carbon conversion of 95\% was experienced at an air fuel ratio of 1 (Margulis, 1988).

\section{A.4 INTEGRATED-GASIFICATION COMBINED-CYCLE SYSTEM}

\section{A.4.1 Technology Description}

The integrated-gasification combined-cycle (IGCC) technology began to develop in the late 1970s, as research was being conducted on numerous gasifier concepts and improvements were being made in gas turbine performance and reliability. EPRI was instrumental in encouraging this development and giving direction to the philosophy of plant design.

From the three gasifier types available (fixed bed, fluidized bed, and entrained bed), EPRI chose an entrained-bed gasifier designed by Texaco for its Cool Water 100-MWe demonstration project. This option was chosen, in part, because it and other non-IGCC Texaco gasifiers in the Federal Republic of Germany (FRG) and the United States had been operated using a variety of coals and had demonstrated the versatility of this gasification technology. Numerous studies on the cost and performance of the Texaco IGCC technology had also been undertaken.

The primary competitor to this entrained-bed technology is the British Gas Corp. (BGC) slagging Lurgi (BGL) fixed-bed gasifier. It has undergone extensive development but has not yet been included in an IGCC plant (British Gas Corp., 1981).

The primary candidate using fluidized-bed technology is Kellogg's KRW gasifier. Development of this technology has been accomplished under several corporate associations. The current version evolved principally from the Kellogg-RustWestinghouse (KRW) organization and is referred to as the KRW gasifier, even though M.W. Kellogg Company currently has the primary interest in its development. A fullscale prototype that has been operating since the mid-1980s at Waltz Mill, Pennsylvania, has been tested on a wide variety of coals. Development on the KRW gasifier was suspended in the fall of 1988. Unlike the other two options, which operate only on oxygen, the KRW gasifier has been demonstrated with both air and oxygen. These three gasifiers are characterized in more detail below. 


\section{A.4.2 Technology Demonstrations}

The Cool Water IGCC with Texaco entrained-bed gasifier is located in Daggett, California. Coal is ground, slurried with water, and pumped into the gasifier with essentially pure oxygen. The gasification reaction takes place at about $2500^{\circ} \mathrm{F}$ and creates hydrogen, carbon monoxide (CO), and a small amount of methane $\left(\mathrm{CH}_{4}\right)$ as fuelgas species. Carbon dioxide $\left(\mathrm{CO}_{2}\right)$ is also produced in addition to a small amount of nitrogen. Sulfur is combined with hydrogen and carbon to form hydrogen sulfide $\left(\mathrm{H}_{2} \mathrm{~S}\right)$ and carbonyl oxysulfide (COS). These sulfur species are removed downstream in a coldgas cleanup system. The dirty coal gas is cooled sequentially in radiant cooler and convective coolers before being cleaned of particulates in a water quench. The raw gas is then sent to a Selexol sulfur-removal process and subsequently combusted with air and steam for $\mathrm{NO}_{\mathbf{x}}$ control in a combustion turbine-generator. The hot exhaust passes through a heat-recovery steam generator (HRSG) to produce steam for plant process needs and the steam turbine. Specific aspects of the Cool Water operation are described in Sec. 2.4 .

The BGL fixed-bed gasifier accepts coarse, screened coal, with the majority of fines agglomerated into briquettes. A mixture of oxygen and superheated steam is fed to the lower combustion zone. Hot combustion products move upward as the coal moves downward in the gasifier, resulting in a heat-exchange process that produces a fuel gas at a far lower temperature than that in the Texaco process. Fats and oils are separated from the gas and reinjected into the combustion zone via tuyeres. The BGL gasifier has been extensively tested in the BGC research plant in Westfield, Scotland.

At the KRW fluidized-bed gasifier (KRW Energy Systems, Inc., 1986) in Waltz Mill, Pennsylvania, minus 6 mesh coal, limestone, and air are introduced through a central feed tube in the bottom. Steam, recycled gas, and recycled particulate material are introduced separately, further up in the gasifier. Coal is devolatilized in the combustion zone, and the remaining char particulates are gasified by steam in the upper areas of the bed. Coal gas at about $1900^{\circ} \mathrm{F}$ is produced. Temperatures in the gasifier favor sulfur reactions with the limestone sorbent. The $\mathrm{H}_{2} \mathrm{~S}$ produced in the gasification process reacts with the lime $(\mathrm{CaO})$ or limestone $\left(\mathrm{CaCO}_{3}\right)$ to form calcium sulfite $\left(\mathrm{CaSO}_{3}\right)$. Desulfurization of 85-95\% in the coal gas is achieved in this way. Tars and oils are broken down to $\mathrm{CO}$, hydrogen $\left(\mathrm{H}_{2}\right)$, and $\mathrm{CH}_{4}$ at these temperatures. The coal ash particles soften and sinter in the hottest area, tending to agglomerate. Both the heavier ash and $\mathrm{CaSO}_{3}$ particles fall out of the fluidized region to the bottom of the gasifier, where they are cooled and removed through a rotary feeder. This mixture is roasted in air to convert the sulfur compounds to calcium sulfate $\left(\mathrm{CaSO}_{4}\right)$, resulting in a residue that meets landfill requirements established under the Resource Conservation and Recovery Act (RCRA).

The exit gas, which is laden with particles, is sent through a primary cyclone, where hot-particulate matter is removed and recycled to the gasifier. The remaining gas and particles are then cooled by a water quench to $1000-1100^{\circ} \mathrm{F}$. Additional particulate material is removed by the water quench, but a candle-type ceramic filter is also employed. More than $99 \%$ of the particles leaving the gasifier have been removed at this point. External desulfurization is carried out by zinc ferrite units. The absorber is 
composed of zine and iron oxides (zine ferrite) that react to form metal sulfides, $\mathrm{CO}_{2}$, and water. A regeneration process uses air and steam to reoxidize the metals and carry off the sulfur as $\mathrm{SO}_{2}$. The process has been tested extensively at the bench and pilot scale.

No IGCC plants using the BGL fixed-bed or the KRW fluidized-bed gasifiers are currently in operation or under construction.

\section{A.5 ATMOSPHERIC FLUIDIZED-BED COMBUSTION}

\section{A.5.1 Technology Description}

In fluidized-bed combustion (FBC), solid, liquid, or gaseous fuel(s), an inert material (such as sand, silica, alumina, or ash), and/or a sorbent (such as limestone) are kept suspended by an upward flow of air and combustion gases that exerts a force on the particles equal to that exerted by gravity. The particles move freely in patterns determined by the hydrodynamics of the bed, which takes on the large-scale characteristics of a homogeneous fluid. The improved mixing generates heat at a substantially lower and more uniformly distributed temperature, typically $1500-1600^{\circ} \mathrm{F}$. The basic FBC process can occur at near-atmospheric pressures in the combustion chamber, i.e., in an atmospheric fluidized-bed combustor (AFBC), or it can occur at pressures ranging from about 8 to 16 atmospheres, i.e., in a pressurized fluidized-bed combustor (PFBC).

Combustion air from a fan or compressor normally is preheated by the flue gas, enters the plenum (an air chamber under the air distributor that acts as a surge tank to temper flow and pressure fluctions), is spread uniformly over the bed area, and passes upward between the particles of the bed at velocities of $0.8-5 \mathrm{~m} / \mathrm{s}$, depending on the size and density of the particles. Coal and sorbent are injected into the combustor by screw feeders or pneumatic conveyors. The position of the injectors may be within the bed (underbed nozzles), above the bed (spreader stokers), or both. The coal's volatile components burn above the feed point, and the remaining solids (char) burn throughout the bed.

The air and combustion gases that pass through the bed cause vigorous agitation and mixing. Some particles are thrown from the bed into the empty space above (called the freeboard). Larger, heavier particles fall back into the bed; smaller, lighter particles are carried out by the gases. A relatively dense $800-\mathrm{kg} / \mathrm{m}^{3}\left(50-1 \mathrm{~b} / \mathrm{ft}^{3}\right)$ bed of solids is maintained at the lower portion of the furnace. This version of the AFBC is referred to as bubbling fluidized-bed combustion (BFBC).

Circulating fluidized-bed combustion (CFBC) is a second-generation descendant of the original bubbling-bed technology. In CFBC, gas velocities are 3 to 4 times higher than in BFBC. Consequently, a high-density bed cannot form, and all of the solid particles are carried up through the furnace. A more uniform, lower-density gas/solid mixture exists throughout the entire furnace. The fluidized bed is actually a swirling cloud of incandescent particles rising right out of the primary combustion chamber, to be 
extracted by a heavy-duty cyclone and returned, directly or indirectly, to the primary chamber. The fuel particles travel with this circulating bed. Their residence time in the combustor (including recirculation time) is longer -- on the order of minutes rather than seconds. This shorter time, coupled with the smaller particle size, produces a high level of combustion efficiency and a high $\mathrm{SO}_{2}$-removal rate with a much lower amount of limestone feed.

Although much of the ash formed is separated from the bed and entrained by the combustion gases, larger ash particles and agglomerates can accumulate; these then need to be removed from the stream of sorbent and spent sorbent leaving the bed through a drain.

Heat-transfer surfaces are located both within the fluidized bed and downstream from it. They are cooled by water, steam, or air. Within the bed, tube bundles or waterwalls may be used. The arrangement of heat-transfer surfaces and the circulation scheme for water and steam depend on the specific boiler.

At high fluidization velocities, a significant amount of incompletely burned smaller particles can be carried into the flue-gas ducts. Secondary overbed-air injection can be used to increase combustion efficiency and burn more of these small particles. Those particles carried into the flue gas are commonly collected by cyclones and a secondary or tertiary particle recovery system, which may be either a bag filter or an ESP.

From an environmental point of view, the valuable feature of FBC is the ability to burn coal in a bed consisting of heated limestone. The calcium oxide from the calcination of the limestone absorbs the $\mathrm{SO}_{2}$ being released from the burning. The result is a dry calcium-sulfate waste product.

The design of fluidized-bed boilers must take into account several features characteristic of the FBC process. The operation of the bed itself, the methods of fuel feed and ash removal, the heat-transfer rates, and the control of particulate carryover all differ radically from those of pulverized-coal and stoker firing.

\section{A.5.2 Technology Demonstrations}

Table A.1 lists the characteristics of U.S. experimental and commercial AFBC facilities. AFBC technology is commercially established for industrial heating. Shop assembled, rail-shippable units can generally be designed for steam capacities up to $200,000 \mathrm{lb} / \mathrm{h}$. The number of manufacturers continues to grow. The potential of the U.S. market is demonstrated by the fact that new suppliers from Europe are still establishing businesses here or strengthening their positions (Power, 1987).

The AFBC technology for electric utility application has reached a significant stage of development, with three utility-size demonstration plants well underway at Northern States Power Co., Colorado-Ute Electric Assn., and Tennessee Valley Authority (TVA). These and other demonstrations are discussed in the sections that follow and elsewhere (Howe, 1987). Table A.2 lists coal technology manufacturing and research organizations of interest. 


\begin{tabular}{|c|c|c|c|c|c|c|c|}
\hline Facility and Location & $\begin{array}{l}\text { Application } \\
\text { and } \\
\text { Bed Mode }\end{array}$ & $\begin{array}{l}\text { Bed } \\
\text { Area } \\
\left(m^{2}\right)\end{array}$ & $\begin{array}{l}\text { Coal Feed } \\
\text { Rate } \\
(t / h)^{b}\end{array}$ & $\begin{array}{l}\text { Steam } \\
\text { Capacity } \\
(\mathrm{kg} / \mathrm{h})\end{array}$ & $\begin{array}{l}\text { Electrical } \\
\text { Output } \\
\text { (MW) }\end{array}$ & $\begin{array}{l}\text { Start-up } \\
\text { Date and } \\
\text { Designer }\end{array}$ & Comments \\
\hline $\begin{array}{l}\text { Rocketdyne/Argonne National } \\
\text { Laboratory Experimental Air } \\
\text { Heater, E1 Segundo, Calif. }\end{array}$ & $\begin{array}{l}\text { Experimental, } \\
\text { bubbling }\end{array}$ & 3.3 & 0.6 & $N A^{d}$ & NA & $1982, \mathrm{RD}$ & None \\
\hline $\begin{array}{l}\text { Reeler/Dorr-01iver Pilot } \\
\text { Plant, Williamsport, Penn. }\end{array}$ & $\begin{array}{l}\text { Experimental, } \\
\text { circulating }\end{array}$ & NA & 14 million & 4,091 & NA & $1985, \mathrm{KDO}$ & $\begin{array}{l}\text { May be filled with a variety of fuels; used } \\
\text { as Btu/h needed for testing }\end{array}$ \\
\hline $\begin{array}{l}\text { Wilkes Barre Steam Heat } \\
\text { Authority, Wilkes Barre, Penn. }\end{array}$ & $\begin{array}{l}\text { Industrial, } \\
\text { bubbling }\end{array}$ & - & - & 27,273 & NA & 1984, KDO & Fueled by anthracite culm \\
\hline $\begin{array}{l}\text { Idaho National Energy } \\
\text { Laboratory Steam generators, } \\
\text { Idaho Falls, Idaho }\end{array}$ & $\begin{array}{l}\text { Industrial, } \\
\text { bubbling }\end{array}$ & 16.7 & 4.7 & 30,682 & NA & $1984, \mathrm{FW}$ & Duplicate units of the same size \\
\hline $\begin{array}{l}\text { Anderson Clayton Foods } \\
\text { Plant, Amarillo, Texas }\end{array}$ & $\begin{array}{l}\text { Industrial, } \\
\text { bubbling }\end{array}$ & 18.6 & 2.7 & 31,818 & NA & 1986 , WH & $\begin{array}{l}\text { Two duplicate units in series to provide } \\
\text { two-stage combustion and desulfurization }\end{array}$ \\
\hline $\begin{array}{l}\text { Iowa Beef Processors Plant, } \\
\text { Amarillo, Texas }\end{array}$ & $\begin{array}{l}\text { Cogeneration, } \\
\text { bubbling }\end{array}$ & 15.8 & 4.6 & 31,818 & 1.25 & $1982, \mathrm{WH}$ & $\begin{array}{l}\text { Anderson } \mathrm{Clayt} \text { on Foods boiler design adapted } \\
\text { to cogeneration }\end{array}$ \\
\hline $\begin{array}{l}\text { Georgetown University, } \\
\text { Washington, D.C. }\end{array}$ & $\begin{array}{l}\text { Industrial, } \\
\text { bubbling }\end{array}$ & 19.8 & 4.3 & 45,455 & NA & $1979, \mathrm{FW}$ & $\begin{array}{l}\text { Installation and testing funded by DOE; } \\
\text { conversion to cogeneration is planned }\end{array}$ \\
\hline $\begin{array}{l}\text { Tennessee Valley Authority } \\
\text { (TVA) Shawnee Station Pilot } \\
\text { P1ant, Paducah, Ky. }\end{array}$ & $\begin{array}{l}\text { Experimental, } \\
\text { bubbling }\end{array}$ & 20.1 & 6.8 & 50,545 & $20^{f}$ & $1982, \mathrm{BW}$ & Funded by DOE and EPRI \\
\hline $\begin{array}{l}\text { Midwest Grain Products } \\
\text { Plant, Pekin, Ill. }\end{array}$ & $\begin{array}{l}\text { Cogeneration, } \\
\text { bubbling }\end{array}$ & 27.7 & 7.2 & 54,545 & 3.5 & $1981, \mathrm{FW}$ & Installation funded by the state of Illinois \\
\hline $\begin{array}{l}\text { Quaker State Refinery, } \\
\text { Newell, Nev. }\end{array}$ & $\begin{array}{l}\text { Industrial, } \\
\text { bubbling }\end{array}$ & - & - & 54,545 & NA & $1985, \mathrm{KDO}$ & Duplicate units of the same size \\
\hline $\begin{array}{l}\text { B.F. Goodrich Chemical Group } \\
\text { Plant, Henry, Ill. }\end{array}$ & $\begin{array}{l}\text { Industrial, } \\
\text { circulating }\end{array}$ & NA & 5.1 & 56,818 & NA & $1985, \mathrm{PA}$ & Installation funded by the state of Illinois \\
\hline $\begin{array}{l}\text { Ashland Petroleum Refinery, } \\
\text { Catlettsburg, } \mathrm{Ky} \text {. }\end{array}$ & $\begin{array}{l}\text { Industrial, } \\
\text { bubbling }\end{array}$ & 123.6 & NA & 47,727 & $\mathrm{NA}$ & $1983, \mathrm{FW}$ & $\begin{array}{l}\text { Duplicate units of the same size; fueled by } \\
\text { low-value, high-temperature refinery gas }\end{array}$ \\
\hline $\begin{array}{l}\text { Foster wheeler Cogeneration } \\
\text { Boiler, Mt. Carmel, Penn. }\end{array}$ & $\begin{array}{l}\text { Cogeneration, } \\
\text { circulating }\end{array}$ & NA & 78.0 & 174,545 & 40 & $1989, \mathrm{FW}$ & $\begin{array}{l}\text { Fueled by anthracite culm, steam used to heat } \\
\text { greenhouses for year-round vegetable growing; } \\
\text { electricity sold to public utility }\end{array}$ \\
\hline $\begin{array}{l}\text { Pennsylvania State Prison } \\
\text { Power Plant, Frackville, Penn. }\end{array}$ & $\begin{array}{l}\text { Cogeneration, } \\
\text { circulating }\end{array}$ & NA & - & 186,364 & 42 & $1987, \mathrm{KDO}$ & Fueled by anthracite culm \\
\hline
\end{tabular}




\begin{tabular}{|c|c|c|c|c|c|c|c|}
\hline Facility and Location & $\begin{array}{l}\text { Application } \\
\text { and } \\
\text { Bed Mode }\end{array}$ & $\begin{array}{l}\text { Bed } \\
\text { Aręa } \\
\left(\mathrm{m}^{2}\right)\end{array}$ & $\begin{array}{l}\text { Coal Feed } \\
\text { Rate } \\
(t / h)^{b}\end{array}$ & $\begin{array}{l}\text { Steam } \\
\text { Capacity, } \\
\quad(\mathrm{kg} / \mathrm{h})\end{array}$ & $\begin{array}{l}\text { Electrical } \\
\text { Output } \\
\text { (MW) }\end{array}$ & $\begin{array}{l}\text { Start-up } \\
\text { Date and } \\
\text { Designer }\end{array}$ & Comments \\
\hline $\begin{array}{l}\text { Archer Daniels Midland Plant, } \\
\text { Decatur, Ill. }\end{array}$ & $\begin{array}{l}\text { Cogeneration, } \\
\text { circulating }\end{array}$ & NA & - & 193,182 & 30 & $1986, \mathrm{KDO}$ & Five units of the same size \\
\hline $\begin{array}{l}\text { Archer Daniels Midland Plant, } \\
\text { Cedar Rapids, Iowa }\end{array}$ & $\begin{array}{l}\text { Cogeneration, } \\
\text { circulating }\end{array}$ & NA & - & 216,818 & 46 & $1988, \mathrm{KDO}$ & Duplicate units of the same size \\
\hline $\begin{array}{l}\text { Scott Paper Company Mill, } \\
\text { Chester, Penn. }\end{array}$ & $\begin{array}{l}\text { Cogenerating, } \\
\text { circulating }\end{array}$ & NA & $\begin{array}{l}695 \mathrm{million} \\
\mathrm{Btu} / \mathrm{h}\end{array}$ & 295,455 & 65 & 1986, CEL & $\begin{array}{l}\text { Largest U.S. single-train circulating-bed } \\
\text { unit; designed to burn alternative solid, } \\
\text { liquid, and gaseous fuels }\end{array}$ \\
\hline $\begin{array}{l}\text { Schuylkill Resources } \\
\text { St. Nicholas Plant, } \\
\text { Mahanoy City, Penn. }\end{array}$ & $\begin{array}{l}\text { Cogeneration, } \\
\text { circulating }\end{array}$ & NA & 192 & 375,000 & 80 & 1990, CEL & Fueled by anthracite coal \\
\hline $\begin{array}{l}\text { Colorado-the Electrical Assn. } \\
\text { Nucla Station, Nucla, Colo. }\end{array}$ & $\begin{array}{l}\text { Utility, } \\
\text { circulating }\end{array}$ & NA & 552 & 420,455 & 55 & $1987, \mathrm{PA}$ & $\begin{array}{l}\text { Duplicate beds of the same size replacing a } \\
\text { 110-MW pulverized-coal boiler; EPRI will fund } \\
\text { a two-year test phase }\end{array}$ \\
\hline $\begin{array}{l}\text { Northern States Power Black } \\
\text { Dog Station, Burnsville, } \\
\text { Maine }\end{array}$ & $\begin{array}{l}\text { Utility, } \\
\text { bubbling }\end{array}$ & 169.5 & 67.4 & 472,273 & 130 & $1986, \mathrm{FW}$ & $\begin{array}{l}\text { Replacement of one of four parallel pulverized- } \\
\text { coal boilers; electrical output will increase } \\
\text { from } 125 \text { to } 131 \text { MW when turbine is replaced in } \\
1987 \text {; EPRI will fund test phase until } 1990\end{array}$ \\
\hline $\begin{array}{l}\text { TVA Shawnee Station } \\
\text { Demonstration Unit, } \\
\text { Paducah, Ky. }\end{array}$ & $\begin{array}{l}\text { Utility, } \\
\text { bubbling }\end{array}$ & 230.8 & 81.8 & 500,000 & 160 & $1989, \mathrm{CE}$ & $\begin{array}{l}\text { Design, installation, and testing funded by } \\
\text { TVA, EPRI, Kentucky, Combustion Engineering, } \\
\text { Fluor Constructors, } 7 \text { utilities, } 3 \text { coal } \\
\text { companies, and } 2 \text { railroads }\end{array}$ \\
\hline
\end{tabular}

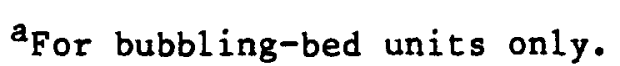

bxcept as noted otherwise.

${ }^{C_{K e y}}$ to abbreviations: $B W=$ Babcock and Wilcox Co.; $\mathrm{CE}=$ Combustion Engineering, Inc.; CEL = Combustion Engineering $/ \mathrm{Lurg} i$; FW $=$ Foster-Wheeler Energy Corp.; KDO = Keeler/Dorr-Oliver; PA = Pyropower Corp./Alstrom PyroflowE; RD = Rocketdyne Div., Rockwell International; and
WE = Wormser Engineering, Inc.

d Not applicable.

e The category "Industrial" includes space heating applications.

$\mathrm{f}_{\text {No electricity }}$ is generated; $20 \mathrm{MW}$ is the equivalent of the steam condensed.

Source: DOE (1988a). 
TABLE A.2 Coal-Technology Manufacturing and Research Organizations

A. Ahlstrom Corp.

Process Equipment Works

P.0. Box 137

SF-78201 Varkaus

Finland

$(+358) 72211$

4363 Alpro SF

$\mathrm{J}$. Neiminen

Sales Manager

A. Ahl strom Corp.

Boiler Works

P.O. Box 184

SF-78201 Varkaus

Finland

$(+358) 72211$

4319 Almek SF

Osmo Kaulamo

General Manager

A. Ahlstrom Corp.

Boiler Division

P.O. Box 329

SF-00101 Helsinski

Finl and

$(+358) \quad 0 \quad 16231$

124518 Altim SF

L. Bengtsson

Marketing Manager

Ahlstrom Products Ltd.

Ahlstrom House

Mill Street

Slough, Berkshire

SL2 5DD

UK

(+44) 753691464

David Miller

Sales Manager

ASEA PFBC AB

S-61220 Finspong

Sweden

(+46) 12281016

64045 Staval 5

$\mathrm{J}$. Hansson
ASEA Stal AB

MBC Boilers Division

S-58101 Linkoping

Sweden

(+46) $13 \quad 1294 \quad 00$

50068 Apparat $\mathrm{S}$

Haakan Stigander

Babcock \& Wilcox Co.

P.0. Box 351

20 S. Van Buren

Barberton, OH 44203

USA

(+1) $216 \quad 8602310$

98-6406 BANDWBARB

R.F. Johns

Manager, FB Program

Babcock Hitachi KK

Industrial Machinery Division

P.0. Box 201 Nippon B1dg.

Tokyo 100

Japan

(+81) 32707351

222-3502 BHK HONJ

S. Kawada

Deputy Division Manager

Babcock Power Ltd.

$156 \mathrm{Gt}$ Dover Street

London

SE1 4YB

UK

$(+44) 14078383$

884151

Babcock Worsley Ltd.

Liverpool Road

St. Helens, Merseyside

WA10 IPQ

UK

(+44) 744612111

627531

J. Miller/W.G. Worsley

Sales Engineer/Director 
TABLE A.2 (Cont'd)

Bergbau-Forschung GmbH

Franz-Ei scher-Weg 61

4300 Essen

Federal Republic of Germany

(+49) 2011059502

857830 berg d

Bharat Heavy Electricals Ltd.

Industrial Power Products Division

Tiruchirapalli 14

620014

India

$(+91) 84311$

K.T.U. Malliah

General Manager

British Gas Corp.

International Consultancy Services

326 High Holborn

London

WC1V 7PT

UK

(+44) 12420789

265812 ICS G

Burns \& Roe

550 Kinderkamack Road

Orade11, NJ 07649

USA

(+1) 2012652000

Carbogel $\mathrm{AB}$

16025

Helsingborg S-250 16

Sweden

(+46) 42262525

72841

E. Thomas

Project Manager

Cockerill Mechanical Inds.

Avenue Greiner 1

B 4100 Seraing

Belgium

(+32) $41 \quad 30 \quad 31 \quad 11$

41225 CKLSAMB

L. Codogno

Marketing Manager, Energy Division
Combustion Engineering

Business Development-7046

1000 Prospect Hill Road

Windsor, CT 06095

USA

(+1) 2032859973

23099297

Lewis Capicano

Product Manager

Combustion Systems Ltd.

CRE Stoke Orchard

Cheltenham, Gloucestershire

GL52 4RZ

UK

(+44) $24267 \quad 4339$

43568 CBCRE G

P. Mills

General Manager

Construction Navales et Industrielles de la Mediterranee (CNIM)

35 rue de Bassano

75008 Paris

France

Gerard Hue

Department of Coal Processing and Utilisation

Ministry of Coal Industry

Beijing

China

Liu Xinquan

Director Engineer

Deutsche Babcock Werke AG

Duisburgerstr. 575

D-4200 Oberhausen 1

Federal Republic of Germany

(+49) 2088332472

856951

Dow Chemical USA

2020 Dow Center

Midland, MI 48640

USA

(+1) $517 \quad 636 \quad 1000$ 
TABLE A.2 (Cont'd)

Electric Power Research Institute 3412 Hillview

Palo Alto, CA 94303

USA

(+1) 4152444

D.F. Spencer

VP, Advanced Power Systems

Energy Equipment Co. Ltd.

Stephenson House

Bletchley

Milton Keynes

MK 220X

UK

$(+44) 90874988$

826387

I. Pentland

Sales Director

Fives-Cail Babcock

Boiler Division

7 rue Montalivet

Paris F-75008

France

(+33) $14266 \quad 3525$

FCBPA $650328 \mathrm{~F}$

P. Cosar

Foster-Wheeler Development Corp.

12 Peach Tree Hill Road

Livingston, NJ 07039

USA

Hank Phillips

President

Foster-Wheeler

110 South Orange Avenue

Livingston, NJ 07039

USA

(+1) 2025331100

138568 or 138428

S. Winberg

Equipment Sales
Foster-Wheeler Energy Ltd.

FW House

Station Road

Reading, Berkshire

RG1 1LX

UK

(+44) 734585211

849171 FWRDG G

Foster-Wheeler Power Products Ltd.

Greater London Road

Hampstead Road

London

NW1 7QN

UK

(+44) 13881212

263984

B.J. Wenban

General Sales Manager

General Electric Co.

Energy Systems

River Road

Schenectady, NY 12345

USA

(+1) $518 \quad 385 \quad 2211$

Generator Industri

P.0. Box 2501

S-175 02 Jarfalla

Sweden

(+46) $758 \quad 50120$

11224 genexps

B. Tenn

Gilbert/Commonwealth Inc.

P.0. Box 1498

Reading, PA 19603

USA

Yongkee Ahn

Manager, Advanced Engineering

Gotaverken Energy Systems

Box 8734

S-41713 Gothenberg

Sweden

(+46) 31501000

2283 GOTAENYS

L. Lindeberg 
TABLE A.2 (Cont'd)

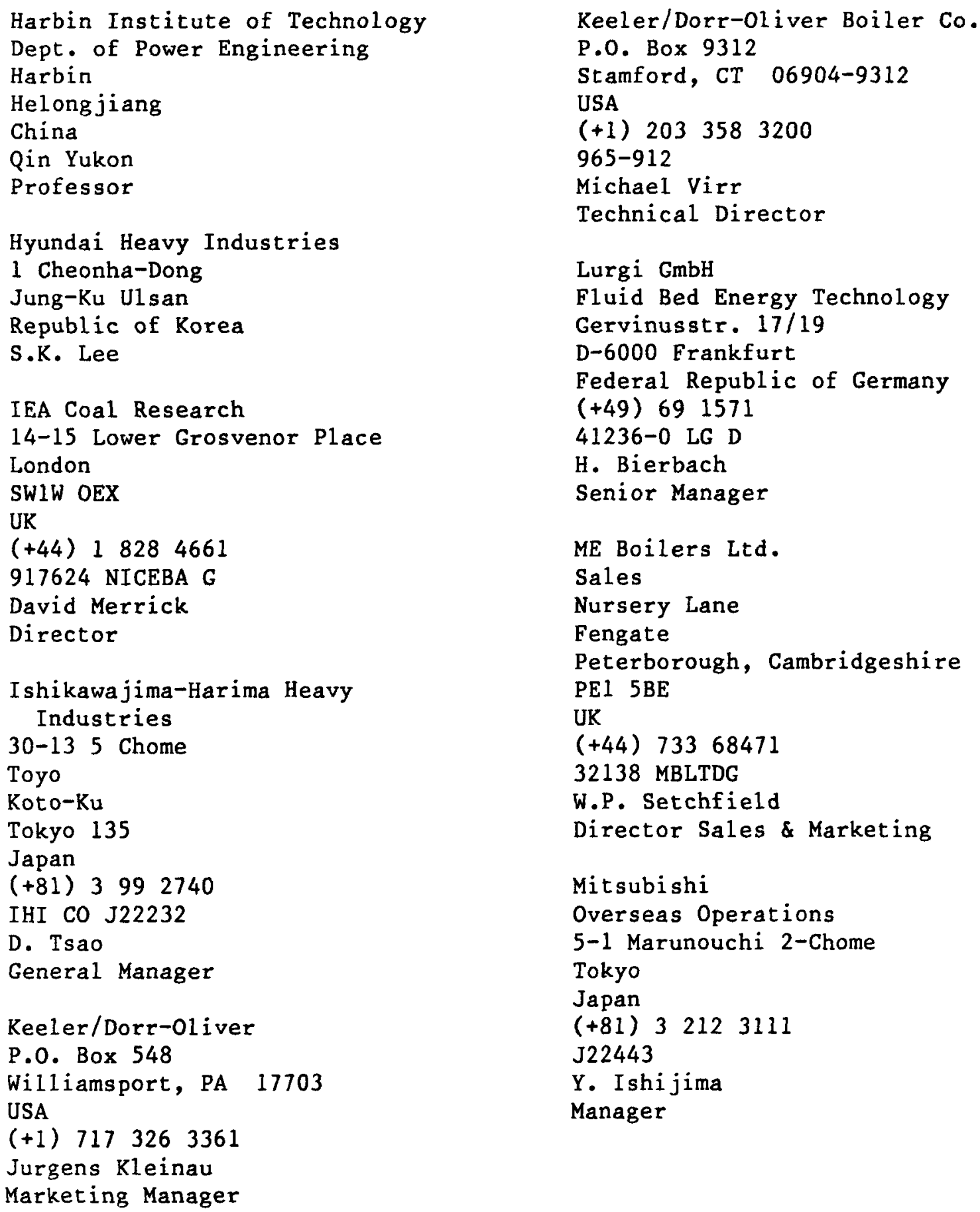


TABLE A.2 (Cont'd)

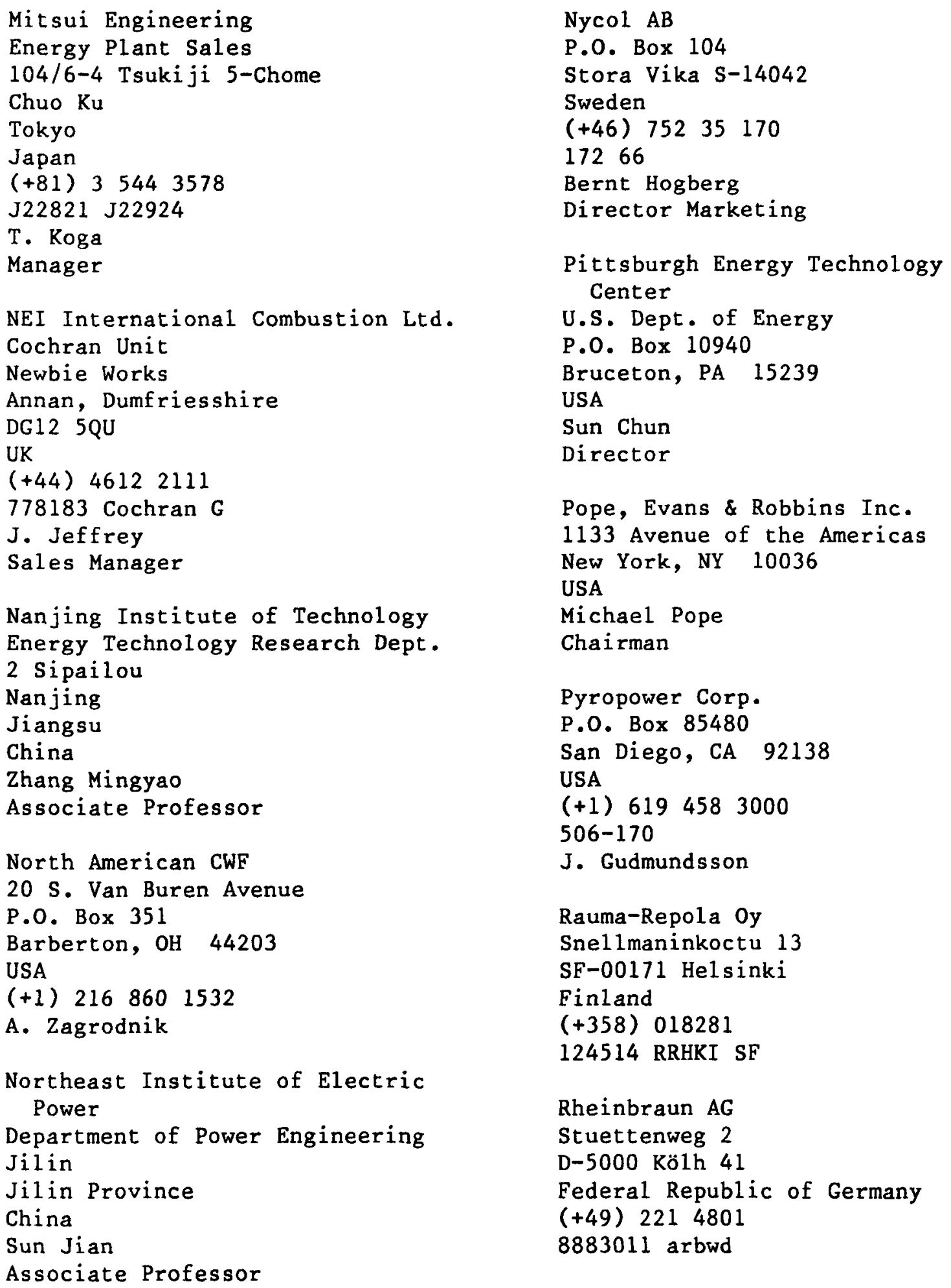


TABLE A.2 (Cont'd)

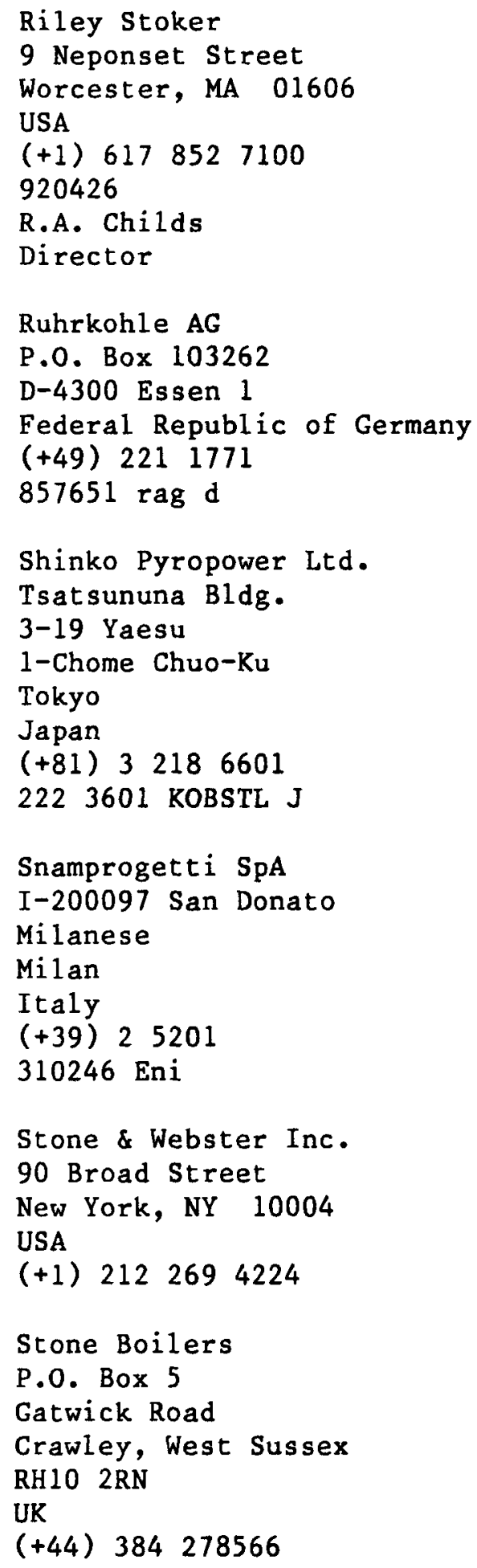

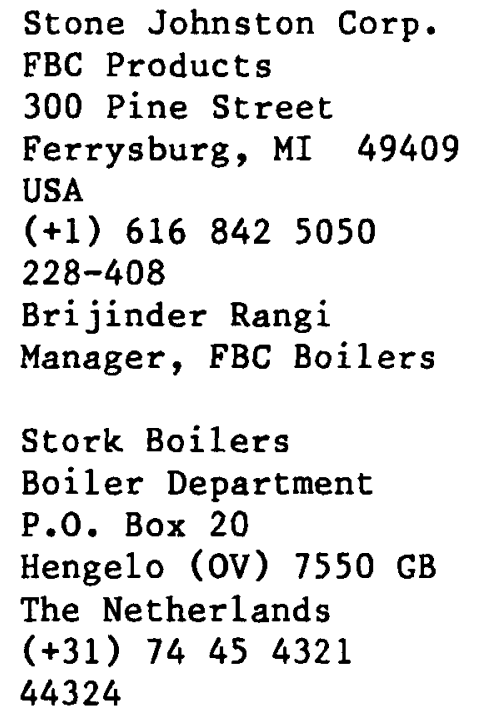

TRW Inc.

Combustion Business

R4-2204 One Space Park Redondo Beach, CA 90278 USA

(+1) 2132974550

258646 CTRW UR

Ronald Viani

Marketing Manager 
TABLE A.2 (Cont'd)

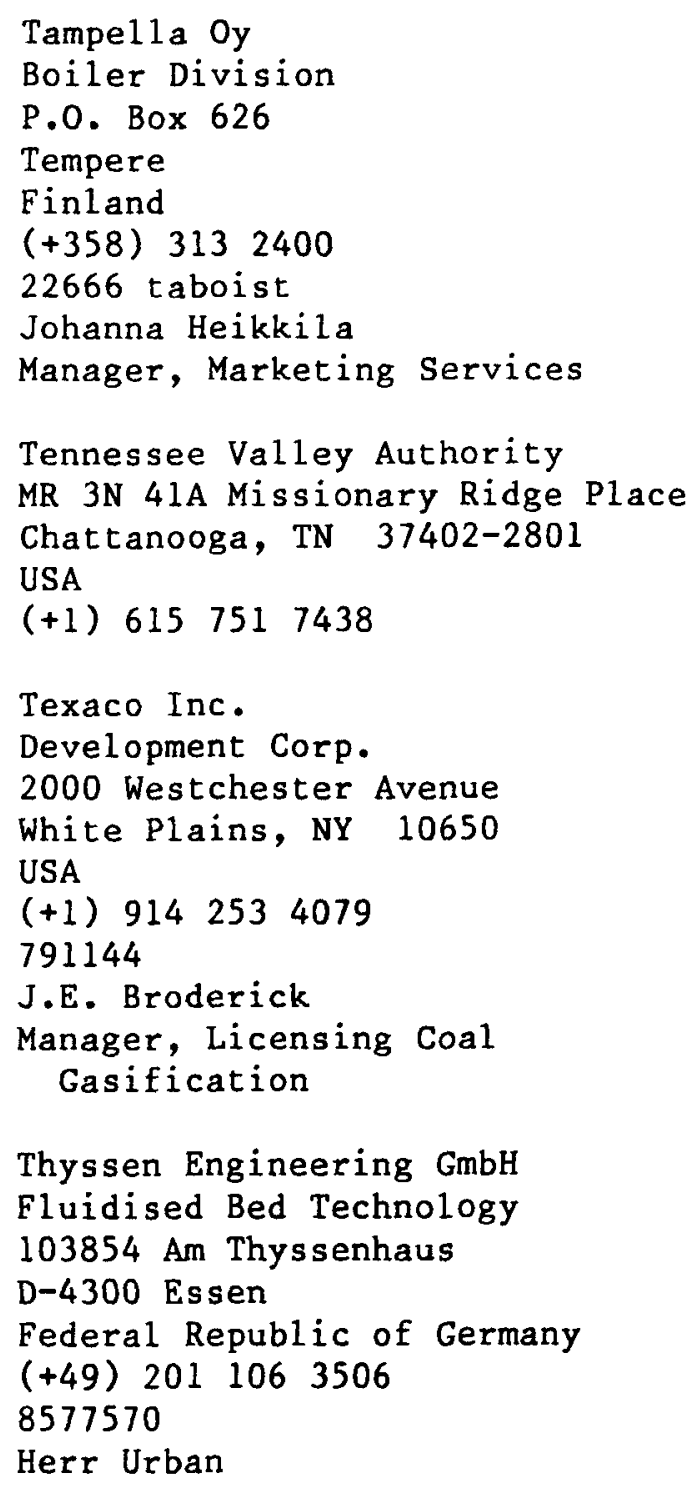

Tsinghua University

Department of Thermal Engineering

Beijing

China

Zhang Lianzhong

Vice Director

Vereinigte Kesselwerke AG

Dept. 413

Werdener 3

D-4000 Dusseldorf

Federa1 Repub1ic of Germany

$(+49) 2117814300$

8582729

K. Sturm

Wallsend Boilers UK

P.0. Box 2, Hadrian Road

Wallsend, Tyne and Wear

NE2 8 6NS

UK

$(+44) 912628395$

537837

A.E. Chadwick

Sales Manager

Westinghouse Electric Corp. Gateway Center

Pittsburgh, PA 15222

USA

(+1) 4122553800

Dale Keairns

Source: Patterson (1987) 


\section{A.5.2.1 Northern States Power - Black Dog Plant}

The Unit 2 boiler at the Black Dog plant near Minneapolis, Minnesota, has been converted to an atmospheric BFBC unit. Built in 1954, this pulverized-coal unit was originally designed to burn Illinois No. 6 coal and generate $100 \mathrm{MW}$. However, as a result of a decision to blend a low-sulfur coal with the Illinois bituminous coal, the unit was limited to an environmentally mandated $85 \mathrm{MW}$ in the 1970s. As part of the AFBC conversion, the unit was uprated to $130 \mathrm{MW}$, and its life expectancy was extended, by some estimates, another 25 years. In March 1989, the utility and EPRI began a threeyear test to look at maximum and minimum loads, fuels, and other characteristics.

The bubbling-bed configuration was based on extensive preliminary studies of numerous design elements. The basic philosophy was to maximize the use of existing equipment. Unit 2 received a three-cell, single-level fluidized bed with overbed-coal and limestone-feed systems. The unit was provided with overfire air ports above the furnace fuel inlets to help disburse coal fines and improve efficiency. Maximum bed superficial velocity was set at $10 \mathrm{ft} / \mathrm{s}$ to minimize the carryover of unburned coal and limestone. The lower furnace that makes up the AFBC unit was expanded horizontally with the addition of two wing cells to provide sufficient bed area based on the design fluidizedbed velocity. A new heating surface was installed on all four sides to enclose the beds, and the beds were bottom supported. This installation required only minimal modification to the boiler's support steel and reduced the complexity and cost of the coal- and limestone-feed systems. The boiler was converted from natural to forced circulation, and all remaining water-cooled, convection-pass, and furnace pressure components were modified accordingly.

Loading within the existing particulate-removal system was maintained at acceptable levels through fly-ash management, whereby a waste-handling system monitors the amount of fly ash reinjected into the furnace. In addition, precipitators were upgraded, and a new multicyclone mechanical dust collector was added between the boiler outlet and the air-heater inlet.

Flue gas is discharged to the atmosphere from Black Dog's common plant stack erected in the mid-1970s, when second-stage precipitators were added as part of plans to comply with more stringent flue-gas emission regulations. The conversion of the unit has resulted in a four-fold decrease in the $\mathrm{SO}_{2}$ emissions (compared with those reported before the retrofit). $\mathrm{NO}_{\mathrm{X}}$ emssions have been reduced by $50 \%$ (Power, 1987).

\section{A.5.2.2 Tennessee Valley Authority - Shawnee Power Station}

In cooperation with EPRI, the State of Kentucky, Duke Power, Combustion Engineering, DOE, and the AFBC Development Corp., the TVA has designed a bubblingbed boiler to replace Unit No. 10 at its Shawnee power station in Paducah, Kentucky. The boiler, nominally rated at $160 \mathrm{MWe}$, uses the existing steam turbine and electrical system of Unit No. 10. The furnace of the unit is divided into six firing zones that can be fired independently to accomplish good boiler turndown. The superheater surface was installed in the bed and convection heat-transfer zone, and all reheat and economizer surface is in the convection zone. A regenerative air heater that reduces flue-gas 
temperature to $270^{\circ} \mathrm{F}$ is used. Two cyclones are located upstream of the air heater to separate the unburned carbon and elutriated bed material/limestone and to recycle this latter material to the furnace. Gas from the top of the cyclone passes through the fabric bag filter to the stack.

The Combustion Engineering-designed coal/limestone-feed system was tested at the 20-MWe pilot plant and demonstrated satisfactory performance using Kentucky No. 9 bituminous coal (discussed below). However, following start-up in October 1988 at the demonstration plant, significant and persistent problems in the solids-handling systems were experienced. Modifications to feed valves, tank side-slope, and vent systems have resulted in improved performance. The TVA reported in May 1990 that a $62 \%$ capacity factor and an average load of $127 \mathrm{MW}$ had been achieved and sustained for 32 days before the plant was taken down for minor repairs (Electric Utility Week, 1990).

An extended commercial-demonstration run following the four-year test program is planned. Commercial operation for six years is also planned, which will result in a total of 10 years of data on this project.

\section{A.5.2.3 ASEA Stal - Sweden*}

The Swedish engineering firm of ASEA Stal, under former corporate names, entered FBC research in the early 1970s. One innovative design produced the multi-bed combustor, in which the lower bed is fluidized by primary air from a plenum below the bed bottom (as usual), and the upper bed is fluidized by the combustion gases from the lower bed (above which an appropriate flow of secondary air has been injected). Coal is fed into the base of the lower bed, after being dried, crushed, and injected pneumatically. The lower bed operates at a temperature of $900-950^{\circ} \mathrm{C}$, the upper bed at about $850^{\circ} \mathrm{C}$. The combustor has membrane water walls, and the bed bases are water cooled. About $50-60 \%$ of the total output of the unit is removed by tubing immersed in the lower bed.

The dual-bed configuration enhances the opportunity for emission control. Twostage combustion minimizes the excess oxygen available, which would otherwise form

$\mathrm{NO}_{\mathrm{x}}$. The sulfur that leaves the lower bed is captured in the limestone in the bed above. The multi-bed arrangement allows the achievement of a combustion efficiency of 97-98\%, while substantially reducing the freeboard volume above the beds.

Under secrecy, ASEA Stal built its first multi-bed unit -- a 2-MW demonstrationpilot plant -- at Linkoping, Sweden, in 1980-1981 and tested it using different fuels. It performed well, and some orders followed. A unit was ordered in January 1983 and put into service in November 1983; this was a 10-MW hot-water boiler used in a districtheating project in Nykoping, Sweden, which converted from oil to coal firing.

*Information for Secs. A.5.2.3-A.5.2.7 and A.5.2.9-A.5.2.11 is from Patterson (1987) unless otherwise indicated. 
ASEA Stal installed a 20-MW unit for the Timfors paper mill in Sweden and four units for the U.S. food-processing firm of Archer Daniels Midland at sites in Minnesota, Nebraska, Illinois, and Iowa; their sizes ranged from 26 to $49 \mathrm{MW}$. The Timfors unit was installed in the original boiler house, and the whole plant is controlled by a computer from a single visual-display unit and keyboard, manned only intermittently by one operator. With the addition of a turbine, the unit is expected to provide not only process steam but also electricity. The unit has burned coals from Poland, the Soviet Union, Australia, and the United States. The suggested module size is $10 \mathrm{MW}$, with suggested applications of 10-100 MW.

\section{A.5.2.4 Deutsche Babcock/Vereinigte Kesselwerke - FRG}

After the international family of boiler manufacturers founded by G.H. Babcock and Stephen Wilcox in the late 19 th century went their separate ways, the Deutsche Babcock Group grew into one of the largest engineering companies, not only in the FRG but in the world. One of its operating units, Deutsche Babcock Werke, with its industrial collaborators (especially the boiler manufacturer, Vereinigte Kesselwerke), has been involved in most of the major FBC projects in the FRG.

One such project was the conversion of the Flingern power plant near Dusseldorf to BFBC firing. With government funding, Deutsche Babcock and Vereinigte Kesselwerke retofitted a 35-MWt unit in September 1979. Although the combustion efficiency was improved, the coal-handling equipment and ash-removal system presented new problems.

Vereinigte Kesselwerke built two coal-fired plants at the Volklingen site of the mining company, Saarbergwerke, in the Saar -- a 5-MWt pilot plant followed by an 80-MWt demonstration plant. The Volklingen design combined BFBC and pulverized coal firing. A tall, central, combustion chamber for pulverized coal is flanked on either side by BFBC units. The central section burns high-quality pulverized coal, while the BFBC units burn high-ash, low-grade rejects from the coal-preparation process. These BFBC units have air-heater tubing in the beds. The hot air is expanded through a gas turbine and fed to the pulverized-coal burners and the bases of the BFBC units at $440^{\circ} \mathrm{C}$ as preheated combustion air. The hot combustion gases from the BFBC units are fed into the bottom of the central combustor, where any entrained fuel in the gases is burned. The hot gases from the central combustor then enter convection passes at the top of the combustor (just like those in a conventional pulverized-coal plant) to raise steam for a steam turbine. The Volklingen pilot plant started up in 1980, and the demonstration began two years later.

In 1981, Deutsche Babcock built a 35-MWt BFBC unit at the Westfalen mine near Dortmund. The Westfalen unit burns high-ash flotation wastes from coal-cleaning to raise process steam for the coal mine. The waste coal is blended with limestone and with the fly ash recovered from the flue gases.

When Atlas Consolidated Mining and Development Corp. decided to convert its Sangi power plant in Cebu, Philippines, to burn domestic high-ash coal or wood, Vereinigte Kesselwerke won the contract. It supplyed two units, each delivering $137 \mathrm{MWt}$. Each unit has a bed that is $72 \mathrm{~m}^{2}$ in area and divided into four 
compartments. The units contain evaporator tubes; underbed pneumatic feeding of blended coal and crushed limestone; overbed feeding of lump coal and wood by four spreaders; water-wall construction of the combustion chamber; the usual convection passes for evaporation, superheat, and reheat plus an air heater to preheat combustion air; cyclones with hot-ash coolers; and a baghouse before the stack. When the Cebu plant started up in 1982-1983, it was the largest FBC plant in the world.

Physically similar to the Cebu units, the Vereinigte Kesselwerke-built Afferde BFBC unit in Hameln, FRG, started up in 1983 and entered service in 1984. This Afferde plant generated not only electricity for the surrounding region but also steam for a district-heating network that supplies about $40 \%$ of the heat load of Hameln. The Affered bed is divided into six compartments that are independently fluidized and fueled, allowing turndown to $30 \%$ of maximum. The unit's output of $128 \mathrm{MWt}$ is used for cogeneration of electricity and heat.

Another BFBC plant was built in 1983 for Hannover-Braunschweigische Stromversorgungs AG at Luneburg-Nord. It includes a fuel storage and processing system; a water treatment system; two BFBC steam generators, each delivering $7 \mathrm{MW}$ of steam; a flue-gas cleanup system; an ash-handling and disposal system; two 1.3-MW condensing turbo alternators; two heat exchangers that transfer heat from the condensers to the district-heating network; and a hot-water generator fired by natrual gas to cover low and peak loads. The design anticipates later expansion of LuneburgNord by $10 \mathrm{MW}$.

A Vereinigte Kesselwerke licensee, Rauma Repola of Finland, built another $\mathrm{BFBC}$ unit. It is a $36-\mathrm{MW}$ coal-fired plant constructed for the major Finnish electrical utility, Imatran Voima OY, at Lohia in Finland. It started up in 1986.

\section{A.5.2.5 Thyssen/Standard Kessel - FRG}

Thyssen began constructing FBC incinerators for awkward industrial sludges and other waste materials in the early 1960s. Many of these units incorporated heat recovery systems for the production of hot water, steam, and electricity. When government funding became available for FBCs in the 1970s, Thyssen joined forces with the boilermaker, Standard Kessel, to carry out an experimental BFBC retrofit of the 6-MW Konig Ludwig coal-fired plant for Ruhrkohle. This plant, started in 1979, provided data for a dozen BFBC plants in the FRG, France, the Netherlands, Turkey, and the United States, which are fired with coal, lignite, bark, waste oil, or industrial sludges and have capacities of up to $40 \mathrm{MW}$.

A typical Thyssen/Standard Kessel BFBC unit is the 18-MW cogeneration plant at the Parenco paper mill at Renkum in the Netherlands. The boiler, the auxiliary equipment, and the building to house it were constructed in 16 months, with startup in 1983. The BFBC unit operates in tandem with an existing gas-turbine cogeneration unit; the BFBC unit adds $22 \mathrm{t} / \mathrm{h}$ of steam to that supplied by the boilers, recovering heat from the gas turbine. Operation training for the staff was completed in three weeks. 


\section{A.5.2.6 Peoples' Republic of China}

In January 1981 in Atlanta, Georgia, a delegate from the PRC informed the audience at the Sixth International Conference on Fluidized-Bed Combustion that 2000 FBC plants were operating in China. This astounding revelation initiated an exchange of information and visits.

Because Chinese coal has a high ash content (up to $70 \%$ ), it is effectively impossible to burn it in a conventional stoker-fired system and very inappropriate to burn it as pulverized fuel. It can be burned quite easily, however, in a fluidized bed. More than 1600 FBC plants in the PRC are fired with stone-like coal to provide industrial and residential heat and steam. Another 400 or more burn ordinary bituminous coal or lignite.

In the mid-1960s, domestic coal of adequate quality for stoker firing fell into short supply. Many small stoker-fired boilers were accordingly retrofitted with indigenous Chinese FBC designs, which were less sensitive to fuel specifications and could burn low-quality coal that was locally available. Despite its lack of automated and computerized control systems (like those of Western units), the PRC technology appears to be essentially equivalent to Western BFBC technology. However, the large-scale commitment to FBC has been directed exclusively to the use of low-grade fuel; the control of emissions has not yet been factored into the design. Neverthless, the use of $B F B C$ in the PRC is quite extensive. This fact is demonstrated in Table A.3, which lists all known industrial AFBCs as of November 1986 (Thomas, Gregory, and Takayasu, 1986).

\section{A.5.2.7 Ahlstrom - Finland}

One of Ahlstrom's major activities, pulp and paper processing, prompted its initial involvement in FBC. Because the raw material, wood (the traditional Finnish fuel), was becoming more valuable, Ahlstrom began work on BFBC in 1968 as a way to incinerate process sludges and other wastes high in water content. A pilot BFBC plant was built at what was then the Hans Ahlstrom Laboratory (currently Ahlstrom's R\&D center). By 1975, Ahlstrom engineers had pursued the bubbling mode to its velocity limit and began to investigate higher fluidizing velocities. This work led to circulating fluidized-bed combustion (CFBC), with Ahlstrom designating the tradename "Pyroflow" for its process.

The first Ahlstrom Pyroflow CFBC unit was a 15-MWt retrofit at Ahlstrom's Pihlava board mill in Finland. It began operation in 1979 and has been essentially in continuous service ever since. A larger unit was installed at a paper mill at Kauttua, Finland; it started up in 1981 with an output of $65 \mathrm{MWt}$, generating electricity and supplying process steam for the plant. When the Kauttua unit came on stream, it was the largest FBC unit in operation in the world. After shakedown, the Kauttua unit's average annual availability was recorded at more than $96 \%$. It became the model and test facility for a family of Pyroflow plants -- more than 50 -- in Austria, Canada, the FRG, Finland, France, South Korea, Sweden, and the United States. 
TABLE A.3 Industrial Atmospheric Fluidized-Bed Combustors

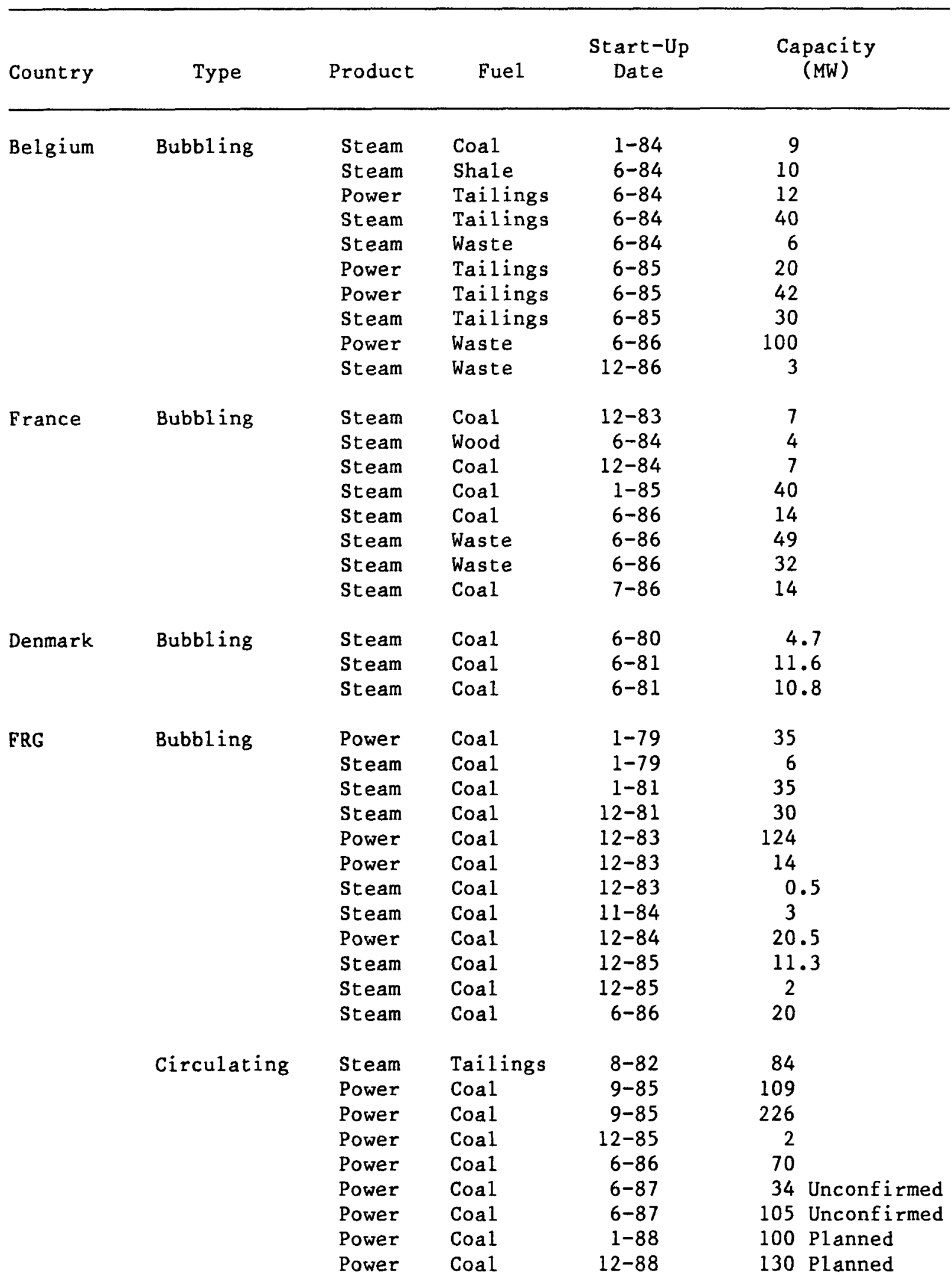


TABLE A.3 (Cont'd)

\begin{tabular}{|c|c|c|c|c|c|}
\hline Country & Type & Product & Fuel & $\begin{array}{l}\text { Start-Up } \\
\text { Date }\end{array}$ & $\begin{array}{l}\text { Capacity } \\
\text { (MW) }\end{array}$ \\
\hline $\begin{array}{l}\text { FRG } \\
\left(\text { Cont }^{\prime} d\right)\end{array}$ & Circulating & $\begin{array}{l}\text { Power } \\
\text { Power }\end{array}$ & $\begin{array}{l}\text { Coal } \\
\text { Coal }\end{array}$ & $\begin{array}{l}12-88 \\
12-88\end{array}$ & $\begin{array}{l}294 \text { Planned } \\
148 \text { Planned }\end{array}$ \\
\hline Italy & Bubbling & $\begin{array}{l}\text { Steam } \\
\text { Power }\end{array}$ & $\begin{array}{l}\text { Coal } \\
\text { Coal }\end{array}$ & $\begin{array}{r}6-82 \\
12-99\end{array}$ & $\begin{array}{l}1.5 \\
270 \text { Planned }\end{array}$ \\
\hline Japan & Bubbling & $\begin{array}{l}\text { Steam } \\
\text { Power } \\
\text { Steam } \\
\text { Power } \\
\text { Steam } \\
\text { Steam } \\
\text { Steam } \\
\text { Power } \\
\text { Power } \\
\text { Steam } \\
\text { Steam } \\
\text { Power } \\
\text { Steam } \\
\text { Power } \\
\text { Steam } \\
\text { Steam } \\
\text { Steam } \\
\text { Steam } \\
\text { Steam } \\
\text { Steam } \\
\text { Power } \\
\text { Power } \\
\text { Steam } \\
\text { Power } \\
\text { Power }\end{array}$ & $\begin{array}{l}\text { Tailings } \\
\text { Coal } \\
\text { Coal } \\
\text { Waste } \\
\text { Coal } \\
\text { Coal } \\
\text { Waste } \\
\text { Coal } \\
\text { Coal } \\
\text { Coal } \\
\text { Coal } \\
\text { Petcoke } \\
\text { Tailings } \\
\text { Coal } \\
\text { Coal } \\
\text { Coal } \\
\text { Waste } \\
\text { Waste } \\
\text { Waste } \\
\text { Coal } \\
\text { Coal } \\
\text { Coal } \\
\text { Coal } \\
\text { Coal } \\
\text { Coal }\end{array}$ & $\begin{array}{r}6-80 \\
3-81 \\
6-81 \\
5-82 \\
6-82 \\
6-83 \\
6-83 \\
10-83 \\
6-84 \\
6-84 \\
6-84 \\
6-84 \\
6-84 \\
3-85 \\
6-85 \\
6-85 \\
6-85 \\
6-85 \\
6-85 \\
6-86 \\
9-86 \\
6-87 \\
6-87 \\
1-95 \\
12-99\end{array}$ & $\begin{array}{l}6 \\
15 \\
13 \\
1.5 \\
20 \\
80 \\
28 \\
2 \\
125 \\
40 \\
2 \\
60 \\
7 \\
3 \\
40 \\
40 \\
5 \\
32 \\
39 \\
72 \\
50 \\
50 \text { Unconfirmed } \\
160 \text { Unconfirmed } \\
350 \text { Planned } \\
-- \text { Planned }\end{array}$ \\
\hline & Circulating & $\begin{array}{l}\text { Steel } \\
\text { Power }\end{array}$ & $\begin{array}{l}\text { Resid } \\
\text { Coal }\end{array}$ & $\begin{array}{l}1-84 \\
6-86\end{array}$ & $--500 \mathrm{~kg} / \mathrm{d}$ \\
\hline $\begin{array}{l}\text { Nether- } \\
\text { lands }\end{array}$ & Bubbling & $\begin{array}{l}\text { Steam } \\
\text { Power } \\
\text { Power } \\
\text { Steam } \\
\text { Power }\end{array}$ & $\begin{array}{l}\text { Coal } \\
\text { Coal } \\
\text { Waste } \\
\text { Coal } \\
\text { Coal }\end{array}$ & $\begin{array}{l}6-82 \\
7-83 \\
1-84 \\
6-84 \\
6-85\end{array}$ & $\begin{array}{r}7 \\
35 \\
18 \\
2 \\
80\end{array}$ \\
\hline
\end{tabular}


TABLE A.2 (Cont'd)

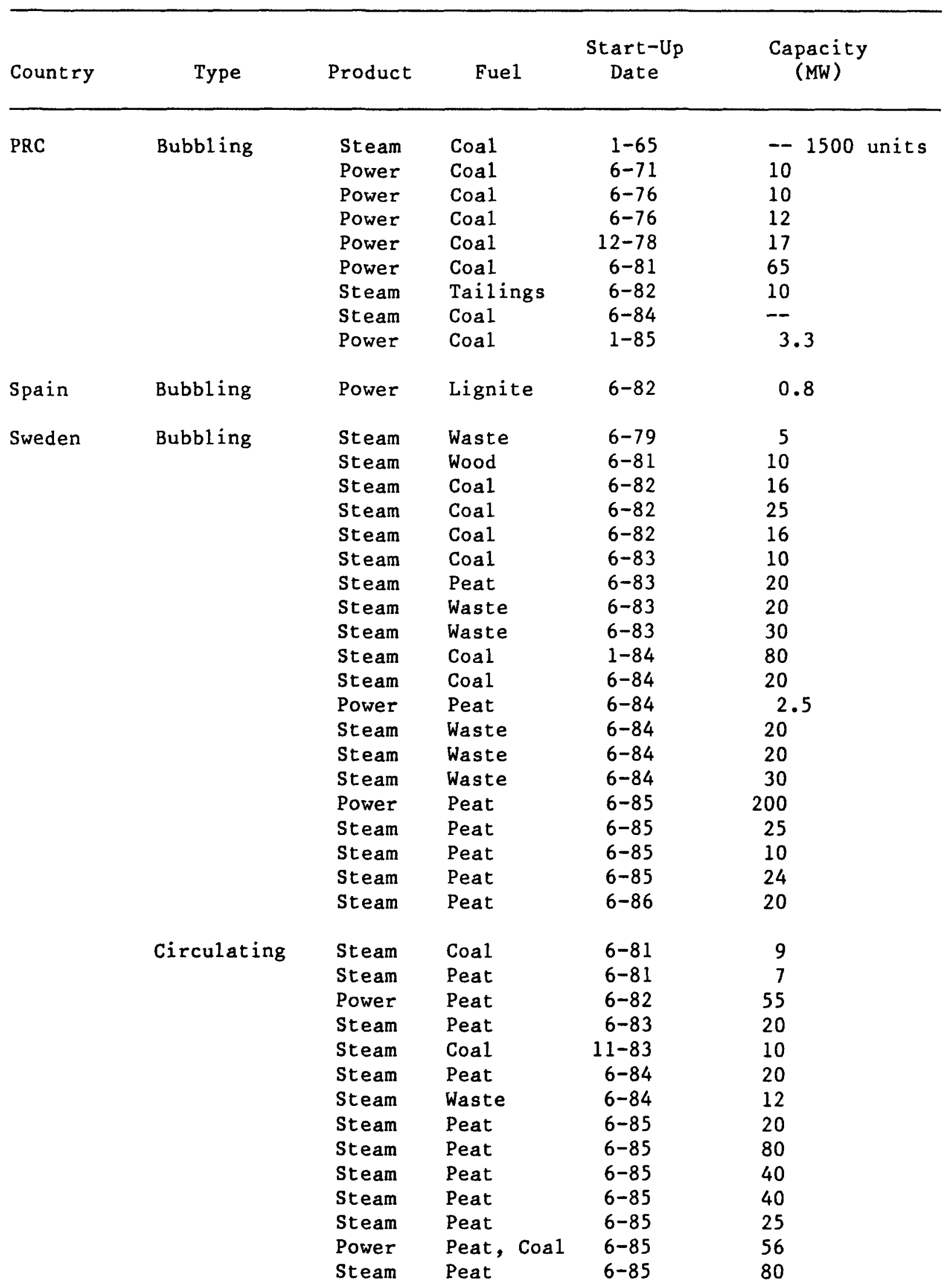


TABLE A.3 (Cont'd)

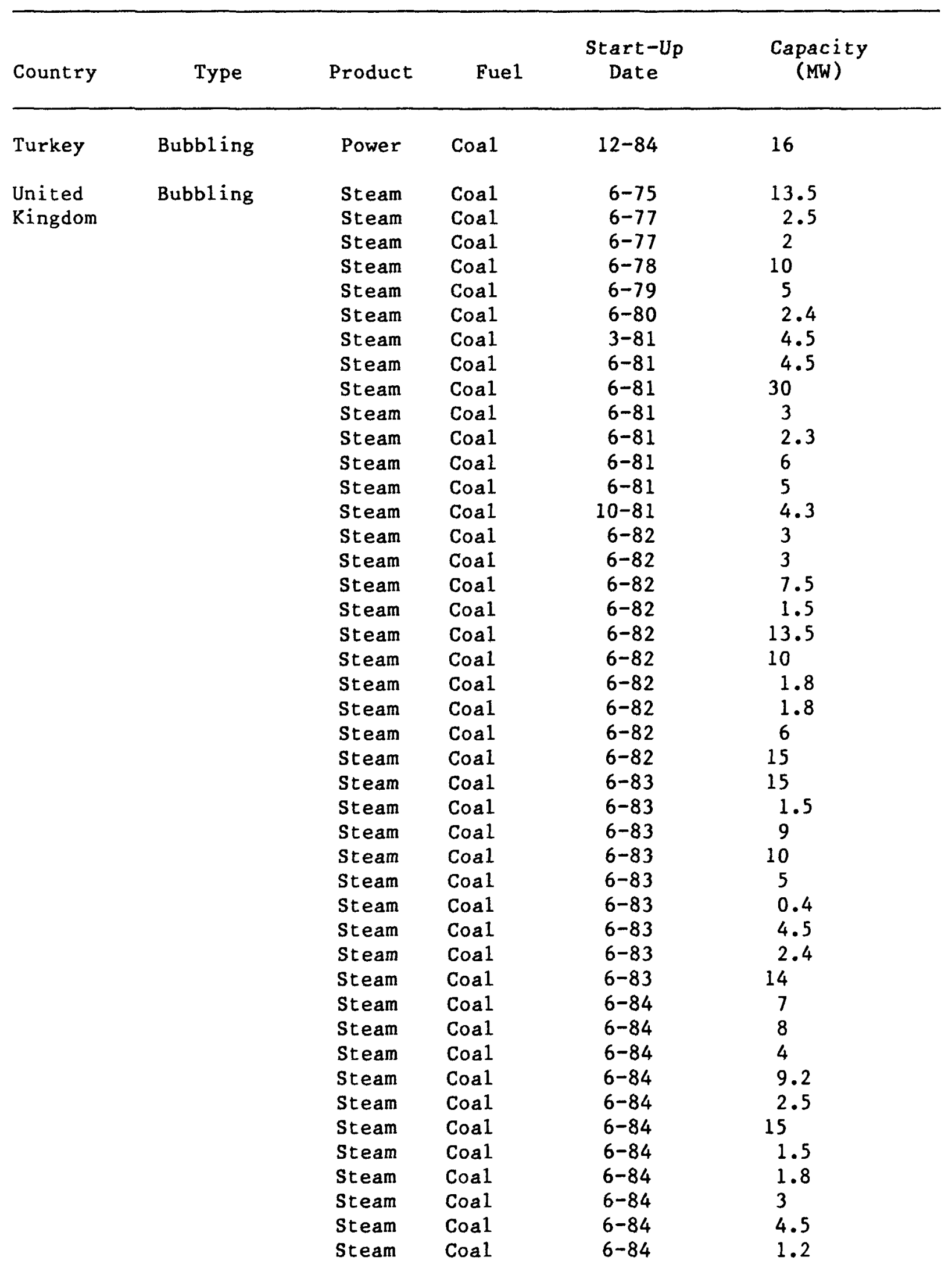


TABLE A.3 (Cont'd)

\begin{tabular}{|c|c|c|c|c|c|}
\hline Country & Type & Product & Fuel & $\begin{array}{c}\text { Start-Up } \\
\text { Date }\end{array}$ & $\begin{array}{l}\text { Capacity } \\
\text { (MW) }\end{array}$ \\
\hline $\begin{array}{l}\text { United } \\
\text { Kingdom } \\
\text { (Cont'd) }\end{array}$ & & $\begin{array}{l}\text { Steam } \\
\text { Steam } \\
\text { Steam } \\
\text { Steam } \\
\text { Steam } \\
\text { Steam } \\
\text { Steam } \\
\text { Steam } \\
\text { Steam } \\
\text { Steam } \\
\text { Steam } \\
\text { Steam } \\
\text { Steam } \\
\text { Steam } \\
\text { Steam } \\
\text { Steam }\end{array}$ & $\begin{array}{l}\text { Coal } \\
\text { Coal } \\
\text { Coa1 } \\
\text { Coal } \\
\text { Coa1 } \\
\text { Coa1 } \\
\text { Waste } \\
\text { Coal } \\
\text { Coa1 } \\
\text { Coal } \\
\text { Coa1 } \\
\text { Coal } \\
\text { Coal } \\
\text { Coal } \\
\text { Coal } \\
\text { Coal }\end{array}$ & $\begin{array}{r}2-85 \\
6-85 \\
6-85 \\
6-85 \\
6-85 \\
6-85 \\
6-85 \\
10-85 \\
10-85 \\
10-85 \\
12-85 \\
1-86 \\
1-86 \\
1-86 \\
6-86 \\
10-86\end{array}$ & $\begin{array}{l}3.5 \\
15 \\
30 \\
12.5 \\
3 \\
12 \\
23 \\
15 \\
10 \\
15.6 \\
25 \\
42 \\
4 \\
100 \\
128 \\
48\end{array}$ \\
\hline & Circulating & Power & Waste & $12-99$ & 75 Planned \\
\hline
\end{tabular}

Source: Thomas, Gregory, and Takayasu (1986).

A typical Pyroflow unit has a tall combustion chamber of water-wall construction; the lower part of the chamber is lined with refractory. Fuel and limestone are fed into the lower part of the chamber. Primary fluidizing air is injected low in the chamber; secondary air is injected at higher points, depending on the detailed operating requirements. Injection of air at different heights leads to staged combustion, such that the excess of oxygen at each stage is limited, which minimizes the tendency for $\mathrm{NO}_{x}$ to form. The hot gases, with their burden of solids, pass out of the combustion chamber at the top and into a heavy-duty, high-temperature cyclone, which extracts almost all the solids. The gases then pass through a superheater bank, down through a reheater bank, and finally through an air heater to preheat the fluidizing air. From these convection passes, the gases are led into an ESP, and discharged through a stack to the atmosphere. Tests at the Kauttua unit showed a precipitator efficiency of $99.7 \%$.

The Kauttua unit was designed to burn wet biofuels, peat, and wood waste; coal was to be used only as a support fuel in the event that the other fuel was too wet. However, after 1000 hours of firing using imported British coal containing up to $2.5 \%$ sulfur, the measured combustion efficiency was above 98.5\%. Emission tests demonstrated that a calcium-to-sulfur ratio of 1.8 to 1 sufficed to capture $90 \%$ of the sulfur in this coal. $\mathrm{NO}_{\mathrm{x}}$ emissions varied between 25 and $250 \mathrm{ppm}$, depending on combustion temperature. 


\section{A.5.2.8 Colorado-Ute Electric Association - Nucla Station}

The decision to upgrade the mothballed Nucla Station with Pyropower Corp.'s Ahlstron Pyroflow steam generator stemmed partly from the opportunity to sponsor the $\$ 86$ million project as a utility demonstration and obtain the financial participation of several organizations. In all, 23 organizations have donated time and money to the Nucla project (Electric Light and Power, 1987).

As a result of this upgrade, the plant's capacity has tripled from 36 to $110 \mathrm{MW}$. The Pyropower CFBC boiler upgrade consists of two identical parallel combustors with a total output capacity of $291 \mathrm{MWt}$. The new boiler, rated at $925,000 \mathrm{lb} / \mathrm{h}$ of steam, was built next to the existing plant. The new boiler supplies steam to a new 75-MW turbine and to three original 12-MW units. Refractory-lined cyclone separators are provided downstream of the furnace. Mixing of the gas occurs downstream of the two cyclone separators. Solids, including unburned carbon and unused limestone, return to the combustion chambers via a nonmechanical loop seal located at the bottom of the cyclones. Flue gas flows through the convective heat transfer sections, tubular air heater, and fabric filters to the stack. A new baghouse is used with the three existing baghouses to remove particles from the flue gas. The CFBC boiler is designed to burn local coal, which is low in sulfur and high in ash.

After attaining full capacity in March 1989, an extensive two-year utilityoriented test phase began. However, having defaulted on its loans (Chicago Tribune, 1990a), the Colorado-Ute Electric Association may not be able to proceed without additional assistance.

\section{A.5.2.9 Lurgi - FRG}

Lurgi engineers believed CFBC to be better suited to large-scale applications than either BFBC or PFBC. They thought that large-scale BFBC would require a very large bed area and give rise to inadequate mixing, whereas $\mathrm{PFBC}$ would require wearresistant gas turbines and an exacting hot-gas cleanup. CFBC also was thought to offer the long residence time necessary for high combustion efficiency using low-grade fuels.

In the late 1970s, Lurgi built a small CFBC unit and a 1.5-MWt CFBC pilot plant at its main facilities in Frankfurt. Tests on the pilot plant demonstrated that Lurgi CFBC could meet the most stringent FRG emission-control standards. At the normal combustion temperature of $850^{\circ} \mathrm{C}$ and while the unit was fluidized with $40 \%$ primary air and $60 \%$ secondary air, $\mathrm{NO}_{\mathrm{x}}$ was kept at $200 \mathrm{mg} / \mathrm{m}^{3}$. When domestic coal with a calcium-to-sulfur ratio of about 1.5 to 1 was burning, $\mathrm{SO}_{\mathrm{x}}$ was restricted to about $200 \mathrm{mg} / \mathrm{m}^{3}$.

Lurgi's first industrial CFBC plant was an 84-MWt unit at Vereinigte AluminiumWerke in Luenen. It started up in 1982 , burning $23 \mathrm{t} / \mathrm{h}$ of waste coal containing $60 \%$ ash and $2 \%$ sulfur. Since shakedown, the unit has been essentially in continuous service. By July 1985, its cumulative availability, including commissioning and all outages, was 90\%. What is remarkable about the unit is that the tubes in its fluidized-bed heat exchanger carry not water but molten salt, heated to $425^{\circ} \mathrm{C}$ for the aluminum process. 
The CFBC unit also delivers $50 \mathrm{t} / \mathrm{h}$ of steam to an existing power station on the site. Ash removed from the main combustion chamber is cooled when it passes through a second heat exchanger that preheats process water. Lurgi claims that the tubes in the convection pass show no sign of wear, despite the ash burden of the gases.

The success of the Luenen plant led to orders for larger CFBC cogeneration plants for the cities of Duisburg (226 MWt) and Flensburg (109 MWt). Depending on the load required, the Duisburg plant can supply $96 \mathrm{MW}$ of electricity or $138 \mathrm{MWt}$ for district heating (enough for 20,000 houses) plus $65 \mathrm{MW}$ of electricity. For more than a year, the Duisburg unit was the largest operating CFBC power plant in the world; in mid-1987, it slipped to second place with the startup of the Nucla CFBC unit in Colorado. The Flensburg unit, feeding a back-pressure turbine, supplies $72 \mathrm{MWt}$ for district heating plus $36 \mathrm{MW}$ of electricity. The Flensburg unit will burn almost any coal available, including dried lignite. Although both the Duisburg and Flensburg units are sited in urban areas, their emissions are well within the required restrictions.

Outside the FRG, Lurgi has been working jointly with the U.S. firm of Combustion Engineering on three other CFBC plants: (1) a 204-MWt unit for the U.S. pulp and paper manufacturer, Scott Paper, at its mill in Chester, Pennsylvania; (2) a 96-MWt unit for Westwood Energy in Pennsylvania to burn anthracite-washery waste; and (3) a 70-MWt lignite-fired CFBC plant for Ione Energy in California to supply electricity to Pacific Gas \& Electric and steam and hot air to American Lignite. Lurgi is also building a 70-MWt steam generator for New Brunswick Electric Power in Canada. It is being promoted by the Canadian government as a plant to demonstrate CFBC technology as applied to various Canadian fuels.

\section{A.5.2.10 Keeler/Dorr-Oliver - United States}

Keeler/Dorr-Oliver, a wholly owned subsidiary of Standard Oil of Ohio, combines more than a century of boilermaking expertise with experience in fluidized-bed technology dating back decades. Its experience began with $\mathrm{BFBC}$, when it designed and constructed a BFBC industrial unit at Shamokin, Pennsylvania, to demonstrate the burning of anthracite culm, the pit spoil from anthracite mines. The Shamokin unit came on stream in 1981 , generating $23,400 \mathrm{lb} / \mathrm{h}$ of low-pressure process steam for a local paper mill. By 1984, four more Keeler/Dorr-Oliver boilers had started up -- one in WilkesBarre, Pennsylvania, burning culm for district heating; two in Clairvivre, France, burning coal and wood for district heating; and one in Lima, Ohio, for Sohio, burning bituminous coal for refinery process steam.

By 1985, in only 10 months, Keeler/Dorr-Oliver had designed, built, and commissioned a $\$ 3$ million CFBC plant at the company's headquarters in Williamsport, Pennsylvania. The basic design is similar to that of other CFBC units, but the operating conditions are distinctive. The main combustion chamber, more than 20 meters high, has membrane water walls. A dense bed about a meter deep, operating in a bubbling mode, is fluidized with primary air from a plenum at the bottom of the chamber. This dense bed operates under reducing conditions, with less oxygen than the fuel requires, to minimize

formation of $\mathrm{NO}_{\mathrm{x}}$. Secondary air is injected at two levels higher up, producing a twofold increase in velocity and defining the interface above which the bed becomes dilute. With 
a coal/limestone residence time of three seconds, the combustion efficiency is better than $99 \%$ when bituminous coal is used.

Starting in early 1987, eight coal-fired CFBC steam generators were produced for Archer Daniels Midland, a food-processing firm -- five 425,000-lb/h units at Decatur, Illinois, and three $477,000-\mathrm{lb} / \mathrm{h}$ units at Cedar Rapids, Iowa. These units produce superheated steam powering both condensing and back-pressure steam turbines to generate electricity and delivering low-pressure process steam. The overall boiler efficiency is $84-86 \%$. Using an Illinois coal with a sulfur content of $4.1 \%$, these units are designed to meet regulatory $\mathrm{SO}_{2}$ limits of $<1.2$ or $0.85 \mathrm{lb} / 10^{6} \mathrm{Btu}, \mathrm{NO}_{\mathrm{X}}$ limits of $<0.5$ or $0.4 \mathrm{lb} / 10^{6} \mathrm{Btu}$, and particulate limits of $<0.3 \mathrm{lb} / 10^{6} \mathrm{Btu}$ for Decatur and Cedar Rapids, respectively.

\section{A.5.2.11 Foster-Wheeler - United States}

In recent years, Foster-Wheeler has diversified from BFBC to CFBC, beginning with its own CFBC test rig at its Blizzard Research Center in Livingston, New Jersey. One of its most recent units is a 40-MW CFBC cogeneration plant reported to be under construction at Mount Carmel, Pennsylvania. It is expected to burn anthracite culm in order to supply steam for up to $\mathbf{4 0}$ acres of greenhouses and electricity for Pennsylvania Power \& Light. Startup was expected in the fall of 1989.

\section{A.6 PRESSURIZED FLUIDIZED-BED COMBUSTION}

\section{A.6.1 Technology Description}

A fluidized bed consists of a mass of granular particles that has an air stream flowing upward through it. As the velocity of the air increases to about $3 \mathrm{ft} / \mathrm{s}$, the particles become entrained in the air flow and are maintained in a highly turbulent suspended state. A bed in this state is said to be fluidized and, in general, it behaves like a fluid. Fluidized motion permits excellent surface contact between the air and the particles. When a combustible material such as coal is introduced into the bed, this mixing leads to efficient combustion. During combustion, the sulfur in coal reacts with oxygen to form $\mathrm{SO}_{2}$.

Pressurized fluidized-bed combustion (PFBC) occurs when a fluidized bed is incorporated within a pressure vessel. In $\mathrm{PFBC}, \mathrm{SO}_{2}$ is removed during combustion by the dolomite or limestone that has been added to the bed. (Dolomite is expected to be used for the Tidd PFBC demonstration project, although limestone may also be tested; see Section A.6.2.3). There are fewer $\mathrm{NO}_{\mathrm{x}}$ emissions from $\mathrm{PFBC}$ than from a conventional PCF boiler. This occurs because the low combustion temperature in the fluidized bed minimizes $\mathrm{NO}_{\mathrm{x}}$ generation. A conventional PCF boiler typically generates $\mathrm{NO}_{\mathrm{x}}$ emissions of $0.6-0.7 \mathrm{lb} / 10^{6}$ Btu; a fluidized bed, which has a combustion temperature of typically less than $1,600^{\circ} \mathrm{F}$, emits approximately $0.3 \mathrm{lb}$ of $\mathrm{NO}_{\mathrm{x}} / 10^{6} \mathrm{Btu}$. 
Because the operating pressure of PFBC is higher than that of conventional combustion, the exhaust gases from a PFBC have sufficient energy to drive a gas turbine, while the steam generated drives a steam turbine. This combined-cycle configuration allows for a power plant design that is more economical and efficient than that of a conventional coal-fired power plant.

\section{A.6.2 Technology Demonstrations}

\section{A.6.2.1 Grimethorpe - United States/U.K./FRG*}

In 1975, as an International Energy Agency (IEA) project and in response to the worldwide oil crisis, the United Kingdom (U.K.), FRG, and United States became joint partners in a multinational facility for research on PFBC. The moving force behind this unique collaboration was the British engineer and administrator, Leslie Grainger, of the National Coal Board.

The Grimethorpe unit was designed to simulate the physical and other characteristics of a full-scale commercial PFBC unit. Its main-combustion chamber is two meters square and eight meters high and has water-cooled walls. The entire chamber is enclosed in an outer pressure shell. Air from a steam-driven compressor enters the upper end of the pressure shell through a flow-measuring device and control valve. It flows down the outside of the combustion chamber and enters the bottom of the chamber through a bubble-cap distributor plate, rising again to fluidize the bed within the chamber. The chamber can accommodate a bed up to six meters deep.

The hot combustion gases from the combustor emerge at the top of the pressure shell and flow into a primary header that passes the gases into four primary cyclones arranged around the outside of the shell. The gases then flow from each primary cyclone into a secondary cyclone and then to a second header that recombines the four streams. The dust loading of the hot gases is so high that the most vulnerable interior surfaces of the cyclones are faced with abrasion-resistant refractory tiles. The hot gases can be passed through a loop containing cascades of gas-turbine blades, so that blade erosion and corrosion can be studied. Then, either through this cascade loop or directly, the hot gases enter the main heat exchanger.

The demonstration consisted of two series of tests that focused on the hardware plus screening tests that involved coals representative of those typically used by the three partners. The first test series revealed design problems severe enough to necessitate fundamental alterations in plant features. Resuls of the second series, in which a new tube bank, rotary-feed valves, and other modifications were employed, were good enough to allow continuation to screening tests for particular coals and sorbents and tests with stationary cascades of turbine blades.

\footnotetext{
*Information for Secs. A.6.2.1 and A.6.2.2 comes from Patterson (1987).
} 
In general, data on heat transfer, sulfur trapping, and $\mathrm{NO}_{\mathrm{x}}$, chlorine, and alkali levels corresponded with predictions from smaller units. Although a combustion efficiency of up to $99 \%$ was thought to be achievable, it was not as high as predicted. After the screening tests were finished in 1984, the persistent erosion and corrosion of tubes prompted installation of yet another design of tube bank, with finned tubes. Subsequently, the partnership dissolved and the unit was handed over to the National Coal Board, which was joined by the Central Electricity Generating Board to continue research, design, and development.

\section{A.6.2.2 ASEA - Sweden}

In the early 1980s, ASEA with Deutsche Babcock of the FRG constructed a 15MWt PFBC pilot plant -- a component test facility (CTF) -- at the Oresund power plant in Malmo, in southwestern Sweden. It started up in 1982. In contrast to the difficulties experienced at the Grimethorpe unit in the United Kingdom, the performance of the Malmo CTF was encouraging. In a 2000-hour run in 1984, in which the Malmo unit burned high-sulfur U.S. coal (4.7\%) mixed with U.S. dolomite, it achieved a combustion efficiency of $99.5 \%$, sulfur retention of better than $90 \%$ at a calcium-to-sulfur ratio of only 1.6 to $1, \mathrm{NO}_{\mathrm{x}}$ emissions of less than $0.07 \mathrm{~g} / \mathrm{MJ}\left(0.16 \mathrm{lb} / 10^{6} \mathrm{Btu}\right)$, and dust loading of less than $200 \mathrm{ppm}$. After the test, inspection revealed no visible corrosion or erosion of cyclones or turbine vanes or blades.

In 1984, the mayor of Stockholm and the chairman of Energiverk, the city's district-heating supplier, announced a plan for four coal-fired PFBC cogeneration units in the heart of Stockholm. The first phase of the project is expected to entail construction of two ASEA PFBC-200 units, with a total output of $131 \mathrm{MW}$ of electricity and $217 \mathrm{MW}$ of heat. The PFBC-200 design employs a super-charged PFBC that uses in-bed tubing to raise steam. The gas turbine's inlet temperature is almost the same as that of the bed itself. The turbine's exhaust gas is cooled to stack temperature by being passed through a heat exchanger that carries feedwater. In the ASEA concept of PFBC, all the hot components -- combustor, cyclones, bed storage vessels, etc. -- are enclosed in a single pressure vessel. The vessel is necessarily costly and complex, with penetrations for coal and sorbent feed, cyclone discharge, ash removal, and other services.

In the second phase of the project, for commissioning in the mid-1990s, two PFBC-800 units are expected to be added. These larger units are broadly similar to the smaller ones, but each is expected to power a 68-MW ASEA Stal GT120 gas turbine and a 216-MW steam turbine, to give a total output of $267 \mathrm{MW}$ of electricity and $423 \mathrm{MW}$ of heat. Whereas the PFBC-200 unit has a cylindrical pressure vessel with domed ends, the PFBC-800 unit has a spherical vessel.

Finally, ASEA PFBC carried out a 250-hour test for the Spanish utility, Empresa Nacional de Electricidad (ENDESA), using 600 tonnes of Spanish coal at the CTF in Malmo. Results were generally encouraging. Both efficiency and emissions met the ENDESA specifications; Spanish limestone and dolomite proved to be suitable sorbents. The cyclones and the gas turbine functioned well, with the turbine showing no evidence of erosion. These trials encouraged ENDESA to designate Unit No. 4 at its Escatron plant for a PFBC boiler retrofit. In late 1986, ASEA PFBC, leading a consortium with 
Babcock \& Wilcox Espana, agreed to supply a PFBC-200 unit to Escatron; it is expected to come into service in 1990 .

\section{A.6.2.3 Tidd Power Plant - United States}

American Electric Power and ASEA Brown Boveri (ABB Carbon, Sweden) began a joint study of coal PFBC systems in 1976, resulting in the decision to repower the Tidd electric power generating plant near Brilliant, Ohio (American Electric Power Service Corp., 1988; ASEA Babcock, 1988a,b). After nearly 10 years of development, ground breaking occurred in April 1988; plant operation is expected to begin in mid-1990. The ASEA Babcock Group is supplying the pressure vessel, combustion system, hot-gas cyclones, hot-bed storage and feed hoppers, and gas turbine.

The pressure vessel that houses all the pressurized components is a cylindrical shell, 44 feet in diameter and 69 feet high, with dished and flanged heads. This carbonsteel vessel weighs approximately 1,340 tons. The combustor is a P-200 module supplied by ASEA/Babcock, complete with bed material, lock hoppers, cyclones, and internal piping. The gas-turbine system is a modified ABB Stal GT35 dual-shaft turbine/compressor unit that has undergone extensive testing under design coal-firing conditions.

The fluidized bed will be supplied with a water-based coal-paste fuel at several injection points. The combustor will operate at a pressure level of 11.5 atmospheres, with air preheated by compression to $563^{\circ} \mathrm{F}$. The steam system will operate at 1300 psia and $925^{\circ} \mathrm{F}$ to match the conditions of the existing steam turbine's inlets. The gas turbine will operate at the conservative inlet conditions of 12 atmospheres and $1500^{\circ} \mathrm{F}$. Approximately $16 \mathrm{MWe}$ is expected to be generated by the gas turbine, and $58 \mathrm{MW}$ will be generated by the steam turbine. The system will operate in the load-following mode. For decreased power, the height of the fluidized bed will be changed to expose superheater tubes, reduce the effective heat-transfer area, and reduce load. The hot-bed material will be dumped into the hoppers located within the pressure vessel for storage and pneumatic reinjection into the bed when the demand is increased (DOE, 1987).

In general, any coal could be burned in this system. However, the coal that is expected to be burned is an Ohio bituminous coal with a gross calorific value of $12,900 \mathrm{Btu} / \mathrm{lb}$, an ash content of $10 \%$, and $4 \%$ sulfur. It is to be crushed to minus $1 / 8$ inch and mixed with water to make a $25 \%$ water paste that will be injected at six locations above the bed. Sulfur capture is expected to be $90 \%$ at a calcium-to-sulfur ratio of 1.5 , and $\mathrm{NO}_{\mathrm{X}}$ emissions will be limited to $0.12 \mathrm{lb} / 10^{6} \mathrm{Btu}$. Combustion temperature will be $1580^{\circ} \mathrm{F}$, which is well below the ash fusion temperature of the selected coal. Ninetyeight percent of the ash will be removed by two stages of hot-gas cyclones in front of the turbine (to less than 10 microns); remaining ash will be removed by ESPs to comply with environmental regulations.

Because of the conservative steam conditions that were deemed necessary to match the existing steam turbine $\left(1300\right.$ psia at $925^{\circ} \mathrm{F}$, no reheat), a plant efficiency of only $35.5 \%$ is expected. Thus, the Tidd plant heat rate is $9,615 \mathrm{Btu} / \mathrm{kWh}$. This efficiency is approximately $4 \%$ more than the original plant's rating. 
The Tidd plant retrofit is expected to cost $\$$ U.S. 185 million, of which DOE will contribute $\$ 60.2$ million as repayable capital (DOE, 1990a).

\section{A.6.2.4 Deutsche Babcock - FRG}

The German Ministry for Research and Technology (Bundesminister fur Forschung und Technologie) is currently sponsoring pilot-scale studies of the processes associated with PFB coal combustion to support the design of large-scale electric plants that could use this technology. A German firm, Deutsche Babcock Werke AG, is in the process of designing modular power plants with a nominal module rating of $330 \mathrm{MWe}$. Several modular units would be used in parallel for more generating capacity.

In May 1988, Deutsche Babcock was in the second and third phases of a six-phase program to develop coal PFBC systems for electrical power and district heating applications (Bunthoff, 1988). The first phase, an engineering feasibility study, proved the economics and technical validity of the concept. The second phase is designed to develop critical components, principally the combustion system, associated feed systems, and hot-gas filter. A third phase involves detailed design engineering. The fourth phase (licensing), fifth phase (construction/erection), and sixth phase (commissioning and trial operation) round out the complete development program. The start of construction is scheduled for 1991 and trial operation for 1995. The pilot plant (part of the second phase), operating at a steam pressure of 100 atmospheres, a temperature of $530^{\circ} \mathrm{C}$, and with a 15-MW thermal rating, was scheduled to be operational in mid-1988 (Leonhardt and Heinrich, 1988).

The Deutsche Babcock FBC system, which was designed as a module, features two water-cooled, fluidized-bed enclosures that are square in cross section, 10 meters high (along an edge), and have a 4-meter nominal bed height. The enclosures taper in cross section, increasing in area with height. The steam-generation surface (tubular heating passages) is positioned within the fluidized-bed space. A spherical pressure vessel encloses the combustor and associated bed-material storage hoppers. For the 330-MWe system, a sphere of 24 meters in diameter is specified. Within the pressurized enclosure, the walls of the combustor and bed storage tank are required only to support dead weights and the small pressure differentials associated with pressure loss in the bed. The design features top tension support of combustors, tube banks, and storage tanks to allow complete freedom for thermal expansion. The design is based upon the extensive data base that Deutsche Babcock developed from having provided the combustion systems for the Grimethorpe (U.K.) and Malmo (Sweden) component test facilities.

The FBC systems are expected to be operated at a pressure level of 16 atmospheres and a bed temperature of $850^{\circ} \mathrm{C}$. Combustion air will be supplied from an external turbine-driven compressor to the space within the spherical pressure vessel surrounding the combustion space and thence into the combustors through bottom-air injection. Thus, this air supply will act to recuperate heat losses from the hotter combustor surfaces and maintain the pressure vessel at a temperature of approximately $250^{\circ} \mathrm{C}$. Alloy steel is required for the pressure vessel at these operating conditions. The hot gases emanating from the combustors will be cleaned of dust loadings using 
pulse-cleaned ceramic filter bags. These filter bags, although not yet operated at high pressure, were successfully tested at 1 atmosphere pressure and $1000^{\circ} \mathrm{C}$. Dust loadings of less than $5 \mathrm{mg} / \mathrm{kg}$ of gas have been obtained. Also, removal of large dust particles (i.e., larger than the size of 1-5 microns imposed by turbine operations) has been easily carried out.

The hot, high-pressure, combustion gas will be passed through an industrial gas turbine that can accommodate an external combustor. In the Deutsche Babcock-designed plant, approximately $60 \mathrm{MWe}$ will be generated by the gas turbine, while steam generated within the fluidized bed will provide another $270 \mathrm{MWe}$. The hot gases exhausting from the gas turbine will flow through a "DENOX" plant (typically using a version of the selective catalytic reduction process) to further reduce $\mathrm{NO}_{\mathbf{x}}$ (if necessary) and then through various feedwater heaters for energy recovery. The cooled exhaust gases will finally be directed to the hybrid cooling towers to be mixed with vapor-laden air, thereby reducing the potential for plume moisture-cloud formation.

Approximately 640 tonnes/h of superheated steam is produced in the Deutsche Babcock FBC system. The combustor membrane walls add further feedwater heating. The superheater surface is incorporated as tube banks within the fluidized beds. The steam circuit is a once-through Benson cycle. Outlet steam conditions are nominally 190 atmospheres and $540^{\circ} \mathrm{C}$, with one reheat at 40 atmospheres and $540^{\circ} \mathrm{C}$. Load following is accomplished by reducing the steaming rate (in conjunction with reducing the fuel feed rate), which is achieved by lowering the fluidized-bed level and exposing the tubes' surfaces to lower heat-transfer conditions. Overall plant efficiency is predicted to be $42 \%$. This corresponds to a net heat rate of $8125 \mathrm{Btu} / \mathrm{kWh}$.

The bed material can be quickly transferred to an in-vessel storage tank by a pneumatic transport system that uses the intrinsic pressure within the pressurized sphere. The storage hoppers are connected at their bottoms to the bottoms of the combustor by a transfer pipe. The storage hoppers for the bed material have ceramic filters at the top, which permits partial depressurization to atmosphere through an exhuast control valve. Upon partial depressurization of the space in the upper region of the storage hopper, higher-pressure gas from the combustor quickly drives bed material into the storage tank. The process can be reversed by an independent compressed-air supply that pressurizes the storage hopper to a level above the combustor operating pressure.

Ash is collected in the pulse-cleaned ceramic filters and discharged to atmospheric storage through heat recovery coolers and a lockhopper pressure-reduction means. The FRG hopes to use the ash and spent bed material for building material.

After evaluation, Deutsche Babcock adopted the water-slurry type of coal-feed system and a dry-air pneumatic feed. Little loss in system efficiency is claimed, provided water in the slurry is limited to approximately 25\%. This amount allows the coal to be pumped with standard, commercial, cement-type pumps. A wide range of coal sizes and classes can be fed with this system. Nominal crushed coal, to minus 3 millimeters, is used. Fines are reduced by simply screening the crushed coal in intermediate stages of preparation. Thus, minus-3-millimeter coal is fed directly to the slurry-preparation system. Limestone is blended in with the coal to maintain 
calcium-to-sulfur stoichiometry and bed height within the combustors. Multiple independent injection points are provided and are supplied by parallel-flow coal/limestone pumps.

Pollution control is inherent in coal PFBC systems using calcium-based bed material and operated at temperature levels near $850^{\circ} \mathrm{C}$. The FRG expects that sulfur capture of nearly $90 \%$ will be obtained using a hard coal of $1.25 \%$ sulfur, at a calcium-tosulfur ratio of 1 to 1.5 . This coal, at $1.35 \%$ nitrogen, is expected to produce $165 \mathrm{mg} / \mathrm{m}^{3}$ (standard temperature and pressure) of $\mathrm{NO}_{\mathrm{X}}$ in the exhaust (Ellison, 1988; Meier and Bunthoff, 1986). This level is below current FRG emission standards. The dust-loading restrictions of the turbine, which will be met using the hot ceramic-filter technology, are an order of magnitude lower than dust emission standards.

\section{A.7 LIMESTONE-INJECTION MULTISTAGE-BURNER COMBUSTION}

\section{A.7.1 Technology Deseription}

Limestone-injection multistage-burner (LIMB) combustion technology has been the subject of major $R \& D$ programs in the United States and abroad. In this process, pulverized calcium-based sorbents, such as calcium hydroxide $\left[\mathrm{Ca}(\mathrm{OH})_{2}\right]$ or limestone, are injected directly into the furnace cavity of a coal-fired boiler to reduce $\mathrm{SO}_{2}$ emissions. In the original design, the sorbent was mixed with pulverized coal and injected into the lower furnace; however, results were not promising. When exposed to hot furnace/gas temperatures, the sorbents rapidly dehydrate or calcine to form reactive lime $(\mathrm{CaO})$ particles, which then capture $\mathrm{SO}_{2}$ in the flue gas to form $\mathrm{CaSO}_{4}$ on the outer layers of these particles. The flue gases carry these particles, along with fly ash, out of the furnace through the heat-transfer sections (superheater and reheater, economizer, and air preheater) and into the particulate-collection device, where particles and fly ash are removed from the flue gases. Of the variety of commercial sorbents tested so far, lime hydrates have been found to be more effective than limestone in terms of $\mathrm{SO}_{2}$ removal.

The injection of calcium-based sorbents into flue gases was found to increase the resistivity of the combined fly-ash/spent-sorbent particulates by several orders of magnitude; this resistivity, in turn, degraded the performance of the existing particulatecollection devices, which were primarily ESPs. To counter this problem, a waterhumidification system to condition the particulates is added to the system, on either a bypass duct or existing ductwork if its dimensions and length are adequate for gas passage. Injecting water into the flue gas can also potentially enhance additional $\mathrm{SO}_{2}$ absorption as the flue gas travels through the ductwork upstream of the particulatecollection devices.

Control of $\mathrm{NO}_{\mathrm{x}}$ is achieved separately by installing a specially designed burner in the lower furnace. A number of low $-\mathrm{NO}_{x}$ burners have been developed for wall-fired, down-fired, and tangentially fired pulverized-coal furnaces. All of them adopt the basic concept of delayed, controlled mixing of the coal particles and the oxidant (air), thereby having a slower heat-release pattern and a longer-flame envelope than do existing 
turbulent pre-NSPS burners. Published results from commercial retrofits of these burners show that they are capable of reducing $\mathrm{NO}_{\mathrm{x}}$ emissions from existing boilers to 0.4-0.6 lb/10 6 Btu heat input (or 300-400 ppm at 3\% oxygen). No low- $\mathrm{NO}_{\mathrm{x}}$ burners have been developed for cyclone and stoker furnaces, however. Stoker furnaces are widely used in the industrial and residential/commercial sectors, and cyclone furnaces are used exclusively in large utility boilers burning low-grade coals.

\section{A.7.2 Technology Demonstrations}

The LIMB technology has been developed primarily as a potentially low-cost, incremental approach for contoling $\mathrm{SO}_{2}$ emissions from existing coal-fired power plants. The development work in the United States, mainly under the sponsorship of the EPA, started in the early $1980 \mathrm{~s}$ and has progressed to two on-going large-scale demonstration projects (Stern, 1988; Drehnel, 1988). The first of these, employing wallfired utility boilers, involves the design, installation, operation, and testing of a LIMB system at a 105-MW boiler (Unit 4) at Ohio Edison's Edgewater station in Lorain, Ohio. The second project, employing tangentially fired utility boilers, was initiated in summer 1987 and is scheduled to be conducted at the 180-MW boiler (Unit 2) at Virginia Power's Yorktown station. Before these large-scale demonstrations, extensive pilot-scale tests had been carried out at Energy and Environmental Research Corp.'s combustion research facility to evaluate the effects of process variables and sorbent types.

\section{A.7.2.1 Ohio Edison - Edgewater Station}

For the wall-fired LIMB demonstration, the design was completed and the system was installed in 1987. The early operating period of the system, however, was plagued by problems with the sorbent-feed system and particulate-collection system; design changes were incorporated to attain full-flow capability (Nolan et al., 1988). By the end of 1987, only a series of tests over a two-week period had been conducted. This two-week testing did not result in a definitive comparison of the normal commercial lime hydrate and the modified lime hydrate being tested, but the data have been considered to be a reliable indicator of the type of results expected. With the commercial lime hydrate, an $\mathrm{SO}_{2}$ removal efficiency of 55-60\% was obtained at a calcium-to-sulf ur stoichiometric ratio of about 2; the project goal for this demonstration was a removal efficiency of $50 \%$ at this ratio. The short-term test results also indicated that $\mathrm{NO}_{\mathrm{x}}$ emissions from the unit retrofitted with low- $\mathrm{NO}_{\mathrm{x}}$ burners were reduced from about 0.9 to $<0.5 \mathrm{lb} / 10^{6}$ Btu heat input, which was the goal for this demonstration. The primary fuel that has been used to date is an Ohio bituminous coal with a nominal sulfur content of $2.5-3 \%$.

In 1988, a flue-gas humidification system was installed so that the entire system could be operated in a continuous mode. As of the winter of 1988-1989, the LIMB system was still being optimized. Following LIMB optimization, the humidification system will be optimized for enhanced $\mathrm{SO}_{2}$ removal, and the entire system is expected to be operated continuously for three to four months.

Under the first round of its CCT demonstration program, DOE has selected as one of the projects an extension to this demonstration project. This 42 -month project is 
expected to include the installation of a bypass duct for EPA's humidification testing; an additional year of testing with up to 12 sorbent/coal combinations, including humidification and simulated sorbent recycle; and an evaluation of the cool-side sorbentinjection technology developed by the Consolidated Coal Co.

\section{A.7.2.2 Virginia Power - Yorktown Station}

The Virginia Power LIMB demonstration project is scheduled to continue for a five-year period; about one year is expected to be dedicated to a performance evaluation (Gogineni et al., 1988). The U.S. government share of the funding is being provided by DOE and EPA. In addition to demonstrating the performance of LIMB technology, this project will involve the evaluation of $\mathrm{SO}_{2}$-removal enhancement through flue-gas humidification and sorbent reactivation and recycle. An intermediate-sulfur-content coal (about 2\%) is expected to be used during the demonstration. The goal for this demonstration was set to be comparable with that of the Edgewater demonstration.

Baseline characterization tests on the host boiler were performed, with the focus on documenting the flue-gas temperature, velocity, and flow-field characteristics of the unit. This information was used to design a cold-flow model of the host unit. Results from these hot-combustion and cold-flow model tests are being used in the preliminary system design to identify the location of sorbent injectors, determine proper injection velocity, and optimize injection patterns under various anticipated unit-load conditions. The preliminary integrated design was expected to be available for DOE/EPA review by the second quarter of 1989; equipment installation, shakedown, and debugging is expected to be completed by July 1990. At that time, a performance evaluation will be undertaken. The entire testing, including long-term operation, is scheduled to be completed by late 1991, with a final report expected by mid-1992. In addition, this demonstration project has been selected for negotiation in the second round of the CCT program.

\section{A.7.2.3 Richmond Power \& Light - Whitewater Valley Station}

In addition to the two demonstration projects, EPA and EPRI are co-sponsoring a project to evaluate sorbent-injection technology on a $60-\mathrm{MW}$ tangentially fired utility boiler at Richmond Power \& Light's Whitewater Valley Station in Richmond, Indiana (England et al., 1988). The first phase of this project involves an evaluation of LIMB technology and its impact on the operation of the boiler and associated equipment. Extensive characterization tests of the host boiler were conducted; then the sorbentinjection and flue-gas humidification systems were designed and procured; installation was completed in August 1987.

Because of problems with the sorbent-handling system, satisfactory long-term, steady-state operation of the system was not achieved during 1987. After the installation of a redesigned sorbent-handling system in August 1988, startup was

reinitiated. Parametric testing to evaluate sorbents, coals, and sorbent-injection schemes at various operating levels was scheduled to continue during 1989 . 
Despite the fact that development of LIMB technology in the United States is in the demonstration stage, Babcock \& Wilcox has already taken an order for this technology from a Canadian utility.

\section{A.7.2.4 Foreign Countries}

Development and commercialization of the LIMB technology have been actively pursued outside the United States -- in the FRG, Austria, Finland, France, and Canada (Chughtai, 1988; Staudinger, Melcher, and Eckersdorfer, 1988; Kenakkala, 1988; Vandycke et al., 1988; Mozes et al., 1988). The FRG and Austria are farthest along in the process. In the FRG, as of the end of 1988, 12 commercial lime hydrate/limestoneinjection systems, with or without low- $\mathrm{NO}_{\mathrm{x}}$ burner retrofitting, were either in operation or under construction. However, most of these plants, including those with both wallfired and tangentially fired boilers, burn low- to medium-sulfur coals. $\mathrm{SO}_{2}$ removal from these commercial systems is typically in the 40-60\% range, with injection of lime hydrate at a calcium-to-sulfur ratio of about 2 . With limestone injection, $\mathrm{SO}_{2}$ removal is reported to be inferior (in the $30-40 \%$ range); this range was also observed in pilot-scale tests conducted in the United States.

In Austria, 12 boilers (plants) were retrofitted with furnace limestone injection (FLI) systems for $\mathrm{SO}_{2}$ control. As is the case for the boilers in the FRG, these boilers all burn low- to medium-sulfur coals with sulfur contents from 0.4-1.9\%. They are either wall-fired or corner-fired units. Nine of the plants with these FLI systems are still in operation to comply with regulations. The other three no longer use the FLI systems routinely but still have them installed in place as a backup. All these boilers have been reported to operate well after accumulating more than 125,000 hours of combined operational experience. Limestone has been used in most of these installations, with $\mathrm{SO}_{2}$ removal typically on the order of $40 \%$ at a stoichiometric ratio of about 3.

In addition, Austria sold an FLI unit with 55-MWe capacity that burns a brown coal containing 3.6\% sulfur to a power station in Hungary. The brown coal contains $46 \%$ ash and has a lower heating value of $3780 \mathrm{Btu} / \mathrm{lb}$. Very good utilization of the limestone added was reported to have been achieved; however, no results on $\mathrm{SO}_{2}$ removal have been reported for this unit.

\section{A.7.2.5 Research and Development Studies}

Research and development studies have been and are still being actively carried out, both in the United States and abroad, in attempts to further improve the economic prospect of LIMB technology. The performance of commercially available sorbents has been extensively characterized, and it appears unlikely that additional significant gains in calcium utilization will be obtained by simply optimizing process parameters (i.e., sorbent particle size, injection temperature). Therefore, most of the on-going $R \& D$ activities take one of the following two approaches (Muzio and Offen, 1987; Offen et al., 1987): (1) modifications to the commercial sorbents or development of new, more reactive sorbents or (2) integration of the LIMB process with downstream processes, such as humidification and spent-sorbent recycling. 
Although a wide variety of additives have been investigated, only sodium-based compounds may be practical for utility applications. In two-week tests at the Edgewater plant, calcium lignosulfonate was shown to slightly improve the $\mathrm{SO}_{2}$ removal efficiency at a constant calcium-to-sulfur ratio. This small improvement, however, still has to be substantiated by additional results from long-term testing. New sorbents with high surface areas or favorable pore sizes have also been under development. These new sorbents may have the potential for a higher removal efficiency but are also expected to be more costly than the commercially available lime sorbents. The economic implications of these new sorbents are uncertain at the present time, even though preliminary studies by the EPA show that they have some promise.

Investigations are also being conducted on integrating the LIMB process with downstream processing to optimize overall $\mathrm{SO}_{2}$ removal. Flue-gas humidification has been evaluated, not only as a remedy to the problems experienced with existing ESPs but also as a potential method of effecting additional $\mathrm{SO}_{2}$ removal inside the flue-gas duct. The expected benefit of improved $\mathrm{SO}_{2}$ diffusion through the product layer on the sorbent particles by moisture addition, however, remains to be demonstrated. Recycle of a portion of the spent sorbent, after further treatment, certainly would improve calcium utilization; however, additional costs would be incurred to treat and handle these spent sorbents. Research organizations in Germany and Austria are also very active in this line of investigation. Finally, a number of investigations have also been conducted on the safe disposal and economic utilization of the spent sorbents from the LIMB technology (Staudinger, Melcher, and Eckersdorfer, 1988; Dawson et al., 1988b).

\section{A.8 GAS-REBURNING SORBENT-INJECTION TECHNOLOGY}

\section{A.8.1 Technology Description}

Gas-reburning sorbent-injection (GRSI) technology is a two-part process in which zoned combustion is used to control $\mathrm{NO}_{\mathrm{x}}$ and sorbent injection is used to control $\mathrm{SO}_{2}$ (Energy and Environmental Research Corp., 1987). The $\mathrm{NO}_{\mathrm{x}}$ and $\mathrm{SO}_{2}$ emissions may be reduced $60 \%$ and $50 \%$, respectively. The concept of reburning gas to reduce $\mathrm{NO}_{x}$ is based on the principle that radicals and compounds from substoichiometric combustion (in which there is not enough oxygen for complete burning of fuel) can reduce $\mathrm{NO}_{\mathbf{x}}$ (Myerson et al., 1957). In sorbent injection, a chemical such as lime is introduced into the gas stream to combine with $\mathrm{SO}_{2}$ (McCarthy et al., 1987).

Reburning consists of the following arrangement:

- Primary Zone: In this zone, the main energy released is in a slightly air-rich condition; the principal fuel is coal.

- Reburning Zone: Here, the reburn fuel (in this case, natural gas, but the primary fuel could also be used) is burned in a fuel-rich condition. 
- Burnout Zone: In this zone, additional air is supplied to provide complete combustion. (Overall, the furnace operates in an excessair condition.)

Approximately $80-85 \%$ of the total heat release occurs in the primary zone. Here coal is burned with little excess air but with sufficient residence time to provide complete combustion before the combustion products enter the reburning zone. The $\mathrm{NO}_{\mathbf{x}}$ is formed in this zone. In the reburning zone, additional combustion occurs, but in a fuel-rich environment. During reburning, fuel molecules decompose into hydrocarbon radicals and low oxidation products that tend to reduce $\mathrm{NO}_{\mathrm{x}}$ to molecular nitrogen, $\mathrm{HCN}$, and ammonia $\left(\mathrm{NH}_{3}\right)$. In the burnout zone, the remaining fuel material is burned in excess air. The $\mathrm{NH}_{3}$ and $\mathrm{HCN}$ is converted to molecular nitrogen and nitrogen oxide (NO).

To control $\mathrm{SO}_{2}$ emissions, lime is injected into either the burnout zone, the upper part of the boiler combustion zone, or the duct downstream of the boiler. The spent lime and other particles are collected in an ESP or in baghouses. Water or steam can be introduced into the ducts to aid the sorbent process.

\section{A.8.2 Technology Demonstrations}

\section{A.8.2.1 Gas Reburning}

Bench- and pilot-scale studies were carried out at Energy and Environmental Research Corp. (EER) to establish the optimal process parameters for the reburning process (Energy and Environmental Research Corp., 1987). The parameters of interest were the fuel type, stoichiometry, and exit NO level in the primary zone; the amount of reburning fuel and the residence time in the reburning zone; and the temperature and overall excess oxygen level in the burnout zone. One of the key results from the parametric studies is that the effectiveness of reburning increases as the excess oxygen level in the primary zone is reduced (Bartok et al., 1987).

Under residence-time conditions that are typical of field practice, a reburning fuel that does not contain bound nitrogen is most effective, and the fractional reduction in $\mathrm{NO}_{\mathrm{x}}$ emissions is independent of the NO concentration entering the reburning zone as long as the concentration is more than approximately $300 \mathrm{ppm}$. The temperature at which burnout occurs is also an important process parameter, as is mixing. Pilot-scale studies have also been carried out to establish the importance of effective mixing in both the reburning and the burnout zones.

The performance of natural gas reburning when applied to coal-fired furnaces was examined by EER in terms of combustion efficiency and $\mathrm{NO}_{\mathrm{x}}$ and $\mathrm{SO}_{2}$ emissions. Experiments were carried out in a small, 300-kWt $\left(1 \times 10^{6} \mathrm{Btu} / \mathrm{h}\right)$ refractory-lined furnace with an inside diameter of 56 centimeters. A high-sulfur Illinois coal was fired in the primary zone; the reburning fuel was natural gas or lllinois coal, and burnout air was injected at $2460^{\circ} \mathrm{F}$ for gas and $2220^{\circ} \mathrm{F}$ for coal. Samples of exhaust gas and solids were extracted from the furnace at $1600^{\circ} \mathrm{F}$. The $\mathrm{NO}_{\mathrm{x}}$ emissions decreased dramatically as the reburning fuel was added while the total load was maintained at $1.0 \times 10^{6} \mathrm{Btu} / \mathrm{h}$. 
These experiments were run for three different reburning fuel loads, and in each case, natural gas proved to be a better reburning fuel than coal. Similar results were also obtained in a 3-MWt pilot-scale furnace.

Southern California Edison carried out a series of power plant experiments that simulated reburning (Weir et al., 1982; Radak, 1987). A reburning fuel (natural gas or methanol) was used instead of a primary fuel (gas or oil). Results showed that the reburning process could significantly reduce the amount of $\mathrm{NO}_{\mathrm{x}}$ emitted from the plants.

\section{A.8.2.2 Sorbent Injection}

The reburning process can be combined with sorbent injection for $\mathrm{SO}_{2}$ control. The burnout air stream can be used as a carrier for the sorbent medium. It is important to mix the burnout air and the sorbent with the combustion coals as quickly and effectively as possible. The design requirements of both processes are similar.

The use of calcium-based sorbents with furnace injection for $\mathrm{SO}_{2}$ control has been studied extensively. The process involves calcinations of a calcium-based sorbent, which may be either a carbonate or hydrate, producing $\mathrm{CaO}$. This $\mathrm{CaO}$ reacts with $\mathrm{SO}_{2}$ and $\mathrm{O}_{2}$ in the sulfation zone, producing solid $\mathrm{CaSO}_{4}$ that can be removed with the fly ash in an ESP or bag filter. Two major parameters control the utilization of the calcium in the sorbent and thus the cost effectiveness of the process:

1. The reactivity of the $\mathrm{CaO}$ formed by calcination: This reactivity is strongly dependent upon the surface area of the calcine, which is a function of the sorbent type and the thermal history of the calcine. Reactivity tends to decrease as the sorbent particle's temperature is increased.

2. The residence time of the calcine under conditions conducive to sulfation: Significant sulfation cannot occur above approximately $2250^{\circ} \mathrm{F}$, and the rate of sulfation becomes negligible below approximately $1600^{\circ} \mathrm{F}$. Thus, the residence time of the active particle within this temperature window is important in the sulfurcapture process.

\section{A.8.2.3 Gas Reburning and Sorbent Injection}

EER plans to conduct a cooperatively funded project at three host utility sites to evaluate the technical feasibility and cost effectiveness of GRSI. The funding project participants are slated to be DOE, the Gas Research Institute, and the Illinois Department of Energy and Natural Resources (Energy and Environmental Research Corp., 1987). 


\section{A.9 NOXSO PROCESS}

\section{A.9.1 Technology Description}

The NOXSO process is a dry, regenerable, flue-gas cleaning process that is capable of removing $90 \%$ of both the $\mathrm{SO}_{2}$ and $\mathrm{NO}_{\mathrm{x}}$ from flue gases generated by coalfired boilers (Haslbeck et al., 1988a,b,c; Yeh et al., 1987; Haslbeck and Neal, 1986). The sorbent used in this process is made by depositing sodium carbonate $\left(\mathrm{Na}_{2} \mathrm{CO}_{3}\right)$ onto a gamma-alumina substrate with a high surface area. As the flue gas from the boilers passes through a fluidized bed of solid sorbent at a temperature of about $120^{\circ} \mathrm{C}$, it is cleaned by chemsorption of the $\mathrm{SO}_{2}$ and $\mathrm{NO}_{\mathrm{x}}$ with the sorbent. The clean flue gas is then directed to a particulate-collection device, ESP, or baghouse filter before it leaves the stack.

After sorption/chemical reaction, the spent sorbent is withdrawn from the sorption vessel and, along with fresh make-up sorbent, is directed to a second fluidizedbed vessel, in which it is heated with hot air to about $600^{\circ} \mathrm{C}$ to desorb the $\mathrm{NO}_{\mathrm{x}^{\circ}}$ The heated spent sorbent is then regenerated by being treated with a reducing gas, such as natural gas, and subsequently with low-pressure steam in a two-stage moving-bed reactor. This regeneration reduces the absorbed sulfur compounds to $\mathrm{SO}_{2}$, hydrogen sulfide $\left(\mathrm{H}_{2} \mathrm{~S}\right)$, and some elemental sulfur. These off-gas streams from the regenerator are then routed to a by-product recovery subsystem for conversion of $\mathrm{H}_{2} \mathrm{~S}$ and $\mathrm{SO}_{2}$ into elemental sulfur or sulfuric acid $\left(\mathrm{H}_{2} \mathrm{SO}_{4}\right)$. The regenerated sorbent, along with the treated make-up sorbent, is returned to the fluidized-bed absorption reactor.

The concentrated stream of $\mathrm{NO}_{\mathrm{x}}$ that has been produced as a result of heating up the reacted sorbents in the second fluidized-bed vessel, as currently configured, is sent back to the furnace with the combustion air for reduction inside the furnace. Thermodynamic equilibrium calculations suggest that a large portion of the recycled $\mathrm{NO}_{\mathrm{x}}$ would be destroyed inside the furnace, thus only slightly increasing the final $\mathrm{NO}_{\mathrm{x}}$ emissions at the boiler outlet.

\section{A.9.2 Technology Demonstration}

Initial development work on this dry process was conducted by Princeton Chemical Research in conjunction with Fluor Engineers. After the rights to this process were acquired by the NOXSO Corp., the process was tested (1982 to 1985) on a small scale on actual flue gas at TVA's Shawnee steam plant; these tests investigated the separate operation of the sorption and regeneration subsystems (Haslbeck and Neal, 1986). Beginning in 1985, mainly under the sponsorship of DOE, a $0.75-\mathrm{MW}$-equivalent system and a small-life-cycle test unit have been evaluated at DOE's PETC. The lifecycle test was scheduled to be completed in September 1989 (Haslbeck et al., 1988a,b; 1989). The small-scale (50 standard cubic feet per minute or sefm) test facility at TVA's site was designed to obtain information on process chemistry, process kinetics, and sorbent life. Actual flue gas from TVA's Shawnee Unit No. 10, containing 2300 ppm $\mathrm{SO}_{2}$ 
and $440 \mathrm{ppm} \mathrm{NO}$, was used in this series of tests. Key results from these tests include the following (Haslbeck et al., 1989):

- Both sodium and alumina chemsorb $\mathrm{SO}_{2}$ and $\mathrm{NO}_{\mathrm{x}}$ at about $120^{\circ} \mathrm{C}$ (i.e., less sorbent is required per mole of $\mathrm{SO}_{2}$ and $\mathrm{NO}_{\mathrm{x}}$ removal than that predicted on the basis of sorbent sodium content alone).

- The sorbent's capacity can be successfully restored by being heated to $600^{\circ} \mathrm{C}$ and being treated with a reducing gas such as $\mathrm{H}_{2}, \mathrm{CO}$, $\mathrm{H}_{2} / \mathrm{CO}$, or $\mathrm{H}_{2} \mathrm{~S}$.

- A sorbent sample exhibited no deterioration in chemical activity toward $\mathrm{SO}_{2}$ or $\mathrm{NO}_{\mathrm{x}}$ after being exposed to 45 cycles of absorption and regeneration.

- The rate of sorbent attrition was found to be $0.02 \%$ of the entire fluidized-bed inventory per hour.

These encouraging results led to a pilot-scale evaluation of the process at PETC. The pilot-scale (0.75-MWe) tests completed at PETC consisted of 17 cycles of absorption and 16 cycles of regeneration. Results show that both $\mathrm{SO}_{2}$ and $\mathrm{NO}_{\mathrm{x}}$ removals are strongly dependent upon the depth of the fluidized bed and the sorbent feed rate. At an expanded bed depth of 0.92 meter, $\mathrm{SO}_{2}$-removal efficiency was $90-99+\%$, averaging about $95 \%$. An $\mathrm{SO}_{2}$-removal efficiency of $90 \%$ was also achieved at a bed depth of 0.46 meter; however, the sorbent flow rate required to achieve this level of removal is about three times greater than that needed at a bed depth of 0.92 meter. Therefore, selection of the optimal absorber bed height involves an economic trade-off, in which the capital cost savings associated with the shallower bed must be balanced against the increased operating costs associated with a higher sorbent feed rate. As expected, the amount of $\mathrm{SO}_{2}$ removed increased with the sorbent amount. The amount of sorbent required to achieve a certain level of $\mathrm{SO}_{2}$ removal, however, appears to be insensitive to the inlet $\mathrm{SO}_{2}$ concentration.

In the same series of pilot tests, $\mathrm{NO}_{x}$-removal efficiency was $71-88 \%$, averaging about $81 \%$. The $\mathrm{NO}_{\mathrm{x}}$-removal efficiency varied considerably with the type of reducing gas used in the previous sorbent regeneration operation. The $\mathrm{NO}_{\mathbf{x}}$-removal levels achieved using sorbent regenerated with methane gas were constantly greater than those using sorbent regenerated with hydrogen gas, even at a shallower expanded bed height. The reason for the improved $\mathrm{NO}_{\mathbf{x}}$-removal performance of methane-regenerated sorbent is still unknown. During the tests, it was also found that the $\mathrm{NO}_{\mathrm{x}}$ removal improved with the ratio of $\mathrm{SO}_{2}$ to $\mathrm{NO}_{\mathrm{x}}$ in the inlet flue gas.

In addition, the proposed scheme for eventual in-furnace $\mathrm{NO}_{\mathrm{x}}$-reduction - by recirculating the hot $\mathrm{NO}_{\mathrm{x}}$-containing gas from the fluidized-bed desorber into the furnace -- was briefly evaluated experimentally (Haslbeck et al., 1988a; Yeh et al., 1987). Results from this series of tests showed that about $52-74 \%$ of the $\mathrm{NO}_{\mathrm{x}}$ gas injected along with the primary air stream into the pilot-scale coal combustor was 
accounted for. Greater $\mathrm{NO}_{\mathbf{x}}$-destruction efficiencies may be achieved by optimizing injection conditions.

The attrition rate of NOXSO sorbents during the absorption/regeneration cycling operation is another important design parameter that governs the economics of the process. The life-cycle tests currently being carried out at PETC are intended to evaluate the chemical and physical durability of the various NOXSO sorbents formulated. Prior tests of NOXSO sorbents indicated an attrition rate of about 0.02-0.03\% per hour. Results from the current life-cycle tests yielded considerably higher attrition rates for the same sorbents (Haslbeck et al., 1989). A major portion of this high sorbent attrition rate, however, was identified to be attributed to the long-pass pneumatic handling of these sorbents within the life-cycle testing facility (Yeh et al., 1987).

DOE recently selected the NOXSO process to negotiate a cost-shared contract for an integrated pilot-scale evaluation. The proof-of-concept test, at a 5-MWe scale, will be conducted at an Ohio Edison coal-fired plant. The layout of the 5-MW, fully integrated plant has been developed and is being refined. The date reported for expected commercialization for the NOXSO process is 1995 , although this date appears optimistic considering the current state of development.

In addition, $\mathrm{R} \& \mathrm{D}$ on the regeneration subsystem of the process is being conducted separately by NOXSO Corp. Natural gas has been successfully used to regenerate the reacted sorbent, but the bed temperature (about $200^{\circ} \mathrm{F}$ ) was somewhat higher than that associated with the use of $\mathrm{H}_{2} / \mathrm{CO}$ gases (Ma, 1989). Small-scale tests are also being carried out at W.R. Grace to evaluate the procedures for preparing new and improved sorbents (Haslbeck et al., 1989).

\section{A.10 DANISH SPRAY-DRYER FLUE-GAS DESULFURIZATION}

\section{A.10.1 Technology Description}

The spray-dryer gas-scrubbing process consists of two commercially available technologies: (1) spray drying, used for over 60 years to produce such diverse products as dry milk, detergents, and instant coffee, and (2) particulate collection, performed by either baghouse fabric filters or ESPs. In this process, the sorbent (lime or sodium carbonate) is slaked or mixed with water to form a slurry or solution. The sorbent/water mixture is then further mixed with the recycled spent materials, and the resultant slurry is sprayed as a fine mist into the drying chamber, in which the large numbers of finely divided droplets come into contact with the hot, $\mathrm{SO}_{2}$-laden flue gases. Two events occur as a result of the contact of the droplets with the flue gases. First the water in the droplets begins to evaporate, lowering the flue-gas temperature. Then the $\mathrm{SO}_{2}$ in the flue gas diffuses to the droplets, is absorbed, and reacts with the sorbent. The primary chemical reaction that takes place, using lime as the sorbent, is as follows:

$$
\mathrm{Ca}(\mathrm{OH})_{2}+\mathrm{SO}_{2} \rightarrow \mathrm{CaSO}_{3}+\mathrm{H}_{2} \mathrm{O}
$$


Some of the calcium sulfite $\left(\mathrm{CaSO}_{3}\right)$ thus formed further reacts with oxygen in the flue gas (while the particles are drying) to form calcium sulfate $\left(\mathrm{CaSO}_{4}\right)$ by the following reaction:

$$
\mathrm{CaSO}_{3}+1 / 2 \mathrm{O}_{2}+\mathrm{CaSO}_{4}
$$

In addition, because of the high concentration of $\mathrm{CO}_{2}$ in the flue gas, a low degree of carbonation of the lime also occurs:

$$
\mathrm{Ca}(\mathrm{OH})_{2}+\mathrm{CO}_{2} \rightarrow \mathrm{CaCO}_{3}+\mathrm{H}_{2} \mathrm{O}
$$

After this drying reaction, a portion of the dried particulates drop to the bottom of the drying chamber. The rest of the particulates are entrained in the cooled flue gas, and together they flow to the particulate-collection device, where the particulates are removed from the gas stream. Most of the $\mathrm{SO}_{2}$ removal that occurs with the spray-dryer gas-scrubbing process takes place inside the drying chamber; however, a significant amount of $\mathrm{SO}_{2}$ removal also occurs in the particulate-collection device when a baghouse fabric filter is used.

The lime-based spray-dryer FGD process, developed by Niro Atomizer in Denmark, is much more advanced than the sodium-based spray-dryer FGD technology.

\section{A.10.2 Technology Demonstrations}

The Danish-developed spray-dryer FGD technology has been commercially available since the early 1980s (Donnelly et al., 1986, 1987, 1988; Felsvang, 1983; JOY/NIRO, 1982). The first system, which came on-line at Northern States Power's Riverside generating station in December 1980, treated the combined flue-gas streams from Units 6 and 7 . The system was installed as a full-scale demonstration plant to prove the technology and confirm scale-up factors from the pilot-plant demonstration. This single-chamber system had been extensively tested for more than three years on a variety of coal types, with sulfur contents of $0.5-3.5 \%$. The system is currently a standby unit, having been in commercial operation for a couple of years.

From 1983 through 1985, five utility-scale systems were started up in the United States; each was equipped with multiple, large, spray-drying chambers. All the units were new installations equipped with reverse-air fabric filters for dust collection. In addition, a number of industrial-scale units were also installed, including the first and only remaining unit for retrofitting high-sulfur-coal boilers, which was installed at Argonne National Laboratory (Farber, 1982; Farber et al., 1983a).

During the past three years, two additional utility-scale units have been started up and undergone performance testing. The unit at Pacific Power and Light's Wyodak station in Gillette, Wyoming, represents the first U.S. utility-scale retrofit application. The other unit at Northern States Power's Sherburne station in Becker, Minnesota, represents the world's largest spray-dryer-absorber (SDA) application (860 MWe) (Donnelly et al., 1988). These two units and the previous units all burn low-sulfur western subbituminous coals or lignites, however. 
Outside the United States, a total of 12 Niro Atomizer utility-scale SDA systems, ranging in size from 60 to $420 \mathrm{MWe}$, were installed (Felsvang et al., 1988). The sulfur contents of the coals burned in the boilers to which these units are attached were 0.3-3\%. All of these non-U.S. units were designed to operate at full load with no spare modules. In some of these units, ESPs are used as primary particulate-collection devices. In other units, pulse-jet fabric filters with a high air-to-cloth ratio were incorporated for final particulate collection. Because of the existing market for fly ash in Europe, a low-efficiency particulate-collection device (such as a one-field ESP) is typically placed upstream of the spray-dryer chamber in the European-designed SDA systems.

A slightly modified version of the basic SDA process was also developed to control $\mathrm{NO}_{\mathrm{x}}$ in addition to $\mathrm{SO}_{2}$ (Felsvang et al., 1983). In this modified operation, caustic soda is added to the lime slurry in the amount of about 5-10\% to create an active sorbent for $\mathrm{NO}_{\mathrm{x}}$ removal in the baghouse. For effective $\mathrm{NO}_{\mathrm{x}}$ removal, the flue-gas temperature at the spray-dryer outlet has to be maintained between $200^{\circ}$ and $220^{\circ} \mathrm{F}$, which is substantially higher than the optimal temperature for $\mathrm{SO}_{2}$ removal. Large-scale tests of the modified system by Niro Atomizer indicated that the level of $\mathrm{NO}_{\mathrm{x}}$ removal achieved was up to $65 \%$ at these high-temperature conditions, while a high level (greater than $90 \%$ ) of $\mathrm{SO}_{2}$ removal was still maintained.

In recent tests carried out by Argonne National Laboratory and PETC, however, somewhat inferior $\mathrm{SO}_{2}$-removal efficiencies (on the order of 70-80\%) were obtained at comparable calcium-to-sulfur ratios (Huang et al., 1987). These latter tests, however, were conducted under different baghouse operating modes (off-line versus on-line cleaning). To date, no commercial system for the combined control of $\mathrm{SO}_{2}$ and $\mathrm{NO}_{\mathbf{x}}$ has been installed on coal-fired units, even though Niro Atomizer has declared that this modified version of operation has been commercially available for more than three or four years.

\section{A.11 DUAL-ALKALI FLUE-GAS DESULFURIZATION}

\section{A.11.1 Technology Description}

The lime dual-alkali process, successfully demonstrated by two domestic vendors at the commercial scale, represents one of the FGD technologies in use with the highest on-line availability. This process is an economically attractive second-generation process for $\mathrm{SO}_{2}$ removal, incorporating lower-cost limestone as a replacement for the lime as the final reagent for sequestering sulfur. Dual-alkali refers to the fact that the process operates with two separate loops of alkali reagent. The first loop is used to scrub $\mathrm{SO}_{2}$, while the second loop regenerates the scrubber liquor and removes the sulfur as a calcium sulfate/sulfite precipitate (Keeth et al., 1983).

In the first reagent loop, soda ash serves as the source of clear sodium sulfite/bisulfite solution that absorbs the $\mathrm{SO}_{2}$ from the flue gas in a spray-tower absorber. The use of clear scrubbing liquor, rather than the slurry that is typical of the majority of lime and limestone FGD systems, provides two mechanical advantages. 
First, slurry-handling pumps, nozzles, and slurry-sensitive items such as demisters in the absorber portion of the circuit are avoided. Second, solids scaling in the absorber portion of the system is also avoided. Significantly higher availabilities are thereby achieved.

In the second loop, the sodium-based solution is put in contact with a limestone slurry from a slacker/ball mill to regenerate the sodium absorbent. This second set of reactions takes place in a mixing/reaction tank and precipitates mixed calcium sulfite and sulfate solids, which have compositions typical of other nonregenerable scrubber sludges, except that they are higher in sodium content. To allow sufficient time for the growth of solid crystals, the slurry is passed on to a thickener.

Washing the solids cake recovers most (but not all) of the sodium present in the original scrubber liquor. However, a portion of the sodium (typically $0.5 \mathrm{moles} / \mathrm{mole}$ of $\mathrm{SO}_{2}$ absorbed) is lost with the dewatered solids (Simpson and Wilhelm, 1986). Sodium is highly mobile, producing a sodium loss that represents a process disadvantage in that it will subsequently be leached from the landfill. The filter-cake solids discharged from this process typically are $50-70 \%$ solids. The cake is nonhazardous and can be landfilled (FMC Corp., 1985).

Two mechanisms account for the $\mathrm{SO}_{2}$-absorption reactions. Sodium carbonate $\left(\mathrm{NaCO}_{3}\right)$ reacts directly with $\mathrm{SO}_{2}$ to form sodium sulfite $\left(\mathrm{Na}_{2} \mathrm{SO}_{3}\right)$ and $\mathrm{CO}_{2}$. The sodium sulfite then reacts with additional $\mathrm{SO}_{2}$, forming sodium bisulfite $\left(2 \mathrm{NaHSO}_{3}\right)$. These reactions may be summarized:

$$
\begin{aligned}
& \mathrm{Na}_{2} \mathrm{CO}_{3}+\mathrm{SO}_{2}+\mathrm{Na}_{2} \mathrm{SO}_{3}+\mathrm{CO}_{2} \\
& \mathrm{Na}_{2} \mathrm{SO}_{3}+\mathrm{SO}_{2}+\mathrm{H}_{2} \mathrm{O}+2 \mathrm{NaHSO}_{3}
\end{aligned}
$$

In Eq. 6, sodium sulfate $\left(\mathrm{Na}_{2} \mathrm{SO}_{4}\right)$ is formed:

$$
\mathrm{Na}_{2} \mathrm{SO}_{3}+1 / 2 \mathrm{O}_{2}+\mathrm{Na}_{2} \mathrm{SO}_{4}
$$

The formation of $\mathrm{Na}_{2} \mathrm{SO}_{4}$ unfavorably affects the process, because this oxidation reaction cannot be reversed when the scrubber solution is regenerated by the limestone. This reaction has a primary influence on the amount of sodium lost from the system. However, for higher-sulfur coals, the formation of sodium sulfate is reduced and is not considered to be a significant constraint on the dual-alkali technology.

The $\mathrm{pH}$ of the absorbing solution must be maintained in the range 6.0-7.0 (FMC Corp., 1985). Although the $\mathrm{SO}_{2}$-removal efficiency improves as the scrubber liquor's $\mathrm{pH}$ increases, it begins to level off after a $\mathrm{pH}$ of 6 . A compromise between scrubbing efficiency and the size of the regeneration tanks for the system further helps to define the $\mathrm{pH}$ value for optimal operation.

The scrubber-liquor regeneration reactions between the sodium species and the limestone can be sum marized as follows:

$$
2 \mathrm{NaHSO}_{3}+\mathrm{CaCO}_{3} \rightarrow \mathrm{Na}_{2} \mathrm{SO}_{3}+\mathrm{CaSO}_{3} \cdot 1 / 2 \mathrm{H}_{2} \mathrm{O}+\mathrm{CO}_{2}+1 / 2 \mathrm{H}_{2} \mathrm{O}
$$




$$
\begin{aligned}
3 / 2 \mathrm{H}_{2} \mathrm{O}+2 \mathrm{NaHSO}_{3}+\mathrm{Na}_{2} \mathrm{SO}_{4}+\mathrm{CaCO}_{3}+ & 2 \mathrm{Na}_{2} \mathrm{SO}_{3}+\mathrm{CaSO}_{4} \cdot 2 \mathrm{H}_{2} \mathrm{O} \\
& +\mathrm{CO}_{2}+1 / 2 \mathrm{H}_{2} \mathrm{O}
\end{aligned}
$$

After separation, the insoluble calcium salts (with $\mathrm{CaSO}_{4}$ incorporated into the $\mathrm{CaSO}_{3}$ crystal matrix) are separated from the liquor by settling in a thickener, followed by vacuum filtration. Clarified liquor and cake-wash water are returned to the scrubber recirculation tank to close the process-liquor loop. Filter-cake washing recovers most of the sodium salts occluded in the cake. However, the sodium losses that do occur are then of fset by the addition of soda ash to the scrubber recirculation tank.

As presently configured, no special provisions for $\mathrm{NO}_{x}$ removal were designed for the dual-alkali system. A network of reactions between the sulfur and nitrogen species in solution was identified (Littlejohn and Chang, 1984), and this series of reactions accounts for approximately $20 \% \mathrm{NO}_{\mathrm{x}}$ removal (Harkness and Doctor, 1985).

The dual-alkali chemistry seems to be particularly amenable to retrofit of singlesystem combined $\mathrm{SO}_{\mathrm{x}} / \mathrm{NO}_{\mathrm{x}}$-control technologies employing metal-chelate additives. One example of this approach is covered by the proprietary set of metal chelates in the ARGONOX process (Harkness et al., 1986). The incorporation of $\mathrm{NO}_{\mathrm{x}}$ controls in a single system may provide significant cost advantages for the dual-alkali approach.

\section{A.11.2 Technology Demonstration}

A commercial-scale limestone dual-alkali system has been demonstrated in the retrofit of a lime dual-alkali system at the Central Illinois Public Service Co. (CIPS) Newton Power Station (Simpson and Wilhelm, 1986). Newton 1 is a nominal 595-MW, pulverized-coal-fired boiler that began operation in November 1977. A lime dual-alkali system, installed by Buell Division of Envirotech (now defunct), successfully went into operation in 1979. The operational availability of this system, scrubbing flue gas from a high-sulfur coal (sulfur content of $2.4 \%$ ), was the highest for any domestic high-sulfur FGD system. In 1984, the system was converted to a limestone dual-alkali system in a cooperative venture between CIPS and Codan Associates (Salt Lake City, Utah).

The leader demonstrating lime dual-alkali technology had been FMC Corp.'s Air Quality Control Operation (which ceased operations in the spring of 1988). In September 1984, FMC successfully demonstrated the operation of a limestone dual-alkali system on a 3-MW slipstream from Unit 17 at Northern Indiana Public Service Co.'s R.M. Schahfer station (Boward et al., 1986). By June 1985, FMC had installed lime dual-alkali technology on utility and industrial steam boilers that totaled $2070 \mathrm{MW}$ of capacity (FMC Corp., 1985). However, FMC then stopped conducting flue-gas cleanup operations, and its basic patents for the dual-alkali process were transferred to Ontario Hydro of Canada (Camponeschi, 1989). Ontario Hydro reportedly intends to contract with an architectural/engineering ( $A / E)$ firm to design and construct a retrofit dual-alkali system at the Lambden power station. The $\mathrm{A} / \mathrm{E}$ firm will then handle future design and marketing of dual-alkali technology. 


\section{A.12 SELECTIVE CATALYTIC REDUCTION}

\section{A.12.1 Technology Deseription}

Selective catalytic reduction ( $\mathrm{SCR}$ ) is a process that reduces the $\mathrm{NO}_{\mathrm{x}}$ formed by fossil-fuel combustion to molecular nitrogen $\left(\mathrm{N}_{2}\right)$ and water. This reduction is accomplished by reacting $\mathrm{NH}_{3}$ with $\mathrm{NO}_{x}$ in the presence of a catalyst at about 600$750^{\circ} \mathrm{F}$. The $\mathrm{NO}_{\mathrm{x}}$-removal efficiency of the catalyst is influenced by the $\mathrm{NO}_{\mathrm{x}}$ concentration at the inlet, flue-gas temperature, molar ratio of $\mathrm{NH}_{3}$ to $\mathrm{NO}_{\mathrm{x}}$, catalyst capacity, oxygen concentration, and chemical and physical characteristics of the catalyst. The reactions that govern this process are as follows:

$$
\begin{aligned}
& 4 \mathrm{NH}_{3}+4 \mathrm{NO}+\mathrm{O}_{2} \rightarrow 4 \mathrm{~N}_{2}+6 \mathrm{H}_{2} \mathrm{O} \\
& 4 \mathrm{NH}_{3}+2 \mathrm{NO}_{2}+\mathrm{O}_{2} \rightarrow 3 \mathrm{~N}_{2}+6 \mathrm{H}_{2} \mathrm{O}
\end{aligned}
$$

The SCR reactor consists of a reaction chamber filled with either a honeycomb screen or plates that are coated with a surface-active catalyst. There are two types of reactors -horizontal flow and vertical flow. The SCR reactor is located just downstream of the boiler economizer to maintain the optimal reaction temperature.

\section{A.12.1.1 Catalysts}

The catalyst choices for SCR are titanium dioxide, combined with either vanadium pentoxide or tungsten trioxide, operating at temperatures between $280^{\circ}$ and $400^{\circ} \mathrm{C}$. Activated carbon may also be used, particularly in lower-temperature applications $\left(\simeq 100^{\circ} \mathrm{C}\right)$. As the flue gas and its inherent fly ash are passed through the reactor, the activity of the catalyst begins to decrease. This decrease can be compensated for by incorporating excess catalyst capacity in the initial design of the reactor. By so doing, constant $\mathrm{NO}_{\mathbf{x}}$-removal efficiency over the catalyst life is ensured.

\section{A.12.1.2 Process Configurations}

There are three configurations for the SCR process: high dust, tail end, and low dust. When the SCR reactor is located upstream of the air preheater and ESP, it is called high dust. Because of the optimal temperatures for $\mathrm{NO}_{\mathrm{x}}$ reduction, this configuration is the most common. When the SCR reactor is located downstream of the FGD plant, it is called tail end. The SCR reactor may also be placed between the ESP and the FGD plant; it is then referred to as low dust.

In the FRG, high-dust SCR is used at hard-coal-fired plants with dry- or wetbottom boilers and at lignite-fired plants. The tail-end configuration is used only in wetbottom boilers burning hard coal (Schonbucker, 1989). 
The decline in catalyst activity is relatively rapid in high-dust SCR configurations with $100 \%$ ash recirculation, especially when the ash contains arsenic. In simple terms, the catalyst activity is affected in the following manner. During normal operation, the $\mathrm{NH}_{3}$ is absorbed by the catalyst surface and reacts with $\mathrm{NO}_{\mathrm{x}}$ to form $\mathrm{N}_{2}$ and $\mathrm{H}_{2} \mathrm{O}$. If arsenic is present, however, arsenic trioxide is absorbed by the catalyst. It occupies much of the space within the catalyst, leaving less space for the $\mathrm{NH}_{3}$ to be absorbed. The $\mathrm{CaO}$ content of the fly ash and the type of firing greatly influence the arsenic content in the flue gas. High temperatures on slag-tap combustion chambers lead to increased arsenic vaporization.

A tail-end SCR configuration may be used to avoid exposing the catalyst to various mineral elements in fly ash, like calcium, magnesium, potassium, sodium, or arsenic.

A low-dust SCR reactor is located between the ESP and the FGD system and requires 50-60\% less catalyst. Low-dust systems typically operate at $300^{\circ} \mathrm{C}$. Catalyst lifetimes for tail-end systems are highest, achieving 24,000 operation hours. By comparison, high-dust systems have catalyst lifetimes on the order of 12,000 operation hours.

\section{A.12.1.3 Feedstock}

The feedstock used for the reaction is liquid $\mathrm{NH}_{3}$. The $\mathrm{NH}_{3}$ is evaporated and diluted with air to $5 \%$ and, for high-dust systems, fed into the duct between the economizer and the SCR reactor. In practice, the process reaction is carried out at a stoichiometric ratio of $\mathbf{0 . 8}$. A typical conversion value for $\mathrm{NO}_{\mathbf{x}}$ in Japanese commercial reactors is $\mathbf{8 0 \%}$.

The unreacted $\mathrm{NH}_{3}$ is called slip $\mathrm{NH}_{3}$. Depending on where the SCR reactor is located with respect to the other environmental components, slip $\mathrm{NH}_{3}$ may contaminate fly ash, FGD products, and FGD wastewater. Pilot plant investigations have shown that $\mathrm{NH}_{3}$ to $\mathrm{NO}_{\mathrm{X}}$ ratios of $>0.85-0.95$ will result in measurable slip $\mathrm{NH}_{3}$ in a short time. Sometimes $\mathrm{NO}_{\mathrm{x}}$-removal efficiency is compromised to reduce slip- $\mathrm{NH}_{3}$ contamination of fly ash and gypsum. Such decisions must balance the need for higher removal efficiency with concerns about disposal problems or by-product purity.

\section{A.12.2 Technology Demonstrations}

\section{A.12.2.1 Altbach-Deizisau Power Station - FRG}

The Altbach-Deizisau (AD) Unit No. 5 is a hard-coal-fired, 420-MW unit, retrofit with an SCR reactor in the high-dust configuration. From 1985 to December 1988, the AD SCR unit accumulated 18,400 hours of operating time. The AD unit must emit no more than $200 \mathrm{mg} \mathrm{NO} \mathrm{x} / \mathrm{m}^{3}\left(\approx 0.15 \mathrm{lb} / 10^{6} \mathrm{Btu}\right)$ (Necker, 1987, 1989). 
Space constraints prevented $A D$ from installing a $S C R$ reactor large enough to handle the total boiler exhaust. The system was designed to handle $80 \%$ of the boiler's $1.1 \times 10^{6} \mathrm{~m}^{3} / \mathrm{h}$ discharge, with the excess bypassing the SCR system and mixing with its exhaust. The $\mathrm{SCR}$ reactor can achieve $\mathrm{NO}_{\mathrm{x}}$-removal levels up to $80 \%$ with intake levels of $600 \mathrm{mg} / \mathrm{m}^{3}\left(\simeq 0.5 \mathrm{lb} / 10^{6} \mathrm{Btu}\right)$.

Operating experience at the $\mathrm{AD}$ unit has shown that the $\mathrm{NO}_{\mathrm{x}}$ concentration downstream of the boiler is greatly dependent on coal quality. $\mathrm{NO}_{\mathrm{x}}$ concentrations into the SCR reactor ranged from $400-800 \mathrm{mg} / \mathrm{m}^{3}$, exceeding the design levels of $550-600 \mathrm{mg} / \mathrm{m}^{3}$. To accommodate larger $\mathrm{NO}_{\mathrm{x}}$ concentrations and therefore create greater fuel flexibility, the reactor was converted from partial load to full load by the addition of a secondary SCR reactor to the flue-gas bypass. The alteration of the system required a three-week shutdown.

The AD plant is an intermediate-load plant. It is shut down daily in the summer months and over the weekends in the winter. These shutdown conditions do not appear to affect the efficiency of the SCR. After shutdown, the SCR takes about 45 minutes to start up again.

Slip $\mathrm{NH}_{3}$ downstream from the primary reactor was $0.6 \mathrm{mg} / \mathrm{m}^{3}$ and downstream from the secondary reactor was $0.15 \mathrm{mg} / \mathrm{m}^{3}$. Difficulties experienced at the AD unit included a difficult $\mathrm{NH}_{3}$ dosing, a short mixing section, and mixing effects accompanied by eddy flow at shutoff dampers. These problems were resolved by allowing for adjustable $\mathrm{NH}_{3}$ dosing, providing for intimate mixing, satisfying reactor conditions at the catalytic converter, and taking measures to protect duct work from harmful flue-gas components.

The SCR reactor can be operated to ensure an $\mathrm{NO}_{\mathrm{x}}$ limit of $200 \mathrm{mg} / \mathrm{m}^{3}$. Optimization work is still being conducted for SCR loads greater than $80 \%$ of boiler capacity.

The average $\mathrm{NH}_{3}$ concentration in the dust is $20-50 \mathrm{mg} \mathrm{NH} / \mathrm{kg}$. The average $\mathrm{NH}_{3}$ concentration in $\mathrm{FGD}$ wastewater is 5-6 ppm. Maximum wastewater concentrations were 8 and 9 ppm.

\section{A.12.2.2 VEBA Kraftwerke Ruhr - FRG}

VEBA Kraftwerke Ruhr (VKR) operates power plants in the North RhineWestfalia region of the FRG (Goldschmidt, 1987). The VKR's power-generating capacity is $5550 \mathrm{MW}$. Most of the boilers are fired with a hard coal. Older boilers are the wetbottom-furnace type; newer boilers are the dry-bottom type. These furnaces must comply with the FRG's limit of $200-\mathrm{mg} / \mathrm{m}^{3}$ for $\mathrm{NO}_{\mathrm{x}}$. To comply with the $\mathrm{NO}_{\mathrm{X}}$ limits, VKR applies primary $\mathrm{NO}_{\mathrm{x}}$-reduction methods to most of its boilers (i.e., combustion modifications for low- $\mathrm{NO}_{\mathrm{X}}$ burning).

In total, VKR operates eight SCR plants on its boilers. Two of the larger plants are the Buer plant and the Knepper $\mathrm{C}$. The Buer plant is a 150-MW district-heating plant. The Knepper $\mathrm{C}$ plant is a molten-ash, 370-MW plant. Only $50 \%$ of the flue gas at 
the Knepper plant is treated with SCR. The SCR used at these plants is the high-dust configuration, i.e., the SCR reactor is located between the boiler and the air heater.

At the Buer district-heating plant, the SCR handles the full $500,000 \mathrm{~m}^{3} / \mathrm{h}$ of flue gas generated. A multicyclone particle crusher had to be added upstream of the SCR reactor, because fly ash particles larger than the catalyst pore diameter clogged the catalyst. Although the SCR reactor clogging problem was resolved by the cyclone, the cyclone interfered with $\mathrm{NH}_{3}$ distribution. This problem was corrected by increasing the gas pressure and $\mathrm{NH}_{3}$ injection rate.

Catalyst deactivation because of fly-ash accumulation on the catalyst as well as chemical catalyst deactivation has been observed. In wet-bottom boilers with fly-ash recycle, the problems are quite severe. Chemical deactivation results from the arsenic content of the FRG's fly ash. Catalyst activity was observed to decrease $50 \%$ in less than 1000 hours of operation. Catalyst research in the FRG and Japan focuses on the development of an "arsenic-proof" catalyst.

\section{A.12.2.3 Walheim Power Station - FRG}

The Walheim Unit 2 was retrofitted with SCR in 1987. Unit 2 is a $150-\mathrm{MW}$, hardcoal-fired boiler equipped with a slag tap. By December 1988, the Walheim unit had accumulated 7553 operating hours with SCR.

Because of the slag-tap design, uncontrolled $\mathrm{NO}_{\mathrm{x}}$ emissions from the Unit 2 boiler were in the range of $1200-2400 \mathrm{mg} / \mathrm{m}^{3}$, depending on the coal. To reduce these emissions to a level below $200 \mathrm{mg} / \mathrm{m}^{3}$, two $\mathrm{NO}_{\mathrm{x}}$-reduction techniques had to be applied. The first approach was to modify the burner to reduce $\mathrm{NO}_{\mathrm{x}}$ in the flue gas. A multistage burner was installed; it reduced $\mathrm{NO}_{\mathrm{x}}$ levels to $1100-1600 \mathrm{mg} / \mathrm{m}^{3}$. Then an SCR system with a removal efficiency of $82-87 \%$ was needed. Because of the high removal requirements, $\mathrm{NH}_{3}$ dosing was optimized, a long mixing section was added, and baffles were added for even flow distribution. The amount of slip $\mathrm{NH}_{3}$ experienced was low.

The coal that was being fired in Unit 2 was high in trace metals, especially arsenic. Catalyst poisoning was minimized, however, because of the slag-tap system, in which flue gas was fed back to the boiler. This technique enhanced the condensation of the arsenic vapor onto the dust particles and thereby reduced the vapor concentration. This process, in turn, reduced catalyst poisoning, since arsenic vapor causes the most damage to catalysts.

\section{A.12.2.4 Heilbronn Power Station - FRG}

The SCR system in Unit 7 at the Heilbronn power station has been in operation since 1985. Unit 7 is a $700-\mathrm{MW}$, hard-coal-fired, dry-bottom boiler with a tangential firing system. The unit has operated $4000 \mathrm{~h} / \mathrm{yr}$ since 1985. 
The average $\mathrm{NO}_{x}$ concentration exiting the SCR system is $160-170 \mathrm{mg} / \mathrm{m}^{3}$. The plant automatically adjusts the $\mathrm{NH}_{3}$-to- $\mathrm{NO}_{\mathrm{x}}$ ratio if the $\mathrm{NO}_{\mathrm{x}}$ concentration at the inlet increases. The slip $\mathrm{NH}_{3}$ did not increase during the first 8500 hours of operation.

The SCR configuration is high dust. Experience shows that as long as the ash content of the flue gas is below $12 \mathrm{~g} / \mathrm{m}^{3}$, erosion and plugging of the catalyst is not significant. However, in the case of hard coal with a relatively high ash content, erosion and plugging are probable.

Special care is taken to ensure that the slip $\mathrm{NH}_{3}$ is maintained below 2 ppm. Slip $\mathrm{NH}_{3}$ above this value would contaminate fly ash and make it unusable in the cement industry. The operation of tail-end SCR plants has proceeded without problems. Tailend plants experience the longest catalyst life.

\section{A.12.2.5 Babcock Hitachi - Japan}

Although SCR is widely used by Japanese utilities, U.S. manufacturers report that the data from these plants cannot be readily extrapolated for use in the United States (Nakabayashi and Abe, 1987). One reason is that the coal used in Japanese utilities does not have the same mineral content as U.S. coal. Moreover, the cost data associated with the Japanese use of SCR are particularly suspicious, because the calculations are based on a catalyst life of more than one year.

Babcock Hitachi reports that is has supplied SCR for 90 plants located in Japan, Europe, and the United States. Of the 90 plants, 30 are gas fired, 27 are oil fired, 28 are coal fired, and 5 use other fuels. Forty-seven plants are used for utility applications; of these, 10 are gas fired, 18 are oil fired, and 19 are coal fired.

The longest Japanese catalyst lifetimes reported are 9 years for gas-fired units, 8 years for oil-fired units, and 6 years for coal-fired units. Arsenic catalyst poisoning is not reported to occur.

To achieve higher SCR economy, the Japanese periodically add new catalyst to old catalyst rather than replacing the old catalyst. The reactor is designed with a space for catalyst addition. This method ensures that the catalyst is completely spent before it is removed.

\section{A.12.2.6 EPDC - Japan}

EPDC installed two-stage, low- $\mathrm{NO}_{\mathrm{x}}$ burners at its power plants to control $\mathrm{NO}_{\mathrm{x}}$. When regulations required $\mathrm{NO}_{\mathrm{x}}$ emissions to be less than $200 \mathrm{ppm}$, however, low- $\mathrm{NO}_{\mathrm{X}}$ burners were no longer adequate. EPDC then installed SCR at its coal-fired stations.

The Japanese prefer SCR technology because it does not produce solid waste. SCR is applied to 22 coal-fired units in Japan -- $46 \%$ of all its coal-fired units. EPDC uses SCR in both the high- and low-dust configurations. The low-dust system allows a wider variety of imported coal to be used. When low-dust SCR is used, a hot-side ESP 


\section{$275 / 276$}

must also be used. When using a hot-side ESP, the resistance of the ash in the imported, low-sulfur coals is lower $\left(10^{10} \mathrm{ohm} \mathrm{cm}\right)$ than if a cold-side ESP were used $\left(10^{12} \mathrm{ohm} \mathrm{cm}\right)$. Therefore, a smaller and less expensive ESP may be used in the low-dust SCR configuration.

Appendix E describes EPDC's experience at its Takehara plant in greater detail (Mori and Shimizu, 1989). 
$2 \times 1$ 


\section{$277 / 278$}

\section{APPENDIX B:}

PARTIAL LIST OF ELECTRICITY GENERATING

FACILITIES REPRESENTING MAJOR SITES

IN SELECTED PROVINCES OF THE

PEOPLES' REPUBLIC OF CHINA 
278 


\begin{tabular}{|c|c|c|c|c|c|c|c|c|c|}
\hline \multirow[b]{2}{*}{$\begin{array}{c}\text { Region and } \\
\text { Province }\end{array}$} & \multirow[b]{2}{*}{ Site } & \multirow[b]{2}{*}{ Fuel } & \multirow[b]{2}{*}{$\begin{array}{l}\text { Year } \\
\text { Built }\end{array}$} & \multicolumn{2}{|c|}{1980} & \multicolumn{2}{|c|}{1985} & \multicolumn{2}{|c|}{$\begin{array}{l}\text { Increments } \\
1986-2000\end{array}$} \\
\hline & & & & $\begin{array}{l}\text { No: of } \\
\text { Units }\end{array}$ & $\begin{array}{l}\text { Total } \\
\text { MWe }\end{array}$ & $\begin{array}{l}\text { No: of } \\
\text { Units }\end{array}$ & $\begin{array}{c}\text { Total } \\
\text { MWe }\end{array}$ & $\begin{array}{l}\text { No: of } \\
\text { Units }\end{array}$ & $\begin{array}{c}\text { Total } \\
\text { MWe }\end{array}$ \\
\hline \multicolumn{10}{|l|}{ East } \\
\hline \multirow{34}{*}{ Jiangsu } & Nanjing & Thermal & 1960 & 2 & 50 & 2 & 50 & 0 & 0 \\
\hline & & Thermal & 1967 & 1 & 50 & 1 & 50 & 0 & 0 \\
\hline & & Thermal & 1971 & 1 & 50 & 1 & 50 & 0 & 0 \\
\hline & & Thermal & 1974 & 1 & 110 & 1 & 110 & 0 & 0 \\
\hline & & Thermal & 1975 & 1 & 125 & 1 & 125 & 0 & 0 \\
\hline & Jianbi & Thermal & 1965 & 1 & 25 & 1 & 25 & 0 & 0 \\
\hline & & Thermal & 1966 & 2 & 100 & 2 & 100 & 0 & 0 \\
\hline & & Thermal & 1970 & 2 & 200 & 2 & 200 & 0 & 0 \\
\hline & & Thermal & 1973 & 1 & 100 & 1 & 100 & 0 & 0 \\
\hline & & Thermal & 1980 & 0 & 0 & 1 & 300 & 0 & 0 \\
\hline & & Thermal & 1983 & 0 & 0 & 1 & 300 & 0 & 0 \\
\hline & & Coal & 1986 & 0 & 0 & 0 & 0 & 1 & 300 \\
\hline & & Coal & 1987 & 0 & 0 & 0 & 0 & 1 & 300 \\
\hline & Xuzhou 1 & Thermal & 1977 & 1 & 125 & 1 & 125 & 0 & 0 \\
\hline & & Thermal & 1978 & 1 & 125 & 1 & 125 & 0 & 0 \\
\hline & & Thermal & 1979 & 2 & 250 & 2 & 250 & 0 & 0 \\
\hline & & Coal & 1986 & 0 & 0 & 0 & 0 & 1 & 200 \\
\hline & & Coal & 1987 & 0 & 0 & 0 & 0 & 1 & 200 \\
\hline & Xuzhou 2 & Coal & 1991 & 0 & 0 & 0 & 0 & 1 & 300 \\
\hline & & Coal & 1992 & 0 & 0 & 0 & 0 & 1 & 300 \\
\hline & Yangzhou & Coal & 1988 & 0 & 0 & 0 & 0 & 1 & 200 \\
\hline & & Coal & 1989 & 0 & 0 & 0 & 0 & 1 & 200 \\
\hline & Tianshengang & Coal & 1988 & 0 & 0 & 0 & 0 & 1 & 350 \\
\hline & & Coal & 1989 & 0 & 0 & 0 & 0 & 1 & 350 \\
\hline & Xinhai & Coal & 1989 & 0 & 0 & 0 & 0 & 1 & 200 \\
\hline & & Coal & 1990 & 0 & 0 & 0 & 0 & 1 & 200 \\
\hline & Sunan & Coal & 1990 & 0 & 0 & 0 & 0 & $i$ & 300 \\
\hline & & Coal & 1991 & 0 & 0 & 0 & 0 & 1 & 300 \\
\hline & & Coal & 1992 & 0 & 0 & 0 & 0 & 1 & 300 \\
\hline & Yanjiang & Coal & 1991 & 0 & 0 & 0 & 0 & 2 & 600 \\
\hline & & Coal & 1994 & 0 & 0 & 0 & 0 & 2 & 600 \\
\hline & & Coal & 1995 & 0 & 0 & 0 & 0 & 2 & 600 \\
\hline & Others & Unk $^{\mathrm{a}}$ & Unk & Unk & 1146 & Unk & 1146 & 0 & 0 \\
\hline & Total & & & $16+$ & 2456 & $18+$ & 3056 & 21 & 5800 \\
\hline
\end{tabular}




\begin{tabular}{|c|c|c|c|c|c|c|c|c|c|}
\hline \multirow[b]{2}{*}{$\begin{array}{l}\text { Region and } \\
\text { Province }\end{array}$} & \multirow[b]{2}{*}{ Site } & \multirow[b]{2}{*}{ Fuel } & \multirow[b]{2}{*}{$\begin{array}{l}\text { Year } \\
\text { Built }\end{array}$} & \multicolumn{2}{|c|}{1980} & \multicolumn{2}{|c|}{1985} & \multicolumn{2}{|c|}{$\begin{array}{l}\text { Increments } \\
1986-2000\end{array}$} \\
\hline & & & & $\begin{array}{l}\text { No. of } \\
\text { Units }\end{array}$ & $\begin{array}{l}\text { Total } \\
\text { MWe }\end{array}$ & $\begin{array}{l}\text { No. of } \\
\text { Units }\end{array}$ & $\begin{array}{l}\text { Total } \\
\text { MWe }\end{array}$ & $\begin{array}{l}\text { No: of } \\
\text { Units }\end{array}$ & $\begin{array}{c}\text { Total } \\
\text { MWe }\end{array}$ \\
\hline \multicolumn{10}{|l|}{ East } \\
\hline \multirow[t]{42}{*}{ Zhejiang } & Xinanjiang & Hydro & 1960 & 2 & 145 & 2 & 145 & 0 & 0 \\
\hline & & Hydro & 1961 & 1 & 73 & 1 & 73 & 0 & 0 \\
\hline & & Hydro & 1964 & 1 & 72 & 1 & 72 & 0 & 0 \\
\hline & & Hydro & 1965 & 1 & 75 & 1 & 75 & 0 & 0 \\
\hline & & Hydro & 1967 & 1 & 75 & 1 & 75 & 0 & 0 \\
\hline & & Hydro & 1968 & 1 & 73 & 1 & 73 & 0 & 0 \\
\hline & & Hydro & 1975 & 1 & 75 & 1 & 75 & 0 & 0 \\
\hline & & Hydro & 1977 & 1 & 75 & 1 & 75 & 0 & 0 \\
\hline & Fucunjiang & Hydro & 1969 & 1 & 57 & 1 & 57 & 0 & 0 \\
\hline & & Hyd ro & 1972 & 1 & 60 & 1 & 60 & 0 & 0 \\
\hline & & Hydro & 1973 & 1 & 60 & 1 & 60 & 0 & 0 \\
\hline & & Hydro & 1975 & 1 & 60 & 1 & 60 & 0 & 0 \\
\hline & & Hydro & 1977 & 1 & 60 & 1 & 60 & 0 & 0 \\
\hline & Wuxijiang & Hydro & 1977 & 2 & 85 & 2 & 85 & 0 & 0 \\
\hline & & Hydro & 1980 & 0 & 0 & 2 & 85 & 0 & 0 \\
\hline & Zhenhai & Thermal & 1978 & 1 & 125 & 1 & 125 & 0 & 0 \\
\hline & & Thermal & 1979 & 1 & 125 & 1 & 125 & 0 & 0 \\
\hline & & Coal & 1986 & 0 & 0 & 0 & 0 & 1 & 200 \\
\hline & & Coal & 1989 & 0 & 0 & 0 & 0 & 1 & 200 \\
\hline & & Coa1 & 1990 & 0 & 0 & 0 & 0 & 1 & 200 \\
\hline & Taizhou & Thermal & 1982 & 0 & 0 & 1 & 125 & 0 & 0 \\
\hline & & Thermal & 1983 & 0 & 0 & 1 & 125 & 0 & 0 \\
\hline & & Coa1 & 1987 & 0 & 0 & 0 & 0 & 1 & 125 \\
\hline & & Coal & 1988 & 0 & 0 & 0 & 0 & 1 & 125 \\
\hline & Ban Shan & Thermal & 1984 & 0 & 0 & 1 & 125 & 0 & 0 \\
\hline & Beilungang & Coal & 1990 & 0 & 0 & 0 & 0 & 1 & 600 \\
\hline & & Coal & 1991 & 0 & 0 & 0 & 0 & 1 & 600 \\
\hline & & Coal & 1992 & 0 & 0 & 0 & 0 & 1 & 600 \\
\hline & & Coal & 1993 & 0 & 0 & 0 & 0 & 1 & 600 \\
\hline & Beicang & Coal & Unk & 0 & 0 & 0 & 0 & Unk & 1200 \\
\hline & Jinshuitan & Hydro & 1986 & 0 & 0 & 0 & 0 & 2 & 100 \\
\hline & & Hydro & 1987 & 0 & 0 & 0 & 0 & 2 & 100 \\
\hline & & Hydro & 1988 & 0 & 0 & 0 & 0 & 1 & 50 \\
\hline & & Hydro & 1989 & 0 & 0 & 0 & 0 & 1 & 50 \\
\hline & Shihtang & Hydro & 1988 & 0 & 0 & 0 & 0 & 1 & 26 \\
\hline & & Hydro & 1989 & 0 & 0 & 0 & 0 & 2 & 52 \\
\hline & Shanxi & Hydro & 1992 & 0 & 0 & 0 & 0 & 4 & 240 \\
\hline & Tang Keng & Hydro & 1993 & 0 & 0 & 0 & 0 & 2 & 300 \\
\hline & & Hydro & 1994 & 0 & 0 & 0 & 0 & 2 & 300 \\
\hline & Others & Thermal & Unk & 0 & 0 & Unk & 580 & 0 & 0 \\
\hline & Others & Hydro & Unk & 0 & 0 & Unk & 370 & 0 & 0 \\
\hline & Total & & & 18 & 1295 & $23+$ & 2705 & $26+$ & 5668 \\
\hline
\end{tabular}




\begin{tabular}{|c|c|c|c|c|c|c|c|c|c|}
\hline \multirow[b]{2}{*}{$\begin{array}{c}\text { Region and } \\
\text { Province }\end{array}$} & \multirow[b]{2}{*}{ Site } & \multirow[b]{2}{*}{ Fuel } & \multirow[b]{2}{*}{$\begin{array}{l}\text { Year } \\
\text { Built }\end{array}$} & \multicolumn{2}{|c|}{1980} & \multicolumn{2}{|c|}{1985} & \multicolumn{2}{|c|}{$\begin{array}{l}\text { Increments } \\
1986-2000\end{array}$} \\
\hline & & & & $\begin{array}{l}\text { No: of } \\
\text { Units }\end{array}$ & $\begin{array}{l}\text { Total } \\
\text { MWe }\end{array}$ & $\begin{array}{l}\text { No. of } \\
\text { Units }\end{array}$ & $\begin{array}{l}\text { Total } \\
\text { MWe }\end{array}$ & $\begin{array}{l}\text { No, of } \\
\text { Units }\end{array}$ & $\begin{array}{c}\text { Total } \\
\text { MWe }\end{array}$ \\
\hline \multicolumn{10}{|l|}{ East } \\
\hline \multirow{30}{*}{ Anhui } & Husinan & Thermal & 1956 & 3 & 18 & 3 & 18 & 0 & 0 \\
\hline & & Thermal & 1957 & 1 & 6 & 1 & 6 & 0 & 0 \\
\hline & & Thermal & 1959 & 1 & 25 & 1 & 25 & 0 & 0 \\
\hline & & Therma 1 & 1960 & 2 & 50 & 2 & 50 & 0 & 0 \\
\hline & & Thermal & 1960 & 1 & 12 & 1 & 12 & 0 & 0 \\
\hline & & Thermal & 1972 & 2 & 240 & 2 & 240 & 0 & 0 \\
\hline & & Thermal & 1975 & 1 & 125 & 1 & 125 & 0 & 0 \\
\hline & & Thermal & 1977 & 1 & 125 & 1 & 125 & 0 & 0 \\
\hline & Huaibei 1 & Thermal & 1973 & 2 & 100 & 2 & 100 & 0 & 0 \\
\hline & & Thermal & 1977 & 1 & 125 & 1 & 125 & 0 & 0 \\
\hline & & Thermal & 1978 & 1 & 125 & 1 & 125 & 0 & 0 \\
\hline & & Thermal & 1981 & 0 & 0 & 1 & 200 & 0 & 0 \\
\hline & & Thermal & 1982 & 0 & 0 & 1 & 200 & 0 & 0 \\
\hline & Huaibei 2 & Coal & 1992 & 0 & 0 & 0 & 0 & 1 & 300 \\
\hline & & Coal & 1993 & 0 & 0 & 0 & 0 & 1 & 300 \\
\hline & Chencun & Hydro & 1970 & 1 & 50 & 1 & 50 & 0 & 0 \\
\hline & & Hydro & 1972 & 1 & 50 & 1 & 50 & 0 & 0 \\
\hline & & Hydro & 1975 & 1 & 50 & 1 & 50 & 0 & 0 \\
\hline & Louhe & Coal & 1985 & 0 & 0 & 0 & 0 & 1 & 300 \\
\hline & & Coal & 1986 & 0 & 0 & 0 & 0 & 1 & 300 \\
\hline & & Coal & 1999 & 0 & 0 & 0 & 0 & 2 & 600 \\
\hline & Hefei & Coal & 1986 & 0 & 0 & 0 & 0 & 1 & 125 \\
\hline & Pingwei & Coal & 1988 & 0 & 0 & 0 & 0 & 1 & 600 \\
\hline & (Husinan) & Coal & 1990 & 0 & 0 & 0 & 0 & I & 600 \\
\hline & & Coal & 1992 & 0 & 0 & 0 & 0 & 1 & 600 \\
\hline & & Coal & 1993 & 0 & 0 & 0 & 0 & 1 & 600 \\
\hline & & Coal & 1994 & 0 & 0 & 0 & 0 & 1 & 600 \\
\hline & & Coal & 1995 & 0 & 0 & 0 & 0 & 1 & 600 \\
\hline & others & Unk & Unk & Unk & 620 & Unk & 620 & 0 & \\
\hline & Total & & & $19+$ & 1721 & $21+$ & 2121 & 13 & 5525 \\
\hline
\end{tabular}




\begin{tabular}{|c|c|c|c|c|c|c|c|c|c|}
\hline \multirow[b]{2}{*}{$\begin{array}{c}\text { Region and } \\
\text { Province }\end{array}$} & \multirow[b]{2}{*}{ Site } & \multirow[b]{2}{*}{ Fuel } & \multirow[b]{2}{*}{$\begin{array}{l}\text { Year } \\
\text { Built }\end{array}$} & \multicolumn{2}{|c|}{1980} & \multicolumn{2}{|c|}{1985} & \multicolumn{2}{|c|}{$\begin{array}{l}\text { Increments } \\
1986-2000\end{array}$} \\
\hline & & & & $\begin{array}{l}\text { No: of } \\
\text { Units }\end{array}$ & $\begin{array}{c}\text { Total } \\
\text { MWe }\end{array}$ & $\begin{array}{l}\text { No. of } \\
\text { Units }\end{array}$ & $\begin{array}{c}\text { Total } \\
\text { MWe }\end{array}$ & $\begin{array}{l}\text { No. of } \\
\text { Units }\end{array}$ & $\begin{array}{c}\text { Total } \\
\text { MWe }\end{array}$ \\
\hline \multicolumn{10}{|l|}{ East } \\
\hline \multirow[t]{31}{*}{ Shanghai } & Wangting & Coal & 1958 & 4 & 88 & 4 & 88 & 0 & 0 \\
\hline & & Coal & 1958 & 2 & 12 & 2 & 12 & 0 & 0 \\
\hline & & Coal & 1959 & 4 & 100 & 4 & 100 & 0 & 0 \\
\hline & & Coal & 1974 & 1 & 300 & 1 & 300 & 0 & 0 \\
\hline & & Coal & 1976 & 1 & 300 & 1 & 300 & 0 & 0 \\
\hline & Zhabei & Coal & 1930 & 2 & 20 & 2 & 20 & 0 & 0 \\
\hline & & Oil & 1937 & 1 & 13 & 1 & 13 & 0 & 0 \\
\hline & & oil & 1956 & $i$ & 22 & 1 & 22 & 0 & 0 \\
\hline & & $0 i 1$ & 1958 & 1 & 25 & 1 & 25 & 0 & 0 \\
\hline & & oil & 1959 & 1 & 25 & 1 & 25 & 0 & 0 \\
\hline & & Coal & 1960 & 1 & 50 & 1 & 50 & 0 & 0 \\
\hline & & Coal & 1966 & 1 & 50 & 1 & 50 & 0 & 0 \\
\hline & & oil & 1974 & 1 & 125 & 1 & 125 & 0 & 0 \\
\hline & & Oil & 1975 & 1 & 125 & 1 & 125 & 0 & 0 \\
\hline & Wujing 1 & Coal & 1959 & 2 & so & 2 & 50 & 0 & 0 \\
\hline & & Coal & 1961 & 1 & 50 & 1 & 50 & 0 & 0 \\
\hline & & Coal & 1966 & 1 & 100 & 1 & 100 & 0 & 0 \\
\hline & & Coal & 1969 & 1 & 125 & 1 & 125 & 0 & 0 \\
\hline & Wujing 2 & Coal & 1991 & 0 & 0 & 0 & 0 & 1 & 300 \\
\hline & & Coal & 1992 & 0 & 0 & 0 & 0 & 1 & 300 \\
\hline & & Coal & 1975 & 1 & 25 & 1 & 25 & 0 & 0 \\
\hline & Mingxing & Oil & 1958 & 1 & 12 & 1 & 12 & 0 & 0 \\
\hline & (Minghang) & Oil & 1959 & 2 & 12 & 2 & 12 & 0 & 0 \\
\hline & & $0 i 1$ & 1959 & 2 & 24 & 2 & 24 & 0 & 0 \\
\hline & & Coal & 1960 & 1 & 25 & 1 & 25 & 0 & 0 \\
\hline & & Coal & 1961 & 1 & 25 & 1 & 25 & 0 & 0 \\
\hline & & Coal & 1972 & 2 & 250 & 2 & 250 & 0 & 0 \\
\hline & & Coal & 1979 & 1 & 125 & 1 & 125 & 0 & 0 \\
\hline & & Coal & 1980 & 0 & 0 & 1 & 125 & 0 & 0 \\
\hline & & Coal & 1985 & 0 & 0 & 0 & 0 & 1 & 125 \\
\hline & & Coal & 1986 & 0 & 0 & 0 & 0 & 1 & 125 \\
\hline
\end{tabular}




\begin{tabular}{|c|c|c|c|c|c|c|c|c|c|}
\hline \multirow[b]{2}{*}{$\begin{array}{l}\text { Region and } \\
\text { Province }\end{array}$} & \multirow[b]{2}{*}{ Site } & \multirow[b]{2}{*}{ Euel } & \multirow[b]{2}{*}{$\begin{array}{l}\text { Year } \\
\text { Built }\end{array}$} & \multicolumn{2}{|c|}{1980} & \multicolumn{2}{|c|}{1985} & \multicolumn{2}{|c|}{$\begin{array}{l}\text { Increments } \\
1986-2000\end{array}$} \\
\hline & & & & $\begin{array}{l}\text { No: of } \\
\text { Units }\end{array}$ & $\begin{array}{l}\text { Total } \\
\text { MWe }\end{array}$ & $\begin{array}{l}\text { No, of } \\
\text { Units }\end{array}$ & $\begin{array}{c}\text { Total } \\
\text { MWe }\end{array}$ & $\begin{array}{l}\text { No: of } \\
\text { Units }\end{array}$ & $\begin{array}{c}\text { Total } \\
\text { MWe }\end{array}$ \\
\hline \multicolumn{10}{|l|}{ East } \\
\hline \multirow{41}{*}{$\begin{array}{l}\text { Shanghai } \\
(\text { Cont'd) }\end{array}$} & Yangshupu & Coal & 1921 & 2 & 36 & 2 & 36 & 0 & 0 \\
\hline & & Coal & 1923 & 1 & 20 & 1 & 20 & 0 & 0 \\
\hline & & Coal & 1923 & 1 & 3 & 1 & 3 & 0 & 0 \\
\hline & & Coal & 1929 & 1 & 3 & 1 & 3 & 0 & 0 \\
\hline & & Oil & 1929 & 2 & 40 & 2 & 40 & 0 & 0 \\
\hline & & Oil & 1934 & 1 & 22 & 1 & 22 & 0 & 0 \\
\hline & & Coal & 1947 & 1 & 18 & $i$ & 18 & 0 & 0 \\
\hline & & Coal & 1948 & 1 & 25 & $i$ & 25 & 0 & 0 \\
\hline & & Coal & 1956 & 1 & 16 & $i$ & 16 & 0 & 0 \\
\hline & & Oil & 1958 & 1 & 6 & 1 & 6 & 0 & 0 \\
\hline & & Coal & 1969 & 1 & 25 & 1 & 25 & 0 & 0 \\
\hline & & Coal & 1980 & 0 & 0 & 1 & 25 & 0 & 0 \\
\hline & & Coal & 1981 & 0 & 0 & 1 & 25 & 0 & 0 \\
\hline & Wusong & Coal & 1935 & 1 & 4 & $i$ & 4 & 0 & 0 \\
\hline & & Coal & 1952 & 1 & 6 & 1 & 6 & 0 & 0 \\
\hline & & Coal & 1985 & 0 & 0 & 0 & 0 & 0 & 0 \\
\hline & Nanshi & oil & 1958 & 1 & 12 & 1 & 12 & 0 & 0 \\
\hline & & $0 \mathrm{il}$ & 1959 & 1 & 12 & 1 & 12 & 0 & 0 \\
\hline & & $0 i 1$ & 1959 & 1 & 50 & 1 & 50 & 0 & 0 \\
\hline & & Coal & 1985 & 0 & 0 & 0 & 0 & 1 & 50 \\
\hline & Jinshan ${ }^{b}$ & Oil & 1966 & 2 & 50 & 2 & 50 & 0 & 0 \\
\hline & & Oil & 1975 & 2 & 100 & 2 & 100 & 0 & 0 \\
\hline & & Oil & 1976 & 2 & 100 & 2 & 100 & 0 & 0 \\
\hline & & Coal & 1981 & 0 & 0 & 1 & 2 & 0 & 0 \\
\hline & Baoshan & Coal & 1982 & 0 & 0 & 1 & 350 & 0 & 0 \\
\hline & Steel b & Coal & 1983 & 0 & 0 & 1 & 350 & 0 & 0 \\
\hline & Gaoqiaob & Oil & 1971 & 1 & 25 & $i$ & 25 & 0 & 0 \\
\hline & & 0 il & 1972 & 2 & 100 & 2 & 100 & 0 & 0 \\
\hline & & Oil & 1984 & 0 & 0 & 1 & 1 & 0 & 0 \\
\hline & $\begin{array}{l}\text { Hongwen } \\
\text { Paper }\end{array}$ & Coal & 1950 & 1 & 2 & 1 & 2 & 0 & 0 \\
\hline & $\begin{array}{c}\text { Shanghai } \\
\text { Cement }\end{array}$ & Coal & Unk & 1 & 3 & 1 & 3 & 0 & 0 \\
\hline & Shihdongkou & Coal & 1987 & 0 & 0 & 0 & 0 & 1 & 300 \\
\hline & No, 2 & Coal & 1988 & 0 & 0 & 0 & 0 & 1 & 300 \\
\hline & & Coal & 1989 & 0 & 0 & 0 & 0 & 1 & 300 \\
\hline & & Coal & 1990 & 0 & 0 & 0 & 0 & 1 & 300 \\
\hline & Shihdongkou & Coal & 1990 & 0 & 0 & 0 & 0 & $i$ & 600 \\
\hline & No. 1 & Coal & 1991 & 0 & 0 & 0 & 0 & 1 & 600 \\
\hline & & Coal & 1994 & 0 & 0 & 0 & 0 & 1 & 600 \\
\hline & & Coal & 1995 & 0 & 0 & 0 & 0 & $i$ & 600 \\
\hline & Haigaoqiao & Coal & 1995 & 0 & 0 & 0 & 0 & 1 & 600 \\
\hline & Total & & & 67 & 2756 & 73 & 3634 & 14 & 5100 \\
\hline
\end{tabular}




\begin{tabular}{|c|c|c|c|c|c|c|c|c|c|}
\hline \multirow[b]{2}{*}{$\begin{array}{l}\text { Region and } \\
\text { Province }\end{array}$} & \multirow[b]{2}{*}{ Site } & \multirow[b]{2}{*}{ Fuel } & \multirow[b]{2}{*}{$\begin{array}{l}\text { Year } \\
\text { Built }\end{array}$} & \multicolumn{2}{|c|}{1980} & \multicolumn{2}{|c|}{1985} & \multicolumn{2}{|c|}{$\begin{array}{l}\text { Increments } \\
1986-2000\end{array}$} \\
\hline & & & & $\begin{array}{l}\text { No: of } \\
\text { Units }\end{array}$ & $\begin{array}{c}\text { Total } \\
\text { MWe }\end{array}$ & $\begin{array}{l}\text { No. of } \\
\text { Units }\end{array}$ & $\begin{array}{c}\text { Total } \\
\text { MWe }\end{array}$ & $\begin{array}{l}\text { No: of } \\
\text { Units }\end{array}$ & $\begin{array}{c}\text { Total } \\
\text { MWe }\end{array}$ \\
\hline \multicolumn{10}{|l|}{ East } \\
\hline \multirow[t]{30}{*}{ Fujian } & Gutianxi & Hydro & Unk & 0 & 0 & Unk & 259 & 0 & 0 \\
\hline & Ansha & Hydro & Unk & 0 & 0 & Unk & 115 & 0 & 0 \\
\hline & Chitan & Hydro & Unk & 0 & 0 & Unk & 100 & 0 & 0 \\
\hline & Husan & Hydro & Unk & 0 & 0 & Unk & 60 & 0 & 0 \\
\hline & Haner & Hydro & Unk & 0 & 0 & Unk & 25 & 0 & 0 \\
\hline & Jitou & Hydro & Unk & 0 & 0 & Unk & 20 & 0 & 0 \\
\hline & Shuikou & Hydro & 1993 & 0 & 0 & 0 & 0 & 2 & 400 \\
\hline & & Hydro & 1994 & 0 & 0 & 0 & 0 & 3 & 600 \\
\hline & & Hydro & 1995 & 0 & 0 & 0 & 0 & 2 & 400 \\
\hline & Shaxikou & Hydro & 1987 & 0 & 0 & 0 & 0 & 2 & 150 \\
\hline & & Hydro & 1988 & 0 & 0 & 0 & 0 & 1 & 75 \\
\hline & & Hydro & 1993 & 0 & 0 & 0 & 0 & 1 & 75 \\
\hline & Fanchuo & Hydro & 1988 & 0 & 0 & 0 & 0 & 3 & 36 \\
\hline & Gungchuan & Hydro & 1989 & 0 & 0 & 0 & 0 & Unk & 32 \\
\hline & Shaxian & Hydro & 1990 & 0 & 0 & 0 & 0 & Unk & 30 \\
\hline & Jingi Cascade & Hydro & 1995 & 0 & 0 & 0 & 0 & Unk & 108 \\
\hline & Shagi Cascade & Hydro & 1995 & 0 & 0 & 0 & 0 & Unk & 128 \\
\hline & Others & Minihydr & Unk & 0 & 0 & Unk & 1366 & 0 & 0 \\
\hline & Yongan & Thermal & Unk & 0 & 0 & Unk & 250 & 0 & 0 \\
\hline & Shaowu & Thermal & Unk & 0 & 0 & Unk & 24 & 0 & 0 \\
\hline & Fuzhou & Thermal & Unk & 0 & 0 & Unk & 12 & 0 & 0 \\
\hline & & Coal & 1988 & 0 & 0 & 0 & 0 & 1 & 350 \\
\hline & & Coal & 1989 & 0 & 0 & 0 & 0 & 1 & 350 \\
\hline & & Coal & 1994 & 0 & 0 & 0 & 0 & 1 & 350 \\
\hline & Xianen & Thermal & Unk & 0 & 0 & Unk & 62 & 0 & 0 \\
\hline & Longyan & Thermal & Unk & 0 & 0 & Unk & 24 & 0 & 0 \\
\hline & Zhangping & Coal & 1986 & 0 & 0 & 0 & 0 & 1 & 200 \\
\hline & & & 1987 & 0 & 0 & 0 & 0 & 1 & 200 \\
\hline & Others & Thermal & Unk & 0 & 0 & Unk & 25 & 0 & 0 \\
\hline & Total & & & 0 & 0 & Unk & 2342 & $19+$ & 3484 \\
\hline \multirow[t]{6}{*}{ Shandong } & Zouxian & Coal & Unk & 0 & 0 & 0 & 0 & Unk & 1800 \\
\hline & Huangtai & Coal & Unk & 0 & 0 & 0 & 0 & 1 & 300 \\
\hline & Șhiheng & Coal & Unk & 0 & 0 & 0 & 0 & 2 & 600 \\
\hline & Ĺngkou 2 & Coal & Unk & 0 & 0 & 0 & 0 & 2 & 400 \\
\hline & Dezhou & Coal & 1988 & 0 & 0 & 0 & 0 & Unk & 700 \\
\hline & Total & & & 0 & 0 & 0 & 0 & $5+$ & $3800+$ \\
\hline \multirow[t]{3}{*}{ Jiang $x i$} & Wanan & Hydro & Unk & 0 & 0 & 0 & 0 & Unk & 500 \\
\hline & Guixi & Coal & Unk & 0 & 0 & 0 & 0 & Unk & 500 \\
\hline & Total & & & 0 & 0 & 0 & 0 & Unk & 1000 \\
\hline
\end{tabular}




\begin{tabular}{|c|c|c|c|c|c|c|c|c|c|}
\hline \multirow[b]{2}{*}{$\begin{array}{l}\text { Region and } \\
\text { Province }\end{array}$} & \multirow[b]{2}{*}{ site } & \multirow[b]{2}{*}{ Fue1 } & \multirow[b]{2}{*}{$\begin{array}{l}\text { Year } \\
\text { Built }\end{array}$} & \multicolumn{2}{|c|}{1980} & \multicolumn{2}{|c|}{1985} & \multicolumn{2}{|c|}{$\begin{array}{l}\text { Increments } \\
1986-2000\end{array}$} \\
\hline & & & & $\begin{array}{l}\text { No, of } \\
\text { Units }\end{array}$ & $\begin{array}{l}\text { Total } \\
\text { MWe }\end{array}$ & $\begin{array}{l}\text { No: of } \\
\text { Units }\end{array}$ & $\begin{array}{l}\text { Total } \\
\text { MWe }\end{array}$ & $\begin{array}{l}\text { No: of } \\
\text { Units }\end{array}$ & $\begin{array}{c}\text { Total } \\
\text { MWe }\end{array}$ \\
\hline \multicolumn{10}{|l|}{$\begin{array}{l}\text { South } \\
\text { Central }\end{array}$} \\
\hline \multirow[t]{30}{*}{ Guang $x i$} & Dahua & Hydro & 1983 & 0 & 0 & 3 & 300 & 0 & 0 \\
\hline & & Hydro & 1985 & 0 & 0 & 0 & 0 & 1 & 100 \\
\hline & $x i j i n$ & Hydro & 1964 & 2 & 114 & 2 & 114 & 0 & 0 \\
\hline & & Hydro & 1964 & 2 & 120 & 2 & 120 & 0 & 0 \\
\hline & Mashi & Hydro & 1972 & 1 & 28 & 1 & 28 & 0 & 0 \\
\hline & & Hydro & 1972 & 2 & 72 & 2 & 72 & 0 & 0 \\
\hline & Etan & Hydro & 1981 & 0 & 0 & 1 & 60 & 0 & 0 \\
\hline & Lalang & Hydro & 1971 & 3 & 51 & 3 & 51 & 0 & 0 \\
\hline & Luodong & Hydro & 1970 & 2 & 40 & 2 & 40 & 0 & 0 \\
\hline & Heshan & Thermal & 1970 & 3 & 75 & 3 & 75 & 0 & 0 \\
\hline & & Thermal & 1970 & 2 & 120 & 2 & 120 & 0 & 0 \\
\hline & & Thermal & 1970 & 1 & 100 & 1 & 100 & 0 & 0 \\
\hline & & Thermal & 1985 & 0 & 0 & 0 & 0 & 1 & 100 \\
\hline & & Thermal & 1986 & 0 & 0 & 0 & 0 & 1 & 100 \\
\hline & Liuzhou & Thermal & 1959 & 3 & 36 & 3 & 36 & 0 & 0 \\
\hline & Nanning & Thermal & 1960 & 2 & 24 & 2 & 24 & 0 & 0 \\
\hline & Tiandong & Thermal & 1974 & 2 & 24 & 2 & 24 & 0 & 0 \\
\hline & & Thermal & 1974 & 1 & 25 & 1 & 25 & 0 & 0 \\
\hline & & Thermal & 1986 & 0 & 0 & 0 & 0 & 1 & 25 \\
\hline & Guilin & Thermal & 1960 & 2 & 12 & 2 & 12 & 0 & 0 \\
\hline & & Thermal & 1960 & 1 & 12 & 1 & 12 & 0 & 0 \\
\hline & Laibin & Thermal & 1988 & 0 & 0 & 0 & 0 & 1 & 125 \\
\hline & & Thermal & 1989 & 0 & 0 & 0 & 0 & 1 & 125 \\
\hline & & Thermal & 1990 & 0 & 0 & 0 & 0 & 1 & 300 \\
\hline & Yantan & Hydro & 1992 & 0 & 0 & 0 & 0 & 1 & 275 \\
\hline & & Hydro & 1993 & 0 & 0 & 0 & 0 & 2 & 550 \\
\hline & & Hydro & 1994 & 0 & 0 & 0 & 0 & 1 & 275 \\
\hline & Longtan & Hydro & Unk & 0 & 0 & 0 & 0 & Unk & 1720 \\
\hline & others & Hydro & Unk & 0 & 0 & Unk & 51 & 0 & 0 \\
\hline & Total & & & 30 & 853 & $33+$ & 1264 & $10+$ & 3595 \\
\hline \multirow[t]{3}{*}{ Hubei } & Gezhouba & Hydro & 1988 & 0 & 0 & 0 & 0 & Unk & 2715 \\
\hline & Unk & Coal & Unk & 0 & 0 & 0 & 0 & 2 & 600 \\
\hline & Total & & & 0 & 0 & 0 & 0 & $2+$ & 3315 \\
\hline \multirow[t]{4}{*}{ Hunan } & Yueyang & Coal & Unk & 0 & 0 & 0 & 0 & Unk & 700 \\
\hline & Wuqiangxi & Hydro & 1994 & 0 & 0 & 0 & 0 & Unk & 1200 \\
\hline & Dongjiang & Hydro & Unk & 0 & 0 & 0 & 0 & Unk & 500 \\
\hline & Total & & & 0 & 0 & 0 & 0 & $4+$ & 2400 \\
\hline Henan & Pingdingshan & Coal & Unk & 0 & 0 & 0 & 0 & Unk & 1500 \\
\hline \multirow[t]{6}{*}{ Guangdong } & Shajiao A & Coal & 1987 & 0 & 0 & 0 & 0 & 2 & 700 \\
\hline & Shajiao B-1 & Coal & 1993 & 0 & 0 & 0 & 0 & Unk & 600 \\
\hline & Shajiao B-2 & Coal & 1987 & 0 & 0 & 0 & 0 & Unk & 600 \\
\hline & Shantou & Coal & Unk & 0 & 0 & 0 & 0 & Unk & 100 \\
\hline & Huangpu & Coal & 1990 & 0 & 0 & 0 & 0 & 2 & 600 \\
\hline & Total & & & 0 & 0 & 0 & 0 & $4+$ & 2000 \\
\hline
\end{tabular}




\begin{tabular}{|c|c|c|c|c|c|c|c|c|c|}
\hline \multirow[b]{2}{*}{$\begin{array}{l}\text { Region and } \\
\text { Province }\end{array}$} & \multirow[b]{2}{*}{ Site } & \multirow[b]{2}{*}{ Fuel } & \multirow[b]{2}{*}{$\begin{array}{l}\text { Year } \\
\text { Built }\end{array}$} & \multicolumn{2}{|c|}{1980} & \multicolumn{2}{|c|}{1985} & \multicolumn{2}{|c|}{$\begin{array}{l}\text { Increments } \\
1986-2000\end{array}$} \\
\hline & & & & $\begin{array}{l}\text { No: of } \\
\text { Units }\end{array}$ & $\begin{array}{l}\text { Total } \\
\text { MWe }\end{array}$ & $\begin{array}{l}\text { No: of } \\
\text { Units }\end{array}$ & $\begin{array}{c}\text { Total } \\
\text { MWe }\end{array}$ & $\begin{array}{l}\text { No. of } \\
\text { Units }\end{array}$ & $\begin{array}{c}\text { Total } \\
\text { MWe }\end{array}$ \\
\hline $\begin{array}{l}\text { Northeast } \\
\text { Liaoning }\end{array}$ & $\begin{array}{l}\text { Qingshe } \\
\text { Jinxi } \\
\text { Dalian } \\
\text { Jinzhou } \\
\text { Total }\end{array}$ & $\begin{array}{l}\text { Thermal } \\
\text { Coal } \\
\text { Coal } \\
\text { Coal }\end{array}$ & $\begin{array}{l}\text { Unk } \\
\text { Unk } \\
1986 \\
\text { Unk }\end{array}$ & $\begin{array}{r}\text { Unk } \\
0 \\
0 \\
0 \\
\text { Unk }\end{array}$ & $\begin{array}{r}\text { Unk } \\
0 \\
0 \\
0 \\
\text { Unk }\end{array}$ & $\begin{array}{r}\text { Unk } \\
0 \\
0 \\
0 \\
\text { Unk }\end{array}$ & $\begin{array}{r}1100 \\
0 \\
0 \\
0 \\
1100\end{array}$ & $\begin{array}{r}0 \\
\text { Unk } \\
\text { Unk } \\
\text { Unk } \\
\text { Unk }\end{array}$ & $\begin{array}{r}0 \\
1200 \\
700 \\
1200 \\
3100\end{array}$ \\
\hline $\begin{array}{l}\text { Heilong- } \\
\text { jiang }\end{array}$ & $\begin{array}{l}\text { Laer } \\
\text { Fulserji } \\
\text { Total }\end{array}$ & $\begin{array}{l}\text { Coal } \\
\text { Coal }\end{array}$ & $\begin{array}{l}1986 \\
\text { Unk }\end{array}$ & $\begin{array}{l}0 \\
0 \\
0\end{array}$ & $\begin{array}{l}0 \\
0 \\
0\end{array}$ & $\begin{array}{l}0 \\
0 \\
0\end{array}$ & $\begin{array}{l}0 \\
0 \\
0\end{array}$ & $\begin{array}{l}\text { Unk } \\
\text { Unk } \\
\text { Unk }\end{array}$ & $\begin{array}{r}85 \\
1200 \\
1285\end{array}$ \\
\hline Jilin & Baishan & Hydro & 1989 & 0 & 0 & 0 & 0 & Unk & 1500 \\
\hline $\begin{array}{c}\text { Northwest } \\
\text { Gansu }\end{array}$ & $\begin{array}{l}\text { Liujiaxia } \\
\text { Jingyuan } \\
\text { Total }\end{array}$ & $\begin{array}{l}\text { Hydro } \\
\text { Coal }\end{array}$ & $\begin{array}{l}\text { Unk } \\
\text { Unk }\end{array}$ & $\begin{array}{r}\text { Unk } \\
0 \\
0\end{array}$ & $\begin{array}{r}\text { Unk } \\
0 \\
0\end{array}$ & $\begin{array}{r}\text { Unk } \\
0 \\
0\end{array}$ & $\begin{array}{r}1225 \\
0 \\
1225\end{array}$ & $\begin{array}{r}0 \\
\text { Unk } \\
\text { Unk }\end{array}$ & $\begin{array}{r}0 \\
800 \\
800\end{array}$ \\
\hline Shaanxi & $\begin{array}{l}\text { Qinling } \\
\text { Datong } \\
\text { Ankang } \\
\text { Total }\end{array}$ & $\begin{array}{l}\text { Coal } \\
\text { Coal } \\
\text { Hydro }\end{array}$ & $\begin{array}{l}1987 \\
\text { Unk } \\
\text { Unk }\end{array}$ & $\begin{array}{l}0 \\
0 \\
0 \\
0\end{array}$ & $\begin{array}{l}0 \\
0 \\
0 \\
0\end{array}$ & $\begin{array}{l}0 \\
0 \\
0 \\
0\end{array}$ & $\begin{array}{l}0 \\
0 \\
0 \\
0\end{array}$ & $\begin{array}{c}\text { Unk } \\
\text { Unk } \\
4 \\
4+\end{array}$ & $\begin{array}{r}1050 \\
1200 \\
800 \\
3050\end{array}$ \\
\hline Ningxia & Dawukou & Coal & 1987 & 0 & 0 & 0 & 0 & Unk & 400 \\
\hline Qinghai & $\begin{array}{l}\text { Longyangxia } \\
\text { Li jiaxia } \\
\text { Total }\end{array}$ & $\begin{array}{l}\text { Hydro } \\
\text { Hydro }\end{array}$ & $\begin{array}{l}1989 \\
\text { Unk }\end{array}$ & $\begin{array}{l}0 \\
0 \\
0\end{array}$ & $\begin{array}{l}0 \\
0 \\
0\end{array}$ & $\begin{array}{l}0 \\
0 \\
0\end{array}$ & $\begin{array}{l}0 \\
0 \\
0\end{array}$ & $\begin{array}{l}\text { Unk } \\
\text { Unk } \\
\text { Unk }\end{array}$ & $\begin{array}{l}1280 \\
1600 \\
2880\end{array}$ \\
\hline Southwest & & & & & & & & & \\
\hline Yunnan & $\begin{array}{l}\text { Xiaolongan } \\
\text { Lubuge } \\
\text { Marwan } \\
\text { Total }\end{array}$ & $\begin{array}{l}\text { Coal } \\
\text { Hydro } \\
\text { Hydro }\end{array}$ & $\begin{array}{l}\text { Unk } \\
1989 \\
1994\end{array}$ & $\begin{array}{l}0 \\
0 \\
0 \\
0\end{array}$ & $\begin{array}{l}0 \\
0 \\
0 \\
0\end{array}$ & $\begin{array}{l}0 \\
0 \\
0 \\
0\end{array}$ & $\begin{array}{l}0 \\
0 \\
0 \\
0\end{array}$ & $\begin{array}{l}\text { Unk } \\
\text { Unk } \\
\text { Unk } \\
\text { Unk }\end{array}$ & $\begin{array}{r}600 \\
600 \\
1500 \\
2700\end{array}$ \\
\hline Sichuan & $\begin{array}{l}\text { Chongqing } \\
\text { Gongzui } \\
\text { Tongjiezi } \\
\text { Ertan } \\
\text { Total }\end{array}$ & $\begin{array}{l}\text { Coal } \\
\text { Hydro } \\
\text { Hydro } \\
\text { Hydro }\end{array}$ & $\begin{array}{l}\text { Unk } \\
\text { Unk } \\
1990 \\
1996\end{array}$ & $\begin{array}{l}0 \\
0 \\
0 \\
0 \\
0\end{array}$ & $\begin{array}{l}0 \\
0 \\
0 \\
0 \\
0\end{array}$ & $\begin{array}{l}0 \\
0 \\
0 \\
0 \\
0\end{array}$ & $\begin{array}{l}0 \\
0 \\
0 \\
0 \\
0\end{array}$ & $\begin{array}{l}\text { Unk } \\
\text { Unk } \\
\text { Unk } \\
\text { Unk } \\
\text { Unk }\end{array}$ & $\begin{array}{r}700 \\
2100 \\
600 \\
3000 \\
6400\end{array}$ \\
\hline Guizhou & Tienshengqiao & Hydro & 1994 & 0 & 0 & 0 & 0 & Unk & 1320 \\
\hline
\end{tabular}


$287 / 288$

\begin{tabular}{|c|c|c|c|c|c|c|c|c|c|}
\hline \multirow[b]{2}{*}{$\begin{array}{l}\text { Region and } \\
\text { Province }\end{array}$} & \multirow[b]{2}{*}{ Site } & \multirow[b]{2}{*}{ Fuel } & \multirow[b]{2}{*}{$\begin{array}{l}\text { Year } \\
\text { Built }\end{array}$} & \multicolumn{2}{|c|}{1980} & \multicolumn{2}{|c|}{1985} & \multicolumn{2}{|c|}{$\begin{array}{l}\text { Increments } \\
1986-2000\end{array}$} \\
\hline & & & & $\begin{array}{l}\text { No. of } \\
\text { Units }\end{array}$ & $\begin{array}{c}\text { Total } \\
\text { MWe }\end{array}$ & $\begin{array}{l}\text { No: of } \\
\text { Units }\end{array}$ & $\begin{array}{c}\text { Total } \\
\text { MWe }\end{array}$ & $\begin{array}{l}\text { No, of } \\
\text { Units }\end{array}$ & $\begin{array}{c}\text { Total } \\
\text { MWe }\end{array}$ \\
\hline \multicolumn{10}{|l|}{ North } \\
\hline \multirow[t]{3}{*}{ Tianjin } & Degang & Coal & 1989 & 0 & 0 & 0 & 0 & 2 & 700 \\
\hline & Jixian & Coal & Unk & 0 & 0 & 0 & 0 & Unk & 1000 \\
\hline & Total & & & 0 & 0 & 0 & 0 & $2+$ & 1700 \\
\hline \multirow[t]{4}{*}{ Shanxi } & Datong & Coal & Unk & 0 & 0 & 0 & 0 & Unk & 2400 \\
\hline & Shentou 1 & Coal & 1986 & 0 & 0 & 0 & 0 & 4 & 800 \\
\hline & Shentou 2 & Coal & Unk & 0 & 0 & 0 & 0 & 2 & 1000 \\
\hline & Total & & & 0 & 0 & 0 & 0 & $6+$ & 4200 \\
\hline \multirow{4}{*}{$\begin{array}{l}\text { Inner } \\
\text { Mongolia }\end{array}$} & Yuanbaoshan & Coal & Unk & 0 & 0 & 0 & 0 & Unk & 2100 \\
\hline & Tongliao & Coal & Unk & 0 & 0 & 0 & 0 & Unk & 800 \\
\hline & Fengzhen & Coal & 1991 & 0 & 0 & 0 & 0 & 4 & 800 \\
\hline & Total & & & 0 & 0 & 0 & 0 & $4+$ & 3700 \\
\hline \multirow[t]{4}{*}{ Hebei } & Xingrai & Coal & Unk & 0 & 0 & 0 & 0 & Unk & 890 \\
\hline & Douhe & Coal & Unk & 0 & 0 & 0 & 0 & Unk & 1500 \\
\hline & Shang'an & Coal & Unk & 0 & 0 & 0 & 0 & Unk & 2400 \\
\hline & Total & & & 0 & 0 & 0 & 0 & Unk & 4790 \\
\hline
\end{tabular}

$a_{\text {Unk }}=$ unknown

${ }^{b}$ Cogeneration plant.

Sources: Johnson (1987) and World Bank (1985; 1986a,b,c; 1987c). 
रे 
APPENDIX C:

ACTIVITIES SUBJECT TO MOROCCANIZATION LAW 
290 


\section{APPENDIX C:}

\section{ACTIVITIES SUBJECT TO MOROCCANIZATION LAW}

\section{Import/export agencies}

Leasing

Wines and spirits

Retail food industry

Various maritime activities

Radios, televisions, and refrigerators - manufacture, assembly, and retail

Tobacco

Soft drinks

Cold storage and cold storage plants and installation

Road transport

Motor vehicle rental activities

Fishing equipment commercial activity

Sewing machines

Bicycle, motorcycle assembling

Vegetable oil industrial activity

Building and public works

Cattle food commercial activity and cattle breeding

Soap and detergent industrial activity

Textile commercial activities

Real estate and insurance agencies

Film importation and distribution

Advertising

Banking

Insurance

Automobile and tractor assembly

Chemical products commercial activity

Rental or commercial activity in accounting machines and calculators

Steel products

Forestry

Fertilizer manufacturing

Coffee roasting and commercial activities

Fish canning

Travel agencies 
292 
APPENDIX D:

COST COMPARISONS FOR COAL-WATER MIXTURES 
$-294$ 


\section{APPENDIX D:}

\section{COST COMPARISONS FOR COAL-WATER MIXTURES}

A major incentive for developing coal-water mixtures (CWMs) has been to cut the operating costs in oil-fired plants. In the United States, the retrofit of oil-fired utility plants was the major intended application for CWMs. Recently, however, because of the actual and projected low price of oil, the importance of this incentive diminished, and development of CWMs slowed considerably. In addition, no new oil-fired utility plants are being built in the United States, so the drive to develop the CWM fuel system has been decreasing even more as the stock of potential units for retrofitting has been aging. The Italians, however, appear very interested in CWMs because they have a significant amount of relatively new, oil-fired capacity and because they have contracted to supply CWM technology to the Soviet Union. In fact, a slurry pipeline to existing Soviet coal-fired plants is being constructed.

Some brief analyses on using a CWM in place of coal in new plants have been made. They show that at some sites, where a coal plant may be difficult to construct because of the large coal storage area required, $\mathrm{CWMs}$ may be a realistic option. At sites that do not have such conditions, analyses usually show that using coal is less expensive than using CWMs (Siemon and Gregory, 1985).

The cost of using CWMs depends on not only the coal price and conversion process but also the amount of CWM being produced. The annual tonnage of CWM for an initial plant (i.e., the first of its kind) might range from 100,000 to $1,000,000$ tons. The smaller tonnage would would be appropriate for a developing market in a country, whereas the larger amount could supply a few hundred megawatts of electrical capacity. The smaller-production plants would, of course, be of considerably less economic risk to the investor.

\section{D.1 INFLUENCE OF PLANT THROUGHPUT AND COAL PRICE ON COST OF COAL- WATER MIXTURES}

The cost of using a CWM depends not only on factors such as the coal price, coal cleaning costs, and coal transportation costs but also on the CWM plant's throughput. Results presented by Siemon and Gregory (1985) show the cost of the CWM product at the plant as a function of throughput, expressed in U.S. dollars per million Btu. The results indicate that at a plant throughput of 100,000 tons of CWM per year, CWMs are very costly -- about $\$ \mathbf{5 . 0 0}-\$ 7.00 / 10^{6} \mathrm{Btu}$, depending on the cost of raw coal and the degree of coal cleaning that is done. At a throughput of 2 million tons per year, these costs decrease on a unit basis, but they are still higher than the 1987 price of industrial fuel oil in the United States $\left(\$ 2.50-\$ 3.00 / 10^{6} \mathrm{Btu}\right)$. 


\section{D.2 BREAKEVEN COST FOR COAL-WATER MIXTURES VERSUS FUEL OIL}

How high would the price of fuel oil have to be for a CWM fuel (at a price of $\$ 3.50 / 10^{6} \mathrm{Btu}$ ) to be competitive? The following assumptions were made to provide an answer to this question:

- Incremental O\&M cost for CWM fuel versus oil: $5 \mathrm{mills} / \mathrm{kWh}$

- Retrofit capital cost: $\$ 200 / \mathrm{kW}$

- Capacity factor: $50 \%$

- Retrofit derating: None

- Annual charge rate on incremental capital: $15 \%$

Under these assumptions, the breakeven price for fuel oil would probably be about $\$ 4.70 / 10^{6} \mathrm{Btu}$, or roughly $\$ 29$ per barrel. No cost was assumed for derating effects, but the breakeven cost could be increased by $30 \%$, depending on the conditions in the system associated with derating. For retrofit applications of $\mathrm{CWMs}$ to most nonutility industrial boilers, however, a significant derating (25-40\%) for single-boiler operation could probably not be tolerated, because the industrial firm manufactures less "product."

\section{D.3 COAL-WATER MIXTURES IN NEW GENERATING UNITS}

An application to consider when building a new generating unit is to incorporate a CWM-fueled boiler. The amount of space needed for coal storage and handling would be reduced if a CWM fuel were used, and under some conditions, the delivery of a CWM rather than coal would be simpler. Coal comminution and dust hazards would be eliminated. The boiler and ash handling would be much the same for a CWM as they are for coal. Nevertheless, a cursory analysis of an application indicates that a new coal unit still produces power at a lower cost than does a new CWM unit. Siemon and Gregory (1985) conclude that a "new coal station ... is still considerably cheaper than building a new oil- or CWM-fired one."

A brief comparison of power production from a CWM and from coal is summarized in Table D.1. This rough analysis shows clearly that a coal-fired unit has a big advantage over a CWM-fired unit. Only significant changes in external factors would alter this conclusion and dictate the consideration of a CWM fuel for new power plants. 
TABLE D.1 Technical and Economic Assumptions for 50-100 MW Plants

\begin{tabular}{lrr}
\hline \multicolumn{1}{c}{ Parameter } & CWM & Coal \\
\hline Efficiency (Btu/kWh) & 11,330 & 11,000 \\
Heat content of fuel (Btu/1b) & 10,000 & 12,000 \\
Euel cost ( $/ 10^{6}$ Btu) & 3.50 & 1.80 \\
Capital cost without flue-gas & 1,800 & 2,000 \\
desulfurization (\$) & 15 & 15 \\
Levelized capital charge rate (\%) & 65 & 65 \\
Capacity factor (\%) & & \\
Electrical energy cost on first- & 47.4 & 52.7 \\
year basis (mi11s/kWh) & 8.0 & 8.5 \\
Capital & $\frac{39.7}{16.5}$ \\
Operation and maintenance & 95.1 & 77.7 \\
Fuel & & \\
Total &
\end{tabular}


298 
$299 / 300$

\section{APPENDIX E:}

SELECTIVE CATALYTIC REDUCTION AT EPDC'S

TAKEHARA PLANT IN JAPAN 
bov 


\section{APPENDIX E:}

\section{SELECTIVE CATAL YTIC REDUCTION AT EPDC'S TAKEHARA PLANT IN JAPAN}

\section{E.1 EPDC TAKEHARA UNIT 1}

A year-long test that began in July 1981 was conducted on a selective catalytic reduction (SCR) system at EPDC's 250-MW, pulverized-coal-fired Takehara Unit 1 in Japan. This demonstration was the first one ever conducted on an SCR system that treats all of the flue gas from the unit. The results from this demonstration were applied to the SCR system at the 700-MW Takehara Unit 3.

The SCR system at Takehara Unit 1 is still operating today. It consists of two SCR reactors, one with the catalyst in a plate-type arrangement and the other with the catalyst in a honeycomb-type arrangement. The $\mathrm{NO}_{\mathrm{x}}$-removal efficiency has been measured to be $80 \%$, with a maximum slip-ammonia $\left(\mathrm{NH}_{3}\right)$ concentration of five parts per million ( $5 \mathrm{ppm}$ ). The slip $\mathrm{NH}_{3}$ is used to regulate the $\mathrm{NO}_{\mathrm{x}}$-removal efficiency. When $\mathrm{NO}_{\mathrm{x}}$-removal efficiency decreases, the amount of $\mathrm{NH}_{3}$ fed into the reactor is increased to improve the efficiency. The air heaters are washed every six months to remove am monium sulfate deposits.

At Takehara Unit 1, additional catalyst was added to the plate-type SCR reactor in 1983 and again in 1985. The amount of catalyst added each time was $17 \%$ of the total catalyst volume. Catalyst was added at these times because trends in the slip $\mathrm{NH}_{3}$ indicated that the air heaters would need to be washed more than once every six months.

For the honeycomb-catalyst SCR reactor, the addition of $30 \%$ of the original catalyst volume was required one year after startup. The addition was necessary because extreme $\mathrm{NH}_{3}$ slip resulted in excessive mineral deposits in the air heater. After four years of operations, the catalyst was completely replaced.

\section{E.2 EPDC TAKEHARA UNIT 3}

Takehara Unit 3 is a 700-MW PCF station. An SCR system has been operating on this unit since 1983. The SCR configuration consists of two reactors, both equipped with plate-type catalysts. The reactors in Takehara Unit 3 are vertical-flow type. Like Unit 1 , Unit 3 operates at $350^{\circ} \mathrm{C}$. At temperatures lower than $350^{\circ} \mathrm{C}$, ammonium sulfate forms, which can clog the catalyst or the air heater. Ammonia injection into the unit is controlled to ensure an $\mathrm{NO}_{\mathrm{X}}$ outlet concentration of $50 \mathrm{ppm}$. This concentration is below the 60-ppm guideline to ensure that short-term peaks in the inlet $\mathrm{NO}_{\mathrm{x}}$ concentration will not cause the guideline to be exceeded. The $\mathrm{NH}_{3} / \mathrm{NO}_{\mathrm{x}}$ ratio used is 1.2 .

In this unit, too, $\mathrm{NH}_{3}$ slip is used to regulate $\mathrm{NO}_{\mathrm{x}}$-removal efficiency. As catalyst activity decreases, less $\mathrm{NH}_{3}$ tends to be absorbed. Even though the feed $\mathrm{NH}_{3}$ remains constant, $\mathrm{NH}_{3}$ increases as catalyst activity decreases. 
In 1987 , four years after operation began, $12.5 \%$ of the original catalyst volume was added to the Takehara Unit 3 SCR reactor. Since this time, air heater washing has been required once every three months to remove ammonium sulfate deposits. 